UNIVERSIDADE DE SÃO PAULO

FACULDADE DE FILOSOFIA, LETRAS E CIÊNCIAS HUMANAS

DEPARTAMENTO DE HISTÓRIA

PROGRAMA DE PÓS-GRADUAÇÃO EM HISTÓRIA SOCIAL

Joseph de Maistre: intérprete da Revolução

Francesa e da Modernidade

(versão corrigida)

José Miguel Nanni Soares

São Paulo

2014 


\section{UNIVERSIDADE DE SÃO PAULO}

FACULDADE DE FILOSOFIA, LETRAS E CIÊNCIAS HUMANAS

DEPARTAMENTO DE HISTÓRIA

PROGRAMA DE PÓS-GRADUAÇÃO EM HISTÓRIA SOCIAL

Joseph de Maistre: intérprete da Revolução Francesa e da Modernidade

(versão corrigida)

José Miguel Nanni Soares

DE Acozolo

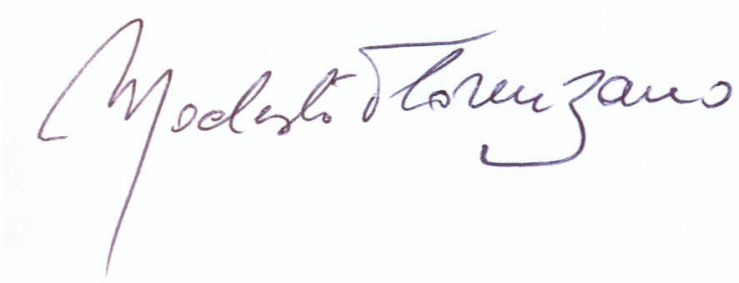

São Paulo 


\author{
UNIVERSIDADE DE SÃO PAULO
}

FACULDADE DE FILOSOFIA, LETRAS E CIÊNCIAS HUMANAS

DEPARTAMENTO DE HISTÓRIA

PROGRAMA DE PÓS-GRADUAÇÃO EM HISTÓRIA SOCIAL

\title{
Joseph de Maistre: intérprete da Revolução Francesa e da Modernidade
}

(versão corrigida)

\section{José Miguel Nanni Soares}

Tese apresentada ao Programa de Pós-Graduação em História Social do Departamento de História da Faculdade de Filosofia, Letras e Ciências Humanas da Universidade de São Paulo, para obtenção do título de Doutor em História Social

Orientador: Prof. Dr. Modesto Florenzano

São Paulo

2014 
À maestrina Genoária, pelo incansável zelo pedagógico e pelo amor providencial dispensados ao autor destas linhas... 


\section{AGRADECIMENTOS}

À Lilian, pelo incentivo, confiança, delicadeza e amor ao longo destes anos.

Ao meu orientador, professor Modesto Florenzano, pela generosidade, encorajamento, paciência e imprescindível ajuda não apenas na redação desta tese, mas na formação humanística de seu autor ao longo de quase uma década. Muito do que aqui se encontra, exceto os possíveis erros, deve-se às suas observações eruditas e sensatas.

Aos professores Richard Allen Lebrun, Michael Kohlhauer, Carolina Armenteros e Élcio Verçosa Filho pelo encorajamento, disponibilização de materiais para a pesquisa e sugestões em diferentes momentos desta tese.

Ao Departamento de História da USP, professores e funcionários, pelo auxílio e presteza ao longo do trabalho.

À FAPESP, cujo auxílio financeiro, por intermédio de uma bolsa de doutorado e dos recursos da reserva técnica, foi fundamental para que buscássemos atingir o nível de exigência que se espera de uma tese. 
Este trabalho foi realizado com o apoio financeiro da FAPESP (Fundação de Amparo à Pesquisa do Estado de São Paulo) 


\section{RESUMO}

O objetivo de nossa pesquisa foi de explorar a interpretação maistreana da Revolução Francesa, a qual, ao contrário do que postula o senso-comum de boa parte da historiografia, não se limitou às Considerações sobre a França (1797) e sua temática providencialista, pois se manifestou em muitos outros escritos distribuídos entre os 14 volumes de suas Obras Completas e seus inúmeros "Registros de Leitura". Maistre teve o mérito de integrar sua leitura da Revolução nos quadros da modernização do Ocidente, cujos pressupostos, expressos pela Reforma Protestante e pela Ilustração, permitiram-lhe explicar não apenas a Revolução em França, mas também profetizar o advento de uma 'era das revoluções'.

Fundamentalmente, procuramos demonstrar como a reação de Joseph de Maistre (1753-1821) ao projeto Ilustrado - e, por extensão, revolucionário - para a humanidade não apenas coincide, surpreendentemente, com o modo como se interpreta contemporaneamente a gênese do mundo moderno, como, apesar de seu caráter e intenções profundamente conservadores, encontra-se amparada em premissas indelevelmente humanistas e racionalistas. 
This thesis aims to study the Maistrean interpretation of the French Revolution, which, contrary to the common view postulated by great part of the historiography, was not confined to the famous providential treatment exposed in the Considérations sur la France (1797), but manifested instead in many other writings distributed along the 14 volumes of his Collected Works, not to mention the thousands pages of his unpublished notebooks. We would like to show that Maistre had the merit of considering the French Revolution in the light of the long-term historical process of modernization of the West, whose guidelines, expressed by the Protestant Reformation and the Enlightenment, allowed him to explain not only the Revolution in France, but also to predict the advent of an 'age of revolutions '.

Above all, we seek to demonstrate how Joseph de Maistre's (1753-1821) critique of the Enlightenment - and, by extension, revolutionary - project to humanity is, surprisingly, not only coincident with the way recent scholars interpret the genesis of the modern world, but, despite its deeply conservative character and intentions, is also supported by indelibly humanist and rationalist assumptions. 


\section{ÍNDICE}

INTRODUÇÃO 10

\section{Parte I - MAISTRE E AS CAUSAS TEOLÓGICO-POLÍTICAS DA REVOLUÇÃO FRANCESA}

Capítulo 1 - Do sans-culottismo da religião ao sans-culottismo político: as origens das "Reflexões sobre o Protestantismo" de Maistre.

Capítulo 2 - A Revolução Francesa, chave para a compreensão do Protestantismo: As "Reflexões sobre o Protestantismo"' de Maistre

Capítulo 3 - 'De l'Église Gallicane': da 'révolution ménagée' ao 'refinamento do espírito revolucionário'. Raizes do anticlericalismo liberal-revolucionário

\section{Parte II - De BACON A LOCKE: UM HUMANISTA DEVOTO CRÍTICO DA MODERNIDADE}

Capítulo 4 - O "Examen de la philosophie de Bacon" ou das raízes humanistas do ethos contrarrevolucionário maistreano

4.1. Por que Bacon? 116

4. 2. Humanismo neoplatônico e "philosophia perennis", de Ficino a Maistre

4. 3. Um túnel humanista neoplatônico no além-Mancha: Maistre e a Escola de Cambridge

4. 4. Examinando ou "boxeando" com Bacon

Capítulo 5 -"Cartas sobre a Educação Pública" e "Quatro Capítulos sobre a Rússia": uma teoria humanista devota sobre o progresso e o desenvolvimento das manners russas.

Capítulo 6 -"Unlocking the Human Mind": crítica à epistemologia de Locke ou a defesa humanista devota da dignidade humana... 


\section{Parte III - UM SABOIANO ULTRAMONTANO}

Capítulo 7 - Sob o signo da dualidade: Joseph de Maistre e a Casa da Saboia na 'Era da Revolução Democrática'.

Capítulo 8 -"Du Pape" ou o manifesto de um ultramontano

8.1. Cristianismo ou Europa: considerações preliminares sobre a religião e a liberdade política entre o Termidor e a Restauração

8. 2. Arquitetura de "Du Pape", ou Do Legislador temporal do

Providencialismo maistreano

Capítulo 9 -"À̀ sua imagem e semelhança": humanismo e providencialismo maistreanos em face da Ilustração e da Revolução

9. 1. Humano, demasiado divino: visão maistreana sobre a dignidade humana 300

9. 2. Humano, demasiado humano: a saciedade do mal e o Terror.

Conclus ão 376

B I B L I O GRA F I A 


\section{INTRODUÇÃO}

Apesar de nuançado pelo avanço das pesquisas ${ }^{1}$, o juízo tradicional a respeito de Joseph de Maistre (1753-1821) costuma não diferir muito daquele esboçado por Ballanche no início do século XIX, que o descreve como um "homem das doutrinas antigas, o profeta do passado", defensor brutal de um mundo que desaparecia e "que se queria ressuscitar em vão"2 ; ou daquele avançado por Émile Faguet no fechamento do mesmo século, para quem o contrarrevolucionário saboiano não passava de "um ferrenho absolutista, um furioso teocrata, um intransigente legitimista, apóstolo de uma trindade monstruosa constituída pelo papa, pelo rei e pelo carrasco, sempre e em todas as partes o campeão do dogmatismo mais feroz, estreito e inflexível, uma figura sombria saída da Idade Média, parte doutor erudito, parte inquisidor e carrasco".3

Com efeito, a reação de Maistre à filosofia das Luzes e à Revolução trouxe à tona uma "filosofia da autoridade" que só pode escandalizar nossas suscetibilidades modernas. Apesar disso e do fato de nossa cultura acadêmica não reconhecê-lo como um grande autor clássico, Maistre é freqüentemente citado nas sínteses e antologias internacionais de história das idéias, filosofia política ${ }^{4}$ e literatura. ${ }^{5}$ Afinal, não

${ }^{1}$ Cf: Owen Bradley, A Modern Maistre: the Social and Political Thought of J. de Maistre (London: University of Nebraska Press, 1999); Jean-Yves Pranchère, L'autorité contre les Lumières: la philosophie de Joseph de Maistre (Genève: DROZ, 2004); Cara Camcastle, The More Moderate side of Joseph de Maistre: views on Political Liberty and Political Economy (Montreal: McGill-Queen's University Press, 2005); Philippe Barthelet (org.). Joseph de Maistre (Lausanne: L'Age d'Homme, 2005); Carolina Armenteros, The French Idea of History: Joseph de Maistre and his heirs (London: Cornell University Press, 2011).

${ }^{2}$ P.-S. Ballanche, Essai de palingénésie sociale, in: Euvres (Paris-Genève, 1830), vol. III, p. 259.

3 Émile Faguet, Politiques et Moralistes du dix-neuvième siècle (Paris: Société Francaise d'Imprimerie \& de Librairie, 1899), $1^{\text {a }}$ série, p. 1.

${ }^{4}$ Por exemplo, Sheldon S. Wolin, Politics and Vision. Continuity and Innovation in Western Political Thought (Princeton, Princeton University Press, 2004), $1^{\text {a }}$ edição de 1960, p.322-3; Alice Gérard, A Revolução Francesa. Mitos e interpretações (1970). Tradução de Sérgio Joaquim de Almeida (São Paulo: Ed. Perspectiva, 1999); Denis Huisman, (org.); Dictionnaire des philosophes (Paris: P.U.F., 1984), vol. II, pp. 1713-1715; F. Furet e Mona Ozouf (org.), Dictionnaire critique de la Révolution française (Paris: Flammarion, 1988); Pierre Manent, "Joseph de Maistre", in Dictionnaire des oeuvres politiques (org.). Francois Chatelet, Olivier Duhamel, et Evelyne Pisier (Paris: PUF, 1986); Michel Vovelle (org.) França Revolucionária (1789-1799). Trad. de Denise Bottman (São Paulo: Brasiliense, 1989); Bruno Bongiovanni e Luciano Guerci (org.), L'albero della Rivoluzione. Le interpretazioni della Rivoluzione francese (Torino: Einaudi, 1989); M. Prélot et G. Lescuyer, Histoire des idées politiques (Paris: Dalloz, 1992), pp. 632-638.

${ }^{5}$ Ferdinand Brunetière enalteceu as inúmeras qualidades da escritura do "teólogo laico" Joseph de Maistre, cuja personalidade foi moldada pelas leituras de Platão, Bossuet, Vico, e pelo "perturbador espetáculo dos acontecimentos da Revolução e do Império". Cf. F. Brunetière, Histoire de la littérature française classique 1515-1830 (Paris: C. Delagrave, 1914), Tomo III, p. 107. Outro célebre historiador da literatura francesa, Gustave Lanson, ao estudar a reação maistreana à filosofia das Luzes, concluiu que o saboiano, com "seu espírito abstrato e razoado", nada mais era senão um "philosophe inimigo dos 
encontramos ecos de sua denúncia à vontade planificadora e construtivista da sociedade moderna tanto na reflexão política de Carl $\mathrm{Schmitt}^{6}$ como na doutrina neoliberal contemporânea? ${ }^{7}$ No outro extremo da filosofia política, importantes autores marxistas como Adorno, Horkheimer e Marcuse não chamaram a atenção de seus leitores para a extrema lucidez - se bem que descartando suas conclusões autoritárias - da crítica maistreana ao projeto da Ilustração? ${ }^{8}$ Por fim, no âmbito da literatura, não se logrou demonstrar o quanto as obras de Maistre contribuíram para o triunfo estético da "reação romântica" francesa do século XIX - reação à democracia, ao individualismo burguês e à sociedade industrial, à república, à igualdade social -, de Baudelaire a Balzac, Barbey

philosophes", o que permite explicar tanto a desenvoltura estilística quanto a radicalidade ideológica de seus escritos. In: G. Lanson, Histoire de la littérature française (Paris: Hachette, s/d), $21^{\mathrm{a}}$ edição, s/d, p. 910.

${ }^{6}$ Schmitt utilizou o pensamento dos contrarrevolucionários, e de Maistre em especial, em seu combate contra o racionalismo das Luzes, contra a abstração das construções especulativas desenraizadas na história. Em sua obra Teologia política (1922), mobilizou o pensamento de Maistre para rejeitar o conceito de soberania popular, que a seu ver só recrudescia a luta de classes e expunha a sociedade alemã a um constante "estado de exceção" e demonstrar que o poder devia ser exercido por uma esfera única, em nome da necessidade "decisionista", exclusivamente capaz de dar cabo nas crises engendradas pelas deliberações parlamentares e pela luta de classes. Em Noção de Política (1927), grosso modo, retoma o argumento dos teocratas - sobretudo de Maistre -, que consideravam o homem corrompido em sua essência pelo pecado original, para desferir uma crítica aos ideais liberais -os quais, amparados numa antropologia otimista, expressavam a "negação radical" do Estado - e à República de Weimar, por considerar impossível o estabelecimento de uma sociedade sem conflito entre o amigo e o inimigo (tudo que representasse ameaça aos interesses nacionais, naquele contexto, o comunismo).

No entanto, é preciso lembrar que o moralismo providencialista, cerne do pensamento maistreano, encontra-se absolutamente ausente do pensamento do jurista alemão, para quem a política (e sua esfera decisionista) deveria ser desvencilhada do jugo da moral (Teologia política). Ademais, Schmitt diferenciava-se de Maistre pelo antissemitismo e pela oposição à maçonaria. Sobre a apropriação de Maistre por Schmitt e a diferença entre ambos, consulte-se J. Zaganiaris, Spectres Contre Révolutionnaires: interprétations et usages de la pensée de Joseph de Maistre XIX ${ }^{e}-X X^{e}$ siècles (Paris: L'Harmattan, 2005), cap. VII.

${ }^{7}$ A convergência entre o pensamento contrarrevolucionário e as teses neoliberais foi estudada por S. Rials, "La droite ou l'horreur de la volonté" in Révolution et Contre-révolution au XIXe siècle. Paris, DUC/Albratros, 1987, p.53-56, G. Gegembre, La Contre-révolution ou l'histoire désespérante (Paris: Imago, 1989), p. 180 e Albert O. Hirschmann, A Retórica da intransigência: perversidade, futilidade, ameaça (São Paulo: Companhia das Letras, 1992), p. 23.

${ }^{8}$ Ambos concluíram que os ideais racionais de emancipação, ao se realizarem, produziram sua própria negação, revertendo-se, na sociedade burguesa-industrial, numa mitologia científica reprodutora da reificação e alienação humanas, de modo que "o terror e a civilização são inseparáveis". Meramente formal, a razão crítica da Ilustração revela-se puramente instrumental, reduzindo-se a um "critério de cálculo e utilidade" reprodutor de "tabus". Adorno e Horkheimer reconheceram que (para além do tom autoritário) nas diatribes epistemológicas que o saboiano dirigira a Bacon e a Locke (Examen de la philosophie de Bacon, 1816 e Soirées de Saint-Pétersbourg, 1821), já se prefigurava uma pertinente e inovadora crítica a essa utopia imanentista de domínio racional sobre o mundo que, nas palavras de Maistre, traziam no seu bojo a "estupidificação" pela ciência (Oeuvres complètes de Joseph de Maistre, “Examen..." Lyon, Vitte et Perussel, 1886 VI:41. De agora em diante, O.C.). Leia-se M. Horkheimer e T. Adorno, La dialectique de la Raison (1944). Trad. francesa de E. Kaufholz (Paris, Gallimard, 1983), especialmente p. 24-95. Vide também o penetrante ensaio de Michael Kohlhauer: "A Dialectical Reading of Joseph de Maistre by Herbert Marcuse", in: C. Armenteros e R. Lebrun (orgs.), Joseph de Maistre and his European Readers (Boston: Brill, 2011), p. 171-186. 
d'Aurevilly e Renan? ${ }^{9}$, isto sem falar das marcas que deixaram na literatura russa, sobretudo nas monumentais obras de Tolstói e Dostoievski ${ }^{10}$

Isto posto, quando se trata de estabelecer o balanço da historiografia da Revolução francesa sobre Maistre, deparamo-nos com duas realidades contraditórias.

Por um lado, identificamos a tentativa de reduzir a importância de sua interpretação da Revolução pelo fato de Maistre subsumir o fenômeno revolucionário numa análise providencialista, de maneira que as causas (sociais, políticas, econômicas) do fenômeno deixariam de ser efetivas para a compreensão do mesmo. É nesta chave de leitura que Jacques Godechot ${ }^{11}$ e Massimo Boffa ${ }^{12}$, especialistas em contrarrevolução, estabeleceram suas conhecidas críticas à interpretação maistreana. Contudo, além do saliente anacronismo de algumas condenações ${ }^{13}$, estes autores equivocam-se não apenas por ignorar as várias camadas de leitura presentes no subsolo de sua interpretação providencialista, mas também por ignorar que a crítica maistreana à Revolução não se limitou às Considerações sobre a França (1797). Por outro lado, uma observação atenta à historiografia da Revolução Francesa simplesmente desmente este quadro monocromático esboçado sobre o saboiano: a despeito dos anátemas pronunciados, a interpretação maistreana do fenômeno revolucionário é a única, dentre as escritas em língua francesa durante e contra a Revolução, que não caiu no esquecimento, sendo

\footnotetext{
${ }^{9}$ A. Compagnon, Les antimodernes: de Joseph de Maistre à Roland Barthes (Paris: Gallimard, 2005), p.126.

${ }^{10}$ Vera Miltchyna. “Joseph de Maistre's Works in Russia: a look at their Reception”(2001). In: R. Lebrun (org.). Joseph de Maistre's Life, Thought and Influence (Montreal \& Kingston: McGill-Queen's University Press, 2001), p. 242-3.

11 Referindo-se a Maistre e à sua interpretação providencialista presente nas Considerações, Godechot destacou o caráter polemista e pouco interessado pelas causas e desenvolvimento da Revolução de sua análise, razão pela qual tem pouco ou nenhum valor historiográfico. Cf. Jacques Godechot. "As grandes correntes historiográficas da Revolução Francesa, de 1789 aos nossos dias", in: Revista de História, $\mathrm{n}^{\circ} 80$, vol. 31, out.-dez. 1969, p. 425.

12 Massimo Boffa emitiu o seguinte juízo sobre Maistre - o qual seria mitigado no verbete "Maistre" que redigiu para o Dictionnaire critique de la Révolution française (1988), de Mona Ozouf e F. Furet: "Por que recomendar à atenção do leitor a obra de Maistre? O interesse de sua obra é, com efeito, longe de ser incontestável... Quando trata da Revolução Francesa, um tema que o perseguirá por toda sua vida, revela-se um historiador medíocre. Pouco importa-lhe saber como o Antigo Regime pôde engendrar a catástrofe em que iria soçobrar, e a preocupação primordial para um historiador - que será aquela dos doutrinários, de Tocqueville, do pensamento liberal: ancorar a Revolução na história da França - é-lhe completamente estranha. A imagem ambígua de um devir em que fatores heterogêneos se interpenetram não estimula seu espírito, atraído pela miragem de uma oposição sumariamente maniqueísta entre a representação da ordem de direito divino e o satanismo revolucionário". Cf. Massimo Boffa, "Joseph de Maistre: la défense de l'autorité", in: Le Débat, março-maio 1986, n³ 39, p.81.

${ }^{13}$ Como os trabalhos de J. Tulard e Peter Davies, que cobram do contrarrevolucionário saboiano uma cultura histórica típica de um historiador social do século XX. Vide: J. Tulard, "Introdução" às Considérations sur la France (Paris, Garnier Frères, 1980),p. 24; Peter Davies, The Extreme Right in France, 1789 to the Present (London: Routledge, 2002), p. 32-33. Tulard incorre no erro ainda mais grave de atribuir a Maistre a nacionalidade francesa.
} 
incessantemente citada pelos historiadores dos mais diversos matizes políticoideológicos.

Neste aspecto, John McManners ${ }^{14}$ e Alice Gérard ${ }^{15}$ observaram que as Considerações - trabalho responsável por sua reputação literária nos quadros da contrarrevolução e do pensamento conservador ${ }^{16}$ - tiveram o mérito de identificar uma fase aristocrática da Revolução, bem como o de atribuir boa parte do Terror à desastrosa política beligerante dos emigrados franceses e príncipes europeus, naquilo que se convencionou chamar de "teoria das circunstâncias". ${ }^{17}$ Não por acaso, alguns dos maiores expoentes da historiografia clássica da Revolução, a saber, F. Mignet ${ }^{18}$, Jules Michelet $^{19}$, Albert Sorel $^{20}$ e A. Mathiez ${ }^{21}$, lançaram mão das Considerações para ilustrar a férrea identidade entre a defesa nacional e o Terror.

${ }^{14}$ John McManners. "The Historiography of the French Revolution", in: The New Cambridge Modern History (1965), vol.8: 621-2.

${ }^{15}$ Alice Gérard, A Revolução Francesa. Mitos e interpretações. (1970) trad. Sérgio Joaquim de Almeida (São Paulo: Ed. Perspectiva, 1999), p. 28.

16 Num escrito publicado postumamente, Lefebvre, ao se referir às interpretações hostis à Revolução (e o autor tinha em mente os trabalhos de Auguste Cochin e Pierre Gaxotte), observou que as mesmas eram profundamente tributárias das interpretações originais de Maistre e Barruel. Cf. G. Lefebvre, Réflexions sur l'histoire (Paris: François Maspero, 1978), p.229.

${ }^{17}$ No segundo capítulo das Considerações, lê-se: "Jamais Robespierre, Collot ou Barère pensaram em estabelecer o governo revolucionário e o regime do terror: foram insensivelmente levados a isso pelas circunstâncias."

${ }^{18}$ Leia-se a seguinte citação das Considerações de Maistre em sua História: "Mas a posteridade, que não se preocupará muito com nossas dificuldades e dançará sobre nossos túmulos, rirá de nossa atual ignorância e consolar-se-á facilmente dos excessos a que nós assistimos e que terão conservado a integridade do mais belo dos reinos depois daquele do Céu" (Considerações..., cap. II). In: F. Mignet., Histoire de la Révolution française depuis 1789 jusqu'en 1814 (Paris: F. Didot père et fils, 1824), p. 271. Nesta obra, classificada por F. Furet (A Revolução em debate, 1999) como a "vulgata liberal" da historiografia nos anos 1820-1830, divisavam-se duas revoluções, a de 1789 e a do ano II, a primeira correspondendo à historicamente "necessária" vitória do terceiro estado sobre a nobreza, a segunda, à vitória das classes populares sobre a burguesia (episódio provocado pelas resistências interna e externa às mudanças trazidas pela Revolução). Assim procedendo (apelando à necessidade histórica e à "teoria das circunstâncias" maistreana para o Terror), Mignet devolveu a Revolução por inteiro ao campo liberal, sendo completamente expurgada de sua parte maldita, já que o jacobinismo é um produto da ContraRevolução.

${ }_{19}$ Quanto a Michelet, o fato de aludir às Considerações em sua Histoire de la Révolution française (1847), apenas confirma a excentricidade da interpretação maistreana, que, apesar de representar uma refutação radical da Revolução Francesa, ofereceu ao professor republicano argumentos contundentes que serviram para reforçar suas críticas aos resquícios feudais e à aristocracia do antigo regime: "Eram uma classe de homens muito heterogêneos, mas em geral fracos e fisicamente decadentes, levianos, sensuais e sensíveis..." É o que reconhece o sr. de Maistre em suas Considerações sobre a França" (Histoire ..., Livro II, cap. 3). Mais adiante, certo é que Michelet se remetia às Considerações quando dizia: "Os emigrados arriscavam vencer, assassinar a pátria, para sua desonra eterna. Ter-lhes-ia dito M. de Maistre: 'Oh, infelizes, felicitai-vos por terem sido derrotados pela Convenção!... Teríeis, pois, querido uma França desmembrada e destruída?” (Histoire..., Livro XIII, cap. 1). Michelet não ignorou o fato de que os grandes alvos da verve crítica de Maistre nas Considerações foram o clero e a aristocracia do Antigo Regime. Do mesmo modo, é bem provável que sua fonte de inspiração retórica para a descrição do jacobinismo como "terrível máquina" tenha partido do mesmo panfleto de Maistre, especialmente do sétimo capítulo, onde usa-se e abusa-se desta metáfora. Cf. J. Michelet. Histoire de la Révolution Française (Paris: Gallimard,1939), t.II, p.8. 
E mesmo alguém como Edgar Quinet, o grande crítico da Revolução no interior da tradição republicano-liberal, remeteu-se a Maistre e à sua "teoria das circunstâncias",22 seja para refutar essa apropriação pela historiografia republicana, seja para ilustrar seu grande pensamento sobre a Revolução, a saber, que a Revolução fracassou porque não logrou separar a França do catolicismo e de seus valores absolutistas. Antes de representar uma forma de governo inédito, o Terror simbolizou uma ressureição daquilo que constituiu os fundamentos do absolutismo: Richelieu e Luís XIV, a noite de São Bartolomeu e as dragonadas contra a Fronda: a violência crua e nua do poder e, da parte da nação, o medo e a servidão. ${ }^{23}$

Mais do que formular uma "teoria das circunstâncias" avant la lettre, as Considerações, conforme destacou F. Furet em A Revolução em debate (1999), ao negarem-se a separar uma "boa" Revolução da "má", avançaram uma leitura da "Revolução-bloco" de tão brilhante futuro. ${ }^{24}$ A exemplo de Burke, Maistre identificou no projeto revolucionário do Iluminismo, isto é, no projeto de (re)fundar a sociedade por meio da razão individualista (a qual teve origem na Reforma Protestante do século $\mathrm{XVI}$ ), as causas da instabilidade política dos sucessivos governos revolucionários (que

${ }^{20}$ Cita várias passagens das Considerações de Maistre, por ele descrito como o "mais eloqüente apologista da contrarrevolução", para ilustrar os riscos que a política contrarrevolucionária trouxe para a integridade nacional. Cf. A. Sorel, L'Europe et la Révolution française. III Partie: La Guerre aux Rois. (Paris: Librairie Plon, 1920), $20^{\circ}$ edição, p.479; p.537; p.565. Todavia, a maior virtude de Maistre nas Considerações consistiu, segundo ele, em haver compreendido melhor do que ninguém a amplitude do fenômeno jacobino que, naquelas injunções de guerras intestinas e externas, foi o maior responsável pelo triunfo da Revolução e pela manutenção da integridade territorial francesa. Cf. Ibidem., p. 530.

21 Albert Mathiez reproduziu a seguinte passagem das Considerações em sua Histoire de la Révolution: "Que pediam os realistas quando pediam uma contra-revolução feita bruscamente e pela força? Pediam a conquista da França...” In: História da Revolução Francesa (1822-4). O Terror (vol.III). Trad. de Paulo Zincg (São Paulo: Atena Editora,s/d), p. 102.

${ }^{22}$ Cf. Alice Gérard, A Revolução Francesa. Mitos e interpretações, p. 28.

23 "Pelo contágio da violência, o teólogo M. de Maistre torna-se, idealmente, o Robespierre do clero. Ele opõe, em teoria, um terrorismo da Igreja ao terrorismo da Convenção. Seu Deus inexorável, assistido pelo carrasco, Cristo de um Comitê permanente de Salvação Pública, é o ideal de 1793, porém de um 1793 eternizado contra a Revolução. Em nome da Igreja, ele admite o sistema da Montanha, o terror, o cadafalso, do qual faz um altar, a 'terra continuamente embebida em sangue', tudo, exceto a liberdade, a igualdade, a fraternidade prometidas. Nesta teologia, que coloca verdadeiramente a morte na ordem do dia, resta, ao fundo, o absolutismo da Convenção, sem a esperança da libertação antes do último dia do globo, Robespierre sem Rousseau, o meio sem o fim. Tão grande é o ódio do catolicismo pela Revolução que, para matá-la no berço, empresta-se dela seu inferno, e rejeita-se apenas seu céu." Cf. E. Quinet, Le Christianisme et la Révolution française (1845), 13 ${ }^{\text {a }}$ lição. Lembremos que todos os pressupostos de sua interpretação crítica à Revolução, condensadas posteriormente em La Révolution (1865), encontram-se em germe na sua obra de 1845, onde a referência a Maistre é abundante. Na obra de 1865, refere-se a Maistre quando trata da "Convenção". Para Quinet, Maistre foi quem melhor penetrou no propósito dos jacobinos, a saber, "forçar um povo a ser livre"(Livro XII, cap.I). Sobre a identidade entre Antigo Regime/catolicismo e o Terror, tanto no plano político quanto moral, consultem-se os capítulos X e XIV do Livro XVII de La Révolution ("Teoria do Terror").

${ }^{24}$ François Furet, A Revolução em debate (1999). Trad. Regina C. B. Prates e Silva (Bauru-SP, Edusc, 2001), p.8. 
ele, mesmo após a Restauração, julgava longe de um final feliz para sua causa) e do Terror, de modo que se torna impossível separar uma "era feliz" daquilo que Constant e, posteriormente, a historiografia liberal da Restauração desde Mme de Stäel, classificou como traição dos princípios: “A Revolução francesa percorreu um período cujos momentos, sem dúvida, diferem entre si; porém, seu caráter geral jamais variou, e desde o berço dava sinais daquilo que viria a ser" (Considerações, Capítulo 5). ${ }^{25}$

Por incrível que pareça, o revisionista e liberal François Furet nada mais fez do que, mutatis mutandis, reproduzir essa tese maistreana em sua principal obra sobre a Revolução de 1789, Pensando a Revolução Francesa (1978). ${ }^{26}$ Neste ínterim, é igualmente possível creditar a Maistre o mérito de haver "profetizado", e com uma extraordinária lucidez, não só a ameaça de degeneração totalitária do ideal democráticorevolucionário $^{27}$, mas, sobretudo, a sede (Rússia) ${ }^{28}$ e a formação (disseminação em solo russo de uma nova filosofia vinda da Alemanha e que, impregnada de 'espinosismo' e 'kantismo', semearia revoluções de uma radicalidade inaudita) deste devir. ${ }^{29}$

Triunfo do individualismo nos âmbitos moral e/ou social, do liberalismo (com todas as assimetrias e miséria que deixa nos seu rastro e que ele, Maistre, assíduo leitor, escritor e aplicador da nascente ciência econômica em seu Estado, não ignorava) ${ }^{30}$ no âmbito econômico e do materialismo ou empirismo no plano epistemológico, tais as grandes obras do espírito moderno consagradas pela Revolução, que "não tinham como

${ }^{25}$ A despeito da diferença de objetos, valeria ressaltar aqui a semelhança de análise (ao menos de ponto de partida) e estilo entre Maistre e Tocqueville, sobretudo quando o último, no primeiro volume de sua A Democracia na América (1835), oferece o caráter e o espírito dos colonizadores (mormente o puritanismo) como a chave para a compreensão da democracia e da liberdade nos Estados Unidos: "O homem acha-se por inteiro, por assim dizer, entre as cobertas do seu berço. No caso das nações, verificase algo de análogo. Os povos guardam sempre as marcas de sua origem. As circunstâncias que acompanham seu nascimento e serviram ao seu desenvolvimento influem sobre todo o resto de sua existência" (Democracia na América; Livro I, cap. II). Devo esta observação ao prof. Modesto Florenzano.

${ }^{26}$ F. Furet, Pensando a Revolução Francesa (1978). Trad. Martha Gambini e Luiz Marques (São Paulo: Paz e Terra, 1989), $2^{a}$ edição, p. 26 e 78-79 respectivamente.

27 George Steiner estabeleceu um interessante paralelo entre Maistre e Soljenitsin, de $O$ Arquipélago Gulag (1947). In: G. Steiner. "Aspects of Counter-revolution”, in: Geoffrey Best (org.), The Permanent Revolution: the French Revolution and its legacy 1789-1989 (Chicago: Univ. of Chicago Press, 1989), p.148.

28 "Se os russos, que têm certa tendência a levar tudo na brincadeira..., brincarem também com essa serpente [Ilustração], nenhum povo terá sido mais cruelmente picado por ela." Cf. Joseph de Maistre, Oeuvres complètes de Joseph de Maistre (Lyon: Vitte et Perussel, 1893), vol. VIII, p. 354 (de agora em diante, conforme o modelo O.C., VIII: 354). Podemos ler estas linhas como uma previsão literária (afinal, em pouco tempo a Rússia produziria uma das melhores literaturas do século XIX) e política (uma Revolução mais radical do que a francesa).

${ }^{29} \mathrm{~J}$. de Maistre, Lettre à Ouvaroff sur le projet d'une academie asiatique (1810) apud S. Ouvaroff, Études de philologie et de critique (Paris: Didot, 1845), $2^{\mathrm{a}}$ ed., p. 56.

${ }^{30}$ Leia-se especialmente a Mémoire sur le commerce des grains entre Carouge et Genève, de 1790, reproduzida por Cara Camcastle em: The More Moderate side of Joseph de Maistre: views on Political Liberty and Political Economy (Montreal: McGill-Queen's University Press, 2005). 
limites senão o mundo" ${ }^{31}$ - isto sem falar do ideal democrático, responsável pela instabilidade política francesa e europeia.

Do mesmo modo, não será difícil demonstrar, na contramão do que sustentaram Godechot e Boffa, que, dentre os 'pecados' da interpretação maistreana da Revolução, certamente não se encontra o de ter feito tábula rasa da história francesa e européia. Afinal, nas Réflexions sur le protestantisme $(1798)^{32}$, Du Pape (1819) e De l'Église Gallicane (1821), explica-se a Revolução francesa à luz de um longo processo iniciado pela Reforma religiosa do século XVI, e que se desdobrou na oposição jansenistaparlamentar à monarquia absolutista durante o século XVIII. Recentemente, e de acordo com os melhores métodos da erudição histórica, Dale K. Van Kley alcançou os mesmos resultados da polêmica hipótese maistrena. ${ }^{33}$ Atente-se para a seguinte passagem de $D e$ l'Église Gallicane:

“Grandes revoluções, grandes convulsões morais, religiosas ou políticas, sempre deixam algo por detrás delas. O calvinismo nasceu na França; sua terra natal, vigorosa o suficiente para vomitar o veneno, ficará, no entanto, notavelmente afetada por isso. Observa-se, então, o que acontece em todas as revoluções: elas acabam, mas o espírito que lhes deu vida sobrevive... O espírito do século XVI foi nutrido e propagado na França principalmente pelos Parlamentos, e especialmente pelo de Paris... Protestante no século XVI, rebelde e jansenista no século XVII, e, finalmente, filosófico nos últimos anos de sua vida, o Parlamento mostrou-se assiduamente em contradição com as verdadeiras máximas fundamentais do Estado [ou seja, proteção à fé católica e união com Roma]... O germe calvinista, nutrido neste grande corpo [Parlamentos], tornou-se muito mais perigoso quando sua essência alterou o nome e designou-se jansenismo" (Livro I, cap. 2).

Com efeito, o galicanismo para Maistre nada mais era senão um disfarce para o jansenismo, o qual, apesar de nascido da Contrarreforma católica, assumiu cada vez mais um aspecto criptocalvinista, quer no tocante à doutrina quer em relação à política. Noutras palavras, o jansenismo desempenhou na França o papel de fio-condutor que

\footnotetext{
${ }^{31}$ J. de Maistre, O.C., XI:352. Em 1808, Maistre relata que a sua época testemunha "uma fusão do gênero humano" (O.C., IX: 33), enquanto que, nas Soirées, vai além: “... tudo anuncia que marchamos na direção de uma grande unidade que devemos saudar à distância... Estamos dolorosa e mui justamente triturados; mas, se olhos miseráveis como os meus forem dignos de entrever os segredos divinos, estamos triturados apenas para que sejamos misturados" (O.C., IV:127).

${ }^{32}$ Publicado apenas em 1870.

${ }^{33}$ Dale K. Van Kley, The Religious Origins of the French Revolution: From Calvin to the Civil Constitution, 1560-1791 (New Haven: Yale University Press, 1996).
} 
liga os dois grandes fenômenos de transformação da vida social e política do Ocidente (até então), a saber, a Reforma e a Revolução Francesa. E justamente pelo fato de sua bildung representar um sincretismo de elementos tão díspares como o filosofismo do século $\mathrm{XVIII}^{34}$ e o jesuitismo, que a análise maistreana revelou-se tão consequente quanto às de Tocqueville ou Taine - aqui, não percamos de vista que ambos tinham atrás de si duas gerações de 'historiadores' da Revolução - em seus inquéritos do Antigo Regime na busca das origens da Revolução ou da "França Contemporânea". 35

Dentre outros aspectos, o que uma corrente historiográfica mais recente tem concluído, é que o século XVIII foi tão ou mais um século de controvérsia religiosa do que única e exclusivamente de Luzes, cujo principal efeito a médio-prazo foi o de demolir um por um os alicerces político-teológicos da monarquia absoluta. Pois as condenações real (1695) e papal (bula Unigenitus, 1713) ao jansenismo reacenderam a oposição entre algumas das maiores vítimas do absolutismo do século XVII (a causa da graça divina, da igreja anti-hierárquica, dos padres, parlamentares e advogados sem 'ofício') e os beneficiários do mesmo (a causa do livre-arbítrio, da igreja hierárquica, da corte, dos bispos e dos jesuítas), cujas controvérsias não apenas dominaram o cenário político francês até meados dos anos 1770, como, de maneira residual mas nem por isso menos importante, ecoaram naquilo que boa parte da historiografia considera o início da “derrapagem” da Revolução, a Constituição Civil do Clero (1790). Pesquisas orientadas pelos pressupostos político-culturais da Revolução, como os trabalhos de Sarah Maza ${ }^{36}$, David Bell ${ }^{37}$, Dale Van $\mathrm{Kley}^{38}$ e Catherine Maire ${ }^{39}$, lograram inclusive demonstrar que o desenvolvimento do "público" como tribunal político - e, por

${ }^{34}$ Leia-se a magistral biografia crítica de Richard Lebrun sobre Maistre, Joseph de Maistre: an Intellectual Militant (Kingston and Montreal: McGill-Queen's University Press, 1988), $2^{\circ}$ capítulo.

${ }^{35}$ A julgar pela crítica de G.P. Gooch a Taine - para quem, nas Origens da França contemporânea (1875), faltou observar que o empirismo inglês, com seu método indutivo, exerceu maior influência na Ilustração francesa (e, por extensão, na Revolução) que o método dedutivo de Descartes -, fica evidente que Maistre envelheceu melhor, na medida em que extraiu os múltiplos desdobramentos (morais, psicológicos, políticos) desta verdadeira revolução epistemológica dos tempos modernos, como seus ataques a Bacon e Locke permitem concluir.Cf. G.P. Gooch, Historia e historiadores en el siglo XIX (1913). Trad. espanhola de E. Champourain e R. Iglesia (México: Fondo de Cultura Econômica, 1942), p. 247.

${ }^{36}$ Sarah Maza, "Le tribunal de la nation: Les mémoires judiciaires et l'opinion publique à la fin de l'ancien régime", in: Annales (Jan. - Fev. 1987), p. 73-90.

37 David Bell, Lawyers and Citizens: The Making of a Political Elite in Old Regime France (Oxford: Oxford University Press, 1994).

${ }^{38}$ Dale K. Van Kley, The Religious Origins of the French Revolution..., p. 193-4.

${ }^{39}$ Catherine Maire, De la cause de Dieu à la cause de la Nation: Le jansénisme au XVIIIe siècle. (Paris: Gallimard, 1998),p. 224-228. 
conseguinte, os germes de uma cultura republicana - esteve estreitamente vinculado às controvérsias religiosas em torno da bula Unigenitus (1713). ${ }^{40}$

Isto equivale a dizer - e totalmente de acordo com a interpretação de Maistre que, em sua potencialidade mais radical, o desafio implícito do jansenismo à monarquia de direito divino reside, a exemplo do calvinismo, na tendência a dessacralizar tudo o que se interpõe entre a consciência individual e Deus, reservando a divindade apenas ao último. ${ }^{41}$

Conclui-se, a partir disso, que a inteligência maistreana foi uma das primeiras a inserir um grande evento como a Revolução na longa duração histórica, inaugurando talvez uma tradição conceitual na historiografia que, enriquecida pelo avanço do método e das pesquisas (e/ou expurgada de suas implicações reacionárias), baliza o modo como interpretamos a gênese do mundo moderno (ao menos no Ocidente).

Nas palavras de um especialista,"Maistre descreve o movimento geral dos tempos modernos como a realização progressiva de um ideal cuja fórmula é dada pelas Luzes: protestantismo, 'filosofismo' e Revolução Francesa são apenas momentos de um único projeto, que se exprime na reivindicação protestante do 'direito ao exame', assim como no imperativo filosófico de 'pensar por si mesmo', ou ainda na vontade revolucionária de fundar o Estado sobre a soberania dos indivíduos". ${ }^{42}$

Portanto, o principal objetivo desta pesquisa foi o de reconstruir, mediante um estudo sistemático da vasta produção de Joseph de Maistre (diluída em 14 volumes de suas Obras Completas, sem contar as incintáveis páginas de seus "Registros de Leitura"), os diversos níveis ou camadas de sua interpretação sobre a Revolução Francesa, buscando reavaliar e mensurar não apenas seu papel na historiografia da Revolução Francesa - destacando as afinidades (o mais das vezes insuspeitas) e discrepâncias com algumas problemáticas do moderno debate historiográfico (sobretudo o que assume como fio-condutor explicativo da Revolução o problema teológico-

${ }^{40}$ Como reconhecera E. Quinet em: Le Christianisme et la Révolution française, 12 a lição: "Caso se queira observar... como a velha sociedade francesa estava condenada há muito tempo antes da Revolução..., basta considerar o primeiro monumento da Santa Sé do século XVIII [bula Unigenitus]... Que não se diga mais, portanto, que os filósofos abalaram a fé. Esta iniciativa foi assumida por uma autoridade estabelecida muito anterior à deles. O século XVIII abre-se com uma solenidade maior do que se diz: eis a primeira journée do século XVIII".

${ }^{41} \mathrm{Se}$, como argumentou Marcel Gauchet, existe uma "lei da emancipação humana por via da afirmação divina", na medida em que quanto mais transcendente for o conceito de Deus, maior será o efeito disso na liberdade do povo, então o 'agostianismo' calvinista - e, por extensão, jansenista - trouxe em seu bojo uma mensagem implícita de emancipação, não importando o quão ortodoxos e prómonárquicos fossem as declarações de seus fundadores e adeptos ilustres. In: Marcel Gauchet, Le désenchantement du monde: une histoire politique de la religion (Paris: Gallimard, 1985), p. 53.

${ }^{42}$ J.-Yves Pranchère, L'Autorité contre les Lumières, p. 21. 
político trazido pela Reforma Protestante) - como a dimensão de seu espectro na história das idéias e da política contemporâneas.

Noutras palavras, trata-se de rastrear na obra de Maistre tudo o que ele escreveu sobre a Revolução Francesa (sempre cotejando com a historiografia da Revolução) - e, por extensão, sobre a Modernidade, seu duplo inseparável -, perfazendo os processos que o levaram da defesa da autoridade monárquica (1793-1798) à crítica ao espírito dos tempos modernos (1803-1821). Admitindo-se como metodologicamente válido o que sugeriu Lawrence Stone, a saber, que "qualquer análise de uma questão tão complexa como o desafio revolucionário a um regime estabelecido, mesmo quando preparado em grande parte no interior das elites dirigentes, deve remontar necessariamente a um passado bem distante e utilizar um enfoque multicausal; deve conceder tanta importância aos defeitos institucionais e às paixões ideológicas quanto aos movimentos sociais e às mudanças econômicas - caso a análise tenha alguma esperança de agarrar todos os fios que conduzem à crise ${ }^{, 43}$; encontramos razões suficientes para considerar Maistre um grande intérprete dos "pressupostos" e da dinâmica da Revolução Francesa e da modernidade.

Neste sentido, este trabalho representa, em termos de campo de conhecimento, uma interface entre historiografia e história intelectual, e, em termos de referência e inspiração metodológica, para a leitura analítica dos textos maistreanos e de seus contemporâneos, julgamos oportuno adotar os procedimentos da "Escola de Cambridge", cujas balizas foram definidas da seguinte forma por Quentin Skinner:

"O que, exatamente, o procedimento aqui proposto nos permite identificar nos textos clássicos que não se possa encontrar na leitura? A resposta, em termos genéricos, penso eu, é que ele nos permite definir o que seus autores estavam fazendo quando os escreveram. Podemos começar assim a ver não apenas que argumentos eles apresentavam, mas também as questões que formulavam e tentavam responder, e em que medida aceitavam e endossavam, ou contestavam e repeliam, ou às vezes até ignoravam (de forma polêmica), as idéias e convenções então predominantes no debate político." 44

${ }^{43}$ Lawrence Stone, As Causas da Revolução Inglesa 1529 -1642 (1972). Trad. de Modesto Florenzano (Bauru-SP: Edusc, 2000), p.114.

${ }^{44}$ Quentin Skinner, As Fundações do Pensamento Político Moderno (1978). Trad. de Renato Janine Ribeiro e Laura Teixeira Motta (São Paulo: Companhia das Letras, 1999), p. 13. 
A exemplo do que postulou Peter Lasllet em seu clássico estudo sobre Locke, nosso primeiro objetivo consistiu num "modesto exercício de historiador", isto é, em estabelecer os textos de Maistre tal como ele pretendia que fossem lidos, situá-los "em seu contexto histórico, no contexto do próprio" Maistre, demonstrando "o vínculo entre seu pensamento e sua obra" com o Maistre"conhecido por sua influência histórica. "45

Dito de outra forma, este procedimento permitiu-nos delinear o que Maistre pretendia comunicar ao emitir seus discursos, ao escrever no momento em que escrevia, e para as audiências específicas que tinham em mente. ${ }^{46}$

Assim, o presente trabalho divide-se em três partes. Na primeira, como o próprio título indica - Maistre e as causas teológico-políticas da Revolução Francesa -, procuramos remontar às origens (mais especificamente, em seus dois primeiros capítulos, respectivamente Do sans-culottismo da religião ao sans-culottismo político: as origens das "Reflexões sobre o Protestantismo"; e A Revolução Francesa, chave para a compreensão do Protestantismo) da interpretação teológico-política da Revolução por Maistre, mostrando como os contextos políticos e linguísticos da emigração ou da França revolucionária (o testemunho pessoal das convulsões revolucionárias nos cantões protestantes suíços; as fundamentais leituras dos panfletos do filocatólico Burke ou dos huguenotes Mme de Stäel e Benjamin Constant; a proeminente participação de célebres figuras protestantes e/ou jansenistas desde as fases iniciais da Revolução Francesa) foram determinantes para a concepção desta chave de leitura, a qual, despojada de seu aspecto "faccioso" ${ }^{47}$, estabelece hipóteses muito plausíveis e, não raro, próximas das que foram consagradas pelas diversas disciplinas das ciências sociais sobre a íntima relação entre o protestantismo e o processo de desencantamento do mundo que culminou na Revolução de 1789. No terceiro e último capítulo dessa primeira parte (intitulado "De l'Église Gallicane": da "révolution ménagée" ao refinamento do espírito revolucionário.Raízes do anticlericalismo revolucionário), lançamos mão do mesmo procedimento metodológico para reconstituir o contexto linguístico da Restauração francesa responsável pela elaboração do De l'Église Gallicane, obra na qual Maistre retoma e desdobra as teses prefiguradas nas

\footnotetext{
${ }^{45}$ Peter Lasllet, "Introdução" a: John Locke: Dois Tradados sobre o Governo. Trad. Júlio Fisher. (São Paulo: Martins Fontes, 1998), p. 2.

${ }^{46}$ Quentin Skinner. Lenguaje, política e historia (2002). Trad. espanhola de Cristina Fangmann (Buenos Aires: Univ. Nacional de Quilmes, 2007), p. 160.

${ }^{47}$ Sainte-Beuve, "Joseph de Maistre", in: Portraits littéraires (Paris, Garnier, 1862-1864), vol. II, p. 393.
} 
Réflexions sur le Protestantisme sobre o vetor eminentemente teológico-político do fenômeno revolucionário francês.

Pois a defesa das teses galicanas por políticos e intelectuais liberais da Restauração - as quais foram admitidas por boa parte da nobreza e do clero - contra a possível assinatura de uma nova Concordata entre o papa e o monarca francês trouxe novamente à tona o papel desempenhado pela própria monarquia absoluta no solapamento do fundamento moral ou religioso de seu poder, sobretudo através do conflituoso histórico da oposição jansenista-parlamentar à bula Unigenitus (emitida pelo papa Clemente XI em setembro de 1713, após solicitação de Luís XIV) que condenava um total de 101 proposições do livro Réflexions morales sur le Nouveau Testament (Reflexões morais sobre o Novo Testamento, 1693) do teólogo oratoriano Pasquier Quesnel.

No final do século XVIII, após a grave crise da negação dos sacramentos (entre as décadas de 1730-1750) resolvida em favor dos jansenistas (os quais, conforme observaram respectivamente Maistre e Tocqueville, promoveram ainda mais o absolutismo estatal dentro da lógica dos "quatro artigos galicanos de 1682" expostos por ninguém menos que Bossuet), mais especificamente em ocasião do golpe de Estado contra os Parlamentos pelo chanceler Maupeou (1771-1774), as críticas dos jansenistas à bula culminaram numa censura à orientação religiosa do clero que, por ricochete, atingia também a monarquia absoluta dos Bourbons, a ponto de culminar numa defesa teórica, em grande medida tributária da terminologia teológica conciliarista tardomedieval galicana, dos Estados Gerais. Defesa esta que não apenas seria retomada quase que nas mesmas linhas pela oposição aristocrático-parlamentar às reformas monárquicas às vésperas da Revolução (1787-1788) - contribuindo com isto decisivamente para o (inesperado) desfecho revolucionário de um processo que começara como uma universalmente celebrada oposição patriótica da nação sob a liderança do "jansenista" Parlamento de Paris -, como estaria na raiz da Constituição Civil do Clero de 1790 e do pathos radicalmente anticlerical da Revolução Francesa.

A segunda parte (intitulada De Bacon a Locke: um humanista devoto crítico da modernidade) trata da extensa e complexa crítica epistemológica maistreana à Filosofia das Luzes. Nos três capítulos que a compõem, esforçamo-nos em demonstrar que, por trás do óbvio conteúdo teológico ou devoto de Maistre, encontra-se também uma argumentação de raiz plenamente humanista e racionalista, seja quanto à forma, seja quanto ao conteúdo. No quarto (intitulado $O$ "Examen de la philosophie de Bacon" ou 
as raízes humanistas do ethos contrarrevolucionário maistreano) e no sexto ("Unlocking the Human Mind": crítica à epistemologia de Locke ou a defesa humanista devota da dignidade humana) capítulos, empreendemos um esforço de reconstrução do contexto discursivo por trás da elaboração da crítica maistreana às epistemologias de Bacon e Locke, cujo conteúdo, seja pela abertura e constante recurso à filosofia clássica (não só a filosofia "espiritualista" e devota de Platão, mas também a filosofia mais "materialista" e racional de Aristóteles), seja pela centralidade atribuída ao "homem" no seu sistema de pensamento (defesa do livre-arbítrio, de sua dignidade na ordem da Criação, de seu intelecto ativo na investigação dos fins), obteve de nossa parte um surpreendente reconhecimento de cidadania na vasta e heterogênea tradição do pensamento humanista.

Baseado nos opúsculos maistreanos sobre a educação russa (1810-1811), o quinto capítulo ("Cartas sobre a Educação Pública" e "Quatro capítulos sobre a Rússia": uma teoria humanista devota sobre o progresso e o desenvolvimento das "manners" russas) apresenta uma curiosa teoria humanista-cristã sobre a história da civilização ou das manners europeias pelo contrarrevolucionário saboiano, a qual será plenamente desenvolvida e constituirá o argumento de fundo de Du Pape.

A terceira e última parte (intitulada Um saboiano ultramontano) inicia-se com um texto (referente ao sétimo capítulo) que, como o próprio título indica (Sob o signo da dualidade: Maistre e a Casa da Saboia na 'Era da Revolução Democrática'), busca lançar luz sobre a complexa questão da identidade de Maistre - que não era nem francês nem italiano, mas saboiano -, a qual, a nosso ver, oferece um ponto de vista privilegiado para a compreensão de suas heterodoxas posições contrarrevolucionárias e diplomáticas (ou seja, marcadas por uma inequívoca francofilia e uma irremissível antipatia pela Casa d'Áustria, com quem seu soberano acabara de estabelecer uma aliança matrimonial).

Procuramos destacar como, na contramão dos emigrados e da maior parte dos contrarrevolucionários europeus, Maistre não desejava a derrota francesa ante os exércitos de coalizão: consciente da nova dimensão conquistada pela esfera da opinião pública, a seu ver, a Revolução só poderia ser derrotada internamente, a partir da França, e não pela intervenção exógena das potências europeias. Exceção feita a seu correspondente suíço e também contrarrevolucionário Jacques Mallet du Pan (com quem manteve assídua amizade durante o exílio em Lausanne, 1793-7), ninguém 
melhor do que ele percebeu o quanto a dinâmica revolucionária jacobina se alimentava dos discursos e dos movimentos militares dos coligados.

Ademais e levando-se em conta a situação particular da Casa da Saboia no tabuleiro de poder europeu, Maistre não poderia deixar de temer pelas consequências advindas de um excessivo engrandecimento da Casa d'Áustria em caso de vitória do exército de coalizão. A França tinha desempenhado durante séculos o papel de contrapeso à hegemonia da Casa dos Habsburgos, posteriormente Casa da Áustria, na Europa. Maistre advertia para o fato de que o restabelecimento do equilíbrio europeu, longe de passar por uma França enfraquecida e desmembrada, deveria preservá-la, sob pena de a Áustria retomar a posição que ostentava na época de Carlos V.

Ainda que não tenha expressado um sentimento nacionalista italiano - pelo contrário, como neoguelfo, Maistre era partidário de um sentimento regionalista/monárquico saboiano sob a tutela espiritual do papa,$- \quad 0$ contrarrevolucionário saboiano não deixou de ser um personagem involuntário, embora não-negligenciável, do processo de unificação italiana, como mais tarde reconheceria ninguém menos do que o protagonista daquele processo, o conde de Cavour.

O oitavo capítulo ("Du Pape" ou manifesto de um ultramontano) aborda o trabalho mais influente de Maistre ao lado das Considerações sobre a França, e o qual desdobra e reelabora de maneira original uma longa discussão (ao mesmo tempo histórica e política) sobre o papel desempenhado pelo cristianismo na história da civilização ou no processo de desenvolvimento das manners europeias.

Procuramos demonstrar como em Du Pape Maistre articulou e desdobrou dois amplos debates culturais a partir de dois centros geográficos ou políticos distintos. Pois uma leitura atenta da obra indicará que a mesma não apenas deitou raízes na ampla discussão francesa sobre a compatibilidade do cristianismo com a liberdade política e/ou o progresso material e moral da humanidade - a qual, iniciada na república termidoriana (através do póstumo Esboço de um quadro histórico dos progressos do espírito humano de Condorcet, determinante junto aos intelectuais e políticos republicanos de orientação filosófica deísta e anticlerical, como Charles Dupuis, La Révellière-Lépeaux, Cabanis e Destutt de Tracy), prolongou-se do Consulado até a Restauração (dos clássicos do início do romantismo literário e defensores da compatibilidade do cristianismo com o desenvolvimento das manners, tais como o Génie du Christianisme de Chateaubriand e o De l'Allemagne de Mme de Staël, aos panfletos galicano-liberais e ultramontanos da Restauração) -, como também refletiu um 
intenso debate político-cultural no interior do Império russo (e do qual ele próprio, através de seus escritos pedagógicos, fora um dos principais protagonistas) durante e após as guerras napoleônicas, e o qual foi marcado pelo advento de uma sensibilidade nacionalista-ortodoxa marcadamente antiocidental e anticatólica entre os influentes oligarcas locais.

A respeito desta que, em grande medida, é a obra responsável pela péssima reputação de Maistre, concluímos que a mesma, apesar de seu conteúdo irrevogavelmente conservador, culmina num projeto político utópico balizado por valores racionalistas e cosmopolitas (anti-imperialistas).

Como não poderia deixar de ser, o nono e último capítulo da tese ("À sua imagem e semelhança": humanismo e providencialismo maistreanos em face da Ilustração e da Revolução) é dedicado ao providencialismo maistreano, um conceito totalizante que abarca não apenas a visão histórica do contrarrevolucionário saboiano (e sua interpretação sobre o fenômeno revolucionário francês), mas também as concepções antropológica e - a partir desta - política do mesmo.

Diante do desafio de interpretar a concepção humanista-devota maistreana (e, no interior da mesma, um elevado conceito sobre a origem e o destino do homem que concilia o livre-arbítrio com a onipotência e a onisciência divinas) à luz de sua concepção providencialista da história, a figura do neoplatônico Orígenes surgiu-nos como um valioso "túnel" na identificação de tópicos surpreendentemente comuns entre o humanismo devoto maistreano com o humanismo neoplatônico de autores florentinos como Marsilio Ficino e Pico della Mirandola.

Fundamentalmente, este exercício comparativo permitiu-nos compreender melhor as premissas epistemológicas que serviram de base para que Maistre erigisse sua refutação à Filosofia das Luzes e aos princípios revolucionários, e a qual, antes de partir de numa concepção antropológica radicalmente negativa da condição humana que, no limite, culminaria em antecipações ultramodernas de teorias políticas reacionárias negadoras da liberdade (conforme sustentaram Cioran e Berlin), subsumia e reelaborava dialeticamente as culturas herdadas da Contrarreforma e da Ilustração no interior de seu quadro referencial neoplatônico-origeniano.

Dividido em duas partes, este capítulo não apenas desdobra as imputações anteriores acerca do humanismo maistreano (e aprofunda o exercício de validação conceitual do mesmo), como apresenta uma interpretação sobre a Revolução Francesa e o Terror à luz do conceito providencialista da história, e o qual, longe de redundar numa 
negação (anti-humanista) da liberdade humana (e, por extensão, da própria história), culmina numa paradoxal (por se tratar de um autor conservador e/ou contrarrevolucionário) afirmação da dignidade ontológica do homem, e isto através de um ethos humanista surpreendentemente semelhante ao exibido pelos neoplatônicos florentinos. 


\section{PARTE I}

MAISTRE E AS CAUSAS TEOLÓGICO-POLÍTICAS DA REVOLUÇÃO FRANCESA 


\section{CAPÍTULO 1}

\section{Do sans-culottismo da religião ao sans-culottismo político: as origens das "Reflexões sobre o Protestantismo" de Maistre}

Publicadas pela primeira vez em 1870 nas Oeuvres inédites du compte Joseph de Maistre, as Réflexions sur le Protestantisme dans ses rapports avec la souveraineté (Reflexões sobre o Protestantismo em suas relações com a soberania) foram concluídas na cidade de Turim, capital do reino do Piemonte-Sardenha, em 1798, mas suas origens remontam a um período um pouco anterior.

Mais do que as Considerações sobre a França (1797) - que tratou literalmente de condenar os revolucionários e seus princípios ao Inferno -, esta obra surpreende pela virulência do requisitório endereçado aos herdeiros de Lutero e Calvino. As Reflexões são um visceral ataque ao protestantismo (e, em menor escala, ao jansenismo), descrito como um sans-culottismo da religião e uma "heresia civil", que, por haver minado a unidade religiosa da Europa e colocado a "discussão no lugar da autoridade"(o“julgamento particular do indivíduo no lugar da infalibilidade dos dirigentes"), foi a fonte de todos os venenos modernos (a começar pela filosofia das Luzes), estendendo-se até a Revolução Francesa e o proselitismo democrático dos jacobinos. De acordo com Maistre, o "grande inimigo da Europa, que é preciso sufocar por todos os meios que não sejam criminosos, a úlcera funesta que se fixa em todas as soberanias e que as corrói sem descanso, o filho do orgulho, o pai da anarquia, o solvente universal, é o protestantismo." "1

Como observou Pierre Glaudes ${ }^{2}$, a violência do ataque é ainda mais surpreendente se levarmos em consideração que em sua memória maçônica redigida em 1782, as Mémoires au duc de Brunswick, Maistre dedicou palavras conciliatórias a seus 'irmãos' maçons protestantes, na esperança de que os mesmos, unidos aos católicos, pudessem combater a impiedade filosófica da Ilustração que já incomodava o futuro contrarrevolucionário saboiano, para, num futuro não muito distante, promoverem a

\footnotetext{
${ }^{1}$ Joseph de Maistre, Réflexions sur le Protestantisme (1798). In: Joseph de Maistre, Écrits sur la Révolution. Textos introduzidos e organizados por J.-Louis Darcel, (Paris: PUF, 1989), p. 219.

${ }^{2}$ Pierre Glaudes (org.), Joseph de Maistre: Oeuvres (Paris: Robert Lafffont, 2007), p. 293.
} 
reunificação de todas as denominações cristãs no seio do catolicismo. Assim, nesta memória endereçada ao duque de Brunswick ${ }^{3}$, o grande mestre de sua ordem maçônica, é que vislumbramos a inserção de Maistre na maçonaria e na Ilustração.

Redigida com a finalidade de defender o cristianismo dos ataques que o mesmo recebia da filosofia da Ilustração e promover a restauração da unidade católica do cristianismo, a memória maçônica maistreana explicitava suas intenções em um tom marcadamente ecumênico:

"É chegado o tempo... de apagar a vergonha da Europa e da mente humana. Qual a vantagem de possuir uma religião divina desde que rasgamos o inconsútil tecido e os adoradores de Cristo..., são levados a excessos que fariam a Ásia ruborizar? O maometismo conhece apenas duas seitas; o cristianismo tem trinta delas... Nossos supostos sábios, ridiculamente orgulhosos por algumas descobertas infantis, escrevem doutamente a respeito do ar fixo, volatizam o diamante, ensinam às plantas o quanto devem durar... mas cuidam em não perguntar uma única vez em suas vidas o que eles são e qual o seu lugar no universo. O entusiasmo sendo um fanatismo mil vezes mais criminoso do que aquilo que eles nunca cessam de deplorar, golpeiam indiferentemente a verdade e o erro, sem conhecer outro modo de atacar a superstição a não ser pelo ceticismo."

Ao recomendar o estudo da moral e da política, o então jovem promotor público do Senado da $\operatorname{Saboia}^{5}$ o fez num tom diametralmente oposto ao que se propagava nos

${ }^{3}$ Líder do movimento maçônico de Estrita Observância Templária, o sobrinho do duque que seria derrotado na batalha de Valmy, em 1792, enviou às lojas um questionário que deveria ser respondido no congresso que se reuniria em 1782 na cidade de Wilhelmsbad (Alemanha). Sabemos que a memória maistreana não chegou a seu destino, devido a uma provável censura das autoridades da loja de rito escocês a que Maistre esteve vinculado entre 1778-1791 (a La Sincerité de Chambéry), e os quais, sob a influência do mercador de tecidos de Lyon, Jean-Baptiste Willermoz, consideravam as opiniões do saboiano excessivamente contrárias à Ilustração.

${ }^{4}$ Citado em R. Lebrun, Joseph de Maistre: An Intellectual Militant (Montreal: McGill-Queen's University Press, 1988), p. 65.

${ }^{5}$ Fruto do casamento do nobre togado de origem plebeia (descendente de uma próspera família de comerciantes de tecidos da cidade de Nice) François-Xavier Maistre (1706-1789) - magistrado de renome, foi transferido de Nice ao Senado da Saboia em 1740, onde obteria, em 1778, a consagração da ascensão social de sua família ao receber o título de conde (em caráter hereditário) por meio de uma carta de patente real - com a nobre local Christine Demotz (1727-1774), Maistre era o mais velho dentre os dez filhos que o casal teve (dentre estes, o escritor Xavier de Maistre, dez anos mais novo que Joseph). Após obter, em 1772, o título de doutor em direito pela Universidade de Turim com apenas 19 anos de idade, Maistre retorna à Saboia, onde realiza estágio bienal obrigatório no Bureau de l'Avocat des Pauvres do Senado local (defensoria pública). Em dezembro de 1774, o filho mais velho do senador François-Xavier debuta oficialmente na magistratura sarda, na função de Substitut Surnuméraire no Bureau de l'Avocat Général (assistente não-remunerado da promotoria pública). Após ser indicado como substituto pleno (deputado com a função de promotor público), em fevereiro de 1780, e reitor dos Substitutos, em 1785, recebe, em 1788, a nomeação de senador. Casado desde 1786 com a nobre Françoise de Morand (seis anos mais jovem) - o casal teria três filhos, Adèle (1787), Rodolphe (1789) e Constance (1793) -Maistre 
"circuitos de sociabilidade democrática". 6 Conforme advertia Maistre a seus colegas maçons, "em política, jamais devemos nos deixar levar por sistemas vãos, pois a metafísica nesta ciência, e em geral tudo o que não for claro e prático, é bom apenas para entreter escolas e cafés". 7

Pode-se dizer que o tom ecumênico do texto era uma necessidade e uma estratégia, jamais uma convicção. O propósito da maçonaria devia ser o de reunir as diversas seitas na religião católica. As lojas - que teriam por função iniciar seus membros na "ciência do homem", que versa sobre a origem e o destino da humanidade - seriam um instrumento privilegiado dessa futura união, uma vez que as mesmas, ao sofrer as influências do século, acostumaram-se às controvérsias religiosas, permitindo a aproximação entre católicos e protestantes sem destruição mútua.

Portanto, muito antes da Revolução (e seus profundos efeitos para ele e sua família) e da leitura do 'Manifesto contrarrevolucionário' de Edmund Burke ${ }^{8}$, a saber, as Reflexões sobre a Revolução em França $(1790)^{9}$, Maistre já demonstrava uma postura crítica, para não dizer abertamente Contra-Iluminista, em relação aos principais

e seu pai administravam conjuntamente os bens da família, uma das mais aquinhoadas da província piemontesa, com 7.400 libras/ano de salários, 5.000 libras/ano de juros e rendas dos bens da família, e um patrimônio superior a 100.000 libras. Para maiores detalhes biográficos, leia-se nossa dissertação de mestrado, "Considerações sobre a França" de Joseph de Maistre: Revisão (historiográfica) e Tradução (São Paulo: FFLCH-USP, 2009), p. 15-21.

${ }^{6}$ F. Furet. Pensando a Revolução Francesa (1978). Trad. de Luiz Marques e Martha Gambini (Rio de Janeiro: Paz e Terra), p. 53-4. Vide também R. Koselleck. Crítica e crise: uma contribuição à patogênese do mundo burguês (Rio de Janeiro: Ed.UERJ/Contraponto; 1999), p. 71 e 75, onde se lê: "Os maçons não têm nada a ver, diretamente, com a política, mas vivem conforme uma lei que, uma vez em vigor, torna supérflua a revolução. Por um lado, separam-se do Estado, subtraem-se à autoridade e constituem um poder indireto que é uma ameaça à soberania - mas uma ameaça apenas moral. Por outro lado, sua virtude deixa de ser um 'crime', isto é, de ameaçar o Estado, quando ela mesma, em lugar do soberano, determina o que é justo e injusto. A moral é o soberano presuntivo... Diretamente apolítico, o maçom é, no entanto, indiretamente político. A moral permanece, de fato, não violenta e pacífica, mas enquanto tal - concebida como antípoda da política - questiona o Estado vigente."

${ }^{7}$ R. Lebrun, Joseph de Maistre: An Intellectual Militant, p. 63.

${ }^{8}$ Esta observação devemos à Introdução à edição de Conor Cruise O'Brien para a Penguin Books (1968) das Reflections, a qual se intitula "O Manifesto de uma contrarrevolução".

${ }^{9}$ A qual, conforme o próprio Maistre confessou numa correspondência de 21 de janeiro de 1791, a seu amigo saboiano, o marquês Costa de Beauregard, reforçou, mas não determinou sua reação contrarrevolucionária: "Lestes Calonne, Mounier e o admirável Burke? O que pensais do modo com que este austero deputado refere-se à grande espelunca do Manège e a todos os legisladores bebês? Quanto a mim, estou encantado, e não saberia expressar o quanto ele reforçou minhas idéias antidemocráticas e antigalicanas. Minha aversão por tudo o que está sendo feito na França transforma-se em horror. Compreendo muito bem como sistemas, ao fermentarem em muitas cabeças, convertem-se em paixões. Crede-me, esta abominável assembléia não pode ser odiada o suficiente. Vede como trinta ou quarenta velhacos conseguem o que o príncipe negro e a Liga foram incapazes de fazer. Massacres, pilhagens, incêndios, não representam nada - são necessários poucos anos para curar tudo isso -, mas o espírito público aniquilado, a opinião pública viciada num nível assustador, numa palavra, a França putrefata, eis o que estes senhores fizeram. E, o que é realmente deplorável, a doença é contagiosa e nossa pobre Chambéry já se encontra bem infectada... Todos os dias o poder recua, mesmo quando quer avançar, pois ele se emprega mal.” Cf. R. Lebrun, Joseph de Maistre: An Intellectual Militant, p. 100-101. 
pressupostos políticos e morais da filosofia das Luzes, assim como já dava sinais de que o problema teológico-político iniciado pela Reforma religiosa do século XVI era algo que já ocupava, ainda que de maneira difusa, suas reflexões políticas. Razão pela qual não seria exagerado dizer que todo o pensamento político-moral do futuro contrarrevolucionário já estivesse contido em germe nesta curta memória maçônica.

Contudo, não seremos capazes de compreender os motivos desta evolução relativamente brusca do pensamento maistreano se não apreendermos as determinações impostas pelas circunstâncias revolucionárias, as quais, uma vez repercutidas na Saboia (invadida pelas tropas francesas no final de setembro de 1792), levaram-no a um exílio em território suíço, mais especificamente em Lausanne, entre abril de 1793 e fevereiro de 1797.

Mais do que as vantagens da língua (francófona) e da geografia (podia manter contato com a família que permanecera na Saboia ${ }^{10}$ ), o que mais o atraiu para essa dependência de Berna foi a oportunidade de iniciar a carreira de écrivain político livre das perturbações dos franceses e, sobretudo, das censuras absolutistas de seu governo. Outro fator que deve ter pesado nesta decisão foi a presença, em Berna, do antigo intendente da Saboia e recém-nomeado correspondente da monarquia piemontesa$\operatorname{sarda}^{11}$, seu amigo Vignet des Etoles.

No dia 20 de abril (instalara-se em Lausanne no dia 13), após ser informado por Vignet des Etoles de que fora acusado de jacobinismo pelas autoridades piemontesas ${ }^{12}$, Maistre inicia a redação de uma memória, a Mémoire sur la Franc-Maçonnerie (finalizada no dia 30), que mais parecia uma defesa da maçonaria do que dele próprio, e na qual argumentava que as lojas saboianas eram "honestas sociedades" dedicadas a atos de benevolência, de modo que a "igualdade" maçônica não passava de puro simbolismo. Nela, Maistre não omitiu seu passado maçônico, embora tenha evitado

\footnotetext{
${ }^{10}$ Apenas em setembro de 1793, diante da iminência das ofensivas austrossardas, é que a esposa e os filhos se juntam ao marido.

${ }^{11}$ Pelo Tratado de Utrecth (1713), que marcou o fim da Guerra de Sucessão espanhola, o duque da Sabóia, Victor-Amadeus II, tornava-se rei da Sicília, situação esta que, diante das pressões austríacas, foi revertida pelo Tratado de Londres (1718), pelo qual o duque ficava com a Sardenha como compensação pela entrega da Sicília à Áustria. Portanto, a partir de 1720, o ducado da Sabóia passa a se chamar reino do Piemonte-Sardenha.

12 Desde 1791, membros de algumas lojas de Chambéry (como os da loja Sept Amis, subordinada ao Grande Oriente de Paris) veiculavam o programa do clube jacobino ou Sociedade dos Amigos da Constituição na província saboiana.
} 
fornecer detalhes de seu envolvimento (o qual, conforme demonstrou Jean Rebotton ${ }^{13}$, prosseguiu até o início de 1793, mesmo após a proibição formal de seu governo a partir de dezembro de 1791).

Assim, se por um lado era praticamente impossível negar-lhes (aos maçons) participação em atividades revolucionárias, por outro, Maistre esforça-se em demonstrar que isto se deu de forma indireta, ou seja, com os maçons fornecendo o modo de organização aos clubes, uma vez que alguns de seus membros eram maçons. Quanto às lojas da Saboia, o Grand Profès "Josephus", como Maistre era designado, admitiu que existissem lojas "burguesas" que acolhiam membros envolvidos em atividades sediciosas, mas negou qualquer envolvimento de sua loja nas mesmas. ${ }^{14}$ Por fim, seguindo a tradição de que a melhor defesa é o ataque, o emigrado saboiano dispara a seguinte crítica a seu governo na missiva ao amigo Vignet des Etoles:

"Se o rei não fosse servido por tolos nesta matéria como em todas as demais, teria sido fácil usar as lojas reformadas para inspecionar as outras e descobrir um sem-número de coisas; porém, com a prevalência do fatal sistema do medo e da desconfiança geral, os bons súditos, paralisados pela suspeita, limitaram-se a resmungar, enquanto os perversos agiram a seu belprazer, sem que o rei de nada soubesse."

Não se sabe ao certo o que Vignet des Etoles fez com esta memória, mas o fato é que o passado maçônico de Maistre prejudicava sua imagem junto ao governo de Turim.

Em meio a tudo isso, começara a redação de seus primeiros panfletos contrarrevolucionários, as quatro primeiras Cartas saboianas (as Lettres d'un royaliste savoisien a ses compatriotes, escritas e publicadas entre abril-julho de 1793), que tinham o triplo objetivo de convencer as autoridades piemontesas a reconquistar a antiga província, galvanizar os habitantes locais a se juntarem às tropas austrossardas, cuja invasão estava programada para o verão de 1793 e, por fim (e de maneira implícita), convencer o governo de Turim a adotar medidas mais 'liberais' como a maneira mais

\footnotetext{
${ }^{13}$ J. Rebotton, "Josephus a Floribus during the Revolution", in: R. Lebrun (org.), Maistre Studies (New York: University Press of America, 1988), p. 145.

${ }^{14}$ Conforme observou Richard Lebrun, preocupado em dissipar as suspeitas de participação em "conspirações maçônicas" que pesavam sobre si, Maistre omitira o fato de que advogara abertamente pela causa das reformas na memória de 1782, onde propunha, dentre outras coisas, "a instrução dos governos" pela maçonaria. In: R. Lebrun, Joseph de Maistre: An Intellectual Militant, p. 121.

15 "Memória sobre a Franco-Maçonaria" de 30 de abril de 1793. Citado em R. Lebrun, Joseph de Maistre: An Intellectual Militant, p. 121.
} 
eficaz de se preservar do contágio Revolucionário (anistiando os saboianos republicanos pró-franceses e substituindo a velha política, caracterizada por ele como a 'batônecratie' ou 'turinismo', por uma atuação mais efetiva junto à opinião pública). No Prefácio à segunda edição (agosto de 1793), em que o autor reagrupou as quatro primeiras cartas publicadas separadamente, Maistre explicitou suas intenções:

"Outrora, a autoridade podia dispensar a ciência, a obediência, e a reflexão: hoje, produziu-se uma grande transformação nos espíritos, e essa transformação é obra de uma nação extraordinária, infelizmente muito influente (...). Nossa situação... é bem melhor do que a vivida pelos franceses: a revolução é um fruto estranho trazido pela França e que ainda não está, a bem dizer, aclimatado entre nós (...). É preciso trabalhar sobre a opinião; desmistificar as teorias metafísicas aos povos..., ensinar-lhes a perceber as vantagens daquilo que possuem; mostrarlhes o perigo de buscar um melhor imaginário sem calcular os infortúnios com os quais pagará pelo mesmo." $" 16$

Assim, na interpretação oferecida pelas Lettres, a Revolução Francesa é retratada como uma conseqüência dos abusos e fraquezas do Antigo Regime e/ou produto de uma "contaminação" da opinião pública local levada a cabo pelos homens de letras. ${ }^{17}$ Além de fracassarem em seus objetivos (pouquíssimos exemplares das cartas chegaram à Saboia), as Lettres trouxeram-lhe mais desventuras em relação a seu governo, que não apenas ignorou a mensagem implícita sobre a necessidade das reformas, como proibiu sua venda no Piemonte por associá-las equivocamente à propaganda jacobina.

Resignado em sua condição de correspondente consular ${ }^{18}$ e testemunha das agitações políticas na Suíça - bem como das atrocidades praticadas na Saboia e em Lyon pelas autoridades em missão do Comitê de Salvação Pública -, Maistre opta por dedicar seu raro tempo livre à redação da quinta Lettre, uma defesa teórica da instituição monárquica contra o proselitismo democrático-republicano francês.

No final de março de 1794, enviou o rascunho daquela carta-panfleto ao padre refratário François de Bovet (antigo bispo de Sisteron), que lhe recomenda as leituras do

${ }^{16}$ Citado em J.-Louis Darcel, “Apresentação” de Joseph de Maistre: Écrits sur la Révolution (Paris: PUF, 1989), p. 21.

17 "Os governos da Europa tinham envelhecido e sua decrepitude era bem conhecida apenas para aqueles que queriam tirar proveito da situação para a execução de seus projetos mortais. Não havia mais coesão, espírito público, energia; uma revolução era inevitável”. Cf: Joseph de Maistre, O.C., VII:84.

${ }^{18}$ Nomeado em três de agosto de 1793 , o cargo equivalia à função de cônsul e garantia-lhe um pífio salário de 100 libras ao ano, apesar do trabalho acachapante a que era submetido - leitura e redação de correspondências e memorandos para informar Turim sobre as condições da Sabóia, prestação de ajuda humanitária aos emigrados, etc. 
Discurso sobre as origens da desigualdade entre os homens e do Contrato Social de Rousseau, uma vez que as ideias do genebrino pouco apareciam em seu panfleto. Assim, entre julho 1794 e meados de 1795, Maistre trabalhou simultaneamente em dois tratados políticos de refutação ao "cidadão de Genebra", os quais nada mais são senão desdobramentos da Quinta Carta saboiana: o De la souveraineté du peuple (Da soberania do povo) e o De l'État de nature (Do Estado de natureza) ${ }^{19}$, ambos inacabados e igualmente publicados postumamente, em 1870.

Antes de analisarmos o De la souveraineté du peuple, tratado em que o autor das Réflexions sur le protestantisme já esboça um vínculo entre filosofia, protestantismo e Revolução, precisamos revisitar o quadro político-intelectual em que Maistre estava inserido.

Durante sua estadia na Suíça protestante, Maistre esteve em contato com os émigrés, especialmente com os padres refratários, cuja reação conservadora à Constituição Civil do Clero (aprovada em agosto de 1790 após um dilacerante debate na Assembléia Nacional) já contava com uma tradição ideológica de acusação aos protestantes, jansenistas e filósofos anterior à própria Revolução.

Ademais, para aqueles refugiados que perderam quase tudo, inclusive os direitos de cidadania, o poder espiritual do papa e a religião católica figuravam como um último recurso, um esforço (na melhor tradição profética do Velho Testamento bíblico) de preservação de identidade religiosa em tempos de ‘êxodo’ e opressão.

Assim, a Revolução apenas lançou mais combustível numa latente ideologia contra-Ilustrada devota, que não tardou em adaptar a teoria conspiratória do "parti dévot" do final do século XVIII para o contexto revolucionário. Como bem demonstrou o historiador holandês Dale K. Van Kley, os protagonistas desta longa conspiração foram facilmente identificados durante as discussões relativas à Constituição Civil do Clero: os calvinistas, nas figuras dos protestantes Barnave, Necker e Rabaut de SaintEtienne; os filósofos, representados por Mirabeau; e, finalmente, os jansenistas - sem o surpreendente auxílio dos quais, adverte Van Kley, a Assembléia Nacional jamais teria conseguido aprovar uma reforma tão radical na organização da igreja católica francesa -, liderados por Camus, abbé Grégoire e Fréteau de Saint-Just. ${ }^{20} \mathrm{Na}$ mesma linha, Darrin McMahon sublinhou o fato de que no início da década de 1780 engendrou-

\footnotetext{
${ }^{19}$ Com o título de Examen d'un écrit de Jean-Jacques Rousseau, acrescentado pelo editor e não pelo próprio Maistre.

${ }^{20}$ Cf. Dale K. Van Kley, The Religious Origins of the French Revolution: From Calvin to the Civil Constitution, 1560-1791 (New Haven: Yale University Press, 1996), p. 366-367.
} 
se na França uma linha de publicação crítica à Ilustração (verdadeiras “jeremiadas”) pronta a ser convertida em discursos contrarrevolucionários quando fosse chegado o ano de 1789. Assim, em grande medida o discurso contrarrevolucionário derivou do discurso contra-Iluminista do último quarto do século XVIII. ${ }^{21}$

Esta convivência, permeada por um crescente interesse do emigrado saboiano pela leitura dos livros da Bíblia, especialmente dos Salmos, do Apocalipse e dos profetas Isaías, Ezequiel e Jeremias (como demonstram seus registros de leitura do período), reforçou ainda mais as suscetibilidades católicas do nosso autor, investindo-o de um espírito de proselitismo que o acompanharia até os últimos dias de sua existência, como o atestam sua expulsão da corte do czar Alexander I, em 1817 (devido ao sucesso, um tanto perturbador às autoridades ortodoxas russas, do proselitismo católico do então ministro plenipotenciário saboiano junto às damas da aristocracia local) e, acima de tudo, aquela que viria a constituir na obra mais cara a si próprio, as Les Soirées de Saint-Pétersbourg (1821).

Isto explica em grande parte a acentuação daqueles elementos embrionários de sua ideologia contra-Iluminista, os quais assumiriam um caráter contrarrevolucionário cada vez mais avançado e agudo, razão pela qual não se pode negar que, se por um lado os temas da Revolução como castigo providencial e/ou filha do Protestantismo já estavam presentes seja no discurso devoto pré-revolucionário francês, seja nos círculos emigrados, por outro, em nenhum outro escrito contrarrevolucionário do gênero esta acusação foi levada a termos tão radicais.

Não menos importantes para a definição do ethos contrarrevolucionário do saboiano foram os testemunhos oferecidos pelas agitações políticas locais, mormente os abalos revolucionários que, irradiando do centro genebrino, repercutiam em Lausanne. Desde o início da Revolução, e apesar das censuras impostas pelos respectivos governos locais, os suíços receberam inúmeras publicações jacobinas, como os libelos do Clube Helvético, formado por patriotas suíços exilados em Paris. $\mathrm{Na}$ condição de correspondente e graças aos contatos com o suíço Mallet du Pan e outras importantes autoridades diplomáticas (mormente inglesas), Maistre tinha pleno conhecimento do

21 Darrin McMahon. Enemies of Enlightenment: The French Counter-Enlightenment and the Making of Modernity (New York: Oxford University Press, 2001), p. 57-58. Vide também Paul Beik, The French Revolution seen from the Right (New York: Howard Fertig, 1970). 
risco daquele contágio, não menos pelo fato de que vivenciara um processo de irradiação revolucionária semelhante na Saboia.

Genebra, que desde dezembro de 1792 passara ao controle dos partidários da Revolução (os quais estabeleceram um tribunal revolucionário antes mesmo dos franceses, em fevereiro de 1793), adotou (em fevereiro de 1794) uma Constituição que previa uma democracia direta fundada sobre os princípios da soberania popular. Se Lausanne, situada no cantão de Vaud, não fora imediatamente ganha para a causa democrática, sua população, a partir de 1795, mostrou-se cada vez mais disposta a se liberar da tutela de Berna para, a exemplo de Genebra, se aproximar da França revolucionária. Até que, em novembro de 1797, bem no fim do exílio suíço de Maistre, as tropas francesas são acolhidas com entusiasmo pela população do cantão do Vaud, a ponto de o líder patriota e revolucionário suíço Frédéric-César de Laharpe (1754-1838) apelar ao governo do Diretório francês para que o mesmo garantisse a liberdade dos valdenses contra o regime de Berna. Pouco depois, Lausanne foi colocada sob a proteção das tropas francesas do general Ménard e, em janeiro de 1798, a cidade proclamou sua independência. Em março daquele ano, terminaria por se juntar à recémcriada República Helvética.

Este duplo contexto, pessoal (a emigração e a perda de seu status político de senador da Saboia e da maior parte dos bens de sua família) e político (contágio dos princípios revolucionários, especialmente rousseaunianos, em território suíço), revelarse-ia fundamental para a formação desta chave interpretativa teológico-política da Revolução por Maistre.

Diante dos relatos de violência trazidos por aqueles padres - especialmente os pertinentes aos massacres de setembro de 1792 (que vitimou 21 padres) e à repressão imposta pelos enviados do Comitê de Salvação Pública (sobretudo Collot d'Herbois) a Lyon -, bem como da perda de suas posses e da posição privilegiada de sua família com a invasão francesa, o fato é que a Revolução interveio na vida de Maistre sob a forma de uma incessante ameaça militar, obrigando-o a deixar a Saboia e depois o Piemonte e, ademais, lançando a sua sombra até a Rússia (de onde acompanhou de perto as guerras napoleônicas), de maneira que a identidade entre os princípios revolucionários e a guerra foi para ele um dado concreto e permanente da experiência. Como destacou JeanYves Pranchère a respeito da reação maistreana à Revolução, o emigrado saboiano viu a Declaração dos Direitos do Homem de 1789 como a destruição do direito público europeu, "pois continha em si mesma uma declaração de guerra contra os princípios de 
legitimidade monárquica, em outras palavras, contra os princípios do direito que então reinavam na França e na Europa... Assim, é em nome do 'direito público' que Maistre condenará até o fim de seus dias a Revolução e suas consequências". ${ }^{22}$

Isto também explica em grande medida por que Maistre, à diferença de Burke que sempre adotou uma postura cética com relação aos extremos da filosofia e da religião (pois julgava que ambos poderiam degenerar em fanatismo) - e sob influência muito mais direta e premente do campo gravitacional revolucionário francês, optou por proceder em seus escritos pelo radicalismo contrário, isto é, numa defesa extrema da ortodoxia religiosa contra a filosofia e o protestantismo, um desdobramento que esteve longe de ser necessário ou dado de antemão. ${ }^{23}$

No entanto, conforme bem demonstrou Richard Lebrun, se tudo indica que a influência de Burke sobre Maistre tenha sido mais de âmbito emocional e estilístico do que conceitual (como sua Memória maçônica de 1782 comprova), ou seja, como um "reconhecimento instintivo de uma repulsa emocional" à Revolução "semelhante à sua" ${ }^{24}$,por sua vez, é possível e até necessário admitir, se quisermos apreender todos os pequenos nervos que compõem a reconstituição desta obra maistreana, que os termos da crítica burkeana à Revolução não foram menos decisivos do que o contexto políticosocial da emigração para sua elaboração conceitual que identifica a Revolução à Reforma.

Maistre, a exemplo de qualquer contrarrevolucionário europeu sob os efeitos da Revolução Francesa e suas idéias, não poderia prescindir das análises de Burke para a refutação dos princípios revolucionários (e, mais especificamente, rousseaunianos, tão em voga naqueles quadros intelectuais de 1793-94), adaptando-as à sua abordagem providencialista (central em todas as suas reflexões morais, políticas e históricas), que já se encontrava plenamente desenvolvida a partir de $1794 .^{25}$

\footnotetext{
${ }^{22}$ Jean-Yves Pranchère, L'autorité contre les Lumières: la philosophie de Joseph de Maistre (Genève: DROZ, 2004), p. 55-61.

${ }^{23}$ Como se pode ver numa anotação de seus registros de leitura feita em 1774: "Há, portanto, tacanhice tanto em acreditar em nada quanto em acreditar em tudo; a sabedoria consiste em duvidar... Senhores filósofos! Curai-vos desta estranha doença de negar tudo o que ultrapassa nossa inteligência mesquinha: procurai saber antes se não existe algum modo de explicar aquilo que achais fácil de negar." In: “Extraits G", 1774, p. 12, apud Lebrun, 1988, p. 41.

${ }^{24}$ R. Lebrun, Joseph de Maistre and Edmund Burke: a comparison” (1999). In: R. Lebrun (org.), Joseph de Maistre's Life, Thought and Influence (Montreal \& Kingston: McGill-Queen's University Press, 2001), p. 158.

${ }^{25}$ Entre o final de 1793 e março de 1794, e talvez como um antídoto para não entrar em desespero existencial diante do fracasso da ofensiva austrossarda e do recrudescimento do Terror na França, Maistre começa a amadurecer sua leitura providencialista do fenômeno revolucionário que o tornaria célebre. Esta interpretação ganhou sua versão completa no Discurso de consolação à Mme Costa, redigido entre 29 e
} 
Portanto, e à guisa do que logrou demonstrar Florenzano ${ }^{26}$ a respeito da condição 'anfíbia' de Burke - isto é, metade político, metade intelectual -, poderíamos levantar a hipótese de que algo muito semelhante dava-se com Maistre, em mais de uma esfera, a saber, graças à sua especial condição simultânea de político e intelectual, ortodoxo (sua educação fundamental na Saboia fora toda orientada pelos padres jesuítas) e maçom (em meio aos quais, passou a ter contato direto com protestantes e deístas), foi possível a ele perceber, em toda a sua dimensão, os perigos, os males e, acima de tudo, as 'afinidades eletivas' entre o protestantismo, o filosofismo e a Revolução.

Dividido em dois livros (o primeiro, mais extenso, com 13 capítulos; o segundo, com sete) e com cerca de 200 páginas no manuscrito original, ainda que o principal objetivo do De la souveraineté du peuple fosse o de defender a monarquia contra as idéias republicanas de Rousseau (e, em menor grau, contra as teses democráticas de Thomas Paine ${ }^{27}$ ), nele se encontra formulado pela primeira vez o vínculo entre o 'filosofismo' e 'seu filho mais velho, o presbiterianismo, 28 .

Após refutar, por meio de uma abordagem providencialista, a tese da soberania do povo no primeiro capítulo do Livro $\mathrm{I}^{29}$, Maistre avança uma veemente crítica às teses contratualistas presentes nas obras de Rousseau/Paine, e as quais foram consagradas na Declaração dos Direitos do Homem de agosto de 1789 pela Assembleia Constituinte francesa, bem como, já no período em questão, nas constituições de Genebra (1794) e da França (1795), a saber:

31 de maio de 1794, em ocasião da morte de seu filho Eugênio, ferido mortalmente enquanto servia ao exército sardo durante a ocupação francesa do Piemonte. Publicado posteriormente em Lausanne, em agosto do mesmo ano, o discurso deixava claro que seu autor atingira uma interpretação original da Revolução. Vide R. Lebrun, Joseph de Maistre: An Intellectual Militant, p. 133.

${ }^{26}$ Modesto Florenzano, Começar o Mundo de Novo: Thomas Paine e outros estudos (São Paulo: Trabalho de Livre-Docência/FFLCH-USP, 1999), p. 169-170.

${ }^{27}$ Afinal, vale para nosso caso o que os historiadores Edward P. Thompson (socialista), Robert R. Palmer (liberal) e A. J. P. Taylor (conservador) afirmaram respectivamente a respeito do Rights of Man, publicado em Londres, em 1791-92, e que Maistre lera numa edição original inglesa de 1792 , in- $8^{\circ}$, a saber, que se tratava do "texto fundador do movimento da classe operária inglesa", "o panfleto político mais amplamente conhecido, citado e bem-sucedido de todo o levante revolucionário internacional" e "a melhor formulação da opinião democrática em qualquer língua". Citados em Modesto Florenzano, Começar o Mundo de Novo..., p. 19.

${ }^{28}$ Joseph de Maistre, De la souveraineté du peuple, Livro I, cap. 11.

29 “Afirma-se que o povo é soberano. De quem? Dele mesmo, aparentemente. Se não cometo nenhum engano, certamente há algum equívoco nessa afirmação, pois o povo que ordena não é o povo que obedece...O povo é um soberano que não pode exercer a soberania. Somente cada indivíduo do sexo masculino desse povo possui o direito de comandar no seu termo e durante um certo período de tempo. Admitindo-se que na França há 25 milhões de homens e 700 deputados elegíveis a cada biênio, compreende-se que se esses 25 milhões de homens fossem imortais, e que os deputados fossem nomeados por todos, cada francês se tornaria rei periodicamente a cada 3.500 anos. Mas como, nesse espaço de tempo, não se deixa de morrer, e que, portanto, os eleitores são livres para escolher segundo seus caprichos, a imaginação assusta-se com o número espantoso de reis condenados a morrer sem jamais terem reinado." Cf. Joseph de Maistre, De la souveraineté du peuple, Livro I, cap. I. 
"Constitui um erro capital representar o estado social como um estado de escolha fundado sobre o consentimento dos homens, sobre uma deliberação, e sobre um contrato primitivo, que são impossíveis. Alguém que fale do estado de natureza como algo em oposição ao estado social delira por completo... A natureza de uma víbora faz com que ela rasteje, tenha a pele escamosa, e os dentes profundos e móveis, de modo que possam inocular um veneno mortal. A natureza do homem é a de ser um animal inteligente, religioso e sociável. Uma experiência invariável nos ensina." ${ }^{30}$

Assim, o conceito de natureza humana veiculado pelos revolucionários sintetizado na Declaração de 1789, explicitado nas Constituições genebrina de 1794 e francesa de 1795, e fundamentado, no parecer de Maistre, em valores apriorísticos e metafísicos - contradizia a experiência de séculos da humanidade, como Burke também percebera numa passagem das Reflexões que se tornou célebre:

"Esses direitos metafísicos, ao penetrarem na vida prática como raios de luz atravessando um meio denso, são desviados, pelas leis da natureza, de sua linha reta. Sem dúvida, na imensa e complicada massa de paixões e preocupações humanas, os direitos primitivos do homem experimentam uma tal variedade de refrações e reflexos, que se torna absurdo discuti-los como se continuassem na simplicidade de sua direção original. A natureza do homem é complicada; os objetivos da sociedade são da maior complexidade possível; logo, quaisquer disposição e direção simples de poder não podem adequar-se nem à natureza do homem, nem à qualidade dos negócios que trata." 31

Não se penetra a natureza humana, adverte Maistre, através de juízos a priori, mas pela análise histórica, a qual, apenas, permite abarcar a verdadeira ontologia do homem. Referindo-se explicitamente (e de maneira bastante elogiosa) a uma passagem do Appeal from the New to the Old Whigs (1791) de Burke - lido através de uma edição inglesa de 1792, e na qual o contrarrevolucionário irlandês sentencia, na sua defesa da prescription, que 'a arte é a natureza do homem' -, Maistre conclui a esse respeito:

“Toda questão sobre a natureza do homem deve ser resolvida pela história. O estado de natureza do homem, portanto, é ser o que ele é hoje e aquilo que ele sempre foi, isto é,

\footnotetext{
${ }^{30}$ Joseph de Maistre, De la souveraineté du peuple, Livro I, cap. 2.

${ }^{31}$ Edmund Burke, Reflexões sobre a Revolução em França (Brasília: Editora Universidade de Brasília, 1997), p. 90.
} 
sociável... Nada se encontra mais fora de propósito do que supor um povo deliberando entre aquilo que se chama, de modo tão insensato, de estado de natureza e o estado social; estabelecendo seu soberano e contratando com o mesmo. A história não demonstra nada parecido; e a história é a política experimental, isto é, a única válida... Representai o homem isolado? Neste caso, não se trata nem de lei, nem de governo, pois não há sociedade. Colocai o homem em contato com seus semelhantes? A partir desse momento, deveis supor o soberano, porque vós admitis a sociedade que não pode existir sem ele."32

Todavia, o aspecto da crítica burkeana que mais se prestará ao ethos conservador maistreano, sendo fundamental para as futuras reflexões do último a respeito do protestantismo, é, a nosso ver, a condenação empreendida por Burke sobre o caráter irreligioso da Revolução, sobretudo no que diz respeito à política revolucionária em relação à Igreja católica (Constituição Civil do clero e confiscos) que ambos, profundamente identificados com o catolicismo e igualmente simpáticos à ordem jesuítica, viam como o esteio da sociedade e do Estado francês.

Após revelar que o clero francês estava longe de estar tão corrompido ${ }^{33}$, e que o confisco de seus bens foi um dos maiores crimes ou 'injustiças' (oferecendo como exemplo de seus propositores o deputado jansenista Camus ${ }^{34}$ ) perpetrados pela Revolução - o qual serviu aos interesses imediatos do monied interest ${ }^{35}$ e da filosofia ${ }^{36}$-,

${ }^{32}$ De la souveraineté du peuple, Livro I, cap. 2. Se, conforme acreditamos que seja, estiver certa a opinião do professor Richard Lebrun a respeito da grande influência retórica (acima de tudo) de Burke sobre Maistre, perceba-se o tom agressivo e irônico que permeou a crítica do primeiro aos Direitos do Homem de 1789: "Não fomos preparados e fixados de modo a que sejamos recheados, como pássaros embalsamados de museus, com farelos e trapos e pedaços miseráveis de papel sujo sobre os direitos do homem." Cf. E. Burke, Reflexões sobre a Revolução em França, p. 107.

33 "Quando tive a oportunidade de ir à França nos fins do último reinado, o clero, em todos os seus aspectos, atraiu grande parte da minha curiosidade. Longe de encontrar - salvo entre um grupo de pessoas que apesar de pequeno, era muito ativo - as queixas e as demonstrações de descontentamento que algumas publicações levaram-me a crer que existissem, percebi que o público em geral não estava contra o clero. Um exame mais aprofundado me fez ver que o clero era composto, em geral, por pessoas de espírito moderado e de maneiras educadas, e incluo aqui os seculares e os regulares de ambos os sexos... Em relação ao alto clero tive relações pessoais com muitos dos seus membros e, sobre os outros, ótimos meios de informação. Eram quase todos homens de origem nobre e que se pareciam com os homens de sua classe... Eles tiveram uma educação mais cuidada e refinada do que a nobreza militar, a fim de não denegrir sua profissão pela ignorância nem pelo despreparo no exercício da autoridade. Eles me pareceram, fora de sua característica eclesiástica, liberais e abertos, com um espírito de homens honrados, sem insolência ou servilidade nas suas maneiras e condutas. Eles me pareceram homens de classe superior, um grupo entre o qual não seria surpreendente encontrar um Fénelon...” Cf. E. Burke, Reflexões..., p. 149-150.

${ }^{34}$ E. Burke, Reflexões..., p. 154.

${ }^{35}$ Conforme observou o historiador John G. A. Pocock num brilhante ensaio, foi a usurpação das propriedades da Igreja em benefício do monied interest, e não o assalto aos aposentos privados de Maria Antonieta, que constituiu o pecado capital da Revolução de 1789 aos olhos do autor das Reflexões. Isto porque, como bom defensor da ordem aristocrática Whig resultante da Revolução Gloriosa, Burke estava ciente de que a prosperidade comercial inglesa dependia da identidade de interesses entre uma 
Burke expressa seu temor de que o exemplo revolucionário francês em relação ao clero pudesse ser difundido em outros países (como, a seu ver, já vinha ocorrendo na República de Berna $^{37}$ ), especialmente na Inglaterra, num plano concertado dos revolucionários europeus (cujo proselitismo fanático ele compara ao dos reformadores religiosos do século $\mathrm{XVI}^{38}$ ) para destruir a religião cristã 'sob todas as suas formas':

"Em resumo senhor, parece-me que essa nova estrutura eclesiástica será temporária e visa à destruição completa da religião cristã sob todas as suas formas, na época em que os homens estiverem já preparados para esse último golpe, como complementação do plano que consiste em menosprezar seus ministros. Aqueles que não crêem que esses filósofos fanáticos, que dirigem todas essas operações, apregoam esse projeto há tempo, ignoram completamente seu caráter e seus atos. Esses entusiastas não têm escrúpulos em confessar que acreditam que seja mais fácil para um Estado sobreviver sem religião do que conviver com uma." ${ }^{39}$

E na opinião de Burke, nada expressava melhor a loucura dos revolucionários franceses do que as palavras proferidas pelo protestante e líder revolucionário francês (então presidente da Assembléia Nacional) Rabaut de Saint-Etienne (1743-1793), por ele transcritas numa nota de rodapé das Reflexões: "Todos os estabelecimentos na França coroam a infelicidade do povo: para torná-lo feliz, é preciso renová-lo; alterar

aristocracia de proprietários de terras e um sistema de crédito público, no qual o investimento do capital rentista em títulos do governo estimulava a prosperidade comercial e política da dinastia hanoveriana. Mas, à diferença do que postulavam seus amigos e mestres da escola filosófica e econômica escocesa (dentre os quais Adam Smith), para quem as maneiras se desenvolviam na esteira do comércio, Burke vinculava a expansão comercial às maneiras, e não o contrário, ou seja, insistia em que o comércio podia florescer somente sob a proteção das maneiras, e que as maneiras, por sua vez, requeriam a preeminência da religião e da nobreza. Não obstante as rígidas barreiras políticas entre as classes, a grande fluidez do capital (financeiro, rentista, manufatureiro, tudo isso englobando o termo monied interest) tornava o edifício político das maneiras inglesas mais harmonioso e seguro, uma vez que não impermeabilizava totalmente o acesso da burguesia à política aristocrática e, sobretudo, situava o "interesse monetário" entre uma classe de proprietários de terra, por um lado, e um governo produtor de dívidas e gerador de créditos, por outro. Enquanto isso, do outro lado da Mancha, Burke lamentava que o confisco das propriedades da Igreja (e, posteriormente, da aristocracia emigrada) fosse feito sob o argumento de uma garantia para a criação de um empréstimo nacional (dando origem aos assignats, que deveriam ser considerados como o papel-moeda legal da França revolucionária), e levado a cabo por um novo e grande "interesse monetário", composto por homens mais preocupados em enriquecer através da especulação financeira da dívida pública, do que por meio de um capital investido no comércio e na manufatura. Assim procedendo, o monied interest francês, com o seu "despotismo do papel-moeda", destruía a propriedade, o comércio e a manufatura ao invés de promovê-los, tornando-se um monstro cada vez mais ávido de bens (na França e alhures, por meio das iminentes guerras sob o pretexto de causas filosófico-humanitárias) a serem sacrificados no altar do crédito nacional e da dívida pública. Vide: J. G. A. Pocock, "A Economia Política na Análise de Burke da Revolução Francesa", in: Linguagens do Ideário Político (São Paulo: Edusp, 2003), em especial p. 245-258.

\footnotetext{
${ }^{36}$ E. Burke, Reflexões..., p. 126 e 156.

${ }^{37}$ E. Burke, Reflexões..., p. 155.

${ }^{38}$ Ibidem, p. 155.

${ }^{39}$ Ibidem, p. 151.
} 
suas idéias; mudar suas leis; mudar seus costumes... mudar os homens; mudar as coisas; mudar as palavras... destruir tudo; sim, destruir tudo, pois é preciso recriar tudo."40

A seu ver, nada poderia ser mais contrário à natureza das coisas, ou mais antagônico com os verdadeiros princípios que deveriam reger uma sociedade e as artes de governar, os quais devem ser pautados pela experiência. ${ }^{41}$

Os revolucionários, afirma mais adiante, "odiando por demais os vícios, deixam de gostar suficientemente dos homens. Não deveria ser, assim, surpreendente que lhes faltassem as qualidades necessárias para servirem aos seus semelhantes? Aí está o segredo dessa tendência congênita de seus governantes a destruir tudo". ${ }^{42}$

E na Letter to a Member of the National Assembly (1791), que Maistre também lera antes de redigir o De la souveraineté du peuple, Burke endereçou a seguinte crítica a Rousseau e aos revolucionários franceses que adotavam o pensador genebrino como modelo:

"Esgota todo o estoque de sua retórica poderosa na expressão da benevolência universal; enquanto seu coração é incapaz de acolher uma centelha da comum afeição parental. Benevolência para com toda a espécie, e ausência de sentimento para todos os indivíduos com os quais os professores entram em contato, forma o caráter da nova filosofia... Ele se derrete de ternura por aqueles que apenas o tocam pela mais remota relação, mas sem nenhuma dor natural, desfaz-se como se fossem restos inaproveitáveis, do produto de seus fastidiosos amores, e envia seus filhos ao orfanato. O urso ama, lambe e forma sua cria; mas ursos não são filósofos." ${ }^{43}$

Assim procedendo com os assuntos relativos ao Estado e à Religião, os revolucionários franceses (lembrando que Burke oferece como exemplo dois personagens que só podem ter incitado a imaginação conservadora do emigrado saboiano, a saber, o protestante Rabaut de Saint-Etienne e o jansenista Camus) incorreram num crime de lesa-pátria:

“É-me impossível compreender como certas pessoas são tão pretensiosas, a ponto de considerarem um país como se fosse uma tábula rasa onde pudessem escrever aquilo que melhor lhes convêm. No plano meramente teórico, é concebível que se deseje que a sociedade tal qual

\footnotetext{
${ }^{40}$ Ibidem, p. 166

${ }^{41}$ Ibidem, p. 167.

${ }^{42}$ E. Burke, Reflexões..., p. 168.

${ }^{43}$ Citado em Modesto Florenzano, Começar o Mundo de Novo..., p. 171.
} 
existe fosse estruturada de uma maneira totalmente diferente, mas um bom patriota e um verdadeiro político procura tirar o melhor partido possível daquilo que existe de material na sua sociedade. Tentar conservar e procurar aprimorar são as duas qualidades que, segundo a minha opinião, deveriam ter um homem de Estado. Fora disso, só há vulgaridade na concepção e perigo na execução..." ${ }^{44}$

Inutilidade, proselitismo fanático, caráter destrutivo ou venenoso ao Estado e à sociedade, todas estas características também serão atribuídas por Maistre aos filósofos, que, no entanto, no seu projeto de 'destruição da França' - cujo maior símbolo foi a expulsão da Companhia de Jesus daquele país, em 1765, pela ação conjunta dos jansenistas e filósofos -, não agiram sozinhos, uma vez que receberam o apoio do protestantismo.

Qual, na visão de Maistre, foi o pecado comum em que incorreram o filosofismo e o protestantismo? No décimo capítulo do livro I, intitulado "Da alma nacional", temos a síntese do problema:

"A razão humana, reduzida às suas forças individuais, é perfeitamente nula, não apenas para a criação, mas também para a conservação de toda associação religiosa ou política, uma vez que ela produz apenas discussões, enquanto o homem necessita de crenças, não de problemas, para se conduzir. Seu berço deve estar cercado de dogmas, e no momento em que sua razão desperta, é preciso que ele encontre todas as suas opiniões formadas, pelo menos sobre todas aquelas coisas que se relacionam com a conduta. Não há nada que lhe seja mais importante do que os preconceitos... Não interpretemos mal esta palavra. Não significa necessariamente idéias falsas, mas apenas, de acordo com a força do uso, opiniões quaisquer assumidas previamente a qualquer exame... Sem elas, não pode haver culto, moral ou governo." $" 45$

No capítulo seguinte, em que trata da aplicação deste princípio ao tema da educação, Maistre refina sua acusação à dupla filosofismo/protestantismo à luz da supressão da ordem jesuítica na Europa, destacando, não por acaso, as opiniões de Rabaut de Saint-Etienne sobre o ocorrido para ilustrar sua hipótese:

\footnotetext{
${ }^{44}$ E. Burke, Reflexões..., p. 157.

${ }^{45}$ J. de Maistre, De la souveraineté du peuple, Livro I, cap. 10.
} 
"De Belarmino ${ }^{46}$, que um robusto protestante do século passado designava ironicamente como 'a deliciosa coqueluche da terrível besta romana', ao padre Berthier ${ }^{47}$, o grande flagelador dos Enciclopedistas, o combate entre os jesuítas e os inovadores de toda espécie não diminui um instante... A esse respeito, pode-se acreditar em Rabaut de Saint-Etienne, fanático Constituinte, philosophe em toda a acepção do termo, pregando, com os bolsos plenos de dinheiro da seita, para rebelar o povo de Paris. Na história da Revolução Francesa que esboçou, fala dos jesuítas como se fosse um poder, sugerindo que a Revolução se deveu em grande parte à abolição desta ordem..." ${ }^{48}$

$\mathrm{Na}$ visão de Maistre, os jesuítas destacaram-se por seu incessante combate aos 'inovadores de toda espécie', dos protestantes na Contrarreforma aos filósofos no século XVIII. 'A Revolução se deve em grande parte à abolição da Ordem', embora isto representasse apenas o último e sangrento episódio de uma série de atentados e guerras civis movidos contra a soberania monárquica, inspirados de maneira direta ou indireta pela Reforma:

"Um doutor protestante que publicou na Alemanha ${ }^{49}$, pouco tempo depois, uma Histoire de l'Eglise chrétienne, acreditava não estar exagerando ao afirmar que 'sem os Jesuítas, a Revolução religiosa do século XVI teria estendido sua ação num raio bem mais amplo, acabando por não mais encontrar alguma barreira', ou que 'se esta ordem, ao contrário, existisse antes, não teria havido reforma, e, provavelmente, ter-se-ia visto estabelecer uma insuperável monarquia universal, nunca antes vista na história'... Foi um ex-Jesuíta que, em 1787 e da maneira mais extraordinária, profetizou a Revolução Francesa, nomeou a Luís XVI todos os seus inimigos, revelando seus planos com uma precisão surpreendente e terminando

${ }^{46}$ Roberto Belarmino (1542-1621), teólogo e cardeal italiano. Jesuíta celebre pelas controvérsias nos quadros da Contrarreforma. Autor, dentre outros, do Disputationes de controversiis fidei christianae e de um Tractatus de potestate summi pontificis que Maistre cita em várias ocasiões em seus registros de leitura.

47 Guillaume-François Berthier (1704-1782), jesuíta erudito e polígrafo, foi encarregado pela direção do Journal de Trevoux em 1745, atividade na qual se destacou graças à sua crítica radical aos filósofos das Luzes, notadamente Voltaire e os enciclopedistas. Além de contribuir na redação do Histoire de l'Eglise gallicane, empreendeu várias traduções para a Bíblia e teve publicado, postumamente, as Observations sur le Contrat Social de J.-J. Rousseau, em 1789. Portanto, um dos principais apologistas católicos do século XVIII francês e freqüentemente citado por Maistre em seus registros de leitura, mais do que Nicolas-Sylvestre Bergier, outro importante apologista. No terceiro diálogo das Les Soirées de Saint-Pétersbourg, foi descrito como um "douto e santo personagem".

${ }^{48}$ Maistre refere-se ao Précis de l'histoire de la Révolution française (livro I, p. 17, in-12 ${ }^{\circ}, 1792$ ). Cf. De la souveraineté du peuple, Livro I, cap. 11.

49 Maistre referia-se à obra Algemeine Geschichte der christlichen Kirche (Helmstadt, Braunsweig, 1794, t. II, p. 69), de D. Heinr. Phil. Conr. Henke, professor de teologia. 
com as seguintes palavras memoráveis: 'Senhor, seu trono está disposto sobre um vulcão ${ }^{50}$... Luís XVI foi destronado pelo filosofismo e pelo presbiterianismo aliados para a destruição da França." 51

Uma prova de que aquele meio clerical refratário (e sua ideologia), bem como a breve referência de Burke a Camus, exerceram uma considerável influência sobre as idéias de Maistre, pode ser percebida nas linhas em que este introduz, ainda que brevemente, os jansenistas no seu repertório condenatório, acusando-os de venalidade e comparando-os aos sans-culottes:

"Observemos ainda que o espírito desta instituição era tão firme, tão enérgico e tão vivo, que o mesmo sobreviveu à morte da Ordem... A terrível perseguição sofrida pelo clero francês nos últimos tempos não foi capaz de vergar nenhum desses homens fragilizados pela idade e pela necessidade.../Comparai esta conduta dos jesuítas com aquela dos infelizes Jansenistas, convulsionários no último século, e sans-culottes no nosso, predicadores da moral severa, cujas mãos complacentes estenderam-se ao primeiro sinal para prestar juramento ao cisma e à revolta. Provaram o suficiente sua filiação!",52

Quanto à inutilidade pretensiosa e nociva dos filósofos, sobretudo quando comparados aos jesuítas, o estilo de Maistre não poderia ser tão burkeano em seu requisitório. Após destacar os feitos pedagógicos e missionários dos tão desprezados jesuítas - descritos como os "diretores de todos os soberanos nesta parte do mundo", "humildes missionários nas oficinas do povo, crianças esclarecidas em relação à infância, mandarins e astrônomos na China, mártires no Japão e legisladores no Paraguai" - entre as mais diferentes nações e culturas, o contrarrevolucionário saboiano desafiou os philosophes nos seguintes termos:

"Onde estão agora os relojoeiros de Ferney que Voltaire designava ridiculamente como sua colônia e com os quais nos entreteve até a saciedade? Se ele tivesse podido reunir sobre as margens do Orenoco ou do Mississipi dois ou três selvagens, desgostá-los da carne humana em nome da filosofia e ensiná-los a contar até vinte, não exagero ao dizer que morreria sufocado

\footnotetext{
${ }^{50}$ Nota de J. de Maistre: Veja-se a Mémoire à lire dans le Conseil du roi sur le projet de donner um état civil aux protestants, in- $8^{\circ}, 1787$, últimas páginas. Obra do ex-jesuíta Jean-Baptiste Bonneau. [Acusado de atividades contrarrevolucionárias e preso em 10 de agosto de 1792, veio a ser uma das vítimas dos massacres de setembro].

${ }_{51}^{51}$ De la souveraineté du peuple, Livro I, cap. 11.

52 J. de Maistre, De la souveraineté du peuple, Livro I, cap. 11.
} 
pelo orgulho, exigindo a apoteose.../"D'Alembert e Voltaire estiveram juntos de Frederico II, e Diderot de Catarina, e a Rússia permaneceu povoada por bárbaros, como a Prússia por escravos"... De qual boca partiu este anátema? Da boca de um membro da Convenção Nacional, dirigindo-se a esta assembleia sobre a educação nacional em nome do Comitê de instrução pública." 53

No capítulo seguinte, Maistre intensificará seus ataques por meio do mesmo procedimento estratégico, a saber, lança mão das declarações dos próprios renomados filósofos para convencer seu potencial leitor de que não exagera ou age de má-fé:

"Quando penso", dizia o rei da Prússia, que sempre cito com satisfação, "que um louco, um imbecil como santo Inácio encontrou uma dezena de discípulos que o seguiram, e que eu não consegui encontrar três filósofos, sou tentado a crer que a razão não serve para nada..." Apesar de ter sido ditada pelo paroxismo, esta passagem é, no entanto, preciosa: o grande homem estava no caminho correto. Sem dúvida, num certo sentido, a razão não serve para nada: temos os conhecimentos físicos que são necessários à manutenção da sociedade; fizemos conquistas nas ciências matemáticas e naquilo que se convenciona chamar de ciências naturais; mas por menos que saiamos do círculo de nossas necessidades, nossos conhecimentos se tornam inúteis ou duvidosos."

E a exemplo de Burke, que na Letter to a Member of the National Assembly (1791) apelou a uma comparação entre a ação dos filósofos (mais especificamente Rousseau) e dos animais selvagens (os ursos) com relação às suas respectivas 'crias', Maistre, de modo ainda mais sardônico e comprometedor aos primeiros, estabelecerá uma relação de semelhança entre os filósofos e as aranhas: ambos são solitários e suas 'teias', apesar de belas, representam na verdade um risco mortal às demais espécies animais:

"Limitemo-nos a repetir que a razão individual não produz e não conserva nada para o bem-estar geral: semelhante àquele inseto impuro que suja os nossos aposentos, sempre solitário, sempre afastado, não produz senão penosas inutilidades; inchada de orgulho, não é senão um veneno, trabalhando para destruir e recusando-se a toda associação de trabalho. E se, por um acaso, atrai à sua teia um ser de sua natureza, precipita-se sobre ele e o devora./ Mas a razão nacional assemelha-se àquele outro inseto que da Ásia se fez presente na Europa: inocente

${ }^{53}$ Idem. O deputado em questão era Lakanal, que fez o seguinte pronunciamento na condição de membro do Comitê de instrução pública (Sessão de 24 de outubro de 1794, Moniteur, nº 37, p. 164). 
e pacífico, ele não está cômodo a não ser em companhia de seus semelhantes e não vive senão para ser útil, a carnificina sendo-lhe estranha. Toda sua substância é um tesouro e o tecido precioso que nos deixa ao morrer forma o cesto da beleza e o manto dos reis." ${ }^{54}$

No mesmo diapasão da acusação de Burke - novamente referido por Maistre em uma nota suprimida do texto publicado em 1870, mas conservada no manuscrito original - aos filósofos (especialmente a Rabaut de Saint-Etienne), Maistre defenderá numa só tacada os preconceitos e/ou as prescrições contra o que julga ser o pecado por excelência dos mesmos - e o qual estaria por detrás de todas as suas formulações políticas -, a saber, o individualismo contraproducente e predatório à sociedade que, sem guias para orientá-la, está sempre prestes a ser atraída para as teias dos predadores, Voltaire e Rousseau em especial:

"Que não se deixem enganar a respeito disto: os sucessos da filosofia podiam encantar alguns olhos desatentos, razão pela qual é importante apreciá-los. Se perguntarmos a estes homens o que eles fizeram, dirão que destruíram os preconceitos e, sobretudo, o fanatismo, pois é a grande palavra de ordem; celebrarão em termos magníficos a espécie de magistratura que Voltaire exerceu sobre seu século durante sua longa carreira. Todavia, estas palavras preconceitos e fanatismo significam, em última análise, a crença de inúmeras nações. Voltaire perseguiu esta crença em um sem-número de cabeças, isto é, ele a destruiu, e é precisamente isto o que eu digo. A filosofia age somente para menos, de modo que um homem deixado à sua razão individual é perigoso à ordem moral e política na proporção exata de seus talentos: quanto maiores forem seu gênio, atividade e perseverança, mais sua existência será funesta." ${ }^{55}$

Diante da crise pela qual atravessava o instável governo do Diretório e das incertezas quanto à sustentabilidade do regime republicano da França pós-termidoriana (bem como da sobrevivência dos legados revolucionários), foi possível a Maistre inverter os termos do conceito revolucionário de patriotismo através do inusitado recurso a ninguém menos do que Rousseau: se para muitos republicanos patriotas que salvaram a França da invasão estrangeira e do desmembramento nos críticos anos de 1792-93 o patriotismo era indissociável de uma 'caça' aos conspiradores internos (mormente o clero e a nobreza) e de uma afirmação cívico-republicana do novus ordo seclorum Revolucionário (o qual buscou promover, conforme preconizara Rabaut de

\footnotetext{
${ }^{54} \mathrm{~J}$. de Maistre, De la souveraineté du peuple, Livro I, cap. 12.

55 J. de Maistre, De la souveraineté du peuple, Livro I, cap. 12.
} 
Saint-Etienne em meados de 1789, uma verdadeira revolução cultural que, a partir de setembro de 1792, não poupou nem mesmo o calendário cristão e o nome de importantes cidades, como Lyon) e seus princípios (sobretudo a Declaração dos Direitos do Homem de 1789), Maistre, por sua vez - e na esteira da fraqueza daquele regime amparado por manobras legislativas ${ }^{56}$-, sustentava que a única solução de futuro político estável para a França residia no retorno aos verdadeiros princípios do patriotismo que a Revolução subvertera, ou seja, a religião cristã e a monarquia:

"Caso se queira, na ordem política, construir grandiosa e duradouramente, é necessário se apoiar numa opinião, numa crença ampla e profunda: pois se a opinião não domina a maioria dos espíritos e se ela não está profundamente enraizada, fornecerá nada além de uma base estreita e passageira... Ora, caso se reflita sobre quais são as grandes e sólidas bases de todas as instituições possíveis da primeira e da segunda ordem, encontrar-se-á sempre a religião e o patriotismo... E caso se reflita com maior atenção ainda, ver-se-á que estas duas coisas se confundem, pois não há verdadeiro patriotismo sem religião: não o vemos brilhar a não ser nos séculos de crença, declinando e morrendo sempre com ela. Desde que o homem se separa da divindade, ele se gangrena e gangrena tudo aquilo que toca. Sua ação é falsa e não se agita senão para destruir./Todavia, desde que a idéia de divindade constitui o princípio da ação humana, esta ação será fecunda, criadora e invencível." 57

No último capítulo do Livro I e que encerra o requisitório maistreano dirigido aos philosophes, somos apresentados à seguinte questão retórica: "ao debitar à filosofia humana os males que ela nos fez, não se arrisca ir demasiado longe e ser injusto em relação a ela, recaindo num excesso contrário?"58

Após responder que em toda discussão é preciso sempre evitar o "entusiasmo", Maistre conclui em relação à filosofia que a mesma "é boa na medida em que se mantém nos seus domínios ou que não participa da extensão de um império superior ao

\footnotetext{
${ }^{56}$ Assim que a Convenção se dissolveu, em 4 brumário do ano III (26 de outubro de 1795), para dar lugar ao Diretório, o partido dos moderados prevaleceu sobre os extremistas de esquerda, reacendendo as pretensões do partido realista, que se reorganizou após o fracassado coup d'état de Quiberon (20-21 de julho de 1795). A partir daí, os realistas, cada vez mais infiltrados na administração, adotam a via legal como estratégia, aproveitando-se do refluxo da cultura revolucionária. Diante desse risco, a Convenção, antes de se dissolver, promulga o decreto dos Dois Terços e a Constituição do ano III (22 de agosto de 1795).

${ }^{57}$ J. de Maistre, De la souveraineté du peuple, Livro I, cap. 12.

${ }^{58}$ J. de Maistre, De la souveraineté du peuple, Livro I, cap.13.
} 
seu, senão na qualidade de aliada ou mesmo súdita, e detestável na medida em que participa da mesma, na qualidade de rival ou inimiga., 59

Portanto, para o futuro autor das Considerações sobre a França, não podia restar nenhuma dúvida: os tigres revolucionários de 1793-94, Marat e Robespierre, eram menos responsáveis pelo Terror do que Espinosa, Voltaire, Rousseau, Mably, Paine (cuja propaganda democrática mereceu especial refutação no capítulo IX do primeiro livro, que versa sobre "A Fraqueza do poder humano") e seus princípios:

"Filósofos, nunca ireis vos desculpar pelas causas das quais são responsáveis, lamentando pelos efeitos! Vós detestais os crimes, dizei. Vós não degolastes ninguém: eis o único elogio que se vos possa fazer. Mas vós fizestes degolar... O tigre que dilacera faz seu métier: o verdadeiro culpado é aquele que o desacorrenta e o lança sobre a sociedade. Não creiais que vossas trenodias afetadas sobre Marat e Robespierre vos absolvereis. Escutai uma verdade: onde quer que estejais e onde quer que se tenha a infelicidade de dar-vos ouvidos, haverá monstros semelhantes, pois toda sociedade abriga celerados que aguardam apenas uma ocasião para dilacerá-la ou serem desembaraçados dos freios legais. Entretanto, Marat e Robespierre não teriam feito nenhum mal sem vós, pois teriam sido contidos por este freio que vós rompestes." 60

Portanto, parece-nos legítimo afirmar que, em meio às agitações políticas de cunho democrático (ainda por cima empreendidas em nome dos direitos do homem) que presenciara em território suíço-protestante, Maistre simplesmente não poderia passar ao largo de um autor como Paine, que, ainda mais do que Rousseau, encarnava a 'era da Revolução democrática', nem, tampouco, de Edmund Burke, cujos argumentos, uma vez adaptados à sua visão providencialista, mostraram-se indispensáveis no esforço de refutação dos valores democrático-republicanos do saboiano:

“A Inglaterra acaba de tomar conhecimento desta afinidade terrível que existe entre o protestantismo e o jacobinismo... Não foi entre os protestantes propriamente ditos, entre os puritanos, que o veneno da Revolução Francesa fez os maiores estragos?... Paine não censurou o venerável Burke por haver 'facilitado aos ingleses o retorno ao catolicismo, e por conduzi-los à infalibilidade religiosa pela infalibilidade política’? ${ }^{61}$

\footnotetext{
${ }^{59} \mathrm{~J}$. de Maistre, De la souveraineté du peuple, Livro I, cap.13.

${ }^{60} \mathrm{~J}$. de Maistre, De la souveraineté du peuple, Livro I, cap. 13.

${ }^{61}$ J. de Maistre, Réflexions sur le Protestantisme (1798), in: Jean-Louis Darcel (org.), J. de Maistre: Écrits sur la Révolution (Genève: Slatkine, 1989), p. 235.
} 
Não por acaso, encerra as Reflexões sobre o protestantismo referindo-se a Paine, deísta de origem protestante (quaker), o qual para Maistre encarnava melhor do que ninguém as afinidades eletivas entre o protestantismo, o filosofismo e a rebelião democrática de seu tempo:

“Assim, o protestantismo é positivamente e ao pé-da-letra, o sans-culottismo da religião. Um invoca a palavra de Deus; o outro, os direitos do homem. Mas na verdade é a mesma teoria, o mesmo percurso e o mesmo resultado. Estes dois irmãos romperam a soberania para distribuíla à multidão." 62

Além disso, uma leitura atenta das Reflexões sobre o Protestantismo deixa claro que no De la souveraineté du peuple Maistre já tinha plenamente formulado para si este conceito histórico que une a Reforma à Revolução. Pois as Reflexões não apenas reiteram literalmente alguns dos argumentos burkeanos do De la souveraineté du peuple contra os filósofos, como, mais importante, repetem e acentuam a acusação do contrarrevolucionário irlandês a Rabaut de Saint-Étienne, em termos que já constavam no tratado antirrousseauniano:

"Rabaut de Saint-Etienne, ministro protestante, celebrara, num discurso mais hipócrita do que eloqüente, as bondades de Luís XVI, o que lhe renderam aplausos de toda parte... Nem bem se fez escutar o sino da revolta, e Rabaut voa a Paris... Figurou na primeira assembléia entre os inimigos mais entusiasmados da monarquia e, na terceira, sua boca, que ousara pregar para Luís XVI, votou pela morte do virtuoso monarca, ao lado de Marat, Lebon e Robespierre." ${ }^{\text {"63 }}$

Os motivos que o levaram a não publicar o tratado crítico ao 'Cidadão de Genebra' deveram-se menos a uma alteração dos conceitos políticos - o que em absoluto não houve, dado que neles já assumia a hipótese providencial ${ }^{64}$ - do que às circunstâncias políticas francesas após o 9 Termidor, que culminaram na queda de Robespierre e numa releitura crítica das teses de Rousseau pelos próprios herdeiros da Revolução.

Todavia, nosso esforço de reconstituição genealógica das Reflexões sobre o protestantismo correria o risco de ficar incompleto se ignorássemos outros dois importantes dados que intervieram na sua redação.

\footnotetext{
${ }^{62}$ J. de Maistre, Réflexions sur le Protestantisme, p. 239.

${ }^{63}$ J. de Maistre, Réflexions sur le Protestantisme, p. 231.

${ }^{64}$ Veja-se especialmente o Livro II, cap. 8 do De la souveraineté...
} 
O primeiro, conforme destacaram Jean-Louis Darcel ${ }^{65}$ e Pierre Glaudes ${ }^{66}$, diz respeito à malograda atividade missionária de Maistre junto aos calvinistas suíços, a qual resultou na redação da Lettre à une dame protestante sur la maxime qu'un honnête homme ne change jamais d'opinion (Carta a uma dama protestante sobre a máxima de que um homem de bem jamais muda de religião), em agosto de $1797^{67}$. Diante do insucesso do seu proselitismo e tendo em vista a cultura de acusação aos protestantes e jansenistas pela Constituição Civil do Clero que lastreava os círculos emigrados, é provável que Maistre tenha formulado essa teoria por indução ${ }^{68}$.

Mas antes disso, um outro fator interveio, e o qual nos parece mais importante, posto que se mostrou decisivo também para a elaboração das Considerações: trata-se da recepção maistreana à atuação de dois célebres ativistas políticos liberais e huguenotes na defesa do instável governo republicano francês: Madame de Stäel e Benjamin Constant.

Na primavera de 1795, Mme de Stäel - que Maistre conhecera pessoalmente no exílio suíço em dezembro de 1793 e com quem desenvolvera uma relação de admiração mútua - publica em Paris as Réflexions sur la paix intérieure, convidando os realistas constitucionais, decepcionados pela Declaração de Verona de Luís XVIII (24 de junho de 1795), a unirem-se aos "republicanos amigos da ordem", em nome do mesmo ideal da liberdade.

Maistre, que mantinha correspondência com os realistas de Paris e considerava Stäel peça-chave numa eventual restauração monárquica - afinal, no início de 1795 , a autora dava indícios de que poderia servir à "boa causa" da monarquia ao criticar abertamente o "quimérico sistema da igualdade" propagado pelos "partidários da tirania demagógica..."69-, ficou profundamente desapontado com a manifestação prórepublicana da filha de Necker, que ele defendera num opúsculo de 1788. Para o saboiano, esse extravio ideológico de Germaine Necker só podia ser obra de Benjamin Constant - que Maistre jamais perdoaria pelo fato de, graças às suas relações com os homens do Diretório, haver tirado proveito dos bens confiscados dos emigrados -, com quem a mesma se aliara a partir de setembro de 1794 .

\footnotetext{
65 Jean-Louis Darcel, "Présentation" a J. de Maistre: Écrits sur la Révolution (Genève: Slatkine, 1989), p. 25 .

${ }^{66}$ P. Glaudes, Joseph de Maistre: Oeuvres, p. 295.

${ }^{67}$ Publicada somente em 1820, sem autorização do autor. Devo ao Prof. Richard Lebrun esta observação.

${ }^{68}$ Pierre Glaudes, Joseph de Maistre: Oeuvres, p. 295.

${ }^{69}$ Réflexions sur la Paix adressées à M. Pitt et aux Français. Citado em J.-L. Darcel (org.), Joseph de Maistre: Considérations sur la France (Genève: Slatkine, 1980), p. 40.
} 
Quando, em maio 1796, o Moniteur (órgão de imprensa do governo) publica o panfleto pró-republicano de Benjamin Constant (no qual se percebia também a "mão" de Mme de Stäel), Da força do governo atual da França e da necessidade de apoiá-lo, Maistre, visando as eleições francesas de março de 1797, sentiu-se impelido a redigir uma obra de refutação, no que foi incentivado por William Wickham (embaixador britânico em Berna), Mallet du Pan e Louis Fauche-Borel (influente editor de Neuchâtel e um dos principais agentes da contrarrevolução europeia), responsáveis pela organização da campanha realista de Paris.

Conforme destacamos acima, aquele momento caracterizava-se por um profundo desencantamento dos franceses com a República, fato este que resultou na vitória dos realistas para os dois conselhos legislativos nas eleições de março de 1797. Não fosse pelo coup d'état do 18 frutidor (4 de setembro de 1797), a primeira experiência republicana francesa teria chegado a seu termo, paradoxalmente pela via eleitoral. ${ }^{70}$

Portanto, o estopim para que Maistre redigisse as Considerações veio com a publicação do panfleto pró-republicano de Benjamin Constant. Pois naquela atmosfera pré-eleitoral, ninguém melhor do que Constant soube defender não somente o regime republicano, mas os princípios (como a igualdade civil) e os resultados da Revolução. ${ }^{71}$

Nesta defesa do governo do Diretório, Constant salienta que, se a república póstermidoriana sobrevivera aos ataques de todos os seus adversários ("terroristas" ou realistas), é porque o governo já representava uma ordem social estável e legítima. Ademais, o governo republicano apoiava-se no número e nos poderosos interesses da sociedade. Com lucidez e avançando um argumento de brilhante futuro, Constant demonstra que não era mais possível recuar diante das conquistas da Revolução, ou seja, que a mera tentativa de anular esses direitos adquiridos precipitaria a nação numa

${ }^{70} \mathrm{O}$ golpe parlamentar de 18 frutidor (4 de setembro de 1797), com o apoio dos militares, anulou o resultado das eleições da primavera (a qual tinha sido amplamente favorável aos moderados e realistas), frustrando as esperanças dos realistas franceses numa Restauração pela via eleitoral. Em decorrência do golpe, estabeleceu-se a censura e a cassação dos deputados suspeitos de simpatias ou implicados em manobras monárquicas (como o recém-eleito presidente do Conselho dos Quinhentos, o general realista Charles Pichegru).

71 “O momento atual é um dos mais importantes da Revolução. A ordem e a liberdade estão de um lado, a anarquia e o despotismo, do outro. Restam poucos momentos ainda para se pronunciar; é preciso se apressar em renunciar às lembranças e aos ódios, ou amanhã estes ódios serão substituídos por inúteis arrependimentos, aquelas lembranças por amargos remorsos... Desejo ardentemente ver terminar a Revolução, porque doravante ela só pode ser funesta à liberdade; e é uma das minhas razões para desejar ardentemente também o fortalecimento da República, à qual, de resto, me parece ligar tudo o que há de nobre e de grande nos destinos humanos". In: Benjamin Constant, "Introdução" a Da força do governo atual da França e da necessidade de apoiá-lo; Tradução de Josemar Machado de Oliveira, in: Revista de História 145 (2001),181-230. 
"nova revolução",72. Nestas circunstâncias, a prudência política tipicamente conservadora - a qual repudia as transformações políticas súbitas e violentas recomendava o apoio ao governo republicano do Diretório, pois, do contrário, o retorno das querelas despertaria paixões políticas ainda mais violentas, uma vez que os defensores da república apoiavam-se em princípios e não somente em interesses pessoais $^{73}$.

Amparado numa análise sutil da relação de forças entre os partidos do contexto pós-termidoriano, isto é, da dinâmica da esquerda e da direita em relação ao governo, Constant demonstra em primeiro lugar que os realistas dificilmente poderiam se ater a um programa de “conservação". De um lado, a relação de forças políticas impossibilitava um compromisso aceitável para os dois partidos em disputa (os radicais de esquerda e os realistas) nos quadros de uma monarquia constitucional (cap. III); de outro, a lógica da "reação" - dominante nos círculos emigrados - implicava numa simples inversão da revolução anterior, a saber, traria consigo as vinganças e lançaria o "terror branco" contra todos aqueles que de uma maneira ou de outra tomaram parte na Revolução ${ }^{74}$.

Diante desse quadro contrarrevolucionário, os republicanos moderados e os "amigos do repouso" viam-se forçados a forjar uma aliança com os radicais de esquerda

72 “Aqueles que querem derrubar a República, são curiosamente vítimas das palavras. Viram que a Revolução foi uma coisa terrível e funesta, e concluem que o que chamam uma contrarrevolução seria um evento feliz. Não se dão conta de que essa contrarrevolução apenas seria ela mesma uma nova revolução". B. Constant. Da força do governo atual da França e da necessidade de apoiá-lo, cap. III.

73 "Aqueles que ligaram sua sorte à República têm a defender, no lugar de preconceitos, o que vêem como princípios, no lugar de interesses pessoais, o que é para eles uma religião, no lugar da vaidade, um orgulho, seja, mas um orgulho mais profundo, mais viril, mais inerente à sua natureza, mais caro ao seu coração, pois é para eles a reabilitação de sua classe, o fruto de uma conquista, a desculpa de sua conduta, e a garantia de sua segurança. Eles têm a defender sua fortuna e além disso sua vida. Qual não seria o abalo de uma semelhante reviravolta?" B. Constant, Da força do governo atual da França..., cap. II.

74 “A Realeza absoluta, isto parece estranho dizer, não teria talvez de início tantos inimigos. Como atrairia a si imediatamente um dos dois partidos extremos, o partido mediano poderia a ela se unir... Uma multidão de homens, fatigados das convulsões, resignar-se-ia ao jugo na esperança enganosa do repouso. Mas os inimigos que a realeza teria de menos, ela não tardaria a criá-los... Os partidários do antigo regime protestam antecipadamente contra toda espécie de acomodamento, de indulgência, de mitigação... Para eles não há prescrição. Seu ódio se exasperou envelhecendo, e sua necessidade de vingança tornou-se mais imperiosa, na proporção em que foi por mais tempo comprimida... Remontaram dos agentes do Diretório aos Convencionais, dos Convencionais aos Jacobinos, destes à Gironda, da Gironda aos Feuillants, dos Feuillants aos Legislativos, dos Legislativos aos Constituintes, dos Constituintes aos Monarquistas, dos Monarquistas a todos os culpados do 14 de julho de 1789." In: B. Constant. op. cit., cap. III. 
e reabrir um novo ciclo revolucionário, uma vez que somente com a ajuda deste "exército de reserva" poderiam defender os princípios e as conquistas da Revolução. ${ }^{75}$

Longe de representar um encerramento da Revolução, a vitória da monarquia não apenas reacenderia a guerra civil como colocaria em risco a integridade territorial francesa ante as potências estrangeiras que exigiriam reparações. $\mathrm{O}$ regime produzido pelo Termidor era o único capaz de neutralizar os extremos internamente - posto que encontrava apoio nos moderados dos dois lados -, bem como de manter a integridade territorial francesa contra as pretensões dos exércitos coligados - e isto graças ao entusiasmo republicano do "exército de reserva" (extremistas de esquerda). ${ }^{76}$

Portanto, os verdadeiros amigos do repouso, da constituição, da ordem, em suma, os "conservadores"conscientes deveriam cerrar fileiras em torno do governo do Diretório, sentencia Constant em seu panfleto.

Que o fator 'Constant' tenha sido determinante (não tanto para engendrar o conceito, mas para aprofundá-lo), acentuando os demais fatores, isto torna-se claro ao lermos o capítulo IV das Considerações, uma resposta de Maistre ao panfleto de Constant, cujo capítulo VI intitulava-se "Das objeções extraídas da experiência contra a possibilidade de uma República em um grande Estado”. Para refutá-lo, o saboiano lança mão dos mesmos argumentos (acentuadamente burkeanos) formulados no De la souveraineté du peuple, sobretudo da história que, através de suas "leis de geometria" e da "probabilidade", demonstra a inviabilidade de um governo republicano durável para a França. ${ }^{77}$ Aqui e no capítulo VI das Considerações, podemos observar que o alvo da crítica maistreana não é tanto Constant quanto Thomas Paine, que na segunda parte de

75 "Vendeias republicanas se formariam, menos atrozes, mas não menos temíveis que a Vendeia católica. A verdade seria sua religião, a história sua legenda, os grandes homens da Antiguidade seus santos, a liberdade sua outra vida. Eles não esperariam ressuscitar em três dias, mas combateriam e morreriam livres... A guerra civil, eis o que traria à França toda espécie de realeza.”In: B. Constant. op. cit., cap. III.

76 "Existe, enfim, para o governo francês, um terceiro e terrível recurso, que ele rejeitaria sempre nos momentos de calma, que a todos fará estremecer ao utilizá-lo e sobre o qual acreditaria dever guardar silêncio, se pela salvação pública não fosse preciso, enfim, olhá-lo uma vez fixamente... Os terroristas são essa artilharia do governo, sempre escondida, mas sempre temível, e que, todas as vezes que ele for forçado a empregá-la, reduzirá a pó seus adversários... Eles poderiam destruir o governo, mas não podem suportar de nenhuma maneira que seja destruído por mãos estrangeiras:são contra o governo, quando este não é atacado, porque são contra tudo o que pesa sobre suas indóceis cabeças...; mas estarão com ele desde que seja atacado, porque sentem que os agressores são ainda mais seus inimigos do que os da constituição estabelecida...” In: B. Constant. Da força do governo atual da França..., cap. II.

${ }^{77}$ J. de Maistre, Considerações sobre a França, cap. IV. 
Os Direitos do Homem (1792) amparou sua defesa do sistema republicano na descoberta do sistema representativo moderno. ${ }^{78}$

Após observar que a descoberta do sistema representativo foi uma "produção" do "governo feudal" - e cuja iniciativa coube à autoridade real -, Maistre submete o sistema representativo francês (conforme definido pela Constituição de 1795) a uma severa crítica, a qual nada mais era do que uma reprodução, nas Considerações sobre a França (1797), de um argumento já exposto no primeiro capítulo do Livro I do tratado antirrousseauniano:

“A comissão, ultimamente encarregada de apresentar um projeto para a renovação do terço da Assembleia, estima o número dos franceses em trinta milhões... A cada ano, nos termos da Constituição, duzentos e cinqüenta pessoas cedem o lugar para outras duzentas e cinqüenta que as substituem. Disso, deduz-se que, se os quinze milhões de varões estimados para esta população fossem imortais, aptos à representação e nomeados pela ordem, invariavelmente cada francês exerceria sua parte de soberania nacional a cada sessenta mil anos... Porém, como não se deixa de morrer de tempos em tempos durante tal intervalo e, portanto, a eleição pode repetir-se em proveito das mesmas cabeças, ou ainda, um sem-número de indivíduos, por bom senso e natureza, estará sempre desabilitado à representação nacional, a imaginação espanta-se diante do número prodigioso de soberanos condenados a morrer sem ter reinado."79

Portanto, as afinidades eletivas entre republicanismo e liberalismo em dois autores tão presentes na crítica maistreana nas Considerações, a saber, Constant e Paine, bem como o fato de ambos serem identificados tanto com o filosofismo quanto com o protestantismo, não poderiam ter oferecido provas mais eloqüentes a respeito da identidade entre Reforma e Revolução.

Talvez não por acaso, no terceiro capítulo das Considerações (o qual antecede a sua refutação teórica às teses da dupla) Maistre estabeleça a seguinte relação causal entre os dois fenômenos históricos:

\footnotetext{
${ }^{78}$ Isto se torna claro pelo fato de Maistre empreender nos capítulos IV e VI uma crítica à república estadunidense, sobre a qual Paine fundamentou sua defesa no sistema republicano no capítulo III, da segunda parte, de Os Direitos do Homem. Da mesma forma, o recurso às leis matemáticas pelo saboiano não foi casual. O próprio Paine, na "Introdução"da $2^{a}$ parte, sustentou sua argumentação nas leis mecânicas de Arquimedes.

${ }^{79}$ J. de Maistre, Considerações sobre a França, cap. III.
} 
"Mas é da sombra de um claustro que surge um dos maiores flagelos do gênero humano: Lutero aparece, seguido de Calvino. Guerras dos camponeses ${ }^{80}$; Guerra dos Trinta Anos; Guerra Civil na França; massacre nos Países Baixos; massacre na Irlanda; massacre em Cévennes; noite de São Bartolomeu; mortes de Henrique III, Henrique IV, Maria Stuart, Carlos I e, finalmente, em nossos dias, a Revolução francesa, que brota da mesma fonte." ${ }^{81}$

Após a assinatura do Tratado de Paris pelo periclitante Victor-Amadeus III e o Golpe de Estado do 18 frutidor, a missão diplomática na Suíça perdera a razão de ser. Com a ascensão ao trono de Charles-Emmanuel IV (1751-1819), em outubro de 1796, tudo fazia crer que a sorte de Maistre junto à corte piemontesa iria mudar.

No início de 1797 (28/01), recebe uma carta de Turim solicitando seu retorno ao Piemonte, onde passaria a receber 2.000 libras anuais. Quando tudo indicava que o saboiano ocuparia um alto cargo na administração do rei, o mesmo foi forçado a abdicar de seu trono e a refugiar-se na Sardenha (dezembro de 1798) após a assinatura do segundo Tratado de Paris, em abril de 1797.

No dia 28 de outubro daquele ano, recebe uma notícia nada animadora vinda da França, responsável pelo cancelamento de sua integração à corte do rei piemontês.

Tropas francesas, sob o comando de Napoleão, interceptaram em Milão uma carta ao marquês d'Avaray, na qual o conselheiro de Luís XVIII informava que os eventos do frutidor tornavam impossível uma nova edição do panfleto em solo francês. Enviada a Paris, a carta foi publicada nos órgãos de imprensa do Diretório para ilustrar a existência de complôs realistas subterrâneos e justificar o golpe de estado.

Desvendada a autoria das Considerações sobre a França, a ascensão política de Maistre passou a ser politicamente inviável a seu governo, uma vez que isto equivaleria a uma declaração de guerra contra o Diretório. Consciente deste fato, Maistre sugere a d'Avaray que poderia trocar Turim pela Suíça, e solicita o apoio do pretendente ao trono francês para empregá-lo como tutor em alguma alta corte do norte europeu (como fizera seu amigo Joseph Victor), mas sem êxito.

80 Sublevação dos camponeses alemães (1524-25) descontentes com sua vida miserável e galvanizados pelo "comunismo evangélico" dos anabatistas de Thomas Münzer. Lutero recomendou aos príncipes alemães uma repressão implacável contra os rebeldes. Apesar dos anacronismos, a obra de Engels sobre o assunto merece ser revista, em razão de suas inúmeras virtudes analiticas. Ver F. Engels, Guerras Camponesas na Alemanha (1850). São Paulo, Grijalbo, 1977.

${ }^{81}$ J. de Maistre, Considerações sobre a França, cap. IV. 
Diante desse forçado otium, dedicou-se à leitura ${ }^{82}$ e à redação - que se daria em 1798 - das Réflexions sur le Protestantisme dans ses rapports avec la Souveraineté.

Infelizmente para o saboiano, no que se tornaria uma tônica em quase toda a sua trajetória de vida, para que o intelectual contrarrevolucionário desabrochasse, e, mais especificamente para o nosso caso, as Reflexões sobre o protestantismo, era preciso que sua ambição diplomática naufragasse...

${ }^{82}$ De autores como Ovídio, Metamorfose; Orígenes, Contra Celsius; Santo Agostinho, Cidade de Deus; Pierre Charron, De la sagesse (1601); Johann August Ernesti, Opuscula Theologica (1773); SaintMartin, l'Homme de désir (1790); etc. 


\title{
CAPÍTULO 2
}

\section{A Revolução Francesa, chave para a compreensão do Protestantismo: As "Reflexões sobre o Protestantismo" de Maistre}

\begin{abstract}
"Conclui-se que o protestantismo é positivamente, e ao pé da letra, o sans-culottismo da religião. Um invoca a palavra de Deus; o outro, os direitos do homem; mas, na realidade, é a mesma teoria, a mesma marcha e o mesmo resultado. Estes dois irmãos romperam a soberania para distribuí-la à multidão." ${ }^{1}$ - J. de Maistre
\end{abstract}

"Condena-se a flutuar sempre à superfície das coisas caso não se abrace de uma vez, numa mesma perspectiva, as revoluções religiosas, das quais as instituições políticas, as literaturas e as artes são uma consequência." ${ }^{2}$ - E. Quinet

Se para os homens de 1789 era possível conciliar a Igreja com o Estado (pelo menos enquanto os espíritos não estivessem maduros o suficiente para abraçar a 'religião natural') - pois, acreditava-se que seria viável nacionalizar ainda mais a Igreja católica francesa (galicana) e adaptar seu clero aos novos tempos -, o mesmo não pode ser dito para os homens da República termidoriana (1794-1799), para quem a união entre a República e a Igreja católica era algo inconcebível após a Constituição Civil do Clero (agosto de 1790), o Terror (com seu processo descristianizador), as guerras civis em nome do trono e do altar (Vendeia e chouannerie) e, sobretudo, após o massacre de religiosos e realistas durante a jornada popular do 13 vindimário do ano IV (5 de outubro de 1795), em que o jovem general Bonaparte disparou tiros de canhões contra

${ }^{1}$ J. de Maistre, Réflexions sur le Protestantisme, em: Oeuvres complètes de J. de Maistre (Lyon: Vitte et Perussel, 1893), vol. VIII, p. 96-97.

${ }^{2}$ E. Quinet, Le Christianisme et la Révolution française (1845). 
os realistas - que protestavam contra o decreto dos dois-terços - na escadaria da Igreja de São Roque. ${ }^{3}$

Nada escancarava mais aquela incompatibilidade (estrutural/social e ideológica) do que o decreto dos dois-terços que deu origem à referida jornada. Promulgada pela Convenção antes desta se dissolver e no mesmo dia da Constituição do ano III (22 de agosto de 1795), tratava-se de uma verdadeira aberração constitucional, a qual estabelecia que 2/3 dos deputados (500 para um universo de 750 ) da Convenção que se dissolvia ocupariam as cadeiras do novo organismo legislativo, composto pelo Conselho dos Quinhentos e pelo Conselho dos Anciãos.

Quando, num escrito de 1814, François-René de Chateaubriand (1768-1848) referiu-se à instável República francesa, definiu em poucas palavras o principal problema de que padecia: duvidava-se da possibilidade da restauração monárquica na mesma proporção que se duvidava da durabilidade daquela República cada vez mais alienada de suas bases sociais (à 'direita', pela oposição católica; à 'esquerda', pelo caráter censitário, liberal e especulador de um regime incapaz de levar os benefícios ou promessas da República à sociedade como um todo, daí o ressurgimento do jacobinismo na sua faceta radical e protocomunista nas figuras de Babeuf e Buonarroti ${ }^{4}$ ). Segundo Chateaubriand, acreditava-se que a monarquia representava teoricamente a melhor solução para o restabelecimento da ordem e das garantias constitucionais (vale dizer, burguesas, liberais), embora fosse ainda mais claro que faltassem uma aristocracia e, principalmente, um rei, liberais/constitucionais. ${ }^{5}$

Do lado republicano, ninguém melhor do que Benjamin Constant (1767-1830) traduziu os dilemas políticos e sociais impostos à República. Diante daquele potencial quadro contrarrevolucionário, os republicanos moderados e os "amigos do repouso" virse-iam forçados a uma aliança com os radicais de esquerda e reabrir um novo ciclo revolucionário (expresso nas journées), uma vez que somente com a ajuda deste “exército de reserva" poderiam defender os princípios e as conquistas da Revolução.

${ }^{3}$ John McManners, The French Revolution and the Church (London: Harper Torchbooks, 1969), p. 118-119. Importa destacar que esta foi a primeira journée popular (posto que contou com a adesão de pelo menos 15 das 48 seções revolucionárias parisienses) de cunho contrarrevolucionário e realista, na qual os cerca de 25 mil insurgentes exigiam a revogação do Decreto dos Dois Terços antes das eleições, então previstas para o dia 20 vindimário (12 de outubro).

${ }^{4}$ Sobre a crise ao mesmo tempo financeira, política e social que culminou na Conspiração dos Iguais de 1796, vide: Georges Lefebvre, A Revolução Francesa (1930). Trad. de Ely Bloem de Melo Pati (São Paulo: Ibrasa, 1989), p. 409-415.

${ }^{5}$ Chateaubriand, De Buonaparte, des Bourbons, et de la nécesité de se rallier à nos princes légitimes, pour le bonheur de la France et celui de l'Europe (1814), in J.-P. Clément (org.), Grands écrits politiques. Paris: Imprimerie nationale, 1993, p. 66. 
Portanto, longe de representar um encerramento da Revolução, a vitória da monarquia não apenas reacenderia a guerra civil como colocaria em risco a integridade territorial francesa ante as potências estrangeiras que exigiriam reparações. O regime produzido pelo Termidor era o único capaz de neutralizar os extremos internamente posto que encontrava apoio nos moderados dos dois lados -, bem como de manter a integridade territorial francesa contra as pretensões dos exércitos coligados $-\mathrm{e}$ isto graças ao entusiasmo republicano do "exército de reserva" (extremistas de esquerda). ${ }^{6}$

Contudo, e já nos primórdios de 1795, diante da ameaça representada pelos incessantes progressos do catolicismo na sociedade, os patriotas, mesmo os mais 'filosóficos', deram-se conta de que a República só se consolidaria se conseguisse finalmente estabelecer uma religião cívica, traduzindo seus princípios em instituições, razão pela qual concluiu-se que a fórmula deísta tinha melhores chances de atrair para a República todos os inimigos das religiões reveladas.

Assim, no dia de 15 floréal do ano III (abril de 1795), um certo J. Le Gaigneur, aluno da École Normale de Paris, venceu um concurso - promovido pela Convenção, entre estudantes de toda a França - com uma redação em que exaltava os protestantes quacres, cujas virtudes (despojamento cerimonial e dogmático, espírito de tolerância e independência intelectual) deveriam ser copiadas na França por meio de um culto cívico-republicano "teísta" e submetido ao Estado. Pois, nas palavras deste estudante, certamente preocupado com a ascendência católica na política termidoriana, "ou os padres serão submetidos ao Estado, ou o Estado será submetido aos padres...". 7

Posteriormente, o cidadão Rallier - um dos 250 membros do Conselho dos Anciãos (designação para o Senado no governo do Diretório) - enviou uma carta a seu colega do Conselho dos Quinhentos (nome da Assembleia), o deputado e jansenista abbé Grégoire (1750-1831). Sem se importar com a abordagem religiosa mais ortodoxa deste último, Rallier comunicou seu plano de que o governo republicano deveria instituir urgentemente um culto cívico para fincar a moral republicana na sociedade, pois, do contrário, a hidra católico-monárquica reapareceria (e, com ela, as reações dos grupos revolucionários extremistas). Apesar de pregar a tolerância a todos os cultos, o curioso da carta é justamente a intolerância do 'senador' vis-à-vis a Igreja católica, a qual, segundo ele, era anacrônica e imiscível com o regime republicano, devendo

\footnotetext{
${ }^{6}$ Benjamin Constant, Da força do governo atual da França..., cap. II.

${ }^{7}$ A. Mathiez, La Théophilanthropie et le culte décadaire 1796-1801 (Paris: Félix Alcan, 1904), p. 73.
} 
portanto ser extinta na França. Ressalte-se que o abbé Grégoire, com a colaboração de dois outros bispos, acabara de fundar a 'Societé libre de philosophie chrétienne' ('Sociedade livre de filosofia cristã'), cujo objetivo era o de reverter o processo de descristianização por meio do restabelecimento e reforço da doutrina jansenista (e seu símbolo maior, Port-Royal) e do combate aos cultos deístas bastante difusos desde o culto ao Ser Supremo.

Aqui, importa-nos menos a resposta de Grégoire do que constatar, como fez o historiador Mathiez em seu importante estudo sobre a religião na Revolução Francesa, que desde o início do regime do Diretório (1795-1799) circularam inúmeros projetos de cultos cívicos, sendo o deísmo a característica predominante da maior parte deles:

"Diante da impotência dos poderes públicos de oferecer à República as instituições morais e religiosas capazes de salvá-la do perigo realista e católico e de restaurar os costumes públicos e privados fortemente comprometidos sob a reação termidoriana, os patriotas de todas as nuanças concordaram em planejar a organização de um culto cívico, o qual teria o deísmo por base." ${ }^{8}$

Coube a um humilde livreiro e ex-jacobino ardoroso (escrevera em 1793 o panfleto L'espion de la révolution française, cujo tom de proscrição e perseguição está denotado no título), Jean-Chemin Dupontès (1760-1852) atender ao chamado da opinião pública letrada republicana, fundando a primeira sociedade teofilantrópica, no vindimário do ano V (setembro de 1796), a qual funcionaria até ser fechada por Napoleão, em 1801. Mathiez, após demonstrar como o mesmo fora acusado de ser ao mesmo tempo católico (pelos patriotas radicais, sobretudo aqueles ligados a Babeuf e Buonarroti) e ateu (neste caso, pelos católicos), destacou o quanto o ex-jacobino e aliado de última hora daquela burguesia liberal e defensora da propriedade era um confesso depositário do protestantismo. Naquilo que viria a ser, nas palavras de Mathiez, o 'evangelho' do deísmo francês, a saber, o Manuel des Théoantropophiles, de setembro de 1796 (Manual dos Teoantropófilos), Chemin expressará sua dívida intelectual para com o calvinismo, cujos cultos inclusive frequentrara:

"A analogia desta instituição com o cristianismo puro" - e o autor refere-se ao protestantismo - "é de tal modo sentida que, assim que a teofilantropia se fez pública, homens de

\footnotetext{
${ }^{8}$ Albert Mathiez, La Théophilanthropie et le culte décadaire..., p.77.
} 
grande mérito e que gozam de uma grande celebridade na República das letras (justamente conquistada), aconselharam os teofilantropos a se chamarem de 'cristãos primitivos'."'9

Pouco após redigir o Manual, Chemin viajou para os territórios suíços de Bâle, a pedido de seu protetor/patrocinador, o ministro da segurança Sotin, para lá cumprir uma missão (a qual Mathiez não especifica). Seja como for, é praticamente certo que Maistre, ainda assentado naquela que era uma verdadeira célula de espionagem contrarevolucionária em Lausanne (a qual, patrocinada pelo embaixador inglês para os cantões suíços, era coordenada por Mallet du Pan), tomou conhecimento daquela 'ilustre' presença, assim como é certo que não ignorou a vaga deísta na França, tão bem expressa pelo The Age of Reason (1794-5, as duas primeiras partes) do radical dissidente inglês Thomas Paine.

Não por acaso, de acordo com um dos biógrafos de Paine, M. D. Conway, o autor do The Age of Reason (A Idade da Razão) não apenas inspirou os deístas franceses (segundo ele, A Idade da Razão e o Senso Comum de Paine, ao lado do Manuel, eram os textos sinóticos daquele crescente deísmo pós-termidoriano), como esteve presente na inauguração solene do culto, onde teria pronunciado um discurso - o Discours sur l'existence de Dieu (Discurso sobre a existência de Deus). ${ }^{10}$ Ademais, Paine tornou-se amigo do franco-maçom e editor Nicolas de Bonneville (1760-1828), célebre pela defesa dos princípios republicanos e democráticos através das sociedades que ajudou a criar - respectivamente, os Amis de la Vérité (Amigos da Verdade) ou Cercle Social (Círculo Social), em outubro de 1790, com a colaboração do bispo Claude Fauchet (1744-1793); e em junho de 1791, logo após a malograda tentativa de fuga da família real, La Societé Républicaine (A Sociedade Republicana), na companhia de Nicolas de Condorcet (1743-1794), Thomas Paine e da influente girondina Mme Roland (17541793) - e de seus órgãos de imprensa (dos quais, o periódico La Bouche de Fer ou A Boca de Ferro, com os resumos dos debates do Círculo Social, era o mais popular). Portanto, tanto quanto o republicanismo radical ou democrático de Bonneville - cujos ideais igualitários concernentes ao gênero e à propriedade o colocavam à esquerda de muitos jacobinos nos primeiros anos de Revolução -, certamente era a moral religiosa

\footnotetext{
${ }^{9}$ A. Mathiez, La Théophilanthropie et le culte décadaire..., p. 108.

10 M. D. Conway, Writings of Thomas Paine (1894-1896), vol. IV apud Albert Mathiez, La Théophilanthropie et le culte décadaire..., op. cit., p. 105.
} 
deísta deste amigo íntimo ${ }^{11}$ de Paine e discípulo de Louis-Claude de Saint-Martin (1743-1803) que poderia ter despertado a atenção de Maistre. ${ }^{12}$

No início de 1798, quando o movimento teofilantrópico vivenciava o seu zênite, uma sociedade protestante de estudos religiosos propôs três questões num concurso aberto ao público: 1. Qual a origem dos teofilantropos?; 2. Qual a relação existente entre seus ritos e dogmas com o(s) do(s) cristãos?; 3. O que esta sociedade tem a oferecer para a República e para o cristianismo ${ }^{13}$

Conforme ilustrou Mathiez, "durante toda a trajetória da Revolução, os patriotas não esconderam suas simpatias pelo protestantismo. É curioso constatar que a théophilanthropie se oferece como uma filha do calvinismo". ${ }^{14}$

Tenha-se como exemplo um discurso-manifesto pronunciado por Révellière (um dos cinco membros do Diretório e protetor da teofilantropia daquela burguesia ilustrada e preocupada em sedimentar a República junto à opinião pública) no Conselho dos Quinhentos no dia de 12 floréal do ano V ( $1^{\circ}$ de maio de 1797), o qual teceu o seguinte retrato encomiástico (poder-se-ia dizer, hiperbólico) relativo ao protestantismo:

"Observai um país católico e um país calvinista e comparai-os... Nos países calvinistas, encontrareis lares mais harmoniosos, mulheres mais castas e mais ecônomas, maridos mais afetuosos e laboriosos, crianças mais amadas e respeitosas, um razoamento mais são, um povo mais ativo, mais industrioso, mais caridoso, melhor e mais feliz, um espírito público muito maior e o verdadeiro amor pela pátria."15

Porém, após o golpe de Estado do 18 frutidor do ano V, um certo Basse (homem de letras, teofilantropo e chefe da divisão do Conselho das Minas do Diretório) encaminhou um relatório (em fevereiro de 1798) a seus superiores no governo, no qual, além de informar os detalhes de seu trabalho técnico, descrevia as dificuldades que ele e seus colegas deístas encontraram em estabelecer o culto teofilantrópico entre as comunidades protestantes de Nîmes, contrariando a crença comum dos patriotas.

\footnotetext{
${ }^{11}$ Tão íntimo que, em reconhecimento ao abrigo concedido pelo amigo e sua esposa desde 1797, levou a mulher e os filhos deste último para morarem consigo nos Estados Unidos após Napoleão decretar a prisão de Bonneville. Devo esta fundamental associação entre as figuras de Bonneville e Paine ao professor Modesto Florenzano.

${ }^{12}$ Expresso num pequeno panfleto intitulado L'esprit des religions ( $O$ espírito das religiões, de 1791), o qual defendia a supressão da Igreja católica na França bem como a substituição da mesma por um novo culto filosófico-científico, cujos novos 'clérigos' seriam formados pelos filósofos e pelos cientistas.

${ }^{13}$ Albert Mathiez, Contributions à l'histoire religieuse de la Révolution Française (Paris: Félix Alcan, 1907), p. 175.

${ }^{14}$ Idem, p. 177.

${ }^{15}$ Ibidem.
} 
Mesmo diante deste contratempo e livres do perigo monarquista representado pelo clube de Clichy após 18 frutidor, os republicanos pretendiam tirar o máximo proveito daquela conjuntura, e para isto decidiram que era preciso extirpar o catolicismo das consciências, pois disto dependia o estabelecimento da República burguesa e liberal (do contrário, o catolicismo e seu oposto como o neo-jacobinismo de Babeuf e Buonarroti, reiniciariam o processo entrópico revolucionário que os membros do Diretório e seus intelectuais tratavam de evitar a todo custo: acreditava-se que a supressão do primeiro termo da equação resolveria de uma só tacada também o problema do segundo).

Mais do que nunca, impôs-se àqueles republicanos o problema da tradução da República em instituições e práticas, noutras palavras, a necessidade de converter as massas, especialmente a maioria camponesa, cujo histórico com a Revolução não fora dos mais animadores, como demonstravam a chouannerie e a Vendéia (apesar de a mesma como classe social ter sido a mais beneficiada da sociedade francesa pelo processo revolucionário).

Apesar da instrução pública merecer a atenção dos representantes do governo e seus intelectuais, as atenções voltaram-se para o estabelecimento de um culto cívico laico e republicano, pois importava assegurar a estabilidade do regime o quanto antes, e para isto era forçoso ganhar os corações e mentes dos adultos.

Diante deste quadro e dada a compatibilidade aparente entre o culto e os valores republicanos defendidos pela burguesia do Diretório, não demorou para que os teofilantropos e seus defensores no governo propusessem o reconhecimento da sociedade como religião estatal, restando apenas a homologação (que, por sua vez, dependia da aprovação de uma comissão especial designada pelo Conselho dos Quinhentos), já que ninguém vislumbrava melhor alternativa do que aquela apresentada por aqueles deístas franceses pós-termidorianos.

É neste contexto que devemos compreender o panfleto de Mme de Stäel (17661817) intitulado Des circonstances actuelles qui peuvent terminer la Révolution et des principes qui doivent fonder la République en France (Das circunstâncias atuais que podem terminar a Revolução e os princípios que devem fundar a República na França), e o qual, redigido no final de 1798 e publicado apenas em 1905, não deixa de apresentar ao historiador um excelente índice sobre as visões daquela elite filosófica e política termidoriana a respeito da relação entre religião e Estado. E não obstante reconhecesse as virtudes da sociedade teofilantrópica, Mme de Stäel avançou a hipótese de que o 
calvinismo era a opção mais adequada para preencher aquela necessidade espiritual e propagandística da jovem República.

E Maistre não só conhecera pessoalmente a intelectual liberal francesa como manteve com a mesma, durante um certo período do exílio suíço de ambos (isto é, entre 1793-95), uma relação marcada pela amizade e admiração recíprocas, pelo menos até a filha de Necker surpreendê-lo ao se engajar na política francesa - e com o apoio de outro protestante, Benjamin Constant - do lado "errado" da disputa, isto é, a favor da República. República, que o contrarrevolucionário saboiano, à guisa de Montesquieu e, mais recentemente, de Burke, julgava incompatível com as liberdades modernas, as quais só existiam sob as 'monarquias temperadas' (pela aristocracia e pelo cristianismo) da Europa.

Mme de Stäel, por sua vez, não só acreditava que o regime Republicano fosse compatível com as liberdades individuais e o equilíbrio dos poderes, como defendia, a exemplo dos teofilantropos, que se fazia necessário combater o catolicismo, a seu ver um sistema religioso incompatível com os modernos valores republicanos. Paradoxalmente, a intelectual liberal e o contrarrevolucionário saboiano não poderiam estar (ainda que por motivos diversos) mais de acordo sobre os efeitos de um específico entrelaçamento entre religião e política (neste caso, o protestantismo e a história política francesa):

"O sistema da República francesa não pode se fundar a não ser admitindo a razão como a base de todas as instituições e ideias... Toda religião que tivesse como base aquilo que se designa como dogmas, isto é, mistérios; que se apoiasse sobre a crença cega; [enfim] toda religião deste gênero teria necessidade de se estabelecer sobre os mesmos argumentos que, diferentemente aplicados, revelariam a nobreza e o trono." 16

Convencida de que o ateísmo era uma ideia negativa e desorganizadora (e na visão de mundo de Stäel, contrariando uma crença filosófica tipicamente voltaireana, as elites tinham ainda mais necessidade de uma sólida orientação moral do que os indivíduos comuns) tão incompatível com a República quanto o catolicismo, a autora admite que não restava à França senão optar por uma de duas alternativas, a teofilantropia e o protestantismo, as únicas adaptadas àquela específica demanda ética e institucional.

\footnotetext{
${ }^{16}$ Mme de Stäel, Des circonstances actuelles qui peuvent terminer la Révolution et des principes qui doivent fonder la République en France (1798). Paris: Librairie Fischbacher, 1906, p. 220.
} 
Diante do categórico reconhecimento de que a teofilantropia consistia na "instituição mais filosófica, isto é, ao mesmo tempo política e moral, que a Revolução instituiu até agora"17, como a autora se justificou para preteri-la em relação ao protestantismo? Porque, responderá Mme de Stäel nos parágrafos seguintes, apesar de ambos guardarem grandes semelhanças, o protestantismo ainda levava certas vantagens.

Em primeiro lugar, os protestantes possuíam uma memória coletiva da qual os teofilantropos, recém-instituídos, ainda estavam destituídos. De acordo com a intelectual protestante assumida, se as instituições políticas podiam prescindir da tradição, o mesmo não poderia ser dito a respeito das instituições religiosas. ${ }^{18}$

Em segundo lugar, e como consequência do item anterior, na opinião de Mme de Stäel as cerimônias teofilantrópicas careciam absolutamente de prestígio e de recursos cerimoniais, de modo que arriscavam circunscreverem-se às elites letradas. Para conquistar novas almas e os corações para a República, era preciso um cerimonial capaz de aguçar a imaginação do mais simples e remoto camponês. ${ }^{19}$

Mas, a principal vantagem do protestantismo sobre a teofilantropia estava no fato de o último ainda estar muito identificado com as divisões/dilacerações políticas recentes, como a própria figura de Chemin demonstrava (apesar de não dá-lo como exemplo, a figura de Chemin fica subentendida no texto), enquanto o protestantismo já havia confirmado (na Europa e nos Estados Unidos) seu compromisso secular com a Liberdade e a Igualdade:

"Decerto, os teofilantropos são amigos ardorosos da República. Criados para defendê-la, não se deve recear que abandonem a causa, embora talvez seja muito evidente que os mesmos tenham uma missão política, e que o povo os veja até agora mais como reuniões de partido do que como sociedades religiosas. Os protestantes também são amigos da liberdade e da igualdade, pela própria organização do culto e de seus ministros, pelas lutas sustentadas contra os católicos, contra os episcopados anglicanos, contra as doutrinas do poder despótico e da hierarquia... Mas pode ser que os seguidores do culto protestante, que não traz nada que lembre a divisão de partido, sejam mais bem ouvidos quando pregarem pela República como algo em acordo com as idéias religiosas. O culto dos teofilantropos é amiúde tratado por muitos como um meio político, e não como uma crença verdadeira."20

\footnotetext{
${ }^{17}$ Mme de Stäel, Des circonstances actuelles..., p. 220.

${ }^{18}$ Mme de Stäel, Des circonstances actuelles..., p. 222.

19 Idem.

${ }^{20}$ Ibidem, p. 225.
} 
O que Stäel não diz, embora deixe implícito - e, de certo modo, antecipando o principal argumento de Constant no De la Religion $(1824-1831)^{21}$ e, posteriormente, de Tocqueville no segundo volume da Democracia na América (1840) -, é que, apesar de suas bases perfeitamente racionais e de seu expresso zelo republicano, o deísmo teofilantropo corria o risco de servir a interesses políticos do Estado (e, no interior deste, a interesses específicos), desta forma atentando contra os pressupostos de uma sociedade livre (baseada na liberdade de imaginação/espontaneidade e no sacrifício dos interesses egoísticos) que julgava promover. Isto, somado ao risco, sempre em potencial, de o mesmo suscitar outro processo descristianizador, direcionou a escolha para a sua profissão de fé protestante.

Receio este, diga-se, não desprovido de causas históricas e pessoais, a saber, uma crítica indireta aos revolucionários franceses de confissão religiosa protestante, divididos entre o agnosticismo e o pietismo.

Pois no que diz respeito ao protestantismo francês, pelo menos dois especialistas no assunto, respectivamente Émile-G. Léonard ${ }^{22}$ e Burdette C. Poland ${ }^{23}$, destacaram o quanto no século XVIII o mesmo, então sob o assédio dos Bourbons e em decorrência disto, permitiu-se influenciar mais do que deveria pelas idéias da Filosofia das Luzes, algo tão bem expresso nas figuras dos pastores Rabaut de Saint-Étienne (o pai e o filho revolucionário). Como demonstraram ambos os estudiosos, mais do que atraírem fiéis à sua religião, eram eles que acabavam atraídos pelas ideias Ilustradas, e não necessariamente por aquelas que lhes diziam respeito mais imediatamente, como a tolerância. Rabaut-pai, cuja ortodoxia não podia ser posta em dúvida, confessara a necessidade de simplificar ao máximo a religião, despojando-a de todos os acessórios e seguindo um modelo ou um "gosto" philosophique. Seu filho, o futuro revolucionário e célebre pelos discursos na Assembléia Nacional que chegou a presidir, deixara-se influenciar tanto pelas teorias do conhecimento de Locke e Condillac que, nele, a doutrina calvinista do pecado original cedera lugar à crença de que "a religião cristã é nada mais do que uma religião natural revelada aos mortais e confirmada por Jesus Cristo", bastando aos homens apenas recorrerem à razão (não inata, como defendiam os

\footnotetext{
${ }^{21}$ Cf. Alan Pitt, "The Religion of the Moderns: Freedom and Authenticity in Constant's De la Religion", in: History of Political Thought XXI (1), 2000, p. 68-87.

22 E.-G. Léonard, Problèmes et expériences du Protestantisme français: l'urbanisation, l'embourgeoisement, les déviations ecclésiastiques, l'attrait catholique (Paris: Fischbacher, 1940), p. 77.

${ }^{23}$ B. C. Poland, French Protestantism and the French Revolution: a study in Church and State, Thought and Religion, 1685-1815 (Princeton: Princeton University Press, 1957), p. 246-252.
} 
padres e teólogos, mas dependente dos sentidos e determinada pelas experiências) para conquistar infalivelmente o melhor dos mundos:

"Todos os nossos pensamentos originam-se nos sentidos, ou seja, nossa alma não possui um pensamento, um raciocínio, um sentimento, que não lhe seja dado pelo corpo... Nossas paixões, criminosas em seus excessos, são inocentes em seu princípio" [pois] " nada mais são do que nossas necessidades, e uma vez que estas nos são dadas por nosso criador, as mesmas são inseparáveis de nossa natureza. ${ }^{24 "}$

Estas considerações prévias ajudem-nos, talvez, a compreender ou iluminar os motivos que levaram Maistre a vincular o protestantismo à Revolução de uma maneira tão contundente e, pode-se até dizer, temerária. Do mesmo modo, pode sugerir uma chave de leitura pela qual o Protestantismo, antes de iluminar a Revolução, é pela mesma explicado...

No texto anterior, vimos como o manuscrito Sur le Protestantisme, conservado nos Arquivos Departamentais da Sabóia ("Fonds de Maistre", 2J7, p. 318-362) em Chambéry, na França, e que deu origem às Reflexões, começou a ser esboçado em 1796, quando Maistre redigia seus tratados antirrousseaunianos. Após revisitar o contexto da composição da obra em seus mais variados ângulos, é chegado o momento de expor seus argumentos.

Neste sentido, pode-se afirmar com ainda mais certeza de que, a exemplo das Considerações sobre a França, as Reflexões sobre o Protestantismo encontram-se em germe no De la souveraineté du peuple (1795-6).

Com base no burkeano argumento de que toda questão filosófica deve ser resolvida pela história (ou seja, de que a história é uma política experimental) - que

\footnotetext{
${ }^{24}$ Rabaut Saint-Étienne, "Superiorité du Christianisme" apud B. C. Poland, French Protestantism and the French Revolution..., p. 248.
} 
"exige mais experiência do que aquela que o homem pode adquirir em vida" ${ }^{25}$-, Maistre empreendeu o seguinte silogismo: se a "Philosophie não é senão a razão humana agindo sozinha, e que a razão humana reduzida às suas forças individuais não é mais do que um bruto cujo poder se reduz a destruir" ${ }^{\prime 26}$; se "o tigre que dilacera faz seu métier...", de modo que o verdadeiro culpado "é quem o desacorrenta e o lança sobre a sociedade", isto é, o espírito filosófico e cético que examina todos os princípios e destrona todas as formas de autoridade ("Marat e Robespierre não teriam feito algum mal, pois teriam sido contidos por este freio que vós" - os filósofos - "rompestes" ${ }^{27}$ ), então a Filosofia foi a principal responsável pela Revolução. Ao aplicar este conceito ao discurso político e religioso então em voga na República termidoriana, fica mais fácil compreender por que Maistre transferiu o eixo de seu combate, da 'Soberania do Povo' para o Protestantismo, de Rousseau e Condorcet a Paine e Rabaud de Saint-Étienne, este último por ele descrito como um "fanático Constituinte e philosophe na melhor acepção do termo" ${ }^{28}$.

Um texto curto (cerca de 34 páginas) ${ }^{29}$ e sem divisão de capítulos, poder-se-ia sugerir (ou pelo menos arriscá-lo) que, caso se queira apreender o 'espírito' e/ou as motivações do autor no contexto da composição da obra, a leitura poderia ser feita na ordem inversa, ou seja, começar pelo fim.

Pois, por detrás do intenso e virulento requisitório que caracteriza o texto desde suas primeiras linhas (uma das causas, senão a principal, de o mesmo nunca ter sido publicado em vida do autor, mas somente em 1870), sobressai um argumento, decorrente da experiência do exílio e do acompanhamento dos debates públicos franceses: o protestantismo e seus seguidores guardavam 'afinidades eletivas' com o jacobinismo:

"No mundo moral como no mundo físico, existem afinidades, atrações eletivas. Certos princípios se convêm e outros se repelem: o conhecimento dessas qualidades verdadeiramente ocultas é a base da ciência. Peço aos observadores para que reflitam sobre a afinidade, verdadeiramente espantosa, que acaba de se manifestar entre o protestantismo e o jacobinismo.

\footnotetext{
${ }^{25}$ E. Burke, Reflexões sobre a Revolução em França (1790). Trad. de Renato de Assumpção Faria, Denis Fontes de S. Pinto e Carmen Lidia R. R. Moura. Brasília: UNB, 1982, p. 90; J. de Maistre, De la souveraineté du peuple, Livro I, cap. 2.

${ }^{26}$ J. de Maistre, De la souveraineté du peuple, Livro I, cap. 8.

${ }^{27}$ J. de Maistre, De la souveraineté du peuple, Livro I, cap. 13.

${ }^{28}$ J. de Maistre, De la souveraineté du peuple, Livro I, cap. 11.

${ }^{29}$ De acordo com a configuração presente no oitavo volume de suas Oeuvres Complètes (Lyon: Vitte et Perussel, 1893).
} 
Desde o primeiro instante da Revolução, os inimigos do trono mostraram pelo protestantismo uma ternura filial. Todos os olhos viram esta aliança e ninguém se enganou a esse respeito, nem mesmo os protestantes estrangeiros. Viu-se alguma vez, nas três assembleias que arrasaram e desonraram a França, não digo um ato, mas um sinal de desconfiança em relação aos protestantes? Não, jamais. Desafio que se encontre a menor evidência." ${ }^{30}$

Como se percebe, a crítica maistreana se dirige menos para o caráter doutrinal do que para o efeito político/social ensejado pelo protestantismo. Diante de uma possível objeção ou defesa do protestantismo em termos doutrinais, o autor insistirá no caráter 'experimental' de sua crítica, numa estratégia indutiva que, não raro, visa reduzir seu adversário ao silêncio. Afinal, se o filósofo Ernest Cassirer estiver correto no que escreveu sobre o huguenote francês Pierre Bayle (o primeiro protestante ilustre citado no ensaio maistreano), a saber, que o núcleo de sua poderosa arma crítica ("uma revolução copernicana" na história) expressa em seu Dictionnaire critique et philosophique (1697), como o próprio título da obra indica, traduzia-se na submissão de todas as verdades estabelecidas ao exame crítico e/ou às evidências factuais ${ }^{31}$, constatamos que um dos principais recursos retóricos do contrarrevolucionário e católico Maistre consistiu em aplicar o critério hermenêutico examinador da Filosofia das Luzes - tão bem expresso pelas figuras de Bayle e Locke (que viria a ser alvo de suas críticas futuras) - contra seus imaginários adversários e leitores filosóficos. Desafia-os a indicar um protestante ilustre que tenha assumido a defesa do soberano ou da monarquia que, havia pouco, concedera-lhes o Edito de Tolerância de 1787.

\footnotetext{
${ }^{30}$ Joseph de Maistre, Réflexions sur le Protestantisme, O.C., VIII: 86-87.

${ }^{31}$ E. Cassirer expôs melhor do que ninguém o caráter revolucionário da crítica de Bayle, cujo dicionário, não por acaso, associou o termo "histórico" ao "filosófico": "Se quisermos dar-nos conta da meta a que se dirige a historiografia de Bayle, teremos que comparar seu trabalho com o último grande intento de uma concepção e construção da história puramente teológicas, tal como as ofereceu Bossuet em seu Discours sur l'histoire universelle. Ali, um plano conjunto da história, sublime em seu gênero, uma interpretação religiosa de seu sentido. Porém, este atrevido edifício repousa sobre débeis cimentos, se considerarmos as bases empíricas, os puros feitos em que se apoia; pois sua verdade se assegura mediante um círculo vicioso. Toda a autoridade dos fatos, do efetivamente histórico, funda-se, para Bossuet, na autoridade literal da Bíblia; embora esta tenha que construí-la sobre a autoridade da Igreja e, com ela, da tradição. Desta maneira, a tradição converte-se no fundamento de toda certeza histórica, se bem que não é possível fundar nem demonstrar seu próprio conteúdo e valor a não ser mediante os testemunhos históricos. Bayle é o primeiro pensador moderno a expor , com um implacável rigor crítico, este círculo vicioso e a chamar constantemente a atenção para as suas fatais consequências. Neste aspecto, sua realização histórica é menor apenas à de Galileu dentro do conhecimento natural. Assim como Galileu reclama a absoluta independência da concepção e explicação dos fenômenos naturais com respeito às palavras da Bíblia e verifica e justifica esta pretensão metodicamente, o mesmo faz Bayle no terreno da história. É ele quem, dentro desta ciência, realiza de certo modo a 'revolução copernicana'; pois funda a verdade histórica, não sobre alguma objetividade dogmática dada (esteja esta na Bíblia ou na Igreja), mas remontando à origem subjetiva e às condições subjetivas desta verdade ." Vide: E. Cassirer, La filosofia de la Ilustración (1932). México, D.F: Fondo de Cultura Económica, 1997, p. 232-233.
} 
"Rogo apenas que se faça uma observação: é que, entre todos os protestantes franceses, não se encontrou um único escritor que tenha usado sua pluma pelo bom partido. Pode-se alegar talvez que eles estavam numa proporção inferior em relação ao resto da nação, embora não esteja solicitando que se me apontem centenas de protestantes defensores da monarquia. Solicito que, entre eles e, sobretudo, entre a classe de ministros, se me indique um único homem que tenha tido a coragem e a nobreza de se juntar à numerosa falange dos franceses de todas as classes que consagraram seus talentos a contrariar os princípios da Revolução ou a deplorar os seus excessos... Que se me aponte apenas um homem que tenha tido a coragem de levantar a voz para dizer: Vós fazeis mal. Onde se encontra este protestante francês e, sobretudo, este ministro?"${ }^{132}$

Mas é sobretudo na passagem seguinte que a indução maistreana visa desarmar seu potencial adversário. Apesar de os ministros protestantes pregarem o mesmo Evangelho do clero católico, as máximas religiosas proferidas pelos protestantes jamais inquietaram "os tiranos da França", os quais "sabiam bem aquilo que ninguém ignora: que não há mais soberania religiosa entre os protestantes, que o princípio governante encontra-se nele reduzido e que um livro separado da autoridade que o explica, não é nada". Confirmando aquela que viria a ser uma das conclusões das pesquisas de um historiador socialista como Mathiez, Maistre sustentará que o protestantismo nunca levantou a menor suspeita entre os jacobinos.

"O Evangelho ensinado pela Igreja protestante nunca despertou temor em Robespierre.I Assim que os Titãs da Convenção Nacional imaginaram aniquilar o sacerdócio, apagar até os últimos traços do cristianismo, consagrar o culto da Deusa Razão, e conduzir à justiça os ministros da religião para obter deles uma infame apostasia, por que não se viu nenhum protestante entre esses miseráveis? É porque aqueles tiranos odiosos não os temiam em nada. É o verdadeiro culto, o culto eterno que odiavam; sentiam o caráter sacerdotal onde ele estivesse e não iam buscá-lo onde ele não existia: queriam loucamente abolir o catolicismo, o único que contrariou eficazmente a Revolução e o único que pode terminá-la. Jamais conceberam a menor suspeita a respeito dos doutores protestantes." ${ }^{13}$

\footnotetext{
${ }^{32}$ Joseph de Maistre, O.C., VIII: 84-85.

${ }^{33}$ Joseph de Maistre, O.C., VIII: 87-88.
} 
Noutro momento e ainda dentro desta lógica de leitura a contrapelo, a experiência recente - dizia Maistre - ensinara duas lições: a primeira, que apesar dos excessos condenáveis de sua política persecutória aos protestantes, Luís XIV estava certo, razão pela qual faleceu em seu trono, não no cadafalso, como o benevolente Luís XVI. E nada demonstrava melhor isto do que a figura que sintetizava todos os aspectos do protestantismo revolucionário (doutrinalmente anti-hierárquico, protofilosófico e, finalmente, ardoroso patriota e revolucionário), isto é, Rabaut de Saint-Étienne:

"Quer-se ter certeza de que Luís XIV era conduzido pelos desígnios da política mais sã?... Basta considerar a conduta dos sectários durante a Revolução Francesa. Luís XVI acabara de conceder aos protestantes um benefício saliente: acabara de acordar-lhes todos os direitos de cidadania... O cego monarca, enganado por seu excelente coração... fez mais do que perdoar a seita inimiga: honrou-a e permitiu-lhe que o tocasse. Como esta lhe retribuiu?... Nem bem se escutou o sino da revolta e Rabaut voa a Paris. Sabe-se o que ele fez por lá. O mesmo figura na primeira assembleia entre os inimigos mais inflamados da monarquia e, na terceira, sua boca, que ousara orar por Luís XVI, vota pela morte do monarca virtuoso, com Marat, Lebon e Robespierre." ${ }^{134}$

Em seguida - naquilo que, a nosso ver, caracteriza um dos aspectos conceituais mais interessantes desta peça polêmica -, Maistre, novamente amparado por sua leitura da experiência revolucionária, comunicará que foi entre os puritanos ingleses que a Revolução Francesa produziu um de seus frutos mais radicais, numa clara alusão a Paine, o qual poderia ser abordado criticamente sob dois ângulos, como democrata radical e como deísta, seja pelo Os Direitos do Homem (1791-2), seja pelo The Age of Reason:

"A Inglaterra acaba de fazer a experiência desta afinidade espantosa existente entre o protestantismo e o jacobinismo: a igreja anglicana é mais católica do que ela própria imagina, de modo que se pode acreditar que aquilo que ela tem de católico salvou o Estado. Mas não é entre os protestantes propriamente ditos, não é entre os puritanos que o veneno da Revolução Francesa produziu as maiores devastações? Entre os inumeráveis panfletos que o grande acontecimento de que somos testemunhas produziu na Inglaterra, tudo aquilo que partiu das mãos dos dissidentes está mais ou menos marcado com o selo da Revolução: estas palavras conservadoras "church and state" levam-nos a entrar em convulsão, e o juramento do Test Act é

\footnotetext{
${ }^{34}$ J. de Maistre, O.C., VIII: 82-84.
} 
para eles um ato da tirania mais insuportável. Eles confessam, pregam ruidosamente a doutrina da soberania do povo e dela extraem as consequências práticas mais assustadoras." 35

Esta percepção maistreana encontra amparo nas investigações do historiador britânico J. C. D. Clark, que numa de suas obras definiu o deísmo como "profundamente influente no século XVIII europeu”, de modo que sua filosofia moral, oculta sob o título de ius naturale, permitiu-lhe abandonar a lei eterna da fé revelada para culminar "na completa autonomia moral da razão", conforme defendida por Kant. O 'alto grau de correlação no início do século XVIII entre republicanos neoharringtonianos e deísmo protestante tem sido corretamente observado; a correlação entre deísmo e política antimonárquica iria sobreviver e, de fato, culminaria em 1776 no mais efetivo de todos os tratados políticos deístas, o Common Sense de Paine." ${ }^{, 36}$ Noutra obra e ainda com respeito a Paine, o mesmo Clark destacará o quanto as ideias e o exemplo da Revolução no além-Mancha radicalizaram aquele deísmo, cuja maior expressão fora justamente a obra The Age of Reason, de Paine. ${ }^{37}$

Através do debate inglês sobre a Revolução Francesa, particularmente o que opôs Burke a Paine, Maistre inferiu uma lei política ou afinidade eletiva típica do catolicismo, qual seja, ao contrário do protestantismo - uma força desagregadora e centrífuga ("inimigo de toda espécie de soberania") -, o catolicismo exerceria uma força social centrípeta, qual seja, favorável ou "defensor ardente de todos os governos".

"(...) a natureza íntima do protestantismo o torna inimigo de toda espécie de soberania, como a natureza do catolicismo o torna o amigo, o conservador e o defensor mais ardente de todos os governos... Eis por que os dissidentes ingleses frequentemente acusaram os defensores célebres da constituição britânica de pender para o catolicismo, isto é, para o sistema de uma lealdade à prova até da injustiça, crime que o protestantismo não perdoa./ Paine não censurou o venerável Burke por "facilitar o retorno do catolicismo aos ingleses, e de conduzi-los à infalibilidade religiosa pela infalibilidade política?"38/ Sem dúvida, este grande patriota, este grande escritor, este célebre profeta que adivinhou a Revolução Francesa, é culpável porque não

\footnotetext{
${ }^{35}$ Joseph de Maistre, O.C., VIII: 88.

${ }^{36}$ J. C. D. Clark, The Language of Liberty 1660-1832. Political discourse and social dynamics in the Anglo-American world (Cambridge: Cambridge University Press, 2004), p. 38.

37 J. C. D. Clark, English Society 1688-1832. Ideology, Social Structure and Political Practice during the Ancien Regime (Cambridge: Cambridge University Press, 2000), p. 493.

${ }^{38}$ Nota de J. de Maistre. "He (M. Burke) has shortened his journey to Rome by appealing to the power of this infallible Parliament of former days" (Paine, Rights of Men, London, 1794, in-8 ${ }^{\circ}$, p. 14).
} 
quer acreditar que o povo tenha o direito de votar nas encruzilhadas a deposição da constituição..."139

Portanto, Paine é criticado menos em razão de suas convicções deístas críticas à religião revelada do que pelas consequências ou efeitos práticos e/ou políticos das mesmas. Ademais, sabe-se que, não obstante o fato de seu livro The Age of Reason representar uma das mais contundentes defesas da religião natural e uma filípica contra os mistérios e a hierarquia do cristianismo, Paine escreveu o mesmo numa chave crítica ao processo descristianizador da Revolução Francesa. Assim, é o aspecto moral do 'protestantismo'/deísmo corporificado em Paine que, na visão de Maistre, demonstrava o perigo ou as afinidades eletivas entre o protestantismo e o jacobinismo.

Desta maneira, Maistre concordará com a conclusão de Paine em Os Direitos do Homem, para quem o espírito democrático (que o saboiano associa ao protestantismo) suscitaria revoluções permanentes nos Estados. Quando associado ao protestantismo, como no caso dos cantões suíços, o risco de 'contaminação', isto é, de uma reivindicação democrática, era certo ${ }^{40}$.

Porém, no contexto da vacilante República francesa (cuja elite política e intelectual tratava, sem muito êxito prático, de associar a estabilidade e o princípio de conservação social à República representativa), admitir a democrática tese da 'Revolução Permanente' de Paine equivalia a dar munição para o 'inimigo' monárquico e contrarrevolucionário' (para o qual o repouso seria impossível sob um regime republicano), uma antinomia ou incongruência conceitual da parte daqueles republicanos e revolucionários não ignorada por Maistre, conforme as críticas dirigidas a Constant nas Considerações sobre a França deixam claro.

${ }^{39}$ Joseph de Maistre, O.C., VIII: 90-91.

${ }^{40}$ Leia-se o seguinte trecho: "Não se exprime com exatidão quando se diz que o protestantismo, no geral, é favorável à república: ele não é favorável a nenhum governo; ataca-os todos. Porém, como a soberania não existe plenamente a não ser nas monarquias, detesta particularmente esta forma de governo, procurando as repúblicas onde tem menos a corroer. Mas aqui como alhures, desgasta a soberania e não pode suportar o jugo social. É republicano nas monarquias e anarquista nas repúblicas. Na Inglaterra, não cessa de vociferar contra a prerrogativa real; a união constitucional do cetro com a cruz ferve seu sangue. Sabe perfeitamente que não pode quebrá-los a não ser separando-os, de modo que trabalha sem descanso nisto. Nas repúblicas, a própria imagem de uma soberania o desagrada; persegue-a como a realeza e, buscando sempre dispor a autoridade ao maior número, tende ininterruptamente à anarquia. A época em que vivemos apresentou um espetáculo interessante deste gênero: viram-se repúblicas federativas, embora religiosamente divididas, submetidas ao veneno da Revolução Francesa, de modo que o olhar menos atento pôde seguir os efeitos disso. Nos estados protestantes, os soberanos balançaram; é possível mesmo que a essência do governo tenha sido alterada sem retorno. Nos estados católicos, porém, a soberania religiosa, combatendo por seu aliado, os povos, irredutíveis em sua fidelidade, não deram um passo na direção dos princípios franceses." Cf. J. de Maistre, O.C., VIII:93. 
No próximo passo, para reforçar o caráter não-doutrinário ou ultramontano de seu requisitório contra o protestantismo, mais do que remeter à afinidade pessoal/intelectual do filósofo ilustrado e republicano Condorcet com o protestantismo (tão bem expresso na amizade deste com Paine ${ }^{41}$ ), Maistre recorrerá ao testemunho histórico do revolucionário francês (síntese perfeita do philosophe com o cientista e o fervoroso revolucionário republicano) conforme exposto no Esboço de um quadro histórico dos progressos do espírito humano (redigido em 1793), para reforçar seu argumento (ou indução) a respeito dos efeitos políticos e sociais do protestantismo, a saber, a democracia e a secularização da cultura:

A grande base do protestantismo sendo o direito ao exame, este direito não encontra limites: aplica-se sobre tudo e não pode receber freio... Não há um autor da execrável Revolução de que somos testemunhas que não tenha elogiado aquela do século dezesseis. Pode-se observar, na obra póstuma de Condorcet, a que ponto talvez o mais odioso dos revolucionários franceses e o inimigo mais fanático do cristianismo era amigo da Reforma... "As novas seitas", afirma, "não podiam sem uma contradição grosseira reduzir o direito de exame a limites muito estreitos, pois acabaram de estabelecer por meio deste mesmo direito a legitimidade de sua separação."42/ Não se pode revelar com maior clareza o segredo da seita: apelando à razão individual diante da razão nacional e ao exame diante da autoridade, o protestantismo submete todas as verdades ao direito ao exame... É o que pretendem Condorcet e seus semelhantes."43

Todavia, Maistre foi além do fato de identificar as 'afinidades eletivas' entre o protestantismo e o republicanismo revolucionário. Naquilo que constitui outra característica importante da obra, o contrarrevolucionário saboiano antecipa uma temática que depois seria plenamente explorada na De l'Église gallicane (1821), a saber, de que na história política francesa pré-revolucionária, o principal órgão condutor dos efeitos ou princípios do calvinismo ( isto é, de oposição seja à ortodoxia católica, expressa pelos jesuítas, seja à monarquia, uma vez que não se podia atacar o aparelho ideológico do Estado sem ricochetear na própria soberania, como sustentara Quinet ${ }^{44}$

\footnotetext{
${ }^{41}$ Além de frequentar a casa de Condorcet, a esposa deste traduzira para o francês e do próprio punho a primeira parte de Os Direitos do Homem de Paine, logo após a malograda tentativa de fuga de Luís XVI. Cf. Elisabeth Badinter e Robert Badinter, Condorcet: un intellectuel en politique (Paris: Fayard, 1988), p. 369.

${ }^{42}$ Nota de J. de Maistre, Esquisse d'un tableau historique des progrès de l'esprit humain, p. 206.

43 Joseph de Maistre, O.C., VIII: 91-92.

${ }^{44}$ E. Quinet. Le Christianisme et la Révolution française (1845), $12^{\mathrm{ème}}$ leçon.
} 
foi justamente uma corrente religiosa surgida no interior da Contrarreforma católica, o jansenismo, sobretudo depois deste assumir uma face menos doutrinal e mais política (através da oposição Parlamentar às medidas das autoridades clericais e ministeriais), após a política persecutória de Luís XIV que redundou no fechamento de Port-Royal e na aplicação, em solo francês, da condenação formal ao jansenismo pela bula papal Unigenitus, de 1713). Se o rei, através de seus bispos e parlamentos, era a expressão da ordem divina e da justiça na terra, o jansenismo parlamentar tratou de perturbar a ambos, abrindo espaço para o domínio do filosofismo junto à opinião pública:

"Quando se reflete sobre este caráter indelével do protestantismo, fica-se menos surpreso com o ódio que lhe professaram certos poderes católicos, Luís XIV, por exemplo, cuja intolerância exerceu forte impressão sobre os filósofos... Citou-se inúmeras vezes as perseguições de P. Le Tellier contra os jansenistas: pode ser que este homem fosse culpado aos olhos de Deus, pode ser que não; não o sei melhor do que aqueles que o acusam. Contudo, que o ódio tenha sido refletido ou cego, o certo é que o mesmo era francês e politicamente bom. $\mathrm{O}$ jansenismo, por sua extrema afinidade com o calvinismo, era um inimigo da França, e aquilo que testemunhamos justifica plenamente aquele famoso jesuíta, pois o jansenismo se mostrou enormemente culpável pela Revolução Francesa, não tendo auxiliado pouco seus dois irmãos, o filosofismo e o protestantismo." 45

Também neste ponto a análise de Maistre encontrará amparo numa historiografia não necessariamente conservadora ou ultramontana, como seria simples supor. Leia-se o que escreveu o filho de mãe huguenote e historiador republicano-liberal Edgar Quinet (1803-1875) em Le Christianisme et la Révolution française (1845):

"Caso se queira observar de um posto mais elevado como a velha sociedade francesa estava condenada muito antes da Revolução, basta considerar o primeiro monumento da Santa Sé no século XVIII... Com efeito, seu perigo" [da Revolução] "(...) apareceu-lhe... pela primeira vez. O jansenismo, impulsionado pelas vias dos reformadores, tendia, a exemplo deles, a diminuir a autoridade dos padres ao abandonar tudo a Deus. O perigo para a antiga Igreja era real; a despeito dos juramentos de obediência, ninguém podia dizer, ao entrar neste caminho, aonde o mesmo ia parar. Port-Royal arruinado se reerguia nas almas. Aquela mesma humildade de Lutero e de Calvino, presságio da revolta, reaparecia sob outros aspectos, em meio à Igreja católica... Em 1712... a Santa Sé publica sua bula Unigenitus, monumento inacreditável da

\footnotetext{
${ }^{45}$ Joseph de Maistre, O.C., VIII: 78-79.
} 
história do cristianismo. Um verdadeiro estupor arrebatou o espírito dos crentes mais ardorosos; o mesmo dilacerou a França por meio século... O século XVIII se inicia com mais solenidade do que se nos diz... Eis a primeira journée do século XVIII... marca de uma nova era" [e] "... primeiro sinal da derrubada do antigo mundo religioso e social. Nem Voltaire, nem Rousseau, tiveram uma autoridade suficiente para precedê-lo." ${ }^{46}$

Para que se faça uma ideia do quanto esta hipótese maistreana era avançava para seu tempo - mesmo levando em consideração o que nos informou Darrin C. McMahon, a saber, que constituía algo nada incomum na tradição contrarrevolucionária do final do século XVIII e início do XIX associar os jansenistas às teorias da conspiração ${ }^{47}$-, seria preciso esperar mais de um século, até 1928, para que a historiografia francesa sobre a Revolução produzisse a primeira obra de fôlego sobre o assunto. ${ }^{48} \mathrm{Nem}$ mesmo na monumental obra de um historiador conservador como H. Taine (1828-1893) fomos capazes de encontrar semelhante desenvolvimento conceitual. Depositário da leitura crítica burkeana e tocquevilleana, Taine atribuiu a Revolução ao absolutismo, o qual fora diretamente responsável pelo desenvolvimento de uma intelligentsia filosófica e revolucionária. Mesmo quando admite, numa passagem do Les Origines de la France Contemporaine (1876-1894), que a oposição parlamentar (ao lado dos economistas) foi a responsável por abrir o terreno para os filósofos na política, o mesmo não estabelece nenhum liame entre aquela oposição e a tradição intelectual (galicana e históricoconstitucional) jansenista. ${ }^{49}$

Após Taine e por muito tempo ainda, a perspectiva hegemônica da historiografia (fosse ela de esquerda ou de direita) insistiu em vincular o nascimento da opinião pública à ação dos filósofos do século XVIII. Ninguém melhor do que o filósofo alemão Jürgen Habermas logrou conferir um estatuto de autoridade a este conceito. Em seu The Structural Transformation of the Public Sphere (1962), Habermas observou que o nascimento da opinião pública esteve vinculado ao desenvolvimento ou cristalização da classe burguesa (professores, escritores, funcionários civis, empresários) nos quadros do

\footnotetext{
${ }^{46}$ Edgar Quinet, Le Christianisme et la Révolution française, $12{ }^{\mathrm{ème}}$ leçon.

${ }^{47}$ Darrin M. McMahon, Enemies of the Enlightenment. The French Counter-Enlightenment and the making of the Modernity (New York: Oxford University Press, 2001), p. 80-83.

${ }^{48}$ Edmond Préclin, Les jansénistes du XVIIIe siècle et la Constitution civile du clergé. Le développement du richérisme, sa propagation dans le bas-clergé, 1713-1791(1928).

49 Hippolyte A. Taine, Les origines de la France contemporaine, Livro IV, cap. 2 (Paris: Hachette, 1891), $6^{\mathrm{a}}$ edição, vol. I, parte I.
} 
Estado absolutista e sua política mercantil. Em termos que em muito se assemelham à opinião de Tocqueville do primeiro volume de O Antigo Regime e a Revolução (1856), Habermas sustenta que a burguesia foi vítima do mesmo processo centralizadoradministrativo da monarquia que lhe deu origem, e o qual consistia em afastá-la do poder ou dos meios de produção (por meio do mercantilismo ou da nobilitação decorrente da compra de cargos de ofício, com as proibitivas normas que necessariamente despojavam da economia francesa contingente considerável de empreendedores), razão pela qual reivindicou uma cidadania de novo tipo e que, à diferença dos cidadãos da antiga polis, representava uma extensão da esfera privada da família burguesa. Esta, baseada em certos conceitos de humanidade que emergiam no bojo deste setor familiar/privado, por sua vez teria inventado a "opinião pública", responsável por submeter tanto a cultura (a religião acima de tudo), quanto a administração absolutista, a uma crítica racional, tornando-se politicamente orientada. Se os salões literários e os cafés foram seus media ou 'redes' iniciais, não tardou para que esta burguesia se apoderasse da mídia impressa e do jornalismo (panfletos inclusos), revertendo-os em seu benefício. Na França, isto teria ocorrido entre as décadas de 1750 e 1760, que testemunharam a emergência dessa nova esfera pública burguesa, bem como de seus soldados avançados, os philosophes ${ }^{50}$.

Portanto, ao pretender mapear as origens de nossa modernidade laica, Habermas negligenciou a importância dos antecedentes teológico-políticos para a emergência e cristalização dessa nova opinião pública.

Posteriormente, nos quadros de celebração do bicentenário da Revolução de 1789 e de retomada das leituras políticas sobre a Revolução (diante da derrocada do socialismo real e da consequente crise do marxismo), verificou-se da parte de uma historiografia focada nos aspectos culturais e políticos da Revolução mais do que uma referência ao papel político da oposição jansenista.

Assim, J. McManners, apoiado na pesquisa de outros autores ${ }^{51}$, optou em seu Church and Society in Eighteenth-Century France (1998) por reconhecer a dimensão

${ }^{50}$ Vale destacar que pouco antes de Habermas, Reinhart Koselleck também procurou associar o desenvolvimento da opinião pública a um quadro dialético originado pela dinâmica do próprio absolutismo. A rigor e descontados os impecáveis esforços de erudição destes autores, prevalece a impressão de que estamos diante do paradigma tocquevilleano. Vide R. Koselleck, Le règne de la critique (Paris: Minuit, 1979).

${ }^{51}$ Keith M. Baker, The French Revolution and the Creation of Modern Political Culture. vol.1: Political Culture of the Old Regime (Oxford: Pergamon, 1987); Durand Echeverria, The Maupeou Revolution. A Study in the History of Libertarianism. France 1770-1774 (Baton Rouge: Louisiana State University Press, 1985); Roger Chartier, Origens Culturais da Revolução Francesa (1991); Dale K. Van 
pública das opiniões religiosas (e seus desdobramentos políticos), conferindo-lhes pleno direito de cidadania na sociedade francesa do século XVIII. Desse modo, enquanto Echeverria e Baker defenderam a hipótese de que foi na primeira metade da década de 1770 (marcada pelo golpe de Maupeou, isto é, pela tentativa de suprimir os Parlamentos) que a opinião pública emergiu (para nunca mais desaparecer) como uma poderosa força política, McManners, sem discordar a respeito da relevância deste episódio político para a galvanização e acirramento das identidades no interior desta esfera pública, sugeriu que a emergência do "império da opinião pública" pode muito bem ter ocorrido uma década antes, no contexto da campanha - liderada pelos jansenistas parlamentares - de reprovação universal aos Jesuítas ${ }^{52}$. E McManners não está sozinho, pois Dale Van Kley ${ }^{53}$ e S. J. Barnett ${ }^{54}$, dentre outros, lograram demonstrar, com base em ampla documentação e sólida análise, que a reação política ao absolutismo dos Bourbons, liderada pelos parlamentares franceses na década de 1760, não representou uma mudança de ordem qualitativa na oposição teológico-política de inspiração jansenista que dominou o cenário político francês entre as décadas de 1710 e1760, razão pela qual associar o nascimento da opinião pública francesa do século XVIII a um fenômeno exclusivamente laico ou 'Iluminista' consiste em algo no mínimo problemático.

Foi por esta razão que Keith Baker criticou Habermas em outro estudo ${ }^{55}$, isto é, pelo fato do filósofo alemão haver negligenciado o potencial corrosivo da oposição política jansenista-parlamentar junto ao absolutismo, assim como sua influência no processo de formação de uma opinião pública patriótica consciente e ativa. Para Baker, o primeiro momentum dessa opinião teria ocorrido na década de 1750 , marcada a seu ver pelos conflitos político-religiosos em torno da negação da administração dos sacramentos pelas autoridades eclesiásticas ortodoxas aos jansenistas e simpatizantes, fato este que suscitou uma decidida e organizada reação dos Parlamentos, sob a

Kley, The Religious Origins of the French Revolution: From Calvin to the Civil Constitution, 1560-1791 (New Haven: Yale University Press, 1996).

${ }^{52}$ J. McManners, Church and Society in Eighteenth Century France: The Religion of the People and the Politics of Religion, vol.2 (New York: Oxford University Press, 1998), p. 534, 672.

${ }^{53}$ Dale K. Van Kley, The Religious Origins..., p. 193-4.

54 S. J. Barnett, The Enlightenment and Religion: The Myths of Modernity (Manchester: Manchester University Press, 2003), p. 72.

${ }^{55}$ Keith M. Baker, "Politics and Public Opinion under the Old Regime: Some Reflections", in Jack Censer e Jeremy D. Popkin (orgs.), Press and Politics in Pre-Revolutionary France (Berkeley: University of Carolina Press, 1987), o qual se encontra reproduzido em Inventing the French Revolution. Essays on French Political Culture in the Eighteenth-Century (Cambridge: Cambridge University Press, 1999), p. 171. 
liderança intelectual do Parlement de Paris. ${ }^{56} \mathrm{Na}$ opinião de Baker, foi a partir deste conflito (eminentemente teológico-político) que a política francesa se preparou, na década de 1770, para romper com o molde absolutista num futuro próximo. ${ }^{57}$ Posteriormente, o mesmo Baker ilustraria o quanto o republicanismo clássico (a seu ver, hegemônico como discurso político somente a partir do último quarto de século) nem sempre dominou a linguagem política da oposição absolutista na França dos setecentos, a qual permanecia sendo "o discurso da justiça incrustado na linguagem constitucionalista dos parlementaires". 58

É nesta chave que devemos analisar as ressalvas de Baker a Tocqueville, criticado por haver subestimado as forças de oposição política no Antigo Regime para melhor justificar o argumento de que foi o absolutismo e o consequente cerceamento da liberdade política na França que permitiu a constituição de uma intelligentsia revolucionária naquele reino.

Mesmo quando admite exceções ao exercício do poder absolutista e seu cortejo centralizador sobre a sociedade francesa - e as atividades parlamentares mereceram seu parcial reconhecimento, posto que consistiam no único exemplo de liberdade política do passado que, resistindo ao duplo efeito da centralização absolutista e, posteriormente, revolucionária, pôde ser legada à sua geração ${ }^{59}$-, prevalece na leitura tocquevilleana a tese de que os franceses do século XVIII tinham perdido o apreço pela liberdade política, cuja noção foi-se perdendo nas brumas do tempo e à medida que o absolutismo erguia seu edifício sobre os escombros do feudalismo ${ }^{60}$ : como a crítica aos philosophes defensores do despotismo esclarecido, mormente aos fisiocratas, deixa claro. ${ }^{61}$

Do mesmo modo, e apesar de reconhecer a exatidão da análise de Tocqueville quanto à influência exercida pelo absolutismo (e sua congênita centralização administrativa) na formação de um 'partido' filosófico, Roger Chartier também criticou o autor de $O$ Antigo Regime e a Revolução pelo fato de haver atribuído a

${ }^{56}$ Keith M. Baker, Inventing the French Revolution...,op. cit., p. 170.

${ }^{57}$ Idem, p. 170.

${ }^{58}$ Keith M. Baker, "Le trasformazioni del repubblicanesimo classico nella Francia del Settecento", in: Maurizio Viroli (org.), Libertà política e virtù civile. Significati e percorsi Del repubblicanesimo classico (Torino: Edizione della Fondazione Giovanni Agnelli, 2004), p. 158.

${ }_{59}$ Alexis de Tocqueville, O Antigo Regime e a Revolução (1856), Livro II, cap. 11.

${ }^{60}$ Keith M. Baker, Inventing the French Revolution..., p. 20-22.

${ }^{61}$ Para uma interessante abordagem não menos crítica ao conceito de despotismo esclarecido ou 'despotismo legal' do Iluminismo francês, leia-se o excelente livro de Gertrud Himmelfarb, The Roads to Modernity: the British, French, and American Enlightenments (New York: Alfred A. Knopf, 2004), p.164-167. 
dessacralização da monarquia ao ataque filosófico, ignorando a ação dos conflitos jansenista-parlamentares no 'cercamento' do poder real:

“A análise dual de Tocqueville parece, portanto válida. De um lado, é certo que a França do século XVIII passou por um processo de abandono de práticas cristãs sem igual em todo o restante da Europa. Deveria isso ser interpretado, como cita Tocqueville, aos furiosos ataques dos Philosophes à Igreja, guiados por uma paixão antirreligiosa que se tornou 'dominante.., feroz, intolerante e predatória'? Provavelmente não, se admitirmos que os livros nem sempre tinham a eficácia que lhes foi atribuída e se concordarmos que as mudanças mais profundas nas formas de ser não foram resultado direto de pensamentos claros e distintos. Mais do que as denúncias 'iluminadas' de Voltaire e dos materialistas, foi o discurso religioso, virado do avesso pelos fiéis em sua incapacidade de atender às suas exigências, que produziu o abandono maciço do cristianismo." 62

Pouco antes no mesmo livro, Chartier sugeriu a respeito da oposição jansenistaparlamentar da década de 1750 (referente à recusa da administração dos sacramentos) que a mesma deveria ser vista como "o pano de fundo que dá maior significado a dois outros casos que tanto Malesherbes como Diderot tinham em mente quando escreveram seus memorandos sobre o comércio livreiro". 63

Adaptando o raciocínio maistreano - que visa justificar as perseguições de Luís XIV aos protestantes e jansenistas à luz de seus benefícios práticos na história ${ }^{64}$ - às condições específicas do absolutismo francês do século XVIII ${ }^{65}$, poderíamos tirar duas

${ }^{62}$ Roger Chartier, Origens Culturais da Revolução Francesa (1990). Trad. de George Schlesinger (São Paulo: Editora Unesp, 2009), p. 179-180.

${ }^{63}$ Roger Chartier, Origens Culturais da Revolução Francesa..., p. 76.

${ }^{64}$ Não por acaso, a estratégia retórica desta parte do texto consiste em comparar os efeitos práticos da perseguição na França com os efeitos do livre curso dado ao Protestantismo na Inglaterra (Revolução Puritana) e na Alemanha (onde milhões pereceram na Guerra dos Trinta Anos). Maistre dirá que, apesar dos condenáveis excessos inerentes a toda soberania (pois o poder corrompe ainda mais uma natureza por si só corrupta), a experiência histórica demonstrava que a Revogação do Edito de Nantes (1785) e a perseguição aos jansenistas pela monarquia francesa foram atos necessários e justificados, pois preservaram os franceses das atrocidades de uma nova Guerra Civil. E arremata esta justificativa com um argumento irônico a respeito da fuga do capital huguenote à Holanda e Inglaterra: " Suponhamos que esta lei tenha custado 400000 homens à França: é mais ou menos como se subtraíssemos 1000 habitantes de Paris. Não se perceberia de modo algum. A respeito das manufaturas levadas ao estrangeiro pelos refugiados, e do erro que disso resultou para a França, as pessoas para quem essas objeções de feirantes significam algo podem ir buscar respostas em outro lugar que não no meu livro." in: J. de Maistre, O.C., VIII: 82 .

${ }^{65}$ Que, de acordo com o clássico estudo de Boris Porchnev, logrou remover, ao fim do século XVII e após as violentas supressões das Frondas e das revoltas populares, todos os obstáculos interpostos em seu caminho, transformando-se naquilo que a historiografia marxista, de Porchnev a P. Anderson, 
conclusões: primeiro, que Luís XIV aprendera com a experiência inglesa, de modo a não permitir que a aparentemente inofensiva e confessadamente católica doutrina jansenista provocasse qualquer ruído na relação entre monarquia de direito divino e seu principal 'aparelho ideológico', a Igreja católica; segundo, que a análise teológicopolítica maistreana pode perfeitamente completar a abordagem materialista de Porchnev, na medida em que reconhece os liames que ligavam a oposição parlamentar representada pela nobreza togada (de profundas consequiências a médio-prazo para a monarquia, como o último admitiu ${ }^{66}$ ) ao jansenismo que, não por acaso, nos piores anos de perseguição real, entre as décadas de 1720-1740, desenvolveu uma moral figurista que guardava muitos traços de semelhança com setores radicais do puritanismo. ${ }^{67}$

Pois, se por um lado "a ventura histórica da monarquia no mundo cristão prendeuse, numa parcela considerável, ao fato de que essa forma política permitia uma ampla acolhida da presença da Igreja e, ao mesmo tempo, detinha um recurso de extremo poder - o monarca de direito divino - para garantir a independência do corpo político frente à Igreja" ${ }^{68}$ após as guerras de religião, por outro, esta independência jamais podia ser absoluta a ponto de prescindir dos circuitos de sociabilidade de uma instituição como a Igreja católica, que reforçava o absolutismo e era por ele reforçada.

Neste sentido, como bem percebeu Maistre (no que foi confirmado por estas e outras pesquisas mais recentes), o principal elemento 'corrosivo' político-cultural do Antigo Regime francês no século XVIII, tão importante quanto o anticlericalismo

classificou como um reforço ou resposta do aparato social aristocrático diante do duplo desafio trazido pela emergência do mercantilismo e de uma sociedade crescentemente burguesa. In: Perry Anderson, Lineages of the Absolutist State (London: Verso, 1979), p. 41; B. Porchnev, Les soulèvements populaires en France au XVII ème siècle (Paris: Flammarion, 1972).

${ }^{66}$ A respeito das relações entre a 'burguesia' e o Estado absolutista no Antigo Regime, Porchnev concluiu que se tratava de um jogo de cabra-cega: "O absolutismo se esforçava por agarrar a burguesia, que reaparecia atrás de si. O absolutismo sangrava a burguesia, ao passo que a parte mais rica e influente da mesma sangrava o absolutismo". In: B. Porchnev. Les soulèvements populaires en France au XVII ème siècle..., p. 399.

${ }^{67}$ De acordo com Patrice Higonnet, é "tentador" supor que sem o moralismo excessivo (quase paranóico) que derivara em parte dos instintos jansenistas (uma visão contricionista e figurista da fé que se refletia na busca incessante pela virtude privada absoluta, sendo a "Verdade", nos momentos de dificuldade, o monopólio de uma minoria eleita), a aplicação dos princípios jacobinos, por mais contraditórios que fossem, dificilmente teria assumido um caráter tão "tirânico". Cf. P. Higonnet, Sister Republics: the Origins of French and American Republicanism (Massachussets: Cambridge Univiversity Press, 1988), p. 312. Importa também mencionar o fato de que o Michelet do Cours professé au Collège de France: 1847-8 (Paris: Chamerot, 1848), mas, atenção, não o da História da Revolução Francesa (para quem a Revolução era rebenta intelectual de Voltaire e Rousseau, Livro III, cap. IX), relacionou o pensamento de Rousseau (presente, segundo ele, em todos os momentos da Revolução) ao jansenismo, de quem o célebre republicano genebrino extraíra seu modo de pensar, muito mais que do calvinismo. Mais do que isto, o jansenismo, nas palavras de Michelet, era uma "secte bourgeoise" (Cours professé... op., cit., p. 198).

${ }^{68}$ Pierre Manent, História Intelectual do Liberalismo: dez lições (Rio de Janeiro: Imago, 1990), p. 19. 
filosófico, foi a oposição jansenista, que em nome das liberdades 'galicanas' logrou separar a monarquia de seu aparelho ideológico, debilitando a ambos. Como argumentou Marcel Gauchet, se existe uma "lei da emancipação humana por via da afirmação divina", na medida em que quanto mais transcendente for o conceito de Deus, maior será o efeito disso na liberdade do povo, então o jansenismo trouxe em seu bojo uma mensagem implícita de emancipação, não importando o quão ortodoxos e prómonárquicos fossem as declarações de seus adeptos. ${ }^{69}$ Esta tendência - traduzida numa visão doutrinal contricionista responsável seja pelo adiamento sine die dos sacramentos pelos curas e fiéis, seja pelo afastamento dos padres de suas respectivas paróquias (sob a égide do cardeal Fleury, emitiram-se cerca de 40.000 lettres de cachet entre 1727 e 1740 contra padres jansenistas ou parlamentares) - certamente foi responsável por uma espécie de processo descristianizador (por mais obtusa e estreita que seja a noção de história cultural admitida) anterior ao da Revolução Francesa, como outros especialistas além de McManners também observaram. ${ }^{70}$

Diante desses pressupostos, pode-se concluir que uma história política do Antigo Regime que contemple seus elementos teológicos não só é viável, como não se limita necessariamente aos estreitos limites da busca pelas "origens intelectuais".

A nosso ver, se existe algum mérito na leitura da Revolução Francesa avançada por Maistre nas Reflexões sobre o Protestantismo, o mesmo consiste precisamente no fato de apreender os complexos elementos de um processo que levou a esta hegemonia da filosofia a partir do século XVIII (a qual, note-se bem, não é negada pelo autor, nem mesmo quando trata do protestantismo), e a qual o saboiano associa diretamente às transformações culturais (com indeléveis consequências políticas) suscitadas pelo Protestantismo na Europa e na França em particular.

\footnotetext{
${ }^{69}$ Marcel Gauchet, Le désenchantement du monde: une histoire politique de la religion (Paris: Gallimard, 1985), p. 53.

${ }^{70}$ Michel Vovelle, Piété baroque et déchristianisation en Provence au XVIII' siècle. Les attitudes devant la mort d'après les clauses des testaments (Paris, Plon, 1973), p. 593-613; Dominique Dinet, "Le jansénisme et les origines de la déchristianisation au XVIIIe siècle: L'example des pays de l'Yonne”, in: Léo Hamon (org.), Du jansénisme à la lä̈cité: Le jansénisme et les origines de la déchristianisation (Paris: Éditions de la Maison des Sciences de l'Homme, 1987), p. 1-33; Ainda a respeito do papel do jansenismo no processo de dessacralização e solapamento da monarquia absoluta francesa, consultem-se os trabalhos de Jeffrey W. Merrick, The Desacralization of the French Monarchy in the XVIII century (London: Louisiana State Universisty Press, 1990) e William Doyle, Jansenism: Catholic resistence to authority from the Reformation to the French Revolution (London: St. Martin Press, 2000), p.88-9. Este último inclusive logra demonstrar que os jansenistas (com sua extensa máquina publicitária), muito mais do que os filósofos, estavam na linha de frente da oposição ao absolutismo Bourbon, pelo menos até a primeira metade dos anos 1770 .
} 
Uma leitura que associa o Protestantismo e a Revolução Francesa por meio do gradual processo de hibridização cultural (isto é, religioso, moral) e político operado na França desde o aparecimento do calvinismo e melhor expresso nas determinações recíprocas entre os fenômenos do jansenismo e do filosofismo na política francesa do século XVIII, da contestação parlamentar dos anos 1750 e expulsão dos Jesuítas (1764) aos quadros de oposição parlamentar à política do chanceler Maupeou, entre os anos 1770-1775. A respeito desta oposição ao golpe de Maupeou, autores como Keith Baker e Dale Van Kley ${ }^{71}$ interpretaram-na como um momento de inflexão seja para o discurso histórico-constitucionalista jansenista-parlamentar, seja para o movimento filosófico (que assume, por meio da panfletagem patriótica, uma oposição diretamente política).

Pois em nenhum momento deste ensaio - ou nas obras que o precederam (como o De la souveraineté, as Considerações) ou o sucederam (sobretudo Du Pape e De l'Église gallicane) -, Maistre nega a primazia da filosofia da Ilustração como origem moral/cultural da Revolução e do mundo que ela continuava a (de)formar. Pelo contrário, com base na sua formação intelectual e experiência de vida, adverte para o fato de que os fatores teológico-políticos do protestantismo foram os pré-requisitos necessários para a Ilustração e a Revolução que a seguiu.

Sendo assim, o que caracteriza, para Maistre, o Protestantismo?

"É a insurreição da razão individual contra a razão geral e, por conseqüência, tudo o que se pode imaginar de pior... Ora, esses inovadores... substituíram o julgamento particular ao julgamento católico; substituíram insanamente a autoridade exclusiva de um livro àquela do ministério pedagógico, mais antigo que o livro e encarregado de no-lo explicar. /Daí decorre o caráter particular da heresia do século XVI. Não se trata tão somente de uma heresia religiosa, mas de uma heresia civil, porque ao liberar o povo do jugo da obediência e ao conferir-lhe a soberania religiosa, ela desencadeia o orgulho geral contra a autoridade e instala a discussão no lugar da obediência." 72

Longe de ser fortuita, a longa referência a Bayle revela uma estratégia retórica e impõe-nos um problema, pelo menos à primeira vista. Pois, se conforme postulou Ernest Cassirer num estudo que se tornou clássico, a essencial e unificadora

\footnotetext{
${ }^{71}$ Dale K. Van Kley, "Du parti janseniste au parti patriote: l'ultime sécularisation d'une tradition religieuse à l'époque du chancelier Maupeou 1770-1775", in: Catherine Maire (org.), Jansénisme et Révolution (Paris: Chroniques de Port-Royal, 1990).

72 J. de Maistre, O.C., VIII: 64-66.
} 
característica da Filosofia da Ilustração foi a rejeição ao pecado original, como é possível associar a Reforma Protestante, cujo efeito doutrinal imediato foi o de restaurar e recrudescer esta noção de pecado (daí a necessidade radical da graça divina entre seus seguidores), ao Iluminismo e a seu principal efeito, a Revolução Francesa ${ }^{73}$, como fez Maistre?

Também aqui esta dificuldade foi superada por meio de uma argumentação poderse-ia dizer bastante 'moderna'. A respeito do célebre autor do Dictionnaire historique et critique (1695-97), Maistre concordaria com os argumentos de autores tão distintos como Cassirer, P. Hazard ${ }^{74}$, Peter Gay $^{75}$ e Q. Skinner ${ }^{76}$, os quais reconhecem a importância do pensamento do humanista huguenote (uma profissão de fé reiterada várias vezes em seu exílio holandês) para o Iluminismo Francês do século XVIII: para os philosophes franceses, como Voltaire e Diderot, mas também para Hume e os homens de letras alemães (de Lessing a Wieland), Bayle e seu Dictionnaire ofereceram duas armas eficazes no combate que a Filosofia das Luzes travou contra a tradição religiosa: o ceticismo e a tolerância. O simples fato de Voltaire e os demais enciclopedistas expressarem sua admiração por Bayle já era motivo suficiente para que Maistre o incluísse no seu Index.

Ademais, na perspectiva contrarrevolucionária de Maistre, era impossível dissociar a história de Bayle de um século atrás com aquela que se desvelara na França revolucionária e com a conspícua participação de notórios protestantes ${ }^{77}$, franceses ou não (como o pastor Rabaut de Saint-Étienne, o auto-proclamado deísta Barnave, e o futuro membro do temível Comitê de Salvação Pública, Jeanbon Saint-André, entre os franceses; os dissidentes ingleses T. Paine, e o "orador do gênero humano" ou 'cidadão da humanidade", o prussiano Anarchasis Cloots, os quais, ao lado de outros quatorze indivíduos de nacionalidade estrangeira, foram agraciados com o título honorário de

${ }^{73}$ E. Cassirer, La filosofia de la Ilustración (México, D.F: Fondo de Cultura Económica, 1997).

74 Paul Hazard, O Pensamento Europeu no século XVIII: de Montesquieu a Lessing (Lisboa: Editorial Presença, 1974), p. 41-42.

${ }^{75}$ P. Gay, The Enlightenment: The Rise of Modern Paganism (1966). New York/London: W.W. Norton \& Company, 1977, p. 291-295.

${ }_{76}$ Q. Skinner, "The History of Ideas", in: History and Theory, 8 (1969), p. 33-34.

77 Timothy Tackett identificou pelo menos quarenta e quatro deputados protestantes nos Estados Gerais de 1789, a maior parte dos quais assumindo uma postura abertamente patriótico-'nacionalista' (ou seja, na acepção clássica encontrada no célebre panfleto de Sieyès, $O$ que é o terceiro-Estado?). Cf. T. Tackett, Becoming a Revolutionary: the Deputies of the French National Assembly and the Emergence of a Revolutionary Culture, 1789-1790 (Princeton: Princeton University Press, 1996), p. 65-66. 
cidadãos franceses pela Assembleia Legislativa num de seus últimos atos ${ }^{78}$ e colocaramse na linha de frente numa revolução que se tinha por filosófica e coroara Voltaire com o título de 'Patriarca de 1789', no dia 11/07/1791).

Assim, se, para Maistre, a história e a razão reuniam-se para demonstrar "que as raízes de toda grande instituição estão dispostas fora deste mundo" e que as "soberanias, sobretudo, não possuem força, unidade e estabilidade a não ser na proporção em que elas sejam divinizadas pela religião" - "sendo o cristianismo, ou melhor, o catolicismo, o cimento de todas as soberanias européias" - então o protestantismo, a exemplo do filosofismo, "ao subtrair o catolicismo sem entregar-lhes outra fé, minou a base de todas as soberanias que tiveram o azar de abraçar a reforma". ${ }^{79}$

Portanto, As Reflexões sobre o Protestantismo chamam a atenção para o processo de formação ou fundamentos daquilo que se tornaria a nossa modernidade secularizada vislumbrada e temida por Maistre. Delimitada pela primazia da opinião pública e pelo exercício legítimo da crítica ou do exame em todas as esferas (do privado ao público), a mesma foi objeto de uma definição crítica de um professor protestante da Universidade de Cambridge, não por acidente escolhida a dedo por Maistre:

"Entre milhares de confissões deste gênero, escolheria uma que me parece infinitamente notável pelo tempo, pelo lugar e pela qualidade da pessoa: a de um professor de teologia da Universidade de Cambridge, que teve a nobre franqueza, durante um sermão pregado no dia 3 de maio de 1795 e em presença daquele corpo respeitável, de desenvolver da seguinte maneira as consequências da Reforma:/ "Nem bem o direito de exame privado foi assegurado", disse o mesmo, "nem bem se começou a colocá-lo livremente em prática, que uma multidão de escritores, adornados com o imponente título de freethinkers, estabeleceram-se como os preceptores do gênero humano, e espalharam por toda a parte suas opiniões fantásticas e temerárias, sobretudo em matéria de religião e governo... Receio realmente que nesta matéria os estados reformados sejam mais passíveis de repreensão do que o imaginam: quase todas as obras ímpias e a esmagadora maioria daquelas em que a imoralidade empresta as armas tão poderosas à irreligião moderna, foram compostas e impressas nos países protestantes."

${ }^{78}$ Robert R. Palmer, The Age of the Democratic Revolution, vol. II: The Struggle (Princeton: Princeton University Press, 1964), p. 55-56.

${ }^{79} \mathrm{~J}$. de Maistre, $O . C$., VIII: 94.

${ }^{80}$ Nota de J. de Maistre. A sermon preached before the university of Cambridge on the third of may 1795 by John Mainwaring, B.D. professor in Divinity. in: J. de Maistre, O.C., VIII: 77-78. 
Mais do que representar uma religião democrática, para Maistre o principal risco inerente ao protestantismo (sobretudo nas suas versões puritanas) estava no fato do mesmo favorecer, na contramão de suas intenções, um processo de secularização da cultura, sendo uma 'religião da saída da religião', como diria Marcel Gauchet no supracitado estudo: pai do deísmo e avô do panteísmo, como reconhecerá (ainda que implicitamente) Tocqueville (ver abaixo). Como pretendemos demonstrar mais adiante num capítulo à parte, as Réflexions completam a trajetória hermenêutica da concepção maistreana sobre o Terror, a qual já fora esboçada nos estudos sobre Rousseau (De la souveraineté e o De l'état de nature) e nas Considerações. Mas em linhas gerais, podese dizer que, para Maistre, o espírito protestante, por meio de seu espírito examinador, forjou aquela que viria a ser a principal ferramenta moral e jurídica que a Ilustração legaria ao Terror, a saber, o culto à Natureza (ou à "deusa Razão"). ${ }^{81}$ Uma vez aplicado este perigoso e cortante instrumento crítico em todas as esferas, a Ilustração engendrou uma classe de tiranos em potencial, os quais, designados por Maistre como portadores de uma "barbárie sapiente",82 e possuídos por um fervor natural-racionalista irreligioso, tiranizaram a opinião pública ou a sociedade como um todo quando as mesmas não coincidiram com seus projetos de poder: um instrumento 'crítico' (a Natureza, as leis da Razão, etc) que, sempre segundo Maistre, pode ser adaptado e reutilizado permanentemente e ao talante dos revolucionários a fim de legitimarem seus desígnios (neste caso, nem sempre a vontade geral expressa a opinião da maioria), mas que não conseguem encobrir uma prática, tão bem expressa durante vários momentos da Revolução e denunciada nas Considerações sobre a França:

"Os tiranos se sucedem, e o povo segue obedecendo. Jamais se viu triunfar um único esforço de sua parte para escapar à sua nulidade. Seus senhores chegaram a aniquilá-lo, escarnecendo-se dele ao mesmo tempo. Disseram-lhe: Credes que não quereis esta lei, mas podeis estar seguros de que a quereis. Se ousardes recusá-la, sereis metralhados como punição por não quererdes o que quereis. - E assim o fizeram." ${ }^{83}$

Antes de concluir, resta esclarecer sobre mais um ponto, a saber, qual o lugar das Réflexions sur le Protestantisme na historiografia da Revolução?

${ }^{81}$ Sem aludir a Maistre, mas amparado em vasta bibliografia (inclusive de época) sobre a Ilustração e a Revolução Francesa, Dan Edelstein concluiu o mesmo em seu desafiador estudo The Terror of Natural Right: Republicanism, the Cult of Nature, and the French Revolution (Chicago: University of Chicago Press, 2009).

${ }^{82}$ J. de Maistre, Considerações sobre a França (1797), cap. 4.

${ }^{83}$ J. de Maistre. Considerações sobre a França (1797), cap. 8. 
Após uma pesquisa sumária e que - substituindo o critério de 'influência', algo sempre perigoso para o historiador das ideais, pela identificação de confluências e simetrias temáticas - de forma alguma tem a pretensão de encerrar um assunto tão vasto, foi possível concluir que apenas na obra de E. Quinet a relação entre Reforma e Revolução configura uma argumentação central, embora alguns autores contemporâneos a Quinet, igualmente importantes para a formação da cultura historiográfica sobre a Revolução Francesa, também tenham abordado o assunto.

Certamente, ninguém se surpreenderia com o julgamento do pensador católico ultramontano Louis de Bonald (1754-1840), para quem "a Reforma foi o acontecimento mais funesto à sociedade dos tempos modernos e a causa próxima ou afastada de todas as revoluções que, desde o século XVI, têm agitado a Europa e de todas as guerras que a ensanguentaram". ${ }^{84}$ Apesar de as diferenças epistemológicas entre ambos não serem desprezíveis, não é segredo para ninguém que ambos compartilhavam um mesmo pathos contrarrevolucionário e ultramontano, bem expresso numa significativa troca de correspondências. ${ }^{85}$

Duas décadas depois e no mesmo diapasão conservador de Bonald, Donoso Cortés (1809-1853) ${ }^{86}$ e Maistre, foi a vez do apologista católico Auguste Nicolas (18071888) associar a Reforma aos distúrbios sociais e políticos que acometiam a França em Du Protestantisme et de toutes les héresies dans leur rapport avec le socialisme (Do Protestantismo e de todas as heresias em sua relação com o socialismo, 1852):

Após explicar a motivação para redigir o livro, isto é, uma proposta de aliança (de autoria de Guizot) entre o catolicismo e as comunhões protestantes para exorcizar o perigo comunista ${ }^{87}$, Nicolas - que trabalhara no ministério da Instrução Pública sob o comando de Alfred de Falloux (autor de uma polêmica lei aprovada em 1850 e que,

${ }^{84}$ Louis de Bonald. Démonstration philosophique du principe constitutif de la societé (1830); Oeuvres complètes (Paris: Leclère, 1847-54), t. IV, p. 524.

${ }^{85}$ Cf. Lettres et opuscules inédits du comte Joseph de Maistre (Paris: A. Vatton, 1851), 2 volumes. Especialmente o Vol. 2, p. 65, com o elogio de Bonald às Considerações sobre a França, obra cuja nova edição de 1814 contribuiu a viabilizar.

${ }^{86}$ Sobretudo pela obra Essai sur le catholicisme, le libéralisme et le socialisme, publicada em junho de 1851, simultaneamente em Madrid e Paris. Apesar de sua maior notoriedade com respeito à obra de Nicolas, preferimos o último pelo fato de nele a crítica conceitual e histórica ao protestantismo representar um aspecto central, para além da apologética católica de Cortès. Vale lembrar que só no seu primeiro ano, a obra de Nicolas teve de ser reeditada nada menos do que oito vezes. Reflexo dos tempos...

87 "O fim a que me propus é o mesmo do Sr. Guizot (1787-1874): salvar a sociedade da última consequência do erro, a morte. Para conjurar este erro, o Sr. Guizot concebeu um meio, emitiu um voto, ou seja, de que todas as comunhões protestantes e o catolicismo..., por mais opostos que estejam sobre o princípio, se entendam para fazer causa comum contra o socialismo." Cf. Auguste Nicolas (1807-1888). Du Protestantisme et de toutes les héresies dans leur rapport avec le socialisme (Bruxelles: Imprimerie de H. Goemaere, 1852), $2^{a}$ edição, p. VIII. 
levando seu nome, permitiu a readmissão de clérigos e religiosos nas instituições primárias e secundárias de ensino público) - acusou a falsidade do projeto de Guizot, pelo fato de o mesmo manter intacto o princípio do protestantismo e sustentar uma 'funesta' união entre a 'Verdade' (a união ontológica da Igreja católica com Cristo) e o erro, 'princípio da morte social'.

Logo em seguida, o autor exibe as premissas de sua argumentação, a qual guardava enormes semelhanças com a argumentação maistreana, e não por acaso: em razão da 'ameaça vermelha' representada por Fevereiro de 1848, a qual amalgamou grupos políticos antes irreconciliáveis, como os legitimistas e os orleanistas, as obras de Maistre passaram por um autêntico boom editorial, mormente Du Pape (donde Nicolas certamente derivou o requisitório maistreano contra o protestantismo, uma vez que as Réflexions só viriam a público em 1870) e as Considerações sobre a França:

“O protestantismo, ao erguer o estandarte da rebelião contra a Igreja, levou a ameaça ao próprio princípio da autoridade e da liberdade no mundo; pois, sob sua influência, deixou de haver uma verdade única, isto é, nada que extraísse sua autoridade em si, nada que no-la pudesse comunicar e, com ela, a liberdade que, antes de mais nada, é a autoridade sobre si. O poder ficou sem autoridade, a sujeição sem liberdade, não restando mais do que um conflito crescente entre as cegas forças do despotismo e da licenciosidade." ${ }^{88}$

Após definir o protestantismo como o "'socialismo contra a Igreja" e o socialismo como "um protestantismo contra a sociedade", Nicolas expôs aquilo que para ele identificava o protestantismo ao socialismo: ao submeter a ordem sobrenatural à razão humana, o protestantismo abriu caminho para o materialismo, “...um dos dois grandes afluentes do socialismo" - o segundo sendo o "panteísmo" (um desenvolvimento lógico do protestantismo e responsável por reduzir todas as questões de princípio, inclusive as metafísicas, à natureza). ${ }^{89}$

No entanto, enganar-se-á quem associar as premissas do requisitório contrarrevolucionário maistreano contra o protestantismo somente aos pensadores conservadores e/ou apologistas do 'trono e do altar'. Paradoxalmente, caso queira-se encontrar referências críticas aos efeitos sociais e políticos da Reforma dentre os

\footnotetext{
${ }^{88}$ Auguste Nicolas, Du Protestantisme et de toutes les héresies dans leur rapport avec le socialisme..., p. VIII-IX.

${ }^{89}$ Idem.
} 
historiadores mais importantes no período coberto pela Monarquia de Julho, veremos que as mesmas estão nas obras de socialistas como Louis Blanc e Philippe Buchez.

Louis Blanc afirma, por um lado, que o espírito do individualismo, inaugurado por Lutero, desenvolveu-se de uma forma irresistível e "triunfou na França pelos publicistas da Constituinte". Mesmo quando argumenta que a Revolução não se resumiu a este caráter liberal/individualista - antes sendo marcada por outros valores (como a fraternidade) -, Blanc conclui que a condenação do papa Leão X por Lutero antecipou, na longa duração, a condenação de Luís XVI pelos revolucionários franceses: "Este papa," [Leão X] "que se trata de derrubar, por mais que seja um rei espiritual, ainda é um rei. Uma vez posto à terra, outros seguir-lhe-iam. Assim se fez do princípio de autoridade, por menos que o atingissem em sua forma mais respeitada, no seu representante mais ilustre."

O julgamento de Louis Blanc (1811-1882) não diferiu daquele expresso por Philippe Buchez (1796-1865), para quem foi preciso que a moral evangélica de Lutero reformasse a cristandade antes de sua realização política e social definitiva, em $1789 .{ }^{91}$ E também como o companheiro de socialismo Louis Blanc, o neo-convertido ao catolicismo Buchez, sem deixar de reconhecer a obra progressista da Reforma (razão pela qual privilegia os hussitas boêmios e os anabatistas alemães, os quais seriam associados à mesma vocação fraternal de um Chaumette e de um Grachus Babeuf durante o processo revolucionário), não deixou de criticá-la por sua 'doutrina de desorganização'92, à qual opunha o modelo de centralização e organização do poder latino e católico, capaz, a seu ver, de conservar os cidadãos sob uma perfeita igualdade e obediência. Impossível não pensarmos na reação de um Tocqueville diante desta leitura particular do nascente socialismo francês.

Mas as acusações e desconfianças não encobriram o legado de um tratamento mais elogioso recebido da parte da historiografia republicana da Revolução, sobretudo pelo par Jules Michelet (1798-1874) e Edgar Quinet (1803-1875), que do Collège de France travavam um combate feroz contra o "partido clerical" encarnado pelos jesuítas

90 Louis Blanc, Histoire de la Révolution (1847) apud Paul Viallaneix, "Réformation et Révolution", in: F. Furet e M. Ozouf (orgs). The French Revolution and the Creation of Modern Political Culture: vol. III (Oxford/New York: Pergamon Press, 1989), p. 362.

${ }_{91}^{91}$ Buchez et Roux, Histoire parlementaire de la Révolution (1834), t. I, p. 10.

92 Buchez et Roux, Histoire parlementaire de la Révolution (1834). Paris: Paulin Librairie, 1838, $\mathrm{t}$. 40 , p. XI-XII. 
e os ultramontanos, claramente expresso no livro Des Jésuites (1843) - uma compilação das lições ministradas por ambos os professores republicanos. ${ }^{93}$

O tom veemente da obra é expresso logo nas primeiras páginas por Michelet: o 'jesuitismo' representava a pior de todas as tiranias, de modo que sua presença nas escolas primárias e nas universidades era um atentado ao espírito dos novos tempos inaugurado pela Revolução: pior do que a tirania da espada e/ou política (que se limitam, segundo o próprio, ao mundo exterior), o jesuitismo era a tirania do espírito, a 'polícia do pensamento', 'mil vezes pior'. ${ }^{94}$

Quando Michelet começa a escrever, em 1846, sua monumental Histoire de la Révolution (1847-1853), o mesmo conservou o tratamento simpático a Lutero - de quem traduziu e reconstitui as Mémoires (1837) -, chamado por ele de 'o restaurador da liberdade'. ${ }^{95}$ Apesar de reconhecer a importância do pastor protestante Rabaut de SaintÉtienne $^{96}$ no processo revolucionário, prevalece no livro do professor democratarepublicano (como Quinet, também de origem familiar huguenote) a ideia de que, no geral, os protestantes foram coadjuvantes (de maneira consciente, para não dar azo às intrigas contrarrevolucionárias e católicas) $)^{97}$ e não protagonistas do grande evento. Antes, porém, - e talvez numa refutação à hipótese avançada por Buchez, o qual, na sua Introduction à la science de l'histoire (1833/1842), criticou o protestantismo (responsável pelo nascimento do individualismo moderno) para, em, seguida, elogiar o catolicismo (cujo espírito orgânico logrou sobreviver e adaptar-se à mensagem da Revolução) ${ }^{98}$-, reconhecera que o Renascimento e a Reforma (e não o catolicismo) pavimentaram o caminho para a Revolução: legítimo filho da crítica renascentista, Lutero imolou a liberdade transcendental (o livre-arbítrio em nome da 'graça' agostiniana) em nome da liberdade prática (emprestando seu nome à grande revolução

93 Após a lei Guizot de 1833, a qual previa o estabelecimento e as condições para o ensino primário (público e privado), seguiu-se uma grande controvérsia política-intelectual a respeito da legitimidade ou não dos colégios privados administrados pelos jesuítas, tão associados aos valores ultramontanos da Restauração. Recorde-se também que os primeiros anos da Monarquia de Julho foram marcados por um reavivamento do sentimento anticatólico na França, expresso em manifestações sociais difusas como depredações de igrejas, monumentos e agressões a membros do clero.

${ }^{94}$ Jules Michelet e Edgar Quinet, Des Jésuites (Paris: Hachette, 1843), $3^{\mathrm{a}}$ edição, p. 14-15.

95 J. Michelet. Mémoires de Luther (1837), in: P. Viallaneix (org.), Oeuvres Complètes de J. Michelet (Paris: Flammarion), t. III, p. 238.

${ }^{96}$ J. Michelet, Histoire de la Révolution française (1847-1853). Livro III, cap. 2.

97 J. Michelet. Histoire de la Révolution française (1847-1853). Livro III, Cap. 8.

${ }^{98} \mathrm{P}$. Buchez, Introduction à la science de l'histoire ou Science du développement de l'humanité (1833). Paris: Guillaumin Éditeur, vol. I, 1842, p. 269-270. 
da Europa pré-revolucionária, o direito ao exame, 'primeiro direito da inteligência humana'). ${ }^{99}$

Mas o reconhecimento de Michelet foi algo tímido se comparado à demonstração que Quinet empreendeu em Le Christianisme et la Révolution (1845), a qual, reproduzida na Philosophie de l'histoire de France (1857), serviu de base para as conclusões originais de sua La Révolution (1865).

Nas palavras deste historiador e poeta, se o Cristianismo, 'encerrado em suas tumbas', tentou ressuscitar durante a Revolução Francesa, isto se deveu ao trabalho anterior dos reformadores, que o arrancaram do sono mortal do formalismo. ${ }^{100}$ Foi assim que, entre os séculos XVI e XVIII, o gênio protestante, reprimido na França, ofereceu alhures inúmeras provas de seu vigor e modernidade. Quinet aprecia muito mais do que Michelet a inspiração ou presença calvinista na Holanda republicana, na monarquia inglesa (livre do absolutismo pelo puritanismo) e na democracia norteamericana:

"Todas estas instituições que o protestantismo engendra pelo próprio espírito são para ele como uma couraça contra a qual se desvanecem todos os traços da religião da Idade Média. Ele se eleva a uma forma de governo mais cristão que o ideal católico... A constituição da Igreja católica, regida pelo Concílio de Trento, é o ideal do poder absoluto. Sobre este modelo regeram-se e formaram-se as monarquias católicas do Midi há três séculos. Pelo contrário, o que são as formas novas senão o próprio protestantismo tornando-se a alma da ordem temporal?"101

Assim como Michelet fizera antes dele nas Memórias de Lutero, Quinet sublinhará o paradoxo da fertilidade mundana imanente ao protestantismo, cujo fundamento, segundo ele, estava na soberania absoluta de Deus (esta, expressa pela necessidade agostiniana da graça): "Era preciso que a vontade humana se abrigasse na plena soberania de Cristo" ${ }^{102}$ para que se libertasse da obediência passiva à Igreja e desenvolvesse suas iniciativas. Protegidos sob a única salvaguarda da Providência, o protestantismo defendeu o "direito de cada homem" desenvolver sem restrições sua dimensão cívica. Por sinal, foi com base neste mesmo paradoxo que o importante historiador contemporâneo e especialista em política e história das ideias, Marcel

\footnotetext{
${ }^{99}$ J. Michelet, Mémoires de Luther (1837), op. cit., p. XI.

${ }^{100}$ Edgar Quinet, Le Christianisme et la Révolution française (1845), $5^{\mathrm{ème}}$ leçon.

${ }^{101}$ Edgar Quinet, Le Christianisme et la Révolution française (1845), $11^{\mathrm{ème}}$ leçon.

${ }^{102}$ Edgar Quinet, Le Christianisme et la Révolution française (1845), $10^{\text {ème }}$ leçon.
} 
Gauchet, vinculou o cristianismo reformado a uma espécie de "lei de emancipação humana". ${ }^{103}$

Todavia e conforme bem observou Paul Viallaneix, também em Quinet (e quase que pelas mesmas razões de Michelet, quais sejam, uma timidez fruto de séculos de perseguições, humilhações e um certo cálculo de prudência) a Revolução de 1789 não se desdobrou sob o signo da Reforma da qual ela deriva; Quinet, Michelet e os demais historiadores simpáticos à Reforma (inclusive os historiadores membros da 'Societé de l'histoire du protestantisme', fundada em 1852) não podiam contar com a assistência teológica ou o testemunho cívico dos protestantes para verificar a hipótese de uma possível filiação direta entre o projeto reformador e o revolucionário. ${ }^{104}$ Limitação esta que, conforme vimos acima, passou ao largo da análise de Maistre.

Somente duas décadas depois, em La Révolution (1865), é que Quinet, na tentativa de explicar o fenômeno do Terror (verdadeiro 'calcanhar de Aquiles' daquela tradição republicano-revolucionária), solucionaria o impasse presente no $L e$ Christianisme et la Révolution française, a saber, a quantia exata a ser debitada ao Protestantismo na Revolução Francesa.

Através do La Révolution, Quinet logra contornar o problema pelo seguinte raciocínio, o qual atravessará toda a obra: o Antigo Regime, com sua história de perseguição e estrangulamento do vigor espiritual protestante e domínio absolutista sobre os espíritos (expresso pelos jesuítas), cobrou uma enorme conta durante a Revolução, da Constituição Civil do Clero ${ }^{105}$ ao pontificado 'inquisitorial/católico' de Robespierre. ${ }^{106}$ Infelizmente, argumentará Quinet na contramão de Maistre (para quem a Revolução moral/espiritual do Protestantismo estendeu as mãos para a Revolução política e civil de 1789), "a França fez uma revolução política e social antes de haver consumado sua revolução religiosa" ${ }^{107}$, de modo que, no momento em que a Revolução de 1789 se apresentou e necessitou de uma ideologia nova, só o que encontrou foram os modelos atávicos do Antigo Regime: a Revolução parou de se reinventar na falta da

\footnotetext{
${ }^{103}$ Marcel Gauchet em Le désenchantement du monde: une histoire politique de la religion (Paris: Gallimard, 1985), em especial p. 122-3.

${ }^{104}$ P. Viallaneix, "Réformation et Révolution", p. 364-365.

105 Para Quinet, responsável por deixar subsistir 'a instituição fundamental do antigo regime religioso', não sem a condescendente e irresponsável colaboração do espírito das Luzes e sua ideia de tolerância. Cf. E. Quinet, La Révolution (1865), Livro V, cap. 3 e 4.

${ }^{106}$ A festa da Razão identificada como um reavivamento da piedade barroca e o terror jacobinorepublicano como a ressurreição da inquisição católica e/ou das dragonadas de Luís XIV. Cf. E. Quinet, La Révolution (1865), Livro XVI, cap. 3. e Livro XVII, cap. 2, respectivamente.

${ }^{107}$ E. Quinet, Le Christianisme et la Révolution française, $13^{\text {ème }}$ leçon.
} 
conversão dos revolucionários e na (falsa) crença (herdada do espírito filosófico da Ilustração) de que uma reforma civil prescindiria de uma revolução religiosa.

Finalmente, para Quinet, o exemplo do Terror, sucedendo às veleidades tolerantes e ecumênicas da Constituinte e da Legislativa para com a Igreja católica, atesta que o não-banimento dos demônios produz o efeito contrário daquele almejado, ou seja, a Revolução 'pecou' por ter começado no ponto em que as outras (como a Puritana/Gloriosa) terminaram, a tolerância. ${ }^{108}$

É precisamente neste ponto - qual seja, a acerba crítica de Quinet ao jacobinismo que, de certo modo, 'contaminou' toda sua interpretação sobre a Revolução - que Michelet dele se separou. Por isso, após ter destacado, na "Introdução" de sua Histoire de la Révolution, em 1847, a incompatibilidade entre a religião da graça e a religião da Justiça e/ou do Direito, é que Michelet não podia admitir, sem incorrer em contradição, a vinculação da Revolução com o Cristianismo (vale dizer, protestantismo). Ainda mais pelo fato de estar convencido de que uma nova fé republicana e laica viera à luz na festa da Federação de julho de 1790, e que a "igreja republicana", pela segunda vez perseguida após o golpe de 2 de Dezembro de 1851 (como já havia sido pelo 18 Brumário, em 1799), acabaria triunfante no final, graças ao catecismo republicano ministrado pelos predicadores cívicos (os professores primários) ao povo.

Entretanto, não se pode perder de vista o tratamento conferido à Reforma por Michelet quando o mesmo retoma a redação de sua Histoire de France (1833-1867), interrompida em 1844 para abordar a história da Revolução (1847-1853). Tome-se como exemplo a conclusão de sua Histoire de France au XVI ème siècle (1857), onde Michelet auto-elogia-se por haver "revelado, defendido" o protestantismo como um "partido do exame e da liberdade internamente idêntico ao Renascimento e à Revolução", chegando inclusive a reconhecer, após visitar os recintos do colégio de João Calvino (1509-1564) e de Théodore de Bèze (1519-1605), em Genebra, que "o grande sopro da Revolução [francesa] esteve por lá". ${ }^{109}$

Mas a principal descoberta relativa ao protestantismo pelo fiel democrata e "historiador do povo" encontra-se na constatação de que o primeiro sínodo da Igreja Protestante francesa (celebrado em 1559 em Paris) prescrevia a "republicana" prática da eleição de ministros do culto, bem como da eleição de fiéis nas assembleias soberanas:

\footnotetext{
${ }^{108}$ E. Quinet, La Révolution (1865), Livro V, cap. 6.

${ }^{109}$ Jules Michelet, Histoire de France, "Guerres de Religion", p. 107 e "La Ligue et Henri IV", p. 466; in: P. Viallaneix (org.), Oeuvres Complètes de J. Michelet (Paris: Flammarion, 1974), t. VIII, 1978.
} 
"Eis aqui a base republicana da Igreja da França" - isto é, a igreja cívico-laica almejada por Michelet - "verdadeiramente republicana". ${ }^{110}$ E mais adiante: "O que vislumbro no século XVI? Que apenas o protestantismo nos oferece a República... Digo que ele oferece a República: a ideia, a coisa e a palavra". ${ }^{111}$

E assim como ocorrera na Histoire de la Révolution, na qual Michelet apela à paradoxal autoridade contra-revolucionária de Maistre para endossar suas críticas republicanas à aristocracia e ao clero do Antigo Regime, também na Histoire de France os juízos do professor democrata-republicano e o do contrarrevolucionário ultramontano vão convergir - por razões bem distintas, é verdade - não só no que concerne ao papel do Protestantismo na história da França (do Antigo Regime à Revolução), mas também no que diz respeito ao próprio caráter epocal (poder-se-ia dizer, 'suficientemente protestante', na contramão de Quinet) da Revolução.

De certo modo, este também será o pensamento de Tocqueville, embora nele (mormente em O Antigo Regime e a Revolução, de 1856) o caráter 'epocal' da Revolução tenha sido sublimado pelos efeitos centralizadores do Antigo Regime. Quando alude implicitamente à Reforma (e, em menor grau e à guisa de Burke das Letters on a Regicide Peace, ao islamismo), será para destacar aquilo que ele considera o "caráter principal da Revolução Francesa, ainda que transitório", a saber, o filosofismo que, devido às suas noções gerais e abstratas, procedeu à maneira das religiões. ${ }^{112}$ Antes, na segunda parte de A Democracia na América (1840), Tocqueville expressara sua preocupação com os efeitos da democracia e/ou da igualdade sobre a razão individual, que ele, Tocqueville (e à diferença de Maistre), se preocupava em salvar. Assim, após afirmar - numa linha de argumentação muito parecida com a avançada por Mme de Stäel no Des circonstances (1798) e por Constant no De la Réligion (1824-1831) - que a religião é mais do que nunca necessária para as sociedades democráticas ${ }^{113}$, constata a inclinação psicológico-moral panteísta (para o autor, uma visão cosmológica aniquiladora da individualidade humana) nas sociedades igualitárias. ${ }^{114}$ Ou seja, o que para Tocqueville consistia no grande oxímoro político a ser resolvido pelos indivíduos nas sociedades democráticas (a tendência para a

${ }^{110}$ Michelet, Histoire de France, in: P. Viallaneix (org.), Oeuvres Complètes de J. Michelet. op. cit., p. 137.

${ }_{111}^{11}$ Idem, p. 285.

${ }^{112}$ Alexis de Tocqueville, O Antigo Regime e a Revolução (1856), Livro I, cap. 3; e L'Ancien Régime et la Révolution: Fragments et notes inédites sur la Révolution, in: André Jardin (org.), Alexis de Tocqueville: Oeuvres Complètes, vol. II (Paris: Gallimard, 1953), $4^{\mathrm{a}}$ edição, p. 239.

${ }_{113}$ A. de Tocqueville, De la Démocratie en Amérique (1840), vol. II, Livro I, cap. 5.

${ }^{114}$ A. de Tocqueville, De la Démocratie en Amérique (1840), vol. II, Livro I, cap. 7. 
igualdade que, favorecida e impulsionada pelas inclinações individualistas, fortalecia as instâncias estatais em detrimento das associativas/representativas), para Maistre era apenas uma consequência lógica e insolúvel (caso se opte pela manutenção de suas premissas morais) da ausência do princípio de autoridade solapado pela Reforma Protestante (só que com o efeito inverso daquele apontado por Tocqueville: ao invés do incremento sem limites da soberania estatal, a sua dissolução a um mínimo).

No início do século XX, o nome de Maistre viria associado sobretudo à Ação Francesa. ${ }^{115}$ Apesar de um grande número de autores ter sublinhado a influência do pensamento de Maistre sobre Maurras ou sobre a Action Française em geral ${ }^{116}$, essa assimilação não se deu tão naturalmente, como demonstrou Jean Zaganiaris em seu estudo.

Para o autor, "seria ilusório pensar as relações entre o pensamento maistreano e a Ação Francesa, em se tratando do monarquismo desse movimento, como algo dado de antemão. Era através da crítica contra aquilo que percebiam ser a triste realidade da III República, decadente, instável e corrompida, e não em razão de uma atração pela realeza, que essa organização contrarrevolucionária se constituiu."117

Isto fica demonstrado pelo fato de o movimento ter silenciado sobre o nome de Maistre até 1901, quando o saboiano faz sua primeira aparição numa coleção intitulada "Nos maîtres" (nossos mestres). Ao selecionar algumas passagens do pensamento de Maistre e dispô-las sob a forma de aforismos - sendo que a maior parte era extraída de seu tratado De la souveraineté du peuple -, a Ação Francesa tinha o duplo cuidado de atrair a atenção do público católico sem, no entanto, aludir ao passado maçônico/místico de Maistre, que poderia escandalizar os adeptos de inclinações positivistas. E a escolha do tratado antirrousseauniano não poderia se encaixar melhor nos desígnios do movimento: afinal, defendia-se a monarquia sem apelo excessivo à Providência, demonstrava-se a impossibilidade da soberania popular numa grande nação e, finalmente, criticava-se a escritura constitucional abstrata. ${ }^{118}$

${ }^{115}$ Fundada em junho de 1899 como um prolongamento da Liga da Pátria Francesa - instituída no ano anterior por um grupo de intelectuais que pretendiam se opor aos defensores de Dreyfus e à Liga dos Direitos do Homem (1898).

${ }^{116}$ P. Burrin. "Le fascisme", in: J. F. Sirinelli, Histoire des droites en France (Paris: Gallimard, 1992), vol 1, p. 623-638; M. Winock. "L’héritage contre-révolutionnaire”, in: M. Winock (org.), Histoire de l'extrême droite en France (Paris: Seuil, 1993), p. 17-49.

117 J. Zaganiaris, Spectres Contre-Révolutionnaires: interpretations et usages de la pensée de Joseph de Maistre XIX $-X X^{e}$ siècles (Paris: L'Harmattan, 2005), p.113.

118 "Nos maîtres: Joseph de Maistre: Aphorismes de politique positive", in: RAF, $1^{\circ}$ de março de 1901. Antes de Maistre, os "mestres" citados foram, respectivamente, Rivarol, Voltaire (com o curioso 
Com respeito a esta chave de leitura antiprotestante e para além dos discursos polêmicos surgidos no contexto da crise de Dreyfus, foi no contexto do pós-guerra que Maurras, em suas Réflexions sur la Révolution de $1789(1948)^{119}$ e referindo-se a Maistre, incluiu os protestantes numa heterogênea conspiração contra a monarquia francesa. ${ }^{120}$ As Réflexions de Maurras definiam a Revolução Francesa como um processo que havia interrompido a monarquia na França - regime que, a seu ver, melhor representava o interesse público, pois remediava o individualismo e a ambição dos interesses particulares, vitoriosos com o advento do sufrágio universal - e abandonado o país a um grupo heterogêneo composto pelos "metecos", "franco-maçons", "protestantes" e "judeus".

De um modo geral, portanto, seria preciso esperar pelo último quarto do século XX, particularmente o contexto do bicentenário da Revolução, para que esta abordagem teológico-política adquirisse relevância e centralidade junto à historiografia, e ainda assim sob o prisma do jansenismo, cujos fundamentos e desenvolvimento histórico abordaremos logo em seguida.

subtítulo de "Abaixo os Judeus!" ) e Bonald. Até mesmo Maquiavel seria citado, na edição de $1^{\circ}$ de julho de 1904. Cf. J. Zaganiaris, Spectres Contre-Révolutionnaires..., p,130.

${ }^{119}$ Importa salientar que as Réflexions, nascidas do encarceramento que lhe infligiram após a Libertação, não foram redigidas ex nihilo, antes constituindo um reagrupamento de idéias anteriores.

${ }_{120}$ Ao compreender a Revolução como um processo histórico que se repetira em 1830, 1848,1871 e 1899 (ano em que Dreyfus foi reconhecido como inocente), Maurras se distanciava da direita anticomunista (mesmo a que integrava os quadros da Ação Francesa), pois, no seu entendimento, a luta tinha de ser dirigida contra os valores de 1789 reiterados pela França da Liberação. 


\section{CAPÍTULO 3}

\section{'De l'Église Gallicane': da 'révolution ménagée' ao 'refinamento do espírito revolucionário'. Raízes do anticlericalismo liberal-revolucionário}

Referindo-se à relação entre a Revolução e a Igreja nas anotações que deveriam compor o segundo volume de $O$ Antigo Regime e a Revolução, Alexis de Tocqueville confessou a necessidade de pesquisar a fundo as causas por trás do "ódio furioso contra os padres e a religião", segundo ele - uma testemunha dos violentos surtos anticlericais dos anos 1830 e das incessantes dilacerações mútuas no mundo das letras entre os membros e partidários da Igreja católica e os intelectuais republicanos e/ou liberais franceses (como, no caso dos últimos, Michelet e Quinet, para citarmos dois exemplos já referidos neste estudo) -, "a mais viva e a última das paixões revolucionárias a ser extinta". Mais especificamente, procurava uma resposta para o fato de que em pleno regime do Diretório, marcado pela condenação do Terror por seus intelectuais e políticos, "o estímulo irreligioso, voltaireano, encicloplédico continua[va] a impelir aqueles que falam e escrevem...", furor este que, para Tocqueville, não se verificara nem contra os emigrados. ${ }^{1}$

Limitado por seu grave estado de saúde, Tocqueville não pôde completar o referido estudo, embora forçosamente conhecesse o pensamento de Maistre a este respeito, cujas obras - especialmente Du Pape (1819) e Considerações sobre a França (1797) - vivenciaram um autêntico boom editorial após a Revolução de 1848 e a instauração do Segundo Império poucos anos depois. Afinal, diante da 'ameaça vermelha' à propriedade, a burguesia descobriu que preferia a ordem à oportunidade de pôr em prática seu programa completo, decidindo-se, no contexto revolucionário, a esquecer velhas rixas dinásticas e cerrar fileiras em torno do "partido da ordem" com os legitimistas. $^{2}$

${ }^{1}$ Alexis de Tocqueville, L'Ancien Régime et la Révolution. Fragments Inédits sur la Révolution. In: J.-P. Mayer (org.), Oeuvres Complètes de Alexis de Tocqueville (Paris: Gallimard, 1953), t. II, $4^{\mathrm{a}}$ edição, p. 238-239.

${ }^{2}$ Sobre os ecos ou fortuna editorial das ideias maistreanas no mundo literário francês do século XIX, leia-se Antoine Compagnon, Les antimodernes: de Joseph de Maistre à Roland Barthes (Paris: Gallimard, 2005). 
Apesar de sua veemente oposição àquela política "da ordem" do Segundo Império francês, a prova de que Tocqueville não ignorava o pensamento do então influente contrarrevolucionário saboiano - o que, repetimos, seria algo impossível no contexto intelectual francês do século $\mathrm{XIX}^{3}$ - encontra-se em algumas passagens do primeiro volume de $O$ Antigo Regime e a Revolução (1856), este sim publicado em vida pelo historiador e político: "Muitos a [a Revolução] consideram como a ação visível do demônio na terra. 'A Revolução Francesa tem um caráter satânico', diz de Maistre, a partir de 1797."4

Porém, é bem provável que o alvo da crítica a seguir seja o célebre panfleto termidoriano de Maistre:

“A Revolução não foi de modo nenhum feita, como se acreditou, para destruir o império das crenças religiosas; ela foi essencialmente, apesar das aparências, uma revolução social e política; e, no círculo das instituições deste gênero, ela em nada tendeu a perpetuar a desordem, a torná-la de algum modo estável, a tornar metódica a anarquia, como dizia um de seus principais adversários, mas antes a fazer crescer o poder e os direitos da autoridade pública.,

A julgar por estes excertos, pode-se supor que o conhecimento de Tocqueville sobre a obra de Maistre se limitasse (muito em razão dos preconceitos associados à figura do contrarrevolucionário saboiano) fundamentalmente a três escritos, respectivamente Considerações sobre a França, Du Pape (Do Papa, de 1819) e o Essai sur le principe générateur des constitutions politiques ${ }^{6}$, pois, se tivesse lido a De l'Église Gallicane (publicada em 1821) ou as Réflexions sur le Protestantisme dans son rapport avec la Souveraineté (Reflexões sobre o Protestantismo nas suas relações com a Soberania $)^{7}$, o autor de Da Democracia na América certamente poderia ter recolhido

\footnotetext{
${ }^{3}$ Como se evidencia, por exemplo, pelo testemunho de seu amigo, igualmente literato e político, o 'doutrinário' Charles de Rémusat (1797-1875), que emitiu o seguinte juízo sobre Maistre, e o qual de certo modo pode tê-lo (isto é, Tocqueville) influenciado no sentido de reprimir e sublimar o quanto fosse possível suas simpatias para com hipóteses maistreanas: "É ao espírito dos tempos modernos que ele declara uma guerra mortal, a esse espírito tal como se manifestou pelos princípios da Revolução Francesa. Não são os excessos, os extravios, os crimes que ele ataca; os excessos, os extravios, os crimes são, para ele, a essência da Revolução, e querer separá-la do mal que ela produziu, é tentar separá-la dela mesma." Ch. de Rémusat, "Du Traditionalisme", in: Revue des Deux Mondes, 9 (27 ano, $2^{\circ}$ período): p. 243,15 de Maio de1857.

${ }^{4}$ Alexis de Tocqueville, L'Ancien Régime et la Révolution (1856). Livro I, cap. 1.

${ }^{5}$ Idem, Livro I, cap.5.

${ }^{6}$ Ensaio sobre o princípio gerador das constituições políticas, redigido em 1809, mas publicado na França a partir de 1814, quase sempre em anexo às edições das Considerações.

${ }^{7}$ Como vimos anteriormente, apesar de iniciado no exílio suíço em 1796 e finalizado em 1798 , veio a público somente em 1870, após o falecimento de Tocqueville portanto.
} 
importantes pistas para a solução daquele específico 'enigma' histórico apresentado pela Revolução de 1789.

E isto é tão ou mais curioso pelo fato de que, mesmo movido por outros desígnios ou defendendo posições políticas sensivelmente distintas, Tocqueville, de certo modo, demonstrou ter pleno domínio conceitual daquele que era o núcleo da crítica teológicopolítica maistreana ao fenômeno revolucionário francês, como se depreende pela seguinte citação:

"Consideremos por um momento o encadeamento dos tempos./ No século XVI, os reformadores submetem à razão individual alguns dos dogmas da antiga fé, mas continuam a subtrair-lhe a discussão de todos os demais. No século XVII, Bacon, nas ciências naturais, e Descartes, na filosofia propriamente dita, abolem as fórmulas recebidas, destroem o império das tradições e derrubam a autoridade do mestre./ Os filófosos do século XVIII, generalizando finalmente o mesmo princípio, trataram de submeter ao exame individual de cada homem o objeto de todas as suas crenças./ Quem não vê que Lutero, Descartes e Voltaire serviram-se do mesmo método, e que eles não diferem a não ser no maior ou menor uso que fizeram do mesmo "18 $^{8}$

Diante das semelhanças entre este julgamento tocquevilleano a respeito de seu objeto de análise (a jovem e democrática sociedade norte-americana) e o que Maistre redigiu de mais importante em sua práxis contrarrevolucionária a partir das Reflexões sobre o Protestantismo (como, por exemplo, o Examen de la philosophie de Bacon e o Les Soirées de Saint-Pétersbourg, publicados respectivamente em 1836 e $1821^{9}$; além, é claro, dos já citados Du Pape e a De l'Église Gallicane), teríamos bons motivos para suspeitar que Tocqueville, ao fim e ao cabo, fosse um melhor leitor de Maistre do que se poderia supor à primeira vista.

Todavia, apesar de reconhecer que o "caráter filosófico" ${ }^{10}$ que tanto distinguia a Revolução Francesa tivera origem na Reforma Protestante do século XVI, a abordagem política de Tocqueville não se preocupou em desdobrar todas as possibilidades daquela fecunda hipótese, ou, quando se deu conta disto, já era tarde.

Pois foi precisamente a partir daquele "princípio" examinador herdado Reforma, qual seja (nos termos tocquevilleanos referidos acima), o que tratava de "submeter ao

\footnotetext{
${ }^{8}$ Alexis de Tocqueville, De la Démocratie en Amérique (1840), vol. 2. Parte I, cap. 1.

${ }^{9}$ Respectivamente Exame da filosofia de Bacon e Saraus de São-Petersburgo ou Diálogos sobre o Governo temporal da Providência.

10 Alexis de Tocqueville, L'Ancien Régime et la Révolution. Fragments Inédits sur la Révolution..., p. 239.
} 
exame individual de cada homem o objeto de todas as suas crenças" e o qual identificava como o caráter mais distintivo, longevo e replicante da cultura revolucionária (sobrevivendo ao regimes termidorianos, napoleônicos e à Restauração e espalhando-se pelo mundo sempre de forma mais radical), que o contrarrevolucionário e estadista saboiano alicerçava sua hipótese a respeito das "afinidades" ou "atrações eletivas" entre o protestantismo (com todas as suas subdivisões, mormente o calvinismo e, no caso específico francês, o jansenismo) e o jacobinismo ${ }^{11}$, responsável, segundo ele, pelo inextinguível combate (à outrance) entre o cristianismo (representado sobretudo pelo catolicismo) e o 'espírito' revolucionário. De modo que aquela que constituía a "mais viva e a última das paixões revolucionárias a ser extinta" ("ódio furioso contra os padres e a religião") era uma consequência direta da "grande base [intelectual] do protestantismo", a saber, "o direito ao exame" (que "não encontra limites: aplica-se a tudo e não pode receber freio"). ${ }^{12}$

$\mathrm{Na}$ França, advertia Maistre, o principal auxiliar da revolucionária coalizão protestante/jacobina contra o absolutismo monárquico (e seu principal 'aparelho ideológico', a Igreja católica) fora o jansenismo, o qual, "por sua extrema afinidade com o calvinismo", mostrou-se "enormemente culpável pela Revolução Francesa, não tendo auxiliado pouco seus dois irmãos, o filosofismo e o protestantismo"13:

"As grandes revoluções, os grandes abalos morais, religiosos ou políticos, sempre deixam algo depois deles. O calvinismo nasceu na França; sua pátria, vigorosa o suficiente para vomitar o veneno, permaneceu entretanto notavelmente afetada por ele. Viu-se então o que se verá eternamente em todas as revoluções: elas terminam, mas o espírito que as trouxe à vida sobrevive. É o que se verificou sobretudo na França, nas dificuldades que ali se ergueram contra a admissão do Concílio de Trento... Foi sobretudo o Terceiro Estado, isto é, a maioria, que se opôs á admissão do Concílio; e assim tinha que ser, pois há no protestantismo um caráter democrático feito para seduzir de todos os lados a segunda ordem/ O espírito do século XVI foi nutrido e propagado na França principalmente pelos parlamentos, e sobretudo pelo de Paris. Protestante no século XVI, frondeur e jansenista no século XVII, filosófico e, finalmente, republicano nos últimos anos de sua vida, o parlamento muito frequentemente mostrou-se em contradição com as verdadeiras máximas do Estado."14

\footnotetext{
${ }^{11}$ Joseph de Maistre, Réflexions sur le Protestantisme, O.C., VIII: 86.

${ }^{12}$ Idem, O.C., VIII: 91.

${ }^{13}$ Ibidem, O.C., VIII:78.

${ }^{14}$ Joseph de Maistre, De l'Église Gallicane (1821), Livro I, cap. 2.
} 
Com efeito, Maistre considerava impossível dissociar aquilo que julgava ser um inusitado impulso centralizador dos revolucionários de 1789 e da geração liberal do século XIX daqueles típicos desdobramentos teológico-políticos da Reforma na França sob o Antigo Regime, mais especificamente da oposição jansenista-parlamentar às determinações políticas ortodoxas da Igreja galicana/francesa, oposição esta responsável por fortalecer as prerrogativas do poder temporal ao mesmo tempo em que este poder era esvaziado dos símbolos sagrados que o definiam numa plataforma absolutista:

"Para me ater ao objeto de que trato, destacaria que o caráter mais distinguido e o mais invariável do parlamento de Paris se extrai de sua constante oposição à Santa Sé. A este respeito, nunca as grandes magistraturas francesas variaram... Este mesmo espírito [protestante] havia se perpetuado até os nossos dias no Parlamento, através do jansenismo, que, no fundo, não é outra coisa senão uma fase do calvinismo. Os nomes mais veneráveis da magistratura foram atingidos por ele, de modo que não sei bem em que medida o filosofismo dos jovens era mais perigoso ao Estado./ Por ser, com justiça, o mais famoso dos concílios gerais e o grande oráculo antiprotestante, o Concílio de Trento desagradava à magistratura francesa, precisamente em razão de sua autoridade." 15

Portanto, mais ainda do que às Reflexões sobre o Protestantismo, é à De l'Église Gallicane que devemos recorrer para recuperar esta construção "histórica" maistreana, ainda que na condição de escoimá-la seja de um parti-pris característico da natureza prática/política da obra, seja do tom (um tanto intolerante) intrinsecamente voltaireano (se bem que com sinais invertidos) - de quem empresta não só o estilo, como também inúmeras opiniões negativas aos parlamentos e ao jansenismo, orientando e concentrando contra este último todo o anticlericalismo do eminente filósofo (decididamente mais universal, isto é, não poupando a nenhum dos envolvidos nas controvérsias religiosas que dilaceraram as consciências dos franceses entre as décadas de 1710-1770).

Assim como o Du Pape, a De l'Eglise Gallicane ${ }^{16}$ foi concebida nos quadros de uma proposta de Concordata de 1817 entre o papa Pio VII (1742-1823) e o monarca francês Luís XVIII (1755-1824), a qual fora explorada pelos liberais daquele país de

\footnotetext{
${ }^{15}$ Joseph de Maistre, De l'Église Gallicane (1821), Livro I, cap. 2.

${ }^{16}$ Originalmente como o livro $\mathrm{V}$ do primeiro e publicada como a $2^{\mathrm{a}}$ parte daquela obra, em 1821 ,
} após o falecimento ao autor. 
modo a provocar uma fratura entre os diferentes atores sociais que compunham as principais esferas de poder durante a Restauração.

Isto porque monarquia, aristocracia e clero, após serem derrotados e exilados pela Revolução de 1789, retornam durante a Restauração na condição de aliados após séculos de disputas durante o Antigo Regime. Diante da nova França, que herdara os valores e as instituições da Revolução, os "aliados" aprenderam a lição: desunidos no passado, tinham de se manter unidos ${ }^{17}$.

Assim, diante do radical deslocamento do eixo político provocado pela Revolução e pelos vinte e cinco anos do exílio, não restou aos liberais senão apelar à história para provocar fraturas naquela frágil aliança. Em 1817, com a proposta da Concordata, os liberais ganharam um presente dos céus, na bela definição de Stanley Mellon. ${ }^{18}$

Os liberais perceberam que a unidade entre e trono e a Igreja poderia ser quebrada precisamente nos mesmos termos em que ambos se dividiram no passado, ou seja, as pretensões de Roma contra a defesa das 'liberdades galicanas' pelo rei. ${ }^{19}$ Apesar de tacitamente unidos até 1817 , a proposta de reforçar os laços entre ambos por meio de

${ }^{17}$ Em 1816, Chateaubriand argumentou em De la monarchie selon la Charte (1816) que não havia nada de extraordinário nesta tríplice aliança, no que foi criticado pelo ex-ministro de guerra de Napoleão (e então historiador) Jubé de la Perrelle (Lettre à M. le vicomte de Chateaubriand, 1816), para quem a versão de Chateaubriand era falaciosa, uma vez que os anais da história francesa atestam a turbulência, a ambição, a ingratidão, e as "rebeliões criminosas do clero", bem como as disputas sangrentas entre os reis e a nobreza.

${ }^{18}$ S. Mellon, The Political uses of History. A Study of historians in the French Restoration (Standford: Standford University Press,1958), p. 103.

${ }^{19}$ Isto é, na De l'Église Gallicane Maistre alude à 'Declaração dos quatro artigos' do Clero galicano de 1682 (edito real de 2 de março): "Cegos corruptores do poder, eles [bispos franceses reunidos na Assembleia Geral do Clero e responsáveis pelos artigos de 1682] prestaram um serviço singular ao gênero humano, dando lições de autoridade arbitrária a Luis XIV, declarando que os maiores excessos do poder temporal não tinham nada a temer de uma outra autoridade, e que o soberano é rei na Igreja como no Estado! E o que há de mais estranho nisto é que, consagrando da maneira mais solene estas máximas que, certas ou falsas, nunca deveriam ter sido proclamadas, os deputados ofereceram ao mesmo tempo todas as bases da demagogia moderna; declararam expressamente que, numa associação qualquer, uma seção pode se reunir, deliberar contra o todo, e dar-lhe as leis. Ao decidirem que o concílio é superior ao Papa, declararam não menos expressamente, ainda que em outros termos, que uma assembleia nacional qualquer está acima do soberano, de modo que podem ocorrer inúmeras assembleias nacionais dividindo legalmente o Estado. Pois, se a legitimidade da assembleia não depende do chefe que a preside, nenhuma força pode impedi-la de se dividir e nenhuma seção pode provar sua legitimidade em detrimento das demais" (Livro II, cap. 4). Grosso modo, os quatro artigos referidos por Maistre eram os seguintes:

I. O soberano pontífice possui apenas autoridade espiritual; portanto, os príncipes não se encontram submetidos à autoridade da Igreja nos assuntos temporais;

II. O papa não pode julgar os reis e nem depô-los;

III. O concílio ecumênico, reunião de todos os bispos da cristandade, toma decisões que possuem um valor superior àquelas adotadas pelo papa, cuja autoridade é, portanto, limitada pela dos concílios gerais;

IV. Em matéria de dogma, o papa não é infalível senão por meio do consentimento da Igreja universal. 
uma concordata trouxe à tona uma série de problemas referentes à relação do Estado com a Igreja, em outras palavras, o galicanismo conforme expresso pelo jansenismo nas controvérsias em torno da bula Unigenitus de 1713.

O típico argumento da campanha liberal contra a Concordata afirmava, a exemplo de Benoît (De la liberté des cultes et du Concordat, 1818), que na história francesa a aliança entre o trono e o papa era uma artificialidade, diferentemente da aliança entre o rei e a igreja galicana, antiga e estável.

A partir deste ângulo, forja-se uma das mais decisivas alianças da Restauração, a saber, a união entre os liberais e o clero galicano (uns lutando pela liberdade política, os outros, pelas liberdades religiosas em relação aos bispos e a Roma). Por toda a Restauração, a estratégia liberal consistirá em convencer os membros do clero galicano a juntar forças no combate contra o ultramontanismo.

Aquela realidade da Restauração (francesa e europeia) mostrara a Maistre que a Revolução estava "em pé"20, uma vez que o solapamento do "sistema da autoridade",21 prosseguia, ainda que de novas maneiras. Primeiramente democrática (1789-1794), depois oligárquica (1794-1799) e tirânica (Napoleão), a Revolução assumiu durante a Restauração uma feição real. ${ }^{22} \mathrm{E}$ isto graças ao galicanismo jansenista, com a condescendência 'irresponsável' da monarquia. ${ }^{23}$

Para Maistre, o único meio de se extinguir a Revolução passava pela afirmação do princípio contrário, a saber, o princípio de autoridade, tanto na esfera política como na esfera religiosa, e o qual tinha por bases o cristianismo e a Igreja católica.

20 “A Revolução está em pé, e não apenas está em pé, como ela marcha, corre, escoiceia. [...] A única diferença que percebo entre esta época e a do grande Robespierre, é que naquela época as cabeças caíam enquanto que hoje elas se viram"(Joseph de Maistre, O.C., XIV:156); "A Revolução é bem mais terrível que no tempo de Robespierre; educando-se, ela se refinou" (Joseph de Maistre, O.C., XIV:148).

${ }^{21}$ No último e inconcluso diálogo das Soirées (undécimo diálogo) declara que a "autoridade é a base de nosso sistema". Leia-se o que declarou nas Considerações (cap. 5): "Não há mais costume, nem autoridade; o espírito de cada homem está encerrado em si mesmo. Desde que a filosofia corroeu o cimento que unia os homens, já não existem agregações morais."

22 "Não terminaria sem observar à Vossa Excelência que se enganaria infinitamente quem acreditasse que Luís XVIII reascendeu ao trono de seus ancestrais. Reascendeu apenas ao trono de Bonaparte, o que já constitui um grande bem à humanidade: mas estamos muito distantes do repouso. A revolução foi num primeiro momento democrática, depois oligárquica, e tirânica: hoje, ela é real, porém segue sempre o seu curso. A arte do príncipe consiste em reinar sobre ela e sufocá-la levemente enquanto a abraça." Cf. A. Blanc, Correspondance Diplomatique de J. de Maistre: 1811-1817 (Paris: Lévy, 1860), vol. I, p. 379.

23 "Longa vida ao rei, a despeito dele próprio", assim resumiríamos o programa político de Maistre no polarizado contexto da Restauração: "Se me sentasse numa das duas Câmaras, defenderia até a última palavra este farrapo de Carta, uma vez que não há outro meio de salvar a França senão marchando com o rei. Do contrário, o Estado lembrará uma carroça cujos cavalos tomam sentidos opostos.” In: A. Blanc, Correspondance Diplomatique de J. de Maistre: 1811-1817..., vol. II, p. 268. 
Com efeito, o galicanismo para Maistre nada mais era senão um disfarce para o jansenismo, um desdobramento do protestantismo na França e o responsável pela Revolução naquele país. No contexto da Restauração, representava uma constante ameaça à monarquia, pois os mesmos jansenistas que "infectaram" os parlamentos durante a regência do duque de Orléans e produziram a Constituição Civil do Clero tentavam demover o monarca de sua aliança com Roma, sob o pretexto das 'liberdades galicanas' e da neutralidade em matéria de religião. Porém, se as liberdades galicanas, consagradas pela Declaração de 1682, levaram (ainda segundo Maistre), num primeiro momento, à licensiosidade parlamentar e à submissão do clero perante o "sultão"Luís XIV, na regência, deram o aval aos parlamentos sitiarem e destruírem o anteparo da monarquia absolutista (isto é catolicismo, através da expulsão dos jesuítas, em 1764), preparando a grande Revolução:

"Encorajados pela fraqueza de uma soberania agonizante" - referência a Luís XV em meio à controvérsia da negação dos sacramentos e da expulsão dos jesuítas das décadas de 1750-1760 -, "os magistrados franceses perderam a noção da medida. Eles ordenaram os bispos, apreenderam sua prerrogativa temporal, apelaram contra um instituto religioso [Companhia de Jesus] tornado francês após dois séculos, declarando-o, através do seu chefe, antifrancês, antissocial, e até mesmo ímpio,sem se deterem um único instante seja diante do concílio ecumênico que o havia declarado pio, seja diante do Soberano Pontífice que respeitava a mesma decisão, seja, ainda, diante da Igreja galicana presente diante deles, a qual conjurava a autoridade real de impedir esta funesta violação de todos os princípios."24

Ao criticar a subserviência do clero em relação à monarquia sob o galicanismo conciliar/liberal (subserviência que os liberais traduziam como "lealdade"), Maistre sabia que caminhava sobre um campo minado: precisava encontrar um meio para criticar o galicanismo que não fosse muito atraente nem à monarquia (que poderia

\footnotetext{
${ }^{24}$ Joseph de Maistre, De l'Église Gallicane, Livro I, cap. 2. Mais adiante, numa nota de rodapé em que tratava de explicar uma citação de Leibniz (para quem os parlamentos, quando se tratava da defesa dos direitos ou prerrogativas do rei em relação à esfera espiritual, eram imprudentes e judiciosos a ponto de extrapolar o poder temporal) contra os parlamentos franceses, Maistre diz o seguinte: "A estas palavras de Leibniz, quando se trata dos direitos do rei, é preciso acrescentar contra o Papa e contra a Igreja; pois, quando se tratava desses mesmos direitos considerados neles mesmos e no interior do Estado, os Parlamentos não solicitavam outra coisa senão a restrição dos mesmos, sobretudo em relação a estes mesmos Parlamentos. Havia no magistrado francês um republicano e um cortesão, segundo as circunstâncias. Esta espécie de Janus mostrava uma face ao rei e outra à Igreja."
} 
incorrer num absolutismo anticlerical de matiz hobbesiano) nem à nobreza ${ }^{25}$ (sob pena de a mesma adotar uma estratégia "zelote" e "liguista" como a de Bonald, que, nos Pensées sur divers sujets, de 1817, sugeriu que os ultras poderiam atacar a realeza em nome da legitimidade religiosa, como nos tempos da Liga católica do século XVI). A solução encontrada foi mostrar a todos os envolvidos que a lealdade ao papado se revertia, em última análise, na lealdade para com a monarquia.

Após demonstrar historicamente que o exercício da autoridade papal sobre o poder temporal não constituía uma usurpação (como gostavam de argumentar os galicano-liberais) $^{26}$ - uma vez que os papas lutavam contra os abusos de soberanos particulares e jamais contra a soberania dos monarcas em si (ao contrário dos filófosos, que lisonjeavam os monarcas particulares enquanto ridicularizavam a instituição da realeza $)^{27}$-, Maistre se depara com o delicado problema da soberania, que atravessa toda a discussão.

O fato de o gênero humano precisar de soberania não representava dificuldade alguma para o saboiano: o homem,“...ao mesmo tempo moral e corrompido, justo em sua inteligência e perverso em sua vontade, deve ser necessariamente governado; de outro modo, ele será ao mesmo tempo sociável e insociável, e a sociedade será simultaneamente necessária e impossível... Sendo o homem necessariamente associado e governado, sua vontade não participa em nada no estabelecimento do governo.”28

A dificuldade para todos os elementos envolvidos na discussão estava em defender e legitimar a soberania após a Revolução Francesa. Como fazê-lo sem cair nos

25 “Ao apoiar deste modo o sacerdócio, a nobreza francesa pagará uma imensa dívida que contraiu junto à França... e à Europa. O maior sinal de respeito e estima que se lhe possa fazer, é o de lembrá-la que a Revolução Francesa, a qual pagou indubitavelmente com todo seu sangue, foi, no entanto, em grande parte obra sua." In: Maistre, Du Pape. "Discurso Preliminar."

${ }^{26}$ Antes, foram os "tutores dos reis, os guardiões e os professores da Europa" durante a barbárie da Idade Média; era natural que os papas, por possuírem mais "sabedoria" e "ciência", no papel de mantenedores da civilização européia durante um estágio de extrema flutuação de poder e violência, em que uma soberania temporal se sucedia à outra, tivessem seu poder e influência reforçados durante este período. Neste quadro, era necessário não só à monarquia, mas à civilização européia que os papas interviessem nos abusos do poder temporal. Cf. Joseph de Maistre, Du Pape, especialmente Livro II, cap. 6. e Livro II, cap. 10.

27 Joseph de Maistre, Du Pape, Livro II, cap. 5.

${ }^{28}$ Joseph de Maistre, Du Pape, Livro II, cap. 1. Vale lembrar que a justificativa de Maistre para a existência do Estado é diametralmente oposta às posições defendidas respectivamente por Paine (O Senso Comum, 1776) e Kant, em Idéia de uma história universal sob o ponto de vista cosmopolita, de 1784. Enquanto para o saboiano era impossível dissociar a sociedade da soberania (sinônimo mesmo de Estado e condição para a ordem e prosperidade), para Paine, "a sociedade é produzida pelas nossas necessidades, e o governo por nossa maldade; a primeira promove nossa felicidade de maneira positiva, unindo nossas afeições, e o segundo [Estado] de maneira negativa, cerceando nossos vícios(...). A sociedade, em qualquer estado, é uma bênção, enquanto o governo, mesmo em seu melhor estado, não passa de um mal necessário". In: Thomas Paine, "Common Sense”, in: Rights of Man, Common Sense and other Political Writings (Oxford: Oxford University Press, 2008), p. 5. 
dois "abismos", representados respectivamente pelo despotismo monárquico e pela "soberania do povo" ${ }^{29}$ ? O pensamento liberal havia compreendido que alguma coisa de absoluto na lógica soberana era responsável pelas explosões revolucionárias. Por natureza, a soberania tende a concentrar o poder num só, seja ele monarca ou povo. Diante disso, os teóricos políticos liberais da Restauração, como, por exemplo, os doutrinários, tentaram eliminar o próprio conceito de soberania, considerado abstrato e teológico. Contudo, ninguém melhor do que o protestante e liberal Constant - como vimos, um dos intelectuais revolucionários que, ao lado de Paine e Condorcet, mais atraíram a atenção da crítica maistreana e, em grande medida, sugeriram à mesma uma estreita vinculação conceitual entre os fenômenos da Reforma Protestante e a Revolução de 1789 - logrou ilustrar melhor este pathos preventivo do pensamento liberal pósrevolucionário com respeito à soberania, como se depreende a partir de sua clássica definição de "poder neutro" ou moderador, o qual, apesar de cunhado e datado nos quadros dos debates constitucionais revolucionários de setembro de 1789 (mais precisamente, em torno das teses monarquianas sobre o veto real), ganhou sua mais célebre formulação em Principes de politique, applicables a tous les gouvernements représentatifs et particulièrement à la Constitution Actulelle de France (redigido em 1806, mas publicado em 1815):

"O vício de quase todas as constituições", explica Constant, "foi o de não ter criado um poder neutro, de haver disposto a soma total da autoridade - da qual o poder neutro deveria estar investido - num dos poderes ativos. Quando esta soma de autoridade encontra-se reunida ao poder legislativo, a lei, que deveria se estender apenas a objetos determinados, aplica-se a tudo." ${ }^{30}$

\footnotetext{
${ }^{29}$ Joseph de Maistre, Du Pape, Livro II, cap. 2.

${ }^{30}$ B. Constant, Principes de politique, applicables a tous les gouvernements représentatifs et particulièrement à la Constitution Actulelle de France (Paris: Chez Alexis Eymery, 1815), p. 38. Mais precisamente, o conceito de "poder neutro" ou moderador do rei (chefe de Estado), apesar de guardar uma relação "passiva" vis-à-vis os demais poderes "ativos" - na ordem, o executivo/ministerial; legislativo (subdividido em duas assembleias: a hereditária ou de "longa-duração", escolhida pelo rei, não destituível mas sem limitação de número; e a assembleia "representativa da opinião", eleita livremente pelos eleitores aptos/proprietários, com limitação de membros e destituível pelo poder neutro em situações específicas) e judiciário -, representava para Constant "a chave de toda organização política", na medida em que (teoricamente) garantia a cooperação e prevenia os choques entre os demais poderes no interior do Estado. Segundo Constant, "é preciso que ela " [força moderadora] "...seja externa [aos poderes ativos descritos acima], que, de alguma forma, seja neutra, para que sua ação se aplique necessariamente onde quer que sua aplicação se faça necessária, e para que ela seja preservadora, reparadora, sem ser hostil". Idem, p. 35.
} 
Contra isso e desiludido quanto ao caráter da monarquia restaurada - que para ele, antes de decepcionar-se com os monarcas e as aristocracias europeias pós-napoleônicas (posto que "infectadas" pelo veneno jansenista/revolucionário) ${ }^{31}$ e numa chave de leitura ao mesmo tempo clássica (através de referência a atores como Plutarco, Cícero, Políbio) e montesquieuniana-burkeana ${ }^{32}$, representava a mais temperada forma de governo e a que melhor dispensava direitos aos povos 33 - Maistre propunha uma "diagonal" política: a união de todas as soberanias monárquicas em torno de uma "república universal sob a supremacia do poder espiritual supremo" e infalível dos papas. ${ }^{34}$ Noutras palavras, o papa passaria (voltaria) a arbitrar a relação dos povos com seus respectivos soberanos, reduzindo o direito de resistência a um direito à oposição (mas só em casos muito especiais e com muita prudência ${ }^{35}$ ) e estabelecendo limites ao poder temporal, que se beneficiaria com isto ${ }^{36}$ : as analogias entre o poder real e o poder espiritual são tantas, diz Maistre, que a agressão a um implica no ferimento do outro ${ }^{37}$.

${ }^{31} \mathrm{Na}$ medida em que, à guisa de Montesquieu, considerava o corpo aristocrático como principal responsável pelo bom e correto funcionamento da máquina pública francesa (afinal, na quarta das suas Cartas saboianas, Maistre não classificara a aristocracia como 'o sangue' que circula e dá vida ao Estado monárquico? Vide: J. de Maistre, Quatrième lettre d'un royaliste savoisien, O.C., VII: 168. Importa destacar que em 1788, e já sob a influência dos últimos eventos na França (a Assembleia dos Notáveis, convocada por Calonne, repudiara suas propostas de reforma e seu sucessor, Loménie de Brienne, tentava forçar o Parlamento de Paris a registrar um programa semelhante), o então senador saboiano Maistre redigiu duas memórias, respectivamente a Mémoire sur la vénalité des charges (Memória sobre a venalidade dos cargos) e a Mémoire sur les Parlements (Memória sobre os Parlamentos), nas quais revelava-se um partidário de uma reforma moderada e manifestava seu apoio à ofensiva aristocrática dos parlamentos franceses contra o regime absolutista.

Na primeira memória, amparando-se em Montesquieu, empreendia a difícil tarefa de defender os cargos venais, criticados por substituir o mérito pela riqueza. Resumidamente, o sistema de venalidades, segundo Maistre, oferecia uma alternativa racional contra o patronato real, ao mesmo tempo em que representava uma barreira contra as usurpações da nobreza feudal, que ele sempre condenara. Na memória seguinte, sobre os parlamentos, após comparar os modelos representativos da França e da Inglaterra, o autor conclui que na última, a admissão do Terceiro Estado no Parlamento teve o efeito de limitar o poder da monarquia, ao passo que na França, com o objetivo de se livrar da "tirania dos barões feudais", o povo concedeu toda autoridade ao poder real.

${ }^{32}$ Como Montesquieu e Burke, o Maistre estava convencido de que o tempo das repúblicas passara (nas suas formas democrática ou oligárquica), e que o tempo presente (das monarquias) corria o perigo do despotismo ("batônecratie" ou "governo do porrete") se os poderes intermediários (encarnados na aristocracia) não fossem preservados. Sobre os ecos da tradição republicano-clássica em Burke, vide Modesto Florenzano, As Reflexões sobre a Revolução em França de Edmund Burke: uma Revisão Historiográfica (São Paulo: FFLCH-USP, 1993), p. 200-216.

${ }^{33}$ Michel Foucault, La volonté de savoir (Paris: Gallimard, 1976), p.115.

${ }^{34}$ Joseph de Maistre, Du Pape, Livro II, cap. 9

35 Joseph de Maistre, Du Pape, Livro II, cap. 4. Leia-se também: "Uma nação grande e poderosa acaba de fazer sob nossos olhos o maior esforço que já se fez no sentido da liberdade, e o que ela obteve? Cobriu-se de ridículo e de vergonha por colocar finalmente sobre o trono um gendarme corso no lugar de um rei francês; e, junto ao povo, a servidão no lugar da obediência... O dogma católico, como todo mundo sabe, proscreve toda espécie de revolta sem distinção...; o protestantismo, ao contrário, partindo da soberania do povo, dogma que transportou da religião para a política, não vê no sistema de nãoresistência senão o último aviltamento do homem..."Cf. Joseph de Maistre, Du Pape, Livro II, cap. 2.

36، (...) Para manter as soberanias em seus limites legítimos, isto é, para impedir que violem as leis fundamentais do Estado, das quais a Religião é a primeira, a intervenção mais ou menos ativa da 
E foi justamente este o papel dessacralizador e revolucionário representado pelo jansenismo, especialmente quando o mesmo, no último século do Antigo Regime, assumiu uma feição judicial-parlamentar:

"O germe calvinista, nutrido neste grande corpo" [isto é, o Parlamento de Paris], "...tornou-se muito mais perigoso assim que sua essência mudou de nome e passou a chamar-se de jansenismo. Então, as consciências foram facilmente expostas a uma heresia que dizia: $E u$ não existo. $\mathrm{O}$ veneno atingiu até aqueles grandes nomes da magistratura que as nações estrangeiras podiam invejar da França. A partir de então, todos os erros, mesmo aqueles inimigos entre si, estando sempre de acordo contra a verdade, a nova filosofia, nos Parlamentos, aliou-se ao jansenismo contra Roma. O Parlamento inteiro, então, tornou-se um corpo verdadeiramente anticatólico, de tal modo que, não fosse pelo instinto real da casa de Bourbon e pela influência aristocrática do clero, a França teria sido infalivelmente conduzida a um cisma absoluto." ${ }^{38}$

Maistre não ofereceu muitos detalhes sobre a relação que deveria existir entre os poderes, mas acreditava que o reconhecimento pelos monarcas do poder arbitral do papa traria um justo e sólido equilíbrio à política européia. Mas na França pós-napoleônica, o principal entrave para a "restauração" de fato (isto é, cultural/espiritual) era expresso pela oposição galicano/jansenista às orientações de Roma.

Intrinsecamente contraditório e visto como uma 'Reforma' no seio da Contrarreforma $^{39}$, o jansenismo expunha, em suas tensões íntimas, os aspectos reformados que agiam sobre o mais puro espírito tridentino. Legítimo filho do contexto de redefinição doutrinal ocorrido no catolicismo em resposta à Reforma protestante e seus ataques às pretensões mediadoras da Igreja, o jansenismo foi quem mais acolheu a teologia e a antropologia agostinianas no interior da última. Este fator, combinado o

supremacia espiritual seria um meio tão plausível quanto todos os demais." Cf. Joseph de Maistre, $D u$ Pape, II, cap. 4.

${ }_{37}^{37}$ Joseph de Maistre, Du Pape, Livro II, cap. 5.

${ }^{38}$ Joseph de Maistre, De l'Église Gallicane, Livro I, cap. 2.

${ }^{39}$ Idem, Livro I, cap. 3: "A Igreja, desde sua origem, nunca viu uma heresia tão extraordinária como o jansenismo. Todas se separaram da comunhão universal ao nascerem, glorificando-se até por não pertencerem a uma Igreja cuja doutrina rejeitavam como errônea em diversos pontos. O jansenismo adotou uma postura distinta a este respeito. Nega estar separado e até comporá, caso se queira, livros sobre a unidade, cuja indispensável necessidade demonstrará. Sustenta, sem ruborizar nem tremer, que é membro desta Igreja que o anatematiza./ Ele [jansenismo] tem a incrível pretensão de ser a Igreja católica, apesar da Igreja católica; prova-lhe que ela não conhece os seus filhos, que ignora os seus dogmas, que não compreende seus próprios decretos, enfim, que não sabe ler. Desdenha das decisões, apela e pisa sobre as mesmas, sempre provando aos outros heréticos que ela é infalível e que nada pode desculpá-los." 
mais das vezes com uma teologia rigorista quanto à necessidade da graça, fizeram com que os jansenistas fossem identificados aos seus adversários protestantes pelos guardiões da ortodoxia.

Para ilustrar esta hipótese, Maistre recorreu ao testemunho de uma jansenista célebre como Mme de Sévigné (1626-1696), que numa de suas cartas (não por acaso, republicadas pelos liberais durante a Restauração na campanha que os mesmos moveram contra os ultramontanos) afirmava: "Lestes então são Paulo e santo Agostinho? Eis os bons trabalhadores para estabelecer a soberana vontade de Deus; eles não negociam para dizer que Deus dispõe de suas criaturas como o oleiro de sua argila: ele a escolhe e a rejeita." ${ }^{40}$ Em seguida, o contrarrevolucionário saboiano teceu o seguinte comentário crítico a respeito da mencionada "soberana vontade de Deus" da renomada jansenista: "Vale dizer que ele [Deus] salva ou condena, para a eternidade, sem outro motivo a não ser o seu bel-prazer".

$\mathrm{Na}$ retórica maistreana, impunha-se condenar enfaticamente (se necessário, com o auxílio de ninguém menos do que Voltaire) a teologia jansenista (interpretada como impiedosa e nada consoladora, a ponto de favorecer moralmente a apreensão de uma epistemologia científica revolucionária, como a de Bacon e Locke, cujos pressupostos empíricos/materialistas eram vistos como contrários às verdadeiras máximas do cristianismo e comparáveis ao 'amoralismo' de Hobbes pelo saboiano ${ }^{41}$ ) antes de enfatizar, como pretendia, seus efeitos políticos:

"Como esta seita logrou fatigar tanto o Estado quanto a Igreja? Inúmeras causas reunidas produziram este fenômeno... 'O sistema de Jansenius', disse Voltaire, 'não é nem filosófico, nem consolador, mas o prazer secreto de ser de um partido, etc.' Que não se duvide disto, todo o mistério encontra-se aí. $O$ prazer do orgulho é o de desafiar a autoridade; sua felicidade, o de apoderar-se da mesma; suas delícias, o de humilhá-la. O jansenismo apresentava esta tripla

\footnotetext{
${ }^{40}$ Joseph de Maistre, De l'Église Gallicane, Livro I, cap. 3.

${ }^{41}$ Joseph de Maistre, De l'Église Gallicane, Livro I, cap. 4: "Não sei se alguém observou que o dogma capital do jansenismo pertence plenamente a Hobbes; sabe-se que este filósofo sustentou que tudo é necessário e, por conseguinte, que não há liberdade propriamente dita ou liberdade de escolha. 'Nós designamos', diz ele, 'agentes livres aqueles que agem com deliberação; mas a deliberação não exclui a necessidade, pois a escolha era necessária assim como a deliberação'. O espírito se revolta de imediato contra esta infâmia, mas por quê? É o puro jansenismo, é a doutrina dos discípulos recônditos de são Paulo e de santo Agostinho; é a profissão de fé de Port-Royal, o asilo das virtudes e dos talentos... Esta é precisamente a doutrina dos jansenistas. Eles sustentam que o homem, para ser culpado, não tem necessidade daquela liberdade que é oposta à necessidade, mas apenas daquela que é oposta à coação, de maneira que todo homem que age voluntariamente é livre e, por conseguinte, culpado se agir mal, mesmo quando age necessariamente (é a proposição de Jansen)."
} 
tentação a seus adeptos e, sobretudo, a segunda satisfação realizou-se em toda a sua plenitude, assim que o jansenismo se tornou uma potência ao se concentrar nos muros de Port-Royal." ${ }^{42}$

Desde o princípio, o jansenismo ${ }^{43}$ teria dado início a uma autêntica revolução cultural, ainda que esta revolução fosse gradual, lenta ou, conforme a célebre definição do republicano Mably sobre a oposição jansenista-parlamentar da década de 1750 - e a qual coincide com o espírito da abordagem maistreana exposta nas Reflexões sobre o Protestantismo e na Da Igreja galicana - 'révolution ménagée'44 (isto é, 'revolução parcimoniosa' ou 'econômica'), na medida em que sua prática religiosa, a despeito das reiteradas profissões de fé monárquicas e católicas, desgastava alguns dos principais símbolos do absolutismo monárquico (tanto na esfera estatal como na esfera religiosa) junto à crescente opinião pública francesa.

Ou seja, assim como uma revolução política deve ser precedida de uma profunda transformação dos parâmetros tradicionais de julgamento moral (por meio de um trabalho de médio e longo prazo de conquista da hegemonia cultural junto aos órgãos da opinião pública) para que possa se efetivar, também a contrarrevolução, advertia Maistre desde as Considerações sobre a França (1797), deveria pautar sua estratégia no sentido de reconquistar uma hegemonia cultural perdida, sob pena de se perder em estéreis e custosas manobras militares que só lograriam aumentar a espiral de violência e favorecer/justificar o campo jacobino/revolucionário. Pois, de acordo com a célebre antimetábola maistreana (que Hannah Arendt, à guisa de I. Berlin e tão equivocadamente quanto este a nosso ver, interpretou como uma vazia estratégia retórica que traía as verdadeiras intenções extremistas de direita do contrarrevolucionário saboiano), a meta a ser alcançada pelos estadistas europeus pósnapoleônicos deveria ser o contrário da revolução (que transcendia o aspecto militar e privilegiava o domínio cultural), não uma revolução contrária. ${ }^{45}$

${ }^{42}$ Joseph de Maistre, De l'Église Gallicane, Livro I, cap. 4.

${ }^{43}$ Cujo maior símbolo era a antiga abadia medieval da ordem cisterciense de Port-Royal-desChamps, a qual, localizada nos arredores de Paris, foi dirigida e reformada no início do século XVII pela soror Maria Angélica Arnauld - irmã daquele que o De l'Eglise Gallicane descreve como um dos futuros triúnviros do jansenismo ao lado de Pascal e Pierre Nicole, a saber, Antoine Arnauld - e pelo humanista e teólogo agostiniano co-fundador do jansenismo e amigo de Cornelius Jansen, Jean du Vergier de Hauranne.

${ }^{44}$ Gabriel Bonnot de Mably, Des droits et des devoirs du citoyen (1758). Paris: Bureau de la Publication, 1868, $2^{\mathrm{a}}$ edição, p. 124.

${ }^{45}$ Sobre o comentário de H. Arendt, vide: Sulla Rivoluzione (1963).Torino: Einaudi, 2006, p. 11. A respeito da célebre condenação de Maistre por Berlin (que associa de um modo um tanto anacrônico a estratégia contrarrevolucionária do saboiano como protofascista), leia-se "De Maistre e as origens do 
Assim, tanto no âmbito cultural - através da tradução da Bíblia, da missa e das interpretações das sagradas escrituras que culminaram na célebre condenação das Réflexions morales sur le Nouveau Testament do teólogo oratoriano e jansenista Pasquier Quesnel, bem como a fundamental defesa do acesso às sagradas escrituras e/ou da alfabetização ao público feminino, medidas estas facilitadas por uma sistematização gramatical de lavra jansenista ${ }^{46}$ - como no político - pela fundamental colaboração intelectual de eminentes jansenistas, como Pascal, nas mazarinadas durante as frondas parlamentares do século XVII, além da oposição teológica e parlamentar à orientação religiosa consagrada pelo absolutismo Bourbon através da bula Unigenitus -, o jansenismo teria 'desafiado', 'fatigado' e 'ferido' não só a Igreja como o Estado monárquico, como sugere Maistre na seguinte passagem (longa, mas que merece ser inteiramente reproduzida) do De l'Église Gallicane:

"Caso se queira considerar Port-Royal como um corpo propriamente dito, seu elogio será curto. Filho de Baius, irmão de Calvino, cúmplice de Hobbes e pai dos convulsionários, viveu apenas por um instante, todo ele empregado em fatigar, desafiar, ferir a Igreja e o Estado. Se os grandes luminares de Port-Royal do século XVII, os Pascal, os Arnauld, os Nicole (é preciso sempre se remeter a este triunvirato), tivessem podido ver, num futuro próximo, o gazetier ecclésiastique [isto é, o renomado periódico jansenista, as Nouvelles ecclésiastiques], os espasmos de Saint-Médard e as horríveis cenas dos socorristas [pessoas encarregadas de prestar auxílio aos 'convulsionários' da paróquia enquanto as mesmas vivenciavam seu 'transe' espiritual], eles estariam mortos de vergonha e de arrependimento./ Para julgar Port-Royal, não basta citar o caráter moral de alguns de seus membros, nem alguns livros mais ou menos úteis [como uma referida gramática francesa, de Arnauld] que saíram desta escola; é preciso ainda colocar na balança os males que ela produziu, os quais são incalculáveis./ Port-Royal se apoderou do tempo e das faculdades de um grande número de escritores que, segundo suas forças, podiam ter sido úteis à religião, à filosofia, mas que foram inteiramente consumidos em disputas ridículas ou funestas. Port-Royal dividiu a Igreja; criou um lar de discórdia, de desconfiança e de oposição à Santa Sé; amargurou os espíritos e os acostumou à resistência; fomentou a suspeita e a antipatia entre os dois poderes [Estado e Igreja], colocando-os num estado de guerra habitual que não cessou de produzir os choques mais escandalosos... Ele

fascismo", in: Limites da Utopia. Capítulos da história das idéias (São Paulo: Companhia das Letras, 1991).

${ }^{46}$ Conforme indica o próprio Maistre em De l'Église Gallicane, Livro I, cap. 6: "Porém, nada aumentou o poder de Port-Royal sobre a opinião pública [grifos nossos] quanto o uso exclusivo que eles fizeram da língua francesa em todos os seus escritos". 
escreveu contra o calvinismo, mas o continuou, menos por sua feroz teologia do que por plantar no Estado um germe democrático, inimigo natural de toda hierarquia." ${ }^{47}$

Portanto, se "A Revolução" ainda estava "em pé" em plena Restauração, e não apenas estava em pé, como 'marchava', 'corria' e 'distribuía coices', era porque, "educando-se, ela se refinou" e assumiu um aspecto "bem mais terrível que no tempo de Robespierre". E na visão do autor da De l'Église Gallicane, nada explicitava tanto aquela comprometida realidade (e anunciava outras revoluções no porvir) da Restauração quanto o ressurgimento das teses conciliares galicano-jansenistas em meio aos debates sobre a Concordata:

"Lê-se, numa coletânea infinitamente estimável, que os jesuítas arrastaram os jansenistas consigo para o túmulo. Trata-se de um grande e espantoso erro, semelhante àquele de Voltaire, que já dizia, no seu Siècle de Louis XIV (Tomo II, cap. XXXVII): 'Aquela seita, possuindo apenas os convulsionários, caiu na degradação; o que se tornou ridículo não pode mais ser perigoso.' Belas frases de poetas, que nunca enganarão um estadista. Não há nada de tão vivo quanto esta seita, e, sem dúvida, ela ofereceu durante a revolução suficientes provas de vida para que não se permita crê-la morta. Ela não se encontra menos viva numa multidão de livros modernos que poderia citar. Não tendo sido esmagada no século XVII como deveria, pôde crescer e enraizar-se livremente.../Importa observar ainda que o famoso usurpador [Bonaparte], que em nossos dias fez tanto mal ao mundo, guiado por este instinto único que move os homens extraordinários, não podia suportar o jansenismo, e que, dentre os termos insultantes que ele distribuía ao redor de si com bastante liberalidade, o de jansenismo ocupava, a seu juízo, o primeiro lugar ${ }^{48}$./Ainda que, durante a Revolução Francesa, a seita jansenista pareça não ter servido a não ser num segundo plano, como o ajudante do executor, no princípio ela foi, talvez, mais culpável que os ignóbeis trabalhadores que terminaram a obra: pois foi o jansenismo quem desferiu os primeiros golpes à pedra angular do edifício, por suas criminosas inovações." ${ }^{49}$

${ }^{47}$ Joseph de Maistre, De l'Église Gallicane, Livro I, cap. 5.

${ }^{48}$ Nota de J. de Maistre: Trata-se de um ideólogo, de um constitucionalista, de um jansenista. Este último epíteto é o máximo das injúrias. (M. de Pradt, Histoire de l'ambassade de Varsovie. Paris, 1815 , in- $8^{\circ}$ p. 4.). Estas três injúrias na boca de Bonaparte são muito dignas de nota. Refletindo sobre isto, pode-se dizer secretamente: $O$ bom-senso do demônio às vezes causa-me medo!

${ }^{49}$ Joseph de Maistre, De l'Église Gallicane, Livro I, cap. 12. Na nota que encerra esta passagem, Maistre nos informa do seguinte: "Quem não sabe que esta constituição civil do clero que, ao lançar entre vós uma fagulha da discórdia, preparou vossa destruição total (aquela do clero), foi obra do jansenismo? (Lettre de Thom. de Soer, editor das Oeuvres complètes de Voltaire, aos Senhores Vigários gerais do capítulo metropolitano de Paris, in- $8^{\circ}, 1817$, p.9). Aceitemos esta confissão, ainda que absolutamente desnecessária. A obra-prima do delírio e da indecência pode, como se vê, ser útil a alguma coisa." 
Diante do que foi exposto, é lícito supor que os delineamentos históricos da polêmica abordagem maistreana - polêmica esta orientada por uma intenção política específica e objeto de um injustificável negligenciamento pela historiografia-, avançam importantes pistas para o esclarecimento daquele questionamento inicial de Tocqueville acerca da paixão irreligiosa da Revolução Francesa. Pois a cultura de oposição filosófica ou enciclopédica - que, para o autor de $O$ Antigo Regime e a Revolução, constituiria a razão principal para aquele fato - foi antecedida e auxiliada direta ou indiretamente por uma série de "personagens" (de eminentes filósofos e teólogos a bispos e padres de paróquia apelantes; magistrados e advogados; convulsionários e apelantes populares; publicações clandestinas, etc) e episódios (publicação do Augustinus por Cornelius Jansen e a condenação de cinco proposições por dois papas nos anos 1650; publicação das Cartas Provinciais e inúmeros outros escritos por Pascal contra os jesuítas e o cardeal Mazarino, os quais marcariam profundamente a cultura francesa; publicação da bula papal Unigenitus em 1713, responsável por condenar oficialmente o jansenismo e orientar a política religiosa da monarquia francesa no sentido da perseguição ao movimento agostiniano; oposição jansenista-parlamentar à bula e às autoridades religiosas 'constitucionais', resumida pelos apelos e memórias judiciais contra a negação dos sacramentos e na expulsão dos jesuítas; processo de hibridização cultural do jansenismo que, após a vitória 'teológica' sobre os jesuítas, adotam uma postura de oposição secular ao absolutismo, como na reação ao golpe de Maupeou e nos debates pré-revolucionários de 1787-1788; a participação de eminentes jansenistas nos debates sobre a Constituição Civil do Clero, etc) no interior daquele trama teológico-político, todos, sem exceção, devidamente aludidos ${ }^{50}$ e, de certo modo, sintetizados na De l'Église Gallicane, como se depreende no trecho a seguir:

"Os parlamentos da França e, sobretudo, o de Paris, aproveitando das facilidades oferecidas por um novo século perverso e frívolo, permitiram-se alterar para lei do Estado proposições teológicas condenadas pelos Soberanos pontífices" [isto é, proposições conciliares], "pelo clero contemporâneo, por um grande rei desenganado, e, mormente, pela razão. O governo fraco, corrompido, desleixado e ao qual não se mostrava senão um aumento de poder, apoiou ou condescendeu com os magistrados que, no fundo, não trabalhavam a não ser para eles. O clero,

50 Os principais 'episódios' e 'personagens' referidos acima foram aludidos na De l'Église Gallicane, embora não tenham sido totalmente esmiuçados e descritos com a objetividade prescrita hoje pela ciência histórica. Reconhecer isto não implica necessariamente na absoluta alienação dos méritos do autor, pelo contrário: pois além deste não ser o propósito da obra, não se pode exigir de um autor forjado no século XVIII uma cultura histórica que só se consolidaria no final do século XIX. 
enfraquecido pelos mesmos artigos, fez juramento de apoiá-los... justamente porque o haviam privado da força necessária para resistir... O clero, por esta funesta condescendência, encontrouse servo em relação ao poder temporal, na precisa proporção da independência que adquiria com respeito a seu superior legítimo, mas, ao invés de consentir em perceber esta humilhação, chamou-lhe de LIBERDADE. E deste feixe de erros, de sofismas, de impressões falsas, de covardias, de pretensões ridículas ou culpáveis, poderosamente amarrado pelo hábito e pelo orgulho, produziu-se um todo, um conjunto formidável, um preconceito nacional imenso composto de todos os preconceitos reunidos, tão forte, enfim, tão compacto e tão sólido..." ${ }^{51}$

Apoiados nas posteriores investigações historiográficas a respeito do tema, podemos concluir sem receio que, a despeito de Maistre não ter sido um historiador ou filósofo profissional, os tortuosos caminhos de sua análise teológico-política sobre a Revolução Francesa iluminam e/ou coincidem com diversos pontos destacados pela historiografia mais recente a respeito das origens culturais da Revolução Francesa...

${ }^{51}$ Joseph de Maistre, De l'Église Gallicane, Livro II, cap. 12. 


\section{PARTE}

DE BACON A LOCKE: UM HUMANISMO DEVOTO CRÍTICO DA MODERNIDADE 


\section{CAPÍTULO 4}

\section{O "Examen de la philosophie de Bacon" ou das raízes humanistas do ethos contrarrevolucionário maistreano}

\subsection{Por que Bacon?}

Maistre iniciou a redação do Examen de la philosophie de Bacon (Exame da filosofia de Bacon) em 1809, mas completou-a somente em 1816. No que diz respeito à publicação desta que é a mais longa, exaustiva e, ao lado das Soirées, a mais erudita das obras maistreanas, a espera foi ainda maior, uma vez que só ocorreu em 1836, quinze anos após o falecimento do autor e depois de transcorridas duas décadas de sua conclusão.

O que teria motivado o contrarrevolucionário saboiano a se engajar, nas palavras dele próprio, numa autêntica luta de pugilismo $^{1}$ com o outrora igualmente senador, pensador e magistrado inglês Francis Bacon (1561-1626), sobretudo se levarmos em consideração a confissão feita por ele próprio ao embaixador francês em São Petersburgo, Antonin Claude Dominique Just de Noailles (1777-1846), segundo a qual nem ele sabia ao certo as razões daquela luta mortal? ${ }^{2}$

Uma das razões mais prováveis para isso encontra-se indicada no próprio corpo do Examen, a saber, o surgimento, entre 1799-1803, da primeira edição das obras completas de Bacon em francês, traduzidas por ninguém menos que o cientista-jacobino Antoine de La Salle (1754-1829), as quais foram utilizadas por Maistre (ao lado de uma edição inglesa de 1803 publicada em Londres) para a redação deste extenso tratado epistemológico contrarrevolucionário.

Descrito por La Salle como um dos maiores gênios lógicos de todos os tempos (ao lado de Aristóteles, Pascal, Descartes, Newton e Leibniz) e precursor da Revolução Francesa ${ }^{3}$, as obras completas de Bacon suscitaram a reedição, em 1804, de um clássico

\footnotetext{
1 "Nós boxeamos como dois broncos de Fleet Street, e se ele arrancou alguns cabelos de mim, estou certo também de que sua peruca não se encontra mais no lugar." In: J. de Maistre, O.C., XIII: 178.

${ }^{2}$ Joseph de Maistre, O.C., VI:178.

${ }^{3}$ Para as opiniões de La Salle sobre Bacon, vide Marta Fattori, "Baconiana: Nuove prospettive nella ricezione e fortuna delle opere di Francis Bacon", Rivista di storia della filosofia 3 (2003): 411.
} 
retrato ateísta e materialista do chanceler inglês feito pelo filósofo ilustrado e revolucionário Alexandre Deleyre (1726-1796) - o Analyse de la philosophie du chancellier Bacon, avec sa vie traduite de l'anglais (Análise da filosofia do chanceler Bacon, com sua vida traduzida do inglês, 1755) -, assim como, em reação àquelas publicações, um retrato não-materialista de Bacon avançado pelo físico, geólogo e membro da Royal Society, Jean André de Luc (1727-1817), cujas obras Bacon tel qu'il est; ou, Dénonciation d'une traduction française des oeuvres de ce philosophe par $M$. Ant. La Salle (Bacon como ele é, ou, Denúncia de uma tradução francesa das obras deste filósofo pelo Sr. Ant. La Salle, 1800) e Précis de la philosophie de Bacon et des progrès qu'on fait les sciences naturelles par ses préceptes et son exemple (Resumo da filosofia de Bacon e dos progressos que as ciências fizeram por seus preceitos e seu exemplo, 1802), Maistre lera e citara abundantemente no Examen.

Todavia, Maistre estava bastante persuadido de que o cientista natural jacobino e ateísta La Salle - que havia declarado possuir, "baseado apenas em sua própria experiência, cem mil razões para não crer em Deus" ${ }^{4}$ - era aquele que havia efetivamente compreendido Bacon, sendo o tradutor natural do mesmo: "Eu vi o espírito do meu século, e publiquei esta tradução. Isto é o que o senhor La Salle poderia ter dito, de maneira que esta declaração explicaria sua iniciativa." ${ }^{5}$

Outro fator preponderante para o interesse do saboiano num autor como Bacon e a definitiva redação do Examen encontra-se na conjuntura política russa dos anos 18091810. Aquele biênio fora marcado pela fulminante ascensão ao poder do físico e matemático russo Mikhail Speransky (1772-1839), um outrora secretário de um influente príncipe da corte russa, mas que lograra cair nas graças do czar, a ponto de ter sido encarregado pelo mesmo de participar pessoalmente das negociações do Congresso de Erfurt (27 set.- 14 out. 1808) com Napoleão, que o descreveu como um reformista brilhante. Speransky, que Maistre julgava ser "um grande partidário de Kant" ${ }^{6}$ e um instrumento da "grande seita que está destruindo as soberanias"", avançara três propostas de reforma pedagógica amplas - a adoção de um currículo nacional baseado nos estudos das ciências naturais; a eliminação da educação religiosa das universidades; a subordinação das instituições de ensino superior privadas (incluindo os colégios

\footnotetext{
${ }^{4}$ Joseph de Maistre, Soirées, O.C., IV:273 ( $\mathrm{V}^{\mathrm{e}}$ Entretien).

${ }^{5}$ Joseph de Maistre, O.C., VI: 514.

${ }^{6}$ Joseph de Maistre, O.C., XI: 257.

${ }^{7}$ Joseph de Maistre, O.C., XI: 385.
} 
jesuíticos) ao novo currículo das universidades públicas -, todas firmemente objetadas pelo embaixador sardo (isto é, da Casa da Sabóia).

Quando o ministro russo para a instrução pública, o príncipe Aleksei Razumovsky (1748-1822), solicitou a opinião do saboiano a respeito daquela reforma, obteve como resposta a redação de três opúsculos pedagógicos teoricamente hostis àquelas reformas, respectivamente Cinq lettres sur l'éducation en Russie (Cinco cartas sobre a educação na Rússia, 1810); Observations sur le "Prospectus disciplinarum"(Observações sobre o "Prospecto disciplinar", 1811); e Mémoire sur la liberté de l'enseignement public (Memória sobre a liberdade do ensino público, 1810). Para Maistre, uma boa educação deveria ir na contramão do que apregoavam a Encyclopédie e Kant, as principais fontes inspiradoras de Speransky. E porque Bacon, ao lado de Locke (este, inspirado no chanceler), era visto como a autoridade epistemológica da educação enciclopédica, importava cortar o mal pela raiz, isto é, os soberanos deveriam envidar todos os esforços no sentido de evitar que as crianças e os jovens recebessem os conteúdos materialistas daquela pedagogia que estava na base da visão de mundo revolucionária. O Examen deixa isto bastante claro quando se lê que Bacon "é o pai de todas aquelas horríveis máximas" que resultaram "na maior e mais terrível conspiração que já se formou contra a religião e os tronos", e a qual devia sua fortuna à pregação antirreligiosa do século XVIII. ${ }^{8}$ Portanto, "lutar mortalmente" com Bacon representava uma maneira de combater aquilo que Maistre julgava ser os efeitos devastadores da pedagogia enciclopédico-Ilustrada para a moral, assim como preservar o futuro dos tronos: "Os Príncipes que preferirão não... lembrar de que os homens são feitos somente a partir das crianças, irão se arrepender cruelmente, mas será muito tarde." ${ }^{9}$

A propósito do pathos devoto da reação maistreana à Revolução de 1789 e à Filosofia das Luzes, não foram poucos os historiadores, comentadores ou críticos de Joseph de Maistre que associaram o pensamento do contrarrevolucionário saboiano a um caráter sombrio, como se a ultima ratio de suas especulações teóricas visasse justificar a autoridade política absoluta ou despótica por meio de um extremo rebaixamento antropológico de um gênero humano decaído após o pecado original. Assim, Bernard de Vaulx, apesar de benevolente em relação ao saboiano, dizia a respeito dele: "Não se pode levar mais adiante do que ele o fez o pessimismo diante da

\footnotetext{
${ }^{8}$ Joseph de Maistre, O.C., VI: 459-460.

${ }^{9}$ Joseph de Maistre, O.C., XIII: 167.
} 
natureza humana". ${ }^{10} \mathrm{Ou}$, mais próximo de nós, Isaiah Berlin observou a respeito do contrarrevolucionário saboiano que a visão de mundo do mesmo se ampara sobre a natureza incuravelmente má e corrupta do homem. ${ }^{11}$ Recentemente, um colaborador da Revue des Études Maistriennes chegou a comparar a abordagem antropológica pessimista de Maistre à visão degradada do homem após o pecado original formulada por Lutero, valendo-se para isto de citações do próprio contrarrevolucionário saboiano extraídas das Soirées de Saint-Pétersbourg (1821), tais como as que destacam "a incrível degradação do homem" ou constatam que "o homem é horrivelmente perverso". ${ }^{12}$

Todavia, e este será o objetivo deste capítulo, esta concepção degradada da natureza humana atribuída a Maistre não resiste a uma análise atenta de sua produção, a qual revelará um humanista para além do simplesmente devoto, e cuja visão antropológica do homem, em muitos aspectos, seria mais humanista que a de muitos filósofos da Ilustração que ele tão veementemente combatia. Prova disso encontra-se nas mesmas Soirées, onde lê-se que "o homem, apesar de sua fatal degradação, carrega sempre as marcas evidentes de sua origem divina [...]." ${ }^{13}$

Deve-se deduzir, a partir disso, que a obra maistreana está toda ela atravessada por uma contradição insolúvel, de modo que as retratações de cunho mais humanístico seriam subsumidas numa abordagem radicalmente pessimista-agostiniana sobre a natureza adâmica da humanidade? Ora, como todo cristão devoto, Maistre não alimentava dúvidas quanto à real degradação da natureza humana em decorrência do pecado original, embora, amparado por seus conhecimentos teológicos e clássicohumanísticos, o mesmo se recusasse a esquecer do lugar eminente que o gênero humano ocupa na criação mesmo após a queda.

Como observou corretamente Jean-Yves Pranchère ${ }^{14}$, Maistre "dramatiza" ou minimiza o peso do pecado original de acordo com o adversário que tem em vista. Quando combate Voltaire e a "seita filosófica" - com sua irremissível crença no

\footnotetext{
${ }^{10}$ Bernad de Vaulx, "Introduction" aos textos escolhidos de Joseph de Maistre em: Une politique expérimentale (Paris: Fayard, 1940), p. 29.

${ }^{11}$ I. Berlin, "Joseph de Maistre e as origens do Fascismo", In: Henry Hardy (org.), Limites da Utopia: Capítulos da história das ideias. Trad. de Valter Lellis Siqueira (São Paulo: Companhia das Letras, 1991), p. 106-107.

${ }_{12}$ Jean-Luc Chabot, "Théologie et politique chez Joseph de Maistre: les insuffisances théologiques de la pensée maistrienne", in: Revue des Études Maistriennes, no 14, 2004, p. 311.

${ }_{13}^{13}$ Joseph de Maistre, Soirées, O.C., IV:202 (IV Entretien).

${ }^{14}$ J.-Yves Pranchère. "L'ordre de la raison, déraison de l'histoire: l'historicisme de Maistre et ses sources classiques."in: Philippe Barthelet (org.). Joseph de Maistre (Paris: Les Dossiers H - L'age de l'homme, 2005), p. 367.
} 
progresso humano imanente -, insiste no poder do pecado original e descreve o homem como um "centauro monstruoso". ${ }^{15}$ Mas, quando se tratava de combater o protestantismo - para ele, a causa da Revolução e de todos os males que afligiam a Europa -, assumia uma perspectiva antropológica menos pessimista e conciliatória com uma visão mais "humanista", e isto graças à teologia emprestada do jesuíta espanhol Luís de Molina (1535-1600) ${ }^{16}$ e de diversas fontes neoplatônicas, mormente Orígenes e os filósofos neoplatônicos da universidade de Cambridge do século XVII. Conforme advertiu o saboiano num tom humanístico que, partindo da premissa de que o homem foi feito à imagem e semelhança de Deus, remete ao neoplatonismo de um Marsilio Ficino, "não vos deixeis seduzir pelas teorias modernas sobre a imensidão de Deus... belas frases que não tendem a exaltar Deus, mas a degradar o homem... O homem reina sobre a terra apenas porque é semelhante a Deus". ${ }^{17}$

${ }^{15}$ Joseph de Maistre, Soirées, O.C., IV: 67 (II Entretien).

${ }^{16} \mathrm{O}$ essencial da teologia de Molina - descrito como um "homem de gênio, autor de um sistema ao mesmo tempo filosófico e consolador" sobre a "temível" questão do livre-arbítrio (De l'Église Gallicane, Livro I, cap. 9 e Livro II, cap. 11) -, consistia em responder como a liberdade humana podia ser conciliada com a graça divina, uma questão que, desde as polêmicas de Santo Agostinho com Pelágio, passando pela doutrina tomista, trouxera sérias dificuldades ao cristianismo.

Sto. Agostinho estabeleceu a distinção entre livre arbítrio e liberdade, atribuindo ao livre arbítrio a capacidade de eleger um determinado propósito, seja bom ou mau, enquanto a liberdade era algo distinto, posto que radicada no bom uso desse livre arbítrio. Ora, dada a corrupção da natureza humana (decorrente do pecado original), o "bom" uso do livre arbítrio ou liberdade não pode ocorrer, advoga o bispo de Hipona, sem o concurso da Providência.

A posição tomista, defendida na época de Molina pelos dominicanos, consistia essencialmente na tese da praemotio (premoção) physica. Tratava-se de saber como era possível que Deus movesse a vontade do homem sem que esta fosse coagida, cabendo a Deus a responsabilidade. S. Tomás julgava que a vontade só poderia ser coagida caso fosse movida contra a sua inclinação própria, o que não sucedia uma vez que Deus, como motor da vontade, era o mesmo que lhe dera a inclinação para o bem. Em todo o caso, a vontade só poderia ser movida «eficazmente» por Deus. Quanto ao modo da intervenção Providencial, a doutrina da praemotio physica defendia que era ela quem proporcionava ao sujeito a capacidade para agir, sendo, portanto, anterior à ação.

A solução encontrada por Molina e defendida em De Concordia Liberi Arbitrii cum Gratiae Donis, divina Praescientia, Providentia, Praedestinatione et Reprobatione (1588), substituiu a doutrina da premoção pela do concurso: o homem, no pleno uso do seu livre arbítrio, planeja, escolhe e decide, mas carece do concurso divino para poder levar a cabo o seu intento, sem que, no entanto, esse auxílio o determine. Ademais, esse concurso da "causa primária" (Deus) com a "causa secundária" (ação humana) é despertado ou provocado pela última, ou seja, pela decisão livre do homem para realizar um determinado propósito, sendo que o concurso de Deus não é anterior à atuação da vontade, mas simultâneo.

O concursus simultaneus, em oposição à tese da praemotio, estabelecia uma condição importante de salvaguarda da liberdade humana, ausente na posição dos dominicanos, pois ao salvaguardar a devida distância entre o infinito e o finito, estabelecia um relativo paralelismo entre potências: a humana, que decide agir, mas que carece de poder para agir, e a divina, que provocada ou movida por essa decisão humana, decide prestar o seu auxílio, que atua simultaneamente com a causa secundária em sua ação e efeito. Molina reconhece que não há ação do homem sem a ação de Deus, como era tradição entre os teólogos, mas abre caminho para a tese de que a ação de Deus não obriga necessariamente a ação do homem, que permanece livre.

${ }_{17}$ J. de Maistre, Soirées, O.C., IV: 202 (IV Entretien). 
A este respeito, Maistre poderia reclamar em seu apoio não apenas as teorias maçônicas e místicas do Philosophe Inconnu, Louis-Claude de Saint-Martin (17431803), cuja abordagem antropológica positiva deixou profundos ecos nas Soirées, mas também e sobretudo a própria tradição católica, que tende a insistir no pecado original a fim de incitar as virtudes cristãs nos homens. Assim como a severidade dos sermões de Jacques Bossuet (1627-1704) eram bem conhecidos de Maistre, a ponto de talvez inspirarem o tom acrimonioso com que denunciava os vícios da humanidade pecadora e especialmente os de seu século, também o eram, por outro lado, as interpretações mais otimistas sobre a natureza humana, como a de seu Sermão sobre a eminente dignidade dos pobres na Igreja (1659) e a afirmação de que "o homem foi rebaixado um pouco abaixo do anjo". ${ }^{18}$ Neste sentido, referindo-se ao Salmo VIII - de que igualmente se serviram, para enaltecer a dignidade humana, são Tomás de Aquino e Bossuet -, Maistre anotou o seguinte em seu inédito Essai sur les Planètes (Ensaio sobre os Planetas, redigido em 1799 em Veneza e disponível somente nos seus volumosos registros de leitura): "mesmo em nosso estado de degradação, o homem está colocado abaixo do anjo só por um instante (minnisti eum paulo minus ab angeli, Ps. VIII, 6)". ${ }^{19}$ Quaisquer que sejam as diferenças entre os pensamentos de Bossuet e Maistre sobre a Criação e o papel da Providência na história, importa salientar que ambos coincidem no fato de amparar suas leituras otimistas sobre a natureza humana com base nos mesmos versos sálmicos ou na leitura do livro do Gênesis.

Isto não significa que todos os teólogos cristãos tenham interpretado o mesmo Salmo de modo a atribuir ao homem um valor tão elevado. Não só os jansenistas clássicas referências da teologia agostiniana francesa -, mas também um jesuíta admirado por Maistre, como Guillaume-François Berthier (1704-1782, o erudito diretor do Journal de Trévoux), interpretava aquele texto antes como uma referência a Cristo do que ao homem. Visão esta, cumpre observar, não compartilhada por são Tomás de Aquino, que no seu Comentário dos Salmos ou Super Salmos (o nome original em latim) interpretava aquele verso como uma referência à dignidade humana. ${ }^{20}$

Este alto valor atribuído ao homem nada mais era senão o reflexo de sua dignidade, conforme somos informados por Maistre desde o primeiro diálogo das

\footnotetext{
${ }^{18}$ Bossuet, Discours sur l'histoire universelle (1681), In: Oeuvres Complètes de Jacques Bénigne Bossuet (Besançon: Outhenin-Chalandre fils, 1840, tomo IX), p. 136.

${ }^{19}$ Joseph de Maistre, Essai sur les Planètes (1799), "Registre de lectures D", p. 662.

20 Maistre não conheceu esta obra de são Tomás, mas importa ressaltar aqui que a visão antropológica do saboiano, vista por alguns de seus críticos como herética pelos ecos místicos de seu passado maçônico, estava em pleno acordo com o principal doutor da Igreja.
} 
Soirées. E o combativo e prestigioso Dictionnaire de Trévoux, cujas edições completas o contrarrevolucionário saboiano possuía, empregava outros predicados além da "dignidade" para se referir à condição humana, tais como "grandeza", "brilho" e "beleza".

Neste sentido, importa salientar que a filosofia do século XVIII atribuiu à dignidade do homem um sentido completamente distinto daquele veiculado pelo cristianismo, pois, se de um lado reconhecia uma certa dignidade ao homem - na medida em que o mesmo é capaz de aceder ao conhecimento e, a partir disso, emancipar-se do peso das tradições ou dos poderes (o "sapere aude" kantiano) -, por outro, subtraía-lhe toda dignidade ontológica ao não considerá-lo senão como um mecanismo animal como tantos outros. Ao romper com a milenarmente admitida analogia entre microcosmo e macrocosmo que preconizava a imagem de um universo "não só criado para o homem, mas estruturalmente semelhante ou análogo ao homem", a epistemologia científica moderna eliminou "qualquer perspectiva de tipo antropomórfico na consideração da natureza" e avançou um método pelo qual "não só ao mundo da natureza, mas também ao mundo da vida, não apenas ao movimento dos astros e à queda dos corpos pesados, mas também à esfera das percepções e dos sentimentos dos seres humanos", tudo reduzia-se a um mecanismo. ${ }^{21}$

E toda a altercação maistreana contra a Filosofia das Luzes gravitava em torno desta contradição: quando se trata de ciência, o homem é capaz de progredir (a perfectibilidade), o que atesta sua dignidade, mas desde que se trata de religião, perde todos os privilégios e se despoja de toda sua dignidade:

"Entre os caracteres ridículos que caracterizam a filosofia moderna, pode-se distinguir suas contradições sobre a dignidade do homem. Quando se trata de armar seu orgulho contra as verdades primitivas, nada se sobrepõe à nossa grandeza, o homem é feito para a verdade, deve investigá-la por suas próprias forças: nenhum poder tem o direito de perturbar seu pensamento. Detalham pomposamente seus conhecimentos e descobertas e tratam-se como deuses. Mas se da verdadeira grandeza do homem pretende-se obter argumentos sobre seu futuro, eles mudam subitamente de lado, rebaixam o homem de todas as maneiras possíveis e não falam senão de sua ignorância, de seus vícios, de sua fraqueza, de seus ridículos, como se fosse um animal, um verme." ${ }^{22}$

\footnotetext{
${ }^{21}$ Paolo Rossi, O nascimento da ciência moderna na Europa (1997). Trad. de Antonio Angonese (Bauru-SP: Edusc, 2001), p. 247.

${ }^{22}$ Joseph de Maistre, Essai sur les Planètes, p. 653.
} 
Com efeito, a filosofia das Luzes inverte as noções cristãs da degradação e da dignidade humanas. Aquilo que a religião compreende sob o prisma da degradação ou como o efeito de uma queda (isto é, um extravio espiritual provocado pelo distanciamento em relação a Deus), o filosofismo do século XVIII interpretava como uma dignidade ou caminho para a autonomia, estando o homem a partir de então livre de todos os entraves supersticiosos e podendo se dedicar apenas à investigação objetiva e científica da realidade. Do mesmo modo, enquanto que para os cristãos a dignidade implica uma relação privilegiada do homem com seu Criador - relação esta que não foi totalmente destruída pelo pecado original -, para a Ilustração, esta mesma dignidade torna-se sinônimo de fraqueza dos homens, sua animalidade (originada nos sentidos e criadas pela imaginação temerosa em relação à mortalidade, diriam os sensualistas Hobbes, Helvétius e La Mettrie), uma vez que, se Deus não existe, o homem é apenas um ser vivo dentre os demais. Percebe-se, a partir disso, que Maistre não poderia deixar de combater a filosofia Ilustrada do século XVIII, uma vez que a mesma, especialmente na sua vertente francesa, desenvolveu-se numa relação dialética (e, portanto, criticamente negativa) com a religião cristã, e o catolicismo em particular.

E para os homens de letras do século XVIII, não restavam dúvidas de que o precursor dessa filosofia que pretendia "separar Deus da razão humana"23 era Bacon.

Ademais, conforme destacou Roy Porter em seu abrangente estudo sobre a Ilustração Britânica, a base para as formulações epistemológicas empíricas de Bacon e Locke encontra-se nos ataques prévios lançados aos dogmas católicos (como a transubstanciação e a existência do purgatório) pelos protestantes dissidentes ingleses, que atribuíram a si a missão de desbastar a fé cristã - que na visão deles, deveria amparar-se apenas pelas Escrituras - da escolástica, com seus ritos e concepções filosóficas eivadas do ecletismo helenístico (aristotélico-platônico). ${ }^{24}$

Porém, e na esteira da crítica religiosa puritana, coube ao Lorde Chanceler Bacon a primazia de ter sistematizado o assédio da filosofia moderna à filosofia antropocêntrica da escolástica tardia e do humanismo, demarcando a ciência da teologia, rejeitando as autoridades clássicas (mormente Aristóteles) em nome da observação livre de preconceitos do "Livro da Natureza" e, por fim, repudiando os

\footnotetext{
${ }^{23}$ Joseph de Maistre, O.C., VI: p. 263 n.

${ }^{24}$ Roy Porter, The Creation of the Modern World: the untold history of the British Enlightenment (New York: W.W. Norton \& Company, 2000), p. 49.
} 
silogismos, pelo fato de serem um jogo de palavras que ignorava a investigação fiel dos fenômenos da natureza e contradizia os sentidos.

Sintetizada em sua obra Instauratio Magna (1620), a filosofia de Bacon foi adotada com entusiasmo pela Royal Society na década de 1660, que o classificou como "o pai da filosofia experimental". Posteriormente, Voltaire elogiaria o homem que d'Alembert, após enumerar seus principais méritos (o assalto à bibliolatria; a rejeição radical da tradição, da especulação e dos sistemas a priori; o estabelecimento da investigação com base na observação e no experimento, acompanhado pela convicção de que a ciência deve emancipar a humanidade), saudaria como "o maior, o mais universal, o mais eloquente dos filósofos". Finalmente, e para que não pairasse mais nenhuma dúvida sobre a influência exercida pelo autor do Novum Organon na Ilustração francesa, o "Discurso Preliminar" da Encyclopédie reproduzia o mapeamento do conhecimento de acordo com a distinção baconiana das três faculdades do intelecto memória, razão e imaginação. ${ }^{25}$

Mas nenhum outro autor do século XVII logrou ir tão longe na crítica aos postulados humanísticos clássico-cristãos quanto o discípulo declarado de Bacon, Thomas Hobbes (1588-1679), para quem o universo sendo corpóreo, tudo o que fosse imaterial ou incorpóreo - como a erudição, as palavras - deveria ceder espaço à observação empírica das Coisas, sob pena de recair no falso dogmatismo (científico) ou no caos (político). Ao fim e ao cabo, o homem seria apenas uma máquina (lembremos de $O$ Homem-Máquina, 1747, de La Mettrie, de tanto impacto na Ilustração francesa) ou mera matéria em movimento, cujos pensamentos ou sentimentos seriam apenas impulsos aplicados nos órgãos sensoriais por pressões externas, enquanto a imaginação reduzir-se-ia a uma consciência daquelas ideias que persistiam na mente após a morte do estímulo original. ${ }^{26}$

Não por acaso, o primeiro capítulo do Livro I do Leviatã ("Do Homem") intitulase "Da Sensação", onde se lê, de maneira inequívoca, que as ideias humanas originam-se dos sentidos, "pois não há nenhuma concepção no espírito do homem, que primeiro não tenha sido originada, total ou parcialmente, nos órgãos dos sentidos... O resto deriva daquela origem." O "Bem" e o "Mal" não passariam de noções falsas estabelecidas pelos filósofos e escolásticos para denotar apetites individuais e desejos, que mais não seriam senão a tendência para se mover em direção a um objeto qualquer.

\footnotetext{
${ }^{25}$ Roy Porter, The Creation of the Modern World..., p. 57.

${ }^{26}$ Hobbes, Leviathan, Parte III, cap. 34.
} 
Quando Hobbes descreve a psicologia humana sem fazer nenhuma referência ao summum bonum da tradição clássico-cristã, não apenas o conceito de bem supremo se torna supérfluo como, dada a variabilidade dos desejos humanos, é impossível que tal condição exista. ${ }^{27}$ Como a humanidade não se orienta por nenhum finis ultimis ou desígnio transcendental, e dada a variedade dos desejos e a escassa capacidade de cumpri-los, Hobbes proclama que o "estado natural" do homem, longe de angelical como supunham humanistas como Ficino, os neoplatônicos de Cambridge e Maistre, seria 'miserável', ou melhor, um estado de guerra de todos contra todos, a menos que o medo da morte, ou o desejo das coisas necessárias para uma vida confortável, prevalecessem contra aquela "pulsão de morte" natural, dotando assim os homens para a obediência na vida civil sob a espada do Leviatã. ${ }^{28}$

Como era de se esperar, a negação, por Hobbes, da existência de uma lei natural e do papel da transcendência divina no mundo suscitou inúmeras acusações de ateísmo como a dos neoplatônicos de Cambridge, tão admirados por Maistre - e de imoralismo "maquiavélico", a ponto de suas obras De Cive (1642) e Leviathan (1651) terem sido queimadas pelas autoridades da Universidade de Oxford, em 1683.

Consciente da importância de Bacon em todo aquele processo, Maistre acusava-o de ter feito de tudo para excluir das investigações científicas toda e qualquer consideração religiosa, de haver retirado do estudo da natureza toda consideração sobre a noção de inteligência, a qual jamais seria redutível a algo material. Todo o esforço epistemológico de Bacon ter-se-ia concentrado no propósito de circunscrever o estudo da natureza aos fenômenos físicos, eliminando do mesmo tudo o que conduzisse a uma outra ordem que não a material. Contra esta abordagem materialista, Maistre advertia que a inteligência participava de maneira conspícua na ordem natural, como a "ordem, a proporção e a simetria no universo" não deixavam dúvidas. ${ }^{29}$ No Examen, Maistre objetava ao método científico estritamente físico de Bacon a consideração das causas finais, responsáveis por mostrar ao homem a inteligência em ato na natureza:

\footnotetext{
27 "Não entendo aqui por costumes a decência da conduta, por exemplo, a maneira como um homem deve saudar a outro, ou como deve lavar a boca, ou limpar os dentes diante dos outros, e outros aspectos da pequena moral. Entendo aquelas qualidades humanas que dizem respeito a uma vida em comum pacífica e harmoniosa. Para este fim, devemos ter em mente que a felicidade desta vida não consiste no repouso de um espírito satisfeito. Pois não existe o finis ultimus (fim último) nem o summum bonum (bem supremo) de que se fala nos livros dos antigos filósofos morais." Cf. Hobbes. Leviatã, Parte I, cap. 11 .

${ }^{28}$ Hobbes. Leviatã, parte I, cap. XIII.

${ }^{29}$ Joseph de Maistre, O.C., VI: p. 388.
} 
"As causas finais sendo o flagelo do materialismo, os filósofos modernos, dos quais Bacon é o líder incontestável, de nada esqueceram para se livrar de um argumento que perturbava tanto os materialistas e incluso os filósofos que, sem ser exatamente materialistas, inclinavam-se mais ou menos para as doutrinas materiais; pois o espírito de um sistema o precede e, ademais, o extrapola sempre, se me for permitido expressar assim, estendendo-se para além daquilo que forma a essência rigorosa deste sistema". ${ }^{30}$

Não por acaso, o Examen apela à tradição epistemológica neoplatônico-clássica, mais especificamente ao modelo expresso pela "grande cadeia do ser" ${ }^{31}$ - caracterizado, dentre outros aspectos, pela ideia da plenitude do universo e pela admissão de uma continuidade entre as formas criadas (cada qual ocupando uma posição imutável no cosmo) que culminavam em Deus - na defesa das causas finais contra o reducionismo materialista, razão pela qual, a exemplo do que fizeram os neoplatônicos de Cambridge contra Hobbes, Maistre lança mão das críticas de Cícero (106a.C.-43a.C.) presentes no De Natura Deorum (Sobre a natureza dos deuses, 45a.C.) às teses sensualistas avançadas pelos epicuristas e estoicos, os quais, apesar das diferenças de fundo entre as suas filosofias, concordavam em que os sentidos constituíam a única fonte do conhecimento:

"A demonstração do trabalho pela obra é vulgar, apresentando-se a todos os espíritos e adaptando-se a todos os degraus de inteligência. Mas se ela pertence a alguém, certamente é a Cícero, pois não há, propriamente dizendo, pensamentos novos a este respeito... Pois foi então Cícero quem disse [através do personagem Cota, seu porta-voz no diálogo com o epicurista Caio Veleio e o estóico Lucio Balbo]: Mas têm dúvidas a respeito do mundo do qual tudo nasce ou se faz, sobre se foi formado pelo acaso ou por alguma necessidade, ou se por uma razão e mente divina, e julgam que Arquimedes tem mais valor ao reproduzir por imitação os giros da esfera celeste do que a natureza em criá-los, ao passo que em muitos detalhes aqueles giros naturais foram feitos com mais engenhosidade do que estes simulados. Seria difícil apresentar o grande argumento de uma maneira mais feliz." ${ }^{32}$

O grande erro de Bacon, portanto, estava no fato de suprimir as causas finais das investigações científicas da natureza, reduzindo-a a um jogo de ações e reações físicas e

\footnotetext{
${ }^{30}$ Joseph de Maistre, O.C., VI: p. 392.

${ }^{31}$ Arthur O. Lovejoy, A Grande Cadeia do Ser: Um Estudo da História de uma Ideia (1933). Trad. de Aldo Fernando Barbieri (São Paulo: Palíndromo, 2005), p. 63.

32 Joseph de Maistre, O.C., VI: 392 . O trecho citado do De Natura Deorum encontra-se no Livro II, parágrafo 35 do diálogo.
} 
mecânicas passíveis de serem traduzidas em leis invariáveis por meio do método indutivo. $\mathrm{O}$ perigo iminente por detrás deste método consistia em favorecer o determinismo e/ou a passividade moral (afinal, para que orar, se as leis são exclusivamente imanentes e inflexíveis?) através da redução do universo a um conjunto de leis que se bastavam a si próprias e dispensavam a transcendência divina. É possível remeter todos os fatos e ações a estas leis, sem que o homem possa fazer alguma coisa a não ser adaptar-se às mesmas. Para Maistre, a consequência mais óbvia desse sistema pedagógico baconiano-enciclopédico era realizar aos poucos, mas efetivamente, o que a Revolução Francesa, através do processo descristianizador, não conseguiu empreender abrupta e violentamente.

Ao fim e ao cabo, a crítica maistreana exerceu-se sobre um método que, de Bacon a Locke e seus sucessores franceses, apresentava a natureza como um sistema apreensível e dominável por meio de leis e mecanismos, tornando a Providência divina dispensável (ainda que, no que diz respeito aos autores ingleses, não tenha sido esta a intenção inicial de suas obras). Sob o disfarce da explicação científica, o que se tem é um imenso ataque contra Deus, classificado no Examen $^{33}$ como théomisie (ódio à divindade) ou théofobie (fobia de Deus) nas Soirées. ${ }^{34}$ A consequência disso para o gênero humano é que "agora vos encontrais curvados sobre a terra, ocupados unicamente das leis e dos estudos físicos, não mais possuindo o menor sentimento de sua dignidade natural". 35

Uma noção de dignidade humana repleta de "afinidades eletivas" com a concepção humanista de homem desenvolvida pela vertente neoplatônica, e a qual, como veremos a seguir, encerrava o núcleo epistemológico humanístico da argumentação devota do saboiano.

\footnotetext{
${ }^{33}$ Joseph de Maistre, O.C., VI: 262.

${ }^{34}$ Joseph de Maistre, Les Soirées de Saint-Pétersbourg (1821), $5^{\circ}$ diálogo.

${ }^{35}$ Idem.
} 


\section{2. Humanismo neoplatônico e "philosophia perennis", de Ficino a Maistre}

Desde são Tomás de Aquino (1225-1274), a filosofia escolástica esforçou-se em reconciliar a filosofia aristotélica clássica com a doutrina católica, o que acabou sendo determinante para o fato de muitos humanistas não verem nenhum conflito entre o catolicismo e os clássicos, vendo os últimos como pagãos na forma, mas cristãos no conteúdo, de modo que inclusive o panteão da mitologia greco-romana poderia ser legitimamente empregado como um veículo para expressar os pensamentos da Igreja sobre os santos.

A respeito das abordagens humanistas estoicas e neoplatônicas (a qual nos diz mais respeito em função do destacado platonismo maistreano), Charles E. Trinkaus Jr observou que além de aquelas escolas insistirem na defesa de uma ética livre, pautada no livre-arbítrio, e na visão do homem como um microcosmo privilegiado na ordem da Criação, ambas concordavam no fato de que o homem era um ser passível de contínuo aperfeiçoamento (perfectibilidade ou entelecheia) e regeneração, por meio de uma natural atração pela inteligência divina. ${ }^{36}$

Constituía um fato comum entre os pensadores da baixa Idade Média e entre os humanistas - sendo Lorenzo Valla (1407-1457) uma das mais célebres exceções que confirmavam esta 'regra' - a divinização do homem paralelamente à humanização de Deus. Os reformadores e, antes deles, Valla (como não deixaram de reconhecer Lutero, para quem o autor do Diálogo sobre o Livre-Arbítrio, 1435-1443, era o "melhor italiano" que ele conhecera, e Calvino), tendiam a enfatizar o abismo que separava a humanidade de Deus, abandonando assim os padrões hierárquicos de pensamento tão destacados em são Tomás ou Marsilio Ficino (1433-1499). Assim, por exemplo, na Summa contra Gentiles (1270-73) são Tomás observou que a finalidade última de toda criatura é alcançar a semelhança para com Deus, razão pela qual seria inconsistente da parte da Providência divina privar os homens dos meios necessários para atingir aquela identidade. "Mas", advertiu o autor da Summa, "o agente voluntário atinge a semelhança em relação a Deus na medida em que age livremente: pois acabamos de provar que

\footnotetext{
${ }^{36}$ Charles Edward Trinkaus Jr, "Introduction" a "Lorenzo Valla: Dialogue on Free Will", in: Ernst Cassirer, Paul Oskar Kristeller e John Herman Randall (orgs.). The Renaissance Philosophy of Man Chicago and London: The University of Chicago Press, 1969, p. 149.
} 
existe livre arbítrio em Deus. Portanto, a providência não priva a vontade de liberdade" (Summa contra Gentiles iii, LXXIII). ${ }^{37}$

Neste sentido, o teólogo norte-americano Reinhold Niebuhr (1892-1971) destacou que o conceito renascentista de individualidade enraizava-se "na ideia da grandeza e da unicidade do homem", a qual implicava necessariamente na noção de liberdade. Disso decorreria o interesse primário dos pensadores renascentistas em provar que a onisciência divina não circunscrevia a liberdade humana, nem tampouco suprimia o papel criativo da mesma na história. ${ }^{38} \mathrm{Na}$ mesma linha, Kristeller destacou o quanto a noção humanista de homem absorveu alguns conceitos das culturas clássico-pagã e cristã (especialmente a escola neoplatônica de Ficino, que a designava como philosophia perennis) ${ }^{39}$, as quais o representavam como um ser dotado de especial dignidade (inventor das artes e da técnica e distinguido dos demais seres pelo uso da linguagem e da razão) no universo. A partir das influentes exposições de Petrarca (1304-1374) acerca do caráter sublime da alma e do homem (considerado pelo humanista italiano como o único objeto digno de atenção do pensamento humano) ${ }^{40}$, alguns humanistas não apenas absorveram estas noções de dignidade do homem, como destacaram a condição única ocupada pelo mesmo no cosmo, ao ponto de situá-lo o mais próximo possível de Deus, nem que para tanto fosse preciso contrariar as concepções mais pessimistas como a do papa Inocêncio III (1161-1216), cujo De Miseria Humanae Conditionis (Da Miséria da Condição Humana,1195) ensejaria a réplica do humanista Gianozzo Manetti (1396 - 1459) - a qual, intitulada De dignitate et excellentia hominis (Da excelência e dignidade do Homem, 1452), inspiraria autores como Marsilio Ficino (1433-1499) e Pico della Mirandola (1463-1494) na defesa da dignidade humana. ${ }^{41}$

Todavia, como acentuou o mesmo Kristeller, talvez nenhum filósofo humanista tenha logrado ir tão longe naquele exercício de conciliação entre pensamento clássico e o cristianismo quanto o neoplatônico florentino Marsilio Ficino, autor dos importantes Corpus Hermeticum (1463) e Theologia Platonica de immortalitate animae (1474).

\footnotetext{
${ }^{37}$ Charles Edward Trinkaus Jr, "Introduction" a "Lorenzo Valla: Dialogue on Free Will", p. 150.

${ }^{38}$ Reinhold Niebuhr, The Nature and Destiny of Man (New York: Charles Scribner's Sons, 1943), p. 64.

${ }^{39}$ Paul O. Kristeller, Renaissance Thought and the Arts (Princeton: Princeton University Press, 1980), p. 98.

${ }^{40}$ Idem, p. 108.

${ }^{41}$ Paul O. Kristeller, "Introduction" a "Giovanni Pico della Mirandola's Oration on the Dignity of Man", in: The Renaissance Philosophy of Man..., p. 219.
} 
Por certo, Ficino não foi o primeiro autor cristão a absorver as ideias do filósofo grego; muito antes dele, Orígenes (185-253); ao lado de Platão, a principal referência teológica de Maistre), Plotino (205-270) e Santo Agostinho (354-430) haviam-no feito, sendo o último talvez o principal responsável pelo interesse do florentino por Platão, caracterizado pelo bispo de Hipona como superior a todos os demais filósofos.

Contudo, enquanto Santo Agostinho, em De doctrina Christiana (397), recomendava um distanciamento entre os cristãos e os platonistas - por mais que os ensinamentos dos últimos estivessem em consonância com a fé cristã -, e grande parte dos autores patrísticos ou escolásticos que o sucederam citassem Platão de forma diluída e/ou descaracterizada de seu contexto, Ficino não só compreendia a doutrina platônica como uma autoridade perfeitamente compatível e necessária à compreensão das leis divinas, como foi o responsável por estudá-la sistematicamente e vertê-la para o latim, num extenso e meticuloso trabalho exegético-filológico de três décadas que abrangeu desde as obras de Platão (427-347 a.C.), aos principais trabalhos de autores neoplatônicos, como Porfírio (aprox. 234-305), Proclo (412-485), Dionísio o Areopagita (450-535) e, sobretudo, Plotino. ${ }^{42}$

Na opinião de Ficino, a filosofia não deveria ser abordada separadamente da religião, fosse como rival ou como auxiliar. Na qualidade de legítimas manifestações da vida espiritual, ambas perseguiam (ou pelo menos deveriam perseguir) o mesmo fim, que era a identificação e a busca do bem supremo, de modo que uma necessita da outra: a religião ampara a filosofia ao impedir que esta opte por uma noção inferior do bem e da virtude, ao passo que a filosofia, sem cujo conhecimento não se pode atingir aquele bem, preserva a religião da ignorância e da superstição. Portanto, a filosofia devia ser religiosa, e a religião, filosófica. Por ser filosófico, o sistema do acadêmico de Careggi ${ }^{43}$ edificava-se através da aplicação de princípios universais a todos os níveis do ser. Ao mesmo tempo, por ser religioso, ocupava-se em última análise com o sistema do universo (daí as investigações astrológicas que, ainda mais do que as referências pagãs ou as acusações de homossexualismo, trouxeram-lhe problemas com o papa Inocêncio

42 Josephine L. Burroughs, "Introduction" a Marsilio Ficino: Five Questions Concerning the Mind", in: Ernst Cassirer, Paul Oskar Kristeller e John Herman Randall (orgs.), The Renaissance Philosophy of Man (1948). (Chicago and London: The University of Chicago Press, 1969), p. 185-186.

43 "Villa" na qual administrava seus ensinamentos platônicos aos jovens florentinos e a qual lhe fora agraciada por Cosimo de Médici em 1462 para esta missão. 
VIII), pelo fato de somente o mesmo justificar a glorificação da alma humana, bem como a habilidade desta para atingir e demonstrar o summum bonum. ${ }^{44}$

Amparado na crença humanística que atribuía ao gênero humano uma inata ou universal habilidade para alcançar o supremo bem e uma natural religiosidade, Ficino defendia a origem divina das reflexões platônicas e, assim como o fariam posteriormente Giambattista Vico (1688-1744; de cuja magna obra, Principi di Scienza Nuova, de 1725, Maistre não só possuía uma edição como foi um dos primeiros homens do século XVIII a lê-la), Ralph Cudworth $(1617-1688)^{45}$ e o próprio Maistre, admitia que a verdade não dependia de uma única revelação, como a cristã (apesar de não questionar sua superioridade). Uma vez que os homens de todas as épocas demonstravam o mesmo desejo e inclinação natural em buscar o bem, Ficino divisou na própria natureza humana a base para a identificação do supremo bem com o conhecimento e o cultivo de Deus, permitindo assim a assimilação pelo cristianismo dos pensamentos de homens de outros tempos e de outras culturas. ${ }^{46}$

Deste modo, em Cinco Questões sobre a Mente (1476), Ficino procurou demonstrar que o fim último de todo desejo humano e de sua atividade (seu appetitus naturalis) não pode ser outro a não ser as "ilimitadas verdade e bondade" de Deus, de modo que a alma deve ser apta a atingir e fruir daqueles bens eternamente. ${ }^{47}$ Uma vez que a totalidade do "Ser' é concebida como uma espécie de genus, Deus, nas qualidades de "Ser" e "Bondade" por excelência, deve ser considerado como o primum daquele genus, de modo que todas as coisas situadas abaixo recebem a vida e a bondade dele, cada qual de acordo com sua origem e fim próprios. Como causa da existência de todos os seres, Deus é a fonte para a qual se orienta o desejo de cada criatura, e o cumprimento do fim apropriado no interior dessa cadeia da existência é garantido pela comunicação particular estabelecida com a divindade por cada ente criado. Na hierarquia do "Ser", estabelecida por Ficino, a alma é a terceira essência ou a essência do meio, assim como a fonte do movimento. Em razão de sua posição central, a alma apresenta uma afinidade com todas as coisas acima e abaixo dela, sendo capaz, graças

${ }^{44}$ Josephine L. Burroughs, "Introduction" a Marsilio Ficino: Five Questions Concerning the Mind", p. 187.

45 Filósofo protestante inglês e principal expoente da Escola platônica de Cambridge, cujos argumentos críticos à filosofia sensualista de Hobbes e em defesa do livre-arbítrio e da religião cristã mereceram uma leitura de Maistre em sua refutação às epistemologias de Bacon e de Locke, como veremos abaixo.

${ }^{46}$ Paul O. Kristeller, Renaissance Thought and the Arts, p. 99.

${ }^{47}$ Paul O. Kristeller, Supplementum Ficinianum: opuscula inedita et dispersa (Firenze: L.S. Olschki, 1937), vol. I, XCV ff. 
ao movimento que lhe é próprio, de se mover em cada uma das direções. Portanto, através do intelecto a alma se esforça para conhecer todas as coisas, assim como, através da vontade, esforça-se por desfrutá-las. No caso da alma humana, o desejo por toda verdade e bondade não podem ser satisfeitos a não ser pela comunicação contemplativa com Deus.

Como todas as demais coisas, a alma deve estar apta a alcançar o fim desejado, mas, em razão de sua posição central e dual, este fim não se realiza inevitavelmente pela simples presença de seu desejo natural. Assim como, por um lado, o homem divide o poder de geração, nutrição e sensação (relacionadas com a parte baixa ou irracional da alma) com as formas mais baixas do ser, por outro, a parte mais elevada de sua alma inclui os poderes de contemplação (que o homem compartilha com os anjos e Deus) e do discurso racional, que lhe são peculiares. Isto explica o fato de a alma humana oscilar entre duas tendências, uma em direção ao corpo (associado aos sentidos), outra em direção a Deus, associado à alma superior, pelo uso de suas faculdades racionais. E pelo fato de sua razão ser livre, o homem pode se opor aos sentidos ou ser enganado por eles, embora o mesmo jamais alcance o fim a que foi destinado através de sua alma inferior ou dos sentidos. Não por acaso, Ficino expressou este paradoxo através de uma leitura humanística do mito de Prometeu. Pelo efeito da razão, a natureza humana é a mais perfeita de todos os seres abaixo de Deus e dos anjos, isto é, de todas as coisas caracterizadas pelo movimento e detentoras de um determinado desejo. ${ }^{48}$

Para efeitos de ilustração do humanismo devoto de Maistre, o que importa destacar aqui é o fato de que Ficino, na contramão do que postulavam os humanistas cívicos florentinos da geração anterior à sua, isto é, a defesa da vita activa ${ }^{49}$ conforme expressa nas obras de Leonardo Bruni (1370-1444) e Matteo Palmieri (1406-1475) ambos críticos ao poder dos Médicis em Florença ${ }^{50}$-, mas na esteira de Platão e Plotino, considerava a experiência contemplativa não apenas como a base da especulação metafísica - uma vez que a mesma comprovaria a existência de Deus e de seus atributos, como desígnio, ordem e inteligência no universo -, mas também como a fonte de uma verdadeira vida moral, virtuosa, racional e, por extensão, verdadeiramente livre e ativa.

\footnotetext{
${ }^{48}$ Josephine L. Burroughs, "Introduction" a Marsilio Ficino: Five Questions Concerning the Mind", p. 191.

${ }^{49}$ Cf. Maurizio Viroli, Republicanism (1999) (New York: Hill and Wang, 2002), p. 69-78.

${ }^{50}$ Hans Baron, The Crisis of the Early Italian Renaissance: Civic Humanism and Republican Liberty in an Age of Classicism and Tyranny (1955) (Princeton: Princeton University Press, 1966), cap. 8.
} 
A seu ver, o homem só logra escapar dos vícios e dos sopros do acaso na medida em que for capaz de cultivar sua vida espiritual interior, purificando assim seu conhecimento e sua consciência e dotando-se plenamente para a liberdade. ${ }^{51}$ Apesar das poucas referências de Maistre ao humanista florentino nos seus registros de leitura ou obras $^{52}$, podemos inferir que o saboiano não poderia estar mais de acordo com os seus pressupostos. E longe disto resultar de uma mera coincidência, isto se deveu a um fator muito concreto e documentado, a saber, a extensiva leitura dos autores neoplatônicos de Cambridge (eles próprios, leitores diretos e admiradores de Ficino) pelo contrarrevolucionário saboiano.

${ }^{51}$ Paul O. Kristeller, Renaissance Thought and the Arts, p. 94-95.

52 Trata-se de uma nota do segundo diálogo das Soirées de Saint-Pétersbourg (1821), obra capital da reflexão maistreana e da qual trataremos mais adiante. Vide: P. Glaudes (org.), Joseph de Maistre: Oeuvres (Paris: Robert Laffont, 2007), p. 520. 


\section{3. Um túnel humanista neoplatônico no além-Mancha: Maistre e a Escola de Cambridge}

"O célebre Cudworth" ${ }^{153}$, é assim que Maistre se refere, em duas ocasiões nas Soirées, ao principal expoente da Escola Platônica de Cambridge, Ralph Cudworth (1617-1688), um teólogo protestante latitudinário e professor de filosofia, defensor do livre-arbítrio e autor do célebre The True Intellectual System of the Universe $(1671)^{54}$, cujo exemplar o embaixador saboiano não apenas possuía - tratava-se de uma tradução latina editada e comentada pelo teólogo e historiador eclesiástico luterano Johann Lorenz von Mosheim (1693-1755) -, como o mesmo trazia as seguintes insígnias de sua autoria: "excelente livro, raro e precioso". ${ }^{55}$

Além da curiosidade metafísica, Maistre sentiu-se naturalmente atraído pelos neoplatônicos de Cambridge em razão dos ataques que receberam da Encyclopédie, pelo fato de defenderem os mesmos princípios que ele julgava válidos para uma crítica racional à Filosofia das Luzes, respectivamente nas figuras de Bacon e Locke. ${ }^{56}$ Desse modo, a primeira menção - presente no início do segundo diálogo das Soirées -, surge num contexto de defesa das ideias inatas contra as proposições sensualistas de Locke e de seu discípulo francês Condillac (1715-1780), o irmão mais novo do abbé de Mably (1709-1785), cujo Traité des Sensations (Tratado das Sensações, 1754) sustentava que as ideias originavam-se nos sentidos.

No processo que move nas Soirées contra o empirismo de Locke e seus seguidores franceses, Maistre, na melhor tradição retórica humanista, apela a um grande rol de respeitadas autoridades clássicas (cristãs ou pagãs, segundo o estilo da philosophia perennis tão célebre em Ficinio) que, de Pitágoras a Platão, Cícero, Tácito, Orígenes, Santo Agostinho, Descartes, Pascal, Pierre Nicole, Bossuet, Malebranche,

${ }^{53}$ J. de Maistre, Soirées, O.C., IV: 358 (VI ${ }^{\mathrm{e}}$ Entretien).

${ }^{54} \mathrm{O}$ Verdadeiro Sistema Intelectual do Universo, em cuja primeira parte toda a razão e a filosofia do ateísmo é refutada, e sua impossibilidade demonstrada (1671).

55 J.-Louis Darcel "Catalogue de la Bibliothèque de Joseph de Maistre", in: Revue des Études Maistriennes, $\mathrm{n}^{\circ} 1$, março de 1975, p. 41.

${ }^{56}$ Sobre a crítica enciclopédica aos platonistas e a Ralph Cudworth em especial, Robert Triomphe destacou que os mesmos eram descritos como indignos da pátria de Locke. Vide: Robert Triomphe, Joseph de Maistre: étude sur la vie et sur la doctrine d'un matérialiste mystique (Geneva: Droz, 1968), p. 472. 
Fénelon, Leibniz e, obviamente, Cudworth, reforçavam os argumentos do saboiano baseados no princípio da autoridade que ele opunha à Filosofia das Luzes. ${ }^{57}$

Apesar de encontrarmos uma única referência direta a Ficino em Maistre (em uma breve nota das Soirées), o fato é que os postulados metafísicos platônicos de sua reação ao sensualismo de Bacon, Locke e dos philosophes franceses continham muitos elementos em comum com as ideias do neoplatônico humanista florentino do século $\mathrm{XV}$, algo que se explica pela apropriação das ideias dos neoplatônicos de Cambridge (em especial de Cudworth, um cuidadoso leitor de Ficino) pelo autor das Soirées. Observando que "os sentidos não têm nada em comum com a verdade", a qual é acessível apenas pelo "entendimento" ${ }^{58}$, Maistre concluía que as teses sensualistas de Locke e dos encoclopedistas eram meros paralogismos, uma vez que "toda doutrina racional é fundada sobre um conhecimento antecedente" e "o homem não pode aprender nada a não ser pelo que ele sabe". ${ }^{59}$ Pois, sublinha Maistre recorrendo a Platão (especialmente ao diálogo Mênon) e Aristóteles, a recusa em admitir as ideias inatas ou primordiais - as quais são anteriores, evidentes, não-derivadas, indemonstráveis e causas em relação à demonstração - implica na impossibilidade da própria demonstração ${ }^{60}$, pois o conhecimento que deriva dos sentidos pressupõe uma fonte intelectual ativa que o fundamente e o ordene.

E conforme destacou Philippe Barthelet, no impressionante rol de leituras empreendidas por Maistre, a do Sistema intelectual de Cudworth está entre as que mais mereceram a atenção do saboiano desde os escritos maçônicos de 1782, razão pela qual foi um dos raros livros que ele fez questão de levar consigo durante a longa emigração iniciada em setembro de $1792 .{ }^{61}$ Em grande medida, o estilo que Maistre empregou na defesa daquilo que ele designava como "o cristianismo total"62 deveu muito à leitura daqueles autores cambridgeanos e ao recurso retórico tipicamente humanista da philosophia perennis mobilizado pelos mesmos. Curiosamente, e assim como ocorria

57"A razão humana está manifestamente convicta de impotência para conduzir os homens, pois poucos têm a condição de refletir corretamente, e não seria nada bom refletir sobre tudo, de modo que em geral é bom, não importa o que se diga, começar pela autoridade." Cf. J. de Maistre, Soirées, O.C., IV:108 (II ${ }^{\mathrm{e}}$ Entretien).

${ }^{58}$ J. de Maistre, Soirées, O.C., IV: 357 (VI ${ }^{\mathrm{e}}$ Entretien).

${ }^{59}$ Trata-se de uma citação do original grego dos Analíticos posteriores, de Aristóteles. Vide: J. de Maistre, Soirées, O.C., IV: 390-391 notas XII a XV (VI ${ }^{\mathrm{e}}$ Entretien).

${ }^{60} \mathrm{~J}$. de Maistre, Soirées, O.C., IV: 354 (VI Entretien).

61 P. Barthelet, "The Cambridge Platonists mirrored by Joseph de Maistre", in: Carolina Armenteros e Richard A. Lebrun (orgs.), Joseph de Maistre and the legacy of Enlightenment (Oxford: Voltaire Foundation, 2011), p. 70.

${ }^{62}$ Joseph de Maistre, Eclaircissement sur les sacrifices, in: O.C., V: 338, nota 4. 
com aqueles autores, as referências epistemológicas clássico-pagãs conviviam e, num certo sentido, suplantavam as cristãs, ou seja numa ordem cronológica, Pitágoras, Platão, Cícero, e só então os cristãos Orígenes (descrito como um "teólogo sublime"), Santo Agostinho e são Tomás de Aquino.

Quando expõe as teses de seu "cristianismo transcendental"63, Maistre destaca a solidariedade mística e física de todas as partes do universo, e em particular do homem com o mundo, do qual ele não apenas é o usufrutuário - "senhor e possessor" na acepção cartesiana -, mas, num certo sentido, também co-criador, através da onomaturgia ${ }^{64}$, o poder de nomeação concedido a Adão por Deus. O politeísmo nada mais seria senão o necessário e natural reconhecimento, anterior à revelação, dos detalhes de uma gradação transcendental, na qual a ação divina pressupunha a participação dos anjos e dos homens (que deveriam se sacrificar por Deus na Terra). ${ }^{65}$ No Eclaircissement sur les sacrifices (Esclarecimento sobre os sacrifícios, escrito em 1810, mas publicado somente em 1821), Maistre cita o neoplatônico origeniano e ficiniano de Cambridge Henry More (1614-1687), o qual, em sua Opera theologica (1675) e à guisa da pia philosophia ou docta religio de Ficino ${ }^{66}$, defendia uma linha de continuidade metafísica entre o paganismo e o cristianismo, pois assim como "os antigos pagãos tiveram suas próprias divindades tutelares dos reinos, províncias e cidades (pelas quais a estabilidade do império foi assegurada), também a Igreja romana possuía as suas autoridades tutelares, os santos, etc." ${ }^{67}$ Esta assimilação entre as divindades pagãs com os santos cristãos - a quem, de certa forma, prefiguravam nas épocas humanas menos iluminadas -, a qual adaptava-se tão bem à religiosidade barroca, era apenas um dos conceitos da "Escola platônica de Cambridge" - para usarmos uma classificação de Cassirer $^{68}$ - absorvidos por Maistre, ao lado do conceito, obtido de uma citação da Geographica, de Estrabão (63 a.C.- 24 d.C.), feita por Cudworth, segundo o qual a

${ }^{63}$ J. de Maistre, Soirées, O.C., V: 248 (XI Entretien).

${ }^{64} \mathrm{~J}$. de Maistre, Soirées, O.C., IV: 103 (II ${ }^{\mathrm{e}}$ Entretien)

${ }^{65}$ P. Barthelet, "The Cambridge Platonists mirrored by Joseph de Maistre", op. cit., p. 73.

${ }^{66}$ Ideia segundo a qual o Verbo ou Logos divino revelara-se de maneira perene não só através dos profetas bíblicos hebreus ou apóstolos, santos e teólogos cristãos, mas também por meio dos poetas e filósofos antigos, sendo a teologia platônica o modelo de docta religio, a qual dizia que a consciência de si só se realiza através da consciência de Deus. In: Eugenio Garin, L'umanesimo italiano (1952). RomaBari: Editori Laterza, 2008, p. 108-109.

${ }^{67}$ Joseph de Maistre, Eclaircissement sur les sacrifices, in: O.C., V:344, nota 1.

${ }^{68}$ E. Cassirer, The Platonic Renaissance in England (New York: Nelson and Sons, 1953). 
'virtude expiatória é útil ao homem", sendo o sangue, "a alma das vítimas", a parte reservada aos deuses no sacrifício. ${ }^{69}$

Todavia, um dos principais aspectos da recepção maistreana às ideias de Cudworth diz respeito à visão cristã neoplatônica (tipicamente ficiniana) exposta no capítulo IV do The True intellectual System of the universe, no qual o filósofo inglês demonstra que os homens de todos os tempos possuem uma noção inata de um único Deus ("naturalidade da ideia Divina"), de modo que o paganismo pressupunha o monoteísmo (a última, embora secreta, palavra de qualquer religião). ${ }^{70}$

$\mathrm{Na}$ visão de Maistre, o que de fundamental unia todos aqueles autores era uma propensão intelectual a nunca separar ou opor a revelação divina às verdades naturais. Assim, no que concerne aos neoplatônicos de Cambridge, quando seu fundador e reitor do King's College, Benjamin Whichcote (1609-1683), defendia um "Cristianismo racional", o mesmo não estava varrendo para debaixo do tapete os conteúdos transcendentais do cristianismo a fim de condescender com o moderno racionalismo, mas afirmando a necessária identidade entre as luzes natural e trancendental, sendo que a primeira advém da segunda. Whichcote distinguia entre dois tipos de verdade: aquelas reveladas diretamente por Deus e sua palavra, e outras, conectadas à primeira, que se encontram inscritas e são conaturais à alma humana, de modo que as verdades reveladas e naturais diferem somente quanto ao modo em que se oferecem para nós. ${ }^{71}$

Num de seus famosos aforismos e bem ao estilo da exegese platônica de Cambridge, Whichcote define a razão como "res illuminata, illuminans", isto é, "acesa por Deus e iluminando-nos para Deus" ${ }^{72}$, denotando uma preocupação daqueles estudiosos em fundar uma teoria do conhecimento que, baseada numa concepção latitudinária do cristianismo, lograsse ultrapassar os limites confessionais e culturais e reunisse os homens ética e politicamente por meio da aceitação de uma "moralidade eterna e imutável". ${ }^{73}$ Diante disso, como não destacar, também aqui, o legado da pia philosophia de Ficino, para quem a mente humana era um olho que tinha necessidade da

\footnotetext{
${ }^{69}$ Maistre reproduz a citação de Estrabão a partir da obra De vera notione coena Domini (I, p. VII) de Cudworth. In: Joseph de Maistre, Eclaircissement sur les sacrifices, in: O.C., V:329, nota 1.

${ }^{70}$ The True Intellectual System of the Universe (New York: Gould and Newman, 1837), Prefácio, p. 42.

${ }^{71}$ Benjamin Whichcote, The Works of the learned Benjamin Whichcote (Aberdeen: J.Chalmers, 1751). vol. III, p. 20.

${ }^{72}$ Benjamin Whichcote, Moral and Religious Aphorisms. Wherein are contained Many Doctrines of Truth, and Rules of Practice, which are of Universal Concernment, and of the Greatest Importance in the Life of Men (London: J. Payne,1753), p. 49.

${ }^{73}$ Ralph Cudworth, Treatise Concerning eternal and immutable morality (London: J. \& J. Knapton, 1731), Livro II, cap. I.
} 
luz divina para enxergar a verdade, e a qual não se manifesta senão aos que se voltam a ela e se libertam do mundo material e dos enganos sensoriais ${ }^{74}$

Com efeito, as reflexões neoplatônicas de Cudworth, Whichcote e More gravitam em torno da defesa da liberdade humana (ou do livre-arbítrio) contra o que Maistre designou como fatalismo em todas as suas formas possíveis (teológica, através do calvinismo, ou científico-filosófico, seja através das filosofias de Gassendi e, sobretudo, Thomas Hobbes, ou através do método empírico de Bacon e Locke).

Para aqueles filósofos e teólogos latitudinários ${ }^{75}$ de Cambridge, o que unia estruturas discursivas aparentemente tão antagônicas como o empirismo e o puritanismo era uma certa orientação para a prática, comum ao espírito de ambos. No âmbito epistemológico-científico, este espírito prático, ditado não pela vita contemplativa, mas para o domínio sobre a natureza e sobre os homens, dera origem às formulações de Bacon e de Hobbes. Para os filósofos neoplatônicos, o desenvolvimento religioso do puritanismo inglês seguia uma linha semelhante àquela observada pelo novo método empírico, qual seja, a mesma limitação e/ou preocupação com a intervenção na realidade e, mormente, a separação entre a Fé e a Razão.

Quando Bacon, em seu De augmentis scientiarum (1623), destaca os limites da razão humana para compreender as verdades da fé - segundo ele, numa compreensão teológica tipicamente calvinista, "o pequeno barco da razão humana", apto a navegar por toda a circunferência do velho e do novo mundo das ciências, era, no entanto, incapaz de nos guiar para a costa da divindade (theologia sacra) -, o mesmo pretendia dizer que os mistérios divinos não podiam ser compreendidos filosoficamente, devendo ser adorados em silêncio. ${ }^{76}$ Conforme advertia no Novum Organum:

"Quão vasta é a diferença... entre os Ídolos da mente humana e as Ideias sobre o Divino. Os primeiros não são mais senão abstrações arbitrárias; as últimas são a estampa do próprio Criador sobre a Criação impressas e definidas na matéria através de linhas verdadeiras e extraordinárias." 77

\footnotetext{
${ }^{74}$ Eugenio Garin, L'umanesimo italiano, p. 108.

${ }^{75}$ Conforme obervou Cassirer em seu referido estudo, os intelectuais de Cambridge podiam ser tachados de tudo, menos de moralmente indiferentes. Pois naquele verdadeiro fogo-cruzado que caracterizou a atmosfera cultural inglesa do século XVII, mostraram-se excepcionalmente firmes ao não assumirem nenhum dos lados da disputa, razão pela qual terminaram por atrair a animosidade de ambos (daí a origem da alcunha pejorativa de "latitudinários").

${ }^{76} \mathrm{~F}$. Bacon, De augmentis scientiarum, livro IX, cap. 2.

77 James Spedding, Robert Leslie Ellis e Douglas D. Heath (orgs.), The Works of Francis Bacon (London: Longman, 1857-1874), vol. IV, p. 110.
} 
Um dos primeiros objetivos de Bacon consistia em promulgar um novo método filosófico que se revelasse capaz de superar a tendência natural da mente humana de contemplar seu próprio "umbigo" ao invés da grandeza da criação de Deus. Educado na fé puritana, Bacon compartilhava da visão calvinista que atribuía à queda no pecado original uma perda para a humanidade de suas faculdades racionais. Incapaz de refletir fielmente a natureza e, portanto, de alterá-la em seu próprio benefício (pois outro não era o desígnio amoroso de Deus para com sua principal criatura), a humanidade oscila entre o embrutecimento e a superstição. ${ }^{78}$

Diante da questão que se impõe a todo cristão (sobretudo na sua acepção calvinista, como veremos a seguir), a saber, de como elevar ao máximo a glória de Deus no interior deste mundo, Bacon sustentou que esta glorificação passava necessariamente pela imposição de um novo método de investigação prática da natureza, cujo fim seria o de restituir a soberania e o poder da humanidade sobre a mesma. Pois a perda de tal domínio - resultante do orgulho humano e da consequente criação de falsos "ídolos" (um termo teológico que Bacon provavelmente emprestara dos epígonos do calvinismo $^{79}$ ) - representava uma prevaricação diante de Deus.

Ao invés de alimentar o orgulho e a soberba na humanidade, esta nova ciência que tinha a seu favor a humildade de se curvar para as maravilhas da Criação para melhor compreendê-las e dominá-las - deveria servir ao benefício e à caridade dos homens, em total acordo com o desígnio amoroso de Deus. Em Bacon, a filosofia da ação do empirismo foi diretamente ao encontro da religião da ação puritana. Isto se torna mais claro quando dirigimos a atenção ao puritanismo.

Conforme observou Weber a respeito do calvinismo e de seus desdobramentos puritanos, os sinais da salvação só poderiam ser percebidos por meio do envolvimento na esfera mundana, mais particularmente através de um incessante e ascético trabalho que visava subjugar a realidade em nome do serviço ao Deus sublime - tão absoluto e

78 "Pois a mente do homem está longe da natureza de um espelho claro e liso, em que os raios das coisas deveriam refletir de acordo com a sua verdadeira incidência; não, é como um espelho encantado, cheio de superstição e impostura, se ela não for liberada e corrigida." In: Spedding et al., The Works of Francis Bacon (London: Longman, 1857-1874), vol. III, p. 394-395.

79 "Dessa imensa mistura de erros, pela qual todo o orbe foi completamente atulhado e coberto, o entendimento de cada um se encontra como num labirinto, de modo que não seja de admirar que cada povo tenha sido levado aos mais variados desatinos, e não somente os povos, mas como se cada homem tivesse seus próprios deuses. Como a temeridade e a lascívia recaem na ignorância e nas trevas, dificilmente se descobriu algum homem que não fabricasse para si um ídolo ou um espectro no lugar de Deus." in: João Calvino, Instituição da Religião Cristã, Livro I, cap. 5, §12. 
sublime (isto é, inapreensível ao intelecto humano) que aos homens não restaria outra alternativa senão a de servi-lo neste mundo.

É certo para o protestantismo que "o único meio de viver que agrada a Deus não está em suplantar a moralidade intramundana pela ascese monástica, mas sim, exclusivamente, em cumprir com os deveres intramundanos, tal como decorrem da posição do indivíduo na vida". Para Weber, deve-se à Reforma a inédita valorização da profissão “como o mais excelso conteúdo que a autorrealização moral é capaz de assumir". 80

A respeito do que nos importa aqui (o calvinismo e seus desdobramentos), podese considerar como dogma central de sua doutrina a noção de predestinação. De acordo com este princípio, os homens, após a queda no pecado original, tornaram-se incapazes de realizar sua própria "justificação". Apenas alguns dentre eles estão predestinados a usufruir da eterna bem-aventurança, enquanto aos demais estão reservadas a desgraça e a desonra eternas. Para Calvino, "não é Deus que existe para os seres humanos, mas os seres humanos que existem para Deus, e todo acontecimento... pode ter sentido exclusivamente como um meio em vista do fim que é a autoglorificação da majestade de Deus". ${ }^{81}$ Assim, devido ao abismo que se interpõe entre Deus e o homem, este último encontra-se impossibilitado seja de conhecer seu próprio destino, seja de interferir, por meio de (boas) obras, nos decretos divinos. ${ }^{82}$

Como destacou Weber, uma vez estabelecida a transcendência absoluta de Deus isto é, que seus decretos são imutáveis e completamente inacessíveis às criaturas humanas -, conclui-se que a graça de Deus será tão "imperdível por aqueles a quem foi concedida como inacessível àqueles a quem foi recusada." ${ }^{83}$

\footnotetext{
${ }^{80}$ Max Weber, A ética protestante e o "espírito" do capitalismo (São Paulo: Cia das Letras, 2009), p. 72.

${ }^{81}$ Idem, p. 94.

82 "Aplicar critérios de 'justiça terrena' a seus desígnios soberanos não faz sentido e é uma ofensa à sua majestade, posto que ele e somente ele é livre, ou seja, não se submete a nenhuma lei, e seus decretos só nos podem ser compreensíveis ou em todo caso conhecidos na medida em que ele achar por bem comunicá-los a nós. Apenas a esses fragmentos da verdade eterna podemos nos ater; todo o resto: - o sentido de nosso destino individual - acha-se envolto em mistérios obscuros que é impossível e arrogante sondar... Pois toda criatura está separada de Deus por um abismo intransponível e aos olhos dele não merece senão a morte eterna, a menos que ele, para a glorificação de sua majestade, tenha decidido de outra forma. De uma coisa apenas sabemos: que uma parte dos seres humanos está salva, a outra ficará condenada. Supor que o mérito humano ou a culpa humana contribuam para fixar esse destino significaria encarar as decisões absolutamente livres de Deus, firmadas desde a eternidade, como passíveis de alteração por obra humana: ideia impossível." Cf. Max Weber, A ética protestante e o "espírito" do capitalismo, p. 94.

${ }^{83}$ Max Weber, A ética protestante e o "espírito" do capitalismo, p. 95.
} 
O sentimento de inaudita "solidão interior do indivíduo" que a doutrina puritana inspirava nos crentes, cabendo ao sujeito percorrer sozinho, sem qualquer ajuda de outrem, a via de sua salvação - daí a "desumanidade patética" ${ }^{84}$ a que se referiu o próprio Weber -, não podia levar senão à recusa das instituições eclesiásticas e de seus respectivos sacramentos (ou "meios mágicos") e, em última análise, à conclusão daquele grande processo histórico teológico-político consagrado nas ciências sociais pela fórmula de "desencantamento do mundo". ${ }^{85}$

Para o calvinista, o mundo está destinado a servir à autoglorificação de Deus, de modo que o cristão (o eleito) existe apenas "para fazer no mundo a glória de Deus", não apenas pela observância de seus mandamentos, mas também pela realização de um trabalho social in majorem Dei gloriam ("para aumentar a glória de Deus"). Reflexo do isolamento interior do indivíduo exercido pela fé calvinista e da consequente subversão da visão tradicional da caridade cristã, este trabalho intramundano traduz-se num serviço prestado pelo fiel em nome da conformação racional do cosmos que o circunda. E tanto a Bíblia como a razão natural ensinam que o cosmos deve servir à "utilidade" do gênero humano, cabendo a este último promover a glória de Deus por meio de um trabalho a serviço de uma utilidade social (impessoal). ${ }^{86}$

Esta ascese intramundana, pela qual o calvinismo reverteu a primazia ontológica de que gozava tradicionalmente o "Outro Mundo" em termos de experiência religiosa, reforçou esta tendência utilitária. Por um lado, constitui um dever do cristão "considerar-se eleito e repudiar toda e qualquer dúvida como tentação do diabo, pois a falta de convicção, afinal, resultaria de uma fé insuficiente e, portanto, de uma atuação insuficiente da graça". ${ }^{87}$ Por outro (mas no mesmo sentido), o meio mais seguro para se conquistar esta autoconfiança consiste no "trabalho profissional sem descanso", único capaz de dissipar a dúvida religiosa e de conferir a certeza do estado de graça. ${ }^{88}$

É bem verdade que o empirismo e o puritanismo abordam o mundo real de maneiras distintas, com suas respectivas ênfases na imanência e na transcendência.

No primeiro caso, o mundo é assimilado através do conhecimento, mais especificamente, através da observação analítica do experimento e do cálculo (método indutivo). Seu objetivo é o de instaurar o regnum hominis por meio da sujeição (a ponto

\footnotetext{
${ }^{84}$ Max Weber, A ética protestante e o "espírito" do capitalismo, p. 95.

${ }^{85}$ Idem, p. 96.

${ }^{86}$ Ibid., p. 99.

${ }^{87}$ Ibid., p. 101.

${ }^{88}$ Ibid., p. 102.
} 
de não prescindir nem mesmo da "tortura" ${ }^{89}$ ) da natureza. No caso do puritanismo, a obtenção dos bens materiais e/ou a satisfação dos instintos naturais humanos são relegados a um segundo plano, de modo a que toda atividade humana sirva à glorificação de Deus no mundo.

Todavia, a avaliação da atividade prática permanecia fundamentalmente a mesma em ambas acepções, a ponto de o puritanismo de Richard Baxter (1615-1691) ter sido apontado por Cassirer como um reforço e legitimação concedidos pela esfera religiosa à concepção de mundo materialista/empírica: "É com vistas à ação que Deus nos preservou, bem como nossas atividades; o trabalho é tanto o fim moral quanto o fim natural do poder". ${ }^{90}$ A severa concepção absolutista de Deus do puritanismo deixa amplo espaço para as esferas finita e empírica, uma vez que nele a laboriosidade e a austeridade são elevados à categoria de exigências morais e religiosas.

Em meio às duas principais forças que lograram cooperar na esfera prática e assim dotar a moderna cultura inglesa de uma autoconfiança, coerência e estabilidade sem precedentes, os neoplatônicos de Cambridge defendiam um outro ideal filosófico e religioso baseado na contemplação e na intuição (vita contemplativa), e não nas novas possibilidades da ação.

$\mathrm{Na}$ contramão da atitude epistemológica de um Bacon - o qual, no Novum Organum (1620), ensejou um assalto aos antigos em defesa do método experimental dos modernos - e dos puritanos ingleses ${ }^{91}$, os teóricos de Cambridge propunham uma reabilitação da vita contemplativa que, por sua vez, era indissociável de uma postura retrospectiva e positiva em relação às fontes clássicas, pois sua ideia de religião não se limitava às fronteiras do cristianismo (e/ou à sua raiz judaica).

Fundamentalmente, os neoplatônicos de Cambridge defendiam o livre-arbítrio e a liberdade humana contra o que julgavam ser o pano de fundo comum tanto do método experimental emergente quanto do puritanismo, qual seja, o fatalismo ético-moral.

${ }^{89}$ Ao esclarecer o leitor a respeito de seu novo método em The Plan of the Work, Bacon nos informa o seguinte: "Entendo não apenas uma história da natureza independente e em liberdade (quando é deixada no seu próprio curso e faz sua obra de sua própria maneira)..., mas muito mais de uma [história da] natureza sob constrangimento e atormentada, quer dizer, quando pela arte e mão do homem ela é forçada a sair do seu estado natural e é constrangida e atormentada... A natureza das coisas se revela mais rapidamente quando submetida ao tormento da arte do que em sua liberdade natural." in: James Spedding, Robert Leslie Ellis e Douglas Heath (orgs.), The Works of Francis Bacon (London: Longman, 18571874), vol. I, p. 233-234.

${ }^{90}$ Richard Baxter, Christian Directory, Vol. I, p. $375 \mathrm{f}$ apud Cassirer, The Platonic Renaissance..., op. cit., p. 70.

${ }_{91}$ Em Bacon, Platão é descrito ora como um "teólogo louco" ora como um "poeta pomposo", enquanto Aristóteles é acoimado de ser o responsável pela "filosofia sofística" que, através da dialética, arruinou as ciências da natureza (Novum Organum, Livro I, cap. 2). 
Apesar do fundamental papel desempenhado pelo puritanismo na consolidação das liberdades políticas inglesas durante o século XVII - por razões óbvias, um dado retrospectivo inacessível aos filósofos de Cambridge -, não podemos perder de vista que o mesmo jamais pretendeu transferir a ideia de liberdade da esfera política para a religiosa, a ponto de seus líderes (Eliot e Pym) condenarem a liberdade de consciência religiosa e o diálogo com os dissidentes.

Ademais, como demonstrou Weber, a relação entre Deus e sua criatura humana no calvinismo não é mais determinada pelo princípio do amor, e sim pelo da eterna e rigorosa justiça. Lançando mão do sínodo de Westminster de 1643 para ilustrar sua tese, o sociólogo alemão destaca como, no calvinismo (e em sua ramificação puritana), os decretos divinos são inalteráveis e inacessíveis à razão humana, pois a mera aplicação da razão para perscrutar os desígnios de Deus implicaria numa barreira à sua absoluta soberania. $^{92}$

Não por acaso, o "estímulo positivo" (grifos de Weber) da ascese calvinista e sua doutrina da predestinação evoluiu no sentido da formação de seitas puritanas (formadas por uma "aristocracia espiritual dos santos") determinadas a perseverar numa estrita observância à Lei (daí a "bibliocracia" do calvinismo) ${ }^{93}$, e cuja validade não deveria ser questionada nem mesmo em razão de seu caráter absolutamente impraticável. ${ }^{94}$ Destarte, toda dúvida referente aos decretos divinos, qualquer exame racional sobre os desígnios da Providência, passaram a ser encarados como um ato de presunçosa rebelião perante a autoridade de Deus.

E qual não foi a surpresa dos humanistas de Cambridge quando, voltando sua atenção para as aplicações políticas do método indutivo de Hobbes, os mesmos deramse conta de que, a despeito dos abismos que separavam a teocracia transcendental de Calvino (e de seus epígonos) da defesa sensualista do Estado absoluto pelo autor do Leviathan, estava-se, ao fim e ao cabo, diante (ainda que por outras vias e mediante outros pressupostos) do mesmo fatalismo ético-moral, a saber, o dever de obediência irrestrita aos decretos religiosos emitidos pelo Estado (que, em nome da paz civil, determina os limites da consciência dos súditos). ${ }^{95}$

Não por acaso, o principal representante daquela escola humanista de Cambridge e também o mais admirado por Maistre, Ralph Cudworth (1617-1688), objetou com

\footnotetext{
${ }^{92}$ Max Weber, A ética protestante..., p. 91-92.

${ }^{93}$ Max Weber, A ética protestante..., p. 111.

${ }_{94}^{94}$ Max Weber, A ética protestante..., p. 112.

95 T. Hobbes, Leviathan, Parte III, caps. 39 e 42.
} 
vigor a tendência de subordinar a razão prática (ética) a uma lei externa (seja esta a lei positiva do Estado ou a absolutamente inacessível e transcendental). Para Cudworth, a doutrina da predestinação, com os seus "decretos horrendos" (ou horrenda ista decreta $)^{96}$, representava uma ofensa à magnanimidade e/ou justiça de Deus e uma perversão de toda religião, na medida em que anulava a verdadeira substância da Providência divina. Cudworth advertia para o fato de que os puritanos, em última análise, estavam nivelando o terreno para o ateísmo (e o autor do The true intellectual System of the Universe remonta suas origens às teorias atomísticas de Demócrito e Epicuro $^{97}$ ) ao reduzirem os decretos da Providência divina a critérios absurdos para o entendimento racional humano.

Para Cudworth, a acepção atomística de Demócrito (e seus sucedâneos modernos, como Bacon e Hobbes), que deriva todas as manifestações do mundo espiritual da matéria e busca explicar os fenômenos espirituais por meio de leis mecânicas inflexíveis, não era menos enganosa e deletéria à inteligência humana do que o fatalismo religioso puritano - que priva as noções do Bem e do Mal de qualquer sentido ou valor por si próprios, deduzindo-os da absoluta e despótica vontade de Deus, razão pela qual alcunhou a doutrina da predestinação de "imoral Destino divino". ${ }^{98}$ Cudworth procura demonstrar que as ideias de Bem/Mal ou de certo/errado prefiguram entidades eternas, inteligíveis e imutáveis até para a onipotência divina que as criou (pois o contrário representaria uma transgressão e uma agressão à sua infinita e suprema benevolência e sabedoria).

A respeito do antigo dilema ético sobre quais ideias sobre o certo e o errado devem ser aceitas como válidas, Cudworth opta sem reservas pela lei natural (substancial e válida por si mesma) em oposição às leis positivas da cidade. ${ }^{99}$ Diante das objeções puritanas - e não foram poucas - de que se tratava de um absurdo estabelecer qualquer vínculo entre a vontade divina e as pretensas leis naturais (inatas e imutáveis), Cudworth e os demais neoplatônicos argumentavam que o reconhecimento daquelas leis estava longe de implicar em qualquer relação de dependência ou limitação por parte da

${ }^{96}$ Carta de Cudworth a Limborch (1688), citada em Cassirer, The Platonic Renaissance in England..., p. 79.

${ }_{97}$ Curiosamente e numa chave conceitual distinta, os supracitados autores foram o objeto da tese de doutoramento do jovem Karl Marx (Diferenças entre as filosofias da natureza de Demócrito e Epicuro, 1840).

${ }_{98}$ R. Cudworth, "Prefácio", in: The true intellectual System of the Universe (New York: Gould and Newman, 1837), p. 34.

${ }^{99}$ R. Cudworth, Treatise on Eternal and Immutable Morality (póstumo, 1731), Livro IV, cap. 6. 
Providência divina, uma vez que as mesmas refletiam sua verdadeira essência (racional e justa) e seus desígnios.

Como bem salientou Cassirer ao analisar esta controvérsia religiosa numa perspectiva mais ampla, os neoplatônicos de Cambridge ocuparam na sociedade inglesa do século XVII a mesma posição que Pelágio e Erasmo adotaram contra Santo Agostinho e Lutero respectivamente. Ademais, quando a filosofia da Ilustração - ainda na esteira do protestantismo - lança as suas bases através de figuras como Bayle e Locke (o primeiro, sustentando a absoluta autonomia e autossuficiência da razão moral por meio de seu racionalismo cético; o segundo, organizando e desbastando a exposição do método experimental de Bacon de suas contaminações jurídico-filosóficas), coube a filósofos como Leibniz e os neoplatônicos de Cambridge avançar uma defesa racional da moral e da religião cristã. ${ }^{100}$

Através da leitura das traduções e exegeses platônicas de Marsilio Ficino, mas também de Plotino e Iamblichus (245-325), os filósofos de Cambridge apreenderam e reelaboraram a filosofia "mais que humana" ${ }^{101}$ de Platão, com o propósito de responder racionalmente aos desafios epistemológicos impostos à religião cristã de seu tempo.

Nos quadros da reação católica francesa aos ataques da Ilustração e da Revolução de 1789 à religião cristã, bastou a Maistre seguir a orientação crítica do mais célebre teólogo e apologista cristão da França pré-revolucionária, Nicolas-Sylvestre Bergier (1715-1790), para que se estabelecesse um parentesco entre os esquemas intelectuais de Hobbes, Bacon e Locke. ${ }^{102}$

Nada mais natural, portanto, que Maistre, no enfrentamento com o pai do empirismo e, em razão disso, o 'herói' da Encyclopédie, fosse atraído pelos argumentos humanísticos inatistas daqueles filósofos ingleses, os quais reforçaram-lhe a convicção tipicamente ficiniana de que a filosofia de Platão era "o prefácio humano do Evangelho". ${ }^{103}$

Assim, seja pela abertura e constante recurso à filosofia clássica (que o levou a aprender a ler e escrever em grego, que descrevia como "uma língua desesperante"), seja pela centralidade atribuída ao "homem" no seu sistema de pensamento (defesa do livre-

${ }^{100}$ E. Cassirer, The Platonic Renaissance in England..., p. 82-84.

${ }^{101}$ Henry More, An explanation of the grand mystery of Godliness (London, 1660), p. VI.

${ }^{102}$ No segundo capítulo do Essai sur le principe générateur (1814), Maistre cita uma passagem do Traité historique et dogmatique de la Religion (1780) de Bergier, na qual o teólogo francês estabelece esta filiação de ideias entre o autor do Leviatã e o do Ensaio acerca do Entendimento Humano.

${ }^{103} \mathrm{~J}$. de Maistre, Soirées, O.C., IV: 271 (V Entretien). 
arbítrio, de sua dignidade na ordem da Criação, e a investigação de sua origem e fim), não encontramos nenhuma razão para não conceder à reação devota de Maistre à Revolução de 1789 e a seus pressupostos epistemológicos um pleno direito de cidadania na vasta e heterogênea tradição do pensamento humanista.

É a partir desta hipótese que, finalmente, abarcaremos a reação maistreana à filosofia de Bacon. 


\section{4. Examinando ou "boxeando" com Bacon}

Composto de mais de 537 páginas distribuídas em duas partes e 21 capítulos, o Examen de la philosophie de Bacon encontra-se no sexto volume das Oeuvres Complètes de Joseph de Maistre.

No duodécimo capítulo da primeira parte do Examen, em que trata "Do Objetivo Geral da Filosofia de Bacon", Maistre reproduz a própria definição de ciência do chanceler inglês ("magnificência da natureza para o uso do homem"), bem como os ambiciosos desígnios da mesma:

"Fazer um homem viver por três ou quatro séculos, trazer um octogenário de volta à idade de quarenta ou cinquenta anos; fazer com que um homem permaneça com idade de vinte anos durante sessenta; curar apoplexia, gotas, paralisia, numa palavra, todas as enfermidades consideradas incuráveis; inventar purgativos que tenham o gosto de peras ou bananas; tornar o homem capaz de carregar uma tábua de trinta e seis pés..; engordar um homem magro; emagrecer um obeso, ou alterar suas características; transformar um gigante num anão, e um anão num gigante, ou, o que resulta no mesmo, um tolo num intelectual; transformar a lama num caldo de galinha e um sapo numa cotovia; criar novas espécies de animais; transplantar as espécies de lobos naquelas das ovelhas; inventar novos instrumentos de morte e novos venenos (sempre QUOAD usus humanos); transportar seu corpo ou de outra pessoa pela simples força da imaginação; amadurecer nêsperas em vinte e quatro horas; obter um vinho perfeito da fermentação em tanques; fazer a tromba de um elefante em dez minutos; produzir uma excelente colheita de trigo no mês de março; alterar água para fontes ou suco de fruta por óleo ou gordura...; finalmente, inventar grandes prazeres para os sentidos, e minerais artificiais e cimentos."104

Referindo-se a esta prometeica visão científica de Bacon e de seus pares da Ilustração, Maistre adapta uma sentença de Sêneca para dizer que "não há nada tão crédulo quanto o descrente" moderno, o qual, a seu ver, era capaz de incorrer abertamente nos piores erros, desde que os mesmos servissem ao propósito de refutar máximas que o incomodavam. Nos casos de Bacon e de seus seguidores franceses (e Maistre destaca Buffon como o principal discípulo do filósofo inglês no campo da

\footnotetext{
${ }^{104}$ Joseph de Maistre, O.C., VI: 230.
} 
fisiologia), a atração que os mesmos demonstravam pela ideia de "geração espontânea" nada mais era senão um meio para evadir a contemplação da ordem divina no estudo do universo, atribuindo tudo ao caos ou ao acaso. ${ }^{105} \mathrm{Na}$ visão de Maistre, o modelo científico baconiano legado à Ilustração enfatizava que o homem, apesar de um membro ordinário da natureza, poderia superá-la através ciência, esquecendo-se de que ele, na condição de membro privilegiado na ordem da criação, era dotado de uma capacidade natural para aperfeiçoá-la, razão pela qual consistia num sofisma observar a natureza como uma instância à parte dos seres que a integram e a constituem numa relação de conjunto. $^{106}$

Neste sentido, a filosofia de Bacon propunha-se como um novo instrumento intelectual, ao mesmo tempo libertador e redentor do homem perante as limitações impostas pela natureza, e o qual pressupunha uma nova ênfase sobre a física em detrimento da filosofia clássica e escolástica, responsáveis por desviarem a atenção da "infeliz" humanidade dos meios necessários para sua emancipação:

"Não existe, a bem dizer, senão uma ciência: a física, que deve ser observada como a mãe augusta de todas as ciências; e todas as artes, e em geral todos os conhecimentos humanos separados desta raiz receberão, talvez, um certo polimento e uma forma que os renderão úteis aos usos dos homens, embora jamais logrem um verdadeiro crescimento." 107

Segundo Bacon, a teologia, pelo fato de não se encontrar enraizada na observação físico-sensorial, deveria ser classificada como "ciência abrupta", isto é, como uma ciência destacada de todas as demais pela ausência de base racional e a insistência no princípio da autoridade dos dogmas. ${ }^{108}$ Consequentemente, a metafísica perderia a precedência e o estatuto autônomo que sempre ostentara entre as demais ciências, tornando-se uma ciência secundária, posterior e determinada pela física ${ }^{109}$, o que para o saboiano equivaleria a suprimir a transcendência divina das investigações humanas:

\footnotetext{
${ }^{105}$ Joseph de Maistre, O.C., VI: 250.

${ }^{106}$ Joseph de Maistre, O.C., VI: 234-235.

107 Joseph de Maistre, O.C., VI: 254.

${ }^{108}$ Joseph de Maistre, O.C., VI: 256-257.

${ }^{109}$ Joseph de Maistre, O.C., VI:258.
} 
"Mas, como apenas os fins provam a inteligência no universo, e uma vez que é preciso conhecer os fatos da história natural, os teoremas da física, e até as formas e a essência das coisas antes de poder se elevar aos fins, segue-se daí que, até a consumação deste grande trabalho preliminar, é impossível divisar alguma intenção, nem, por conseguinte, alguma inteligência no universo, o que, com efeito, é a doutrina de Bacon."110

Maistre apela a um versículo da Carta de são Paulo aos Romanos ${ }^{111}$ para reforçar seu julgamento acerca do caráter ímpio da epistemologia de Bacon, para quem o reconhecimento de uma suprema inteligência no universo seria o atributo de um "ser depravado". ${ }^{112}$ Ora, prossegue Maistre, se o mesmo Bacon admitia que Deus é santo na multiplicidade de suas obras e na ordem reinante no interior delas, como admitir as existências da ordem e da unidade na multiplicidade sem o concurso de um desígnio inteligente? Não podendo proceder em relação à religião com a mesma ousadia demonstrada por seus discípulos franceses, a efusiva profissão de fé de Bacon era prontamente desmentida por sua filosofia, cuja théomisie constituía o principal elemento da Ilustração e da Revolução Francesa. ${ }^{113}$ De acordo com Maistre, a estratégia utilizada por Bacon para acomodar a possível ira de seus leitores cristãos - numa época caracterizada pela entusiasmo religioso e expansão do puritanismo na Inglaterra consistia em declarar Deus absolutamente inapreensível pela razão humana, de modo que a verdadeira fé deveria relegar-se somente à revelação presente nas Sagradas Escrituras: "Dai à fé o que é da fé", dizia Bacon, uma vez que seria um absurdo "pretender que os homens tenham encontrado pela razão a existência de um ser DO QUAL NÃO PODEM FORMAR ALGUMA IDEIA". ${ }^{114}$

A proibição imposta pelo método científico moderno à razão humana de investigar qualquer coisa exterior ao alcance da natureza, aliada à incapacidade humana a comparar Deus com qualquer objeto natural, conduzia necessariamente à negação de que o homem pudesse conceber uma ideia racional sobre Deus ou possuísse alguma ideia constitutiva de sua essência. Mas como o chanceler poderia conciliar sua categórica profissão de fé com um postulado filosófico que sustentava a impossibilidade

\footnotetext{
${ }^{110}$ Joseph de Maistre, O.C., VI: 258-259.

${ }^{111}$ Romanos 1:20.

112 Joseph de Maistre, O.C., VI: 260.

${ }^{113}$ Joseph de Maistre, O.C., VI: 262.

${ }^{114}$ Joseph de Maistre, O.C., VI: 263. Maiúsculas do próprio Maistre.
} 
de a razão humana conceber uma ideia perfeita, o principal atributo de Deus no monoteísmo?

Pior do que as potencialidades ímpias desse postulado de inspiração protestante e que, de acordo com Maistre, não teria poupado no mesmo período nem mesmo o jansenista Pascal ${ }^{115}$, eram as consequências intrínsecas ou lógicas do mesmo para o desenvolvimento científico que se almejava. Pois, como o homem poderia receber ou formular uma nova verdade sem que já possua os pré-requisitos cognitivos ou formas do conhecimento que, anteriores às sensações, organizam-nas e dotam-nas de sentido? Designando esses pré-requisitos como ideias inatas, Maistre declara, a exemplo dos neoplatônicos de Cambridge, que nada poderia dar uma ideia ao homem, de modo que a mesma só poderia ser despertada, pois se ele (homem) ou qualquer inteligência recebesse alguma ideia que não lhe fosse natural, teria necessariamente de abandonar sua espécie e deixar de ser o que é.

Assim, Maistre observou que se por um lado é certo que Deus não pode ser comparado a qualquer objeto material, por outro, nada impede que a inteligência humana se compare a uma inteligência perfeitamente apreensível através de seu poder e ordem envolventes: "Não sejamos enganados pela hipocrisia que não cessa de apelar à Bíblia e de nos convidar a dar à fé o que é da fé. Este respeito de comédia não tende de nenhum modo a elevar as Sagradas Escrituras, mas a degradar a razão, tornando-a, por assim dizer, estranha a Deus." 116

E a defesa das ideias inatas por Maistre reverbera de modo inequívoco a acepção humanista neoplatônica, seja na forma (num pathos semelhante ao de Ficino ${ }^{117}$, atribuindo a Moisés e a Hesíodo o mesmo peso de verificação ontológica quanto à existência da inteligência divina), seja no conteúdo, concedendo ao gênero humano uma condição elevada na ordem da criação, dada a sua semelhança com Deus ${ }^{118}$ :

${ }^{115}$ No Examen, Maistre recorda a crítica endereçada por Voltaire ao filósofo jansenista pelo fato do mesmo sustentar, nos Pensées, a capacidade de a razão humana compreender o pecado original, ao mesmo tempo em que negava a possibilidade de a mesma atingir o conhecimento sobre Deus. In: Joseph de Maistre, O.C., VI: 263. Não raramente, Maistre lançava mão do recurso retórico de citar Voltaire, cujas obras possuía e lera como poucos e a quem considerava o mais culpável dos philosophes, para reforçar uma ideia sua em defesa dos valores cristãos.

${ }^{116}$ Joseph de Maistre, O.C., VI: 268.

117 "O que mais é Platão, senão um Moisés falando grego?" Cf. M. Ficino, Opera omnia apud Dennis F. Lackner, "The Camaldolese Academy", In:Michael B. J. Allen, Valery Rees e Martin Davies (orgs.), Marsilio Ficino: His Theology, his Philosophy, his Legacy (Leiden: Brill, 2001) p. 30

${ }^{118}$ Sobre este conceito teológico central para o humanismo italiano extraído do livro do Gênesis, leia-se: Charles Edward Trinkaus Jr, In our image and likeness: humanity and divinity in Italian humanist thought (Chicago-London: University of Chicago Press, 1970), 2 vols. 
"Numa palavra, o objetivo da revelação não é outro senão o de levar o espírito humano a ler em si mesmo aquilo que a mão divina traçou nele, de modo que a revelação seria nula se a razão, após o ensinamento divino, não se tornasse capaz de demonstrar a si mesma as verdades reveladas, assim como o ensinamento matemático, ou qualquer outro ensinamento humano, só é reconhecível como verdadeiro e legítimo quando a razão, examinando os teoremas sobre a lei eterna escondida no fundo de sua essência, diz à revelação humana: TENDE RAZÃO, isto é, vós sois a razão."119

Conforme adverte Maistre na conclusão do capítulo XIII, a Bíblia por si mesma (como defendiam Bacon e os dissidentes protestantes) não revela em parte alguma a existência de Deus, mas a supõe como uma verdade conhecida anteriormente pelo intelecto humano, e a qual foi confirmada pelo testemunho dos homens sábios (daí o recurso à grande cadeia do ser presente em sua philosophia perennis) de todos os tempos. O objetivo da revelação, portanto, seria o de conduzir o espírito humano a ler em si mesmo os traços do divino em seu interior, de modo que o verdadeiro conhecimento do homem (cuja finalidade última é aprimorar cada vez mais sua liberdade) não estaria na matéria que lhe é exterior, mas na contemplação da grandeza e bondade das obras de Deus, na comunicação espiritual com a divindade, ao mesmo tempo em que aprofunda o seu autoconhecimento (dispondo assim sua vontade para um uso consciente e virtuoso da razão inabalada pelo pecado original).

Em outro momento, a crítica maistreana observa que para estabelecer a tese de que tudo deve ser atribuído à matéria, Bacon viu-se obrigado a efetuar uma paradoxal operação, que consistia em transferir às coisas e à matéria as operações características do sentimento e dos atos humanos. Aos olhos de Maistre, esta atribuição à matéria das características propriamente humanas não era outra coisa senão um artifício para suprimir da ciência qualquer explicação que não fosse o movimento inerente da matéria e das coisas.

"Querem nos dizer, por acaso, que nada se opera na natureza sem movimento? Não, sem dúvida: não se trata de uma verdade tão trivial que se nos revele num tom de hierofante; é o movimento essencial que se nos indica aqui com o único meio de atingir o conhecimento das causas, e nós veremos em breve que estas causas nos dispensam de procurar uma outra."120

\footnotetext{
${ }^{119}$ Joseph de Maistre, O.C., VI: 269.

${ }^{120}$ Joseph de Maistre, O.C., VI: 336.
} 
Como esperado, o que mais indignava Maistre no sistema de Bacon era a exclusão da transcendência divina de todo o processo intelectivo do universo pelo homem e a consequente substituição da mesma pelas causas imanentes puramente materiais. A principal característica daquilo que identificava como atomismo - numa linha genealógica que o saboiano estendia de Demócrito (460 a.C.-370a.C.) ao filósofo e poeta romano Lucrécio (99 a.C.-55a.C), Bacon e os enciclopedistas - consistia em considerar o átomo como responsável por tudo o que existe, motivo pelo qual ele não deveria conter em sua natureza nada próprio ao que fosse produzido, conforme o saboiano exemplifica sardonicamente a seguir:

"Assim, o átomo é aquilo que produz tudo e não é nada; de maneira que, se ele fosse qualquer coisa, não poderia produzir qualquer coisa. O átomo que é o princípio da madeira não possui nenhuma qualidade da madeira, etc; mas contanto que ele seja CEGO ou SURDO e que assim nada se destaque (Emineat ne quid), ele está apto a tudo, inclusive à produção de um animal, como acabamos de ver. Não existe nada de tão luminoso em todo o círculo da filosofia."121

Para Maistre, o absurdo do sistema atomístico consistia em procurar a origem do universo numa fonte que não contivesse nenhuma inteligência ou vontade, o que equivaleria a reconhecer que o mundo e seu destino não possuíam destinação e/ou significação. Bacon lamentara que a filosofia de Demócrito tivesse sido "entendida... puerilmente pela multidão"122, o que, para Maistre, significava que "o vulgo entendia esta doutrina puerilmente, isto é, que ele não sabia extrair da mesma as conclusões convenientes sobre o átomo todo-poderoso e a eternidade da matéria". ${ }^{123}$ Não por acaso, Maistre reproduziu no Examen um trecho no qual Bacon tratava de exaltar Demócrito em detrimento de Platão e Aristóteles, o que motivou a seguinte defesa de Platão pelo saboiano (de modo que as palavras em itálico são do chanceler inglês):

"E o que diremos desses filósofos antigos, vangloriados por terem submetido a inteligência às coisas, e opostos a Platão, que havia submetido o mundo às ideias. O que Bacon pretende dizer? Platão reconduz tudo à inteligência, sobretudo o movimento; e ele afirma, ademais, que o mundo se formou segundo uma ideia arquetípica, ou plano preexistente na

${ }^{121}$ Joseph de Maistre, O.C., VI: $351 \mathrm{n}$.

122 Joseph de Maistre, O.C., VI: 357.

123 Idem. 
inteligência organizadora; pensamento não apenas verdadeiro, mas necessariamente verdadeiro. Trata-se, pois, do contrário defendido por aqueles filósofos que Bacon honra com sua aprovação; e devemos crer, sob pena de sermos declarados desertores da experiência, que as coisas são anteriores à inteligência, que ela não tem nenhuma participação no princípio do movimento, e que, portanto, a ordem a precedeu ou não depende dela. Todas as ideias contrárias a esta teoria não merecem a pena de serem refutadas em detalhe; basta rejeitá-las em massa, pois elas não poderiam pertencer senão a homens que pretendem falar muito, $e$ saber pouco." ${ }^{\prime 124}$

Desse modo, a questão do materialismo remete ao questionamento da relação existente entre o movimento da matéria e a inteligência, ou seja, de saber se é possível pensar o mundo unicamente como espaço ou se, pelo contrário, não se deveria colocar o espaço sob o jugo de outro fator que o dotasse de um sentido, como o tempo. Ademais, como abarcar o conceito de tempo: como o lugar das tentativas empreendidas pela matéria a partir de seus próprios arranjos imanentes, ou como um quadro no interior do qual se realizam progressivamente as realidades determinadas anteriormente num plano de conjunto concebido por uma inteligência dotada de um desígnio próprio? $\mathrm{Na}$ primeira hipótese, o tempo é absolutamente secundário e apenas o espaço (matéria ou extensão) permite a compreensão científica do mundo; na segunda, o espaço está subordinado, uma vez que remonta a uma explicação transcendente. A julgar pelas palavras do contrarrevolucionário saboiano, a despeito das profissões de fé e das tentativas de Bacon em conciliar seu sistema com acepções criacionistas/cristãs, este teria optado indelevelmente pela primeira hipótese, ao balizar inequivocamente sua epistemologia na assunção de que somente a matéria, e não o mundo, é eterna, razão pela qual deveria ser visto por seus leitores como um incrédulo. Como, aliás, permitia concluir seu comentador M. de Luc que, a propósito da hipótese baconiana para a criação, falava "de um começo de arranjo" e não "de um começo da existência". ${ }^{125}$

Como pano de fundo de todo este questionamento sobre a criação e a origem, impunha-se a questão primordial sobre a existência de Deus e sua natureza. "Pode haver mais de um ser necessário", escreve Maistre, "se... o mais belo atributo da Divindade não pertence exclusivamente a Deus, como a ordem, a forma, o arranjo da matéria eterna seriam menos independentes dele, e donde viria seu poder sobre ela? Pode-se

\footnotetext{
${ }^{124}$ Joseph de Maistre, O.C., VI: 361-362.

125 Joseph de Maistre, O.C., VI: 378.
} 
imaginar facilmente um ser independente quanto à existência, e dependente quanto ao todo o resto?"126

Percebe-se que para Maistre a questão da criação e a da natureza de Deus estavam interligadas. Para ele, as consequências eram cruciais para a defesa da fé: se Deus não é responsável pela totalidade do real, então Deus não é independente. De resto, o saboiano admitia que a palavra criação podia ser admitida de acordo com dois sentidos diferentes: ou bem isto implica a causa, o ato de criação, ou então o efeito, a existência em curso de um desdobramento. Se Bacon, de acordo com o autor do Examen, julgava o gênero humano inapto para conceber a criação na primeira acepção, resultaria disso que "a geração, a vegetação, a gravidade, a expansibilidade, as afinidades, a elasticidade, etc.," coisas cujas realidades são indubitáveis ${ }^{127}$, seriam totalmente ininteligíveis, uma vez que não conheceríamos nenhuma causa. A premissa baconiana de que nenhum esforço do intelecto humano poderia conceber o ato de criação era correta, mas, advertia Maistre, a conclusão obtida a partir disso pelo chanceler era falsa: a impossibilidade de conceber um efeito qualquer jamais anula a realidade da causa. A natureza da coisa não está em questão aqui, adverte Maistre; esta incapacidade deve-se apenas à natureza humana impotente para conceber o conceito de causa. Razão pela qual a criação deveria ser pensada em termos de tempo, e não de espaço: não se pode compreender o ser humano reduzindo-o apenas à categoria de movimento, assim como, por seu turno, o mundo se torna cognoscível ao elevarmos as coisas à categoria do tempo.

A partir disso, o capítulo XVII do Examen propõe a questão fundamental: o que significa o NADA? Qual sentido pode-se dar a esta palavra? Ao esboçar as respostas a esta questão, Maistre propõe a via humanista neoplatônico-clássica de apreensão do mundo:

"O célebre axioma EX NIHILO NIHIL FIT, que todos os materialistas... repetem segundo seu mestre, encerra também um abuso de expressão. Lucrécio, usando a mesma forma de linguagem, teria dito: ex aere fit tympanum. Dir-se-ia que o nada é uma matéria, uma coisa qualquer da qual nos dizem que não se pode fazer nada. Não se faz nada de nada; sem dúvida que com o nada não se faz nada; mas alterai o enunciado, e dizeis: Nada pôde começar; é absolutamente a mesma coisa, e, contudo, a impressão será diferente... Tudo aquilo que vimos é um efeito, como dizíamos acima, e há poucas ideias que entram mais naturalmente em nosso espírito do que aquela de efeito ou de começo. Não se poderia, sem lastimar igualmente a lógica

\footnotetext{
${ }^{126}$ Joseph de Maistre, O.C., VI: 384.

${ }^{127}$ Joseph de Maistre, O.C., VI: 385.
} 
e a consciência, argumentar a respeito da obscuridade da causa contra a certeza, nem mesmo contra a inteligência do efeito." ${ }^{, 128}$

"Toda a minha metafísica", confessou Maistre numa missiva ao almirante russo Tchichagof, "conduz a este princípio inabalável de que tudo foi feito para e pela inteligência", e acrescenta:

"A própria matéria, a bem dizer, não existe independentemente da inteligência. Tentai, Sr. Almirante, conceber a ideia do mundo material sem a inteligência, e jamais conseguireis. Acrescento ainda que a vida isolada é de uma grandeza infinita se comparada à matéria bruta que nada é, e que um inseto é mil vezes mais admirável que o anel de Saturno. Não pretendo, porém, fazer com que o mundo gire ao redor de um inseto, embora sustente que, se no universo existissem apenas ele e a matéria bruta, não haveria a menor razão de recusar-lhe esta honra." ${ }^{129}$

De acordo com Maistre, o homem moderno, tal como moldado pela filosofia do século XVIII, deixou de apreender o mundo na sua amplitude, permanecendo sempre na superfície fenomênica e acreditando ter encontrado o sentido profundo das coisas, quando mais não fez do que identificar e ordenar uma série de eventos. Bacon teria sido o responsável por abrir a via a este raciocínio que reduz todo o real à matéria, razão pela qual os escritos do saboiano buscam restabelecer a visão do mundo como um conjunto de fenômenos ligados a uma vontade e uma intenção exteriores. $\mathrm{O}$ autor do Examen pretende que o pensamento, no momento de apreensão do mundo, remonte a Deus, restabelecendo desse modo a finalidade e a dimensão criada do universo.

Pois o grande legado de Bacon à ciência moderna consistiu em suprimir as pesquisas das causas finais no sistema da natureza, por considerá-las um obstáculo à descoberta das causas físicas dos fenômenos. ${ }^{130}$ Diante disso, Maistre observa que o termo "causas finais" não era o mais apropriado para o que ele pretendia dizer, preferindo ao invés disso o termo "causas intencionais" e destacando que o intelecto não deveria pensar o universo como um todo no qual todos os detalhes estariam ordenados a um fim preciso, mas em termos de criação, isto é, de uma vontade inicial que oferece seu sentido e sua estrutura ao conjunto dos fenômenos a que a ciência é chamada a descrever e explicar. Para o autor das Considerações sobre a França, é preciso

\footnotetext{
${ }^{128}$ Joseph de Maistre, O.C., VI:387. Maiúsculas e grifos de Maistre.

129 Joseph de Maistre, O.C., XI: 450.

${ }^{130}$ Joseph de Maistre, O.C., VI: 402.
} 
considerar o mundo em sua inteireza como o fruto de uma inteligência original, cuja prova é fornecida precisamente pelos admiráveis encadeamentos que a ciência experimental põe em evidência.

Ademais, Maistre demonstrou que a objeção de Bacon contra as causas finais estava repleta de contradições. Como justificar que a pesquisa sobre as causas de um fenômeno impediria a compreensão e a descrição do mesmo? A este respeito, o saboiano, como de hábito, concilia a lógica com a fina ironia: "Antes valeria precisamente sustentar que as pesquisas anatômicas atrapalham infinitamente a medicina." ${ }^{131} \mathrm{O}$ grande argumento avançado pelo autor de Novum organum consiste em devolver os partidários das causas finais ou intencionais à experiência. Pesquisar as causas finais, segundo Bacon, seria passar da física à metafísica. Em resposta, Maistre observou que a realidade não pode ser reduzida apenas à sua dimensão material:

"É preciso ter muito cuidado ao passar por esta palavra REAL, pois é um dos arcanos da Filosofia de Bacon [a proposição de] que somente a física é real, e esta ideia fez fortuna entre seus sucessores, como veremos mais adiante. Insensatos, que não veem ou não querem ver que não há o realmente real a não ser aquilo que parece real, que todas as ciências, sem distinção, têm sua realidade na inteligência que as possui, que é o mesmo princípio que julga o todo e que a própria matéria não é real, senão espiritualmente!"132

Conclui-se, pois, que na opinião de Maistre o argumento principal do método de Bacon era falacioso: ou bem aquele que pensa o mundo em termos de causas finais não é físico de profissão, sendo a fé e a piedade responsáveis por isto, ou bem este homem é um físico e, não importa qual a situação, o resultado não será prejudicial às ciências, pois: I. as causas finais e as causas físicas encontram-se juntas; II. com frequência elas são idênticas; III. o estudo e a veneração das causas aperfeiçoam o físico e preparam-no para as descobertas. ${ }^{133} \mathrm{O}$ autor do Examen pensa que a procura das causas finais de um fenômeno não é contrária ao método científico, desde que se tenha estabelecido a lei de seu funcionamento:

"Aquele que descobrisse pela primeira vez o grande mecanismo que faz girar o ponteiro de um relógio, não aprenderia simultaneamente que esse mecanismo o conduz ao movimento, e

\footnotetext{
${ }^{131}$ Joseph de Maistre, O.C., VI: 404.

132 Joseph de Maistre, O.C., VI: 404, nota 2. Maiúsculas e grifos de Maistre.

133 Joseph de Maistre, O.C., VI: 405.
} 
que ele foi disposto no cilindro PARA produzir este efeito? Pode-se descobrir que os planetas são retidos e movidos em suas órbitas por duas forças que se equilibram (quaisquer que sejam essas forças) sem descobrir, ao mesmo tempo, que elas foram estabelecidas no princípio PARA este grande resultado?"134

A este respeito, Maistre não se privava de citar Robert Boyle (1627-1691) e Carolus Linnaeus ou Lineu (1707-1778), que enxergava Deus em todos os fenômenos da natureza que ele dispunha em sistema. A questão fundamental na visão de Maistre seguia sempre a mesma: a ciência seria capaz de explicar um fenômeno ou, dito de outra forma, de oferecer-lhe a causa no instante em que estabelece um fato? É a partir disso que o saboiano denuncia o paralogismo muito comum no pensamento moderno, que consiste em "confundir um fato com uma causa, como se a descoberta ou a generalização de um fato tivesse qualquer coisa de comum com a descoberta de uma causa, como se, por exemplo, tivessem encontrado a causa da eletricidade se pudessem estabelecer a identidade desse fenômeno com o do galvanismo". ${ }^{135}$

A segunda objeção diz respeito ao antropomorfismo: a verdadeira filosofia deveria conduzir tudo ao homem. Maistre constata que a filosofia busca pelas causas finais pelo fato dela direcionar todas as coisas ao homem, o que para o contrarrevolucionário saboiano estava de pleno acordo com as Sagradas Escrituras e a tradição cristã, que viam o homem como o centro da criação. Isto porque a razão humana tende a demonstrar que tudo foi criado para o gênero humano e em função do mesmo. "O homem sendo a maior e o fim da criação terrestre e, em função disso, possuindo um lugar sublime na criação universal, ele não faz mais senão usar de seu direito ao contemplar sobretudo os seres em sua relação com ele". ${ }^{136}$ De acordo com Maistre, por detrás da reprovação filosófica ao estudo das causas finais, oculta-se o defeito característico da filosofia do século XVIII: o homem, pelo lugar que ocupa na hierarquia do universo, busca compreender, e é esta pretensão a compreender as coisas e o mundo que se denuncia sob a crítica das causas finais. Na investigação das causas finais, não estaria o homem investigando a si próprio?

\footnotetext{
${ }^{134}$ Joseph de Maistre, O.C., VI: 405-406. Maiúsculas e grifos de Maistre.

${ }^{135}$ Joseph de Maistre, O.C., VI: 411, nota. Grifos de Maistre.

${ }^{136}$ Joseph de Maistre, O.C., VI: 419.
} 
"[...] ainda que o homem não faça, como acabo de dizer, nada mais a não ser exercer seus direitos ao remeter tudo a si, entretanto, não se poderia dizer, sem um exagero visivelmente caluniador, que ele só pensa em si na contemplação das causas finais; pois é notório que a cada instante todos os homens, e sobretudo os naturalistas, examinam os fins nas relações infinitas dos seres entre si e o universo, por meio de uma total abstração do homem." 137

De acordo com o neoplatônico saboiano, outro erro comum compartilhado por Bacon e seus sucessores philosophes consistia em afirmar que se Deus fosse realmente Deus, ele não poderia ser o autor da criação tal como ela é, o que mereceu a seguinte resposta de sua parte:

"[...] os filósofos inimigos dos fins entregam-se ao erro imperdoável de introduzir o acaso e os inconvenientes às obras divinas. Uma vez que o homem é frequentemente enganado em seus desígnios, forçado pelas circunstâncias e arrastado para além de seus fins primitivos por acidentes imprevistos, ele transporta tolamente esta fraqueza a Deus. A filosofia acusa com frequência o mais comum dos homens de fazer Deus semelhante a eles; antes, porém, é ela quem comete esse erro ao raciocinar sobre os fins dessa maneira. Ela nos dirá, por exemplo: Provai detalhadamente que fazeis uso de inúmeros animais, que sabeis fazê-los obedecer e que exerceis em geral um grande império sobre toda espécie animal: este fato não carece de demonstração; mas ele prova apenas que possuis este império; provai agora que vos foi dado. Esta objeção, na boca de um filósofo que se declara teísta, é o cúmulo da sandice, pois supõe que um dos grandes fatos do universo, a dominação do homem sobre os animais, teve lugar, ao pé da letra, sem o conhecimento de Deus. Com efeito, se ele soube, o quis; e se ele o quis, tratase de um fim." 138

Dito de outra maneira, a demonstração maistreana consiste em afirmar que o fato de remeter as coisas ao homem não significa em absoluto subordiná-las exclusivamente ao mesmo. Para deixar isto claro, Maistre recorre a uma variação da célebre questão a respeito do ovo e da galinha para sustentar sua visão epistemológica humanista devota:

"A respeito das causas finais em sua relação particular com o homem, a questão diz respeito mais ao amor do que à inteligência. O ovo da galinha é feito para nos fazer omeletes? Existem inúmeras boas razões para respondermos afirmativamente; mas quanto à questão da

\footnotetext{
${ }^{137}$ Joseph de Maistre, O.C., VI: 422.

${ }^{138}$ Joseph de Maistre, O.C., VI: 423-424. Grifos de Maistre.
} 
intenção e do fim abstrato, que importa? A fábrica do ovo, como todas as demais coisas do mundo, supõe ou não um trabalhador inteligente? É disso que se trata." ${ }^{139}$

Portanto, toda esta reflexão deve ser relacionada com a interrogação que norteia a filosofia maistreana, a saber, a questão do homem. No momento em que se reflete a respeito do mundo e da ciência, é preciso sempre retornar à questão do gênero humano: a ele cabe a iniciativa inteligente de pensar o real, assim como a vontade deliberada de atribuir o sentido das coisas a uma intenção que não seria a sua; ao homem, enfim, cabe a iniciativa de considerar que as menores manifestações fenomênicas do mundo são portadoras de uma significação que não depende a não ser de sua origem, vale dizer, de Deus. Conclui-se, pois, que o mundo não foi feito pelo (ou se dirigia para o) nada, mas sim por uma inteligência onipotente que ordenou o menor dos fenômenos a uma intenção, de modo que o valor humano consiste justamente em investigar a mesma.

"Devemos, todavia, evitar de sermos excessivamente modestos sobre este ponto e esquecer de nossa dignidade. Se se considera a importância do homem na sua qualidade de ser inteligente, quando, ademais, se considera o império que o mesmo exerce sobre este globo, as provas de uma vontade soberana se manifestam de todas as partes, mesmo à razão mais simples, que não deve encontrar nada de tão grandioso para o homem, de modo que a revelação vem em seguida para nos dizer: Todas estas coisas vos foram dadas, [e então] ela encontra as vias preparadas e não faz mais senão confirmar o julgamento da razão." 140

Ao fim e ao cabo, o saboiano observa que a compreensão das causas finais são antes uma questão de sentimento moral do que de inteligência, e tanto é assim que Bacon e seus seguidores não hesitaram em ridicularizar a escolha filosófica das causas finais, razão pela qual afirmou: "Não se discute que a sobrancelha exista para a proteção dos olhos; que importa? Trata-se de saber se o olho é feito para ver, se há uma relação de intenção entre este órgão e a luz, etc." ${ }^{141}$ No fim de sua argumentação, Maistre conclui:

"Que importa a questão pura e simples dos FINS? A inteligência não se prova à inteligência a não ser pela palavra e pela ordem, também ela uma palavra, pois a palavra nada

\footnotetext{
139 Joseph de Maistre, O.C., VI: 422-423. Grifos de Maistre.

${ }^{140}$ Joseph de Maistre, O.C., VI: 425-426. Grifos de Maistre.

${ }^{141}$ Joseph de Maistre, O.C., VI: 436. Grifos de Maistre.
} 
mais é senão o pensamento manifestado, de modo que não poderia haver ordem sem um pensamento ordenador. Toda simetria é um fim em si mesmo e independentemente do fim ulterior. Um camponês que observa um compasso certamente não sabe o que vê; entretanto, a existência do artista é-lhe tão perfeitamente provada quanto ao astrônomo que emprega este instrumento. Do menor ao maior, o argumento é o mesmo. Não se pergunta se o cão, o cavalo, o boi foram criados para o homem; mas se a organização dos animais anuncia uma intenção. Não se pergunta tampouco por que o mundo foi criado, mas se o mundo, tal como ele é, assemelhase a um amontoado de partículas agitadas e reunidas por si mesmas no espaço, para formar, sem inteligência, tudo o que nós vemos, e mesmo os seres inteligentes." ${ }^{142}$

No que há de fundamental, Joseph de Maistre conclui assim seu exame crítico da filosofia de Francis Bacon. Seu projeto é bastante claro, na medida em que se deu mediante um longo processo de apreensão, estudo e análise do sistema epistemológico ilustrado.

Todavia, no afã de se opor ao método científico do chanceler, Maistre incorreu (voluntariamente ou não) em esquecimentos e contrassensos típicos de toda obra polemista. O maior deles, talvez (e certamente decorrente de uma intenção do saboiano), consista em fazer crer ao leitor do Examen que Bacon excluiu a investigação das causas finais no seu método de conhecimento quando, na verdade, ele sabia perfeitamente que o chanceler as havia excluído da física a fim de restituí-las à metafísica (e, assim procedendo, sem diminuir em nada o papel da Providência).

Seja como for, o retrato de Bacon traçado pelo saboiano foi em grande medida influenciado pela fortuna crítica que o chanceler inglês recebera da Ilustração e dos publicistas franceses nos anos que compreenderam o Diretório, o Império e, por fim, a Restauração. E se a queda de Napoleão e a restauração dos Bourbons ao trono francês deram a impressão de que a Revolução estava politicamente encerrada, Maistre, por sua vez, não se deixou enganar por isso, pois estava plenamente ciente da profunda transformação operada nos espíritos ao longo daqueles trinta anos, e a qual prometia ainda uma longa carreira através dos projetos educacionais de teor ilustrado propostos pelos reformadores liberais no interior das monarquias, como foi o caso da Rússia.

Numa perspectiva verdadeiramente humanista, o grande temor de Maistre não era tanto o avanço da ciência em si - que ele julgava um atributo da natureza humana e um produto de sua inexorável inclinação ao aperfeiçoamento -, mas a adoção de uma

\footnotetext{
${ }^{142}$ Joseph de Maistre, O.C., VI: 447-448. Maiúsculas e grifos de Maistre.
} 
filosofia que, ao suprimir a investigação das "causas finais", levasse os homens a optarem por noções inferiores do bem e da virtude, com o agravante de que os instrumentos ou meios auferidos por sua razão eram progressivamente acrescidos.

Daí a constatação de que, ao invés de liberar ou dotar o homem de maior autonomia e promover seu progresso ou felicidade, aquele projeto científico produzia dialeticamente o seu contrário: ao bloquear a comunicação do homem com o divino, aquela epistemologia truncava o mecanismo psíquico do autoconhecimento humano e enfraquecia o domínio de sua alma superior sobre a alma inferior, produzindo a alienação espiritual que estava por detrás da grande crise europeia que - iniciada pela Reforma e levada a cabo pela Revolução de 1789 -, antes de gerar mais civilização e progresso, era responsável pela destruição dos costumes (manners) e um regresso civilizatório na Europa. Como ele próprio afirmara, "quanto mais a teologia for cultivada, honrada, dominante, e mais... a ciência humana será perfeita, vale dizer, maiores serão sua força e extensão, e mais desembaraçada estará de toda aliança perigosa ou funesta." 143

É precisamente para esta curiosa teoria humanista-devota da história da Europa (ou melhor, de suas manners) que dirigiremos nossa atenção agora.

${ }^{143}$ Joseph de Maistre, O.C., VI: 461. 


\section{CAPÍTULO 5 \\ "Cartas sobre a Educação Pública" e "Quatro Capítulos sobre a Rússia": uma teoria humanista devota sobre o progresso e o desenvolvimento das manners russas}

Após os imperadores Alexandre I e Napoleão firmarem o Tratado de Tilsit (1807), formou-se no interior da nobreza russa um discreto movimento de oposição ao czar e às suas reformas educacionais de cunho Ilustrado, o qual se dividiu em duas facções. A primeira delas abrigava a aristocracia urbana, menos rica e mais "progressista", enquanto que o segundo, conhecido como os "taristas", compreendia a maioria dos grandes proprietários de terra e de servos, dentre os quais alguns amigos de Maistre. De acordo com Carolina Armenteros, o programa dos taristas almejava reduzir o poder da autocracia czarista, melhorar a condição dos servos a ponto de prepará-los para a liberdade futura e, finalmente, promover os valores tradicionais da sociedade e das comunidades russas contra o viés excessivamente pró-ocidental do governo e da aristocracia urbana. Com o propósito de reviver tais valores, formou-se, em 1810, a partir do grupo literário Shishkov-Derzhavin, o "Simpósio dos Admiradores do Mundo Russo", cujo propósito era o de difundir a literatura e a língua russa no interior de uma aristocracia francófona, fortalecendo assim a cultura nacional sem o recurso a valores estrangeiros. ${ }^{1}$ Bastante difundido em São Petersburgo, este tradicionalismo efusivo teve no conde Alexander Stourdza (1791-1854) um de seus principais expoentes, o qual sustentava que a estabilidade do Estado dependia da preservação da moralidade, da criação ou fortalecimento das instituições extragovernamentais e do cultivo das tradições históricas nacionais.

Sobretudo em razão da oposição aos valores ocidentais associados à Ilustração francesa, é bastante provável que Maistre tenha se sentido atraído ideologicamente pelos taristas, chegando inclusive a frequentar alguns de seus encontros. Apesar do caráter oposicionista à monarquia, Maistre via com bons olhos a limitação do absolutismo do czar em nome do respeito às leis naturais e/ou divinas, de modo que as instituições tradicionais poderiam assumir seu papel como "formadoras de homens".

\footnotetext{
${ }^{1}$ Carolina Armenteros, The French Idea of History: Joseph de Maistre and his heirs (Ithaca and London: Cornell University Press, 2011), p. 127-128.
} 
Entre aqueles conservadores russos, destacava-se um diagnóstico comum que tratava de identificar a servidão como o grande problema da sociedade russa, por ser inconsistente com os direitos humanos e com as leis da natureza, impedindo, portanto, a plena integração da Rússia na história europeia moderna. Ao mesmo tempo, porém, prevalecia entre os taristas a noção de que a emancipação dos servos não deveria ser abrupta, mas antecedida por reformas graduais e extensivas, e nas quais a religião ortodoxa desempenharia o papel principal, preparando moralmente os servos através de uma educação tradicionalista e piedosa. Foi na esteira dessa reação conservadora dos taristas às reformas do conselheiro pessoal do czar para assuntos domésticos entre 18081812, Mikhail Speransky, que Maistre redigiu, em 1809, o Essai sur le principe générateur des constitutions politiques (Ensaio sobre o princípio gerador das constituições políticas), uma das mais suscintas obras de Maistre e dividida em 68 capítulos. $^{2}$

Publicado somente em 1814 como apêndice para uma nova edição francesa das Considerações pela iniciativa de Louis de Bonald (1754-1840) - com quem o saboiano passou a se corresponder assiduamente a partir de 1812 e até o fim de sua vida -, o Essai apelava aos ensinamentos clássicos de Platão e de Tácito (ao lado de Cícero, suas principais referências clássicas) para demonstrar que o polimento dos costumes e das paixões (sempre um processo lento, gradual e, no mais das vezes, levado a cabo por um "gênio" político que jamais legisla a priori e que quase sempre obtém resultados distintos do que designara, mas cujo princípio ativo e eficiente encontra-se, paradoxalmente, no fato de se colocar como um "instrumento da Providência") era mais eficiente para o ordenamento, estabilidade e progresso de uma sociedade do que as leis.

Assim, apoiado em Platão, que no diálogo Fedro manifestara a opinião de que as grandes instituições jamais dependiam das leis escritas ${ }^{3}$, em Tácito, para quem corruptissima republicae plurimae Leges ("muitas são as leis quando a república é corrupta") ${ }^{4}$, e, finalmente, em Cícero, cujo De Legibus (II, 6) demonstrava que as prerrogativas e liberdades do senado romano não se deviam a nenhuma lei escrita ${ }^{5}$, o embaixador sardo buscava convencer seus interlocutores russos de que jamais se governa uma grande nação somente por meio das leis positivas escritas ou a priori,

\footnotetext{
${ }^{2}$ Concluído em maio de 1809.

${ }^{3}$ Joseph de Maistre, Essai sur le principe générateur des constitutions politiques, capítulo XIX. In: Pierre Manent (ed.)., Considérations sur la France, suivi de l'Essai sur le principe générateur... (Paris: Complexe, 2006), p. 229-230.

${ }^{4}$ Joseph de Maistre, Essai sur le principe générateur...,capítulo IX, p. 219.

${ }^{5}$ Joseph de Maistre, Essai sur le principe générateur..., capítulo IV, p. 214-215.
} 
senão através da religião cristã (o principal agente formador ou polidor de costumes) e seu vegetativo, paciente, mas efetivo trabalho formador/pedagógico na linha do tempo. Para ilustrar esta ação eficiente da religião em relação aos costumes, e a precedência dos mesmos em relação à razão, Maistre apelou a um verso das Odes do poeta latino Horácio, onde se lia que a grandeza "crescit occulto velut arbor aevo" ("cresce imperceptível através do tempo, como acontece com a árvore"). ${ }^{6}$

Naquele contexto russo, o Essai representava um esforço original de adaptação do modelo aristocrático liberal de Montesquieu aos desígnios católico-clericais do contrarrevolucionário saboiano, uma vez que no seu esboço histórico da Europa (o qual será plenamente desenvolvido em $D u$ Pape, como veremos mais adiante), o clero católico era visto como o principal mediador ou contrapeso entre o Estado e a sociedade, assim como um garantidor de reformas graduais e pacíficas.

No entanto, enquanto os principais epígonos do tarismo defendiam a exclusividade da religião ortodoxa e sua estreita colaboração e/ou perfeita submissão em relação ao Estado (que teria todo o controle sobre a educação, inclusive a cristã), a sociologia da religião de Maistre advogava uma colaboração entre as igrejas grega e latina, assim como a autonomia de ambas em relação ao Estado, sob pena de o cristianismo perder-se em palavras vazias.

O fato é que o sucesso obtido pelas poucas cópias do Ensaio entre as frações conservadoras e antirreformistas da aristocracia russa fizeram com que Maistre fosse solicitado pelo novo ministro da instrução pública, Alexis K. Razumovsky (1748-1822), a expor seu ponto de vista sobre um projeto de reforma educacional, sobretudo para o liceu onde estudavam os irmãos do czar. Maistre então respondeu através de uma série de cartas datadas entre junho e julho de 1810, nas quais criticava a ênfase dada às ciências naturais e a negligência para com os ensinamentos morais. ${ }^{7}$

Intituladas "Cinco Cartas sobre a Educação Pública na Rússia", a primeira delas inicia-se com o seguinte raciocínio, que norteará toda a crítica maistreana à epistemologia moderna:

"A ciência torna o homem preguiçoso, inábil aos negócios e às grandes empresas, crítico, teimoso em relação às suas próprias opiniões e depreciativo em relação às alheias, observador crítico do governo, inovador por essência, depreciador da autoridade e dos dogmas nacionais,

\footnotetext{
${ }^{6}$ Joseph de Maistre, Essai sur le principe générateur, capítulo XXIII, p. 233.

${ }^{7}$ Reunidas e publicadas na edição Vitte das Obras Completas de Joseph de Maistre (O.C.) sob o título de Cinq lettres sur l'éducation publique en Russie (O.C., VIII:161-232).
} 
etc... Com efeito, a moral é necessária para interromper a ação excessivamente perigosa da ciência, se a deixarem caminhar sozinha./ É neste ponto que se incorreu num erro cruel no último século. Acreditou-se que a educação científica fosse toda a educação, ao passo que não era senão uma parte dela, sem comparação, a menos interessante, e que não vale a menos que repouse sobre a educação moral. Orientaram todos os espíritos para a ciência e fizeram da moral uma espécie de aperitivo, um enchimento de pura conveniência. Este sistema, adotado na destruição dos Jesuítas, produziu em menos de trinta anos a espantosa geração que derrubou os altares e degolou o rei da França." 8

Maistre observa na primeira das cinco epístolas que a ciência sempre fora um apanágio de um grupo muito restrito de homens sábios, o mais das vezes sacerdotes, e que as nações em que a ciência mais logrou se desenvolver entre a população foram aquelas em que o sacerdócio desempenhou funções de destaque na esfera civil, um quadro que certamente não se aplicava à Rússia ortodoxa em tela.

Enquanto o czar Alexander I (1777-1825) concedia bolsas-moradias de 300 rublos para evitar que colégios e escolas da capital fechassem as portas por falta de público, na capital francesa, em que o sacerdócio cristão desempenhou as atividades civis ao longo de mais de mil anos, a Universidade de Paris registrava mais de quatro mil estudantes que, vindos de todas as partes da França e da Europa, custeavam a si próprios. $^{9} \mathrm{Na}$ mesma linha, a observação da história demonstraria que as principais academias científicas da Europa, como a Royal Society de Londres, a Academia parisiense e a Academia del Cimento de Florença, formaram-se espontaneamente pela iniciativa dos próprios cientistas, e só depois foram oficialmente reconhecidas e auxiliadas pelo Estado. Daí a conclusão de que em todas as nações as academias estabeleceram-se "à causa dos sábios que se possuía, jamais na esperança de possuílos", de modo que seria uma "grande idiotice empregar somas enormes para construir uma gaiola à fênix antes de saber se ela virá". ${ }^{10}$

No entanto, a questão que mais intrigava o autor das Considérations era o fato de os homens de Estado russos, preocupados por constatarem, especialmente durante as guerras napoleônicas, o atraso científico de sua nação, promoverem em seu território a adoção de um processo pedagógico responsável pelo enfraquecimento dos tronos e da

\footnotetext{
${ }^{8}$ Joseph de Maistre, O.C., VIII: 165.

${ }^{9}$ Joseph de Maistre, O.C., VIII: 166.

${ }^{10}$ Joseph de Maistre, O.C., VIII: 167.
} 
religião ao sul e a oeste do rio Dwina, e ainda por cima com uma impetuosidade e entusiasmo característicos do russo.

Longe de o embaixador sardo na corte do czar considerar os russos permanentemente inaptos à ciência - o que contradiria sua concepção humanista de homem fundada no conceito de entelecheia ou perfectibilidade -, o problema para ele girava em torno do tempo e da história, em pelo menos dois sentidos. Primeiro, a constatação de que as nações europeias abraçaram a ciência após um longo processo vegetativo iniciado no fim da escolástica medieval e concluído pelo Renascimento (uma vez que o marco temporal era o século XVII das Academias científicas e de Bacon, Maistre identificava o início deste processo no século XII), o qual, devido a circunstâncias históricas específicas, fora interrompido na Rússia. Em segundo lugar, dado o caráter da população russa - composta em sua maioria por servos sem a menor instrução e, no que dizia respeito à nobreza, extremamente influenciada pelas ideias "venenosas" da Ilustração francesa -, a abrupta e abrangente difusão da ciência moderna redundaria no enfraquecimento do Estado (pois, dentre outras coisas, ver-se-ia obrigado a importar professores estrangeiros de qualidade moral duvidosa, os demi-savants sem prestígio e/ou expulsos de suas respectivas nações, a um alto custo ao erário) e no provável solapamento de suas já frágeis fundações. ${ }^{11}$

No que tange ao primeiro aspecto, as principais razões oferecidas pelo saboiano para o atraso científico russo diziam respeito ao Cisma do cristianismo do século XI (1054) e à invasão dos Tártaros do século XIII, responsáveis por isolar a Rússia do processo civilizatório comum europeu. ${ }^{12}$ No fundo, apesar da natureza distinta dos referidos fenômenos, ambos concorreram decisivamente na determinação de um mesmo processo, qual seja, a formação de uma Igreja ortodoxa fraca, com pouca penetração civil ou social e inteiramente dependente ou servil ao Estado (Maistre sublinha a todo instante o fato de que no restante da Europa o sacerdócio desempenhava as funções civis e políticas dos Estados, assim como sua palavra lograva ultrapassar os púlpitos e atingir os mais humildes dos fiéis). ${ }^{13}$ Embora não o dissesse expressamente por razões de decoro, as Lettres sugeriam que a consequência lógica disso era o despotismo (uma monarquia destemperada e ignorante das leis naturais ou divinas) e a barbárie da maior parte da população, composta quase que inteiramente de camponeses. Daí a realista

\footnotetext{
${ }^{11}$ Joseph de Maistre, O.C., VIII: 168-171.

12 Joseph de Maistre, O.C., VIII: 168-169.

${ }^{13}$ Joseph de Maistre, O.C., VIII: 173.
} 
constatação do humanismo devoto maistreano - a qual de forma alguma pode ser vista como uma pretensa justificativa para o fenômeno da servidão -, de que isto era um produto natural daquele processo que combinava a barbárie, de um lado, e os recrimináveis abusos de uma elite destituída de freios morais, de outro.

Ademais, com um misto de realismo e ironia, Maistre lembrava seu interlocutor russo de que naquele momento a Rússia era o país em que a ciência se fazia menos necessária (afinal, a guerra contra Napoleão era iminente), e para reforçar seu argumento lembrava o Ministro da Instrução Pública russa de que o poder dos romanos não derivou do aprendizado da cultura grega, mas do seu próprio gênio militar e dominador, assim como, de maneira análoga e mais recentemente, as fragatas napoleônicas repletas de cientistas fracassaram diante da experiência náutica britânica. ${ }^{14}$

Na segunda Lettre, Maistre alonga-se na comparação entre o sistema pedagógico que ele considerava o ideal, a saber, o humanista-clássico, e o currículo moderno Ilustrado proposto pelo reformador francófono Speransky. Lançando mão de expoentes científicos modernos como Copérnico, Kepler, Galileu, Descartes, Pascal Newton, Leibniz, etc., Maistre pretendia demonstrar que a educação clássica, menos pretensiosa e ao mesmo tempo mais rigorosa e realista na escolha e aplicação dos conteúdos (orientados para favorecer o "bem pensar", o "bem falar" e o "bem escrever"15), providenciava todos os instrumentos cognitivos necessários para que o jovem, ao fim dos estudos, lograsse 'saber por si mesmo' ou, nas palavras do saboiano, "aprendesse a aprender"16 $^{\prime 16}$ quando chegasse o momento de optar por uma especialização na Universidade $^{17}$, algo que não ocorria com o pretensioso currículo moderno, que ao longo de dez anos descarregava uma pletora de conteúdos os mais disparatados sobre os alunos (do grego clássico à história geral, história da Rússia, história sagrada, arqueologia, numismática, geometria, álgebra, matemáticas puras, aplicadas, cálculo

\footnotetext{
${ }^{14}$ Joseph de Maistre, O.C., VIII: 172.

${ }^{15}$ Joseph de Maistre, O.C., VIII: 178.

${ }^{16}$ Joseph de Maistre, O.C., VIII: 181.
}

${ }^{17}$ Resumidamente, o curso escolar humanista referido por Maistre tinha duração de sete anos e distribuía-se da seguinte forma: $1^{\circ}$ La cinquième: introdução à língua latina por meio do estudo e tradução, linha por linha, de um clássico, normalmente as Églogas de Virgílio. Paralelamente, explicação em sala de aula do catecismo que se aprendia de cor na diocese local; $2^{\circ}$ La quatrième: mesmo procedimento da anterior com a introdução de autores mais complexos; $3^{\circ}$ La troisième: ou suprema grammatica, tratava de garantir o domínio gramatical da língua latina, privilegiando a elegância; $4^{\circ}$ Les humanités: estudo aprofundado de autores mais complexos no qual os alunos deveriam memorizar algumas passagens de certos autores (religiosos ou morais) e desdobrá-las com suas próprias ideias; $5^{\circ} \mathrm{La}$ rhétorique: continuação da anterior, somente a partir da qual introduzia-se a língua nacional. Ao cabo deste quinto ano, considerava-se o aluno apto a iniciar sua educação na lógica, metafísica e matemática, respectivamente o $6^{\circ}$ (Lógica) e $7^{\circ}$ (Física) períodos. Detalhe: o ensino de "física" clássica compreendia antes aulas teóricas de matemática e cálculo do que exposições teóricas obtidas da física experimental. 
infinitesimal,química, física, geografia física, estética, ética, educação moral, ginástica, dança e natação, dentre outros), os quais não conseguiam atingir um conhecimento satisfatório em nenhuma daquelas disciplinas que julgava fundamentais (com o agravante de que se desinteressavam pelos estudos) ou - o que aos olhos de Maistre era o mais grave -, no pouco que aprendiam, eram inculcados nas teorias epistemológicas sensualistas de Bacon, Locke e Condillac. ${ }^{18}$

Outro obstáculo ao desenvolvimento científico da Rússia, e o qual fora ignorado pelos reformadores pedagógicos russos, dizia respeito ao carreirismo militar no quadro das guerras napoleônicas, cuja melhor descrição encontra-se no Guerra e Paz (1863), de Liev Tolstói. Maistre considerava inviável conciliar a necessária demanda por soldados no exército russo com aquele extenso e pretensioso programa curricular, razão pela qual recomendava um programa mais sucinto, assim como a imposição de uma idade mínima aos cadetes pelo Estado russo, de modo a evitar que os pais alistassem seus filhos antes que a formação básica dos mesmos estivesse completa. ${ }^{19}$

Nas cartas seguintes (III, IV e V), Maistre retomará grande parte de seu requisitório contra o protestantismo expresso nas Réflexions sur le Protestantisme (o qual, apesar de completado em 1798, não foi publicado em vida), pretendendo com isso alertar as autoridades russas para o duplo perigo representado pelo emprego de professores alemães (na medida em que a maioria seguia o protestantismo que, por seu turno, mantinha inúmeras "afinidades eletivas" com o jacobinismo e a epistemologia de Bacon/Locke) bem como, ao cabo da exposição, defender não só autonomia dos colégios jesuíticos, como a ampliação e proteção dos mesmos.

Quanto à primeira advertência, poderíamos dizer que Maistre alerta para o risco eminente de o emprego excessivo de professores alemães (protestantes e iluministas de todas as denominações e eivados de kantismo) contribuir para a formação na Rússia de uma intelligentsia revolucionária nos moldes da francesa, responsável pela destruição daquilo que ele designa como "sistema europeu" (isto é, o cristianismo, com o respectivo imbricamento do sacerdócio nas esferas civil e política, chave para o desenvolvimento civilizatório e, por extensão, científico da Europa cristã ${ }^{20}$ ) a partir da Revolução de 1789.

\footnotetext{
${ }^{18}$ Joseph de Maistre, O.C., VIII: 184.

${ }^{19}$ Joseph de Maistre, O.C., VIII: 187-188.

${ }^{20}$ Joseph de Maistre, O.C., VIII: 203.
} 
A exemplo das Réflexions sur le protestantisme, as Lettres sur l'Éducation Publique reproduzem a opinião de diversos filósofos ou políticos protestantes célebres para sugerir, à guisa de Condorcet - que no Esboço de um quadro histórico dos progressos do espírito humano (1793) julgava o protestantismo como o "prefácio da revolução política" ${ }^{21}$ - ou do pastor protestante e ex-presidente da Assembleia Nacional Constituinte, Rabaut de Saint-Étienne - para quem a expulsão dos jesuítas foi um prérequisito indispensável à Revolução Francesa ${ }^{22}$-, que o emprego dos jesuítas e de sua educação humanista-clássica pelo Estado russo era a solução mais "preservativa" e menos onerosa para a instrução dos jovens e o desenvolvimento do progresso científico, sem que isto trouxesse algum risco à sociedade e ao Estado. A respeito deste último ponto, Maistre fazia questão de defender os jesuítas das acusações dos taristas e dos protestantes ou iluminados (sob a influência do pietismo alemão) de que constituíam uma espécie de "Estado dentro do Estado"23: "Os Jesuítas estão engajados por seus votos a ensinar gratuitamente a juventude na religião e nas ciências, assim como civilizar as nações selvagens, sob o beneplácito dos dois poderes, o temporal e o espiritual."24

Todavia, os jesuítas não seriam úteis somente para a instrução das nações "bárbaras" - Maistre mal disfarçava o fato de que o empenho pedagógico e catequético dos jesuítas na Rússia guardava estritas semelhanças com o evidenciado na América -, mas, sobretudo, para os soberanos, pois conciliavam a coragem e a elevação de espírito necessários para criticar as medidas injustas do príncipe quando julgassem necessário para a proteção do próprio, isto é, sempre que o mesmo, por sede de poder ou má orientação, decidisse invadir os limites da esfera eclesiástica (como ocorreu na França através do galicanismo e do jansenismo ${ }^{25}$ ), reduzindo assim o alcance do cristianismo no interior da sociedade de modo a torná-la uma presa fácil para o philosophisme, inimigo natural das soberanias, ou melhor, das monarquias.

$\mathrm{Na}$ contramão dos jesuítas, os inúmeros professores protestantes ou iluministas alemães sustentavam as doutrinas de Kant (cuja doutrina, para indignação ainda maior do saboiano, fora adotada como o método oficial para o ensino da metafísica), para

\footnotetext{
${ }^{21}$ Joseph de Maistre, O.C., VIII: 213.

${ }^{22}$ Joseph de Maistre, O.C., VIII: 205.

${ }^{23}$ Joseph de Maistre, O.C., VIII: 225.

${ }^{24}$ Joseph de Maistre, O.C., VIII: 207.

${ }^{25}$ Joseph de Maistre, O.C., VIII: 207-211.
} 
quem não havia meio racional de se provar a existência de Deus no universo ${ }^{26}$ e "o melhor governo, o único sólido é a república". ${ }^{27}$

Mas como o objetivo principal das epístolas era o de defender a autonomia do colégio jesuítico de Polotsk (ameaçada pela reforma pedagógica centralizadora), assim como sua elevação ao status de universidade e a criação de outras academias dirigidas pela ordem, e do lado dos reformadores alinhados a Speransky levantavam-se objeções a respeito dos conteúdos anacrônicos da pedagogia adotada pelos padres (excessiva ênfase nas letras e pouco ou nada de ciências naturais), Maistre recorre a ninguém menos que à autoridade de Francis Bacon para suprimir todas as dúvidas epistemológicas remanescentes a respeito da validade do currículo humanista da Companhia de Jesus:

"O século que acaba de chegar a seu termo proclamou Bacon o restaurador das ciências, embora ele próprio concedesse expressamente este título à ordem dos jesuítas. É ele quem diz: $A$ educação da juventude, esta nobre parte da disciplina antiga, foi reanimada em nossos dias e como que chamada do exílio pelos Jesuítas... E acrescenta: Para chegar a um bom sistema educacional, o caminho mais curto, basta dizer: 'Consultai as escolas dos Jesuítas, jamais se inventou nada melhor. ${ }^{128}$

E para dissipar todos e quaisquer receios epistemológicos a propósito do emprego dos jesuítas para uma pedagogia moderna, Maistre recorria à estratégia retórica que consistia em obter testemunhos favoráveis aos mesmos de figuras protestantes ou filosóficas célebres, como o de Hugo Grotius (1583-1645), segundo quem "os Jesuítas exerciam um grande poder sobre a opinião em razão da santidade de suas vidas e do perfeito desinteresse com o qual instruíam a juventude nas ciências e na religião" ${ }^{29}$; de Frederico II (1712-1772), em cujas cartas a Voltaire, o soberano da Prússia exultava de alegria pela supressão da ordem na França, ao mesmo tempo em que fazia questão de preservar "aquele precioso grão" no seu Estado ${ }^{30}$; e, finalmente, do astrônomo ateu Jérôme Lalande (1732-1807), para quem Carvalho (Marquês de Pombal) e o duque de

\footnotetext{
${ }^{26}$ Joseph de Maistre, O.C., VIII: 219.

${ }^{27}$ Joseph de Maistre, O.C., VIII: 219; citação extraída do Ensaio filosófico sobre um projeto de Paz Perpétua (1795).

${ }^{28}$ Joseph de Maistre, O.C., VIII: 199. Grifos de Maistre.

${ }^{29}$ Joseph de Maistre, O.C., VIII: 200.

${ }^{30}$ Joseph de Maistre, O.C., VIII: 201.
} 
Choiseul (1719-1785) haviam destruído "a mais bela obra dos homens; a sociedade que apresentava a mais espantosa reunião que jamais se viu das ciências e da virtude". ${ }^{31}$

Em outubro de 1811, o novo mandatário da ordem jesuítica na Rússia, o padre Tadeusz Brzozowski, solicitou ao conde Razumovsky e ao príncipe Alexander Golitsyn (superprocurador do Santo Sínodo) autorização para que a escola de Polotsk adquirisse o status de universidade autônoma, tornando-se assim o centro administrativo das instituições de ensino da Companhia de Jesus. E com a intenção de reforçar a petição dos jesuítas junto ao czar, Maistre endereçou em 19 de outubro uma Mémoire sur la liberté de l'enseignement public (Memória sobre a liberdade do ensino público) a Golitsyn, na qual defendia a utilidade político-pedagógica dos padres - ferrenhos opositores daqueles que pretendiam derrubar os tronos e a cristandade - e criticava o monopólio estatal do ensino público, o que faria do ministro da educação e das universidades sob seu controle um Estado dentro do Estado (como se percebe, Maistre revertia a acusação dos reformadores aos jesuítas). Os monopólios eram sempre perigosos ao Estado e, no caso da Rússia, o czar deveria conceder autonomia aos jesuítas, visando seus próprios interesses.

Golitsyn (1773-1844) ficou tão admirado pela memória que interveio em favor dos padres junto a Alexandre I (o qual aquiesceu à solicitação em janeiro de 1812) e estimulou o embaixador saboiano a escrever mais sobre a Rússia, no que foi correspondido pela redação dos Quatre chapitres sur la Russie (Quatro capítulos sobre a Rússia) ${ }^{32}$, de 28 de dezembro de 1811.

A exemplo do que fizera nas Cinq Lettres, o embaixador da Casa da Sabóia procurará demonstrar neste ensaio que o cristianismo não apenas era compatível com o progresso das ciências, das artes, e, fundamentalmente, da liberdade humana tout court, como a história europeia demonstrava que as mesmas germinaram lentamente sob a cuidadosa e zelosa iniciativa e orientação do sacerdócio católico.

\footnotetext{
${ }^{31}$ Joseph de Maistre, O.C., VIII: 202-203.

${ }^{32}$ A qual, numa demonstração de profunda formação humanista do saboiano, trazia a seguinte epígrafe de Orlando Furioso (I,3), célebre obra de Ludovico Ariosto:

"Quel ch' io vi debbo, posso di parole pagare in parte, e d' opera d' inchiostro; né che poco io vi dia da imputar sono; che quanto io posso dar, tutto vi dono."

"Parte do que devo, em obra verbosa a tinta gravada pagar-vos posso; de pouco vos dar culpável não sou; pois, quanto dar-vos posso, tudo dou." Tradução portuguesa de Margarida Periquito in: Margarida Periquito (ed. e tradutora), Ludovico Ariosto:" Orlando Furioso" (Lisboa: Cavalo de Ferro, 2007).
} 
Dividido em quatro capítulos que se estendem ao longo de pouco mais de oitenta páginas do oitavo volume das Obras Completas, os Quatro Capítulos repercutem, nos quadros da reforma educacional de cunho Ilustrado-científico, os quatro temas mais discutidos entre os governantes russos em seus respectivos salões, reuniões maçônicas ou sociedades bíblicas, a saber, a "liberdade", a "ciência", a "religião" e o "iluminismo", respectivamente.

Intitulado "Da Liberdade", o primeiro capítulo propõe as seguintes questões, nesta ordem: por que a escravidão, antes do cristianismo, sempre foi considerada como uma peça necessária do governo e do estado político das nações, seja nas repúblicas, seja nas monarquias? E por que a servidão ainda predominava na Rússia?

Maistre indica que a resposta estava no fato de o homem, apesar de preservar a razão intacta após o pecado original, ter sofrido um enfraquecimento de sua vontade, a ponto de só poder realizar sua "natureza social" ou política num determinado Estado e sob o jugo de um soberano, o qual, na ausência do cristianismo (fator responsável pela lenta, mas efetiva, transformação do coração ou das paixões humanas para o exercício prudente e responsável da liberdade civil), não poderia prescindir da escravidão para governar tantas paixões desenfreadas e impor as leis. ${ }^{33}$

Sem tocar nas espinhosas questões a respeito da escravidão moderna, mas frisando o papel "libertador" desempenhado pelo cristianismo na Europa medievalcristã, todo esforço de Maistre busca demonstrar que a servidão na Rússia devia-se à fraqueza do cristianismo naquele país, de modo que as causas históricas oferecidas pelo saboiano não diferiam essencialmente das que foram expostas nas cartas anteriores (isto é, o Cisma religioso do século XI e a invasão dos Tártaros no século XIII). ${ }^{34}$

Diante do diagnóstico proposto pelos reformadores e adotado pelo Estado, qual seja, o de acelerar a ocidentalização da sociedade russa através de um sistema de ensino balizado nas premissas epistemológicas ilustradas, Maistre teceu duas ressalvas. Em primeiro lugar, e com base na história que demonstrava ser o cristianismo o principal agente educador do coração ou das paixões humanas, como a parcamente cristianizada sociedade russa poderia prescindir da servidão abruptamente na ausência absoluta das manners (Maistre não utiliza o termo, substituindo-o pelos termos "costumes" ou

${ }^{33}$ Joseph de Maistre, O.C., VIII: 279-283.

34 "O cristianismo não é uma mera palavra, mas uma coisa concreta; se ele não tem sua força, sua influência penetrante, sua antiga simplicidade e seus poderosos ministros, não será mais ele; ele não é mais o que fora quando tornou a libertação geral possível. Mas que o governo não se engane: seu clero não tem a palavra no Estado, não ousa falar ou, quando o faz, é o mínimo possível." Joseph de Maistre, O.C., VIII: 287. 
"moral") por parte de seus súditos, o que tornaria toda e qualquer lei presente ou futura irrelevante? ${ }^{35}$

Em segundo lugar, admitido o princípio teológico de que a razão é impotente para guiar ou controlar a vontade e que os costumes e a moralidade são mais importantes para um governo do que as leis positivas no interior de um Estado, como a Rússia (insuficientemente cristã $\tilde{a}^{36}$ ) poderia adotar justamente a filosofia da Ilustração, quando a mesma fora responsável pela destruição das manners (isto é, de seu principal agente, a religião) no país que a adotou mais radicalmente (a França) $?^{37}$

A partir desta constatação, o embaixador sardo fez duas advertências. A primeira delas procurava mostrar que a liberação imediata dos servos numa nação como a Rússia ("a mais móvel, a mais impetuosa, a mais empreendedora do universo", a ponto de o "confinamento de um desejo russo numa cidadela, a saltaria pelos ares" ${ }^{38}$ ) equivaleria a arrancá-los imediatamente da superstição para transformá-los em ateus "bárbaros", passando-os da "obediência passiva à atividade desenfreada" ${ }^{39}$, uma vez que não havia no interior do Estado russo nenhuma instituição intermediária (entre o Estado e a sociedade civil) apta (funcional e ideologicamente) a assumir a função de educá-los para a vida civil. Em seguida, o contrarrevolucionário saboiano apontava para o risco iminente de que a libertação dos servos, por um lado, e a adoção de princípios enciclopédicos nos liceus e universidades, por outro, destruíssem a nobreza russa (principal alvo das reformas pedagógicas) material e espiritualmente. Uma vez que a monarquia é inseparável da aristocracia e a queda desta última arrasta consigo a primeira, era do interesse do czar velar pela preservação da nobreza, cuidando ao mesmo tempo para que os abusos dos senhores contra os servos cessassem. ${ }^{40}$

Portanto, antes de libertar os servos, ou melhor, a fim de tornar sua libertação efetiva (ao contrário do que uma leitura precipitada possa sugerir, Maistre era favorável à abolição da servidão), cumpria fortalecer e melhorar a nobreza, por meio de uma educação voltada para as manners, e não para a "razão", ainda mais segundo os critérios estabelecidos pela Ilustração (de acordo com o saboiano, fundada em premissas sensualistas/materialistas pretensamente racionais e imorais).

\footnotetext{
${ }^{35}$ Joseph de Maistre, O.C., VIII: 286.

${ }^{36}$ Joseph de Maistre, O.C., VIII: 284-285.

${ }^{37}$ Joseph de Maistre, O.C., VIII: 283.

${ }^{38}$ Joseph de Maistre, O.C., VIII: 288.

${ }^{39}$ Joseph de Maistre, O.C., VIII: 291.

${ }^{40}$ Joseph de Maistre, O.C., VIII: 293-294.
} 
Neste sentido, o segundo "capítulo"(intitulado "Da Ciência") das Cartas sobre a Educação pretende chamar a atenção do czar Alexandre sobre os inconvenientes da ciência para o Estado, em especial para a nobreza. Referindo-se a autoridades tão distintas como Tácito ${ }^{41}$ e, novamente, Bacon ${ }^{42}$, para garantir a plausibilidade de sua tese polêmica, Maistre observa que o currículo científico proposto pelos reformadores russos trazia em si um potencial de corrupção material e espiritual da nobreza, por duas razões.

A primeira, de ordem espiritual, relacionava-se com o fato de a ciência moderna desviar a nobreza da "vida ativa", sua "verdadeira vocação". ${ }^{43}$ E nos quadros da Rússia sob a égide napoleônica, vita activa significava acima de tudo formação e prática nas artes militares - e, em menor grau, judiciárias -, e não o envolvimento nas artes mercantis ou atribuições burocráticas menores vinculadas ao poder executivo.

Embora não dissesse com todas as letras, a argumentação maistreana apontava para o fato de que além de tornar o homem "soberanamente orgulhoso, embevecido por si mesmo e por suas próprias ideias, inimigo de toda subordinação, crítico de toda lei e de toda instituição e partidário nato de toda inovação" ${ }^{44}$, a exigência de um amplo conhecimento científico como critério para a admissão nas carreiras administrativa e militar implicaria na substituição da "honra" como "paixão" social dominante de uma monarquia (conforme estabelecido por Montesquieu em $O$ espírito das Leis), por critérios burgueses ${ }^{45} /$ revolucionários fundamentados na "igualdade" (uma vez que as carreiras estariam abertas ao talento e ao mérito).

Talvez em razão de sua experiência de emigrado na corte piemontesa, Maistre, cuja nobilitação familiar fora obtida havia pouco tempo por seu pai após um secular esforço de seus antepassados, estava melhor do que ninguém ciente das vantagens que aquele critério reformista conferia às ambições da burguesia em detrimento da nobreza hereditário-territorial, razão pela qual o considerava perigoso ao Estado.

Em grande medida, podemos dizer que, a exemplo do que ocorreu no De la souveraineté du peuple e nas Reflexões sobre o Protestantismo, também no Essai e nas cartas russas a influência de Burke fez-se presente, de modo que o contrarrevolucionário

\footnotetext{
41 "Pode-se ousar dizer sobre as ciências aquilo que um dos maiores escritores da antiguidade proferiu sobre os metais preciosos: que "não sabemos se o céu no-los concederam em sua bondade ou em sua cólera". Cf. Joseph de Maistre, O.C., VIII: 297 apud Tacito, Moeurs des Germains, cap. 5.

${ }^{42}$ Trata-se da frase de Bacon na qual o chanceler inglês sugere que a "religião é o aroma que impede que a ciência se corrompa". Cf. Joseph de Maistre, O.C., VIII: 298.

${ }^{43}$ Joseph de Maistre, O.C., VIII: 297.

${ }^{44}$ Joseph de Maistre, O.C., VIII: 297.

${ }^{45}$ Maistre não utiliza o termo, mas alude à riqueza não-territorial ou mercantil em seu texto. Joseph de Maistre, O.C., VIII: 303-304.
} 
saboiano reelabora, de uma maneira única e polêmica, uma das hipóteses originais avançadas pelo autor das Reflexões sobre a Revolução em França (1790), a qual sustentava, na contramão do que postulava Adam Smith (1723-1790) - por quem Burke nutria uma admiração recíproca e cujo falecimento, em julho de 1790, levou-o a fazer uma releitura das teses 'humanistas comerciais' consagradas pelo Iluminismo escocês, as quais, associadas às críticas aos valores religiosos e aristocráticos da sociedade inglesa pelos dissidentes (ainda impulsionados pela fase 'feliz' ou pacífica da Revolução no além-Mancha), poderiam convergir perigosamente numa modalidade local de ação política revolucionária -, que a Europa devia sua civilização (com suas maneiras e costumes refinados) menos ao comércio do que à união do cristianismo com a aristocracia, da qual o próprio comércio seria um tributário.

Como observou J. G. A. Pocock num brilhante ensaio sobre a "Economia Política" na análise de Burke da Revolução Francesa, o autor das Reflexões era um defensor do governo aristocrático Whig, identificado com o desenvolvimento da sociedade mercantilista. A Revolução Francesa, no entanto, apresentou-se a Burke como um desafio àquela ordem Whig, o qual emergia "de dentro das condições que a ordem tornava possíveis", razão pela qual empregou a linguagem e as categorias da economia política a fim de analisar a ameaça revolucionária e responder a ela. ${ }^{46}$

A este respeito, Pocock destacou como os principais expoentes britânicos e europeus da ideologia das 'maneiras' (manners) eram os filósofos da moral e os historiadores e economistas políticos escoceses, com os quais Burke compartilhava a visão de que o progresso histórico da sociedade vinculava-se com o desenvolvimento das cidades e do comércio, o qual trazia no seu bojo a diversificação do trabalho humano e o refinamento/enriquecimento de suas maneiras. ${ }^{47}$

Só que diante da Revolução Francesa - e da usurpação promovida pela mesma sobre as terras do clero (garantia e condição para a criação de um empréstimo nacional viabilizado pela emissão de um papel-moeda, os assignats) -, e após o sermão do dissidente Richard Price na Revolution Society (em 4 de novembro de 1789), criticando a política de endividamento e corrupção do primeiro-ministro Pitt (um dos aspectos mais delicados do regime Whig a seus defensores), Burke viu-se impelido a empregar, em todo o seu diagnóstico da Revolução de 1789, uma linguagem originalmente criada

${ }^{46}$ J. G. A. Pocock, "A Economia Política na Análise de Burke da Revolução Francesa", in J. G. A. Pocock, Linguagens do Ideário Político (1995). Trad. de Fábio Fernandez (São Paulo: Edusp, 2003), p. 247.

${ }^{47}$ J. G. A. Pocock, "A Economia Política na Análise de Burke...", p. 248-249. 
pelos autores Ilustrados escoceses para atacar os fundamentos da ordem Whig que ele estava preocupado em defender.

Logo após completar a denúncia da Revolution Society e do sermão de Price, Burke acusa o fato de que na França os espíritos de fidalguia e da religião - dos quais, a seu ver, dependem diretamente a civilização e as boas maneiras - terem sido sacrificados aos ídolos do crédito público e da bancarrota nacional pela ação combinada dos agentes do monied interest (do "grande interesse monetário"48) e dos homens de letras: ${ }^{49}$

"Nada é mais certo do que o fato de que nossas maneiras, nossa civilização e todas as boas coisas que estão vinculadas às maneiras e à civilização têm dependido, há eras neste nosso mundo europeu, de dois princípios, e foram, na verdade, resultado da combinação de ambos: refiro-me ao espírito de fidalguia e ao espírito da religião. A nobreza e o clero, um por vocação e o outro por patronagem, mantiveram o saber vivo, mesmo em meio a armas e atribulações, ao mesmo tempo em que os governos eram mais propriamente originados do que forjados por eles. O saber retribuiu à nobreza e ao clero o que havia recebido: e pagou com juros, ampliando suas ideias e nutrindo suas mentes. Felizes todos se houvessem permanecido cônscios de sua indissolúvel união e de seu lugar apropriado! Felizes todos se o saber, não corrompido pela ambição, tivesse se satisfeito em continuar sendo o instrutor e não houvesse aspirado a ser o senhor! Junto com seus naturais protetores e guardiães, o saber será afundado na lama e pisoteado pelas patas peçonhentas de uma suína multidão." ${ }^{\text {50 }}$

Burke afirmará ainda que o comércio depende das maneiras, não o contrário. Uma sociedade civilizada é o pré-requisito para as relações de troca, e estas, por si só, não podem produzir uma sociedade civilizada. Muito antes do saboiano e certamente inspirando-o, Burke dirá, portanto, na contramão dos historiadores ou economistas políticos da escola escocesa (lembrando que Maistre, que chegou a redigir dois memorandos sobre economia, não só lera os fisiocratas franceses como, sobretudo, admirava Adam Smith ${ }^{51}$ ) - os quais, de Hume a Robertson, Smith, Millar e Gibbon

${ }^{48}$ E. Burke, Reflexões sobre a Revolução em França (1790). Trad. de Renato de Assumpção Faria, Denis Fontes de S. Pinto e Carmen Lidia R. R. Moura (Brasília: UNB, 1982), p. 125.

${ }^{49}$ Idem, p. 126.

${ }^{50}$ E. Burke, Reflexões sobre a Revolução em França, p. 102.

51 Além dos clássicos da fisiocracia, como Turgot, Quesnay, Dupont de Nemours, Mirabeau pai, Maistre lera uma tradução francesa de 1790 de As Riquezas das Nações (1776), de Adam Smith, além de o Essay on the History of Civil Society de Adam Fergunson (1767) - o qual não era propriamente um livro de "economia". Mas o autor que exerceu maior influência sobre sua formação econômica foi indubitavelmente Necker, cujos De la législation et du commerce des blés (1775) e De l'administration 
tinham destacado a divisão do trabalho e o incremento das trocas como as forças motrizes para o desenvolvimento das maneiras, da cultura e do esclarecimento - que os mesmos tomavam o efeito (divisão do trabalho e comércio) pela causa (maneiras). Insistindo em que o comércio só logra florescer sob a sombra das maneiras - as quais requerem a preeminência da religião e da nobreza, os protetores naturais da sociedade -, o liberal-conservador irlandês sustenta que a derrocada da religião e da nobreza implicaria na destruição da própria possibilidade do comércio:

"Se, como desconfio, as letras modernas sempre devem mais às antigas maneiras do que estão dispostas a dever, o mesmo vale para outros interesses que valorizamos tanto quanto merecem ser valorizados. Mesmo o comércio, a troca e a manufatura, os deuses de nossos políticos economicistas, talvez sejam apenas criaturas, apenas efeitos que decidimos venerar como causas originais. Eles certamente cresceram à mesma sombra em que a cultura floresceu. Eles também podem decair com a queda de seus princípios protetores naturais. Juntamente com vocês, no presente ao menos, eles ameaçam desaparecer por completo. Quando o comércio e as manufaturas inexistem para um povo, mas permanece o espírito de nobreza e religiosidade, o sentimento elevado supre seu lugar, e nem sempre mal. Mas, se o comércio e as artes devem ser perdidos em um experimento para averiguar o quão bem um Estado pode aguentar-se sem estes velhos princípios fundamentais, que tipo de coisa será essa nação de brutos, estúpidos, ferozes e, ao mesmo tempo, pobres e sórdidos bárbaros, destituídos de religião, honra ou orgulho varonil, não possuindo nada no presente e não esperando por nada de agora em diante?" ${ }^{52}$

Neste sentido, mais do que configurar uma reação conservadora e reacionária ao mundo liberal-burguês descortinado pelas revoluções industrial e francesa, a análise maistreana deveria também servir de testemunho sobre a aguda capacidade crítica daquele gentilhomme saboiano em apreender a queda do Antigo Regime a partir de uma sofisticada e moderna releitura de Burke que, de certo modo, culminaria numa análise "sociológica" da aristocracia ou 'sociedade de corte', a ponto de a mesma convergir em

des finances de la France (1784), possuíra, lera e comentara. Isto posto, os referidos escritos maistreanos sobre economia são, respectivamente: Mémoire sur le commerce des grains entre Carouge et Genève, em 1790 (Memória sobre o comércio dos grãos entre Carouge e Genebra, 1790) e Intorno allo stato del Piemonte rispetto alla carta moneta, agiuntevi alcune riflesione generali sovra quel punto di economia politica (A respeito do papel-moeda relativo ao estado do Piemonte, acrescido de algumas reflexóes gerais sobre este ponto da economia política, publicada em 1798). Sobre Maistre leitor e admirador (porém crítico) da economia-política de Adam Smith, leia-se Cara Camcastle, The More Moderate Side of Joseph de Maistre. Views on Political Liberty and Political Economy (Montréal \& Kingston: McGillQueen's University Press, 2005), p. 99.

${ }_{52}^{5}$ E. Burke, Reflexões sobre a Revolução em França, p. 103. 
diversos aspectos com a clássica abordagem historiográfica de Nobert Elias (18971990).

Em A sociedade de corte ${ }^{53}$ Elias demonstrou como a lenta ascensão das famílias burguesas à condição de membros da nobreza promoveu os fenômenos do "acortesamento" (algo mais profundo que a mera nobilitação, já que abrange a assimilação gradual de uma série de mecanismos comportamentais e éticos traduzidos em autocontroles ou etiquetas) da burguesia e o aburguesamento da nobreza. Isto aconteceu porque as expressões e valores que simbolizavam a sociedade de corte passaram às famílias burguesas ascendentes, que assimilaram tais valores e expressões da nobreza.

Para o autor, a etiqueta não existia por acaso, mas constituía uma função simbólica muito importante, de modo que renunciar a ela significava para todos os membros da corte o mesmo que renunciar aos privilégios e às oportunidades de poder. Aquele "fetiche de prestígio" ou "jogo de máscaras" proibia que seus participantes questionassem a tradição, uma vez que toda intenção de reforma trazia consigo uma diminuição de privilégios. Em suma, a etiqueta e o cerimonial de corte garantiam a manutenção do status da nobreza como uma categoria distinta e elevada.

No interior da corte, o "círculo de competição por status" possibilitava uma perpétua mobilidade em função da competição, a qual era contrabalançada pela etiqueta, fundamental para a manutenção do domínio e prestígio do rei que, por sua vez, tinha interesse em conservar a nobreza de corte como um ordenamento privilegiado.

Uma vez que o rei tinha por ideal não somente reinar, mas também apresentar-se como soberano em cada uma de suas ações, cumpria aperfeiçoar uma organização observável e previsível sob seus domínios, em especial, no seu grupo central, assim como submeter-se a uma ordem estritamente calculada por meio da etiqueta e do cerimonial de corte. Assim, as menores ações do soberano participavam da economia da conservação da própria reputação da realeza.

No caso da Rússia, Maistre apontava para o risco eminente para a própria monarquia em interromper aquele circuito de sociabilidade aristocrática, na medida em que a "etiqueta" cortesã perderia para a ciência (e, por extensão, para a riqueza) a condição de principal critério para a ascensão social através da admissão em cargos

${ }^{53}$ Norbert Elias, A Sociedade de corte: investigação sobre a sociologia da realeza e da aristocracia de corte (Rio de Janeiro: Zahar, 2001). Publicada somente em 1969, embora tivesse sido composta como tese de livre-docência em 1933. 
administrativos estatais. O que para o saboiano era algo inadmissível, pois, a seu ver, o estadista deveria ser sempre um nobre, e este, um proprietário "polido pela literatura e pelas ciências morais", dotado, portanto, de forte ascendência e liderança sobre os homens.

Na contramão desse modelo civilizatório aristocrático-cristão de inspiração, por assim dizer, burkeana, a educação científico-enciclopédica não apenas traria no seu bojo um nivelamento social, como, superiormente, um rebaixamento cultural e dos costumes, na medida em que o cálculo e a transformação da natureza teriam precedência sobre o conhecimento (intrinsecamente humanista) e governo dos homens. Na melhor das hipóteses, os novos administradores "sapientes" seriam homens bem-intencionados, embora incapazes de se comunicar com seus inferiores ou de se fazerem obedecer por eles. $^{54} \mathrm{Na}$ pior, e até em função da formação intelectual materialista e calculista, tenderiam a se irritar com as dificuldades inerentes ao governo dos homens, o que levaria alguns a abusar do enorme poder que adquiriram no Estado e a governar imprudentemente, sem a observância das leis divinas ou naturais, transmitidas somente pela assimilação da cultura clássico-cristã.

Diante da questão de como desenvolver a ciência sem perda das manners aristocráticas, Maistre repete no terceiro capítulo ("Da Religião") o argumento principal das Cinq Lettres, qual seja, o de que a educação clássica ministrada pelos jesuítas representava a via mais segura para desenvolver culturalmente o país sem que houvesse risco para o Estado ou para a religião grego-ortodoxa, como receavam os taristas. A fim de sustentar sua hipótese, o contrarrevolucionário saboiano retoma o requisitório contra o protestantismo para demonstrar que não poderia haver pior circunstância do que aquela para importar professores protestantes alemães simpáticos aos critérios epistemológicos de Bacon, Locke e Kant, uma vez que a provável discussão dos dogmas religiosos levada a cabo por eles levaria rapidamente às críticas dos dogmas políticos. ${ }^{55}$

Paradoxalmente, o principal aliado de "Sua Majestade Imperial" para o progresso da ciência na Rússia deveria ser o catolicismo e seu programa pedagógico clássicohumanista, o qual não apenas demonstrara ser compatível com o desenvolvimento científico na Europa, como, sobretudo, respeitoso em relação ao cristianismo de rito grego.

\footnotetext{
${ }^{54}$ Joseph de Maistre, O.C., VIII: 305.

${ }^{55}$ Joseph de Maistre, O.C., VIII: 317.
} 
Pois se "por toda a parte a ciência matou a religião, em especial nos países protestantes", e o conhecimento científico, antes de determinar as manners, deveria antes subordinar-se às mesmas, como prescindir da colaboração e "emulação" sadia entre ortodoxos e católicos? ? $^{56}$

Portanto, sem adentrarmos no último capítulo ("Do Iluminismo"), que, em grande parte, reitera e desdobra as acusações ao protestantismo, pode-se dizer que os Quatro Capítulos, a exemplo das Cinq Lettres anteriores, avançam uma curiosa teoria humanista-cristã sobre a história da civilização ou das manners europeias pelo contrarrevolucionário saboiano, a qual será plenamente desenvolvida e constituirá o argumento principal de Du Pape.

${ }^{56}$ Joseph de Maistre, O.C., VIII: 320-321. 


\section{CAPÍTULO 6}

\section{"Unlocking the Human Mind": crítica à epistemologia de Locke ou a defesa humanista devota da dignidade humana}

Ao abordar a epistemologia maistreana, um dos maiores especialistas sobre o contrarrevolucionário saboiano observou, com razão, que além de existirem poucos estudos sobre a crítica do autor das Considerações à epistemologia da Ilustração, o nome de Maistre é, mui amiúde, incluído no bloco dos pensadores tradicionalistas, dos adversários incorrigivelmente reacionários do racionalismo do século XVIII. ${ }^{1}$

Como ilustração deste quadro, podemos nos referir a Jacques Godechot, que em seu célebre estudo sobre a contrarrevolução europeia destacou as "diferenças bem profundas" existentes entre as doutrinas tradicionalistas do saboiano e de Bonald, embora mantendo um tratamento relativamente homogêneo de ambos ${ }^{2}$; ou a Isaiah Berlin, que descreveu a epistemologia maistreana como um furioso e intolerante ataque ao racionalismo do século XVIII que, em sua antecipação ultramoderna das visões autoritárias e irracionalistas dos movimentos fascistas, suprimiu qualquer traço do racionalismo tomista em sua apologética cristã, sendo esta ausência o principal "mérito" do pensamento maistreano em relação ao de seu fiel correspondente ultramontano francês, Louis de Bonald ${ }^{3}$ (visto por Berlin como excessivamente mecânico e inflexível

\footnotetext{
${ }^{1}$ Richard Lebrun, "L'Epistemologie Maistrienne: Rationalité et Connaissance Transcendante", in: Revue des Études Maistriennes, $\mathrm{n}^{\mathrm{o}}$ 5-6 (1980), p. 225. Como veremos em seguida, o autor contesta esta 'tradicional' associação.

${ }^{2}$ Em seu estudo sobre o movimento contrarrevolucionário à Revolução de 1789, Godechot reservara um capítulo inteiro (o sexto) ao tratamento dos "Castor e Polux da teocracia". Cf. Jacques Godechot, La Contre-Révolution: Doctrine et Action, 1789-1804 (Paris: PUF, 1961), p. 93.

${ }^{3}$ Iniciada em 1812, quando Maistre escreveu a Bonald para agradecer uma referência elogiosa às Considerações avançada na Législation primitive considérée dans les derniers temps par les seules lumières de la raison (1802) do último, a intensa troca de missivas entre os dois autores só cessaria com a morte do saboiano, que colaborou decisivamente para esta associação ao realçar as afinidades eletivas que mantinha com o pensamento de Bonald em uma de suas cartas (de 8 de julho de 1818). Vide: J. de Maistre, O.C., XIV: 137.
} 
na sua conformação aos cânones "intelectuais, morais e políticos derivados de Tomás de Aquino"). ${ }^{4}$

No entanto, um exame mais cuidadoso (e, poder-se-ia dizer, desprovido de preconceitos) da crítica maistreana à epistemologia de Bacon e Locke - a qual é indissociável da defesa das ideias inatas - revelará o caráter problemático desta vinculação quase automática do nome de Maistre aos autores tradicionalistas, pois a reação do contrarrevolucionário saboiano à Filosofia das Luzes não apenas absorveu e reelaborou aspectos específicos da doutrina tomista, como realizou-se em nome de um desígnio indelevelmente racionalista, ainda que, em razão de algumas de suas premissas, não se encontre totalmente isenta de um caráter ambivalente para nossos modernos critérios epistemológicos.

A este respeito, podemos datar o interesse de Maistre pelos problemas epistemológicos a partir da leitura de um longo artigo da Edinburgh Review a respeito do livro Philosophie de Kant ou Principes de la Philosophie Transcendentale (1801) do filósofo e tradutor francês Charles de Villers (1765-1815), a qual levou o contrarrevolucionário saboiano a não apenas traduzir a maior parte do texto, mas também a tecer longos comentários sobre o mesmo (os quais encontram-se conservados nos Registros de Leitura entre as páginas 491-559 do segmento Philosophie C). ${ }^{6}$ Numa passagem em que se refere aos comentários de Kant sobre as "suscetibilidades inatas" de Leibniz, Maistre expressou as motivações daquela leitura com clareza:

"Os escritos dos últimos metafísicos franceses espalharam com uma extrema rapidez o sistema do Sensualismo que funda todos os nossos conhecimentos sobre as impressões recebidas do exterior ou sobre as abstrações ou novas combinações dessas impressões primitivas. Contra este sistema que nos seduz até quando o negamos, em razão da aparência de verdade que ele apresenta, a simples exposição da suscetibilidade inata não teria provavelmente bastado. Seria preciso uma enunciação mais ousada da força desse sistema para nos lançar na discussão pela surpresa; e... para corrigir os erros mútuos de Kant e Condillac.." ${ }^{7}$

${ }^{4}$ I. Berlin, "Joseph de Maistre e as origens do Fascismo", in: Henry Hardy (org.), Nos limites da Utopia: Capítulos da história das ideias (São Paulo: Companhia das Letras, 1991), especialmente as páginas 91-92, 97 e 140.

${ }^{5}$ Edinburgh Review, vol. I, no 2 (janeiro de 1803), p.253-28, resenha sobre: Charles de Villers, Philosophie de Kant, ou Principes Fondamentaux de la Philosophie Transcendentale (Metz, 1801).

${ }^{6}$ Em um genuíno esforço de paleografia, as anotações maistreanas foram editadas e publicadas por Yves Madouas em " "Joseph de Maistre, Lecteur de Kant", in: Revue des Etudes Maistriennes, n 12 (1996), p. 23-64.

${ }_{7}^{7}$ Yves Madouas, "Joseph de Maistre, Lecteur de Kant", p. 33. 
Em 1805, portanto um ano antes de iniciar suas longas anotações sobre o Novum Organum de Bacon - as quais, presentes na série Philosophie D dos Registros de Leitura maistreanos, serviriam de base ao póstumo Examen e precederam imediatamente as volumosas anotações sobre Locke -, e logo após tomar conhecimento seja da primeira edição francesa das obras completas de Bacon (traduzidas pelo cientista-jacobino Antoine de La Salle, entre 1799-1803), seja dos comentários elogiosos de Jean André de Luc ao jurista e filósofo inglês (entre 1800-1802), Maistre lera atenciosamente uma nova edição dos Rapports du Physique et du Moral de l'Homme (Relações entre o Físico e o Moral no Homem, 1802), do médico fisiologista e filósofo Pierre Jean George Cabanis (1757-1808), que, ao lado do filósofo (igualmente materialista) Destutt de Tracy (1754-1836), liderava o mais influente grupo de intelectuais da França termidoriana, mais conhecidos sob a alcunha de ideólogos.

Apesar do extenso e meticuloso estudo sobre Kant, Maistre resolveu interrompêlo menos pela falta de curiosidade intelectual ou limitação estrutural - por depender das traduções de seu filho Rodolphe, não lograva avançar muito na consulta direta das obras do filósofo alemão -, do que pela necessidade mais premente de combater a epistemologia sensualista avançada pelos ideólogos nos quadros da França imperial, cuja radicalização da filosofia ilustrada ele temia ver logo espalhada como uma moda pela Europa, perpetuando indefinidamente o processo revolucionário.

Política e culturalmente sediados no Institut national - a quem o $298^{\circ}$ artigo da Constituição do Ano III conferira a missão de "registrar as descobertas, aperfeiçoar as artes e as ciências" e, sobretudo, promover a regeneração espiritual de vinte e seis milhões de franceses (por meio da formação de professores devidamente instruídos na moral republicana na recém instituída École Normale), os ideólogos endossaram um projeto epistemológico-pedagógico de cunho material e sensualista que, por seu radicalismo, foi descrito pelo filósofo e epistemólogo contemporâneo Georges Gusdorf como uma "eutanásia da divindade" e, na medida em que representou um "declínio da antropologia" (ou seja, no sentido de rebaixamento ontológico da humanidade), uma "eutanásia da individualidade" humana. ${ }^{8}$

\footnotetext{
${ }^{8}$ G. Gusdorf, L'Homme Romantique (Paris: Payot, 1984), p. 26-27.
} 
Não foi por mero acaso o fato de as obras completas de Helvétius (1715-1771) e de La Mettrie (1709-1751) terem sido publicadas respectivamente em 1795 e 1796. A partir da ideia central de Helvétius que, amparado nos pressupostos sensualistas do Ensaio acerca do Entendimento Humano (1690) de Locke, sustentava na conclusão do De l'Homme que o "espírito" humano é o produto da reunião de nossas ideias (as quais, por sua vez, não podem ter outra origem a não ser nos sentidos) ${ }^{9}$, Cabanis sublinhava que é nas impressões que os corpos exteriores produzem sobre seus órgãos que o homem encontra "a fonte de seus conhecimentos e as próprias causas que o fazem viver: pois viver é sentir", isto é, da "ação contínua dos corpos exteriores sobre os sentidos do homem", resultaria, de acordo com o médico sanitarista e fisiologista francês, "a parte mais destacada da existência." ${ }^{10}$

Uma vez que a "sensibilidade física é o último termo em que se chega no estudo dos fenômenos da vida e na pesquisa metódica de seu verdadeiro encadeamento", bem como "o princípio mais geral que fornece a análise das faculdades intelectuais e das afeições da alma", Cabanis concluía que "o físico e a moral se confundem em sua fonte; ou, melhor dizendo, a moral não é senão o físico considerado sob certos pontos de vista mais particulares." 11

E após observar que os filósofos não estavam "mais obrigados a provar que a sensibilidade física é a fonte de todas as nossas ideias e de todos os hábitos que constituem a existência moral do homem", e de indicar "Bonnet, Condillac, Helvétius" como autoridades que "levaram esta verdade ao último grau de demonstração" na França $^{12}$, Cabanis estabeleceu uma genealogia dos autores responsáveis por aquela revolução epistemológica:

"O imortal Bacon havia descoberto, ou pressentiu, tudo o que podia exigir a refundação total, não apenas da ciência, mas, segundo sua expressão, do próprio 'entendimento humano'. Hobbes, sobretudo, unicamente pela precisão de sua linguagem, foi conduzido sem desvio à verdadeira origem de nossos conhecimentos. Traçou-lhes os métodos com sabedoria e fixou-

\footnotetext{
${ }^{9}$ Razão pela qual os indivíduos e as nações (independente de suas características históricas, físicas ou morfológicas) poderiam alcançar a felicidade e a grandeza por meio da aplicação de um adequado (e, portanto, padronizado) método pedagógico (sendo o "homem nada mais senão um produto de sua educação", segue-se que a "ciência do homem faz parte da ciência do governo"). Cf. Helvétius, "De l'Homme", in: Oeuvres Complètes d'Helvétius (Paris: Caprelet, 1818), vol. II, p. 604-605; 3-4 respectivamente.

${ }^{10}$ Cabanis, Rapports du Physique et du Moral de l'Homme (Paris: Chez Béchet Jeune, 1824), $4^{\mathrm{a}}$ edição, vol. I, p. 82-83. Publicado pela editora da Academia Real de Medicina francesa.

${ }^{11}$ Cabanis, Rapports du Physique et du Moral de l'Homme, vol. I, op. cit., p. 36.

${ }^{12}$ Cabanis, Rapports du Physique et du Moral de l'Homme, vol. I, op. cit., p. 77.
} 
lhes os limites com segurança. Mas coube a seu sucessor, Locke, dar o primeiro impulso à maior e mais útil revolução da filosofia! Era através de Locke que, pela primeira vez, devia ser exposto claramente... este axioma fundamental, de que todas as ideias vêm dos sentidos, ou são o produto das sensações." ${ }^{13}$

Além de reduzir a definição antropológica humana a um rígido critério biológico-naturalista que, como bem observou o historiador Xavier Martin, eliminava qualquer diferenciação axiológica entre o gênero humano e os animais ${ }^{14}$ - afinal, para o autor dos Rapports, "viver não é outra coisa senão receber as impressões e executar os movimentos que estas impressões solicitam" ${ }^{15}$-, e desembocava no fatalismo moral (ao vincular a vontade humana, o "cumprimento dos deveres mais severos, os atos do mais generoso altruísmo", ao "interesse direto e à felicidade daqueles que os praticam" ${ }^{16}$ ), Cabanis descrevia o intelecto humano como algo passivo e mecânico, a ponto de comparar o processo intelectivo no interior de seu sistema epistemológico - que, conforme ele próprio admitia, tinha a pretensão de "revisar e corrigir a obra da natureza" humana através de uma prática pedagógica que poderíamos designar como precursora do "behaviorismo"17 - ao processo digestivo. Nas palavras do autor dos Rapports:

${ }^{13}$ Cabanis, Rapports du Physique et du Moral de l'Homme, vol. I, op. cit., p. VII. Mais adiante, Cabanis observou o seguinte a respeito do método filosófico de Locke, destacando que o filósofo inglês, a exemplo dele, era médico de profissão: "Sentir com atenção; representar o que se sente através de expressões bem determinadas; encadear em sua ordem natural os resultados das sensações: tal é, em poucas palavras, sua arte de pensar. É preciso observar que Locke era médico, e que foi pelo estudo do homem físico que ele antecipou suas descobertas na metafísica, na moral e na arte social." Cf. Cabanis, Rapports du Physique et du Moral de l'Homme, vol. I, op. cit., p. 34-35.

${ }^{14}$ Xavier Martin, Human Nature and the French Revolution: From the Enlightenment to the Napoleonic Code (New York: Berghahn, 2001), p. 157.

${ }^{15}$ Cabanis, Rapports du Physique et du Moral de l'Homme, vol. II, op. cit., p. 113.

${ }^{16}$ Cabanis, Rapports du Physique et du Moral de l'Homme, vol. II, op. cit., p. 3.

17"Sem dúvida, é possível, por meio de um plano de ação combinado sabiamente e seguido constantemente, agir em um grau suficientemente alto sobre os hábitos... e, por conseguinte,... melhorar a natureza particular de cada indivíduo; e este objeto, tão digno da atenção do moralista e do filantropo, convoca todas as pesquisas do fisiologista e do médico observador. Mas se podemos modificar utilmente cada temperamento tomado à parte, podemos influenciar de uma maneira mais extensa e profunda a própria espécie, agindo de acordo com um sistema uniforme e sem interrupção sobre gerações sucessivas.../Após termos nos ocupado tão curiosamente dos meios para tornar mais belas e melhores as raças dos animais ou das plantas úteis e agradáveis; após ter alterado centenas de vezes as raças de cavalos e cães, transplantado, enxertado, trabalhado de todas as maneiras as frutas e as flores, quão vergonhoso seria negligenciar totalmente a raça humana!... É chegado o tempo... de seguir um sistema de ideias mais digno de uma regeneração: é tempo de ousar fazer sobre nós mesmos o que fizemos, com enorme sucesso, sobre inúmeros companheiros de existência; de ousar revisar e corrigir a obra da natureza." Cf. Cabanis, Rapports du Physique et du Moral de l'Homme, vol. I, op. cit., p. 409-411. Sobre o papel desempenhado pelo cientificismo de Cabanis na genealogia dos futuros ideais eugênicos, leia-se Léon Poliakov, Le mythe arien: Essai sur les sources du racisme et des nationalismes (Paris: Calmann Lévy ,1971) p. 222-224. 
"Dir-se-á que os movimentos orgânicos pelos quais se executam as funções do cérebro são-nos desconhecidos? Mas a ação pela qual os nervos do estômago determinam as diferentes operações que constituem a digestão, a maneira pela qual impregnam o suco gástrico da potência dissolvente mais ativa, em nada se excluem de nossas pesquisas. Vemos os alimentos cair nesta víscera com as qualidades novas, e concluímos que ela fez-lhes sofrer verdadeiramente esta alteração. Vemos igualmente as impressões chegarem ao cérebro, por intermédio dos nervos: elas ainda estão isoladas e desconexas. A víscera entra em ação; age sobre elas, e logo as envia metamorfoseadas em ideias que a linguagem da fisionomia e do gesto, ou os signos da palavra e da escritura, manifestam exteriormente. Concluímos com a mesma certeza que o cérebro digere de alguma maneira as impressões; que ele realiza organicamente a secreção do pensamento." ${ }^{18}$

Assim procedendo, Cabanis não apenas negava ao intelecto humano um papel ativo no processo do conhecimento, como, fundamentalmente, suprimia de seu sistema epistemológico quaisquer considerações sobre as ideias ou princípios inatos, abordagem esta de profundas consequências para a concepção ontológica da humanidade.

A leitura de uma figura influente como Cabanis - além de amigo íntimo de Mirabeau e membro do Conselho dos Quinhentos durante o Diretório, ocupou uma posição política e cultural de destaque nos salões termidorianos (a ponto de atrair a atenção de Bonaparte) e no Institut - e o vínculo estabelecido pelo mesmo com a epistemologia de Locke (descrito nas Soirées como um "prefácio do século XVIII") ${ }^{19}$, naturalmente despertaram o zelo humanista devoto de Maistre que, em 1806, iniciou a leitura e fez as primeiras anotações do Ensaio de Locke (presentes entre as páginas 93325 do segmento Philosophie D dos Registros de Leitura) com vistas a refutar as críticas ilustradas às ideias inatas.

Isto porque, como bem pontuou Cassirer em seu clássico estudo sobre a filosofia da Ilustração, todo empenho epistemológico da filosofia francesa do século XVIII em diante consistiu em procurar absorver e ultrapassar Locke - cuja autoridade em todas as questões de psicologia e de teoria do conhecimento era "quase incontestada durante a primeira metade do século XVIII' - numa única direção: a liquidação do que restava de dualismo no princípio de sua análise, isto é, a distinção entre sensação e reflexão (de modo a reduzir todo o conhecimento humano a uma só e mesma fonte, a sensação) responsável pela preservação de um resquício de autonomia à esfera intelectual no

\footnotetext{
${ }^{18}$ Cabanis, Rapports du Physique et du Moral de l'Homme, vol. I, op. cit., p. 133-134.

${ }^{19} \mathrm{~J}$. de Maistre, Soirées, O.C., IV: 373 (VI ${ }^{\mathrm{e}}$ Entretien).
} 
pensamento lockeano. ${ }^{20}$ Pois apesar de o autor do Ensaio ter sido o primeiro a traçar o percurso a ser adotado pela investigação empírica, o mesmo, nas palavras do estudioso alemão, tornou-se "infiel ao seu método geral" quando abordou as faculdades intelectuais de comparar, distinguir, julgar e querer. Contumaz combatente das ideias inatas, Locke "não derrubou o preconceito das operações inatas da alma ". ${ }^{21}$

Mais recentemente, o filósofo Kenneth Winkler ${ }^{22}$ sublinhou que qualquer consideração sobre o debate do século XVIII acerca da origem das ideias deve começar com o ataque de Locke às ideias inatas, e o qual foi elogiado e prosseguido na França através de autores como Voltaire (Lettres philosophiques ou Lettres sur les Anglais, 1733), d'Alembert (Discours préliminaire de l'Encyclopédie, 1751) e, sobretudo, Condillac, cujo expressamente lockeano Essai sur l'origine des connaissances humaines (1746 ) fora objeto de leitura (em 1813) e cuidadosas anotações por Maistre. ${ }^{23}$

Apesar de remontar às clássicas formulações de Platão (teoria da reminiscência das ideias) e Cícero (para quem os homens trazem consigo desde o nascimento as semina innata ou as "sementes da virtude") ${ }^{24}$, a teoria das ideais inatas era modernamente identificada pela figura de René Descartes (1596-1650), que assim definiu aquele conceito em suas Méditations Métaphysiques (Meditações Metafísicas, 1641): "Quando digo que alguma ideia nascera conosco, ou que ela se encontra naturalmente impressa em nossas almas, não tenciono dizer que ela esteja sempre presente em nosso pensamento, pois assim não haveria nenhuma; mas apenas que possuímos em nós mesmos a faculdade de produzi-la". ${ }^{25}$

Em vez de expressarem uma ideia pronta e acabada que os homens trazem em seu espírito desde o nascimento ${ }^{26}$, as ideias inatas compreendiam uma virtualidade ou

${ }^{20}$ Ernst Cassirer, A Filosofia do Iluminismo(Campinas-SP: Editora da Unicamp, 1992), p. 143.

${ }^{21}$ Ernst Cassirer, A Filosofia do Iluminismo, p. 144.

${ }^{22}$ Kenneth P. Winkler, "Perception and Ideas, Judgement", in: Knud Haakonssen (org.), The Cambridge History of the 18th Century Philosophy (Cambridge: Cambridge University Press, 2006), vol. I, p. 249.

${ }^{23}$ J. de Maistre, Archives de Joseph de Maistre et de sa famille, 2J9, p. 651-713.

${ }^{24}$ David Konstan, "Epicurus on the Gods", in: Jeffrey Fisch e Kirk R. Sanders (orgs.), Epicurus and the Epicurean Tradition (Cambridge: Cambridge University Press, 2011), p. 68.

${ }^{25}$ R. Descartes, "Objections faites par des personnes très doctes contre les précédantes méditations avec les réponses de l'auteur", in: L. Aimé-Martin (org.), Oeuvres Philosophiques de René Descartes (Paris: Panthéon Littéraire, 1852), p. 131.

${ }^{26}$ Como pensaram muitos contemporâneos, do teólogo Mersenne (1588-1648) - que, nas "Segundas Objeções" às Meditações, observou que os "Huronianos e os outros homens selvagens" não tinham a ideia de Deus no espírito -, ao filósofo Hobbes, cujas "Terceiras Objeções" indagavam ironicamente se os homens traziam sempre consigo a ideia de Deus mesmo quando dormiam. Cf. R. Descartes, "Objections faites par des personnes très doctes contre les précédantes méditations avec les réponses de l'auteur", op. cit., p. 107 e 130 respectivamente. 
faculdade da mente humana de produzir determinadas ideias em resposta aos estímulos concretos dos sentidos. Assim, por exemplo, a mera percepção gráfico-visual do triângulo jamais seria capaz de, por si só, produzir no homem a compreensão geométrica daquela figura se o mesmo não trouxesse a ideia de "triangulidade" em seu espírito. $^{27} \mathrm{O}$ mesmo se aplica ao indissociável desdobramento teológico daquele conceito. $^{28}$ Segundo Descartes, "ainda que a ideia de Deus encontre-se impressa no espírito humano" de um modo tal que todas as pessoas tragam consigo a faculdade de conhecê-la, isto, segundo ele, "não impede que muitas pessoas pudessem atravessar toda sua vida sem que jamais representassem esta ideia distintamente para si". ${ }^{29}$

Contestada precocemente por eminentes filósofos e teólogos contemporâneos (como Hobbes e Pierre Arnauld), coube sobretudo a Locke, através de seu Ensaio acerca do entendimento humano, formular a primeira crítica sistemática à teoria das ideias inatas, e a qual, a partir de Voltaire ${ }^{30}$, tornou-se extremamente popular entre as figuras mais eminentes da Ilustração francesa.

Apesar de sua expressa admiração por Descartes e pelo padre oratoriano Nicolas Malebranche (1638-1715) $)^{31}$ - cuja principal obra, De la recherche de la vérité (Da

${ }^{27}$ R. Descartes, "Objections faites par des personnes très doctes contre les précédantes méditations avec les réponses de l'auteur", op. cit., p. 207. Antes de Descartes, Ficino, em sua Theologia Platonica, expôs uma defesa do inatismo em linhas próximas daquela que seria avançada por Maistre: "Todo espírito louva a forma redonda desde que a encontra pela primeira vez nas coisas e sem saber por que a louva. E assim louvamos nas construções a superfície plana dos muros, a ordenação das pedras, a forma das janelas e das portas, e mesmo no corpo humano a proporção dos membros ou, numa melodia, o acordo dos sons. Se todo espírito aprova essas coisas e se ele deve aprová-las sem conhecer a razão desta apreciação, isto só pode ocorrer devido a um instinto natural e necessário... As razões desses julgamentos são inatos ao espírito." Cf. M. Ficino, Theologia Platonica sive de immortalitate animae, Livro XI, cap. 5.

28 A respeito do pressuposto teológico por trás das concepções inatistas, Cassirer destacou o seguinte: "O ponto de partida de toda a filosofia, de Descartes em diante, está nessas noções primitivas que consideramos em nós mesmos e que, de certa maneira, são os arquétipos pelos quais se modelam todos os nossos outros conhecimentos. Entre essas noções primeiras encontramos as de ser, número e duração, que possuem um valor absoluto para todo o conteúdo do pensamento, ao passo que as ideias de extensão, forma e movimento só valem para o mundo dos corpos e a ideia de pensamento só para a alma. Toda a realidade empírica, toda a diversidade dos corpos e toda a vida complexa da alma estão contidas nesses modelos simples e primitivos, que se relacionam de antemão com essa realidade objetiva pela única razão de que assim se relacionam também, simultaneamente, com a sua própria origem. As ideias inatas são 'as marcas do artista impressas em sua obra'."Cf. Ernst Cassirer, A Filosofia do Iluminismo, p. 137.

${ }^{29}$ Descartes, "Lettre à Clerselier" (1645), in: L. A. Gruyer, Métaphysique de Descartes (Bruxelles: Meline, Cans et Compagnie, 1838), p. 347.

${ }^{30}$ Referindo-se especificamente à crítica de Locke às ideias inatas, Voltaire avançou a seguinte observação: "Depois que tantos arrazoadores fizeram o romance da alma, eis que chegou um sábio para lhe fazer modestamente a história. Locke expôs e explicou ao homem a razão, tal como um excelente anatomista explica os mecanismos do corpo humano". Cf. Voltaire, Lettres sur les anglais, "Lettre XIII", in: Oeuvres (Paris: Leguien, 1821), vol. XXVI, p. 65.

${ }^{31}$ Elogiado por Maistre ao lado de Descartes por ter ensinado o homem sem insultá-lo (O.C., VI: 131-132), Malebranche era referido como um "Platão cristão" nas Soirées, que lamentavam o fato de os 
pesquisa da verdade, 1674), Maistre lera cuidadosamente entre maio-julho de 1807 (ocupando, entre cópia de trechos e comentários, cerca de cem páginas do segmento Philosohie $D$ de seus Registros de Leitura), certamente em razão dos ataques que a mesma sofrera de Locke, Kant, Voltaire e demais filósofos franceses ${ }^{32}$-, o contrarrevolucionário saboiano não encontrou nas proposições teológicas de Malebranche o devido ponto de apoio lógico para balizar sua defesa das ideias inatas. Conforme as notas ao De la recherche de la vérité indicam, Maistre discordava da perspectiva ocasionalista do padre oratoriano, a qual, por considerar Deus como a única causa de todos os fenômenos, negava a causalidade própria dos fenômenos naturais (descritos como meras causas "ocasionais"). Ainda que Maistre admirasse outros aspectos da apologética malebranchista (como a defesa da imortalidade da alma) e admitisse que todas as causas, em última análise, remetiam-se a Deus, a teoria da causalidade do oratoriano parecia-lhe perigosa na medida em que ameaçava a autonomia e ignorava o poder ativo do intelecto humano. ${ }^{33}$

Diante da inexistência de uma exposição teórica sistemática a favor das ideias inatas, não restou outra alternativa a Maistre senão a de reconstruir uma ilustre linhagem de autores antigos e contemporâneos que, de Pitágoras a Leibniz, defenderam proposições que poderiam amparar sua própria formulação daquele princípio.

Ciente da importância da filosofia de Aristóteles, em especial do papel que o mesmo atribuíra aos sentidos em sua teoria do conhecimento ${ }^{34}$, Maistre empreendeu desde 1806 a leitura sistemática das obras do Estagirita, a qual seria completada pelo estudo da Summa contra Gentiles (1258-1264) do aristotélico são Tomás de Aquino (1225-1274) entre 1810 e o início de 1811 (preservado entre as páginas 421-437 do segmento Registre $F$ dos Registros de Leitura). Incomuns naquela época - seja pelo fato de a filosofia de Aristóteles ser mais facilmente associada ao materialismo que Maistre pretendia combater, seja, sobretudo, pelo fato de o tomismo ter sido praticamente abandonado pela apologética cristã até seu renascimento a partir do século XIX aqueles estudos permitiram ao saboiano conciliar a defesa das ideias inatas com o

franceses terem abandonado aquele autor que podia ter errado na busca, mas "jamais abandonou o caminho da verdade" (O.C., IV: 364 e 109 respectivamente).

${ }^{32}$ Ernst Cassirer, A Filosofia do Iluminismo, p. 140.

${ }^{33}$ J. de Maistre, Archives de Joseph de Maistre et de sa famille, 2J20, Philosophie D, p. 607.

${ }^{34}$ Como destacou Marc Froidefont a partir dos testemunhos de Charles de Rémusat e Henri Braudillart, Maistre foi um dos raros pensadores francófonos do início do século XIX a mostrar um sólido conhecimento (de primeira mão, diga-se, posto que aprendera o grego clássico) das filosofias de Platão e de Aristóteles. CF. M. Froidefont, Théologie de Joseph de Maistre (Paris: Classiques Garnier, 2010), p. 74-75. 
inescapável reconhecimento ${ }^{35}$ do papel desempenhado pelos sentidos (pois o homem, em seu "estado de degradação", possui um corpo terrestre $)^{36}$ no processo cognitivo.

$\mathrm{O}$ resultado concreto de todas essas investigações epistemológicas viria à luz através das Les Soirées de Saint-Pétersbourg ou Entretiens sur le gouvernement temporel de la Providence (Saraus de São Petersburgo ou Diálogos sobre o governo temporal da Providência, publicadas de forma póstuma e incompleta em 1821), uma obra redigida entre 1809 e 1817 - em meio a uma atividade verdadeiramente febril (seja no desempenho de suas funções diplomáticas, seja na dedicação aos estudos e redação de inúmeros trabalhos) junto à corte russa ${ }^{37}$ - e na elaboração da qual Maistre confessara ter literalmente "vertido a cabeça" 38 . Conforme confessaria ao erudito leigo Guy-Marie de Place (versado em filosofia, teologia e história eclesiástica, fora o revisor de $D u$ Pape) a respeito das Soirées:

"Este livro é tudo o que posso fazer e tudo o que posso saber. Mas o que posso fazer e que coisa sei? Não cabe a mim decidir... O trabalho é endereçado... a todos. Vereis, Monsieur, como decidi fazer a filosofia (a antiga, especialmente) caminhar com a teologia, e como tornei o trabalho dramático e sentimental. Em suma, Monsieur, este é meu grande trabalho; infelizmente, o pronome possessivo estraga tudo, uma vez que o grande trabalho de um homem só pode ser um átomo diante da razão universal.",39

Inspiradas nos diálogos platônicos e distribuídas em onze "saraus" mantidos entre três personagens - o "Conde"40, o "Senador" 41 e o "Chevalier"42 -, as Soirées

\footnotetext{
${ }^{35} \mathrm{Em}$ seu inédito Essai sur les Planètes (Ensaio sobre os Planetas, 1799), que representa o primeiro ensaio maistreano de formulação sistemática crítica à epistemologia moderna, Maistre já havia aludido para a necessidade de os autores adaptarem suas demonstrações filosóficas aos "conhecimentos em circulação", sob pena de não chocarem "excessivamente as opiniões consagradas". Cf. J. de Maistre, Essai sur les Planètes (Philosophie D), p. 665.

${ }^{36}$ J. de Maistre, Soirées, O.C., IV: 115 (II ${ }^{\mathrm{e}}$ Entretien).

37 Além de uma volumosa correspondência pessoal e diplomática, o saboiano escreveu cinco trabalhos extensos e mais de uma dezena de trabalhos menores nos quatorze anos em que habitou a capital russa (1803-1816). Destes, apenas dois foram publicados antes de seu retorno a Turim, o Essai sur le principe générateur, publicado em Paris em 1814, e uma tradução de Plutarco, o Sur le Délais de la justice divine, publicado em Lyon em 1816. Outro grande trabalho concebido na Rússia e publicado em vida foi Du Pape, em 1819. As Soirées e o De l'Eglise Gallicane foram publicadas alguns meses após sua morte, em 1821. Como dissemos acima, o Examen de la philosophie de Bacon não foi publicado até 1836, enquanto os trabalhos menores foram publicados alternadamente, entre 1822 e 1884 .

38 J. de Maistre, "Carta a De Place, 11 de dezembro de 1820", in: O.C., XIV:250.

39 J. de Maistre, "Carta a De Place, 9 de julho de 1818", in: R. Lebrun, Joseph de Maistre: an intellectual militant (Quebec: McGill-Queen's University Press, 1988), p. 255.

${ }^{40}$ Representando o próprio Maistre e suas opiniões ultramontanas.

${ }^{41}$ Representando seja Basile Stepanóvitch Tamara (senador sob o reinado de Catarina II, conhecera Maistre na Rússia, em 1809, e conhecido pelo envolvimento em atividades maçônicas e pela oposição à
} 
representam o zênite de uma reflexão teológico-política desenvolvida desde 1794 e amadurecida nas Considerações (que, no entanto, foram concebidas como obra de circunstância, "limitando-se" a "considerar" a Revolução Francesa e a defender a monarquia como regime político). Das Considerações sobre a França - que avançam uma defesa do "cristianismo" sem identificá-lo ao catolicismo - ao Du Pape (1819) que faz do catolicismo a base de um "sistema divino"43 - , o centro de gravidade do pensamento maistreano fora deslocado. Após a Restauração, a defesa da monarquia absoluta temporal subordinou-se à defesa da "monarquia absoluta espiritual" do papa; a defesa da autoridade, tendo a monarquia como base, cedeu espaço à defesa da autoridade, tendo o catolicismo como centro. As circunstâncias da Restauração, demonstrando cada vez mais a impossibilidade da consecução de seus projetos políticos ${ }^{44}$, levaram o autor das Soirées a elaborar uma filosofia cristã da história para salvar seus ideais e refutar toda pretensão de durabilidade e realidade à Revolução Francesa, razão pela qual emprestou-lhe a forma de uma teodicéia.

Nas Soirées, Maistre rejeitava igualmente a idéia calvinista e jansenista da predestinação que privaria a humanidade de toda a liberdade (desencorajando o maior bem que Deus concedeu aos homens, a perfectibilidade), bem como o "belo sistema de leis invariáveis" dos filósofos modernos, responsável segundo ele por engendrar uma espécie de fatalismo moral ao dissuadir o homem de orar. ${ }^{45}$ Conforme Maistre expressaria no segundo diálogo da obra (concluído por volta de 1809) ${ }^{46}$, o

filosofia das Luzes), seja o próprio Maistre sob o ângulo de suas visões esotéricas, as quais, é bom que se diga, não conflitam com as opiniões ortodoxas do "Conde".

${ }^{42}$ François-Gabriel de Bray, cavaleiro da Ordem de Malta, emigrou da França após a jornada de 10 de agosto de 1792, quando abraçou a carreira diplomática e partiu à Rússia, onde conheceu Maistre em 1809. Personagem crucial na economia da obra, pois representa um "tipo-ideal" de leitor ao qual o diálogo se dirige, a saber, a elite política francesa responsável por fazer a Restauração funcionar, mas que nada compreendera do caráter providencial por detrás da Revolução Francesa. Galicano e ainda sob influência do ceticismo das Luzes, demonstra certa impermeabilidade às verdades cristãs, exigindo todo o esforço pedagógico do "Maistre-ultramontano" e do "Maistre-maçom". Sua presença também serve de pretexto pedagógico e missionário para a obra: no segundo diálogo, o "Chevalier" expõe as razões para este didatismo (trata-se de um nobre com formação prático-militar, portanto pouco afeito aos sistemas e longos tratados) que também é uma justificativa para a forma literária eleita (diálogo no estilo do symposium platônico).

${ }^{43}$ J. de Maistre, Du Pape, Livro I, cap. 11.

${ }^{44} \mathrm{Ou}$ seja, pela percepção de que uma Europa monárquica e católica estava com os dias contados e que por muito tempo ainda a Europa estaria condenada à "estável instabilidade" da Revolução. Razão pela qual sua correspondência a partir da Restauração (especialmente após seu retorno a Turim) ficou marcada por um profundo pessimismo: "Morro com a Europa, estou em boa companhia". Cf. J. de Maistre, "Carta ao conde Marcellus, 9 de agosto de 1819", in: O.C., XIV:183.

${ }^{45} \mathrm{~J}$. de Maistre, Soirées, O.C., IV: 213 (IV Entretien).

${ }^{46}$ Jean-Louis Darcel, "Genèse et publication des Soirées de Saint-Pétersbourg", in: J.-Louis Darcel (org.), Les Soirées de Saint-Pétersbourg ou Entretiens sur le Gouvernement Temporel de la Providence (Geneve: Slaktine, 1993), p. 18. 
procedimento epistemológico típico do século XVIII que, eludindo o "ponto principal" sobre a "essência da alma humana", consistia em vincular as ideias aos sentidos, resultava num "sistema absurdo" que pretendia... materializar a origem de nossas ideias" $^{47}$ e, em última análise, desembocava no fatalismo, razão pela qual a defesa das ideias inatas pelo saboiano estava, nas palavras de Richard Lebrun, "ligada à defesa da espiritualidade e da imortalidade da alma, da existência de Deus e do mundo espiritual, da moralidade e da religião cristã". ${ }^{48}$

Não por acaso, Maistre mobiliza o mecanismo retórico do vitupério (no melhor estilo de um "Voltaire às avessas") para introduzir sua crítica ao "absurdo" Ensaio de Locke - descrito como uma obra tão árida quanto o deserto da Líbia e com um insuportável odor de mercadoria ("Quelle odeur de magasin!") ${ }^{49}$-, destacando a respeito do filósofo inglês que ele não apenas refutou logicamente seu próprio trabalho ("ao nos dizer que todas as nossas ideias vêm dos sentidos"), como declarou sua inutilidade perante os leitores, que não precisavam recorrer à sua obra" - ou às publicações dos expressamente referidos "ideólogos" - para saber que certas ideias são excitadas pelos sentidos. $^{50}$

Numa demonstração de profundo conhecimento da tradição filosófica crítica às ideias inatas - cujo argumento principal consistia em caracterizar as mesmas como um conhecimento pronto que dispensava a educação e a experiência (interpretação esta que, como vimos, foi objetada pelo próprio Descartes) na sua formação -, Maistre tomou para si o encargo de redefini-las com maior precisão, não sem antes provocar o tradutor francês de Bacon (Antoine de Lassalle), que recentemente zombara do inatismo precisamente nos mesmos termos que o fizeram Hobbes e Mersenne, isto é, emprestava aos "filósofos espiritualistas a crença de que um feto no ventre de sua mãe sabe as matemáticas, ou que podemos saber sem aprender". ${ }^{51}$

Diante disso e com vistas sobretudo à abordagem de Locke, Maistre adverte seu leitor sobre a diferença entre a noção (que é inata) e a afirmação/julgamento coletivo ou pessoal (uma ideia casual ou particular e portanto, passível de erro) para demonstrar que

\footnotetext{
${ }^{47}$ J. de Maistre, Soirées, O.C., IV: 109-110 e 118 (II ${ }^{\mathrm{e}}$ Entretien).

${ }^{48}$ Richard Lebrun,"L'Epistemologie Maistrienne: Rationalité et Connaissance Transcendante", in: Revue des Études Maistriennes, n ${ }^{\circ}$ 5-6 (1980), p. 229.

${ }^{49}$ J. de Maistre, Soirées, O.C., IV: 319 (VI ${ }^{\mathrm{e}}$ Entretien).

${ }^{50}$ J. de Maistre, Soirées, O.C., IV: 345 (VI ${ }^{\mathrm{e}}$ Entretien).

${ }^{51}$ J. de Maistre, Soirées, O.C., IV: 120 (II ${ }^{\mathrm{e}}$ Entretien).
} 
a existência das ideias inatas não dispensava a humanidade de pensar/raciocinar (ou seja, não a imunizava contra os erros de julgamento):

"Limito-me aqui a advertir-vos sobre uma confusão evidente da ideia ou da simples noção com a afirmação, duas coisas... totalmente diferentes: a primeira que é inata, e não a segunda, pois ninguém, segundo creio, atreveu-se a dizer que há raciocínios inatos. O teísta diz: há apenas um Deus, e ele tem razão; o idólatra, por seu turno, diz que há vários, e ele se engana, mas como um homem que se enganaria numa operação de cálculo. Seguir-se-ia disso por acaso que este não teria a ideia do número? Pelo contrário: é uma prova de que ele a possui, pois sem esta ideia ele não teria sequer a honra de se enganar... Não haveria pois, sem a ideia anterior de um Deus, nem teístas e nem politeístas, na medida em que não se pode dizer sim ou não sobre aquilo que não se conhece, e que é impossível de se enganar sobre Deus sem ter a ideia de Deus. É pois a noção ou a ideia pura que é inata e necessariamente estranha aos sentidos..." ${ }^{52}$

E uma vez que o método argumentativo de Locke alicerçou-se numa indução que, partindo da observação histórica e dos relatos de viagem, concluía pela inexistência das ideias inatas a partir da absoluta e radical pluralidade dos costumes entre os povos ${ }^{53}$, Maistre pontuou a respeito do autor do Ensaio que se o mesmo tivesse tido maior penetração ou boa-fé, em vez de concluir, com base em exceções, que "uma ideia" que "não se encontra no espírito de tal povo não é inata", ele teria induzido justamente "o contrário" a partir da mesma observação, a saber:

${ }^{52}$ J. de Maistre, Soirées, O.C., IV: 121-122 (II Entretien).

53 "(...) Locke, no primeiro livro de seu triste Ensaio, destila a história e os relatos de viagens para ruborizar a humanidade. Ele cita os dogmas e os costumes mais vergonhosos; ele se perde ao ponto de exumar de um livro desconhecido uma história que provoca náuseas; mas teve o cuidado de nos dizer que, sendo o tal livro raro, julgou mais apropriado citar a anedota nos próprios termos do autor, e tudo isto para estabelecer que não existe nenhuma moral inata. "Cf. J. de Maistre, Soirées, O.C., IV: 349-350 ( $\mathrm{VI}^{\mathrm{e}}$ Entretien), grifos de Maistre. Um pouco mais adiante, o autor das Soirées avança uma refutação que subsume a lógica indutiva de Locke: "Uma mulher indiana sacrifica seu filho recém-nascido à deusa Gonza. Eles dizem, então, que não há moral inata; pelo contrário, é preciso dizer ainda: portanto ela é inata, posto que a ideia do dever é suficientemente forte nesta infeliz mãe para determiná-la a sacrificar a esse dever o sentimento mais terno e poderoso existente no coração humano. Abraão atraiu outrora para si um mérito imenso ao se determinar a esse mesmo sacrifício, que ele acreditava com razão realmente ordenado; ele dizia precisamente como a mãe indiana: a divindade falou, é preciso fechar os olhos e obedecer. Um, prostrando-se sob a autoridade divina que queria apenas testá-lo, obedecia a uma ordem sagrada e direta; a outra, cega por uma superstição deplorável, obedece a uma ordem imaginária; mas a ideia primitiva é comum em ambos: é aquela do dever levado ao mais alto grau de elevação. Devo fazêlo! Eis a ideia inata cuja essência é independente de nosso erro na aplicação." Cf. J. de Maistre, Soirées, O.C., IV: 351 (VI ${ }^{\mathrm{e}}$ Entretien). Grifos de Maistre. 
"(...) ela é inata para todo homem que a possui, pois é uma prova de que se ela não preexiste, os sentidos jamais lhe darão nascença, pois a nação que se priva dela possui igualmente cinco sentidos como as demais; e ele teria buscado saber como e por que tal ou qual ideia pôde ser destruída ou desnaturada no espírito de tal família humana. Mas ele estava muito longe de um pensamento assim fecundo, ele que se perde novamente ao ponto de sustentar que um único ateu no universo bastar-lhe-ia para negar legitimamente que a ideia de Deus seja inata no homem; ou seja, que uma única criança deficiente, nascida sem os olhos..., provaria que a vista não é natural ao homem. ${ }^{\text {"54 }}$

Ademais, Maistre também observou como a negação das ideias inatas por Locke comprometia na raiz o argumento jusnaturalista-liberal avançado nos Dois Tratados sobre o Governo Civil, pois como seria possível sustentar a existência de uma "lei natural" anterior às leis positivas e "reconhecidas apenas pela luz da razão", se o filósofo negava as premissas que tornavam aquela mesma razão operativa e universalmente válida? Nas palavras de Maistre:

"Em vão, Locke, sempre agitado interiormente, busca iludir-se de uma outra maneira pela declaração expressa que ele nos faz de 'que ao negar a lei inata, ele não pretende em absoluto negar uma lei natural, isto é, uma lei anterior à toda lei positiva'. Como você vê, isto é um novo combate contra a consciência e o engajamento. O que é, afinal, essa lei natural? E se ela não é nem positiva nem inata, qual é a sua base? Que ele nos indique um único argumento contra a lei inata que não tenha a mesma força contra a lei natural: esta, diz-nos ele, pode ser reconhecida apenas pela luz da razão, sem o recurso de uma revelação primitiva. Mas o que é esta luz da razão? Vem ela dos homens? Então, ela é positiva. Vem de Deus? Então é inata." ${ }^{55}$

Existentes, portanto, "independentemente dos sentidos" e anteriores ao uso dos mesmos ("que não podem excitá-las a não ser porque elas existem") ${ }^{56}$, sem as ideias inatas - "essas noções originais comuns a todos os homens" -, o gênero humano não apenas se confundiria ontologicamente com os animais, como, fundamentalmente, a própria noção de totalidade do mundo natural e o ato experimental pelo qual o compreendemos tornar-se-iam inviáveis ${ }^{57}$, pois a "experiência", sem a referência

\footnotetext{
${ }^{54}$ J. de Maistre, Soirées, O.C., IV: 350-351 (VI ${ }^{\mathrm{e}}$ Entretien). Grifos de Maistre.

55 J. de Maistre, Soirées, O.C., IV: 350-351(VI Entretien). Grifos de Maistre.

56 J. de Maistre, "Notas sobre Locke", in: Philosophie D, p. 119.

${ }^{57}$ Yves Madouas, "Joseph de Maistre, Lecteur de Kant", p. 27-28.
} 
daqueles princípios inatos, seria "sempre solitária", e poderia se repetir "ao infinito, deixando sempre um abismo entre ela e o universal". ${ }^{58}$

"A ideia deste todo" natural, advertia Maistre (referindo-se a Aristóteles) em sua análise ao livro de Charles de Villers sobre a filosofia de Kant, "é produzida em nós pela inteligência; por este poder que, recebendo os produtos da sensibilidade, e distribuindoos em classes, produz as concepções" (um termo kantiano que ele preferia ver substituído pelo de "ideias gerais"). Após observar que não poderia haver um ato de inteligência separado das "categorias" ou formas inatas de pensamento (as quais "existem a priori e independentemente de toda experiência no sujeito que intelige"), e apropriando-se da reelaboração kantiana daquela original formulação aristotélica, Maistre dividiu-as em quatro grandes classes ("quantidade, qualidade, relação $e$ modalidade),como se segue: "À primeira pertencem as três categorias unidade, pluralidade e totalidade. À segunda, a afirmação, ou realidade, negação ou privação e limitação. À terceira, substância e acidente, causalidade ou lei das causas e efeitos, reciprocidade da ação ou reação. À quarta, a possibilidade e a impossibilidade, existência e inexistência, necessidade e contingência." ${ }^{59}$

Causa simplesmente "ocasional e excitadora" e não, como sustentavam Locke e seus discípulos franceses, "produtora das ideias" ${ }^{60}$, a experiência dos sentidos suscita uma reação que é determinada pelas ideias inatas ou primeiros princípios que são próprios à natureza humana. ${ }^{61}$ Graças à existência desses primeiros princípios da inteligência, o gênero humano é capaz de procededer pela afirmação ou negação, operação esta que permeia todo o processo de conhecimento e sem a qual "não há mais demonstração possível", de modo que "toda doutrina racional é fundada sobre um conhecimento antecedente, pois o homem não pode aprender nada a não ser pelo que ele já sabe". ${ }^{62}$ Apoiado nos Analíticos Posteriores de Aristóteles ${ }^{63}$, Maistre concluía que o aspecto mais importante a respeito do processo de aprendizado é o fato de que os seres humanos reagem à experiência sensorial de um modo determinado pelas idéias inatas ou primeiros princípios da natureza humana, razão pela qual a negação das idéias inatas

${ }^{58}$ J. de Maistre, Soirées, O.C., IV: 356 (VI ${ }^{\mathrm{e}}$ Entretien).

${ }^{59}$ Yves Madouas, "Joseph de Maistre, Lecteur de Kant", p. 28.

${ }^{60}$ J. de Maistre, Soirées, O.C., IV: 119 (II ${ }^{\mathrm{e}}$ Entretien).

61 "Há uma relação estabelecida pelo criador entre a impressão feita pelos objetos sobre os sentidos e a percepção operada no espírito, donde se segue que a maneira de perceber depende da natureza da inteligência que apreende, e sendo esta natureza original ou inata..., há, pois, as ideias inatas." Cf. J. de Maistre, "Notas sobre Locke", in: Philosophie D, p. 319.

62 J. de Maistre, Soirées, O.C., IV: 354 (VI ${ }^{\mathrm{e}}$ Entretien).

${ }^{63}$ J. de Maistre, Soirées, O.C., IV: 153 nota XXXVI (II ${ }^{\mathrm{e}}$ Entretien). 
implicaria na negação ou impossibilidade da prova, uma vez que esta é sempre derivada de um princípio (o qual é anterior, evidente, não-derivado, indemonstrável e causa em relação à conclusão). ${ }^{64}$

Curiosamente, o principal procedimento demonstrativo adotado por Maistre em sua defesa espiritualista das ideias inatas consistiu justamente em apelar à observação da natureza ou, mais especificamente, à comparação entre as espécies ou gêneros naturais que, a seu juízo, reforçavam a teoria cristã e humanista neoplatônica acerca da fixidez das espécies (e, no interior desta ordem cósmica divina, da condição privilegiada da natureza humana). Neste sentido, "nenhum ser vivo pode ter outros conhecimentos a não ser aqueles que constituem sua essência, e que são exclusivos ao lugar que ele ocupa no universo", pois, do contrário - isto é, se cada ser vivo não detivesse "ideias desse gênero" (inatas) -, cada espécie, "obtendo suas ideias dos acasos da experiência, poderia sair de seu círculo", algo que "não acontecerá jamais".

Conforme demonstra o segundo diálogo das Soirées, a interpretação tomista da Ética a Nicômaco de Aristóteles, mais especificamente a distinção entre o intelecto passivo (potência que recebe as impressões) e o intelecto ativo ("a inteligência propriamente dita que reflete sobre as impressões") ${ }^{65}$, possibilitou a Maistre integrar e subsumir as sensações em sua defesa racional das ideias inatas (e, por extensão, do cristianismo), pois não obstante aquele postulado aristotélico-tomista reconhecer o importante papel dos sentidos como elemento desencadeador ou excitador das ideias, ele também sublinhava o caráter passivo, secundário e subordinado dos mesmos, preservando assim o papel ativo e primordial reservado à inteligência no processo do conhecimento, e o qual era inseparável de uma visão ontológica transcendental sobre a natureza humana, já que as operações do intelecto ativo (que Maistre associa às ideias inatas) eram próprias apenas aos homens, ao passo que as do intelecto passivo (responsáveis pela percepção dos dados particulares dos sentidos) eram comuns também aos animais. ${ }^{66}$ Por esta lógica, Maistre explicava que o "cão, o macaco, o elefante" eram capazes de raciocinar parcialmente, isto é, seriam capazes de, instintivamente, se aproximar do fogo ao sentirem frio, mas não saberiam como "acender o fogo"; podiam ver "um, dois, mil triângulos juntos, mas jamais a triangulidade". ${ }^{67} \mathrm{O}$ cão que

\footnotetext{
${ }^{64}$ J. de Maistre, Soirées, O.C., IV: 354-355 (VI Entretien).

${ }^{65}$ T. de Aquino, Somme de la foi catholique contre les Gentils (Paris: Louis Vivès, 1854), vol. II, p. 69.

${ }^{66}$ J. de Maistre, Soirées, O.C., IV: 115 e 155 nota XL (II ${ }^{\mathrm{e}}$ Entretien).

${ }^{67}$ J. de Maistre, Soirées, O.C., IV: 248 ( $\mathrm{V}^{\mathrm{e}}$ Entretien).
} 
testemunha a execução de um condenado ao lado de seu dono vê o mesmo que o seu amo ("a multidão, o triste cortejo, os oficiais de justiça, os gendarmes, o cadafalso, o paciente, o executor"), mas nunca logrará formar a partir daquelas sensações a menor noção que seja da justiça ou do direito. "Todos os signos dessas ideias o cercam, o tocam, o pressionam, por assim dizer, mas inutilmente; pois o signo só pode excitar uma ideia preexistente." 68

Ademais, os próprios animais tomados separadamente do homem "fornecem um outro argumento direto e decisivo" na defesa das ideias inatas (e, poder-se-ia dizer, à guisa do neoplatônico Cudworth, de um "sistema intelectual" ou divino do mundo). Pois Maistre sugere que os instintos entre os animais são inatos "ao pé da letra, vale dizer, absolutamente independentes da experiência". A natureza exibe todos os dias os exemplos das diferentes espécies de animais que reagem instintivamente e independente da experiência individual de cada ser ante determinados fenômenos. A jovem "galinha" que, por exemplo, "jamais viu o gavião manifesta, contudo, todos os signos do terror no momento em que o mesmo se lhe depara pela primeira vez". ${ }^{69} \mathrm{Ou}$ seja, apesar de o instinto animal, como resposta característica de uma espécie, depender da experiência para se manifestar, ele não é formalmente derivado da mesma. E se esta observação repete-se invariavelmente em todas as espécies de animais, por que a experiência seria mais necessária ao homem no tocante a todas as ideias necessárias que o tornam humano?

Portanto, além de reduzir a inteligência humana a um mecanismo cujas engrenagens poderiam ser expostas como uma máquina, a epistemologia de Locke culminava, segundo Maistre, na eliminação lógica de quaquer barreira entre a humanidade e o restante do mundo animal. E isto mesmo sob o estrito ângulo materialnaturalista da própria biologia, pois ao pressupor que o espírito humano forma raciocínios complexos a partir das ideias simples que lhe são fornecidas pelos sentidos, Locke era forçado a admitir em seu célebre Ensaio que, em última análise, aquilo que designamos como geral ou universal nada mais é do que uma solução arbitrária de um entendimento individual que, limitado a um certo número de ideias sobre o real, é incapaz de afirmar a realidade absoluta da natureza (e, por consequinte, a validade da classificação científica em espécies).

\footnotetext{
${ }^{68}$ J. de Maistre, Soirées, O.C., IV: 249 ( $\mathrm{V}^{\mathrm{e}}$ Entretien).

${ }^{69}$ J. de Maistre, Soirées, O.C., IV: 251 ( $\mathrm{V}^{\mathrm{e}}$ Entretien).
} 
Na contramão da epistemologia sensualista (e individualista) de Locke, a teoria maistreana das ideias inatas aborda a natureza como uma ordem real que o intelecto humano apreende (ou melhor, reconhece) ativamente através de sua capacidade (inata) de derivar o universal do particular. Assim como o homem não compreende a ideia do triângulo a não ser pela ideia inata da triangulidade que se atualiza mediante a observação concreta do mesmo, ele também não poderia valorar um determinado ato como justo ou injusto se não possuísse aquelas noções em caráter inato. ${ }^{70} \mathrm{Em}$ sua crença de que não é possível reconhecer nenhuma ordem universalmente válida, a epistemologia sensualista de Locke deixava o espírito humano literalmente à deriva ou, melhor, suscetível ao arbítrio de quem (indivíduo ou grupo) se mostrasse mais competente na persuação ou imposição de suas próprias ideias à coletividade, já que o real enquanto tal não passa de um produto das combinações aleatórias de nossas ideias.

E tão importante quanto Platão, Aristóteles, são Tomás e Leibniz para a formulação da teoria maistreana das ideias inatas, foi a figura de Ralph Cudworth, cujo pensamento sugeriu a possibilidade de conciliar - sem prejuízo lógico às convicções cristãs do saboiano - os princípios aristotélicos ao platonismo na defesa racional do inatismo. Como destacou Marc Froidefont em seu recente estudo, o contrarrevolucionário saboiano encontrou na leitura do neoplatônico de Cambridge três pressupostos fundamentais para sua defesa das ideias inatas, na ordem: 1. que as ideias inatas diferenciam os homens dos animais; 2. que elas não devem ser confundidas com determinados juízos ou afirmações particulares (de um indivíduo ou uma coletividade); 3. que não se compreende o caráter eminentemente ativo do intelecto humano a não ser por meio delas (isto é, "o espírito não deve ser preenchido do exterior como um recipiente, mas antes excitado e despertado" pelos sentidos, pontuou Cudworth citando uma passagem de $O$ Banquete de Platão). ${ }^{71}$ Não por acaso, o próprio Maistre expressou claramente esta influência no sexto diálogo das Soirées, ao comentar a seguinte

\footnotetext{
${ }^{70}$ Como a parábola maistreana sobre dois bandidos que decidem compartilhar "justamente" o resultado de seu crime deixa claro: "As leis da justiça e do belo natural estão impressas em nossas almas em caracteres indeléveis, e o mais abominável celerado invoca-as diariamente. Observai esses dois bandidos que esperam o viajante na floresta; eles o massacram e o despojam: um toma-lhe o relógio, o outro, a caixa, mas a mesma está repleta de diamantes: 'isto não é justo!', exclama o primeiro; 'é preciso partilhar igualmente'. Ó divina consciência, tua voz não cessa de ser ouvida: ela sempre nos fará ruborizar daquilo que somos; sempre nos advertirá daquilo que poderíamos ser." Cf. Joseph de Maistre, De l'état de nature, O.C., VII: 565.

${ }^{71}$ Marc Froidefont, Théologie de Joseph de Maistre (Paris: Classiques Garnier, 2010), p. 97. Vide Soirées, O.C., IV: 357 ( $\mathrm{VI}^{\mathrm{e}}$ Entretien), em que Maistre sintetiza sua teoria sobre as ideias inatas precisamente nos mesmos termos.
} 
passagem do The True Intellectual System ("O Verdadeiro Sistema Intelectual do Universo, 1671) de Cudworth:

"Li que o célebre Cudworth, discutindo... com um de seus amigos sobre a origem das ideias, disse-lhe: Por favor, tome o primeiro livro de minha biblioteca que se apresentar à sua mão e abra-o ao acaso; a escolha do amigo recai sobre o começo do primeiro livro dos Ofícios de Cícero: AINDA QUE, após um ano, etc. - É o bastante, retomou Cudworth; tenha a generosidade de me dizer como você pôde adquirir pelos sentidos a ideia de AINDA QUE. O argumento era excelente sob uma forma bastante simples: o homem não pode falar, não pode articular o menor elemento de seu pensamento, não pode dizer $E$ sem refutar Locke." 72

Portanto, se "o desprezo de Locke" representava para o contrarrevolucionário saboiano "o começo da sabedoria"73, isto se dava pelo fato de o filósofo inglês haver "aprisionado" (e Maistre fazia um sardônico trocadilho com o nome do autor do Ensaio para classificar este encarceramento espiritual: Locked Fast-in) ${ }^{74}$ o espírito dos franceses na matéria, ou melhor, por havê-los feito esquecer que "tudo fora feito por e para a inteligência; que todo movimento é um efeito, de modo que a causa propriamente dita de um movimento não pode ser um movimento ${ }^{75}$; que as palavras causa e matéria excluem-se mutuamente como o círculo e o triângulo, e que tudo deste mundo que nós vemos se relaciona com um outro mundo que não vemos", uma vez que "vivemos, de fato, em meio a um sistema de coisas invisiveis manifestadas visivelmente". ${ }^{76}$

Importa salientar, assim como fizera Richard Lebrun, que "a teoria epistemológica exposta por Maistre nas Soirées encontra-se no contexto de uma discussão mais geral sobre a utilidade da oração", de sua eficácia como "causa secundária" no interior de uma ordem cósmica transcendente. Diante dos desdobramentos materialistas e fatalistas da epistemologia lockeana no campo moral, a defesa das ideias inatas por meio da demonstração da fixidez e da hirarquia entre as espécies apresentava a vantagem de sustentar lógica e racionalmente ao cético e sensualista leitor pós-revolucionário que

\footnotetext{
${ }^{72}$ J. de Maistre, Soirées, O.C., IV: 358 (VI ${ }^{\mathrm{e}}$ Entretien).

${ }^{73}$ J. de Maistre, Soirées, O.C., IV: 380 (VI ${ }^{\mathrm{e}}$ Entretien).

74 J. de Maistre, Soirées, O.C., IV: 364 (VI ${ }^{\mathrm{e}}$ Entretien).

75 Trata-se de uma citação da Summa contra Gentiles de são Tomás de Aquino. Cf. Joseph de Maistre, Soirées, O.C., V: 178.

${ }^{76}$ J. de Maistre, Soirées, O.C., V: 178-179 ( $\mathrm{X}^{\mathrm{e}}$ Entretien).
} 
aquilo que apreendemos como o mundo material e visível é apenas uma parte ínfima (e marginal) da realidade, cujos conteúdo e origem são transcendentais. ${ }^{77}$

Nossas ideias inatas são os primeiros princípios de nosso conhecimento que, por sua vez, é determinado por nossa natureza e por nossa posição no universo. Elas determinam a extensão possível de nosso conhecimento e fundamentam nosso caráter perfectível, mas não nos franqueiam o conhecimento pleno do universo e do ser. Assim como os animais são "cercados, tocados e premidos por todos os signos da inteligência" sem a menor compreensão de sua significação, nós também podemos ser "cercados, tocados e premidos pelas ações e agentes de uma ordem superior da qual não possuímos outro conhecimento a não ser aquele que se relaciona com a nossa situação atual". ${ }^{78}$ No entanto, Maistre destaca aos leitores das Soirées a profunda diferença existente entre as duas situações, e a qual consiste do fato de que o homem, à diferença do cão (que "não sabe que não sabe"), detém o "sublime privilégio" de saber que não sabe e de se inquietar por isto. ${ }^{79}$

Esta dúvida ou inquietação inata constitui, segundo Maistre, a prova do status ontológico privilegiado da humanidade que, por ser feita "à imagem de Deus", é suscetível de aperfeiçoamento (através dos atos de seu livre-arbítrio) em razão de sua relação de semelhança com a inteligência divina. Após advertir para o erro envolvido no fato de o homem emprestar os atributos e paixões humanas à inteligência divina, Maistre sublinha que um erro muito maior consiste em suprimir qualquer traço daquela semelhança na consideração de sua própria natureza, razão pela qual aconselha seu leitor a não se deixar "seduzir pelas teorias modernas sobre a imensidão de Deus..., belas frases que não tendem a exaltar Deus, mas a degradar o homem." Assim, se o homem reina absoluto sobre a terra mesmo após sua degradação pelo pecado original, se domina e transforma todos os elementos da natureza para o seu usufruto, não é por outra razão senão pelo fato de que "é semelhante a Deus", semelhança esta lógica e historicamente comprovada pela mediação de Cristo, o "Homem-Deus" que, ao unir sua natureza divina à humana, demonstrou que as "inteligências não podem diferir entre si a não ser em perfeições". 80

$\mathrm{Na}$ contramão do que fizeram Bacon e Kant, para quem a ideia de Deus era absolutamente inacessível à razão humana, que deveria se limitar à investigação dos

\footnotetext{
${ }^{77}$ R. Lebrun, "L'Epistemologie Maistrienne: Rationalité et Connaissance Transcendante", p. 233.

${ }^{78} \mathrm{~J}$. de Maistre, Soirées, O.C., IV: 253-254 ( $\mathrm{V}^{\mathrm{e}}$ Entretien).

${ }^{79}$ J. de Maistre, Soirées, O.C., IV: 250 ( $\mathrm{V}^{\mathrm{e}}$ Entretien).

${ }^{80}$ J. de Maistre, Soirées, O.C., IV: 200-202 (IV Entretien).
} 
fenômenos naturais ${ }^{81}$, Maistre insistiu em vincular a crença numa realidade transcendente à razão. Diante da conclusão do protestante Bacon, segundo o qual era preciso "dar à fé o que pertence à fé", o contrarrevolucionário saboiano advertiu que:

"Sustentar que não se possui nenhuma ideia de Deus porque não se tem uma ideia perfeita dele, e que é absolutamente a mesma coisa ignorar o que ele é ou se ele existe, constitui não apenas uma blasfêmia contra o próprio Deus, mas uma blasfêmia contra o bom-senso. Resultaria disso que não temos ideia sobre nada, posto que não existe nada cuja essência nos seja perfeitamente conhecida; e certamente conhecemos bem menos a matéria do que o espírito./ Os filósofos que, a exemplo de Bacon..., apelam unicamente à Escritura santa [para demonstrar a religião], acreditam dizer alguma coisa quando nada dizem. O que é a revelação? É um ensinamento divino. O que é um ensinamento humano? É uma revelação humana. Um teorema matemático demonstrado àquele que o ignora é uma revelação. Ora, como aprender o que não se sabe a não ser em virtude daquilo que já se sabe?" 82

Crítico dos que "fizeram da ciência uma espécie de monopólio" e pretendiam que não se soubesse "mais ou diferentemente do que eles" ${ }^{83}$, Maistre, em que pese sua sincera militância ultramontana, era acima de tudo um homem de notáveis curiosidade e habilidade intelectual que o levavam a querer compreender e investigar tudo o que fosse possível, razão pela qual impacientava-se com os limites da ortodoxia católica de seu tempo, como seu histórico maçônico deixou evidente.

Isto posto, o aspecto mais marcante de seu pensamento, a defesa da autoridade pontifical, amparava-se em grande medida sobre razões epistemológicas. Como ele próprio expressou numa missiva a respeito de controvérsias bíblicas, somente uma "autoridade visível e infalível" seria capaz de estabelecer metafisicamente uma crença comum, uma vez que nenhum julgamento individual lograria se impor sobre os demais. $^{84}$

Todavia, por mais que o método apologético de Maistre tenha algumas semelhanças tópicas com o tradicionalismo enunciado por autores como Louis de Bonald (1754-1840) e Félicité de Lammenais (1782-1854), importa sublinhar, na esteira do que fizeram respectivamente R. Lebrun e Jean-Yves Pranchère, que a posição

81 J. de Maistre, Examen, O.C., VI: 262; e Observations sur le Prospectus Disciplinarum de Fessler (1809), O.C., VIII: 241.

${ }^{82}$ J. de Maistre, Examen, O.C., VI: 264-265.

${ }^{83}$ J. de Maistre, Soirées, O.C., V: 238 (IV Entretien).

${ }^{84} \mathrm{~J}$. de Maistre, O.C., XII: 460. 
tradicionalista maistreana possuía fundamentos distintos daqueles avançados por seus correspondentes franceses. Se Maistre, a exemplo de Bonald e Lamennais, inquietava-se com os "abusos" da razão individual e insistia no papel inevitável da autoridade no estabelecimento e defesa das convicções religiosas e políticas, defendendo assim "as crenças e tradições estabelecidas", o mesmo, no entanto, tomava distância da argumentação tradicionalista que, ao não deixar nenhum espaço para a certeza racional e amparar a defesa da tradição unicamente na fé, corria o risco de incorrer numa postura fideísta que, além de guardar estreitas semelhanças com o protestantismo de Lutero, reforçava o argumento epistemológico ilustrado contra a religião revelada e a tradição. Não por acaso, quando Lammenais publicou o segundo volume de seu Essai sur l'indifférence en matière de religion (Ensaio sobre a indiferença em matéria de religião, 1817-1823), Maistre advertiu o jovem religioso precisamente sobre este ponto: ao elogiar o Traité philosophique de la foiblesse de l'esprit humain (Tratado filosófico sobre a fraqueza do espírito humano, publicado postumamente, em Amsterdam, no ano de 1723) do célebre teólogo Pierre-Daniel Huet (1630-1721), Lammenais esquecera-se de que Voltaire apoiara-se nos argumentos do mesmo autor para refutar sua demonstração evangélica. ${ }^{85} \mathrm{Um}$ pouco antes, mais especificamente no segundo diálogo das Soirées, Maistre avançou uma sutil crítica a Bonald ${ }^{86}$ pelo fato de o mesmo, no "Discurso preliminar" de sua Législation primitive (Legislação primitiva, 1802), haver negado as ideias inatas quase que nos mesmos termos do tradutor francês de Bacon. ${ }^{87}$

Curiosamente, a visão fideísta do tradicionalismo francês - para quem a razão humana seria incapaz de conhecer o que quer que fosse além daquilo que lhe foi ensinado por Deus através de uma revelação primitiva, e da qual a Igreja católica era a única depositária - atraiu a condenação do Concílio do Vaticano I (1869-1870) quase que nos mesmos termos das advertências de Maistre, isto é, enfatizando os perigos envolvidos naquela radical negação da racionalidade humana na defesa da tradição, negação esta que alcançava, ainda que pela via contrária, o mesmo desígnio da epistemologia ilustrada, a separação da fé com a razão.

E como bem destacara R. Lebrun, na medida em que a teoria das ideias inatas implicava no reconhecimento da razão individual como sede da verdade e último juiz da

${ }^{85}$ J. de Maistre, Carta de 6 de setembro de 1820, O.C., XIV: 236.

${ }^{86}$ Além do tradicionalismo de Bonald suprimir qualquer vínculo entre a fé e a razão, o mesmo, como bem pontuou Gegembre, não raro avançou proposições galicanas (igualmente condenado no Concílio do Vaticano I) na defesa da monarquia. Cf. Gerard Gengembre, La Contre-Révolution ou l'histoire désespérante (Paris: Imago, 2001), p. 145 (nota 49).

${ }^{87} \mathrm{~J}$. de Maistre, Soirées, O.C., IV: 121 (II ${ }^{\mathrm{e}}$ Entretien). 
evidência, a tradição não podia ser o único critério da verdade no sistema epistemológico maistreano, ou melhor, não podia vir desacompanhada da razão ${ }^{88}$, pois, como não se cansou de lembrar o saboiano, desde que se separa a fé da razão, "a revelação, não podendo mais ser provada, não prova mais nada", razão pela qual repetia "o axioma tão conhecido de são Paulo: Que a fé é justificada pela razão". 89

Em sua condenação às filosofias de Bacon, Locke e Kant, Maistre não havia deplorado o procedimento epistêmico moderno que consiste em fazer da "teologia uma ciência abrupta..., isto é, uma ciência separada de todas as outras, e que não conserva nada da raiz-materna; uma ciência que, por consequinte, não tem nada em comum com a razão e repousa inteiramente sobre a autoridade" ${ }^{90}$ Por mais que a teologia e a religião repousem sobre a autoridade, como esta última poderia prescindir da razão que informa justamente a autoridade certa a que devemos nos submeter?

A respeito desta relação dialética entre fé e razão no interior da epistemologia maistreana, bem como do considerável mérito representado pelo incomum recurso ao tomismo pelo saboiano, Richard Lebrun observou que:

"Poder-se-ia sugerir também que a epistemologia maistreana, como a epistemologia neotomista, desenvolveu-se para servir a fins bem práticos. Em face do racionalismo do século XVIII, ambos ofereciam um meio de preservar a razão e a autoridade clerical. De acordo com ambas as teorias, é teoricamente possível para a razão humana conhecer Deus e seus principais atributos, bem como as implicações gerais de tal conhecimento para a moralidade humana. Mas dadas as fraquezas humanas, a revelação divina permanece sempre necessária para que a maior parte da humanidade adquira um conhecimento suficiente de Deus e da lei moral. E a autoridade da Igreja é necessária para fornecer uma interpretação segura da revelação." 91

Portanto, mais do que a razão em si, o que Maistre recusa é o filosofismo ("a razão que marcha completamente só") ${ }^{92}$, cuja pretensão de ser o guia absoluto da vida ignora o fato de que a razão é impotente, por si só, para organizar o todo da existência humana, dada sua incapacidade de determinar o coração do homem. ${ }^{93}$ Uma vez que o homem não se define somente pela razão mas também e sobretudo pelo coração (ou

\footnotetext{
${ }^{88}$ R. Lebrun, "L'Epistemologie Maistrienne: Rationalité et Connaissance Transcendante", p. 236.

${ }^{89}$ J. de Maistre, Examen, O.C., VI: 270.

${ }^{90} \mathrm{~J}$. de Maistre, Examen, O.C., VI: 256.

${ }^{91}$ R. Lebrun, "L'Epistemologie Maistrienne: Rationalité et Connaissance Transcendante", p. 241.

92 J. de Maistre, Sur les délais de la justice divine, O.C., V: 446 nota I.

93 J. de Maistre, Soirées, O.C., V: 152, nota III (IX ${ }^{\mathrm{e}}$ Entretien).
} 
vontade), o autor das Soirées concluía que o moderno projeto ilustrado de afirmar uma absoluta autonomia da razão humana não apenas produziria um coração "endurecido pelo orgulho e por uma filosofia glacial" ${ }^{94}$, como seria incapaz de se fazer obedecer entre homens, pois não existe busca sincera pela verdade sem uma vontade orientada pelos preceitos da boa-fé (e, por conseguinte, da religião).

Conforme sublinhou Jean-Yves Pranchère a respeito do papel reservado à razão no "sistema da autoridade" de Maistre, se na perspectiva lógica do saboiano a razão antecede a fé na autoridade religiosa, nas perpectivas ontolológica e psicológica, pelo contrário, "a fé na autoridade vem em primeiro lugar, pois é pela graça da fé que o homem adquire a boa vontade que o torna capaz de aprender e de compreender racionalmente". ${ }^{95}$ Ou seja, se Maistre, por um lado, afirmava - naquilo que poderia ser visto como um excesso de racionalismo - que o "objetivo da revelação não é outro senão o de fazer com que o espírito humano leia em si próprio o que a mão divina escreveu nele", de modo que "a revelação seria nula se, após o ensinamento divino, a razão não fosse capaz de demonstrar as verdades reveladas a si própria" ${ }^{96}$, por outro, o autor das Soirées admitia que a "autoridade" é a "âncora" ou "regra" que nos "protege de todos os erros" da razão individual e da vontade extraviada. ${ }^{97}$

$\mathrm{E}$ ao vincular sua apologética cristã à defesa racionalista ${ }^{98}$ das ideias inatas, Maistre antecipava em suas linhas principais aquela que, mediante o I Concílio do Vaticano, se tornaria a doutrina oficial da Igreja Católica para as complexas relações entre a "Fé e a Razão". Como indica o IV capítulo da terceira sessão (celebrada em 24/04/1870) conciliar:

"Não só não pode jamais haver desarmonia entre fé e a razão, mas uma serve de auxílio à outra, visto que a reta razão demonstra os fundamentos da fé, e cultiva, iluminada com a luz desta, a ciência das coisas divinas; e a fé livra e guarda a razão dos erros, enriquecendo-a de múltiplos conhecimentos. Por isso a Igreja, longe de se opor ao cultivo das artes e das ciências humanas, até as auxilia e promove de muitos modos. Porquanto não ignora nem despreza as vantagens que delas dimanam para a vida humana; pelo contrário, ensina que, derivando elas de Deus, o Senhor das ciências [1 Rs 2,3], se forem bem empregadas, conduzem para Deus, com o auxílio de sua graça. Nem proíbe [a Igreja] que tais disciplinas, dentro de seu respectivo âmbito,

\footnotetext{
${ }^{94}$ J. de Maistre, Soirées, O.C., V: 137 (IX Entretien).

95 Jean-Yves Pranchère, L'autorité contre les Lumières..., p. 315.

96 Joseph de Maistre, Examen, O.C., VI: 268-269.

${ }^{97}$ J. de Maistre, Soirées, O.C., IV: 48 (I Entretien).

${ }^{98}$ Jean-Yves Pranchère, L'autorité contre les Lumières..., p. 312.
} 
façam uso de seus princípios e métodos próprios; mas, reconhecendo embora esta justa liberdade, admoesta cuidadosamente que não admitam em si erros contrários à doutrina de Deus ou ultrapassem os próprios limites, invadindo e perturbando o que é do domínio da fé." 99

Como tudo o que diz respeito a Maistre, também o exame mais detalhado de sua epistemologia revela um autor muito mais complexo do que aquele dogmático tradicionalista retratado pelos cânones tradicionais da história das ideias. É bem verdade que a virulência de sua retórica conservadora permanece fora de questão - e neste ponto, cumpre repeti-lo, Maistre não fez mais senão reproduzir boa parte dos mecanismos retóricos do ilustrado Voltaire -, mas quando se trata de considerar o conteúdo de seu tradicionalismo, as coisas mudam completamente de figura, a ponto de ser impossível negar-lhe um substrato racionalista, ainda que ambivalente.

Para encerrar, e diante dessa dificuldade em que se depara o crítico do contrarrevolucionário saboiano para classificar seu sistema epistemológico, valeria a pena reproduzir a opinião de dois especialistas maistreanos sobre o tema.

De acordo com R. Lebrun, Maistre poderia ser considerado um autor racionalista "se entendermos por racionalismo a 'doutrina segundo a qual tudo o que existe tem sua razão de ser e pode, portanto, ser considerado como inteligível', ou a 'doutrina segundo a qual todo conhecimento vem da razão (em oposição ao empirismo)'." Por outro lado, o mesmo lembrou que "se entendermos por racionalismo a 'crença e confiança na razão, no conhecimento natural (oposto ao misticismo e à revelação religiosa)', a questão não será mais tão clara". Isto posto, o historiador norte-americano optou por concluir que a teoria maistreana "é tão racional e razoável quanto as teorias concorrentes de sua época." E para reforçar seu ponto de vista, ele destacou que a teoria das ideias inatas fora retomada com êxito pelo filósofo e linguista norte-americano Noam Chomsky para explicar a capacidade humana de adquirir e fazer uso da linguagem. ${ }^{100}$

Quanto ao filósofo francês Jean-Yves Pranchère, em que pese o caráter mais pormenorizado de sua abordagem e o tom predominantemente crítico à figura de Maistre, pode-se concluir que ele adotou uma posição semelhante daquela avançada por seu colega e historiador norte-americano. Segundo ele:

\footnotetext{
${ }^{99}$ Concílio do Vaticano I, "Constituição Dogmática Sobre A Fé Católica", cap. IV ("A Fé e a Razão").

${ }^{100}$ Richard Lebrun, "L'Epistemologie Maistrienne...", p. 236-237.
} 
"Em vista da insuficiência da elaboração racional de sua filosofia, é difícil considerar Maistre como seriamente racionalista. Todavia, esta insuficiência não permite negar que Maistre professa um racionalismo. Esse racionalismo pode ser racionalmente deficiente e ideológico, mas não repousa menos sobre a tese da evidência dos princípios da razão... Maistre não é um racionalista no sentido da Ilustração, contra a qual ele não cessa de afirmar os direitos da fé e da autoridade... Mas ele se quer como um racionalista na medida em que reconhece na razão uma fonte de certeza. Alguém dirá que Descartes não era racionalista porque ele reverenciava sem exame racional as verdades da fé 'sempre primárias em sua crença' ou porque ele sustentou que a liberdade da vontade era tal que ela podia refutar as evidências da razão? Esta última tese é precisamente aquela de Maistre, razão pela qual, a seus olhos, a razão necessita ser fortalecida pela fé." ${ }^{101}$

Com efeito, longe de negar a importância da ciência para a humanidade ${ }^{102}$, Maistre pretendia refutar a pretensão de Locke (e de seus discípulos franceses) que consistia em aplicar um critério epistemológico reconhecidamente limitado a todas as esferas da vida humana (sobretudo a espiritual). Fundamentalmente, o contrarrevolucionário saboiano advertia sobre os riscos envolvidos na pretendida separação da fé com a razão no interior do projeto iluminista, e a qual arriscava produzir o paradoxal efeito de promover um imenso progresso técnico-científico na mesma proporção em que reduzia a esfera da razão essencial da humanidade, tornando-a cada vez mais inábil para as complexas decisões prudenciais/racionais relativas à existência moral e política da sociedade e, portanto, comprometendo sua autonomia e liberdade. $\mathrm{O}$ resultado dessa separação, ou melhor, da completa emancipação da ciência dos pressupostos éticos e morais que devem reger a condição humana, não poderia ser outro senão a paradoxal "estupidificação" ou "embrutecimento" pela ciência. ${ }^{103}$

Não por acaso, Adorno e Horkheimer referiram-se ao contrarrevolucionário saboiano ao analisarem a "dialética do Esclarecimento", reconhecendo na crítica maistreana à Ilustração - ainda que descartando suas conclusões autoritárias - alguns pontos de extrema lucidez. Concluíram que ao se realizarem, os ideais racionais de

${ }^{101}$ Jean-Yves Pranchère, L'autorité contre les Lumières..., p. 314.

102 Neste sentido, discordamos da posição de Pranchère, para quem a crítica epistemológica maistreana culminava numa completa negação do empirismo. Como acabamos de demonstrar, a intenção de Maistre era menos a de combater o empirismo em si do que a má-aplicação ou os abusos do mesmo, conforme sua assimilação das premissas 'materialistas' de Aristóteles confirmam. Cf. Jean-Yves Pranchère, L'autorité contre les Lumières: la philosophie de Joseph de Maistre (Genève: Droz, 2004), p. 300.

103 J. de Maistre, Examen de la philosophie de Bacon, O.C., VI:41 e Essai sur le principe générateur..., capítulo XXXIX. 
emancipação produziram sua própria negação, revertendo-se, na sociedade burguesaindustrial, numa mitologia científica reprodutora da reificação e alienação humanas, de modo que "o terror e a civilização são inseparáveis". ${ }^{104} \mathrm{O}$ progresso da razão instrumental - expressada pela hipertrofia da pedagogia técnico-científica -, a serviço dos processos reprodutores do sistema capitalista, não teria refinado as técnicas de dominação social e recrudescido o processo desumanizador e reificador do capitalismo, processo este verificado em todas as esferas da vida, do trabalho à clínica hospitalar?

${ }^{104}$ M. Horkheimer e T. Adorno, La dialectique de la Raison (1944). Trad. francesa de E. Kaufholz (Paris: Gallimard, 1983), p. 100 e 228. 


\section{PARTE}

UM SABOIANO ULTRAMONTANO 


\section{CAPÍTULO 7}

\section{Sob o signo da dualidade: Joseph de Maistre e a Casa da Saboia na 'Era da Revolução Democrática',}

A cinco dias de seu falecimento, o contrarrevolucionário saboiano Joseph de Maistre (1753-1821) fez a seguinte pergunta: "somos ou não [somos] italianos? Ao passo que em Florença somos chamados de nação anfíbia, ou enquanto por aqui dissermos 'chegou o correio da Itália?', viverei sempre com a mesma dúvida." ${ }^{2}$

Nos quadros de celebração do sesquicentenário da independência e da unificação italiana, gostaríamos de destacar algumas das circunstâncias históricas específicas responsáveis pelo paradoxal desfecho do processo de unificação da península itálica, cuja liderança coube a uma monarquia absolutista provinciana e de origem estrangeira (partindo da periferia para o centro, portanto). Paralelamente, buscaremos reconstituir a maneira pela qual, na era da revolução democrática ${ }^{3}$, os conceitos de nacionalidade e patriotismo articulavam-se no pensamento do contrarrevolucionário saboiano Joseph de Maistre.

Nosso relato tem início na segunda metade do século XV, a qual coincide com fim da 'era de ouro' do Renascimento italiano, quando as ricas cidades do centro e do norte da península italiana foram incapazes de sustentar suas liberdades frente aos novos e poderosos inimigos, as monarquias absolutistas estrangeiras (mormente França e Espanha).

Mais ou menos no mesmo período em que as repúblicas perdiam suas liberdades (como Florença) e/ou eram obrigadas a se retrair numa política oligárquica conservadora para sobreviver (Gênova, Luca e Veneza), o ducado da Saboia tornava-se uma exceção entre as monarquias europeias, as quais ainda enfrentavam suas nobrezas recalcitrantes no processo de centralização. Apesar do acréscimo do poder monárquico no seu conjunto - exércitos (permanentes) mais fortes, maiores facilidades financeiras,

\footnotetext{
${ }^{1}$ Este capítulo foi publicado sob a forma de artigo na Revista Almanack (n $n^{\circ}$ /novembro de 2012), com o apoio da bolsa de Doutorado concedida pela Fundação de Amparo à Pesquisa do Estado de São Paulo (FAPESP).

2 Joseph de Maistre, "Lettre A M. le Marquis D’Azeglio", 21/02/1821, in: OC XIV: 258-259.

${ }^{3}$ Robert Palmer, The Age of the Democratic Revolution: The Challenge (Princeton: Princeton University Press, 1959).
} 
uma organização administrativa mais eficaz e um controle mais estreito sobre a igreja nacional -, importa salientar, como fez J. H. Elliott, que "o monarca do século dezesseis era, apesar de tudo, pouco mais do que um primus inter pares." Contudo, para Manuel Felisberto da Saboia, "testa de ferro" de Filipe II e responsável pela vitória do exército espanhol sobre as tropas francesas de Henrique II na batalha de Saint-Quentin (1557), em Flandres, as condições eram diferentes: herdeiro de um Estado destruído e "estando as classes dirigentes desintegradas e desmoralizadas após meio século de ocupação estrangeira, não havia alternativa para uma política radical de reconstrução do Estado, pessoalmente dirigida por um duque absolutista. Mas o Piemonte era uma exceção".

O tratado de Cateau-Cambrésis (responsável pela transferência da capital do ducado de Chambéry, na Saboia, para Turim), de 1559, e as fracassadas políticas expansionistas à oeste do seu sucessor, Carlo Emanuele I, orientaram definitivamente a política expansionista dos duques para a península itálica, a despeito das origens francesas (ou melhor, borgonhesas) do ducado. No final do século XVII e início do XVIII - isto é, após nova invasão francesa de 1690 sob a égide do "rei sol" -, o liame orgânico que ligava o Estado piemontês com seus súditos francófilos saboianos arriscava ser rompido, como testemunharam os comandantes e oficiais de ocupação franceses entre 1690 e 1703, recebidos e aclamados em Chambéry como "libertadores". Como todas as iniciativas dos duques dirigiam-se para os domínios da Itália, os observadores diplomáticos estrangeiros descreviam a Itália como uma alcachofra que os duques da Saboia devoravam folha por folha. ${ }^{5}$

Como destacou Perry Anderson, “o avanço rumo ao absolutismo centralizado foi decisivamente concluído por Vittorio Amadeo II, no início do século XVIII. Uma habilidosa mudança de lados na Guerra da Sucessão Espanhola, da França para a Áustria, garantiu aos duques da Saboia, através do Tratado de Utrecht (1713), o condado de Montserrat e a ilha da Sardenha, e o reconhecimento europeu de sua elevação de ducado para monarquia, que passou a se chamar reino do PiemonteSardenha. Sinuoso na guerra, Vittorio Amadeo usou a paz que se seguiu para instalar uma severa administração copiada à de Colbert, onde não faltavam sequer um Conselho e um sistema de intendants. Ele então desenfeudou amplas faixas de terras da nobreza

\footnotetext{
${ }^{4}$ J. H. Elliott, A Europa Dividida: 1559-1598 (Lisboa: Editorial Presença, 1985), p. 55-7.

${ }^{5}$ Conforme célebre e nada diplomática "boutade" proferida pelo embaixador francês, Charles de Brosses, nos anos 1740: a Itália era como uma "alcachofra" que a Casa de Sabóia devorava "folha a folha. Jean Nicolas, La Savoie au XVIII siècle: noblesse et bourgeoisie (Montmélian: La Fontaine de Siloé, 2003),p. 626-7.
} 
com o recurso a um novo registro cadastral, aumentando desse modo as receitas fiscais, já que os domínios alodiais estavam sujeitos a impostos; construiu um amplo aparelho diplomático e militar ao qual se integrou a aristocracia, extinguiu as imunidades do clero e subordinou a Igreja."

Não obstante o enquadramento e cerceamento da nobreza feudal, a auto-imagem que a monarquia fazia de si persistiu sendo feudal. A este respeito, Jean Nicolas pontuou o seguinte:

"Com efeito, situada no cume de uma hierarquia única, a monarquia piemontesa-sarda coroava uma estrutura nobiliárquica centralizada, ampliada a partir de então pelas elites plebeias cujos membros eram absorvidos um a um e transformados em células de execução do sistema administrativo e político. Como na Prússia de Frederico, no Piemonte o serviço civil desenvolvia-se 'segundo uma concepção feudal da função pública' e num espírito de completa lealdade em relação ao soberano." 7

Especialistas como Jean Nicolas e Stuart Woolf sublinharam o fato de que a monarquia savoiarda, à diferença da francesa - onde, na bela definição de Boris Porchnev, a burguesia fazia um jogo de "cabra-cega" com a monarquia ${ }^{8}$-, $\operatorname{lograva}$ amortecer os conflitos entre as diferentes ordens ao acomodá-las em seu grande regaço burocrático, num processo que culminava na formação de uma ética comum ("funcionalismo") entre os membros daquela elite.

Segundo Stuart Woolf, essas reformas de caráter "prussiano" produziram um duplo efeito: por um lado, fizeram do reino subalpino "o mais eficientemente organizado, burocrático-militarista Estado da Itália, com uma genuína tradição de lealdade para com a dinastia entre as classes dominantes", por outro (e, curiosamente, devido ao êxito das mesmas), impermeabilizaram o Estado para o surgimento de uma classe intelectual independente e crítica. ${ }^{9}$

Este último aspecto levou Antonio Gramsci a comparar o papel desempenhado pelo reino do Piemonte-Sardenha na unificação italiana ao de um moderno "partido",

\footnotetext{
${ }^{6}$ Perry Anderson, Linhagens do Estado Absolutista (São Paulo: Brasiliense, 2004), $3^{\mathrm{a}}$ edição, p. 171-172.

${ }^{7}$ Jean Nicolas, La Savoie au XVIII siècle: noblesse et bourgeoisie (Montmélian: La Fontaine de Siloé, 2003), p. 596.

${ }^{8}$ Boris Porchnev, Les soulèvements populaires en France au XVII siècle (Paris: Flammarion, 1972), p. 399.

${ }^{9}$ Stuart Woolf, A History of Italy 1700-1860. The Social Constraints of Political Change (New York: Routledge, 1991), p. 68.
} 
sem o qual não se compreende o caráter "passivo" da Revolução/Unificação italiana. ${ }^{10}$ Dadas as condições da península itálica após a Revolução Francesa de 1789 e o período napoleônico (período marcado pela pulverização das reminiscências republicanas medievais e dos pequenos ducados), só a monarquia saboiana dispunha da "base lógica" para a unificação, pois só ela fora capaz de desenvolver na península um verdadeiro absolutismo nativo claramente alicerçado numa nobreza feudal, numa formação social dominada pela aristocracia. O fato da Casa da Saboia, na era das revoluções burguesas $^{11}$, dispor de um exército e de uma diplomacia independentes e bem consolidadas, não seria de menor relevância para seu futuro papel histórico de condutor da unificação da península itálica.

A história do conde saboiano Joseph de Maistre após a Revolução de 1789 mais do que confirma esta excepcionalidade piemontesa: não seria incorreto dizer que Maistre nasceu e viveu sob o signo da dualidade: primeiramente, uma dualidade cultural e social, e, por outro lado, uma dualidade geopolítica.

Maistre nasceu, se formou e ultrapassou o "mezzo del cammin" de sua vida (39 anos) em Chambéry, quando foi atingido em cheio pela invasão das tropas revolucionárias francesas na Saboia (setembro de 1792).

Com efeito, por sua origem e meio social, Maistre era burguês e nobre a um só tempo: membro do senado local e, portanto, pertencente à nobreza de toga saboiana, a nobilitação de sua família foi a coroação de um longo esforço de ascensão social de uma casa de comerciantes de tecidos da província de Nice. Paradoxalmente, um olhar mais atento sobre a biografia de Maistre mostrará que a chave para a explicação do contrarrevolucionário e fiel súdito do rei do Piemonte-Sardenha está justamente nesta origem 'burguesa' do mesmo, e não o contrário. ${ }^{12}$

${ }^{10}$ A. Gramsci, Il Risorgimento (Torino: Riuniti, 1991), p. 132.

${ }^{11}$ Isto é, levando-se em conta o conceito de a "grande revolução de 1789-1848" consagrado pelo historiador Eric J. Hobsbawm, vale dizer, da "revolução dupla": na economia, triunfo da indústria capitalista; na política, ascensão da classe média e triunfo do conceito burguês de liberdade. Aplicado à situação histórica da península itálica posterior à existência de Maistre, este conceito permite destacar ainda mais a excepcionalidade política piemontesa (cuja estrutura social aristocrática, decisiva para a unificação, logrou sobreviver, não sem concessões, à ascensão das classes médias, sobretudo após 1848) no interior da península, cujo papel no processo de unificação italiana só pode ser comparável - o que não significa dizer que foi idêntico - ao que a Prússia desempenhou no processo de unificação da Alemanha (em linhas gerais, liderado também por um Estado periférico, fortemente centralizado e socialmente marcado pelo controle político da aristocracia). Cf. Eric J. Hobsbawm, A Era das Revoluções 1789-1848 (São Paulo: Paz e Terra, 2005), 19 ${ }^{\mathrm{a}}$ edição, p. 16.

12 Dualidade esta já abordada, dentre outros, por Richard Lebrun, Joseph de Maistre: An Intellectual Militant (Quebec: McGill-Queen's University Press, 1988); e Jean-Yves Pranchère, L'autorité contre les Lumières: la philosophie de Joseph de Maistre (Genève: DROZ, 2004). 
Antes que a Revolução o transformasse num dos expoentes mais veementes do pensamento conservador em língua francesa, Maistre exercia a função de Senador da Província da Sabóia, cargo que desempenhou de 1788 a 1792.

A respeito do Senado da Saboia, devido às reformas absolutistas do começo do século XVIII (as quais tiveram a estreita colaboração de seu pai), o mesmo teve - a exemplo dos parlements franceses no século precedente - sua competência restringida quase que exclusivamente aos assuntos jurídicos. Entre 1717 e 1731, o rei Vittorio Amadeo II reorganizou o Conselho de Estado em Turim e reforçou a autoridade monárquica nas províncias, por meio do envio de intendentes.

Essas medidas visavam disciplinar a recalcitrante e orgulhosa nobreza saboiana, cujo histórico de atritos com a administração central piemontesa remontava a meados do século XVI: apesar de suas origens político-culturais borgonhesas, havia muito que os duques da Saboia orientavam sua política cada vez mais para a conquista de territórios setentrionais da península italiana, especialmente após o tratado de Cateau-Cambrésis (1559) entre França e Espanha, política esta que tendia naturalmente a privilegiar a nobreza piemontesa em detrimento da saboiana.

Assim, pode parecer à primeira vista estranho o fato de os saboianos Maistre (tanto o pai, François-Xavier, um dos formuladores das reformas absolutistas dos anos 1730; quanto o filho, Joseph) estarem entre os funcionários mais abnegados na execução desta política centralizadora piemontesa naquele senado provincial. Contudo esse estranhamento é disperso assim que analisamos a trajetória familiar dos senadores.

Sem nunca ter possuído um feudo, os rendimentos da família de Maistre provinham em sua maior parte (cerca de 60\%) dos salários de seus cargos, e não das exações sobre os camponeses em seus domínios (que representava pelo menos 2/3 dos ganhos dos feudatários). Por outro lado, detinham o signo distintivo da nobreza, qual seja, o privilégio ou isenção de tributos, mormente a talha real. ${ }^{13}$

Isto explica o fato de que, apesar de cooptados pela nobreza hereditária, os Maistre sempre manifestaram oposição aos anacrônicos direitos feudais que ainda pesavam sobre as terras, pelo que se depreende pela conclusão dada pelo filho Joseph a respeito de um julgamento de 1784 , em que um pleiteante reclamava seus direitos feudais:

\footnotetext{
${ }^{13}$ J. Nicolas, La Savoie au XVIII ${ }^{e}$ siècle: noblesse et bourgeoisie..., p. 613.
} 
"No lugar das Luzes, da Ordem, da Tranquilidade que reinam em nossos dias, é preciso imaginar os distúrbios, a anarquia, as devastações da Idade Média; é preciso lembrar da feroz independência dos nobres, a influência ilimitada do clero, a nulidade do povo e a ignorância de uns e de outros." 14

Quando a Assembleia Nacional francesa, em sua última reunião antes de ceder lugar à Convenção Nacional (em 20 de set. de 1792), votou pela guerra contra o reino piemontês (pelo fato do mesmo acolher os émigrés franceses), todos na Sabóia sabiam que a invasão era uma questão de tempo. Nesta mesma data, Maistre e sua família já haviam recolhido o máximo que podiam e partido para os Alpes italianos.

Após a rápida e fácil invasão liderada pelo general Montesquiou no dia 22 de setembro, os franceses organizaram eleições para deputados em todos os distritos da Saboia, dando origem à Assembleia Nacional dos Allobroges. O primeiro ato desta assembleia, que se reuniu em 21 de outubro de 1792, foi enviar à Convenção Nacional de Paris uma petição unânime, requerendo a incorporação da província à França. O que pretendiam os franceses com aquela invasão e, para além do argumento sobre os emigrados, como a justificavam?

Com base na tese republicano-natural ${ }^{15}$, a qual se tornaria hegemônica a partir do processo de Luís XVI, a França revolucionária enviava duas mensagens aos saboianos e aos soberanos europeus: 1. Pelo direito natural, válido acima de todas as leis e códigos, os saboianos eram os legítimos soberanos de sua pátria (justificando-se, assim, a quebra do vínculo político com o reino do Piemonte); 2. A nação francesa generosamente convidava os seus vizinhos, os habitantes da Saboia e com quem possuíam um longo histórico de convivência, para integrarem, mediante decisão livre e soberana de seus membros, a República Francesa una e individível, a fim de melhor assegurarem seu direito natural reconquistado contra os monarcas, especialmente o soberano do Piemonte-Sardenha.

Diante disso, a Assembleia foi dissolvida e o poder entregue a um comitê executivo, cujo primeiro ato foi o de ordenar um inventário das propriedades da Igreja e ameaçar com o confisco todos os emigrados que não retornassem até a data de $1^{\mathrm{o}} \mathrm{de}$

\footnotetext{
${ }^{14}$ Maistre, Arquivos da Saboia, B 1167, conclusões de 28 de julho de 1784.

15 Sobre a história do conceito de "direito natural" na cultura política francesa do século XVIII, da Ilustração até o momento em que o mesmo se torna hegemônico como argumento político, vale dizer, nos quadros de radicalização e dissensão republicana durante o julgamento de Luís XVI, leia-se Dan Edelstein, The Terror of Natural Right: Republicanism, the Cult of Nature, and the French Revolution (Chicago: University of Chicago Press, 2009).
} 
janeiro de 1793. Em 18 de novembro de 1792, a Convenção Nacional promulgou um decreto que unia a Saboia à França, passando-se a chamar Departamento de MontBlanc.

Neste ínterim, a maior parte dos cidadãos saboianos que, a exemplo de Maistre, preferiram conservar sua lealdade dinástica, emigraram para a capital do reino (Turim), na esperança de que seriam tão bem ou melhor recebidos do que os emigrados franceses. Para consternação dos saboianos, o tratamento dispensado a eles pela corte e pela população piemontesa em geral foi a mais hostil possível. Diante da falta de ocupação, da má recepção e da ameaça da perda dos bens, não foram poucos os refugiados saboianos que, como Maistre, optaram por abandonar Turim e se apresentar, com a autorização do rei, às autoridades da Sabóia francesa/revolucionária.

Com respeito a Maistre, é preciso dizer que em sua breve estadia de pouco mais de três meses na Chambéry 'francesa', o mesmo não empreendeu nenhum esforço para se adaptar ao 'novus ordo seclorum'. Pelo contrário, antes de emigrar definitivamente de sua terra natal, redigiu anonimamente (fev. 1793) um curioso relatório dirigido aos deputados franceses ("Súplica de alguns pais de militares saboianos à Convenção Nacional dos Franceses"), no qual não apenas compreendia a punição imposta pela Convenção aos émigrés franceses, como questionava veementemente a identificação, pela Convenção Nacional Francesa, dos emigrados saboianos com aqueles (ou seja, não havia justificativa legal para enquadrá-los na lei contra os émigrés). Pois, segundo Maistre, enquanto a emigração francesa foi um abandono e traição à realeza - na medida em que minava sua autoridade junto à opinião pública e alimentava o jacobinismo -, a saboiana foi justamente o oposto: representou uma demonstração de patriotismo para com seu soberano legítimo e à 'pátria universal', o reino do PiemonteSardenha. ${ }^{16}$

Portanto, foi em reação à anexação da Sabóia à França e ao enquadramento da aristocracia saboiana na lei de emigração francesa que Maistre redigiu o panfleto, demonstrando, pela lógica interna dos próprios revolucionários franceses, que os saboianos apenas cumpriram seus deveres patriótico-constitucionais e obedeciam à lei de sua pátria universal ao emigrarem, a qual prescrevia, como primeira lei do reino, a obediência ao soberano da Casa da Saboia. Ademais, provocava Maistre, a província da

\footnotetext{
${ }^{16}$ Joseph de Maistre, Adresse de quelques parents des militaires savoisiens à la Convention Nationale des Français (1793), in: J. de Maistre, O.C., VII: 72.
} 
Sabóia não integrava o território 'uno e indivisível' do reino do Piemonte, condição esta reconhecida e legitimada pelo direito internacional havia mais de oito séculos?

"A pátria de um homem é o país inteiro submetido à dominação de seu soberano, qualquer que seja o mesmo. As subdivisões deste país podem ainda formar, num sentido muito estrito, pátrias particulares, mas cujos interesses -subordinados ao bem geral - não podem perturbar a pátria universal, nem prejudicar o exercício da soberania: do contrário, não haverá mais governo... O que significa, pois, esta afetação com a qual alguns se obstinam a ver nesta imperceptível Saboia um país isolado, autônomo e, por assim dizer, uma quinta parte do globo? Como se a Sabóia fosse outra coisa senão uma província dos Estados de S. M. o Rei da Sardenha! Como se o governo não tivesse sido sempre perfeitamente uno e indivisível!"17

Este parágrafo sintetiza exemplarmente a dualidade cultural e geopolítica na qual se inseria o contrarrevolucionário saboiano. Maistre não ignora as dificuldades postas pela Revolução Francesa e seu momento republicano-democrático às monarquias europeias, especialmente ao reino do Piemonte, cuja estratégica e histórica província, não só era francófila, como se tornara o primeiro alvo dos deputados republicanos franceses, que reivindicavam a anexação daqueles territórios alpinos sob o pretexto das fronteiras naturais.

À diferença de boa parte de seus amigos saboianos, Maistre preferiu perder a maior parte dos bens a trair sua lealdade dinástica e religiosa. Razão pela qual decidiu emigrar novamente, desta vez para a cidade suíça de Lausanne, donde redige, logo após sua chegada (em 15 de abril de 1793) e graças ao incentivo do contrarrevolucionário suíço Jaques Mallet du Pan (1749-1800), as quatro primeiras Cartas de um realista saboiano a seus compatriotas, panfletos publicados entre maio e agosto daquele ano.

$\mathrm{O}$ aspecto mais curioso desta peça de propaganda realista designada para circular na Saboia e composta sem a autorização do governo (que enxergava suspeitas jacobinas em qualquer iniciativa intelectual de caráter político), era a defesa da monarquia sarda (vale dizer, Casa da Saboia) em termos utilitários e racionais, e não mediante os apelos tradicionais à honra e ao dever. Numa passagem do "Prefácio" em que demonstra o pleno domínio da escritura polêmica e dos recursos de linguagem disponíveis a um panfletário, compara os revolucionários franceses a uma criança que estragou o próprio brinquedo enquanto tentava desvendar o mecanismo oculto de seu funcionamento:

\footnotetext{
${ }^{17}$ Joseph de Maistre, Adresse de quelques parents des militaires savoisiens à la Convention Nationale des Français (1793), in: J. de Maistre, O.C., VII: 55.
} 
"No momento em que se oferece a uma criança um desses brinquedos que executam, por meio de mecanismos internos, movimentos inexplicáveis a ela, a mesma, após ter se divertido por algum tempo, quebra-o, para vê-los de fora. É assim que os franceses trataram seu governo. Quiseram ver de fora: expuseram os princípios políticos, abriram os olhos da multidão sobre objetos a respeito dos quais jamais suspeitara examinar, sem refletir que existem coisas que se destroem ao mostrá-las." 18

Isto não o impedia de reconhecer o 'outro' lado da moeda (um lado crítico de Maistre tão bem observado e explorado por ninguém menos que o historiador republicano Jules Michelet em sua monumental História da Revolução Francesa, 1847$1853^{19}$ ), a saber, que se o contágio dos 'falsos' princípios revolucionários era demasiado rápido, isto se devia à fraqueza geral do corpo político do Antigo Regime (razão pela qual, para seu desespero, soube que o governo de Turim confiscara todos os exemplares de seus panfletos, sob a suspeição de jacobinismo!):

“Todavia, é preciso ter a coragem de confessá-lo com a mesma franqueza [que] na época memorável em que a França começa a se agitar, todos os governos da Europa haviam envelhecido, e esta decrepitude era conhecida apenas por aqueles que dela queriam tirar proveito na execução de seus projetos funestos. Milhares de abusos acumulados minavam estes governos, e, sobretudo o da França decaía em corrupção."20

Chama a atenção o fato de as Cartas lançarem mão da lógica interna do discurso revolucionário francês ao defenderem que a 'massa da nação' saboiana (isto é os camponeses) era contrária à anexação francesa, a qual só foi possível graças à colaboração de uma minoria (a elite local) com os jacobinos franceses: "As vozes de uma condenável minoria levaram a melhor sobre os receios e a honra do resto da nação. Esta minoria queria a conquista e a revolução, e tivemos ambas. Agora podeis comparar e julgar." ${ }^{21}$ Ou seja, considerada a lógica do princípio rousseauísta vigente (não sem contradições, é bem verdade) na França revolucionária, os adesistas saboianos, e não os emigrados locais, é que afrontavam a 'vontade geral' da nação saboiana.

\footnotetext{
${ }^{18}$ Joseph de Maistre, Lettres d'un royaliste savoisien a ses compatriotes (1793), in: O.C., VII: 36.

${ }^{19}$ Vide "Introdução", p. 13 nota de número 19.

${ }^{20} \mathrm{~J}$. de Maistre, Lettres d'un royaliste savoisien a ses compatriotes (1793), in: O.C., VII: 83-4.

${ }^{21} \mathrm{~J}$. de Maistre, Lettres d'un royaliste savoisien a ses compatriotes (1793), in: O.C., VII: 162.
} 
$\mathrm{Na}$ perspectiva maistreana (alicerçada numa leitura liberal-aristocrática de Montesquieu), o exemplo oferecido pela Assembleia dos Deputados do Allobroges expôs risco do assembleísmo ou centralismo democrático, por detrás da atuação jacobina, para o sistema representativo: "Numa palavra, se excetuarmos um pequeno número de facciosos que ousaram se proclamar 'a Nação', temos que uma parte da Assembleia não escutou nada, a outra não compreendeu nada, e uma terceira não disse nada. Eis a história de vossa Assembleia popular e, talvez, de todas as outras." ${ }^{22}$

Farsa ou não, o fato é que o proselitismo da Revolução Francesa atuou como um poderoso solvente na esgarçada estrutura identitária das monarquias europeias, e isto era ainda mais válido para o reino do Piemonte. A terceira Carta expressa bem a dificuldade do contrarrevolucionário em exortar os sentimentos patrióticos dos saboianos a favor de uma monarquia que, desde o século XVI, definia-se cada vez mais como 'italiana', cujo absolutismo (tardio, consolidado em meados do século XVIII) coincidiu com o zênite dos movimentos reformistas nos países que haviam consolidado seu absolutismo havia tempos: "Não há nada mais importante para vós do que vos identificar com o Piemonte, e de acostumar-vos a observá-lo como a porção mais considerável de nossa pátria comum". 23

Ou seja, para Maistre, o amor pela pátria era consubstancial ao amor, ou melhor, respeito pelo soberano; de modo que a Saboia era uma pátria menor inserida na grande pátria, o reino do Piemonte-Sardenha.

Para surpresa universal, todos os esforços militares contra a república revolucionária francesa redundaram em fracasso. Diante disto, estava cada vez mais claro para Maistre que a Revolução não poderia ser derrotada pela iniciativa dos exércitos coligados (os quais, pelo contrário, galvanizavam os sans-culottes parisienses e os camponeses em apoio à política terrorista dos jacobinos, pelo menos até que a ameaça estrangeira estivesse posta): para derrotá-la, era preciso ‘destronar’ os jacobinos da opinião pública e, para tanto, os ataques externos e ameaças deveriam cessar o quanto antes, sobretudo as ameaças de fragmentação da França que partiam da Prússia e da Áustria.

As Considerações sobre a França, panfleto responsável pela reputação literária e política de Maistre, publicado em abril de 1797, agravou a situação do súdito saboiano junto às autoridades de Turim, que passaram a designá-lo pejorativamente como ' $I l$

\footnotetext{
${ }^{22}$ Joseph de Maistre, Lettres d'un royaliste savoisien a ses compatriotes (1793), in: O.C., VII: 99.

${ }^{23}$ Joseph de Maistre, Lettres d'un royaliste savoisien a ses compatriotes (1793), in: O.C., VII: 146.
} 
Francese'. A percepção da corte piemontesa sobre Maistre só degenerou após a Revolução Francesa, basicamente por dois motivos: por seu envolvimento na maçonaria, até 1791; por suas ousadas opiniões a respeito da corrupção das primeiras ordens do reino da França, o que era interpretado em Turim como uma crítica indireta à administração piemontesa. Neste ínterim, as Considerações não só eram mais enfáticas na crítica ao Antigo Regime, como avançavam um paradoxal reconhecimento ao jacobinismo:

"O rei nunca teve aliados, e o fato de que a coalizão atentava contra a integridade da França constitui algo tão evidente que não representa nenhuma imprudência enunciá-lo. Ora, como resistir à coalizão? Por via de qual meio sobrenatural quebrar o esforço da Europa conjurada? Somente o gênio infernal de Robespierre podia realizar esse prodígio... Todas as vidas, as riquezas, os poderes estiveram nas mãos do poder revolucionário; e esse monstro de força, ébrio de sangue e sucesso, fenômeno espantoso, jamais visto e que nunca mais se verá, foi ao mesmo tempo um castigo horrível imposto aos franceses, e o único modo de salvar a França..."24

Poucos estudiosos perceberam que as Considerações articulam e/ou equilibram o pensamento do contrarrevolucionário europeu com o do patriota piemontês/saboiano, sentimentos que caminharão quase sempre paralelos na futura carreira diplomática de Maistre (1803-1817).

Leia-se, por exemplo, a seguinte fórmula provocativa presente nas Considerações, a qual opõe as identidades factuais italiana, francesa, russa e persa à entidade imaginária dos filósofos e revolucionários ('homem’):

"A Constituição de 1795, assim como suas antecessoras, foi feita para o homem. Mas não existe no mundo nada que se possa chamar de homem. Ao longo de minha vida, tenho visto franceses, italianos, russos, etc.; sei também, graças a Montesquieu, que se pode ser persa. Mas, quanto ao homem, afirmo que, em toda minha vida, jamais o encontrei; se ele existe, desconheço-o completamente". ${ }^{25}$

Contudo e levando-se em conta a leitura retrospectiva de suas obras completas, é possível vislumbrar algo mais nesta incomum alusão aos italianos, uma entidade que, por vias distintas, era tão imaginária e não-factual quanto o homem genérico de Tom

\footnotetext{
${ }^{24}$ Joseph de Maistre, Considérations sur la France (1797), in: O.C., I: 18.

${ }^{25}$ Idem, p. 74.
} 
Paine, um dos alvos preferenciais de sua crítica. A nosso ver, isto era o reflexo do patriotismo piemontês, o qual assumia cada vez mais um aspecto de política defensiva contra a Áustria e sua política expansionista sobre a península itálica, como se lê num outro trecho das Considerações:

“O que reivindicavam os realistas, quando pediam uma contrarrevolução tal como eles imaginavam, isto é, feita bruscamente e pela força? Exigiam a conquista da França e, portanto, sua divisão, o amesquinhamento de sua influência e o aviltamento de seu rei, ou seja, massacres talvez de três séculos, consequência infalível de uma semelhante ruptura do equilíbrio."26

A perspectiva da rica carreira diplomática maistreana estava influenciada pelo fato dele representar os interesses de um Estado que, apesar de não ser uma grande potência (não detinha grandes territórios nem grandes exércitos), podia ser considerado a 'pedra angular' do equilíbrio político na península italiana e, por extensão, na Europa, devido à sua privilegiada posição geográfica, isto é, um Estado-tampão que evitava o choque entre duas potências, França e Áustria.

A seu juízo, a Casa d'Áustria, símbolo da coligação europeia-cristã contra a Revolução, representava um risco maior que a França revolucionária para sua dinastia. Por mais absurdo que isto parecesse à primeira vista, Maistre percebera com acerto que a Casa da Saboia nada tinha a temer da França, fosse a mesma republicana ou monárquica. No primeiro caso, o máximo que o reino do Piemonte tinha a perder era sua província da Sabóia (segundo o princípio revolucionário das fronteiras naturais). $\mathrm{Na}$ segunda hipótese, a qual julgava mais plausível (ou seja, após uma provável Restauração), um enfraquecido Luís XVIII seria o primeiro interessado em estabelecer alianças monárquicas, razão pela qual restituiria, sobretudo por razões estratégicas, a Sabóia ao Piemonte. Mas quando se tratava da Áustria, o julgamento de Maistre era severo: amparado em opiniões de diplomatas austríacos, o saboiano concluiu que a razão de Estado daquela dinastia previa necessariamente a absorção e extinção do reino do Piemonte, como passo decisivo para o controle político da Itália. E do ponto de vista do direito internacional europeu, isto era tão ilegítimo e despótico quanto a ação revolucionária dos jacobinos, com o agravante de ser um crime perpetrado por um monarca contra o outro.

\footnotetext{
${ }^{26}$ Joseph de Maistre, Considérations sur la France, in: O.C., I: 18. Grifos nossos.
} 
O fato de Maistre sustentar estas ideias num momento em que o Piemonte vivenciava um sentimento universal de hostilidade antifrancesa (tão bem expresso nas obras de figuras tão distintas como o pró-absolutista Galeani Napioni e o reformista liberal Vittorio Alfieri, autor do célebre Il Misogallo), demonstra o quão heterodoxa era a sua perspectiva contrarrevolucionária.

Já em 1794 Maistre confidenciava a um de seus amigos o receio de que a contrarrevolução, sob o pretexto de esmagar a revolução na França, provocasse um desequilíbrio ainda maior no cenário político europeu: "É para a pobre Casa da Áustria que queremos entregar a Alsácia, a Lorena e Flandres. Por Deus, que equilíbrio! É do interesse de todos que o imperador nunca adentre na França como conquistador... Não precisamos de um Carlos V.,27

Apesar da notável correção da análise, as desventuras do súdito saboiano do rei piemontês junto a seu Estado aumentaram ainda mais em 28 de outubro de 1797, quando as tropas francesas na Itália, sob o comando de Napoleão, interceptaram em Milão uma carta do favorito de Luís XVIII, o conde d'Avaray, na qual informava que os eventos do frutidor tornavam impossível uma nova edição das Considerações em solo francês. Enviada a Paris, a carta foi publicada nos órgãos de imprensa do Diretório para ilustrar a existência de complôs realistas subterrâneos e justificar o golpe de estado.

Desvendada a autoria do virulento panfleto contrarrevolcionário, a ascensão política de Maistre passou a ser politicamente inviável a seu governo, uma vez que isto equivaleria a uma declaração de guerra contra o Diretório, com quem o mesmo acabara de assinar um tratado, em maio de 1796.

Era preciso que a Revolução Francesa exercesse um efeito 'libertador' para Maistre, invertendo sua fortuna. E foi o que aconteceu quando Napoleão, em junho de 1798, invadiu e conquistou o Piemonte, forçando o rei da Casa da Saboia, então aliado da Áustria, a se exilar. Com a ocupação francesa do Piemonte e a fuga do rei Carlo Emanuele IV em dezembro do mesmo ano, Maistre atravessa com sua família o vale do Pó para ganhar Veneza, onde passaria os próximos sete meses.

No final de julho de 1799, tropas austrorrussas derrotam os franceses em Turim, permitindo à família de Maistre deixar Veneza, em 26 de agosto. Posteriormente, em 19 de setembro, o autor das Considerações é informado por seu governo que fora nomeado

${ }^{27}$ Jean-Louis Darcel, Lettre au Baron Vignet des Etoles, 15 agosto 1794, in: Jean-Louis Darcel (org.), De la terreur à la restauration: correspondance inédites, vol. 10 da Revue des Études Maistriennes, Paris: Belles-Lettres, 1986-7, p. 97. 
ao cargo de regente da ilha da Sardenha, com um salário de 20.000 libras anuais, enquanto a Áustria impedia que Carlo Emanuele IV retornasse à sua antiga capital.

Entretanto, após a solapadora vitória de Napoleão frente aos austríacos na batalha de Marengo (1800) e a nova invasão francesa sobre a Itália e o Piemonte (dez. 1800), o soberano da Casa da Saboia teve de se refugiar na ilha da Sardenha.

É neste momento que a Revolução Francesa, a qual, como ele próprio dissera, já o havia 'libertado'da solapadora insignificância burocrática na Saboia em 1792, lhe oferece uma segunda oportunidade para servir não só a seu soberano, mas também à soberana das soberanas, a opinião pública.

Antes mesmo da chegada de Maistre à capital do império russo, o antecessor de Alexandre I, o czar Paulo I, já havia mostrado no Congresso de Rastadt (1797) uma firme disposição em defender o soberano da Casa da Saboia contra as pretensões da República Francesa e da Áustria. Esta iniciativa isolada rendeu frutos em 1799, com a vitória dos cossacos russos comandados pelo general Souvarov (o qual seria evocado por Stálin nos momentos derradeiros da invasão nazista à Rússia) sobre as tropas de ocupação francesa, devolvendo o Piemonte, a Lombardia, Roma, os ducados de Parma, Toscana, Modena e o reino de Nápoles (em cujos territórios foi instituída a efêmera República Partenopea, que durou menos de um ano, em 1799) a seus antigos soberanos (na ordem), o rei sardo, a Áustria, o papa, os duques da casa de Lorena (um ramo da Casa da Àustria) e os Bourbons.

Mais do que nunca, o rei sardo (reduzido à Sardenha entre 1800 e 1814) dependia do apoio diplomático e dos subsídios ingleses e russos para subsistir. Por uma ironia do destino, coube àquele que a corte piemontesa suspeitava de filojacobinismo e desdenhava como 'Il Francese' a execução de parte deste plano vital às pretensões da dinastia. Isto porque o decreto de 10 messidor (29 de junho de 1802) obrigava todos os piemonteses ausentes a retornar imediatamente a seu novo 'país" ${ }^{28}$, sob pena de confisco das propriedades. Diante disto e das insistentes reclamações do Regente Charles-Félix (irmão de Vittorio Emanuele), contra Maistre (pois este opunha inúmeras barreiras legais às medidas extrajudiciais daquele, como a proibição da tortura e concessão de habeas corpus a presos políticos sem provas), bem como do retorno forçado do piemontês conde de Vallaise da embaixada sarda de São Petersburgo e da redução aguda dos quadros após o decreto napoleônico, não restou ao despossuído e

\footnotetext{
${ }^{28}$ Entenda-se por 'país' a região do Piemonte, a qual fora anexada à França pelas tropas de Napoleão.
} 
'abandonado' soberano da Casa da Saboia senão nomear o súdito saboiano mais bem preparado para aquela missão. E assim, em 23 de outubro de 1802, Maistre recebe a investidura do cargo de "Envoyé extraordinaire" (embaixador) da monarquia sarda na corte do czar, em São Petersburgo.

As perspectivas para o novo diplomata sardo não eram as melhores naquela importante corte européia. Coube a Maistre a dupla missão de mendigar por mais subsídios e de assegurar a proteção de seu reduzido e (praticamente) proscrito Estado pelo czar. Para o exercício desta função, receberia 20.000 libras anuais, o mesmo que recebera como vice-regente da Sardenha, com a diferença de que o padrão de vida em São Petersburgo era incomparavelmente mais alto. Por razões de decoro público e privado, viu-se impossibilitado, diante dos parcos salários, de levar consigo a família, que permaneceu em Turim. Este não seria o único desgaste em relação a seu governo. Além de suas origens saboianas, do passado maçônico e das suspeitas de francofilia, o ardor e a eloqüência do embaixador inquietavam e aborreciam as autoridades sardas. ${ }^{29}$

Com uma notável consciência dos prós e contras de sua personalidade, o embaixador da Sardenha sabia que a única avenida aberta para um pobre representante de uma monarquia impotente era ganhar a confiança e a amizade de pessoas influentes do círculo diplomático russo e, se possível, do próprio czar. Afinal, a expectativa de reaver seus bens espoliados passava pela restauração dos Bourbons na França, a qual dependia da coalizão antifrancesa formada por Áustria, Inglaterra e Rússia. Inevitavelmente, a Rússia e o czar Alexandre I eram os principais candidatos para o projeto de salvação do reino do Piemonte-Sardenha.

Decidido, portanto, a fazer o melhor uso possível de seu "capital", qual seja, sua brilhante conversação, inteligência, memória e uma reputação de porta-voz do conservadorismo, não demorou muito para que Maistre ganhasse destaque na corte do czar. Um dos principais expoentes daquela corte russa, o conde Alexander Stourdza, que futuramente se oporia ao proselitismo católico do embaixador sardo em solo russo $^{30}$, assim se referiu a Maistre:

\footnotetext{
${ }^{29}$ R. Lebrun, Joseph de Maistre: An Intellectual Militant (Montreal: McGill-Queen's University Press, 1988), p. 314.

${ }^{30} \mathrm{Em} 1816$, como reação às atividades missionárias dos jesuítas (e também de Maistre) na Rússia, publicou Considérations sur la doctrine et l'esprit de l'Eglise orthodoxe, na qual defendia, num tom nacionalista, a igreja ortodoxa contra as "impurezas heterodoxas trazidas pelos estrangeiros". Cf. R. Lebrun, Joseph de Maistre: An Intellectual Militant, p. 315.
} 
"Ainda posso ver diante de mim aquele nobre e velho homem, a caminhar sempre de cabeça erguida e coroada por um cabelo esbranquiçado graças à natureza e ao capricho da moda. Sua grande fronte, sua face pálida marcada por figuras tão impressionantes quanto seus pensamentos, também marcados pelas desventuras de sua vida, seus olhos azuis meio turvos pelos profundos e laboriosos estudos e, finalmente, a rematada elegância de seu vestuário, a urbanidade de sua linguagem e de suas maneiras... O sr. de Maistre foi, sem sombra de dúvidas, a mais destacada personagem do tempo e do lugar em que vivemos, a saber, a corte do Imperador Alexandre e o período entre 1807 e $1820 \ldots$ Éramos todos ouvidos quando, sentado em sua poltrona, de cabeça erguida... o conde de Maistre abandonava-se ao límpido curso de sua eloquiência, gargalhando, argumentando com graça, animando e governando a conversação."31

No auge de sua influência política junto ao czar, isto é, em dezembro de 1812, portanto logo após a 'vitória' napoleônica na sangrenta Batalha de Borodino (set. 1812), Maistre, testemunha privilegiada dos eventos (afinal, seu único filho homem, Rodolphe, esteve no campo de batalha ao lado dos russos: o que não foi de pouca relevância política para o rei sardo...) e, portanto, consciente de que aquela batalha era um prelúdio da Restauração, endereça uma memória diplomática ao soberano da Casa da Sabóia na qual sugere, dentre outras coisas, que seu soberano estabeleça uma política de aliança declarada com os Bourbons franceses e o rei da Prússia, pois, do contrário, a Áustria, a partir da Lombardia, absorveria o Piemonte. Vale a pena reproduzir a linha de raciocínio de Maistre:

"Felicitou-se amiúde a Casa da Saboia por sua feliz posição entre duas potências de primeira ordem cuja desconfiança mútua servia de proteção, mas os inconvenientes desta situação não foram expostos./ Em primeiro lugar..., lançando-se alternadamente de um lado para o outro, segundo seu interesse imediato, [a Casa da Saboia] declarava assim a seus dois vizinhos poderosos que ela não tinha preferência por nenhum deles, o que, por um justo retorno, fazia com que nenhum deles tivesse uma preferência real por ela. Cada um queria defendê-la do outro, mas sem se inquietar com ela e suas glórias, de modo que valeria perguntar se os seus

${ }^{31}$ R. Lebrun, Joseph de Maistre: an Intellectual Militant, p. 183. Isaiah Berlin demonstrou que na obra-prima de Tolstói, Guerra e Paz (1865-8), existem profundos ecos do pensamento de Maistre (o qual chega a ser citado no volume IV, parte III, cap. 19, da obra). Para o filósofo liberal, Maistre e Tolstói estavam "unidos pela incapacidade de escapar do mesmo paradoxo trágico: eram ambos por natureza raposas de olhar perspicaz, inevitavelmente conscientes das simples diferenças de facto que dividem e das forças que desintegram o mundo humano, observadores totalmente imunes aos enganos de muitos estratagemas sutis, de sistemas, credos, e ciências unificadoras, pelos quais os superficiais ou os desesperados procuravam ocultar o caos de si mesmos e dos outros". I. Berlin, "O ouriço e a raposa", in: H. Hartig e R. Hawsheer (orgs.), Estudos sobre a humanidade: uma antologia de ensaios (São Paulo, Cia das Letras, 2002), p. 447-505. 
interesses não seriam melhor defendidos no caso dela se aliar exclusivamente a uma dessas potências... Em segundo lugar, poderia existir mais aparência do que realidade nesta pretensa alternância de posição...; pois nada é mais duvidoso do que a vantagem que resultaria disso, ao passo que o inconveniente produzido por ela é visível e incontestável. ${ }^{32}$,

Diante da cada vez mais iminente queda de Napoleão e de um futuro congresso europeu, Maistre sugere ao soberano da Casa da Saboia que o mesmo não medisse esforços para restaurar o status quo anterior à Revolução (isto é, de 1792), tomando o máximo de cautela para evitar que a França e, sobretudo, a Áustria, tocassem seus territórios. Feita esta ressalva, lança a seguinte pergunta retórica: qual seria a melhor estratégia diplomática para lograr este objetivo?

A resposta não deixa de surpreender os estudiosos de hoje, quanto mais o soberano e sua corte - os mais prejudicados pelas conquistas da Revolução Francesa (do período republicano ao napoleônico) -, pela ousadia da proposta, a saber, a Casa da Saboia tinha mais a temer da Áustria do que da França, cujo interesse limitar-se-ia no máximo a Nice e à Saboia. Curiosamente, a opinião de Maistre era reforçada pela teoria revolucionária jacobina das 'fronteiras naturais', a qual deslocava a ambição territorial francesa da península itálica para as fronteiras orientais do Reno: deste modo, o Piemonte, eterna ambição de Viena, não entraria nos desígnios dos futuros governos da França, quaisquer que fossem os mesmos.

Ademais, o rei Vitório Emanuele I deveria esquecer as justas mágoas e apoiar o restaurado Luís XVIII (mais do que nunca pressionado a agir segundo os parâmetros da legitimidade) nas futuras discussões europeias, evitando que as compensações territoriais e financeiras dos coligados fossem gravosas à França e ressuscitassem o sentimento patriótico-nacionalista latente dos franceses: não havia salvação para a Europa ou equilíbrio europeu a não ser pela França pacificada. ${ }^{33}$ Com a Áustria, dava-se o oposto: num futuro congresso europeu, a mesma poderia legitimamente reclamar a Lombardia, a Toscana e Veneza. Ou seja, suas pretensões sobre a Itália setentrional seriam reforçadas após a Restauração, ao contrário da França.

Portanto, para não ser sufocada entre as duas potências (Áustria e França), a Casa da Saboia deveria proceder por uma abertura diplomática com a França, cujos interesses naturais estavam voltados para as fronteiras do Reno. Por sua vez, seja pela raison

\footnotetext{
32 Joseph de Maistre, Mémoire a S.M. le Roi de Sardaigne, 15/12/1812, in: O.C., XII: 321-322.

${ }^{33}$ J. de Maistre, Mémoire a S.M. le Roi de Sardaigne, 15/12/1812, in: O.C., XII: 323-4.
} 
d'Etat ou pela natureza das coisas, a Casa d'Áustria era levada irremediavelmente a avançar sobre a Itália setentrional, principalmente sobre a Casa da Saboia.

As preocupações de Maistre foram endossadas pelo comentário feito por um diplomata austríaco durante as conferências de Lunéville (1801), que selaram um tratado entre a França e a Áustria: "E qual a necessidade de que haja um rei da Sardenha?"34

Diante disso, coube ao contrarrevolucionário saboiano levar adiante esta delicada missão política, mostrando, através de contatos pessoais ou por meio de inúmeras cartas e mementos diplomáticos (seja ao czar em pessoa, ou ainda ao rei sardo, a Luís XVIII e seu correspondente na Rússia, o conde de Blacas), que a Restauração do reino do Piemonte era do maior interesse para o restabelecimento do equilíbrio europeu, especialmente para a França a Rússia e a Prússia (do contrário, a Casa da Áustria teria caminho livre para concentrar suas forças na expansão a oeste do Reno e a leste do Elba).

Neste contexto, uma das maiores proezas diplomáticas de Maistre consistiu em convencer o czar Alexandre I de que era do interesse do império russo a Restauração do reino do Piemonte-Sardenha, pois ambas as dinastias precisavam conter o avanço da Áustria.

Assim, se num dos memorandos diplomáticos que endereça ao czar Maistre mostra-se preocupado com o futuro da 'Itália' pós-napoleônica, veremos que esta preocupação refletia mais uma preocupação de conservação e restauração do poder de sua dinastia - assim como das demais soberanias da península itálica, à exceção da Áustria - do que um sentimento protonacionalista italiano. Ou seja, 'a liberdade da Itália' confundia-se aqui com a Restauração plena e ampliada do reino do Piemonte e o enfraquecimento da Áustria.

Naquela conjuntura de recuos de Napoleão na Rússia, Polônia e Alemanha, Maistre receia que a 'Itália' fosse usada como moeda de troca entre as potências europeias num futuro congresso e, sobretudo, que as solicitações de reintegração de domínios continentais do reino da Sardenha fossem ignoradas devido às pressões austríacas, razão pela qual argumenta a favor da Casa da Saboia para o czar, esforçandose em demonstrar que a defesa daquela longínqua dinastia na Península Itálica iria ao encontro de seus interesses: "Não se pode esquecer que S.M.I. confina com o rei da

${ }^{34} \mathrm{~J}$. de Maistre, Mémoire à consulter sur l'état présent de l'Europe, 12 de outubro de 1806, in: O.C., X: 468 . 
Sardenha, pois... a Áustria toca de um lado a Rússia e, d'outro, o Piemonte, de modo que a Rússia e o Piemonte se tocam. O rei da Sardenha... é uma mão com a qual...” [o czar] "pode agir sobre o Pó como sobre a Duma." 35

Após demonstrar brevemente ao czar a (improvável) convergência de interesses do seu império com o reino da Sardenha, Maistre busca legitimar junto ao influente soberano russo uma provável anexação de Gênova ao reino do Piemonte restaurado, pelas seguintes razões: 1. A secular República de Gênova, assim como as outras repúblicas italianas (Veneza e Luca), não mais conseguiria se reorganizar como unidade política autônoma depois que Napoleão quebrou a 'delicada máquina' do 'relógio' republicano (oligárquico); 2. Não lhe restando outra possibilidade de existência política autônoma, era uma questão de tempo a anexação da mesma a uma monarquia, fosse francesa, austríaca ou, como defendia Maistre, piemontesa; 3. Seria do maior interesse da Itália e de todo o equilíbrio Europeu que a importante cidade portuária fosse integrada ao reino vizinho do Piemonte, com a dupla vantagem de fechar definitivamente a Itália para a França pelo mar e fortalecer a Casa da Saboia em detrimento de Viena. ${ }^{36}$

Portanto, é bem no espírito desse conceito de 'equilíbrio de poder' (um produto do Tratado de Vestfália, que substituiu a hegemonia do Sacro Império pelo reconhecimento de Estados soberanos e independentes), o qual herdara da leitura de autores como Charles Davenant, David Hume e Fénelon (os quais, diante das pretensões de Luís XIV, também formularam teorias sobre o equilíbrio de poder), que o embaixador sardo na corte do czar aconselharia as potências a restaurar os domínios italianos da Casa da Saboia, bem como a deixar claro ao povo francês que lutavam contra o tirano da Europa (Napoleão) e não contra a nação francesa, a qual não teria nada a temer futuramente com a queda de seu imperador: "O problema político reduz-se a um só: persuadir os franceses de que a guerra é só contra Bonaparte, e de que nunca terão paz com ele."37

A seu ver, uma grande calamidade adviria no caso das potências coligadas levarem em conta apenas seus interesses particulares: este fato esteve na raiz da fraqueza das monarquias ante a França revolucionária; perpetuava a força de Napoleão, cujo mérito consistia em dividir para governar. Maistre acusava os soberanos europeus de não serem realistas na acepção do termo: movidos pelo próprio interesse,

\footnotetext{
${ }^{35}$ J. de Maistre, Mémoire à S.M. l'Empereur de toutes les Russies, 20/03/1813, in: O.C., XII: 351.

${ }^{36}$ Idem, p. 352.

${ }^{37}$ Joseph de Maistre, "Lettre à M. le Chevalier de Rossi", 18 de agosto de 1810, in: O.C., XI: 218.
} 
estabeleceram acordos particulares com quem atacava outras soberanias e feriam na raiz o princípio da legitimidade monárquica na Europa ${ }^{38}$ - razão pela qual jamais hesitou em considerar o poder exercido por Napoleão sobre o continente europeu como 'revolucionário'. ${ }^{39}$ E foi justamente para defender uma coalizão com 'perspectivas mais sábias, amplas e europeias" ${ }^{\prime 40}$ que Maistre avançou uma teoria em defesa da conservação dos Estados e soberanias de médio-porte, como o reino do Piemonte-Sardenha, pelo insubstituível papel que teriam a desempenhar no restabelecimento do equilíbrio europeu.

Isto porque, apesar de sua formação jurídica, Maistre duvidava do potencial persuasório dos acordos diplomáticos legais para arbitrar as relações entre os Estados. À diferença de Hugo Grotius, Maistre não acreditava que a formalidade dos contratos internacionais fosse capaz de garantir a paz per se. Antes, a exemplo de Hobbes, julgava que no plano internacional os Estados se comportavam como indivíduos egoístas, como se os mesmos ainda estivessem numa espécie de 'estado natural' 41 (isto é, suas ações são mais passionais e impulsivas do que racionais; eram não apenas insociáveis, mas também violentos), de modo que a justiça seria definida pela raison d'état de cada um.

Para que os Estados lograssem um consenso sobre um determinado conjunto de leis, um considerável número de características comuns deveria ser alcançado, o que estava longe de ocorrer. Como representante de um Estado de médio-porte (sob os aspectos demográfico, territorial e militar), Maistre receava que as intenções cosmopolitas (fossem do Sacro Império, fossem da França republicana ou Imperial) encobrissem projetos de dominação da França e da Áustria sobre a Europa: na esfera das relações internacionais, a experiência demonstrava, os princípios abstratos nada podiam diante dos interesses e das ambições.

Mas, à diferença da perspectiva hobbesiana - a qual sustentava que os Estados menos poderosos não poderiam se manter -, a maistreana enxergava outra vantagem, que não apenas a manutenção do equilíbrio de poder, na preservação dos Estados de pequeno e médio porte: a preservação da diversidade cultural no interior do sistema estatal europeu, diversidade esta que deveria florescer para o bem de todos e da

\footnotetext{
${ }^{38}$ Joseph de Maistre, "Lettre a M. le Chevalier de Rossi", setembro de 1806, O.C., X: 203.

${ }^{39}$ Joseph de Maistre, "Mémoire à son excellence M. de Novosiltzof', 1805, O.C., IX:405.

${ }^{40}$ Maistre, "Mémoire à consulter sur l'état présent de l'Europe", janeiro de 1804, O.C., IX:131.

${ }^{41}$ Apesar de concordar com as conclusões absolutistas de Hobbes, Maistre foi um crítico contumaz de suas premissas contratualistas, uma vez que para ele semelhante hipótese de 'estado natural' era uma suposição arbitrária (uma hipótese não amparada na experiência ou na história), cujo potencial revolucionário fora demonstrado pela filosofia Iluminista do século XVIII (sobretudo através de Rousseau) e pela Revolução Francesa.
} 
civilização (pois os incrementos nas técnicas medicinais e gastronômicas, por exemplo, dependem da existência de Estados particulares, para só depois serem compartilhados e absorvidos por outras culturas: neste caso, um império traria o risco - Maistre não diz, mas avança o conceito - de pasteurização cultural).

Apesar do tamanho e do potencial militar reduzidos, os pequenos e médios Estados tinham um impacto importante no equilíbrio de poder, pois constituíam zonas neutras entre duas potências rivais, evitando que as mesmas entrassem em permanente choque. ${ }^{42}$ Ademais, se fosse verdadeiro o princípio (muito debatido como uma das causas das fraquezas monárquicas diante da Revolução) de que só deveriam existir grandes potências, os Estados seriam levados inevitavelmente a adotar um modus operandi beligerante de expansão e domínio perpétuos. O resultado final disto seria uma escalada inaudita na guerra e no derramamento de sangue: "A sociedade das nações, similar à dos indivíduos, é composta de grandes e pequenos exemplares, onde a desigualdade é algo necessário". ${ }^{43} \mathrm{O}$ princípio de que "só deveriam existir grandes potências" deveria ser substituído por outro, a saber, que "nenhuma nação está destinada pela natureza a estar submetida a uma outra". ${ }^{44}$

Quando o prestígio de Maistre na corte russa e junto ao czar havia alcançado o seu zênite (no final de 1811, foi investido para a função de redator de todos os documentos públicos e privados do czar), a invasão francesa de 1812 estragou suas pretensões (de representar diretamente as dinastias sarda e russa no futuro Congresso de Viena), ao provocar um recrudescimento do sentimento nacional russo, representado numa atitude profundamente hostil e xenofóbica a tudo que remetesse ao ocidente, inclusive os jesuítas, que terminaram sendo expulsos do império, em 1816.

Maistre, que pensara em se estabelecer na Rússia com a chegada de sua família às vésperas do natal de 1814, viu-se obrigado a abandonar os domínios do czar quando soube que Alexandre I exigira seu retorno a Turim, em abril de 1816. O saboiano, assim como os jesuítas, pagava o preço pela bem-sucedida atividade missionária desempenhada na corte russa, convertendo figuras eminentes como a condessa de Rostopchin (esposa do governador de Moscou), a condessa Tolstoy (esposa do mestrede-cerimônias da corte), a condessa Golovine (dona de um freqüentado salão) e Mme

\footnotetext{
42 Joseph de Maistre, Mémoire a S.M. le Roi de Sardaigne, 15/12/1812, in: O.C., XII: 410.

${ }^{43}$ Joseph de Maistre apud Darcel, 1986-7, p. 97.

${ }^{44}$ Joseph de Maistre, Mémoire a S.M. le Roi de Sardaigne, 15/12/1812, in: O.C., XII: 411.
} 
Sophie Swetchine (que se tornaria uma figura influente nos círculos intelectuais católicos franceses do século XIX).

Do seu retorno a Turim, em 1817, a seu falecimento, em 26 de fevereiro de 1821, dedicaria a maior parte de sua energia às publicações de Du Pape (1819) e das Soirées de Saint-Pétersbourg (1821), obras que consolidaram sua reputação de contrarrevolucionário teocrata e ultramontano.

Somente em dezembro de 1818 teve a situação definida ao ser nomeado como ministro de estado e "Régent de la Grande Chancellerie" (acumulando as funções de vice-chanceler e de Ministro da Justiça) do restaurado reino do Piemonte-Sardenha. Apesar do desapontamento gerado pela nomeação - Maistre esperava por algo mais, como a embaixada da Casa da Saboia em Roma -, cumpriu seriamente suas responsabilidades, as quais se prolongaram até 24 de julho de 1820, quando uma repentina crise de saúde condenou-o a ficar paralisado em casa até o fim de seus dias. Além do mais, o quase setuagenário saboiano poderia gozar do merecido descanso da política, uma vez que a Casa da Sabóia teve todos os seus domínios restaurados (Saboia, Nice e Piemonte), com o fundamental acréscimo da Ligúria.

Londe de descansar, o saboiano ainda encontrou forças para combater o espírito (que julgava mais vivo do que nunca) da Revolução Francesa (através de obras como Du pape, De l'Eglise gallicane e Soirées de Saint-Pétersbourg) e, no outono de 1820, fazer oposição a um apelo constitucional (inspirado nas Cortes espanholas) movido pelos nobres oficiais do exército, os quais também queriam que o Piemonte liderasse a guerra de liberação da Itália.

Os ministros piemonteses mostraram-se favoráveis a uma reforma amparada tanto na Carta francesa de 1814, como na espanhola para, logo em seguida, liderar a Itália numa guerra de libertação contra a Áustria. Maistre então remou na contramão do que pretendia a maior parte da aristocracia do reino do Piemonte-Sardenha - a qual, contando com figuras como a de Cesare Balbo, conciliava e/ou equilibrava sentimentos de fidelidade dinástica com desígnios de unificação nacional -, sugerindo que aquelas propostas ('apesar de úteis e boas em si') não deveriam ser levadas adiante tendo em vista as circunstâncias: "A terra treme sob os vossos pés e pensais ainda em construir!"45

\footnotetext{
${ }^{45}$ Joseph de Maistre, 'Notice Biographique,' in: O.C., I: XLI.
} 
Importa dizer que a sua proposta foi a que prevaleceu junto a Vittorio Emanuele I (o qual, em 1821, preferiu abdicar a fazer concessões liberais aos revoltosos). Somente em 1848, na atmosfera da Primavera dos Povos (fevereiro de 1848) é que o grupo de nobres liberais-reformistas piemonteses, responsáveis pela malograda e efêmera conspiração liberal do Piemonte (1821), conseguiram obter do rei Carlo Alberto o Statuto Albertino, ainda inspirado na Constituição orleanista de 1830 e belga de 1831 .

Quis o destino que a Itália ocupasse os últimos pensamentos de Maistre. Na mesma carta citada acima, o autor de Du Pape (1819) fez as seguintes reflexões:

"Como vós, por mais de mil vezes meditei sobre esta bela Itália, sem chegar a uma conclusão. Certamente, a grande desgraça para uma nação é ter de obedecer a uma outra... O homem sábio... não sabe ao certo no que pensar quando alguém menciona o espírito italiano..., mas logo retorna a si mesmo e se mantém em repouso após observar as terríveis catástrofes que teria de passar para ressuscitar a Itália. Ela paga caro pela terrível unidade que outrora esmagava o mundo... Hoje, por sua vez, o anátema que a esmaga é o da divisão, cujo fim não se pode imaginar."

Maistre não diz aqui como remediá-la (a divisão italiana), mas em Du Pape (1819) expôs com clareza sua posição a este respeito. "Neoguelfo", via o papa não apenas como um protetor do catolicismo (ou melhor, da religião, da monarquia e da sociedade civil tout court), mas também como um "líder natural da associação italiana" (o qual presidiria, por assim dizer, um conselho ou confederação de soberanos italianos). Não por acaso, o sentimento antiaustríaco de Maistre deita raízes profundas na política josefista do século XVIII (cuja versão francesa fora o galicanismo/jansenismo), responsável, dentre outras coisas, pela expulsão e supressão da ordem jesuítica em quase toda a Europa (para ele, um dos pré-requisitos da Revolução). ${ }^{47}$

Conclui-se que esta carta denota claramente o caráter defensivo de um gentilhomem relutante em substituir os critérios identitários consolidados no Antigo Regime por outro (rebento da era da revolução democrática): na ausência de algo mais preciso, considerava-se tão somente um cristão saboiano e súdito da Casa da Saboia, não um 'italiano', identidade esta típica da era da revolução democrática e a qual, antes de nascer, teria de subsumir todas as demais.

\footnotetext{
${ }^{46}$ Joseph de Maistre, “Lettre A M. le Marquis D’Azeglio”, 21/02/1821, O.C., XIV:257

${ }^{47}$ Joseph de Maistre, Du Pape (1819), in: O.C., II: 237-247.
} 
Curiosamente, a publicação (em 1858) de sua correspondência diplomática foi patrocinada por ninguém menos do que o conde Cavour (1810-1861), cuja ascensão política foi pautada por um duplo combate intestino no Piemonte: contra o influente partido neoguelfo piemontês (de Vincenzo Gioberti e Massimo d'Azeglio) e contra os nacionalistas conservadores (municipalistas exclusivistas e pró-austríacos), encabeçados por Solaro della Margarita.

Portanto, se por um lado é verdade que, conforme demonstrou o historiador Gaetano Salvemini em seu estudo sobre o Risorgimento, “... jamais em sã consciência os soberanos saboianos ou seus funcionários contaram com este resultado distante [isto é, a unificação] ${ }^{48,,}$, por outro, levando-se em conta a estrutura sócio-política da península, como ignorar que aquele era o caminho mais viável, razão pela qual, na visão do mesmo Salvemini, trata-se de algo ocioso considerar o processo de unificação italiana (liderada pela monarquia piemontesa e, em menor grau, pelas elites da classemédia) como uma "Revolução traída"?

Ademais, como ignorar o forte impacto exercido indiretamente por Maistre neste processo, ele que, na condição de embaixador da Casa da Saboia (entre 1803-1816) na corte russa, foi o principal responsável não só por recolher os subsídios que sustentaram diretamente o rei sardo e sua despossuída corte durante todo o período napoleônico, como, sobretudo, por convencer pessoalmente o czar Alexandre I, bem como o futuro rei francês Luís XVIII, da necessidade da restauração plena do pequeno reino transalpino (do contrário, a Áustria concentraria seus esforços na expansão a oeste do Reno e a leste do Elba)? Uma contribuição involuntária e possivelmente à revelia, mas certamente eficaz (e, paradoxalmente, movida por paixões e interesses contrarrevolucionários não necessariamente antifranceses)...

\footnotetext{
${ }^{48}$ G. Salvemini, Scritti di storia moderna e contemporanea (Milano: Feltrinelli, 1973), p. 524.
} 


\section{CAPÍTULO 8}

\section{"Du Pape" ou o manifesto de um ultramontano}

\subsection{Cristianismo ou Europa: considerações preliminares sobre a religião e a liberdade política entre o Termidor e a Restauração}

A vitória dos realistas e dos moderados republicanos nas eleições de abril de 1797 trouxe em sua esteira mais do que o golpe do 18 frutidor e os seus expurgos e deportações de 53 deputados eleitos, a prisão de 32 jornalistas e a censura e fechamento de 42 jornais. ${ }^{1}$ Uma vez que os líderes daquele regime (os diretores La RévellièreLépeaux, Paul Barras e Jean-François Reubel) e seus principais apoiadores associaram a derrota eleitoral às forças morais obstrucionistas representadas pelo catolicismo na conversão dos franceses à República, o segundo Diretório, como ficou conhecido o regime, foi caracterizado também e sobretudo por uma "nova era de perseguição" ${ }^{2}$ ao catolicismo, e a qual, apesar de menos mortal que a verificada no período do Terror, não foi menos cruel e destruidora, a ponto de Albert Mathiez observar que "nunca na França houve um governo mais hostil ao catolicismo do que o do Diretório" ${ }^{3} \mathrm{e}$, mais recentemente, Denis Woronoff comparar aquela perseguição a uma "guerra de extermínio". 4

\footnotetext{
${ }^{1}$ Donald M. G. Sutherland, The French Revolution and Empire: Quest for a Civic Order (Oxford: Blackwell, 2003), p. 286.

2 A. Latreille, J.-R. Palanque, E. Delarvelle e R. Rémond (orgs.), Histoire du catholicisme en France: La période contemporaine (Paris: Éditions Spes, 1962), vol. III, p. 148.

${ }^{3}$ A. Mathiez, La Révolution et l'Église (Paris: Armand Colin, 1910), p. 219.

4 D. Woronoff, La République bourgeoise 1794-1799 de Thermidor à Brumaire (Paris: Seuil, 1972), p. 142. Na mesma linha argumentativa, vide também: Jean de Viguerie, Christianisme et Révolution: Cinq Leçons d'histoire de la Révolution Française (Paris: Nouvelles Éditions Latines, 1986), p. 203-222; Claude Petitfrère, "Un anticlérical angevin: La Révellière-Lépeaux et sa religion (17531824)", in: Jean-Clément Martin (org.), Religion et Révolution (Paris: Anthropos, 1994), p. 79-90.
} 
Após declararem que os padres não estavam aptos a educar a juventude nos princípios da virtude republicana purificada e que, a partir de então, as bases exclusivas da instrução pública seriam a filosofia e a racionalista moral da religião natural, os diretores promulgaram a lei de 19 Frutidor que restabelecia pesadas sanções aos padres refratários e impunha novos juramentos de "ódio à realeza" para todo o clero. Combinado com o ressurgimento do jacobinismo como força política, aquele zelo anticlerical implicaria em inúmeros atos de vandalismo e fechamento ou destruição de várias igrejas, além de um novo confisco e venda das propriedades religiosas a valores abaixo do mercado. Em termos humanos, representou a prisão e deportação à Guiana de 1.400 padres (dos quais, mais de duas centenas morreriam no cárcere).

Tamanha foi a animosidade daquele governo e de seus principais apoiadores intelectuais e "burgueses" em relação ao catolicismo, que até mesmo um Benjamin Constant, futuramente célebre por suas críticas às resoluções governamentais arbitrárias e pela defesa de uma liberdade política moderna que preservasse o direito à intimidade e à liberdade de consciência dos indivíduos, apelou publicamente (em um discurso pronunciado no Cercle constitutionnel em 16 de setembro de 1797) à necessidade de o governo do Diretório não mais permitir a menor vacilação em relação ao catolicismo, visto por ele como o principal fator de instabilidade e divisão na França com a sua "multidão de escravos" seduzidos pela "moda" monárquica que readquiria prestígio. ${ }^{5}$

Diante da necessidade urgente de formar cidadãos para a República e, sobretudo, de mantê-la dentro dos marcos constitucionais e sem a necessidade de golpes e repressões futuras, os políticos e intelectuais do Diretório, apesar de críticos ao legado do pensamento de Rousseau (estreitamente vinculado ao Terror jacobino após o 9 Termidor), atribuíram-se o papel de "legisladores" ou formadores de uma vontade-geral republicana, cuja tarefa precípua consistia em suscitar o sentimento patriótico entre os

\footnotetext{
${ }^{5}$ E o próprio intelectual liberal suíço, na condição de presidente do cantão de Luzarches (cargo ao qual fora designado por um decreto do Diretório logo posterior ao golpe), seria responsável pela prisão de um padre refratário (o qual posteriormente seria uma das vítimas fatais da deportação à Guiana). Cf. Helena Rosenblatt, Liberal Values: Benjamin Constant and the Politics of Religion (Cambridge: Cambridge University Press, 2011), p. 60, 62. Esta breve experiência governamental de Constant, marcada por um ardoroso zelo cívico e republicano, permite ilustrar o quanto o pensamento e a prática do autor não podem ser reduzidos a um conceito negativo e individualista de liberdade. Pelo contrário, foi com base neste 'apostolado' republicano e francamente anticatólico que autores como Henri Grange e Etienne Hofmann lançaram dúvidas sobre o real conteúdo do liberalismo de Constant. Assim, enquanto o primeiro referiu-se ao "presidente" do cantão como um "apparatchik" de um regime ditatorial, o segundo sublinhou como o Constant daquele período ainda não podia ser considerado um liberal na acepção plena do termo.Vide: Henri Grange, Benjamin Constant: amoureux et républicain, 1795-1799 (Paris: BellesLettres, 2004), p. 281; E. Hofmann, Les 'Principes de politique' de Benjamin Constant: la genèse d'une oeuvre et l'évolution de la pensée de leur auteur, 1789-1806 (Geneva: DROZ, 1980), p. 94.
} 
franceses por meio de cerimônias públicas e festivais suntuosos que, a exemplo da religião civil de Rousseau, apelavam mais ao coração do que à razão.

A fim de "transferir a sacralidade" ${ }^{6}$ do catolicismo para a República, e dada a escassez de recursos para o estabelecimento de um ensino público, a orientação do governo - para além de incitar a denúncia aos padres e intelectuais católicos - consistiu em reforçar o calendário revolucionário (o decadário) e promover o maior número possível de festivais cívicos, então identificados como as principais "instituições republicanas". 7

À luz da perspectiva histórica, pode-se afirmar que nenhum outro fator contribuiu mais para o desgaste do governo do Diretório junto à sociedade francesa do que a imposição daquelas "instituições republicanas" (especialmente a substituição da observância cristã dominical pelo décade), e as quais Isser Woloch definiu como "recorrentes exercícios de futilidade" que não faziam mais senão atrair a indiferença, quando não a franca hostilidade dos franceses (cientes de que a imposição do calendário contradizia o princípio de liberdade de pensamento ou de religião que se supunha garantido pelo $354^{\circ}$ artigo da Constituição de 1795). ${ }^{8}$

Ao refletir sobre as causas que levaram à queda da República durante o Consulado, Mme de Staël destacou, naquele que seria seu último e influente livro, as Considérations sur la Révolution française (publicado postumamente, em 1818), que o governo republicano teria satisfeito a opinião pública francesa (eminentemente católica) se abandonasse a coercitiva e errática política do Diretório em matéria religiosa e adotasse, em contrapartida, uma política de tolerância como a que existia nos Estados Unidos. No parecer da filha de Necker, a maioria católica francesa exigia apenas o fim dos impedimentos legais e perseguições que pesavam sobre o culto e seus ministros, e teria se acomodado perfeitamente ao regime republicano não fosse pela intervenção oportunista e deletéria do ambicioso cônsul Napoleão, que lançou mão de um uso instrumental e oportunista da religião católica a fim de pavimentar o caminho de seu despotismo pessoal. ${ }^{9}$

\footnotetext{
${ }^{6}$ M. Ozouf, Festivals and the French Revolution (Cambridge/MA: Harvard University Press, 1989), p. XI.

I. Woloch, " 'Republican Institutions,' 1797-1799", in: Colin Lucas (org.), The French Revolution and the Creation of Modern Political Culture, vol II: The Political Culture of the French Revolution (Oxford, Pergamon Press, 1988).

${ }^{8}$ Idem, p. 382.

${ }^{9}$ G. de Staël, Considérations sur la Révolution française, (org.). Jacques Godechot (Paris: Tallandier, 2000), p. 373-374.
} 
Apoiado nos relatórios policiais e dos prefeitos que informavam um redespertar da opinião pública católica, e a qual, através dos populares periódicos Journal des débats e Mercure de France, denunciava a corrupção moral da sociedade francesa (e para tanto, os jornais serviam-se dos relatórios policiais e dos crescentes índices criminais e de suicídio para confirmar sua tese) provocada pela filosofia (invariavelmente equacionada com a Revolução e o Terror) para ressaltar, através de argumentos paradoxalmente utilitários (isto é, enfatizando os benefícios sociais e políticos na promoção do culto católico), a necessidade de o Estado restabelecer em sua plenitude a religião católica, Napoleão - bastante elogiado por haver colocado um fim à anarquia e restabelecido a ordem, e ciente de que precisava expandir a base social de seu governo para além das forças armadas - finalmente decidiu lançar mão do catolicismo (isto é, deu início, em agosto de 1801, às negociações de uma Concordata com o papa Pio VII), visto por ele como um instrumento útil para a consecução de suas pretensões políticas. ${ }^{10}$

Assim procedendo, o primeiro cônsul frustrou conscientemente sua base de apoio junto aos ideólogos e intelectuais liberais republicanos (como Necker, Mme de Staël e Benjamin Constant), os quais, apesar de reconhecerem o diagnóstico católico e contrarrevolucionário a respeito da crise moral que se abatia sobre a sociedade francesa na virada do século, absolviam o filosofismo (e, por extensão, a Revolução) da responsabilidade por aquele estado social anômico, atribuindo-o justamente à imobilidade e à passividade/subserviência intelectual e política resultantes de séculos de catolicismo, que deveria, portanto, ser substituído pelo protestantismo, única religião capaz de, diante do fracasso das sucessivas tentativas de imposição de uma "religião

\footnotetext{
${ }^{10}$ Louis Madelin, Le Consulat et l'empire (Paris: Hachette, 1932-33), p. 91.
} 
revolucionária" ${ }^{11}$, atender às necessidades de regeneração moral da sociedade francesa sem prejudicar o progresso moral e material da mesma. ${ }^{12}$

Tamanho era o consenso no interior daquela elite intelectual republicana a favor da adoção do protestantismo (visto como compatível com as exigências deístas de uma religiosidade natural) pelo Estado - e, poderíamos dizer, o crescente temor de que Napoleão, por meio do uso instrumental da religião, impusesse um golpe definitivo à República declarando-se imperador -, que o Instituto Nacional, em ocasião de um concurso por ele organizado no outono de 1801 - e no qual perguntava sobre as causas que mais ajudaram a desenvolver o espírito da liberdade na França, de Francisco I a 1789 -, premiou um discurso francamente apologético à Reforma, retratada como "mais análoga aos princípios" da forma republicana de governo e contrária ao despotismo monárquico e clerical. ${ }^{13}$

E ninguém melhor do que o conselheiro de Estado e ex-deputado montanhês durante o Terror, Antoine-Claire Thibaudeau (1765-1854) - bastante crítico da dupla Staël e Constant durante o Diretório -, expressaria aquele desejo da elite intelectual e política do Consulado de converter a França ao protestantismo como forma de manter a república e os ganhos da Revolução. Conforme revelaria em suas memórias, Thibaudeau tentara, em vão, dissuadir o primeiro cônsul de restabelecer em sua plenitude o clero católico através de uma Concordata com Roma, demonstrando-lhe que a França estava a um passo de dar um golpe mortal no papismo e de se tornar protestante. $^{14}$

${ }^{11}$ Ao acusar a Igreja de estar comprometida com o poder político e condená-la por haver exercido um poder obscuro sobre os homens, a Revolução tornava-se ela própria uma "igreja", de modo que, como bem salientou Mona Ozouf referindo-se à interpretação de Michelet, "se a Revolução Francesa não adotara qualquer igreja, era porque ela própria era uma Igreja." $\mathrm{Na}$ medida em que ignorou as considerações de espaço e de tempo no avanço de suas promessas de liberdade e igualdade, que procurou destacar o indivíduo dele próprio com o propósito de ligá-lo aos seus semelhantes no culto da pátria, que buscou introduzir um novo marco para a divisão do tempo e substituir o culto e o calendário cristãos, devemos admitir que "existiu uma religião consubstancial à Revolução", "se definirmos como religião revolucionária o desvio do sentimento do sagrado para a Pátria e para a Humanidade." Longe de pretender expulsar o sagrado da vida social, os revolucionários buscavam eliminar o que julgavam ser o caráter sombrio e trágico da religião católica, substituindo-o por um culto marcadamente deísta e anticlerical que conciliava a noção de uma sacralidade da Humanidade com a exigência do sacrifício do indivíduo à pátria. Vide: Mona Ozouf, "Religião Revolucionária", in: F. Furet e M. Ozouf (orgs.), Dicionário crítico da Revolução Francesa (Rio de Janeiro: Nova Fronteira, 1989), p. 597 e 605.

${ }^{12}$ Como sustentou, por exemplo, Mme de Staël em seu panfleto De la littérature dans ses rapports avec la morale (1800).

${ }^{13}$ Helena Rosenblatt, Liberal Values: Benjamin Constant and the Politics of Religion, p. 85.

${ }^{14}$ Antoine-Clair Thibaudeau, Mémoires sur le Consulat, $1799-1804$ (Paris: Ponthieu et C $\left.{ }^{\mathrm{ie}}, 1827\right)$, p. $153-156$. 
Diante daquela proposta de seu conselheiro - a qual pode ser entendida como a última tentativa da elite intelectual republicana manter sua influência no governo -, Napoleão censurou Thibaudeau por sugerir que ele fizesse o oposto de Henrique IV, numa clara demonstração de desconhecimento das circunstâncias políticas. Conforme explicaria o Ministro dos Assuntos Religiosos e Culto Público - Jean-Étienne Marie Portalis (1746-1807) - ao corpo legislativo em seu discurso de 15 Germinal do ano X (5/04/1802), a "multidão precisava de uma religião", a qual, seja por seu enraizamento e penetração social, seja por seus mistérios, ritos e dogmas (mais adequados a conquistar o povo do que uma religião "puramente intelectual" como o deísmo teofilantrópico e/ou o protestantismo), tinha de ser católica. ${ }^{15}$

Com efeito, um dos aspectos mais curiosos daquele prolixo discurso de Portalis consistiu em defender o catolicismo - tanto das acusações feitas pela protestante Mme de Staël no De la littérature considérée dans ses rapports avec les institutions sociales (1800), quanto dos ideólogos deístas ou ateus que ecoavam a clássica abordagem anticlerical de Condorcet - por meio de uma argumentação que privilegiava antes as utilidades ou vantagens da religião ao corpo social do que a sabedoria ou verdade de suas mensagens.

Após observar que os homens de seu tempo, indiferentes "pelas instituições religiosas, e por tudo o que não se relaciona com as ciências e as artes, aos meios da indústria e do comércio..., e aos objetos da economia política" - tidos como as únicas causas da "prosperidade dos Estados" -, eram "excessivamente confiantes" em suas "luzes adquiridas" e "orgulhosos do estado de perfeição" a que chegaram - a ponto de imaginar, "sem nenhum prejuízo do bem comum", que "poderiam a partir de então renunciar" aos "preconceitos antigos" e separar os homens "bruscamente de tudo aquilo" que os "civilizou"16-, Portalis destacava que as leis de um Estado eram impotentes sem o concurso da moral, a qual, para ser efetiva, necessita ser "sensível ao povo."17 Em termos que antecipariam o Génie du Christianisme de Chateaubriand, Portalis observou o seguinte:

${ }^{15}$ Portalis, Discours prononcé par le Citoyen Portalis, orateur du Gouvernement, dans la séance du Corps législatif du 15 germinal an X, sur l'organisation des cultes (Paris, An X), in: Pierre Pradié, La Question Religieuse en 1682, 1790, 1802 et 1848 (Paris: Sagnier et Bray, 1849), p. 38, 42 e 82.

${ }_{16}^{16}$ Portalis, Discours prononcé par le Citoyen Portalis, orateur du Gouvernement..., p. 39-40.

${ }^{17}$ Idem, p. 41. 
"Uma das grandes vantagens das religiões positivas é ainda a de ligar a moral aos ritos, às cerimônias, às práticas que se tornam seu apoio. Pois não devemos crer que se possa conduzir os homens com abstrações ou máximas friamente calculadas. A moral não é uma ciência especulativa... ${ }^{18} / \mathrm{O}$ interesse dos governos humanos é, pois, o de proteger as instituições religiosas, pois é através delas que a consciência intervém em todos os assuntos da vida... ${ }^{19}$ Longe de a superstição..." - para ele, um mal infinitamente menor em relação ao ateísmo "nascer do estabelecimento das religiões positivas, podemos afirmar que, sem o freio das doutrinas e das instituições religiosas, não haveria mais limites à incredulidade, à superstição, à impostura. Os homens, em geral, têm necessidade de ser crentes para não ser crédulos; precisam de um culto para não ser supersticiosos."20

Como era de se esperar, a reação da elite política e intelectual republicana à proposição da Concordata foi imediata, de modo que coube ao presidente do corpo legislativo, o renomado ideólogo Charles-François Dupuis e autor do profundamente condorcetiano Origine de tous les cultes (1795), atacar o cristianismo (e, mormente, o catolicismo).

Em seu póstumo e ainda influente Esquisse d'un tableau historique des progrès de l'esprit humain (1794), Condorcet não deixava dúvidas quanto ao caráter negativo das religiões e, sobretudo, do clericalismo (sob quaisquer formas), por ele vistos como os maiores óbices ao progresso do espírito humano.

Descrito inicialmente por Condorcet (e seu seguidor Dupuis) como uma autoilusão honesta - fruto da incompreensão do intelecto humano em abarcar os aspectos causais dos fenômenos naturais que lhe favoreciam ou prejudicavam -, o sentimento religioso teria sido prontamente açambarcado pelos padres, que rapidamente passaram de vítimas de sua própria ignorância a tiranos da simplicidade alheia: "homens dotados de uma imaginação mais viva e mais apta a realizar as ilusões, exercendo assim um enorme império sobre a crença dos outros", os padres (levados pelo "orgulho", pela "avidez", pela "ambição") "aprenderam rapidamente a inventar coisas extraordinárias" com o objetivo de "enganar o povo" e "dominar os espíritos". ${ }^{21}$ Conforme detalhou Condorcet:

\footnotetext{
${ }^{18}$ Portalis, Discours prononcé par le Citoyen Portalis, orateur du Gouvernement..., p. 42.

${ }^{19}$ Idem, p. 43.

${ }^{20}$ Portalis, Discours prononcé par le Citoyen Portalis, orateur du Gouvernement..., p.45.

${ }^{21}$ Condorcet, Esquisse d'un tableau historique des progrès de l'esprit humain (Paris: Agasse,
} 1794), p. 61-62. 
"Como seu objetivo não era o de esclarecer, mas de dominar, não apenas eles não comunicavam ao povo todos os seus conhecimentos, mas corrompiam através de erros aqueles que estavam dispostos a revelá-los; ensinavam-lhe não o que acreditavam ser verdadeiro, mas o que lhes era útil. Tiveram então duas doutrinas, uma somente para eles, outra para o povo." 22

E uma vez que estes homens estiveram (e ainda estavam) movidos pelo interesse de enganar, deviam necessariamente perder o interesse pela autêntica busca da verdade ${ }^{23}$, razão pela qual se esqueciam progressivamente de uma parte de suas verdades ocultas expressas sob formas alegóricas: "não mantiveram de sua antiga ciência a não ser o que era rigorosamente necessário para conservar a confiança de seus discípulos; e acabaram eles mesmos vítimas de suas próprias fábulas." ${ }^{24}$

Que a religião assim concebida fosse inimiga de todo progresso moral e material, Condorcet não deixava espaço a nenhuma dúvida. Assim, desde que a religião se torna a alma de uma nação, no instante em que ela serve de estrutura para o edifício político e social, não se pode esperar mais senão uma irremediável decadência civilizatória e o despotismo, como a representada no Esquisse pelo advento do cristianismo.

De acordo com Condorcet, a religião, que não passara de um instrumento nas mãos da política até o advento do cristianismo, tornara-se, a partir do mesmo, um instrumento de poder da própria religião. Assim, se para o poeta alemão Novalis - cuja obra Cristandade ou Europa, redigida em 1799, acabara de ser publicada na Alemanha (isto é, em abril de 1802) - a Idade Media representara o ápice da civilização europeia, para Condorcet, o mesmo período significou uma época de trevas e de profunda corrupção do espírito humano: "O triunfo do cristianismo foi o sinal da completa decadência das ciências e da filosofia." ${ }^{25}$

No dia 24 germinal do ano X (14 de abril de 1802), a poucos meses de a instável República revolucionária francesa completar sua primeira década de existência (e pouco depois de o primeiro cônsul Napoleão Bonaparte promulgar a tão debatida Concordata entre a França e o papado), François-René Chateaubriand (1768-1848) publicou o Génie du Christianisme, uma defesa do cristianismo (e, vale dizer, do catolicismo) e um ataque à filosofia da Ilustração conduzidos mais nos planos histórico e literário do que propriamente filosófico-doutrinal. Pretendendo demonstrar a natureza excepcional da

\footnotetext{
${ }^{22}$ Condorcet, Esquisse d'un tableau historique des progrès de l'esprit humain..., p. 65-66.

${ }^{23}$ Idem, p.70.

${ }^{24}$ Ibidem, p.70-71.

${ }^{25}$ Ibidem, p. 136.
} 
religião católica, seja em seu núcleo interno (doutrinal) seja, sobretudo, em todas as suas manifestações externas (as letras, as artes dramáticas e plásticas, a música, a arquitetura, a agricultura, as ciências, o comércio, etc), o Génie era uma autêntica obra apologética contra os ataques vindos da elite intelectual republicana (de intelectuais liberais e republicanos protestantes como Mme de Staël e Benjamin Constant, a ideólogos como Charles Dupuis e Destutt de Tracy $^{26}$ ), e os quais haviam suscitado não apenas perseguições religiosas, como um furor iconoclástico responsável pela destruição de igrejas, abadias, monumentos e obras de arte relacionadas ao cristianismo ao longo do processo revolucionário.

E num momento em que as inúmeras "famílias mutiladas" e "corações despedaçados" pelas dilacerações revolucionárias sentiam "uma necessidade de fé" e "uma avidez de consolação religiosa"27, a apologética de Chateaubriand pretendia demonstrar racionalmente não apenas que a religião natural era fraca ou insuficiente para atender àquela carência espiritual, mas que a religião revelada (mais especificamente, o cristianismo em sua acepção católica) era plenamente compatível com um alto ideal de humanidade e, portanto, favorável ao progresso material e moral da mesma.

Ciente das escassas possibilidades de triunfo de qualquer apologética que, em meio àquela atmosfera de relaxamento doutrinal (um produto do longo processo de assimilação da epistemologia ilustrada e da completa desorganização social do clero), se mostrasse eivada de sutilezas teológicas ${ }^{28}$, Chateaubriand logrou apresentar no Génie uma espécie de "Enciclopédia da religião cristã" e a qual, apesar de apresentar a mesma

\footnotetext{
${ }^{26}$ Sobretudo através dos colóquios e discursos sediados no Instituto Nacional e artigos publicados no Décade philosophique. No caso de Tracy, o mesmo republicaria em 1804 seu virulento requisitório contra o cristianismo - o Analyse raisonné de tous les cultes (1795) - após a coroação de Napoleão e sua bem-sucedida aliança (sem grandes fricções pelo menos até 1808) entre o Imperador francês e o papado.

${ }^{27}$ François-René de Chateaubriand, Genio del Cristianesimo, in: Sara Faraoni (Bompiani: Milano, 2008), p. 3-5. Edição bilíngue.

"Eis diante do leitor a nossa obra. Os demais gêneros de apologia estão esgotados, e, possivelmente, seriam inúteis hoje. Quem, em nossos dias, leria uma obra de teologia? Alguns homens piedosos que não têm necessidade de serem convencidos, alguns verdadeiros cristãos já persuadidos. Mas [perguntam-me] não é perigoso abordar a religião sob um prisma puramente humano? E por quê? Nossa religião teme as luzes? Uma grande prova de sua origem celeste é que ela suporta o exame mais severo e mais minucioso da razão... O cristianismo seria menos verdadeiro quando parecer mais belo? Guardemonos de um temor pusilânime; por excesso de religião, não deixemos a religião perecer. Não estamos mais no tempo em que se podia dizer: Crede e não examinai... É tempo de demonstrar que, longe de limitar o pensamento, ele [cristianismo] se presta maravilhosamente aos impulsos da alma, e pode encantar o espírito tão divinamente quanto os deuses de Virgílio e de Homero... Esquece-se talvez com muita frequência, nas obras deste gênero, de falar a língua de seus leitores: é preciso ser doutor com o doutor, e poeta com o poeta. Deus não proíbe as estradas floridas quando estas levam a Ele; e não é sempre pelas veredas rudes e sublimes da montanha que a ovelha extraviada retorna ao redil." Cf. François-René de Chateaubriand, Génie du Christianisme, $1^{\mathrm{a}}$ Parte, Livro I, cap. 1.
} 
estrutura e estilo da célebre obra Ilustrada, exaltava mais as belezas do cristianismo do que seu aspecto doutrinal. ${ }^{29}$

Afinal, para o escritor romântico não se tratava mais de iluminar a humanidade com a débil luz da razão, mas de indicar com veemência o caminho para uma renovação moral da França através do cristianismo, demonstrando racionalmente que as "Belezas da religião cristã" - o subtítulo presente na primeira edição da obra -, suas manifestações estéticas na arte e na literatura, faziam do cristianismo uma religião capaz de interpelar o homem em sua totalidade e promover o seu progresso material na ordem temporal. $\mathrm{O}$ desígnio do autor do Génie não era o de reconciliar os "sofistas" com a religião, mas "o mundo que eles extraviaram" com "os dizeres de que o cristianismo era um culto nascido no seio da barbárie, absurdo em seus dogmas, ridículo em suas cerimônias, inimigo das artes e das letras, da razão e do belo; um culto que não fizera mais senão derramar o sangue, acorrentar os homens e retardar a felicidade e as luzes do gênero humano." Impunha-se, portanto, "provar o contrário", isto é:

"Que de todas as religiões que já existiram, a religião cristã é a mais poética, a mais humana, a mais favorável à liberdade, às artes e às letras; que o mundo moderno lhe deve tudo, da agricultura às ciências abstratas, dos hospitais para os desvalidos aos templos construídos por Michelangelo e decorados por Rafael. Era preciso mostrar que não há nada mais divino que a sua moral, nada mais amável, mais grandioso que os seus dogmas, sua doutrina e o seu culto; era preciso dizer que ela favorece o gênio, depura o gosto, desenvolve as paixões virtuosas, dá vigor ao pensamento, oferece formas nobres ao escritor e modelos perfeitos ao artista." 30

Originada por Voltaire - o qual, "em meio a um povo caprichoso e amável", tornara "a incredulidade uma moda" e convocara "todos os amores-próprios" no ataque ("desde o panfleto à brochura, do epigrama ao sofisma") ao cristianismo, que passou a ser encarado como "um sistema bárbaro cuja queda não podia chegar tão cedo para a liberdade dos homens, o progresso das luzes, os prazeres da vida e a elegância das $\operatorname{artes}^{\prime 31}$ - e continuada pela elite política e intelectual republicana francesa, a incredulidade era "a principal causa da decadência do gosto e do gênio" ${ }^{\prime 32} \mathrm{e}$, por conseguinte, da profunda crise moral e social - com o aumento expressivo dos índices

${ }^{29}$ Cf. C. Garboli, "Apresentação", in: Chateaubriand, Memorie d'oltretomba (Torino: EinaudiGallimard 1995), p. XXIX.

${ }^{30}$ François-René de Chateaubriand, Génie du Christianisme, $1^{\mathrm{a}}$ Parte, Livro I, cap. 1.

${ }^{31}$ Idem, $1^{\text {a }}$ Parte, Livro I, cap. 1.

${ }^{32}$ Ibid., $3^{\text {a }}$ Parte, Livro IV, cap. 5. 
de criminalidade devidamente explorados pelas publicações católicas -, que assolava o país, pois assim como "os bons costumes" (anteriores às leis) "são dependentes do bom gosto e o bom gosto dos bons costumes":

"O mau-gosto, quando incorrigível, é uma falsidade de julgamento...; ora, como o espírito age sobre o coração, é difícil que as vias do segundo sejam retas quando aquelas do primeiro não o são. Aquele que ama o feio, em um tempo em que mil obras-primas podem advertir e corrigir o seu gosto, não está longe de amar o vício; quem quer que seja insensível à beleza, poderia perfeitamente desconhecer a virtude. ${ }^{\text {"33 }}$

Tudo considerado, o Génie pretendia demonstrar que "os progressos das letras eram inseparáveis dos progressos da religião, pois era na língua de Homero e de Virgílio que os Padres explicavam os princípios da fé", de modo que "o sangue dos mártires..., a semente dos cristãos, também fez crescer o laurel do orador e do poeta." E para desarmar os espíritos com relação à crescente influência do Papa na cultura francesa e dissipar o temor (tão difundido pelos ideólogos) de que a Concordata instituiria um Estado dentro do Estado, Chateaubriand argumentava que o poder do Sumo Pontífice, na condição de "pastor geral do rebanho" que "unia as diversas partes da cristandade", limitava-se ao de "conservar os fiéis nos deveres" ou de "defendê-los da opressão", uma vez que seus Estados, grandes o bastante para dar-lhe a independência, eram "demasiado pequenos para que ninguém" temesse seus esforços e não lhe deixavam "senão o poder da opinião." ${ }^{34}$

Para convencer seus leitores de que "aqueles que representam o cristianismo" - "o princípio" do "movimento geral para as luzes" - como um "freio ao progresso"

${ }^{33}$ François-René de Chateaubriand, Génie du Christianisme, $3^{\mathrm{a}}$ Parte, Livro IV, cap. 5.

${ }^{34}$ Idem, 4 a Parte, Livro VI, cap. 6. Mais adiante, quando confrontado com o problema do abuso dos papas, o autor lembra que o "mal passageiro que alguns maus papas fizeram desapareceram com eles; mas sentimos ainda todos os dias a influência dos bens imensos e inestimáveis que o mundo inteiro deve à corte de Roma. Esta corte que quase sempre se mostrou superior a seu século. Ela tinha ideias de legislação, de direito público; ela conhecia as belas-artes, as ciências, a polidez, no momento em que tudo estava mergulhado nas trevas das instituições góticas; ela não se reservava exclusivamente a luz, mas a espalhava entre todos; derrubava as barreiras que os preconceitos elevavam entre as nações; procurava moderar nossos costumes, subtrair-nos de nossa ignorância, arrancar-nos de nossos costumes grosseiros ou ferozes. Entre nossos ancestrais, os papas foram missionários das artes enviados aos bárbaros, legisladores entre os selvagens." Cf. Chateaubriand, Génie du Christianisme, $4^{\mathrm{a}}$ Parte, Livro VI, cap. 6. 
contradiziam "manifestamente os testemunhos históricos", Chateaubriand empreende uma catalogação verdadeiramente "enciclopédica" dos serviços prestados pela Igreja em diversos ramos de atividade humana (da agricultura, às ciências; da marinha ao comércio, através das Cruzadas $^{35}$ ), na qual destaca o trabalho das ordens superiores pela educação da juventude em toda Europa, bem como a descoberta e explicação dos manuscritos antigos. ${ }^{36}$

"É ao cristianismo que as belas-artes devem seu renascimento e sua perfeição", recapitulava Chateaubriand no penúltimo capítulo do Génie. Além de não se opor "a nenhuma verdade natural" na filosofia, o cristianismo desenvolve "por toda parte o esplendor e a majestade" em paralelo com "as intenções morais", as "orações sublimes e tocantes", razão pela qual "os homens devem ao clero secular e regular, às instituições, ao gênio do cristianismo", as principais conquistas políticas e materiais desfrutadas pela modernidade. ${ }^{37}$ Diante da extrema limitação da "ciência política" (afinal, "o último grau de perfeição que ela pode atingir é o sistema representativo", nada mais), "quanto mais conhecida e praticada" for a moral evangélica, "mais esclarecidos serão os homens a respeito de sua felicidade e de seus verdadeiros interesses", pois no cristianismo os preceitos são um código de moral e de virtude". ${ }^{38}$

Uma vez que, "na ordem presente das coisas" da França, era impossível restabelecer a ordem social apenas pela coerção política - pois, como "reprimir uma imensa massa de camponeses livres e distantes do olhar do magistrado"; como prevenir nos "subúrbios da grande capital" os crimes "de um populacho independente sem uma religião que prega os deveres e a virtude a todas as condições da vida?" -, Chateaubriand perorava com a seguinte advertência: "Destruí o culto evangélico, e vos faltará em cada aldeia uma polícia, prisões e carrascos." ${ }^{39}$

E graças "à superidade de suas luzes", ao "seu gênio conciliador, sua missão de paz", e à "própria natureza de seus interesses", a Igreja exercia um papel de mediadora universal nos sistemas políticos nacional e internacional. ${ }^{40}$ E para endossar sua tese que certamente serviu de inspiração ao livro ultramontano de Maistre -, Chateaubriand apelou a um trecho de o Espírito das Leis (1748) em que "Montesquieu provou categoricamente que o cristianismo é oposto por espírito e sabedoria ao poder arbitrário,

\footnotetext{
${ }^{35}$ Chateaubriand, Génie du Christianisme, 4 a Parte, Livro VI, cap. 6.

${ }^{36}$ Idem.

${ }^{37}$ François-René de Chateaubriand, Génie du Christianisme, $4^{\mathrm{a}}$ Parte, Livro VI, cap. 12.

${ }^{38}$ Idem, $4{ }^{\text {a }}$ Parte, Livro VI, cap. 13.

${ }^{39}$ Idem.

${ }^{40}$ Ibid., $4^{\mathrm{a}}$ Parte, Livro VI, cap. 11.
} 
e que os seus princípios fazem mais que a honra nas monarquias, a virtude nas repúblicas, e o medo nos Estados despóticos". ${ }^{41}$

O fato é que Napoleão, uma vez consagrado imperador pelo papa Pio VII (dezembro de 1804) na catedral de Notre-Dame de Paris (para desespero e estupefação de Maistre), e a despeito do caráter ecumênico daquela coroação (que contou com a presença das principais lideranças protestantes francesas) e do uso manifestamente instrumental do catolicismo por ele, tinha todos os motivos para estar satisfeito com a cooperação da Igreja Católica, e que, de acordo com o ministro Portalis, traduzia-se em pedidos de orações e/ou discursos favoráveis ao alistamento dos fiéis ao exército imperial nos púlpitos.

Como bem pontuou Schumpeter em seu clássico Capitalismo, Socialismo e Democracia (1942), diante do impasse representado pela coexistência (conflituosa) de um forte sentimento anticlerical (que não se limitava aos derrotados jacobinos) com uma "forte onda de furioso sentimento católico" na França pós-termidoriana, coube ao primeiro cônsul resolver uma luta que se revelaria "interminável" e/ou fratricida se desenvolvida dentro do escopo democrático. ${ }^{42}$

Elogiado como um "novo Ciro" - o imperador persa que, em 538 a.C., permitiu o retorno dos judeus à Palestina -, Napoleão afastou-se definitivamente dos ideólogos cujo elitismo filosófico ou desdenho pelas massas (mais do que nunca, vistas como irracionais e ignorantes ${ }^{43}$ ) não servia aos desígnios populistas do imperador -, os quais, por sua vez, retirar-se-iam da vida pública ou, cedendo à solapadora máquina patrimonialista do imperador, abandonariam a defesa da República por lucrativos cargos senatoriais e pensões (como foram os casos de Cabanis, Volney e Tracy), a defesa dos princípios republicanos da liberdade política por considerações econômico-materialistas

\footnotetext{
${ }^{41}$ Chateaubriand, Génie du Christianisme, $4^{\mathrm{a}}$ Parte, Livro VI, cap. 11.

42 Joseph A. Schumpeter, Capitalismo, Socialismo e Democracia (Rio de Janeiro: Editora Fundo de Cultura, 1961), p. 311-312.

${ }^{43}$ Não por acaso, as publicações católicas enveredavam por um discurso que, na defesa da sabedoria (religiosa) popular, muitas vezes beirava o populismo. Leia-se, por exemplo, o seguinte trecho do Génie de Chateaubriand: "O povo é muito mais sábio que os filósofos. Cada fonte, cada cruz sobre um caminho, cada suspiro do vento noturno, trazem consigo um prodígio. Para o homem de fé, a natureza é uma constante maravilha. Se sofre, reza à sua pequena imagem, e é consolado. Tem necessidade de rever um parente ou um amigo, faz uma promessa, apanha o bastão e o bordão do peregrino; atravessa os Alpes ou os Pirineus, visita Nossa Senhora de Loreto ou São Tiago na Galícia; ele se prostra, roga ao santo para que lhe devolva o filho (talvez um desventurado marinheiro disperso nos mares), salve sua esposa, prolongue os dias de um pai. Seu coração encontra-se aliviado... Felizes, três e quatro vezes mais felizes, os que creem! Não podem sorrir sem saber que sorrirão sempre; não podem chorar sem pensar que estão ao fim de suas lágrimas. Suas lágrimas não foram em vão: a religião as recolhe em sua urna, e as apresenta ao Eterno." Cf. Chateaubriand, Génie du Christianisme, $3^{\mathrm{a}}$ Parte, Livro V, cap. 6
} 
favoráveis ao industrialismo e ao comércio, identificados como os promotores do "interesse bem compreendido" e do progresso social. ${ }^{44}$

Em resposta ao que julgava ser o degradante estado moral, social e político da França napoleônica - caracterizada pela "traição dos intelectuais", pelo despotismo político e pelo uso instrumental (e supersticioso) da religião -, Mme de Staël concluiu em 1810 o De l'Allemagne, para cuja edição final, e apesar da recente e dolorosa separação, Benjamin Constant colaborou intensa e decisivamente.

Através de exemplos da literatura e da filosofia alemã, Staël pretendia demonstrar as deficiências da cultura francesa em suas duas principais ramificações, a filosófica e a sacra. Naquilo que pode ser considerado como um símbolo da ruptura definitiva da autora (e também de Constant) com os intelectuais da Ideologia, o De l'Allemagne atribuía o quadro degradante da cultura e da sociedade francesa imperial invariavelmente descrita como "frívola", "egoísta" e obcecada pelo "bem-estar" - não apenas ao passado autoritário do Antigo Regime e ao recente despotismo de Napoleão, mas também à epistemologia sensualista da Ilustração (e seus sucessores, os ideólogos), principalmente pelo fato de suas doutrinas sustentarem uma moral que, baseada numa "degradante" epistemologia materialista e irreligiosa (e a autora citava exemplos de Voltaire, Diderot, Condillac, Helvétius), pervertia a moral do povo e fortalecia objetivamente o despotismo napoleônico ao ensinar que o "cálculo prudente" e o "interesse bem compreendido" constituíam um fundamento aceitável para a moral.

Contra aquele sistema de ideias que aviltava o espírito humano e sustentava o despotismo político, Staël advertia que o "destino do homem sobre esta terra não é a felicidade" que se compra a bom preço na ordem (mesmo quando despótica) e no repouso político-social, "mas o aperfeiçoamento moral" conquistado através de sacrifícios, razão pela qual "procurar-se-á em vão fundamentar a perfectibilidade no interesse" ou nos cálculos prudenciais (ou seja, segundo a fórmula bastante difundida do "interesse bem compreendido"). ${ }^{45}$ E sendo a moral fundada sobre o interesse pessoal absolutamente incapaz de exercer o menor "império sobre as paixões" (que "pisam sobre todos os cálculos"), Staël concluía que somente um sentimento contrário igualmente poderoso, isto é, o "entusiasmo" religioso (possível apenas nas religiões que, a exemplo

\footnotetext{
${ }^{44}$ Helena Rosenblatt, Liberal Values: Benjamin Constant and the Politics of Religion, p. 115.

${ }^{45}$ Mme de Staël, De l'Allemagne (New York: Roe Lockwood and Son, 1860), p. 513.
} 
das denominações protestantes, promovem o direito ao exame), poderia inspirar "o sacrifício de nós mesmos" e "afastar toda espécie de egoísmo" entre os homens. ${ }^{46}$

Dotada de uma intuição filosófica e uma sensibilidade estética aguçadas, Staël sublinha que aquela moral utilitarista da Ilustração francesa (da qual os ideólogos eram os principais herdeiros) fora assimilada pela apologética católica, a qual, sobretudo a partir do Génie de Chateaubriand ${ }^{47}$ - um dos alvos da obra -, justificava o cristianismo por meio de uma argumentação que subordinava a verdade aos imperativos de ordem e progresso social. Conforme destacou Mme de Staël numa alusão crítica aos católicos franceses, "não é para as vantagens desta vida, para assegurar algumas fruições a mais em alguns dias da existência, e retardar um pouco a morte que a consciência e a religião nos foram dados", mas "para que as criaturas em posse do livre-arbítrio escolham aquilo que é justo, sacrificando o que é lucrativo; preferindo o porvir ao presente, o invisível ao visível, e a dignidade da espécie humana à própria conservação dos indivíduos". 48

Ao emprestarem seu apoio ao despotismo político de Napoleão sob os pretextos da ordem social e do progresso, tanto os católicos quanto os ideólogos sufocavam o princípio sobre o qual deveria repousar de maneira sustentável o desenvolvimento de qualquer sociedade, a saber, a livre busca pela verdade (seja em matéria religiosa, da qual ela recebe o primeiro impulso, seja em matéria filosófica, consequência do entusiasmo religioso) dos cidadãos de um país. Do contrário, católicos e filósofos, igualmente críticos ao Terror revolucionário (embora por razões e argumentos distintos), teriam de reconhecer a incoerência de suas críticas, pois a "época mais sangrenta da revolução" (durante o governo "que se nomeou comitê de salvação pública") nada mais fez senão justificar "todos os seus crimes" através da "máxima universalmente aceita" de que "a salvação do povo é a lei suprema". Assim procedendo, cristãos e filósofos esqueciam-se de que "a lei suprema é a justiça" e que "a integridade dos princípios da moral importa mais que os interesses dos povos"; que o "indivíduo e a sociedade são responsáveis... pela herança celeste que deve ser transmitida às gerações

\footnotetext{
${ }^{46}$ Mme de Staël, De l'Allemagne, p. 516.

${ }^{47}$ Aqui, importa salientar que Chateaubriand, no momento em que Staël redige o De l'Allemagne, já havia entregue sua demissão à secretaria da embaixada francesa em Roma e passado à oposição (em razão do sequestro, condenação e morte do duque d'Enghien em 1804). Não por acaso, o imperador proibira-lhe de estabelecer residência em Paris e de tomar posse na Academia Francesa, para a qual havia sido eleito em 1811. No entanto, parece-nos que a intenção de Staël não era a de acusar pessoalmente Chateaubriand de desonestidade (como faria com os ideólogos), mas antes de mostrar a aliança objetiva do conteúdo do Génie com o despotismo imperial.

${ }^{48}$ Mme de Staël, De l'Allemagne, p. 506.
} 
sucessivas da raça humana". ${ }^{49}$ Conforme escreveu Staël em uma clara demonstração de o quanto o seu romantismo logrou uma perfeita e rara combinação com o pensamento cosmopolita e liberal:

"A injustiça sempre sacrifica uma porção da sociedade à outra. Em nome de que cálculo aritmético este sacrifício é ordenado? A maioria pode dispor da minoria se, com dificuldade, supera a outra em poucas vozes? Os membros de uma família, de uma companhia de negociantes, os nobres, os eclesiásticos, não têm o direito de dizer que tudo deve ceder ao seu interesse; mas quando uma reunião qualquer..., denomina-se uma nação, tudo the é permitido para a realização de seu bem? A palavra nação sempre será sinônimo de legião, [nome] que se atribuiu o demônio no Evangelho; contudo, não há mais motivo para sacrificar o dever a uma nação do que a qualquer outro grupo de homens." ${ }^{50}$

No caso dos apologistas católicos (como Chateaubriand e Bonald) ${ }^{51}$ que, em nome de premissas utilitárias (paz, harmonia social, progresso das artes, etc...), propunham aos homens a submissão ao dogma e à autoridade clerical, Staël censurava os mesmos por ignorarem não só os homens como o próprio cristianismo em nome do qual falavam, pois a religião cristã representava uma "revelação das leis morais do homem e do universo" contra a "ignorância", o "segredo", as "trevas". ${ }^{52}$ Numa clara alusão ao De

\footnotetext{
${ }^{49}$ Idem, p. 504-505.
}

${ }^{50}$ Mme de Staël, De l'Allemagne, p. 505.

51 Desde o retorno do Egito, Bonaparte interessara-se pelo autor do Théorie du pouvoir (1796), junto ao qual Louis de Fontanes (1757-1821) - presidente do corpo legislativo imperial e futuro grandemestre da Universidade do Império em 1808 - desempenhou o papel de um zeloso intermediário. Na conturbada transição da República ao Império, o constante e vigilante ódio demonstrado por Bonald pela filosofia do século XVIII e pela Revolução chamou a atenção de Napoleão, que enxergou no monarquista teocrata um possível teórico da nova legitimidade.

Um exemplo disso encontra-se em um texto datado de 6/10/1805, no qual Bonald avançava o que poderia ser visto como um "catecismo imperial", ao escrever que "o espírito democrático acaba na Europa com os governos republicanos, e os princípios monárquicos renascem por toda parte, pois a unidade do poder, elemento de toda sociedade, sobrevive às revoluções... Os espíritos, fatigados pelos erros, retornarão à religião cristã, único meio seguro de tranquilidade, de força e de prosperidade para os Estados." No entanto, cumpre ressaltar que Bonald declinou de todos os convites oficiais que recebera em 1807, como a direção do Journal de l'Empire (o antigo e filosófico Journal des Débats, confiscado em 1805), um assento no Conselho da Universidade Imperial e, sobretudo, de uma nova publicação do Théorie du pouvoir, desde que ele retirasse o nome do futuro rei Luís XVIII do livro. De acordo com Derré, somente após os insistentes convites do de seu amigo realista Fontanes, e sem abrir mão de suas convicções, que Bonald, enfim, integrou o conselho da universidade em 1810 (onde desempenhou uma função secundária), pois tudo leva a crer que, naquelas circunstâncias, estava persuadido (sem nenhuma transgressão de seus princípios) de que a Providência havia designado o imperador dos franceses para estabelecer uma nova monarquia. Cf. J. R. Derré, "Chateaubriand et Bonald", in: Cahiers de l'association internationale des études françaises, vo. 21 (1969), p. 151-153.

${ }^{52}$ Mme de Staël, De l'Allemagne, p. 555. 
l'unité religieuse en Europe (1806) ${ }^{53}$ de Louis de Bonald (1754-1840), Staël sublinhará que o catolicismo, "apesar de desarmado" e de ter "a majestade de um velho leão que outrora fazia tremer o universo" - a autora certamente se refere ao novo cativeiro imposto por Napoleão ao Papa e seus Estados a partir de meados de 1809 -, foi o principal responsável por dispor "entraves ao espírito humano", de modo que a Reforma, longe de promover a "aridez de espírito" imputada por Chateaubriand, realizou-se "em nome do uso de todas as faculdades do espírito e de sua imaginação". ${ }^{54}$

Referindo-se à Educação do gênero humano (1780) de Lessing - "um dos espíritos mais vigorosos da Alemanha" -, Staël destacou que não "há verdades perigosas", sendo a pesquisa da verdade "a mais nobre das ocupações, e sua publicação, um dever. Não há nada a temer pela religião nem pela sociedade nesta pesquisa, se ela for sincera." ${ }^{55}$ Ao invés de o exame religioso "perturbar e resfriar o sentimento da fé", foi o catolicismo quem, através de sua intolerância dogmática levada a cabo pelo Estado confessional absolutista, reduziu a religião a um "código penal" e dotou a teologia de "todas as formas de um governo despótico". 56

E uma vez que "o direito ao exame é o fundamento do protestantismo" ${ }^{57}$, nada mais natural que "as nações germânicas" fossem "todas naturalmente religiosas" e inclinadas ao "entusiasmo" 58 , isto é, tomadas pelo "sentimento do infinito" e "do belo

53 Neste livro, Bonald procurou demonstrar que a Revolução Francesa, com tudo o que ela representou em termos de ecumenismo democrático (para ele, sinônimo de anarquia), fortaleceu o apreço pela monarquia nos Estados protestantes e, através da emigração do clero refratário e do contato prolongado do mesmo com os religiosos protestantes, teria dissolvido antigos preconceitos e desarmado os espíritos, pavimentando a via para reunião futura das denominações protestantes em um único e católico cristianismo. Amparado na história da Reforma e da Revolução, Bonald concluía que "a unidade religiosa" era "uma grande necessidade de uma sociedade civilizada", e que a "unidade política" promovida pela França imperial e católica deveria necessariamente avançar a unidade religiosa. Cf. Bonald, De l'unité religieuse en Europe, in: Oeuvres Complètes de L. de Bonald (Paris: J.-P. Migne, 1859), vol. III, p. 675-678 e p. 702.

${ }_{55}$ Mme de Staël, De l'Allemagne, p. 565.

55 Idem, p. 554.

${ }^{56}$ Ibidem, p. 550.

${ }^{57}$ Ibidem, p. 555.

${ }^{58}$ Assim como fizera Constant em Princípios de Política, Staël difere o entusiasmo, a livre e autônoma expansão do espírito em sua experiência com o infinito, do fanatismo (ou superstição), caracterizado pelo dogmatismo clerical que, por seu turno, é resultado da intromissão do Estado nas consciências individuais e nas questões religiosas. Não por acaso, o De l'Allemagne traz um elogio à "teoria dos sentimentos morais" de Smith, cuja defesa do "livre-mercado" das denominações cristãs (pois naquilo que poderíamos chamar de uma "teologia evolucionista", o filósofo ilustrado escocês acreditava, à guisa de David Hume, que a livre competição entre as seitas evitaria os acessos de fanatismo e permitiria o aperfeiçoamento filosófico das mesmas e o desaparecimento natural, isto é, sem traumas, violência, e interferência de qualquer tipo a não ser o da opinião, de outras ) servira de modelo para que Constant sustentasse a liberdade e inclusive o incentivo pelo Estado da proliferação das seitas. Vide respectivamente: Gertrude Himmelfarb, The Roads to Modernity: The British, French, and American Enlightenments (New York: Alfred A. Knopf, 2004), p. 44; B. Constant, Principes de Politique, in: Marcel Gauchet, Benjamin Constant: Écrits politiques (Paris: Gallimard, 1997), p. 476-479. 
ideal"59 ${ }^{59}$ suscitado pela autêntica (isto é, autônoma, livre de todo dogmatismo clerical) experiência religiosa. De acordo com Staël, a dignidade humana só se confirma quando os homens, colocando-se em "harmonia com o sentimento do infinito" (o que só uma autônoma e livre experiência religiosa pode produzir), tornam-se capazes de "sacrificar os interesses" de sua "existência passageira "a esta imortalidade que começa para nós desde o presente, se formos dignos dela". ${ }^{60}$

Portanto, longe de a religião cristã - desenvolvida de maneira autônoma - obliterar o avanço das letras ou das ciências, a mesma representa a "teoria de todas as ideias e o segredo de todos os talentos", sendo "o gênio criador" e a "fonte inesgotável" das "virtudes". 61

Diante da retomada da guerra em 1809 e da escalada da censura que resultou num congelamento do debate político até a queda de Napoleão - a ponto de o De l'Allemagne só vir à luz através de uma publicação londrina de 1813 -, seria preciso esperar pela Restauração para que aquele debate cultural em torno da religião fosse retomado. $\mathrm{E}$ conforme pontuou Stanley Mellon em seu clássico estudo sobre a história política da Restauração, a queda de Napoleão criou as condições ideais para o reacendimento daquele debate, pois a mesma uniu "pela primeira vez" na história francesa (isto é, em um "destino comum" de "desastre") os eternos rivais do passado francês - a monarquia, o clero e a aristocracia -, os quais aprenderam durante a provação revolucionária e o exílio que as "diferenças históricas" deveriam ser esquecidas em nome de uma necessária união política. ${ }^{62}$

${ }^{59}$ Mme de Staël, De l'Allemagne, p. 547. Impossível não perceber aqui o eco de Constant dos Princípios de Política, bem como a influência no De la Religion. Vide o que escreveu Constant nos Princípios a respeito da religião: "Consoladora da infelicidade, a religião é, ao mesmo tempo, de todas as emoções, a mais natural. Todas as nossas sensações físicas, todos os nossos sentimentos morais, fazem-na renascer em nossos corações imperceptivelmente. Tudo o que nos parece sem limites, e produz em nós a noção de imensidão, a visão do céu, o silêncio da noite, a vasta extensão dos mares, tudo o que nos conduz ao enternecimento ou ao entusiasmo, a consciência de uma ação virtuosa, de um generoso sacrifício, de um perigo enfrentado corajosamente, da dor do próximo socorrida ou aliviada, tudo o que levanta do fundo de nossa alma os elementos primitivos de nossa natureza, o desprezo do vício, o ódio da tirania, alimenta o sentimento religioso." Cf. B. Constant, Principes de Politique, p. 465. Sobre a articulação no De la Religion entre anticlericalismo ou antidogmatismo católico e a defesa de uma religião que, a exemplo das denominações protestantes, seja pautada pela autonomia e pelo livre exame e, portanto, capaz de suscitar o sentimento de entusiasmo (o germe de toda orientação filosófica e libertária) e o sacrifício (sem o qual a liberdade política entre os modernos corre o risco de recair na passividade moral que gera o despotismo político) entre os homens, leia-se: Alan Pitt, "The Religion of the Moderns: Freedom and Authenticity in Constant De la Religion", in: History of Political Thought, vol. XXI, $\mathrm{n}^{\circ} 1$, 2000, p. 67-87.

${ }^{60}$ Mme de Staël, De l'Allemagne, p. 549.

${ }^{61}$ Idem, p. 550-551.

${ }^{62}$ S. Mellon, The Political Uses of History: a Study of Historians in the French Restoration (Stanford: Stanford University Press, 1958), p. 101. 
Em contraste com os liberais do século XVIII e as primeiras fases da Revolução, quando o campo liberal (patriótico) não se deparou com esse tipo de problema - pois havia um alto clero aristocrático (jesuítico) e um baixo clero galicano-jansenista (mais "liberal"), assim como uma nobreza mais aristocrática (responsável por julgar e expulsar os jesuítas ou, em sua oposição contra os desígnios reformistas da monarquia, iniciar a Revolução através da "revolta parlamentar" de 1787-1788) e outra mais liberal e filosófica (Voltaire, Mirabeau, Condorcet) -, os liberais da Restauração defrontaramse com uma perigosa coalizão em torno da monarquia constituída por um clero ultramontano (exemplificado pela restauração dos jesuítas - como o superior geral da ordem e amigo pessoal de Maistre, o prussiano de origem polonesa Thaddeus Brzozowski -, na França e na Europa após o longo exílio russo iniciado em 1773) e uma aristocracia mais realista do que o rei.

Diante da necessidade de defender as instituições, os interesses e os homens da Revolução em meio à presença das tropas cossacas em Paris, ao controle da Câmara dos Pares pelos ultras e do terror branco marcadamente antiprotestante no Sul $^{63}$, a saída encontrada pelos campos doutrinário e liberal para rachar aquela aliança, e a qual, na feliz expressão de Stanley Mellon, representou uma autêntica "virada de mesa" política $^{64}$, consistiu em apelar ao campo da história, que desde a Revolução, e salvo ilustres e raras exceções (como Constant e Staël), fora dominado pelos autores contrarrevolucionários, de Burke aos emigrados Barruel, Chateaubriand, Bonald e o saboiano Maistre.

Uma vez que era impossível, num primeiro momento, enfrentar semelhante bloco político de frente, o método histórico permitiu aos intelectuais e políticos liberais da Restauração manterem suas pessoas invulneráveis enquanto defendiam as conquistas da Revolução. E uma das principais estratégias no interior deste método histórico consistiu em produzir narrativas apologéticas a um "reformista" e "constitucional" Luís XVI, cujo martírio teria sido causado pela desastrosa "conspiração" aristocrática dos nobres emigrados em associação com os padres refratários que, inspirados pelos princípios regicidas da Liga católica, opuseram-se ao rei (ao não aceitarem a Constituição Civil do Clero) e, pior do que isto, justificaram teologicamente junto ao povo (mormente o da

${ }^{63}$ Entre setembro e novembro de 1815 , os ultrarrealistas católicos atacaram os protestantes franceses pelo fato de seu grande e precoce envolvimento no governo de Napoleão durante os Cem Dias (sobretudo através de Constant e seu profundamente anticatólico Acte additionnel que trazia em anexo os Princípios de Política). Além de saques e depredações a igrejas, estes ataques deixaram um rastro de mais de mil mortes. Cf. H. Rosenblatt, Liberal Values..., p. 176.

${ }^{64}$ S. Mellon, The Political Uses of History: a Study of Historians in the French Restoration, p. 6. 
Vendeia) a conspiração aristocrática do exterior que ameaçou a integridade territorial francesa, desestabilizando o poder monárquico e preparando a ascensão dos jacobinos ao poder.

Ao diferenciarem uma revolução "boa" (a monárquica constitucional de 1789-1791) da "má" (a derrapagem "ultra"-jacobina de 1792-1794), autores como Mme de Stäel e Constant procuravam demonstrar ao restaurado Luís XVIII que a base mais segura para o seu poder estava naqueles que o apoiaram em 1789 contra a reação aristocrática, isto é, no "Terceiro Estado" de Sieyès ou nos "comuns", sendo a associação entre o povo (entendido aqui como classe-média ou burguesia) e a monarquia a mais antiga e comum da história da França, cujo fio-condutor era dado por uma "luta de classes" entre a burguesia (favorável à monarquia e apoiada por ela) e aristocracia feudal (uma força centrífuga e desestabilizadora). ${ }^{65}$

No ano seguinte, em ocasião do Congresso de Viena, Bonald escreveu um panfleto intitulado Réflexions sur l'intérêt général de l'Europe (1815), no qual argumentava que o sucesso do Congresso dependeria da capacidade dos Estados agredidos pela França revolucionária refletirem em termos de futuro, no sentido de promoverem um auxílio mútuo "contra o único perigo a temer para os povos chegados a um alto grau de civilização e de conhecimentos," a saber, "contra o perigo das falsas doutrinas que minam silenciosamente as leis, os costumes, as instituições". Naquele momento, impunha-se conscientizar os Estados vencedores sobre Napoleão de que todos os esforços deveriam ser concentrados não no sentido de lançar sanções contra a França (o que faria ressurgir o fervor jacobino), mas de evitar que a Europa fosse consumida pelo "dogma ateu da soberania do povo", que ela deixasse de ser "cristã e monárquica", sob pena de não existir mais. ${ }^{66}$

Mais adiante, Bonald chamava a atenção para o fato de que tão fundamental quanto a paz e a ordem na França para o futuro equilíbrio europeu, era o pleno restabelecimento do Papa e da Santa Sé de Roma, pois era "de lá, ainda", que viriam "a ordem e a paz dos espíritos e do coração." 67 Os "Estados Gerais da Europa" (de acordo com o político ultra, pela segunda vez desde o Tratado de Vestfália) sediados em Viena depois da "guerra de irreligião" ("excitada por doutrinas pretensamente filosóficas que

\footnotetext{
${ }^{65}$ Como um tratamento mais detalhado da historiografia liberal da Restauração ultrapassa o escopo desta tese, sugerimos a leitura do referido livro de S. Mellon (The Political Uses of History: a Study of Historians in the French Restoration), mormente o segundo capítulo.

${ }^{66}$ Bonald, Réflexions sur l'intérêt général de l'Europe (Paris: Le Normant, 1815), p. 22.

${ }^{67}$ Idem, p. 49.
} 
nada mais são senão uma degeneração da Reforma") tinham a missão de consolidar a paz e a ordem no continente, o que para Bonald era sinônimo de cristianismo (vale dizer, catolicismo) e monarquia, nesta ordem. ${ }^{68}$

Portanto, os governos deveriam trabalhar "em concerto para restaurar em suas bases antigas" a "coluna que carrega os destinos da Europa", para fortalecer "este liame misterioso que une entre eles todos os seus filhos, mesmo aqueles que, reconhecendo por pai comum o divino fundador do cristianismo, nasceram de mães diferentes." ${ }^{69}$ Nas palavras de Bonald:

"A política se fortalece com tudo o que ela doa à religião, assim como se enfraquece com o que lhe recusa. Foi sobre este grande princípio que Carlos Magno construíra a cristandade, e infeliz da sociedade se, para sempre extraviados pelas opiniões falsas e estreitas, ou pérfidas intenções, os governos se esqueçam de que, entre as nações independentes e proprietárias, não há dignidade sem independência, nem independência sem propriedade; e que a religião, seu líder e seus ministros, que, mais do que nunca necessitam de dignidade e de consideração, devem ser independentes dos erros dos governos, das necessidades dos administradores, e das paixões humanas." ${ }^{70}$

No entanto, após a dissolução da ultra chambre introuvable (1815-1816) por Luís XVIII e a ascensão dos liberais ao poder, Bonald, cada vez mais preocupado com a influência dos liberais doutrinários sobre o rei - muitos dos quais, com um comprometedor passado revolucionário ou imperial (como Royer-Collard, Maine de Biran e o barão de Barante) -, avançou em seu panfleto Pensées sur divers sujets et discours politiques (impresso pela editora da cúria metropolitana administrada pela diocese de Paris em 1817) uma imprudente defesa da Liga católica (e, por extensão, dos restabelecidos jesuítas), cujos princípios, representando para ele os verdadeiros interesses da legitimidade e da religião, ensinavam que a oposição ao monarca não apenas era legítima em casos extremos - como foram os casos de Henrique III e de Henrique IV -, como expressava o mais autêntico realismo ou defesa da instituição monárquica, na medida em que, em última análise, a defesa da ortodoxia católica implicava necessariamente na defesa do trono, que não poderia existir separadamente daquela:

\footnotetext{
${ }^{68}$ Bonald, Réflexions sur l'intérêt général de l'Europe, p. 6 e 9.

${ }^{69}$ Idem, p. 50.

${ }^{70}$ Ibidem, p. 50-51.
} 
"Nossos reis, desde Henrique IV, e nossos philosophes, defenestraram em concerto a Liga; os últimos, porque ela impedira a democracia calvinista de se estabelecer na França; os primeiros, porque ela fizera da religião do Estado uma condição necessária à realeza... Quando a religião era atacada, não se separava a realeza da religião. Nos dias de hoje, em que a legitimidade é desconhecida, não se separa a realeza da legitimidade. A França queria então, como quer hoje, a realeza consagrada pela religião ou fortalecida pela legitimidade. O objeto é o mesmo, os motivos são diferentes; os ligueurs daquela época seriam os realistas da nossa.. ${ }^{71}$

Como era de se esperar, a resposta liberal ao panfleto do deputado Bonald foi imediata e, através de um artigo publicado na revista Archives philosophiques, politiques et littéraires, expunha com todas as letras o perigo representado pelos ultras aristocráticos à realeza e à estabilidade política da França. Lembrando à opinião pública nacional que "um dos primeiros resultados da Liga foi o assassinato do rei" e que os aristocráticos ultras, a exemplo dos ligueurs, pretendiam criar um Estado dentro do Estado, a revista doutrinária e liberal concluía que a defesa da "Liga" por Bonald simplesmente "continua a guerra contra a realeza e a religião". ${ }^{72}$

Como se as trocas de insultos como estes na opinião pública e nos debates parlamentares não bastassem, a proposta (também em 1817) de uma nova Concordata entre o Papa e o rei francês esquentou ainda mais a temperatura política, caindo "como uma luva" para os liberais, que logo perceberam que a aliança entre o clero e a monarquia poderia ser rachada por meio da mesma questão que, ao opor Roma contra as prerrogativas reais expressas nas liberdades galicanas, provocara inúmeras fraturas durante o Antigo Regime.

Diante disso, o típico argumento liberal consistia em colocar o dedo em feridas mal cicatrizadas do passado de ambos os lados, enfatizando sobretudo a falsidade histórica do argumento ultramontano que preconizava uma tradicional aliança entre o trono francês e o altar romano na história francesa. E a principal estratégia encontrada pelos escritores e políticos liberais para dividir o bloco conservador consistiu em associar a defesa da monarquia constitucional à história do galicanismo. Conforme destacou Stanley Mellon, foi sob este ângulo (o da defesa liberal das tradições galicanas) que se forjou uma das alianças mais decisivas durante a Restauração - entre

\footnotetext{
${ }^{71}$ Bonald, Pensées sur divers sujets (Paris: Adrien Le Clere, 1817), vol. I, p. 17-18.

${ }^{72}$ Archives philosophiques, politiques et littéraires (Paris: Fournier, 1817), vol. I, p. 112-113. Infelizmente, não conseguimos identificar a autoria do artigo.
} 
os políticos e intelectuais liberais, de um lado; o clero e os políticos galicanos, de outro -, "uns lutando pelas liberdades políticas, outros pelas liberdades religiosas". Por toda a Restauração, "os liberais tornaram-se 'galicanos' e, como tais, buscaram arrastar os 'verdadeiros' galicanos do clero francês contra os ultramontanos". ${ }^{73}$ Apesar de o galicanismo também trazer em seu bojo um risco (para os liberais, eminentemente despótico) de confusão das esferas espiritual e temporal - o uso do catolicismo durante o império napoleônico ainda era muito vivo nas memórias -, os liberais estavam plenamente conscientes de que o galicanismo era uma arma muito importante para ser abandonada.

Neste ínterim, enquanto o escritor e dramaturgo liberal Denis Baillot enfatizava que a verdadeira ortodoxia para a França era dada pelo galicanismo (como em Des libertés de l'eglise gallicane, 1817), e, remetendo ao acordo religioso de 1516 entre Francisco I e o papa Leão X (segundo ele, fonte das intolerâncias que resultaram no massacre de São Bartolomeu e nas guerras religiosas que ensanguentaram a Europa), advertia sobre as inclinações temporais abusivas e desestabilizadoras dos papas (a seu ver, Leão X pavimentara os triunfos de Lutero e Calvino, assim como, no passado, "o ódio fomentado pelo sofismo teológico" católico favorecera a invasão dos turcos em Constantinopla) ${ }^{74}$, autoridades do clero galicano, como os abades de Pradt (emigrado de primeira hora que retornou à França logo após o golpe do 18 Brumário, tornando-se posteriormente arcebispo de Malines e, ao lado de Portalis, o principal conselheiro de Napoleão para assuntos religiosos) e o célebre revolucionário jacobino, o jansenista Grégoire (ao lado do orador e igualmente jansenista Camus, autor da Constituição Civil do Clero), insistiam no fato de que a submissão do clero a Roma durante a Revolução fora a causa do martírio e suplício dos padres, uma vez que os mesmos, ao se negarem a prestar o juramento constitucional, associaram a sua causa à da nobreza emigrada, atraindo assim a fúria popular. ${ }^{75}$

De acordo com Grégoire - que se opunha à Concordata lembrando, provocativamente, que os ultramontanos não se opuseram à Concordata de 1801 com o usurpador 'revolucionário' Napoleão, ao passo que se negaram a jurar lealdade a um rei legítimo e verdadeiramente cristão em novembro de 1791 -, enquanto o ultramontanismo traduzia-se numa devoção ao papado que subordinava a lealdade ao rei

\footnotetext{
${ }^{73}$ S. Mellon, Political uses of History, p. 104.

74 Baillot, Dialogue entre François I, Louis XI, Charles VII, et Louis XII, sur le nouveau Concordat, avec les preuves et les éclaircissements historiques (Paris: Locard et Davi, 1818), p. 29 e 36.

${ }^{75}$ Dominique de Pradt, Les Quatre Concordats (Paris: Chez F. Béchet, 1818), vol. II, p. 25-26.
} 
e ao país, o verdadeiro legitimismo ou defesa da monarquia dava-se através do galicanismo (o cristianismo livre de ambições temporais dos Papas). ${ }^{76}$

Naturalmente, Maistre acompanhou ativamente todo aquele debate teológicopolítico francês, do período em que ainda era correspondente consular no exílio suíço (quando redigiu as Considerações), ao seu retorno (em agosto de 1817) a Turim, quando assumiu, em dezembro de 1818, a condição de "Régent de la Grande Chancellerie" do restaurado reino do Piemonte-Sardenha (no qual acumulava as funções de vice-chanceler e de Ministro da Justiça), cargo que desempenharia até 24 de julho de 1820, quando uma repentina crise de saúde condenou-o a ficar em casa até o fim de seus dias (26 de fevereiro de 1821). ${ }^{77}$

Como bem destacou Richard Lebrun, é bem provável que a ideia de Maistre para redigir Du Pape tenha surgido no curto e angustiante período dispendido em Turim, entre março de 1797 e dezembro de 1798, quando o contrarrevolucionário saboiano recebeu (em 28/10/1797) a fatídica notícia da interceptação de uma missiva do conde d'Avaray (favorito do conde da Provença e futuro Luís XVIII) pelas tropas do general Napoleão estabelecidas em Milão, e a qual, revelando a autoria das Considerações, obstruiu sua nomeação para o Conselho de Estado de seu reino (devido aos tratados de paz firmados entre a Casa da Saboia e o governo do Diretório francês entre fevereiro e abril de 1797). Desempregado e com muito tempo livre, Maistre dedicara aquele inédito tempo ocioso às leituras e iniciara, possivelmente em setembro de 1797, os delineamentos ou fragmentos de uma obra sobre "o sistema católico", a qual, contendo cerca de 800 páginas de anotações próprias e das mais diversas obras, encontra-se nos Registros de Leitura sob o título de "Religion E". ${ }^{78}$

Forçado novamente a abandonar seus manuscritos e o possível projeto de um livro sobre o "sistema católico" após a invasão, em dezembro de 1798, da capital do reino do Piemonte pelas tropas francesas, que resultou em um novo período de exílio - desta vez "italiano", entre Veneza (janeiro a agosto de 1799), Sardenha (entre janeiro de 1800 e fevereiro de 1803, quando, no exercício de seu cargo de Regente daquele que era o único domínio remanescente da Casa da Saboia, entrou em franca rota de colisão com o

76 Abbé Grégoire, Essai historique sur les libertés de l'eglise gallicane (Paris: Chez Baudoin Frères, 1818), p. 200.

77 Rodolphe relata que uma das últimas atitudes de Maistre como ministro de estado foi o de sugerir oposição a um projeto de reforma constitucional de seu reino nos moldes das Cortes espanholas. Cf.: Rodolphe de Maistre, "Notice biographique", in: Joseph de Maistre, O.C., I: XLI.

78 R. Lebrun, Joseph de Maistre: an Intellectual Militant (Montreal: McGill-Queen's University Press, 1988), p. 159-160. 
absolutista e truculento Vice-Rei Charles Félix) ${ }^{79}$ e Roma (7-22 de março de 1802) -, Maistre voltaria a "considerar" a França durante a missão diplomática na corte do czar (chegou a São Petersburgo em maio de 1803), quando, em setembro de 1804, conheceu o conde (futuramente duque) Pierre-Louis Jean Casimir de Blacas (1771-1839), que fora enviado à capital do império russo a mando do conde d'Avaray a fim de angariar fundos à corte francesa emigrada e redigir, ao lado do embaixador sardo, a declaração de protesto do conde da Provença contra a consagração de Napoleão como imperador.

Foi a partir daquela vivência diplomática (que terminou numa profunda relação de amizade) com o futuro conselheiro de Luís XVIII e representante não-oficial do Bourbon na corte russa (entre 1804-1808) que Maistre, pouco antes da Restauração (por volta de 1812), obteve a inspiração definitiva para redigir um livro sobre o Papa. E isto porque o contrarrevolucionário saboiano convencia-se cada vez mais de que os Bourbons ainda aderiam às doutrinas galicanas que, a seu juízo, foram co-responsáveis (ao lado do pombalismo e do josefismo) pela destruição do "sistema religioso europeu" (catolicismo). A monarquia francesa preparou o leito da Revolução ao encorajar os padres a insistirem nas "liberdades galicanas", ao tolerar as usurpações dos Parlamentos às jurisdições eclesiásticas e ao impor seus próprios interesses sobre os assuntos espirituais da Igreja. Ademais, e conforme observou Emile Perreau-Saussine, a desconfiança maistreana com relação ao galicanismo era consubstancial à sua teologia política, na medida em que a afirmação galicana da autonomia da esfera espiritual promovia a separação da política com a religião (isto é, acelerava o fim do Estado confessional), e por extensão, dessacralizava a própria monarquia em cuja defesa Bossuet e seus sucessores tanto se empenharam (como veremos abaixo). ${ }^{80}$

Portanto, se é possível admitir que o Du Pape (publicado em 1819) foi concebido a partir da troca de correspondências entre Maistre e Blacas até 1814 - nas quais o saboiano esforçava-se em dissuadir o jovem diplomata e seu "soberano" das convicções

${ }^{79}$ Desde que começou a desempenhar sua função na administração do poder judiciário da ilha, Maistre notabilizou-se pela oposição às medidas repressivas e violentas (como as prisões arbitrárias e práticas de tortura) ordenadas pelo Vice-Rei, a ponto de o biógrafo François Descostes destacar o ardoroso zelo legalista de Maistre na defesa daquilo que hoje designamos como direitos humanos contra as arbitrariedades de seu governo. Cf. François Descostes, Joseph de Maistre inconnu: Venise, Cagliari, Rome (1797-1803) d'après des documents inédits (Paris: H. Champion, 1904), p. 46.

80 Emile Perreau-Saussine, "Why Maistre became Ultramontane", in: Carolina Armenteros e Richard Lebrun (orgs.), Joseph de Maistre and the legacy of the Enlightenment (Oxford: Voltaire Foundation, 2011), p. 149. 
galicanas $^{81}$-, não se pode negar, por outro lado, que a obra assumiria a forma que conhecemos graças às influências determinantes dos debates teológico-políticos no interior da Restauração Francesa, bem como da política interna russa (de extrema importância nos quadros do Congresso de Viena e da Santa Aliança), então marcada pela emergência de um zelo nacionalista ortodoxo hostil ao Ocidente e ao catolicismo.

Paradoxalmente, pode-se dizer que o próprio Maistre colaborou decisivamente para aquele estado de coisas, na medida em que seus escritos pedagógicos russos caíram como uma bomba sobre as suscetibilidades dos aristocratas taristas, como foi o caso do personagem mais influente daquele grupo, Alexander Stourdza (1791-1854), secretário do extraoficial embaixador russo no Congresso de Viena e futuro líder carismático grego, Ioannis Capodistrias (1776-1831).

Provocado pelos ensaios pedagógicos maistreanos, Stourdza redigiu uma apologia da igreja ortodoxa grega (e por exetensão, russa) e um virulento requisitório (no melhor estilo de um "Maistre às avessas") contra o catolicismo em seu panfleto intitulado Considérations sur la doctrine et l'esprit de l'église orthodoxe, o qual, escrito em francês e publicado na protestante Weimar, não poderia ser visto senão como uma resposta ao influente embaixador sardo na corte do czar, conforme lemos a seguir:

"A obra que se oferece neste momento ao público foi sugerida por motivos tão imperiosos quanto legítimos. O que acaba de acontecer em São Petersburgo; as tentativas de alguns heterodoxos ${ }^{82}$ domiciliados na Rússia para agitar as consciências e excitar dúvidas entre os fiéis sobre a pureza dos dogmas professados pela Igreja do Oriente; a flutuação dos espíritos que resultou deste choque de opiniões: em uma palavra, a agressão abertamente dirigida contra a Religião do Estado, fez com que se sentisse a necessidade de romper o silêncio, e de se defender."${ }^{183}$

Ao término da longa introdução de seu panfleto, Stourdza lamenta a "arrogação da jurisdição temporal" pelos bispos da Igreja católica romana, segundo ele algo "completamente incompatível com os cuidados do padroado e do episcopado", assim

\footnotetext{
${ }^{81}$ Lebrun nos informa que a maior parte do Du Pape foi composto entre 1815 e 1816 , uma vez que o manuscrito já estava pronto quando o autor partiu de São Petersburgo. In: R. Lebrun, Joseph de Maistre: an Intellectual Militant, p. 194.

${ }^{82}$ A heterodoxia em questão representa antes o catolicismo de Maistre e dos jesuítas do que o protestantismo dos estrangeiros alemães.

${ }^{83}$ Alexander Stourdza, Considérations sur la doctrine et l'esprit de l'église orthodoxe (Weimar: Bureau d'Industrie, 1816), p. 1.
} 
como "fonte de inúmeros conflitos entre as esferas espiritual e temporal" que "atraíram o flagelo e o opróbrio" ao nome cristão. ${ }^{84}$

De acordo com este ortodoxo simpático ao pietismo (protestante) germânico, as causas históricas da rivalidade entre as igrejas cristãs latina e grega remontariam à queda do império romano do Ocidente, quando, em meio às desordens provocadas pelas invasões bárbaras, "as províncias mais expostas às incursões dos povos do Norte recorreram à autoridade da Sé Romana", a qual, por sua vez, "orgulhosa de sua preponderância e de seus êxitos", e "encorajada pela fraqueza da corte de Constantinopla" - frequentemente "exasperada com seus próprios problemas" -, "estendeu insensivelmente seu poder a despeito dos demais bispos. Unicamente ocupada na consolidação de seu poder temporal, a sede romana inquietou-se pouco com as alterações sempre crescentes que o dogma e o culto público sofriam." ${ }^{85}$

No momento em que, ao fim do século IX, deu-se a grande colisão entre as igrejas cristãs a respeito da conversão da Bulgária ao cristianismo (vencida pelos bizantinos, a disputa desdobrou-se naquilo que se convencionou chamar de "Cisma de Fócio", em alusão ao patriarca leigo estabelecido pelo imperador Miguel III no lugar de Inácio I de Constantinopla, o que gerou escândalo e o não reconhecimento do mesmo pelo papa Nicolau I), "os papas acreditaram-se "muito avançados" para retornar à tradição conciliar e, levados pelas "ambições políticas", precipitaram a Igreja do Ocidente num "estado de obstinação e ignorância." Enquanto isso, Stourdza sustentava que a igreja ortodoxa, "fundada sobre o solo sagrado que fora o berço da igreja primitiva", mantevese em "perfeita conformidade" com as tradições e os costumes dos primeiros apóstolos. $^{86}$

Apoiado na Carta aos Efésios (4: 3-5) de são Paulo, Stourdza destacou que o apóstolo nunca se referiu a um "único chefe dos bispos e da igreja universal"; "jamais ensinou que Cristo tivesse um representante visível sobre a terra, nem que este Vigário, administrador soberano de todos os fieis, tivesse o direito de exigir a obediência e a submissão da parte deles." E a prova disto, segundo ele, estava no fato de que os próprios apóstolos, ainda "cobertos de todos os dons do espírito da sabedoria" e desconfiados "de tal maneira de sua infalibilidade individual", nunca terem pretendido arrogar-se "uma jurisdição suprema", razão pela qual decidiram a famosa questão sobre

\footnotetext{
${ }^{84}$ Alexander Stourdza, Considérations sur la doctrine et l'esprit de l'église orthodoxe, p. 24.

${ }^{85}$ Idem, p. 25.

${ }^{86}$ Ibidem, p. 25-26.
} 
a circuncisão dos gentios através de um Concílio celebrado em Jerusalém (cerca de 48 d.C.), o primeiro do cristianismo. ${ }^{87}$

Além de "anticristã", a "pretensão" do bispo de Roma ao "vicariato terrestre" como "sucessor de São Pedro" era vista por Stourdza como a causa dos "problemas e das divisões na ordem moral" que transformaram a "religião do amor" - com seu jugo puramente espiritual "leve" e "doce" - num "faustoso arco do triunfo" com as "pompas criminais da antiga Roma'". De acordo com o apologista ortodoxo, se os humildes membros da igreja primitiva pudessem prever um "abuso tão escandaloso de suas instituições tão humildes e fraternais", teriam tomado as precauções para "determinar com uma rigorosa exatidão a menor das prerrogativas do poder pontifício do qual faziam pouco caso". ${ }^{88}$

Diante da vigorosa expansão do catolicismo nos domínios do império russo e dos escritos apologéticos que, de Chateaubriand, Novalis a Bonald, anelavam por uma Europa antirrevolucionária e cristã reunida novamente sob a égide de Roma, Stourdza avançava um raciocínio válido tanto à defesa da igreja ortodoxa quanto do protestantismo em geral. Uma vez que a "Igreja universal... não reconhece por chefe a não ser Jesus Cristo..., sua unidade" era "puramente espiritual, pois qualquer outra espécie de unidade" traria "evidentemente consigo prejuízo à ordem social, à independência das nações e à salutar verdade que resulta de uma série incalculável de causas naturais e locais". Deste modo, o "único ponto de reunião" do cristianismo Restaurado, "a casa deste espírito de regeneração e do amor", residiria "na reunião dos chefes ou pastores desta igreja universal convocados em concílio geral", cabendo este direito aos soberanos temporais. E como a Igreja ortodoxa era quem conservava o cristianismo em suas formas puras ${ }^{89}$ e a Grécia encontrava-se sob o domínio otomano, nada mais natural que esta prerrogativa recaísse sobre a autoridade do czar russo, assim como o "Concílio de Niceia, este grande arquétipo de todas as reuniões ecumênicas, foi convocado pelo imperador Constantino, o Grande, em sua qualidade de protetor da ordem social". 90

\footnotetext{
${ }^{87}$ Alexander Stourdza, Considérations sur la doctrine et l'esprit de l'église orthodoxe, p. 111.

${ }^{88}$ Alexander Stourdza, Considérations sur la doctrine et l'esprit de l'église orthodoxe, p. 112.

${ }^{89}$ De acordo com Stourdza, o conjunto dos dogmas fora estabelecido pelos sete primeiros concílios ecumênicos, razão pela qual não deveria ter havido mais nenhuma alteração dogmática no interior do cristianismo, restando apenas os ritos e as disciplinas como objetos de mudança através dos concílios e sínodos nacionais, cuja convocação dependeria inteiramente do poder soberano (temporal). Cf. Alexander Stourdza, Considérations sur la doctrine et l'esprit de l'église orthodoxe, p. 115.

${ }^{90}$ Idem, p. 114-115.
} 
Mesmo quando os cânones do segundo e do quarto concílios ecumênicos atribuíam uma precedência de antiguidade e de honra ao bispo de Roma ("em sua qualidade de bispo da antiga capital do mundo"), e ao de Constantinopla ("em virtude do nome de nova Roma"), os mesmos, de acordo com Stourdza, não continham nada "daquela pretendida supremacia universal que os papas atribuíram-se depois." Pelo contrário, o aristocrata russo de origem romena sustentava que os concílios situavam o pontífice romano e o patriarca de Constantinopla na mesma categoria que os de Alexandria e o de Antioquia. ${ }^{91}$

Apoiado naquelas premissas históricas, Stourdza concluía pelo seguinte, na ordem: I. que "a igreja universal é uma santa federação entre todas as raças humanas, cujo chefe supremo, visível e invisível, é Jesus Cristo" (única "pedra angular do edifício cristão"); II. que "esta santa federação não traz nenhum risco a quaisquer dos liames sociais domésticos e individuais que ligam o cristão à sua pátria, à sua família, à sua língua materna e a seus deveres"; III. que "a doutrina da supremacia universal... atribuída à sede de Roma não se fundamenta senão sobre uma interpretação errônea de algumas passagens do Evangelho cuja significação integral foi deturpada e alterada", como demonstravam as renovadas "divergências de opiniões entre os ultramontanos e a Igreja Galicana"; IV. uma vez que a Igreja reina apenas "sobre as consciências, as afeições, as relações individuais, em uma palavra, sobre o homem interior", não seria possível conciliá-la com o poder temporal "sem violar os preceitos do amor redentor", pois "a instituição usurpadora do vicariato terrestre não poderia subsistir realmente e sustentar sua gigantesca estrutura sem atrair a si todos os recursos, sem mover todas as molas, sem empregar todos os prestígios de poder temporal", confundindo-se assim com "um reino deste mundo, misturando-se com todas as paixões e erros humanos". ${ }^{92}$

Portanto, diferentemente de sua rival ocidental que, "não satisfeita em desdenhar o berço da igreja primitiva" e não suportando mais a humilde obediência devida aos imperadores, iniciou sua irresistível marcha rumo à corrupção temporal ao final século VIII - através do apoio concedido pelo usurpador monarca carolíngio Pepino, o Breve, ao papa Zacarias contra os reis lombardos (que resultou na doação dos territórios pontifícios em caráter de feudo) ${ }^{93}$-, quis a Providência que a igreja do Oriente

\footnotetext{
${ }^{91}$ Alexander Stourdza, Considérations sur la doctrine et l'esprit de l'église orthodoxe, p. 122.

92 Alexander Stourdza, Considérations sur la doctrine et l'esprit de l'église orthodoxe, p. 125-128.

93 Aqui, estamos diante daquela que seria a visão tipicamente galicana de Tocqueville em $O$ Antigo Regime e a Revolução sobre a história da Igreja católica do Ocidente e do impacto negativo exercido sobre a mesma pelo contato político com a monarquia francesa: "Sabe-se que os eclesiásticos gozavam
} 
("implicada nos destinos de um Império cuja caducidade não podia resistir aos ataques do maometismo e à fúria cega dos bárbaros do Ocidente") sofresse com inúmeras "perseguições e sujeições" após a queda de Bizâncio, e isto com o objetivo de preservála "das funestas tentações... da grandeza" que perverteram sua rival latina. ${ }^{94}$ Assim, enquanto a Igreja latina perturbava a ordem política e social dos Estados do Ocidente ao "arrogar-se o direito de distribuir coroas" e de excomungar soberanos, a Igreja grega, ao contrário, "foi perseguida e atravessada pelo ferro e pelo fogo, resistiu ao islamismo, converteu o norte: foi despojada... de suas ricas vestes e pompas, mas nada pôde arrancar-lhe o depósito da fé e da tradição que ela conservara intacto.".95

Portanto, quando os estadistas e intelectuais da contrarrevolução europeia discutiam a necessidade e a viabilidade de se promover uma nova reunião do cristianismo em um único lar, Stourdza observava, na contramão do que pregavam os apologistas católicos como Bonald, Chateaubriand ${ }^{96}$ e Maistre, que "a pedra angular" do novo edifício religioso da Europa pós-revolucionária encontrava-se na Igreja ortodoxa russa sob a proteção de seu patrono e do grande promotor da nova ordem social e política europeia, o czar.

Ademais, e numa clara alusão crítica ao Génie de Chateaubriand e, sobretudo, aos escritos sobre a educação pública russa de Maistre, Stourdza sustentará que no instante em que o bispo de Roma, apoiado pelo soberano carolíngio, "usurpou" o poder dos reis lombardos na Itália, o poder do mesmo cresceu "constantemente em razão inversa do progresso das luzes" na Europa, uma vez que sua "sede profana daria tiranos e monstros ao universo". A seu ver, o cúmulo da impostura ter-se-ia dado na Idade Média, mais especificamente através da falsa atribuição da "Doação de Constantino" sob o pontificado de Gregório IX, responsável por elaborar (no século XIII) o "labirinto do direito canônico do Ocidente". 97

das mesmas regalias; porque a Igreja, que tinha outra origem, um outro objetivo e uma natureza diferente da feudalidade, se havia, contudo, misturado intimamente com ela e, embora nunca tenha sido completamente incorporada por essa substância estranha, havia-a tão profundamente penetrado que nela permanecia como incrustada." Cf.Tocqueville, L'Ancien Régime et la Révolution, Livro II, cap. 1.

${ }_{94}$ Alexander Stourdza, Considérations sur la doctrine et l'esprit de l'église orthodoxe, p. 129.

${ }^{95}$ Alexander Stourdza, Considérations sur la doctrine et l'esprit de l'église orthodoxe, p. 131.

${ }^{96}$ Independente do fato de Stourdza referir-se expressamente a Chateaubriand pelo fato deste, no prefácio à segunda edição de seu Génie (de 1803), ter cedido às pressões ultramontanas e alterado/corrigido o que escrevera sobre o celibato dos padres na primeira edição da obra), sabemos, graças aos relatos do próprio Maistre (perfeitamente confirmados pelo célebre romance Guerra e Paz de Tolstói, profundamente inspirado nas reflexões sobre a guerra das Soirées e na eloquente personalidade do diplomata sardo), que para se destacar na corte do czar era imprescindível o domínio da língua e dos assuntos culturais e políticos da França pela nobreza.

${ }_{97}$ Stourdza, Considérations sur la doctrine et l'esprit de l'église orthodoxe, p.163-164. 
Implacável em sua diatribe antirromana, Stourdza acusa os papas de terem precipitado através das Cruzadas a queda do Império Romano do Oriente ao favorecerem a "ferocidade dos povos bárbaros que se armavam para servir aos fins mercantis dos venezianos". Misto de vingança latina (pela supremacia oriental imposta por Justiniano no século VI) e empresa mercantil vil dos venezianos, as Cruzadas teriam preparado o terreno para a conquista muçulmana do Império. ${ }^{98}$

Em sua abordagem providencialista (paradoxalmente, tributária das Considerações de Maistre, como o próprio título indica), Stourdza sustenta que a perda do Império em 1453 permitiu à Igreja oriental atravessar a prova do "cativeiro" e das humilhações" ("a mais formidável e também a mais salutar de todas"), saindo-se "radiosa do crisol do paganismo", isto é, firme em sua fé, enquanto a igreja ocidental "inebriava-se com os frutos da terra e experimentava avidamente as pérfidas delícias do poder temporal". 99

Para refutar a tese maistreana de que a Igreja ortodoxa era demasiado frágil para, sem o auxílio católico, promover o avanço da religião cristã e, portanto, das manners no império russo, Stourdza sublinhou - talvez inspirado no Génie de Chateaubriand -, que a Europa devia sua ciência precisamente à emigração dos padres gregos no século XV à Itália, a qual, por sua vez, não representou nenhum prejuízo ao culto oriental, pois "se a chama dos conhecimentos humanos serve para decorar os templos, não é de sua pálida e vacilante luz que a revelação do Homem-Deus empresta seus clarões divinos". ${ }^{100}$

Assim, se a opressão otomana impediu um maior desenvolvimento exterior (isto é, artístico e poético) do rito ortodoxo, o cristianismo oriental não foi menos responsável pela conservação da identidade cultural e nacional grega e, por conseguinte, pela transmissão da língua filosófica e cristã à Europa. ${ }^{101}$ E naquilo que poderíamos caracterizar como um típico exercício moderno de "invenção das tradições" ${ }^{102}$, Stourdza ressaltava o papel desempenhado pelos padres ortodoxos durante as invasões e domínio dos tártaros (entre os séculos XIII e XV), mormente o de preservação da identidade russa e do sentimento de obediência para com os soberanos moscovitas. ${ }^{103}$

E como era impossível dissociar a crítica à apologia católica de Maistre junto ao czar e ao conde Razoumovski (ministro da Instrução Pública do império russo) da

\footnotetext{
98 Alexander Stourdza, Considérations sur la doctrine et l'esprit de l'église orthodoxe, p.165-166.

99 Idem, p.168.

${ }^{100}$ Ibidem.

${ }^{101}$ Ibidem, p. 176-177.

102 E. Hobsbawm e T. Ranger, A Invenção das Tradições (Rio de Janeiro: Paz e Terra, 1984).

${ }^{103}$ Stourdza, Considérations sur la doctrine et l'esprit de l'église orthodoxe, p.182-183.
} 
ordem jesuítica tão louvada pelo embaixador sardo, Stourdza destacou como, do século XVI a Pedro I, "os jesuítas e outros religiosos do rito romano não cessaram de se introduzir na Rússia sob mil pretextos especiais", perturbando "a ordem pública pelas correspondências nocivas e declamações audaciosas". Apesar das reiteradas tentativas como as de Maistre, os ultramontanos não conseguiram alterar "o espírito de tolerância inerente à doutrina e às instituições da Igreja ortodoxa", espírito este responsável pela "segurança interior" e pelas "vantagens da civilização" do império russo, cujo governo, tão criticado pelos observadores estrangeiros pelo "atraso na carreira dos conhecimentos e das ideias ditas liberais, realizara em atos os princípios que as demais nações europeias contentaram-se apenas em preconizar". ${ }^{104}$

$\mathrm{Na}$ contramão do conselho maistreano que consistia em dissuadir o Estado russo a empregar professores protestantes nas escolas, seminários e universidades russas (fossem elas administradas pelos jesuítas ou pelo Estado russo), Stourdza exaltava a influência positiva (no sentido da tolerância) da religião ortodoxa sobre a lei russa, que facultava indistintamente a todos os cidadãos, independente do culto ou do rito que eles professavam, "uma integral paridade dos direitos civis em virtude da qual podiam aspirar a todos os cargos públicos e desfrutar das mesmas prerrogativas". ${ }^{105}$

Apesar de constituir "o princípio de coesão mais ativo e desejável para qualquer sociedade", a pretendida unidade do culto (uma "vantagem tão importante em si mesma", mas "de uma natureza tão elevada") não poderia ser obtida por meios ordinários, razão pela qual não se deveria "sacrificar o espírito à letra, a teoria à aplicação, e a ordem intelectual à ordem temporal". ${ }^{106}$ Enquanto a Rússia, a Prússia, a Inglaterra, a América setentrional, a Holanda (e, nos tempos mais remotos, Roma e Atenas) demonstravam que uma tolerância uniforme, combinada a um zelo esclarecido, fortalecia "as bases da existência social", favorecia "o progresso e o aperfeiçoamento dos povos", desarmava "as resistências mais obstinadas", neutralizava "o germe da destruição inerente a todas as instituições humanas", países como Espanha, Portugal, Itália, Turquia, Pérsia, Japão, no outro extremo, exibiam "os efeitos perniciosos do fanatismo perseguidor que, semelhante às grandes secas da zona tórrida, transforma uma luz benfazeja em fogo devorador, e atinge com a esterilidade o solo mais abundante". Portanto, a história confirmava os efeitos funestos da intolerância religiosa

\footnotetext{
${ }^{104}$ Alexander Stourdza, Considérations sur la doctrine et l'esprit de l'église orthodoxe, p. 186.

105 Idem, p. 187.

${ }^{106}$ Ibidem, p. 201-202.
} 
(maior responsável pela difusão do destruidor "filosofismo") para as distintas sociedades civis. $^{107}$

E uma vez que a ciência do governo "é intimamente ligada" à ciência da "educação" - a ponto "de uma não pode agir sem a outra" -, o projeto nacionalista de modernização conservadora de Stourdza preconizava uma educação "realmente nacional" (isto é, não estrangeira ou jesuítica) e "essencialmente religiosa", sobre a qual "o poder supremo" do Estado teria "o direito de trabalhar para produzir a unanimidade das consciências entre os povos confiados aos seus cuidados". ${ }^{108}$

Como era de se esperar, este panfleto caiu como uma bomba sobre o autor de $D u$ Pape, que resolveu acrescentar um livro inteiro de sua obra já concluída à refutação das diatribes ortodoxas (e, na visão de Maistre, filoprotestantes) de Stourdza.

A partir de agora, podemos dirigir nossas atenções para a obra que, desdobrando os argumentos do Génie du Christianisme e dando-lhes uma conotação ultramontana no quadro político da Restauração francesa, também pode ser definida como uma obra eminentemente anti-stourdziana.

${ }^{107}$ Ibidem,p. 205-206, 212.

${ }^{108}$ Alexander Stourdza, Considérations sur la doctrine et l'esprit de l'église orthodoxe, p. 206. 


\section{2. Arquitetura de "Du Pape", ou Do Legislador temporal do Providencialismo maistreano}

Maistre inicia seu Du Pape com um longo "Discurso Preliminar" em que justifica ao leitor o "surpreendente" fato de que "um homem do mundo atribua-se o direito de tratar de questões" que, até então, "pareciam exclusivamente reservadas ao zelo e à ciência da ordem sacerdotal". Naquele contexto da Restauração francesa, era forçoso que a nobreza - "eminentemente culpável em relação à religião" - fornecesse soldados na defesa da ordem sacerdotal, que a Revolução havia "despojado, exilado, massacrado."109 Durante aquela espécie de interstício pós-revolucionário em que a Igreja se reconstruía - e que, a exemplo do cristianismo primitivo, fazia com que os confessores e os mártires precedessem os doutores -, era necessário que os leigos "preenchessem os vazios do exército do Senhor". ${ }^{110}$

Diante da natureza "selvagem e assustadiça" do homem pós-revolucionário em matéria de religião, Maistre observava que a intervenção dos leigos era mais do que pertinente naquele momento (sobretudo entre os franceses, de todos os povos o que mais necessita de "religião"), pois apesar de o padre merecer "toda a nossa estima", aos olhos do leigo ele não fazia mais do que cumprir o seu dever, e com um ar de quem defende "a sua própria causa". 111

E naquilo que certamente pode ser lido como uma defesa da França e de suas heranças latina e católica contra a teutomania protestante de Mme de Staël e os ataques ortodoxos de Stourdza, Maistre observa que foi graças ao gênio de sua "língua nacional" e ao elemento religioso (herdado dos gauleses e polido pelos romanos, sobretudo quando convertidos ao catolicismo), que a nação francesa logrou uma preponderância na condição de "cabeça do sistema religioso" europeu. ${ }^{112}$ Pois se a grandeza da Alemanha, de acordo com Stäel, enraizava-se no livre exame protestante que desembocava na filosofia idealista, Maistre, por sua vez, sustentava que a grandeza da França - e condição sine qua non para sua plena "restauração" política e social relacionava-se com o fato dela ser um instrumento que a Providência escolheu - desde

\footnotetext{
${ }^{109}$ J. de Maistre, "Discours Préliminaire", in: Du Pape (Paris: Charpentier, 1854), p. 1.

${ }^{110}$ Idem, p. 2.

${ }^{111}$ Ibidem, p. 3 .

112 Ibidem, p. 7.
} 
"Carlos Magno" (o "trimegisto moderno") - para promover "a Igreja católica no mundo, elevando seu augusto líder [o Papa] ao status indispensável devido às suas funções divinas, e sem o qual ele não teria sido mais que um patriarca de Constantinopla, deplorável joguete dos sultões cristãos..." [os imperadores bizantinos] "e dos autocratas muçulmanos." 113

A exemplo do que fizeram Chateaubriand no Génie e o conde Antoine Ferrand em seu galicano L'esprit de l'histoire, ou lettres politiques et morales d'un père à son fils $(1803)^{114}$, Maistre procura exaltar o papel civilizatório (isto é, em termos de desenvolvimento das artes, do comércio, e da liberdade na esfera civil) desempenhado pela França na história europeia, o qual, iniciado pelas Cruzadas, seria indissociável de seu impulso religioso e católico: reproduzindo as palavras de Torquato Tasso (15441595) do épico Gerusalemme Liberata (1581), Maistre observava que para os muçulmanos "Il popolo Franco" era sinônimo de europeu, cuja "glória literária" e "ciência" eram tributárias de seu "grande número de estabelecimentos eclesiásticos" e dos serviços que recebia do clero católico em reconhecimento à proteção e promoção do sistema religioso, uma das mais "brilhantes prerrogativas" da qual a coroa francesa se privara ao aderir às teses galicanas que culminaram na Revolução de $1789 .{ }^{115}$

Reerguida "por um milagre" após ter sido derrubada pela "sobrenatural" tempestade da Revolução, a "coluna" religiosa católica tinha novamente diante de si o espírito revolucionário, que Maistre julgava estar "incomparavelmente mais forte e perigoso" na Restauração do que no período napoleônico. Enquanto o "usurpador"' sabia "reprimir aquele espírito "com sua mão de ferro, e reduzi-lo a não ser mais que uma espécie de monopólio em proveito de sua coroa", o rei legítimo, além de não poder agir a não ser dentro dos limites constitucionais, tinha o inconveniente de ter de dividir o seu

\footnotetext{
${ }^{113}$ J. de Maistre, "Discours Préliminaire", in: Du Pape, p. 7.

${ }^{114}$ Discípulo de Montesquieu e, como Montlosier (1755-1838), defensor de um constitucionalismo aristocrático-germânico parlamentar e hostil ao ultramontanismo - tanto que, para consternação do embaixador sardo na corte do czar, o então conselheiro de Luís XVIII defendeu as liberdades da Igreja galicana ou a plena soberania do poder temporal nos assuntos do Estado (inclusive os relativos à administração da Igreja) durante as acaloradas discussões sobre uma nova Concordata que tiveram início logo após a segunda Restauração -, Ferrand encerrou o segundo volume de seu L'esprit de l'histoire com a seguinte observação: "no momento em que se busca a causa do luxo e da civilização, é preciso olhar para a exaltação de uma superstição universal", ao "cavalheiresco delírio de uma feudalidade ignorante e pobre que, obstinando-se em obter um martírio... distante, reencontra inevitavelmente em seu caminho algum começo de luxo, alguma centelha de luz", razão pela qual era preciso não se admirar com o fato de que "as luzes", "os costumes", "as opiniões" europeias terem conservado a "cunhagem de sua antiga barbárie". Cf. Antoine Ferrand, L'esprit de l'histoire, ou lettres politiques et morales d'un père à son fils (Paris: Nyon, 1803), vol. III, 2 a edição, p. 489.

115 J. de Maistre, "Discours Préliminaire", p. 8-9.
} 
governo com uma aristocracia profundamente eivada do espírito galicano que enfraquecia o sistema religioso católico na França.

Assim como fizera nas Considerações sobre a França - obra que paradoxalmente caiu em desgraça junto à elite política ultra da Restauração, em razão do paradoxal "elogio" feito ao jacobinismo e, sobretudo, pelas acerbas críticas à nobreza e ao clero do Antigo Regime, que contrariavam a hegemônica (ao menos no campo contrarrevolucionário) 'teoria da conspiração' de Barruel para explicar o fenômeno revolucionário $^{116}$-, em Du Pape Maistre também avançará uma forte acusação à nobreza francesa, segundo ele diretamente responsável pela Revolução ao promover a divisão e o enfraquecimento do clero galicano (a pretexto de protegê-lo das intromissões romanas) através das decisões judiciais parlamentares favoráveis aos padres jansenistas durante a secular crise da bula Unigenitus, favorecendo assim o avanço do campo filosófico nas instituições e na opinião pública.

Longe de ter sido esclarecida pelas provações revolucionárias, a aristocracia francesa - através dos escritos dos aristocráticos Ferrand e Montlosier ${ }^{117}$, que se opunham a uma nova Concordata entre o rei francês e o Papa durante a Restauração por julgá-la prejudicial às prerrogativas temporais da coroa francesa - dava mostras de que ainda estava repleta daquele espírito jansenista-parlamentar que, segundo Maistre, fora responsável pela "apostasia" da nobreza e, consequentemente, pela derrubada do trono.

\footnotetext{
${ }^{116}$ Nascido em 1741 de uma família nobre do Vivarais, tornou-se padre jesuíta em 1756 e ensinou em Tournon (até 1764), quando a ordem foi expulsa da França e, em decorrência disso, partiu para o exílio na Áustria, Boêmia e Itália. Retorna à França em 1773, tornando-se, em 1777, editor do jornal antifilosófico L'Année Littéraire. Redigidas no exílio londrino (o qual se deu após os massacres de setembro de 1792), suas Mémoires pour servir à l'esprit du jacobinisme (1792) avançam a hipótese de que a Revolução de 1789 foi provocada pela combinação de uma tripla conspiração: a "conspiração da impiedade" contra Deus e a religião cristã; a "conspiração da rebelião" contra reis e magistrados; e, finalmente, a "conspiração da anarquia" contra a sociedade civil no seu todo. Resumidamente, no esquema de Barruel os maçons teriam oferecido o exemplo para a estrutura das sociedades secretas, espalhando lojas por toda a Europa e estabelecendo uma organização interna que, embora proclamada como apolítica, afrontava os princípios políticos do Antigo Regime. Os illuminatis (membros de uma sociedade secreta fundada na Bavária, em 1776, por Adam Weishaupt - professor de direito da Universidade de Ingolstadt - e que pregavam o igualitarismo e o racionalismo, bem como a forma republicana de governo, sendo descobertos e suprimidos pelas autoridades bávaras em 1785) funcionaram como uma radicalização do movimento contra o trono e o altar, atraindo a adesão de mais pessoas para as lojas. Finalmente, uma vez desencadeada a Revolução, bastou aos jacobinos aproveitar o modelo das organizações maçônicas, expandindo seus clubes por todo o território francês e até no exterior, e aplicar as doutrinas contra a sociedade civil. Sobre a obra de Barruel, ler Jacques Godechot, La ContreRévolution: Doctrine et Action, 1789-1804 (Paris: PUF, 1984). Sobre o aspecto político desempenhado pela maçonaria e os efeitos de sua crítica no desmantelamento do Antigo Regime, ver: Reinhart Koselleck, Le règne de la critique ( Paris: Minuit, 1979).

${ }^{117}$ Montlosier julgava o ultramontanismo e/ou o jesuitismo, com tudo o que poderiam trazer de intromissão da esfera espiritual na esfera civil e, portanto, de reanimação dos debates que dilaceraram o absolutismo no século XVIII, o maior perigo não só para a monarquia restaurada, como à própria religião. Cf. Montlosier, Mémoire a consulter sur un système religieux et politique tendant a renverser la religion, la societé et le trône (Paris: Moutardier et Compagnie, 1826), p. 14-15.
} 
De acordo com Maistre, "por sua monstruosa aliança com o princípio corrupto no último século, a nobreza francesa perdeu tudo", isto é, seu poder, suas propriedades, seu rei, sua vida, de modo que cabia a ela "reparar" o estrago através da "aliança natural, essencial, necessária, francesa" com o sacerdócio e, sobretudo, com o "Sumo Pontífice", sem o qual "o edifício católico" seria "minado". ${ }^{118}$

Dividido em vinte capítulos, o primeiro dos quatro livros de Du Pape emprestava a defesa da monarquia absoluta do galicano Bossuet na demonstração de que a "infalibilidade na ordem espiritual" e a "soberania na ordem temporal" eram "duas palavras perfeitamente sinônimas", de modo que se deveria aplicar à Igreja o mesmo critério que se admitia na ordem temporal: a exemplo de qualquer associação, a Igreja precisava ser governada, sendo a principal característica de todo governo (fosse ele monárquico ou republicano) a existência de uma última instância decisória ("infalível" e absoluta), pois, do "contrário, não haveria mais agregação, conjunto, unidade". ${ }^{119}$ No caso da Igreja, Maistre chamava a atenção para o fato de que "a própria ideia de universalidade" pressupunha a forma monárquica (papal) de governo (devidamente temperada pela "aristocracia" dos bispos), "cuja absoluta necessidade" repousava "sobre a dupla razão do número de seus súditos e da extensão geográfica do império". ${ }^{120}$

Referindo-se às teses conciliares tão caras aos galicanos e ortodoxos, Maistre sustentava que até as autoridades protestantes - como o historiador e teólogo luterano Lorenz von Mosheim (1693-1755) - e galicanas - tal como o historiador e advogado da Igreja francesa, Claude Fleury (1640-1723) - concordavam que o apelo ao concílio era não apenas perigoso à Igreja, como absolutamente vinculado à vontade soberana do Papa:

"No século dezesseis, os revoltosos atribuíram a soberania à Igreja, isto é, ao povo. O século XVIII não fez senão transportar estas máximas para a política; é o mesmo sistema, a mesma teoria, mesmo em suas últimas consequências. Qual a diferença entre a Igreja de Deus, unicamente conduzida por sua palavra, e a grande república una e indivisível, governada apenas pelas leis e pelos deputados do povo soberano? Nenhuma. É a mesma loucura, mudando apenas de época e de nome." 121

\footnotetext{
118 J. de Maistre, "Discours Préliminaire", p. 11-12.

119 J. de Maistre, Du Pape, Livro I, cap. 1.

${ }^{120}$ Idem, Livro I, cap. 1.

${ }^{121}$ Ibidem, Livro I, cap. 1.
} 
Em seguida, Maistre demonstrava como a divisão da Igreja cristã em patriarcados, tal como elogiada por Stourdza, enfraquecia-a perante o Estado, como era o caso da Rússia, onde o czar fazia pouco caso da autoridade do patriarca e pulverizava a Igreja ortodoxa por meio dos sínodos nacionais por ele patrocinados. Não por acaso, o Discurso preliminar indicava que, a despeito das grandes diferenças dogmáticas, os teólogos protestantes e ortodoxos guardavam uma relação respeitosa entre si, de modo que a Rússia teria de escolher entre o catolicismo ou a fraca ortodoxia que, suscetível à ação estatal, favorecia a difusão do protestantismo e, em última análise, anunciava uma futura revolução ainda mais radical que a francesa. ${ }^{122}$

No segundo capítulo do primeiro livro, Maistre destacava como os autores galicanos e ortodoxos equivocavam-se ao sobrepor a autoridade dos concílios - para ele, recursos legítimos e necessários em condições muito específicas - à dos papas, por duas razões. Em primeiro lugar, não se podia confundir a soberania da Igreja, uma instituição eterna, com instituiçõos de caráter intermitente, provisório e raro. Ademais, além de os concílios não decidirem nada sem apelo a uma autoridade absoluta - do contrário, expor-se-iam a discórdias e divisões tão inócuas quanto intermináveis -, eles não poderiam sequer existir sem a convocação e a presidência do Papa.

E para reforçar sua tese, o ultramontano saboiano recorria à história de modo a denunciar o anacronismo por trás das teses conciliares galicanas. "Fáceis de se reunir" nos primeiros séculos do cristianismo (pelo fato de a Igreja ser bem menos numerosa e de a unidade política do Império romano permitir a convocação de "uma massa suficiente de bispos"), "nos tempos modernos", em que "o universo civilizado encontrou-se, por assim dizer, cortado por inúmeras soberanias, e imensamente engrandecido por nossos ousados navegadores, um concílio ecumênico tornou-se uma quimera. Para convocar todos os bispos apenas, e para verificar legalmente esta convocação, cinco ou seis anos não seriam suficientes", advertia o saboiano. ${ }^{123}$

Sem contestar a eminente prerrogativa dos concílios ecumênicos ou gerais, Maistre observava como os mesmos, nos primeiros anos do cristianismo, abriam-se ao arbítrio e à manipulação da "raça teológica" dos imperadores bizantinos (um "dos grandes escândalos da história"), que convocavam e impunham sua vontade aos bispos a seu bel-prazer. ${ }^{124}$ Para o ultramontano saboiano, as modernas teses conciliares galicanas

\footnotetext{
122 J. de Maistre, Du Pape, Livro I, cap. 1.

123 Idem, Livro I, cap. 2.

${ }^{124}$ Ibidem, Livro I, cap. 3.
} 
e ortodoxas insistiam na influência do poder temporal sobre os concílios, bem como no caráter quase que permanente do mesmo, a fim de questionar o vicariato do bispo de Roma sobre a Igreja cristã. Expressão da vontade arbitrária dos imperadores bizantinos que, ao convocarem constantemente os concílios, logravam assim lisonjear os bispos pela importância que os mesmos adquiriam naquelas frequentes reuniões, Maistre advertia que se os bispos "tivessem visto outros tempos" e "refletido sobre as dimensões do globo..., teriam percebido perfeitamente que um tribunal acidental, dependente do capricho dos príncipes e de uma reunião excessivamente rara e difícil, não podia ser escolhido para reger a Igreja eterna e universal". ${ }^{125}$

A fim de responder às objeções galicanas que, amparadas na autoridade de Bossuet, apontavam para o caráter recorrente dos concílios nos tempos primitivos da Igreja, e de modo a não entrar em conflito com o seu princípio providencialista que identificava a história como uma "política experimental", Maistre, amparado na defesa histórica da irrevogabilidade da decisão papal exposta pela principal autoridade teológica da Igreja sob o pontificado de Clemente XIII, o teólogo dominicano florentino Giuseppe Agostino Orsi (1692-1761), sublinhou que a resposta não deveria ser buscada no reconhecimento pelos papas da suprema instância conciliar, mas nas "heresias" e nos "imperadores gregos, que desejaram absolutamente os concílios" e "excitaram inutilmente" a "desordem na Igreja". ${ }^{126}$ E sendo a Igreja universal e eterna, a defesa galicana - como a do teólogo e historiador do século XVIII Claude Fleury - da prerrogativa imperial para a convocação dos concílios era anacrônica e doutrinalmente falsa: anacrônica, porque ignorava a pulverização das soberanias e a formação dos Estados modernos, o que tornava o apelo aos concílios a qualquer autoridade que não a dos papas algo impossível (a quem recorrer: ao czar, ao rei da França, ao imperador Habsburgo?); falsa, porque Deus não poderia "colocar as leis de sua Igreja em contradição com as da natureza": somente uma autoridade naturalmente indivisível, universal e perpétua (requisitos ausentes nas soberanias temporais) poderia se conformar com os desígnios providenciais e pedagógicos de Deus para a humanidade (através da Igreja), os quais não poderiam ser acidentais ou periódicos. ${ }^{127}$

Após concluir o quarto capítulo com a observação de que os concílios gerais eram próprios à "infância do cristianismo", Maistre avança aquele que talvez seja o principal

\footnotetext{
125 J. de Maistre, Du Pape, Livro I, cap. 3.

126 Idem.

${ }^{127}$ Ibidem.
} 
argumento do livro, e o qual, subsumindo o argumento historicista no providencialismo, aponta a Igreja como o instrumento providencial 'por excelência' na história, cujo desenvolvimento a um só tempo refletia e transcendia a ordem do tempo. Após criticar as teses galicanas e ortodoxas fundamentadas no relato das origens (de acordo com o saboiano, o "falso" raciocínio que "pretende nos conduzir aos primeiros séculos" da Igreja), Maistre avança aquilo que poderíamos classificar como um autêntico "manifesto ultramontano":

"Talvez fosse válido acrescentar, que, num certo sentido, a Igreja não tem idade. A religião cristã é a única instituição que, por ser divina, não admite decadência. No que concerne ao exterior, às práticas, às cerimônias, ela permite algumas variações humanas. Mas a essência é sempre a mesma, et anni ejus non deficient ("e seus anos jamais se acabarão"128). Assim, embora tenha se deixado obscurecer pela barbárie da Idade Média - pois não quer derrogar as leis do gênero humano -, naquela época ela produziu uma série de homens superiores, e que não devem sua superioridade senão a ela. Ela se reergue em seguida com o homem, acompanhando-o e aperfeiçoando-o em todas as situações; o que a diferencia, e de uma maneira impressionante, de todas as instituições e de todos os impérios humanos, que possuem uma infância, uma virilidade, uma velhice, e um fim." ${ }^{129}$

Principal instrumento da ordem providencial - isto é, instituída por Deus para prover e educar a humanidade na sua busca de realização da semelhança com o divino -, a Igreja insere-se no tempo, mas não é por ele determinada: "não falemos", adverte Maistre, "dos primeiros séculos, como se o tempo exercesse alguma influência sobre a Igreja. As feridas que ela recebe não vêm senão de nossos vícios, e os séculos, deslizando sobre ela, não podem senão aperfeiçoá-la". ${ }^{130}$

Após elencar, entre os capítulos 6-10, inúmeros testemunhos de autoridades teológicas ou filosóficas católicas, gregas, russas, galicanas e até mesmo protestantes (como o De l'Allemagne, referido para mostrar a crítica da autora protestante à pretensão de infalibilidade dos próprios líderes da Reforma ${ }^{131}$ ) para provar a supremacia do pontífice romano e alertar seus leitores franceses de que a defesa das liberdades galicanas levara-os à humilhação perante a magistratura jansenista-parlamentar e aos suplícios da Revolução Francesa no século XVIII, Maistre aponta uma lei de

\footnotetext{
${ }^{128}$ Adaptação do livro dos Salmos 101, versículo 28.

${ }^{129}$ J. de Maistre, Du Pape, Livro I, cap. 5.

${ }^{130}$ Idem, Livro I, cap. 5.

${ }^{131}$ Ibidem, Livro I, cap. 9.
} 
desenvolvimento histórico para as igrejas cristãs, e a qual consiste no risco de "dominação absoluta da autoridade civil" sobre as mesmas (suprimindo assim a liberdade de consciência da sociedade civil em relação ao Estado) em caso de separação com Roma, sendo o recente exemplo da Igreja russa o melhor de todos (na medida em que nem o consistório nacional existia independente do arbítrio e da vontade do czar). ${ }^{132}$

Para demonstrar que os católicos galicanos franceses nada teriam a temer com a soberania papal, Maistre avança uma crítica respeitosa à maior autoridade teológica galicana, ninguém menos que Bossuet, para demonstrar o caráter tautológico e involuntariamente revolucionário de seu raciocínio tipicamente sorbonniano, e o qual, remontando às teses conciliares de Jean Gerson, Jacques Almain e John Mair -, consistia em refutar a soberania da autoridade papal sobre a Igreja:

"O que ele" - Bossuet - "pretende dizer, por exemplo, quando nos diz: O poder que é preciso reconhecer na Santa Sé é tão eminente, tão estimado e venerado por todos os fiéis, que não há nada acima dele em toda a Igreja católica? Pretendia dizer-nos, por acaso, que toda a Igreja pode se encontrar lá onde o Sumo Pontífice não se encontra?... Admiti esta teoria insensata, e logo vereis desaparecer a unidade... Esta palavra Igreja separada de seu chefe não faz o menor sentido. É o Parlamento da Inglaterra menos o rei." ${ }^{133}$

Através de sua crítica ao autor da Declaração de 1682 das liberdades galicanas, Maistre procurava alertar os galicanos da Restauração - fossem eles autoridades civis (mormente o rei) ou eclesiásticas - sobre o potencial revolucionário a que se expunham: pois a primazia que, no passado e a pretexto de defender as prerrogativas reais, se dera ao "poder abstrato" da Igreja sobre o Papa, servira posteriormente aos revolucionários para deslocarem a soberania do rei à nação. ${ }^{134}$

A este respeito, é preciso dizer que algumas produções recentes da historiografia política sobre a Revolução Francesa confirmaram plenamente o raciocínio de Maistre, pois a defesa da verdade "agostiniana" (jansenista) contra a bula Unigenitus (1713) assumiu desde o princípio o caráter de uma precoce crítica ao absolutismo, conforme testemunham, respectivamente, o panfleto Du Témoignage de la Vérité dans l'Église (Do Testemunho da Verdade na Igreja, 1714) do teólogo oratoriano Vivien de La Borde (1680-1748), e o livro Du renversement des libertés de l'Église gallicane dans l'affaire

132 J. de Maistre, Du Pape, Livro I, cap. 10.

${ }^{133}$ Idem, Livro I, cap. 11.

${ }^{134}$ Ibidem. 
de la constitution "Unigenitus (Da queda das liberdades da Igreja galicana na questão da constituição "Unigenitus", 1716) do padre, teólogo e professor de direito canônico da Sorbonne, Nicolas Le Gros (1675-1751).

Admitindo que o papado e a maioria dos bispos sob sua autoridade haviam condenado a verdade da Igreja por meio da bula, La Borde redigiu aquilo que Catherine Maire designou como um "manifesto programático" da eclesiologia de resistência jansenista ${ }^{135}$ ao tentar explicar, numa teologia figurativa da história, como a verdadeira Igreja Católica continuava a existir a despeito da injusta condenação papal, isto é, como os "eleitos" ou a "verdadeira" Igreja mantinha-se viva apesar das sombras lançadas pela Unigenitus. Pois, argumentava La Borde, assim como a glória de Cristo passou despercebida a não ser para os eleitos e verdadeiros israelitas, cujos "simples, retos e puros corações aguardavam pela redenção de Israel", também para aqueles religiosos franceses a "humilde e tímida" verdade de Cristo raramente ousava "levantar sua voz", de modo que só os "puros de coração" percebiam a mensagem. Com efeito, para La Borde era este infalível testemunho, a ser escutado apenas pelos dotados de um "coração puro", ou seja, não "tão forte e poderoso a ponto de não ser ignorado" pelas autoridades e pela maioria (mesmo sob as melhores circunstâncias), que constituía a promessa de Cristo à sua Igreja. ${ }^{136}$

Portanto, se em "tempos de liberdade" a verdadeira voz da igreja é transmitida pela maioria dos pastores, em tempos de opressão e de "violência", quando o medo favorece a "prevaricação", é preciso emprestar os ouvidos à voz baixa do menor número, sugeriu La Borde em sua eclesiologia que, em muitos aspectos, como bem lembrou Dale K. Van Kley, antecipa a procura rousseaniana pela vontade geral - nesta hipótese, as "paixões", o "vil interesse", o "medo", numa palavra, o egoístico "amorpróprio" representariam, nas palavras de La Borde, a vontade de todos ou da maioria de Rousseau, ao passo que apenas os poucos "corações retos" representariam a verdadeira e "geral" fé. No esquema teológico de La Borde, estes poucos eclesiásticos resistentes seriam fortalecidos e amparados pelo "clamor público" dos "leigos fiéis", os quais, apesar de não serem "juízes" pastorais da verdade, eram "testemunhas" mais do que válidas da fé devido ao particular despojamento de interesses materiais, condição sine qua non para o amor pela verdade. Desse modo, a defesa inicial da minoria por La

${ }^{135}$ Catherine Maire, De la cause de Dieu à la cause de la Nation: le jansénisme au XVIII siècle (Paris: Gallimard, 1998), p. 206.

${ }^{136}$ Vivien de La Borde, Du Témoignage de la Vérité apud Dale K. Van Kley, The Religious Origins of the French Revolution (New Haven and London: Yale Univ. Press, 1996), p. 77. 
Borde era integrada numa apologia dos padres de paróquia, do clero monástico e, mais importante, de um laicismo eclesiástico. Pois, a seu ver, o critério final da verdade teológica era algo parecido com a verdade política conforme estabelecida posteriormente pelo 'Cidadão de Genebra', isto é, a "vontade geral" ou, conforme definição de La Borde, o "unânime testemunho oferecido pelo corpo inteiro dos fiéis" (inclusive dos leigos). ${ }^{137}$

Ainda que La Borde distinguisse claramente entre o clero ("juízes da fé") e os fiéis do laicato ("testemunhas" da fé), esta distinção era praticamente dissolvida na sua concepção implicitamente galicana, segundo a qual a autoridade da Igreja não estava restrita aos bispos e ao papa, mas a todo o corpo dos fiéis, incluindo os leigos. O galicanismo ou concepção "republicana" da Igreja verificada em Du Témoignage de la Vérité era ainda mais explícito quando o autor tratava da matéria específica do "julgamento" pastoral (pelo papa, bispos e padres), o qual, a seu ver, deveria se limitar a um ato passivo, submetido ao "testemunho" dos fiéis, os legítimos legisladores da fé. Daí que os bispos de La Borde nada mais faziam senão representar ou declarar o testemunho de suas paróquias; em linguagem rousseauniana, representariam um poder meramente "executivo", cabendo aos legisladores (a "vontade geral" para Rousseau ou o testemunho dos fiéis da paróquia em linguagem galicana radical) a decisão final sobre a verdadeira fé. ${ }^{138}$

Ademais, Dale K. Van Kley também destacou como a linguagem judicial permeava a eclesiologia de La Borde, a ponto de o mesmo abrir a possibilidade de os magistrados leigos dos Parlamentos intervirem (por meio de apelos judiciais) em defesa dos padres e fiéis leigos nos casos de extravios e más interpretações da fé pelos bispos. $^{139}$

Le Gros, por sua vez, como o próprio título de seu livro indica ( $D u$ renversement des libertés de l'Église gallicane), foi mais explícita e radicalmente galicano do que La Borde na defesa de uma concepção eclesiológica protorrepublicana, cuja noção de soberania confundia-se com a ideia de unanimidade ou o corpo inteiro da Igreja, isto é, a mesma segundo ele pertencia aos padres de paróquia e aos leigos, não se limitando, portanto, ao papa e aos bispos: "É para a unanimidade, para o concerto, para a caridade,

\footnotetext{
${ }^{137}$ Dale K. Van Kley, The Religious Origins of the French Revolution..., p. 78.

${ }^{138}$ Vide Catherine Maire, De la cause de Dieu à la cause de la Nation: le jansénisme au XVIII siècle..., p. 206-212.

${ }^{139}$ Dale K. Van Kley, The Religious Origins of the French Revolution..., p. 78-79.
} 
para fins logrados pelo consenso que Jesus Cristo prometeu seu auxílio e aos quais vinculou sua autoridade soberana". ${ }^{140}$

Nos passos de Jean Gerson (1363-1429) e Edmond Richer (1560-1631), o livro de Le Gros foi ainda mais claro e enfático do que o panfleto do padre oratoriano na elevação do status dos padres paroquianos em nome do princípio da unanimidade da Igreja. Conforme destacou Edmond Préclin em seu pioneiro estudo sobre o jansenismo e a Revolução, Le Gros identificava o baixo clero aos setenta e dois discípulos a quem o próprio Cristo, junto aos demais apóstolos, confiara a missão de comunicar a mensagem divina ao mundo (dentre estes, convém lembrar, estão os dois autores dos Evangelhos sinóticos, Lucas e Marcos), de modo que os bispos estavam obrigados a consultar a opinião dos padres sob sua jurisdição permanentemente, através de sínodos diocesanos. $^{141}$

E apesar de manter a distinção espiritual entre juízes pastorais e testemunhas leigas da fé, Le Gros, assim como La Borde, posicionou-se favoravelmente do lado do público leigo:

"Certamente, não se reflete o suficiente a respeito da participação que devem ter os príncipes e os povos nas publicações dos decretos dogmáticos. Parece que, salvo quando as liberdades da Igreja e do Reino não sejam diretamente atacadas por certas fórmulas, os mesmos não tenham nenhum interesse sobre as mesmas, e que todo o resto seja unicamente um domínio dos prelados. Antigamente, as coisas não eram assim, em absoluto. Aqueles que leram a história Eclesiástica sabem como os povos, os monges - leigos na maior parte -, e todos os fiéis ofereciam geralmente seu ardoroso testemunho em todas as questões e com tal liberdade que chegavam a anatematizar os seus pastores, assim que eles prevaricavam". ${ }^{142}$

Razão pela qual, continua o autor em alusão ao contexto da bula (e diante da evidência de que os prelados poderiam aceitar os termos da Unigenitus movidos por pressões ou interesses políticos), era mais do que legítimo o protesto ou clamor do

${ }^{140}$ Le Gros, Du renversement des libertés de l'Église gallicane (1716), I Parte, p. 171. In: (http://books.google.com.br/books?id=zTTmc3WTDxUC\&printsec=frontcover \&hl=pt$\mathrm{BR} \# \mathrm{v}=$ onepage $\& \mathrm{q} \& \mathrm{f}=$ false $)$.

${ }^{141}$ Edmond Préclin, Les Jansénistes du XVIII siècle et la Constitution civile du clergé: le développement du richérisme, sa propagation dans le bas clergé, 1713-1791 (Paris: Gamber, 1928), p. 63.

${ }^{142}$ Le Gros, Du renversement des libertés de l'Église gallicane..., op. cit., p. 230-231. 
público leigo (os "mais livres e simples" de coração) contra as eventuais prevaricações da Igreja. ${ }^{143}$

Portanto, não foi por acaso que os estudiosos sobre a história política do movimento jansenista - de E. Préclin a Dale Van Kley e Catherine Maire - destacaram as respostas oferecidas por La Borde e Le Gros à crise teológico-político suscitada pela bula Unigenitus. Pois naquele universo de mais de 200 escritos a respeito da bula, coube a estes autores expressar uma versão radical do galicanismo temporariamente eclipsada pela Declaração de 1682 (responsável por deslocar, na França, a soberania nos assuntos doutrinais e eclesiásticos do papa aos bispos franceses e, em última análise, destes últimos ao monarca). Ao explicar a famosa passagem em que Jesus entregou as chaves de seu reino ao apóstolo Pedro, Le Gros fez questão de dizer, em nome das "indubitáveis... máximas da Igreja Galicana", que "as chaves foram dadas antes à Igreja do que a São Pedro", cujo papel restringiu-se ao de representar a Igreja - também aqui, vista na acepção lata de La Borde, que incluía ativamente o baixo clero e o corpo dos leigos na sua constituição e administração - perante Cristo, isto é, de receber simbolicamente as chaves em nome de todos os apóstolos e discípulos, mas sem jamais apoderar-se delas. $^{144}$

E apesar de, no melhor estilo jansenista, apelar à autoridade do bispo de Hipona para legitimar sua interpretação das Escrituras, era através dos autores escolásticos tardios - como os "teólogos de Paris" Jean Gerson, Jacques Almain (1480-1515) e John Major (1467-1550) - que Le Gros orientava seus argumentos galicanos. Assim, a exemplo dos autores pró-conciliares da Sorbonne, o mesmo estabelecia a distinção entre, de um lado, o "fundamento" ("fonds"), a "propriedade" e a "radical autoridade" do poder espiritual da Igreja e, de outro, seu "uso", "exercício" e "ministério", cabendo a propriedade do poder espiritual a toda a Igreja (leigos inclusos), de modo que aos pastores e ministros confiava-se apenas o seu usufruto ${ }^{145}$.

Nem mesmo quando elevava o status espiritual do baixo clero - ao admitir que os pastores recebiam seus poderes sacerdotais diretamente de Cristo (sendo o corpo de fiéis apenas o condutor institucional para que aquilo ocorresse) -, conseguia Le Gros mascarar o cunho republicano de sua eclesiologia galicana, segundo a qual "a autoridade da Igreja" diferenciar-se-ia "pouco da jurisdição temporal de uma República", isto é

\footnotetext{
${ }^{143}$ Le Gros, Du renversement des libertés de l'Église gallicane..., p. 235.

${ }^{144}$ Idem, p. 335-6.

${ }^{145}$ Ibidem, p. 336-7.
} 
(citando Jacques Almain), "... que o poder de vida e morte... pertence em propriedade ao corpo da República, embora aquele poder seja exercido por um ou por muitos que agem, ordenam, julgam e punem em nome dela". Mais adiante, Le Gros explicita sua concepção conciliarista para a Igreja ao estabelecer um paralelo com o governo temporal republicano, ou seja, "assim como" [nos assuntos temporais] "toda a República consente através daqueles que a governam, também a Igreja consente por meio de seus pastores", explicitamente por meio dos concílios ecumênicos, implicitamente nos casos de excomunhões e censuras arbitrárias. ${ }^{146}$

Não obstante o fato de predicar a obrigatória obediência dos súditos perante os soberanos, era bastante evidente que o conteúdo da crítica à bula por parte de autores como Le Gros ultrapassava o campo teológico, pois a comparação do que julgava ser o governo legítimo da Igreja com o regime republicano exercia uma espécie de efeito bumerangue contra a legitimidade da monarquia francesa. Pois, nas palavras do autor, a exemplo do poder espiritual, o poder temporal "encontra-se essencialmente mais vinculado à sociedade do que ao chefe que a governa", de modo que "as pessoas que exercem" o poder temporal "morrem e são substituídas por outras, ao passo que o corpo político nunca morre". ${ }^{147}$

Receoso de que seus leitores mais desavisados pudessem excluir a monarquia francesa do seu modelo, Le Gros deixou claro que as ordenações e/ou editos reais aferidos nos conselhos do Estado só seriam válidos e se tornariam leis mediante aprovação (na ausência dos Estados Gerais) do Parlamento de Paris e dos demais. ${ }^{148}$

Portanto, as críticas galicanas de La Borde e de Le Gros à bula Unigenitus culminaram numa censura à monarquia absoluta e numa velada defesa teórica, ainda que revestida de uma terminologia teológica galicana, dos Estados Gerais (por meio do elogio dos substitutos Parlamentos). Se o Parlamento de Paris acabou por registrar a bula papal, aquilo se devia à pressão do despotismo, devendo, portanto, a mesma ser considerada inválida e nula como lei de Estado.

Após observar, na contramão daquela teologia conciliar galicano-jansenista, que a soberania papal era a melhor garantia para a obediência às leis ou cânones da Igreja do contrário, isto é, sem um juiz para decidir em última instância, os mesmos poderiam ser subvertidos ou engendrar inúmeras divisões -, e que a mesma se exercia

\footnotetext{
${ }^{146}$ Le Gros, Du renversement des libertés de l'Église gallicane..., p. 343-344, 395-396.

${ }^{147}$ Idem, p. 343-344.

${ }^{148}$ Ibidem, p. 237-239.
} 
moderadamente $^{149}$ e dentro de seus limites (isto é, apenas em questões relativas ao dogma e no direito de nomeação dos bispos), Maistre conclui a defesa da infalibilidade ou soberania papal do primeiro livro sublinhando que as decisões dogmáticas expressas pelas bulas papais sofreram oposição apenas dos hereges, como foram os casos da oposição jansenista à bula Unigenitus e a reação de Lutero à Exsurge Domine (1520) de Leão $X^{150}$

Encerrada a defesa (histórica, política e teológica) da supremacia papal no governo da Igreja, Maistre precisava convencer as soberanias temporais - mais especificamente, o "cristianíssimo" rei Bourbon e, sobretudo, o poderoso czar russo sobre a importância de ambos restaurarem o papado e de promoverem o catolicismo em seus territórios, sob pena de, em meio ao que julgava ser uma autêntica "era das revoluções" ${ }^{151}$, todos virem a perder suas coroas cedo ou tarde. Ao mesmo tempo, cumpria mostrar a seus potenciais leitores franceses e europeus que a alternativa democrático-revolucionária à francesa para restringir o governo absoluto dos reis Maistre estava absolutamente convencido de que não só a dinastia Bourbon restaurada, mas todos os monarcas sentavam-se sobre o trono de Napoleão, na medida em que estavam à frente de um Estado burocratizado e engrandecido (sendo este talvez o maior efeito do império napoleônico e de suas guerras sobre a Europa contrarrevolucionária), que não mais reconhecia barreiras à sua marcha niveladora e despótica - não podia redundar senão em maiores violências, dilacerações e uma perda ainda maior das liberdades civis.

Portanto, diante do problema de como salvaguardar a liberdade política e os direitos naturais dos súditos em meio ao abismo intransponível representado, de um lado, pelo absolutismo monárquico, e de outro, pela anarquia e a tirania jacobina - ou, nas palavras do próprio contrarrevolucionário saboiano, de como "restringir o poder soberano sem destruí-lo"152-, Maistre apresentou o papado como uma ponte civilizatória e libertária para os povos, e, no que concerne aos soberanos, a única garantia contra o avanço do espírito revolucionário.

\footnotetext{
149 J. de Maistre, Du Pape,Livro I, cap. 13-14.

${ }^{150}$ J. de Maistre, Du Pape,Livro I, cap. 19.

${ }^{151}$ Desapontado com os rumos da Restauração, Maistre advertia em uma missiva de 1819 que a "Revolução" não apenas estava "em pé", mas corria, marchava e distribuía coices (ainda que de uma maneira mais refinada e polida); ao passo que, já em seu leito de morte, profetizou "uma revolução mais terrível do que aquela que pôs fim ao último século". Cf. Joseph de Maistre, O.C., XIV:156; Constance de Maistre, "Un portrait de Joseph de Maistre", in: Études, tomo 125, 20 de novembro de 1910, p. 502.

${ }^{152}$ J. de Maistre, Du Pape, Livro II, cap. 2.
} 
Se, na melhor tradição teológica tomista e, sobretudo jesuítica, Maistre admitia in extremis o direito de resistência contra uma monarquia tirânica, restava-lhe todavia a questão política de saber quando o exercício de tal direito tornava-se lícito, bem como através de quais homens ou corpo político o mesmo seria executado. Como lançar mão de um direito (ainda que legítimo) sem medir as consequências humanas envolvidas em seu exercício? A história não ensinava que "as revoluções iniciadas pelos homens mais sábios são sempre encerradas pelos loucos; que os autores são sempre suas vítimas, e que os esforços dos povos para criar ou aumentar sua liberdade terminam quase sempre por agrilhoá-los"? ${ }^{153}$

A resposta de Maistre - na melhor estratégia de que o ataque é a melhor defesa consistirá em pontuar para os soberanos que eles teriam todo o interesse em promover o catolicismo, pois somente o sistema católico seria capaz de conter o direito de resistência (que ele admite ser um direito natural inalienável) dentro de seus limites estreitos e legítimos.

Uma vez que o "dogma católico" proscrevia indistintamente "toda espécie de revolta" - ao passo que o protestantismo transportava o dogma da soberania do povo da religião à política (a ponto de ver no "sistema da não-resistência senão o último grau de aviltamento do homem"154) - e, ao longo dos séculos, protegeu e foi protegido pelos soberanos, "não seria absurdo pensar que", pelo próprio bem dos últimos, os súditos pudessem ser "desligados do juramento de fidelidade" por meio de um "poder espiritual superior, único sobre a terra" capaz de "conter a autoridade temporal" sem "apagar seu caráter". ${ }^{155}$

Longe de contrariar a tese da "origem divina da soberania", o providencialismo maistreano pretendia conservá-la ao observar que somente o tribunal papal lograria solucionar o grande impasse político moderno, e o qual poder-se-ia traduzir pela necessidade de se afastar um "Nero" (uma referência ao soberano sueco Gustavo-Adolfo IV) do trono sem que isto implicasse no menor prejuízo "ao direito divino" dos soberanos. Mais do que uma instância decisória favorável aos desígnios revolucionários dos povos, o Papa deveria ser visto pelos príncipes (se não pela fé, pelo menos em nome de um interesse bem compreendido) como uma instituição judicial sublime que, "ao privar um pai de família do direito de criar seus filhos", conservaria intacto (quando não

\footnotetext{
153 J. de Maistre, Du Pape, Livro II, cap. 2.

${ }^{154}$ Idem, Livro II, cap. 2.

155 Ibidem, Livro II, cap. 3.
} 
fortaleceria) o princípio divino da "autoridade paternal" ${ }^{156}$, de modo que os "Papas lutaram algumas vezes com os soberanos, mas nunca com a soberania", e no próprio ato pelo qual "eles desobrigavam seus súditos do juramento de fidelidade", declaravam a "soberania inviolável". Assim, os papas advertiam os povos de "que nenhum poder humano podia atingir o soberano cuja autoridade não era suspensa a não ser por um poder inteiramente divino", razão pela qual o anátema papal dirigido aos monarcas, ao contrário de "derrogar... as máximas católicas sobre a inviolabilidade dos soberanos", antes reforçavam-nas. ${ }^{157}$

"Enganados pelas gritarias filosóficas" ${ }^{158}$ do século XVIII e seus sucedâneos da Restauração (os liberais monarquistas) que buscavam apresentar a ação dos papas na história como um fator de desestabilização política e um poder usurpador, os monarcas, de acordo com Maistre, precisavam ser instruídos de que nada tinham a temer com o veto pontifical, pois além dele se limitar ao poder de impedir (uma resistência que não se confunde com a revolução) e de ser exercido dentro dos princípios da moderação e da sabedoria política (posto que reunia as características menos suscetíveis "aos erros e paixões" humanas, isto é, tratava-se de um poder desempenhado por um "idoso, celibatário e padre"), o mesmo, devido ao caráter universal da autoridade que desempenhava, adaptava-se "a todas as constituições e a todos os caracteres nacionais". ${ }^{159}$ Ao reprimir a autoridade real em determinados pontos, "tornando-a menos feroz e menos esmagadora, ao assustá-la por seu próprio bem que ela ignorava", a excomunhão papal fazia-a mais "venerável" junto aos súditos, razão pela qual o papado devia ser encarado pelos soberanos da Santa Aliança como um autêntico "poder conservador". ${ }^{160}$

$\mathrm{Na}$ contramão dos filósofos modernos e dos políticos e intelectuais liberais da Restauração, cuja atitude em relação à soberania monárquica, de acordo com Maistre, era similar à adotada pelos protestantes desde Lutero - isto é, elogiavam a pessoa do soberano enquanto atacavam a instituição -, os papas opunham-se aos indivíduos dos reis sem prejudicar a soberania real, com a qual o papado mantinha uma relação de profunda "analogia, fraternidade e dependência" recíprocas, a ponto de o direito público

\footnotetext{
${ }^{156}$ J. de Maistre, Du Pape, Livro II, cap. 3.

${ }^{157}$ Idem, Livro II, cap. 5.

${ }^{158}$ Ibidem, Livro II, cap. 5.

${ }^{159}$ Ibidem, Livro II, cap. 4.

${ }^{160}$ Ibidem, Livro II, cap. 5.
} 
europeu (ou seja, a monarquia de direito divino) ser inseparável da imbricação entre a monarquia espiritual e a monarquia temporal. ${ }^{161}$

Os próximos capítulos do segundo livro (6-16) de Du Pape dedicar-se-ão quase que exclusivamente à refutação das teses ortodoxas de Stourdza e, sobretudo, do livro L'esprit de l'histoire, ou lettres politiques et morales d'un père à son fils (1803, em 4 volumes) do émigré contrarrevolucionário e membro do conselho privado de Luís XVIII durante a Restauração, o galicano conde Antoine Ferrand (1751-1825).

Em vista da dificuldade de "julgar os papas sem preconceitos" ou sem o "ódio" que o "século dezesseis" e a "incredulidade" da Ilustração ("filha mais velha da Reforma") ${ }^{162}$ lhes reservaram, Maistre propunha não apenas uma defesa histórica da soberania temporal dos papas contra as teses galicano-parlamentares de Ferrand $^{163}$ que, pelo fato de ignorar o espírito ou o contexto geral da época relativo às querelas das investiduras, pecava tanto por miopia quanto por má-fé ao avaliar as condenações papais aos imperadores germânicos, segundo o saboiano ${ }^{164}$-, mas também um virulento ataque ao feudalismo (e, de forma subjacente, ao germanismo austríaco e suas pretensões italianas) no interior daquilo que poderíamos classificar como uma teoria da história ultramontana das manners europeias.

Conforme vimos, Maistre não estava sozinho naquela defesa histórica dos papas e tampouco precisava iniciá-la do zero. Antes dele, Chateaubriand realçara em seu Génie o "belo papel de moderador" desempenhado pelo clero católico, que "acalmava, moderava os espíritos" e prevenia "as resoluções extremas" quando "os barões arrogantes e comuns ignorantes não conheciam senão as facções e uma obediência absoluta". Somente a Igreja opunha-se aos excessos do povo, apresentava queixas aos reis e desafiava a cólera dos nobres, graças à "superidade de suas luzes, seu gênio conciliador, sua missão de paz" e à "própria natureza de seus interesses", que a dotavam de "ideias políticas generosas" ausentes nas "duas outras ordens". Colocada entre os reis/nobres e os comuns, a Igreja "tinha tudo a temer dos grandes e nada dos comuns, de quem se tornava, por esta única razão, defensora natural. Assim a vemos, nos momentos de crise, votar preferencialmente com os últimos". ${ }^{165}$

\footnotetext{
${ }^{161}$ J. de Maistre, Du Pape,, Livro II, cap. 5.

${ }^{162}$ Idem, Livro II, cap. 6.

${ }^{163}$ Conforme Maistre insinua no Livro II, cap. 13 da obra.

164 J. de Maistre, Du Pape, Livro II, cap. 6, 7. Cf. Du Pape (Paris: Charpentier, 1854), p. 159 e 169.

${ }^{165}$ Chateaubriand, Génie du Christianisme, $4{ }^{\mathrm{a}}$ Parte, Livro VI, cap. 11.
} 
E a conclusão do Génie sobre os méritos políticos do cristianismo no interior da história europeia não poderia senão causar um grande efeito sobre o "Régent de la Grande Chancellerie" da Casa da Saboia. Segundo Chateaubriand, "se existisse na Europa um tribunal que julgasse, em nome de Deus, as nações e os monarcas, que prevenisse as guerras e as revoluções", este tribunal "seria a obra-prima da política e o último grau da perfeição social: os papas, pela influência que eles exerciam no mundo cristão, estiveram próximos de realizar este belo sonho". ${ }^{166}$

Diante disso, não devemos ficar surpresos com os esforços feitos pelo ministro da justiça do reino piemontês no sentido de convencer o autor do Génie a corrigir e editar o manuscrito original de seu $D u$ Pape, o que não ocorreu seja pela falta de tempo disponível ao então político oposicionista ultra ao governo francês (que se tornou predominantemente "liberal" após a dissolução da chambre introuvable, em setembro de 1816), seja pela alegada incapacidade de, nas palavras do próprio Chateaubriand, o "aprendiz emendar a pintura de seu mestre". ${ }^{167}$

E assim como no primeiro livro sobre os concílios, também no segundo a melhor defesa será o ataque, na medida em que Maistre admite plenamente o caráter temporal da soberania papal (algo que Chateaubriand teve todo cuidado em evitar), vista por ele como indispensável ao exercício de sua benfazeja e legítima "onipotência espiritual" na história da Europa. Pois se havia uma soberania capaz de justificar aquilo que possuía, tratava-se justamente da soberania papal, a única a quem estava "reservada a honra de não possuir hoje senão o que possuía há dez séculos", e sem a menor necessidade de "tratados, combates, intrigas... usurpações" e até mesmo das alegadas doações dos monarcas carolíngios aludidas por Stourdza e Ferrand (e, futuramente, Tocqueville). ${ }^{168}$

Disposto num trono de mártires e proscritos, os papas tornaram-se soberanos insensivelmente, isto é, por meio de "uma lei invisível" da Providência e sem que "nenhuma causa humana" concorresse para isto. Graças ao "respeito, ao amor, à piedade, à fé" que suscitou no interior do Império romano, a Igreja logrou reunir desde muito cedo (através de doações ou conversões de ricos patrícios) quantias admiráveis de

\footnotetext{
${ }^{166}$ François-René de Chateaubriand, Génie du Christianisme, $4{ }^{\mathrm{a}}$ Parte, Livro VI, cap. 11.

167 Carta de Chateaubriand a Maistre (sem data, mas provavelmente de meados de setembro de 1817). Citada em Camille Latreille, Joseph de Maistre et la papauté (Paris: Hachette, 1906), p. 99. Ademais, conforme destacou Richard Lebrun, uma terceira e determinante razão para a recusa de Chateaubriand dizia respeito ao caráter radical da crítica maistreana ao galicanismo, e a qual não poupava nem figuras célebres da tradição filosófico-religiosa galicana, como Pascal e Bossuet. Cf. R. Lebrun, Joseph de Maistre: An Intellectual Militant (Kingston and Montreal: McGill-Queen's University Press, 1988), p. 233.

${ }_{168}$ J. de Maistre, Du Pape, Livro II, cap. 6.
} 
riquezas que, abominadas pelos protestantes e filósofos modernos, permitiram-lhe enviar seus oficiais e a mensagem de Cristo por toda a humanidade, algo que se revelaria fundamental para a sociedade europeia após a queda do Império Romano do Ocidente.

Invadida pelos sucessivos povos bárbaros e, apesar das recorrentes invocações papais (que admitiam e respeitavam a supremacia temporal dos imperadores bizantinos), abandonada temporalmente pelo Império do Oriente (cujos "miseráveis príncipes", mais preocupados em defender Constantinopla da invasão dos bárbaros, traíam os súditos ocidentais ao fazer acordo com os reis bárbaros), coube ao Sumo Pontífice - "em meio àquelas grandes calamidades" - assumir o papel soberano, de único refúgio temporal dos europeus ocidentais reduzidos ao desespero. Diante disso, Maistre advertia que independentemente da "fábula" ou prestidigitação em torno da polêmica "doação de Constantino" (refutada pelo galicano Ferrand e pelo ortodoxo Stourdza nas mesmas bases com que o humanista italiano Lorenzo Valla empreendera no passado), a história, mais do que um mero "pergaminho", confirmava a soberania temporal dos papas e a "doação" do imperador romano, razão pela qual durante mais de três séculos sua autoridade foi reconhecida pelos italianos, hérulos, lombardos e, sobretudo, franceses. $^{169}$

"Abandonados por seus senhores, dilacerados pelos bárbaros", os italianos escolheram como seu líder a única autoridade que restou, razão pela qual os papas tornaram-se "duques" de Roma ("de fato e de direito") muito antes e independente das supostas "doações usurpadoras" dos carolíngios. Apesar de exercerem de facto o poder, os papas não apenas permaneceram fiéis à legitimidade dos imperadores bizantinos, como imploravam pela proteção dos mesmos contra a expansão muçulmana na península ibérica e as usurpações temporais (vistas por eles como prejudiciais ao imperador) e espirituais dos reis lombardos. E foi graças a esta reiterada indiferença bizantina pelos destinos do Ocidente e, sobretudo, da península itálica, que os pontífices romanos recorreram aos reis francos, os quais, desde Pepino, não fizeram mais senão reconhecer oficialmente uma soberania que já se exercia na prática, cunhando moedas, enviando embaixadas no sentido de estabelecer e paz e, se necessário (e apenas em última instância), fazer guerras em casos de notórios abusos. ${ }^{170}$

\footnotetext{
${ }^{169}$ J. de Maistre, Du Pape, Livro II, cap. 6.

${ }^{170}$ Idem.
} 
Portanto, se a "soberania, por sua natureza, assemelha-se ao Nilo" e "oculta sua cabeça", a dos papas, por seu caráter providencial, foi a única a "derrogar" esta lei política universal, a fim de que sua origem fosse visível a todos:

"Não há nada evidentemente tão justo em sua origem quanto esta soberania extraordinária. A incapacidade, a baixeza, a ferocidade dos soberanos que a precederam, a insuportável tirania exercida sobre os bens, as pessoas e a consciência dos povos, o abandono formal dos mesmos, abandonados indefesos aos impiedosos bárbaros; o grito do Ocidente que abdica o antigo senhor; a nova soberania que se eleva, avança e substitui a anterior sem abalo, sem revolta, sem efusão de sangue, impulsionada por uma força recôndita, inexplicável, invencível, e jurando fé e fidelidade até o último instante ao débil e desprezível poder que ela iria substituir; [e] o direito de conquista, enfim, obtido e solenemente cedido por um dos maiores homens que já existiram [Carlos Magno]: (...) tais são os títulos dos papas, e a história não apresenta nada semelhante." 171

Distinta das demais soberanias por sua origem, o pontificado romano diferenciava-se também em outro aspecto, qual seja, o de que jamais fizera uso de sua constante e reduzida soberania temporal a não ser para preservar suas prerrogativas espirituais, quase sempre objetos de açambarcamento dos príncipes temporais (dos lombardos aos imperadores germânicos). Mesmo aqueles papas que, como Julio II, notabilizaram-se por seu ativismo militar, deveriam ser considerados à luz de um contexto histórico que apresentava um painel de soberanos ambiciosos, dissolutos e tirânicos. Admitindo, à guisa de Montesquieu, que apenas o poder é capaz de controlar outro poder ("os poderes não se equilibram a não ser pelos esforços contrários"), Maistre justifica a seus leitores a "escandalosa" (e ele se referia a Voltaire e Ferrand) interferência dos papas na esfera temporal como providencial e historicamente necessária, pois "jamais a violência foi interrompida pela moderação". ${ }^{172}$ Para demonstrar empiricamente sua hipótese, o saboiano (amparado no relato histórico do político e historiador inglês, o abolicionista e presbiteriano William Roscoe) recordava que na mesma época em que Luís XII passava a espada sobre todos os habitantes da rendida cidade de Peschiera (controlada pelos venezianos) e mandava enforcar o governador André Riva e seu filho, o papa Júlio II, igualmente comprometido na Liga

\footnotetext{
${ }^{171}$ J. de Maistre, Du Pape, Livro II, cap. 6.

${ }^{172}$ Idem, Livro II, cap. 7 (artigo II).
} 
de Cambrai (1508-1509) e vencedor do cerco de Mirandola, declarou indulto a todos os seus inimigos. ${ }^{173}$

Portanto, ao invés de condenar peremptoriamente a ação dos papas ao longo da história e de tachá-la como "escandalosa", o Du Pape advertia sobre a necessidade de os historiadores se voltarem para o imaginário da época estudada, uma vez que "cada século tem seus preconceitos e sua maneira de ver". ${ }^{174}$ Sob este prisma "histórico", era preciso considerar "a ferocidade e a depravação, a anarquia e a pobreza" que caracterizavam o estado de loucura da Europa após a dissolução do império carolíngio, bem como os esforços açambarcadores dos sucessivos imperadores germânicos para "aniquilar o sacerdócio" (vendendo "publicamente os benefícios eclesiásticos" a nobres guerreiros), para que se lograsse compreender sem parti pris a oposição abrangente e universal da "Santa-Sé, e a qual fora responsável por manter a ordem eclesiástica que restaurou a Europa da dissolução feudal. Portanto, Maistre pontuava que "sem a intervenção extraordinária dos papas", dos "legisladores"175 (ou "força constituinte" ${ }^{176}$ ) da Europa como Gregório VII (os quais agiam não para engrandecer seus domínios territoriais, mas apenas para manter suas prerrogativas espirituais), "teria sido o fim da Igreja, humanamente falando", assim como da "monarquia europeia", uma vez que os soberanos civilizados (e cristãos) teriam sido substituídos por "autoridades extraviadas" que conciliavam a "corrupção romana com a ferocidade dos bárbaros". ${ }^{177}$

Ademais, e naquilo que podemos classificar como uma resposta às germanófilas teses do De l'Allemagne de Mme de Staël - para quem o espírito de cavalaria (segundo ela, o equivalente moderno dos "tempos heroicos dos antigos"), com tudo o que ele representava em termos de nobre defesa dos mais fracos e, sobretudo, de dignidade para as mulheres, nascera e conservara-se melhor na feudalidade germânica e protestante do que na católica e "imoral" França pós-regencial ${ }^{178}$-, Maistre observa que coube ao cristianismo e, em especial, ao seu soberano, domesticar o "animal feroz" do amor ("capaz dos mais terríveis excessos" sem uma barreira civilizatória que funcione como uma espécie de superego) e preservar a "santidade dos matrimônios, base sagrada da felicidade pública". ${ }^{179}$

\footnotetext{
173 J. de Maistre, Du Pape, Livro II, cap. 6.

${ }^{174}$ Idem, Livro II, cap. 7 (artigo II).

175 Ibidem, Livro II, cap. 9.

${ }^{176}$ Ibidem, Livro II, cap. 14.

${ }^{177}$ Ibidem, Livro II, cap. 7 (artigo II).

${ }^{178}$ Mme de Staël, De l'Allemagne, Parte I, cap. 4.

179 J. de Maistre, Du Pape, Livro II, cap. 7 (artigo I).
} 
E o principal meio escolhido pelo cristianismo para aperfeiçoar o homem consistiu justamente na proteção e na exaltação da condição feminina, a qual, mais do que qualquer outra, "é devedora ao cristianismo", uma vez que o mesmo desnaturaliza a condição biológica de "fêmea" e a transforma no ente quase "sobrenatural" da mulher. Apoiado nos relatos do célebre teólogo e missionário protestante Claudius Buchanan (1766-1815), Maistre destacou como "em todos os países onde o cristianismo não reina, observa-se uma certa tendência à degradação das mulheres". ${ }^{180}$ E conforme sublinhará em seu Éclaircissement sur les sacrifices (1821) - cuja redação teria iniciado um pouco antes de Du Pape (isto é, por volta de 1810) -, apenas a civilização do "Evangelho", dentre todas as demais, elevara as "mulheres ao nível dos homens ao torná-las melhores"; somente o cristianismo - ao se "estabelecer no coração das mulheres" - soube proclamar os "direitos da mulher" (estaríamos aqui diante de uma alusão ao panfleto de Mary Wollstonecraft em defesa dos direitos da mulher?), que se tornaram assim o "instrumento mais ativo e mais poderoso para o bem" do cristianismo, que as protege e é por elas protegido (através da primeira educação moral dos filhos). ${ }^{181}$

Instrumentos providenciais da paideia divina, protetores das manners (sendo a defesa da santidade do matrimônio o fundamento das mesmas) e educadores dos monarcas, os papas também se destacaram na história como os guardiões da liberdade italiana contra o imperialismo germânico que, observa Maistre à guisa de Voltaire, "não era nem santo, nem império, nem romano". ${ }^{182}$

Mais do que uma justificação da ação dos papas na defesa da liberdade dos povos da península itálica contra a tirania dos imperadores germânicos, o $D u$ Pape também deve ser lido como uma veemente defesa do nacionalismo e uma virulenta crítica seja à intervenção estrangeira nos destinos dos povos (conforme previa, por exemplo, a Santa Aliança), seja contra toda espécie de imperialismo (fosse ele germânico ou britânico), segundo ele o pior dos males para os povos subjugados ("nenhuma humilhação, nenhum tormento do coração", se lhe compara, pois o "ódio da dominação" é algo "inato no

180 J. de Maistre, Du Pape, Livro III, cap. 2.

181 J. de Maistre, Éclaircissement sur les Sacrifices, in: P. Glaudes (org.), Joseph de Maistre: Oeuvres (Paris: Bouquins, 2007), p. 822-823. E uma vez que o casamento expressa um profundo desígnio político no regime monárquico, Maistre indicava que um assunto tão relevante para a segurança dos soberanos e dos súditos deveria passar pelo arbítrio papal, a fím de evitar que os monarcas católicos e latinos da Europa restaurada contraíssem matrimônio com as princesas protestantes ou germânicas (como o de Maria Teresa d'Asburgo-Este da "inimiga" Áustria com o seu soberano Vittorio Emanuele I do Piemonte em 1802, contrariando a política e a histórica união da Casa da Saboia com a monarquia franca), o que, cedo ou tarde, acabaria enfraquecendo a ascendência católica sobre os reinos (mesmo no caso da católica, porém "josefista", Casa da Áustria). Cf. Maistre, Du Pape, Livro II, cap. 7 (artigo I).

182 J. de Maistre, Du Pape, Livro II, cap. 7 (artigo III). 
homem") e principal causa da corrupção e perda de sabedoria para os dominadores. ${ }^{183}$ Além de exortar os italianos ("harmoniosos herdeiros da Grécia", a quem "não falta senão a unidade e a independência") a elevar "altares ao sublime Pontífice" (que realizou "prodígios" para defendê-los da tirania imperial ${ }^{184}$ ), Maistre observava que a onipotência espiritual dos papas poderia ser igualmente benéfica na defesa da liberdade dos povos contra dominadores estrangeiros e soberanos extraviados ou enlouquecidos que, a exemplo do rei Gustavo-Adolfo IV da Suécia, poderiam expor seus súditos às guerras inconsequentes ou revoluções (no caso sueco, a deposição do rei pelo tio e a coroação, pela nobreza, do general napoleônico Bernadotte em 1810).

Como bem pontuou Carolina Armenteros, o episódio da loucura e deposição do monarca sueco, bem como a amizade e o contato diplomático com o galicano Blacas, produziram uma importante ruptura no pensamento de Maistre, que substituiu sua antiga crença no absolutismo real e nos controles internos aristocráticos (cada vez mais nulos após o nivelamento proporcionado pelas guerras napoleônicas, o crescimento exponencial da burocracia nos Estados e, no interior dos mesmos, o avanço inexorável de uma impetuosa classe-média, todos estes fenômenos precocemente percebidos pelo autor de Du Pape ${ }^{185}$ ) pela defesa da Igreja como o grande pilar dos Estados, da civilização e, em última análise, até mesmo da liberdade dos povos (nem que isto implicasse na deposição dos monarcas). ${ }^{186}$

De modo a prevenir crises como a que depôs o soberano sueco e prevenir guerras cada vez mais mortais (seja pelo avanço da tecnologia armamentista, seja pela "democratização" ou nacionalização dos combates), Maistre avançou uma utopia cosmopolita devota e conservadora alternativa ao cosmopolitismo liberal-republicano exposto por Kant em A Paz Perpétua (1795), e a qual, expressando seu ideal para a Santa Aliança, consistia na reunião de todas as soberanias cristãs em uma "espécie de república universal" (nos moldes dos "Anfictiões" gregos arcaicos) "sob a supremacia

183 J. de Maistre, Du Pape, Livro II, cap. 7 (artigo III).

${ }^{184}$ Paradoxalmente, a primeira tentativa democrático-republicana de unificação e independência da Itália, a curta República Romana de Mazzini (1849), sofreu justamente a oposição do Papa e da França. Assim como não foi menos paradoxal a profunda influência exercida pelos escritos maistreanos sobre o então ministro das finanças do Piemonte e futuro arquiteto da Unificação italiana, Cavour - mormente através de Du Pape e da correspondência diplomática (publicada em 1859 com patrocínio do estadista piemontês) -, cuja carreira política começou a ganhar destaque após a defesa das leis Siccardi (responsáveis por reduzir drasticamente os privilégios do clero nos domínios da Casa da Saboia).

185 J. de Maistre, Du Pape, Livro III, cap. 2.

${ }^{186}$ Carolina Armenteros, The French Idea of History: Joseph de Maistre and his heirs (London: Cornell University Press, 2011), p. 155. 
comedida do poder espiritual supremo". ${ }^{187}$ Simulando a aplicação deste teocrático tribunal internacional à crise sueca, Maistre diz que o mesmo poderia ter impedido que o monarca Gustavo-Adolfo (que faleceu num estado de extrema pobreza, alcoolismo e loucura no exílio suíço) declarasse a insensata guerra contra a Rússia ou, na hipótese de o mesmo permanecer recalcitrante, evitado (através de sua deposição) as perdas humanas e territoriais (a Finlândia) naquele conflito. ${ }^{188}$

Longe desta mediação temporal papal (como as excomunhões lançadas aos imperadores germânicos durante a querela das investiduras) afrontar o princípio da legitimidade monárquica, ela seria positiva aos soberanos - que seriam preservados de suas próprias decisões individualistas e irracionais ${ }^{189}$ - e também aos povos, que não tinham nada a temer de uma soberania que, desde a bula In Coena Domini (publicada em 1363 pelo papa Urbano V e reimpressa anualmente durante a celebração da Páscoa cristã até o pontificado de Clemente XIV), prescrevia aos soberanos o respeito às liberdades dos súditos. ${ }^{190}$

Dividido em sete capítulos e uma conclusão, o terceiro livro, conforme anuncia o seu título, trata "Do Papa em sua relação com a civilização e a felicidade dos povos". Apoiado no relato de autores protestantes ingleses, Maistre empenha-se em demonstrar que o cristianismo só logra ter "ação exterior" ou propagar a "luz evangélica" aos povos através dos papas, de modo que os próprios missionários ou viajantes protestantes como o célebre orientalista William Jones e o renomado missionário presbiteriano Buchanan ${ }^{191}$ - confessavam "a nulidade do proselitismo protestante" e a "indiferença absoluta do governo inglês pelo estabelecimento religioso naquele [a Índia] grande país". ${ }^{192}$

Após observar que o espírito de divisão das denominações protestantes anulava os esforços missionários empreendidos por seus representantes e prejudicava/retardava os êxitos das missões católicas, Maistre adverte os soberanos da Santa Aliança (tendo em vista sobretudo o czar russo e o monarca francês, cuja ação conjunta em favor do

${ }^{187}$ J. de Maistre, Du Pape, Livro II, cap. 10.

${ }^{188}$ Idem, Livro II, cap. 10.

${ }^{189}$ Ibidem, Livro II, cap. 11.

${ }^{190}$ Ibidem, Livro II, cap. 15.

${ }^{191}$ O qual, à guisa do que dissera Burke sobre o governo imperial britânico na Índia em ocasião do processo de impeachment do governador-geral Warren Hastings, admitiu que a "indiferença britânica" era tal, que se os ingleses se retirassem da Índia, não restaria o menor traço de que aquela nação "fora governada por uma nação que recebera a iluminação evangélica."Cf. Buchanan, Christian Researches in Asia (Londres, 1812), citado em Du Pape, Livro III, cap. 1.

${ }^{192}$ J. de Maistre, Du Pape, Livro III, cap. 1. 
catolicismo deveria sufocar lentamente, de Norte a Sul, o protestantismo e o filosofismo) que os mesmos deveriam empregar todos os esforços para propagar o "cristianismo legítimo" em seus territórios, sob pena de cedo ou tarde atraírem para si ou para suas dinastias um "castigo temporal e visível". ${ }^{193}$

Naturalmente, a lógica ultramontana de Maistre recomendava que a difusão do Evangelho só poderia ser plenamente atingida através do clero católico sob a liderança temporal e espiritual do Papa, responsável por assegurar a independência do clero junto ao Estado e, sobretudo, por conservar a "alta disciplina" ou "sacrifício" do celibato entre os seus padres. Assim, enquanto o clero ortodoxo ("empregado como uma máquina" pelo Estado) era "impotente" e tremia "diante daqueles que ele deveria fazer tremer", e o caráter sagrado encontrava-se "absolutamente apagado da fronte" dos ministros protestantes (vistos como meros "oficiais civis" por seus governos que reduziam a religião a um "servo do Estado"), o clero católico (especialmente graças ao celibato) dava reiteradas provas de sua superioridade, que se traduzia na consideração obtida junto aos diferentes povos, dos gentios no Novo Mundo aos orientais (japoneses e chineses) e, mais recentemente, até mesmo entre os protestantes durante a emigração do clero. $^{194}$

Naquilo que caracteriza o ponto mais alto de sua apologética, Maistre descreve os papas como os demiurgos da civilização universal e os responsáveis por promover, contra a "cega" e obstinada oposição dos "príncipes", a liberdade civil ao longo da história europeia. Portanto, aquilo que o filosófico Voltaire, o galicano Ferrand, e o ortodoxo Stourdza condenavam em nome do que julgavam ser uma usurpação temporal dos papas (a qual ensanguentara a história do continente), Maistre apresentava como uma lei histórica providencial (e, vale dizer, origeniana) de desenvolvimento das liberdades europeias, a qual poderia ser sintetizada pela fórmula da "luta entre as soberanias":

"A Providência havia confiado aos Papas a educação da soberania europeia. Mas como educar sem punir? Daí os inúmeros choques, ataques - algumas vezes até demasiado humanos e resistências ferozes; entretanto, o princípio divino não estava menos presente, sempre (...); sobretudo por este maravilhoso caráter que já indiquei..., a saber: que toda ação dos Papas contra os soberanos redundava em proveito da soberania. Jamais agindo a não ser como

\footnotetext{
193 J. de Maistre, Du Pape, Livro III, cap. 1.

${ }^{194}$ Idem, Livro III, cap. 3.
} 
delegados divinos, mesmo lutando contra os monarcas, eles não cessavam de advertir o súdito de que ele não podia fazer nada contra seus senhores. Imortais benfeitores do gênero humano, eles combatiam simultaneamente pelo caráter divino da soberania e pela legítima liberdade dos povos." ${ }^{195}$

A própria monarquia europeia, caracterizada pela moderação e pela liberdade civil que a distinguia das soberanias orientais, era plenamente tributária da ação pedagógica dos papas sobre os monarcas, e a qual, como toda pedagogia que se preza - ainda mais quando se trata de "extirpar" um "elemento feroz" que caracterizava os reis bárbaros -, perturbava e punia com o intuito de aperfeiçoar o "aluno".

Portanto, teria sido graças ao Sumo Pontífice que "os reis abdicaram do poder de julgar por eles próprios, e os povos, por seu turno, declararam os reis infalíveis e invioláveis." Sem a ação pedagógica (portanto, naturalmente conflituosa e punitiva) dos papas ao longo da história, esta "lei fundamental da monarquia europeia" ("maravilha inaudita, contrária à natureza do homem natural"), e que servia de ponte entre a "servidão" e a "revolta", cairia por terra. ${ }^{196}$ Logo, não havia meio-termo para os soberanos da Santa Aliança. Sendo o coração do homem "excessivamente perverso para ser livre" e o governo impossível "sem alguns recursos extraordinários", somente pelo concurso da pedagogia divina cristã seria possível conciliar a liberdade civil numa era revolucionária com o governo e a soberania tout court. ${ }^{197}$

Com o objetivo de compatibilizar o cristianismo (isto é, o catolicismo) com os anseios libertários dos povos, Maistre demonstrava que a escravidão fora o "estado natural de uma grande parte do gênero humano" até o estabelecimento do mesmo, que sempre "trabalhou - e ainda trabalhava, especialmente nas Américas (segundo ele, "consolando" a espécie humana escravizada e "abrandando" e limitando de inúmeras maneiras o jugo naquelas regiões) - incansavelmente pela abolição da mesma, "algo que nenhuma outra religião, nenhum legislador, nenhum filósofo, ousara empreender ou sonhar". E se a servidão fora condenada por um Papa apenas em 1167 (por Alexandre

195 J. de Maistre, Du Pape, Livro III, cap. 4. Mais adiante no sétimo capítulo, Maistre avança uma espécie de teoria avant la lettre sobre o "choque das civilizações" de Samuel Huntington, ao sustentar que a oposição papal aos muçulmanos (inexorável, dado o caráter conquistador do islamismo) desde as defensivas Cruzadas ("organizadas" e "patrocinadas" pelos Sumos Pontífices) à Batalha de Lepanto (concertada por Pio V), preservou a liberdade europeia do extermínio ou da escravidão (abolida na Europa cristã, a servidão mantinha-se viva nos estados governados pela religião muçulmana, especialmente na África).

${ }^{196}$ Idem, Livro III, cap. 4.

${ }^{197}$ Ibidem, Livro III, cap. 2. 
III) e ainda se mantinha nas Américas (inclusive na sua vasta extensão católica), isto se devia à ação divina e providencial do cristianismo, que sempre age "lentamente" e "de uma maneira insensível" na história, e jamais com "barulho, choques, impetuosidade, destruição" (marcas do "crime" ou da "loucura" e incompatíveis com qualquer ação duradoura ou legítima). ${ }^{198}$

E após enunciar o aludido efeito libertário do cristianismo para as mulheres, Maistre antecipa uma reflexão que posteriormente se tornaria célebre pela pena de Tocqueville. Descrevendo o cristianismo como uma "escravidão enobrecida" que, "ao invés de aviltar o homem", "o santifica" ao "purificar" suas vontades, o autor de $D u$ Pape adverte os soberanos para o fato de que o fortalecimento e a promoção da religião cristã fazia-se mais necessária do que nunca naquela 'era da revolução democrática' em que, nas palavras do ultramontano saboiano, "os homens, por toda parte, caem em massa nos braços do governo, que não sabe o que fazer"; em que "uma juventude impetuosa, inumerável..., ávida por distinções e riquezas, se precipita como enxames na carreira dos empregos" públicos, que cresceram exponencialmente pelas necessidades das guerras revolucionárias. No momento em que, num "excesso de movimento" e de "vontades desenfreadas", todos "se lançam ao poder e aos cargos", era do "maior interesse" dos soberanos "moderar o movimento intestino do Estado, e aumentar o número de homens que não lhe exigem nada". Pois toda instituição que logra "amortecer as vontades sem degradar os súditos", presta "um serviço inestimável à sociedade", desonerando o governo da obrigação de "vigiar, empregar e, sobretudo, remunerar" a estes homens. $^{199}$

A respeito deste exercício maistreano de sociologia da religião, como não lembrar de um autor como Tocqueville, que, na segunda parte de sua A Democracia na América (1840), destacava a premente necessidade da religião - ou melhor, de uma "autoridade em matéria de religião" -, para as sociedades democráticas (constante agitadas e marcadas por uma independência sem limites, pela paixão da igualdade e pelo "amor do bem-estar"), concluindo não crer que fosse possível à humanidade "suportar ao mesmo tempo uma completa independência religiosa e uma inteira liberdade política", de modo que se não houvesse fé, seria preciso que ela servisse, e, se ela fosse livre, que acreditasse ${ }^{200}$

\footnotetext{
${ }^{198}$ J. de Maistre, Du Pape, Livro III, cap. 2.

${ }^{199}$ Idem, Livro III, cap. 2.

${ }^{200}$ Alexis de Tocqueville, Democracia na América, Parte I, cap. 5, vol. II.
} 
E de todas as nações europeias, aquela na qual a mensagem cristã se fazia mais necessária era justamente a Rússia czarista, que, apesar de seu poderio militar e do crescente refinamento e sofisticação de sua nobreza, conservava a infame instituição da servidão. Por outro lado, era fundamental para os desígnios apologéticos maistreanos tentar conquistar, pela última e derradeira vez, a simpatia do czar pela causa católica, indispensável ao seu ideal de Restauração (e como vimos, inseparável do desejo de retorno das denominações cristãs protestantes ao catolicismo).

Se a Rússia, portanto, ainda era a menos "europeia" entre as nações do continente, isto se devia à ausência da ascendência papal em seu desenvolvimento histórico. Cristianizada sob a égide do patriarca ortodoxo Fócio no século IX (quando ainda se chamava Reino de Kiev) e sofrendo, posteriormente, com a dominação dos tártaros (entre os séculos XIII e XV), a civilização russa fora cortada pela raiz do princípio civilizatório católico, de modo que a retomada de sua civilização coincidiu com a época da corrupta Regência francesa e os ataques à religião revelada (e ao catolicismo em especial). Lamentando que a Rússia tivesse sido cristianizada pelos "miseráveis gregos do Baixo-Império, detestáveis sofistas, prodígios do orgulho e de nulidade", Maistre concluía novamente que não havia outro caminho para a Rússia ascender "ao nível da civilização e da ciência europeia" a não ser por meio de Roma. ${ }^{201}$

Neste sentido, o quarto e último livro de Du Pape (composto de 11 capítulos, também foi o último a ser redigido) pode ser visto sob o duplo prisma de uma refutação às teses de Stourdza (ou melhor, um tratado de anti-Stourdza, conforme ele próprio confessou numa missiva de 1817$)^{202}$ e uma condenação racionalista à pietista e sentimental política czarista da Santa Aliança.

Pois além de o projeto de modernização-conservadora aristocrático-tarista de Stourdza para a Rússia chocar-se frontalmente com a proposta pedagógica conservadora-jesuítica de Maistre - a qual, inspirada na tradição pedagógica clericalhumanista do Antigo Regime e na contramão da atitude acrítica e submissa dos ortodoxos taristas em relação ao czar $^{203}$, pressupunha a plena autonomia das instituições educacionais administradas pela Igreja em relação ao Estado (de modo que os escritos pedagógicos russos sustentavam a promoção e a proteção da ordem jesuíta pelo império

\footnotetext{
${ }^{201}$ J. de Maistre, Du Pape, Livro III, cap. 6.

202 J. de Maistre, O.C., XIV: 212.

203 O qual, influenciado pelas ideias ilustradas e cientificistas de Speransky e pelo pietismo germânico de Stourdza e de sua irmã Roksandra, tornou-se favorável a um currículo escolar centralizado pelo Estado e baseado na epistemologia cientificista da Ilustração (na promoção da qual, o Estado russo deveria intensificar a importação de professores protestantes alemães).
} 
russo, que não deveria interferir em sua grade curricular) - e de o apologista ortodoxo ter sido grandemente responsável pela expulsão dos jesuítas ${ }^{204}$ e do próprio embaixador sardo do império czarista (na primavera de 1817, devido às conversões de inúmeras princesas e condessas russas ao catolicismo pelo saboiano, como Sophie Swetchine) ${ }^{205}$, o mesmo revelou-se determinante para que o plano ultramontano (cosmopolita e racionalista) de um novo equilíbrio europeu de Maistre fosse frustrado no interior da Santa Aliança, e isto graças à ascendência que os irmãos Stourdza exerceram sobre o czar Alexander I durante aquele processo.

Paradoxalmente, conforme observou Carolina Armenteros em seu recente e original estudo sobre Maistre, o próprio saboiano colaborou indireta e involuntariamente para este desfecho, uma vez que foi por sua decisiva iniciativa que a irmã de Stourdza (a ortodoxa não-tradicional Roksandra) tornou-se a dama de honra da imperatriz russa e, a partir disso, logrou converter o czar às ideias místicas da pietista russo-germânica Juliane de Krüdener (1764-1824), que determinaram a política imperial russa durante toda a vigência da Santa Aliança. ${ }^{206}$

Inicialmente favorável ${ }^{207}$ àquela coalizão contrarrevolucionária fortemente marcada pela orientação iluminista-pietista entre os soberanos (que se incumbiram da tarefa de preservar a "indissolúvel fraternidade" da "mesma e única nação Cristã" e, se necessário, prestar auxílio mútuo na repressão das revoltas internas) - como os escritos pedagógicos russos comprovam, Maistre chegou a observar com simpatia aquele pietismo iluminista de orientação germano-maçônica, uma vez que, segundo ele, "preparava todos os homens ao catolicismo, eliminando o ódio das seitas" ${ }^{208}$-, Maistre mudou radicalmente de opinião após os eventos que culminaram na expulsão dos jesuítas e, mormente, depois de ler, no início de 1817, as Considérations de Stourdza. Por volta de 1818, ano em que escreveu a Lettre à Monsieur le marquis... sur l'état du christianisme en Europe (a qual, publicada em maio de 1819, tratava-se de uma mensagem cifrada endereçada ao czar) -, o ultramontano saboiano desesperava ao constatar que a Santa Aliança (da França galicana à Rússia ortodoxa e filoprotestante)

${ }^{204}$ Entre dezembro de 1815 e início de 1816, em resposta à pressão dos poderosos aristocratas feudais taristas, cujos zelo nacionalista e hostilidade em relação aos jesuítas (vistos como corruptores "poloneses" ou "franceses" dos valores eslavos e ortodoxos) só aumentaram desde a retomada da guerra contra Napoleão (1812) e a oposição jesuítica às reformas educacionais de Speransky.

${ }^{205}$ R. Lebrun, Joseph de Maistre: An Intellectual Militant, p. 223.

${ }^{206}$ C. Armenteros, The French Idea of History: Joseph de Maistre and his Heirs 1794-1854, p. 149.

${ }^{207}$ Em 1816, quando seu soberano Vittorio Emanuele foi convidado a assinar o documento, o então embaixador saboiano da corte czarista aconselhou-o a fazê-lo.

208 J. de Maistre, O.C., XIII: 291. 
esforçava-se por consolidar todas as seitas e restringir o catolicismo em seus domínios, principalmente a Rússia czarista tomada por um renovado zelo ortodoxo eivado de pietismo protestante (especialmente na sua condenação virulenta ao catolicismo). ${ }^{209}$

Portanto, o quarto livro, como indica o título de seu capítulo inicial, busca demonstrar, com base no testemunho recente oferecido pelos russos, que a "cismática" igreja ortodoxa não apenas não se diferenciava das demais "seitas" protestantes, como guardava estreitas afinidades com as mesmas, sobretudo o ódio comum pelo catolicismo (segundo Maistre, o suficiente para que ambos, ortodoxos e protestantes, estabelecessem relações de fraternidade entre si, a despeito das diferenças dogmáticas que deveriam afastá-los). Como se lê ao término do primeiro capítulo, "o ensinamento" (discursivo-racional filoprotestante) "não inspirando nenhum tipo de alarme na Rússia, e o mesmo império abrigando perto de três milhões de súditos protestantes, os inovadores de todos os gêneros souberam tirar proveito dessa vantagem para insinuar livremente suas opiniões em todas as ordens no Estado", de modo que "tudo se reduz ao julgamento particular e à supremacia civil, que constituem a essência do protestantismo", e "todos estão de acordo, mesmo sem sabê-lo; pois todos protestam contra a Santa-Sé, o que basta à fraternidade comum". ${ }^{210}$

Tamanho foi o efeito da leitura do livro de Stourdza e dos eventos que culminaram na expulsão dos jesuítas e na perseguição extraoficial ao catolicismo (quando o mote apologético dos taristas gravitava em torno da tolerância ortodoxa em oposição à "tirania" e "corrupção temporal" católicas) sobre Maistre, que o mesmo preferia ver a completa absorção da igreja russa no protestantismo ${ }^{211}$ - uma vez que os protestantes, durante a emigração, deram inúmeras demonstrações de aproximação e tolerância para com o clero católico ${ }^{212}$ - a vê-la conservada no "âmbar" otomano como "um inseto" (numa clara resposta aos argumentos de Stourdza relativos à pureza doutrinal da igreja ortodoxa promovida pela "providencial" dominação muçulmana, responsável por afastar o cristianismo grego do contágio temporal romano e purificá-lo dos erros bizantinos). ${ }^{213}$

209 J. de Maistre, Lettre à Monsieur le marquis... sur l'état du christianisme en Europe O.C., VIII:512.

${ }^{210}$ J. de Maistre, Du Pape, Livro IV, cap. 1.

${ }^{211}$ Vista por ele como inevitável, especialmente pela epistemologia ilustrada ou científica veiculada pelos professores alemães, "uma espécie de ácido que dissolve todos os metais, exceto o ouro" católico. Cf. J. de Maistre, Du Pape, Livro IV, cap. 1.

${ }^{212}$ Idem, Livro IV, cap. 2.

213 J. de Maistre, Du Pape, Livro IV, cap. 3. 
Longe de a tão exultada "invariabilidade dos dogmas escritos, das fórmulas nacionais, das mitras, das vestes, dos crucifixos, das genuflexões, etc..." configurar um sinal de vitalidade do rito ortodoxo, ela antes confirmava a debilidade e a petrificação do mesmo, pois, adverte Maistre, se "César e Cícero" pudessem ressuscitar, eles certamente não se vestiriam com a antiga toga. ${ }^{214}$ Por outro lado - e numa clara demonstração de que o providencialismo maistreano subsumia um sentido moderno da História -, a execrada transformação sofrida pelo catolicismo em "algumas" de suas "formas exteriores" representaria "um signo indispensável da vida" e uma prova de seu caráter divino (que logrou resistir aos inúmeros "ataques" e provações" ao longo da história). Se o catolicismo mudou através dos tempos, "é porque vive", "e tudo o que vive no universo, muda de acordo com as circunstâncias", razão pela qual a "imobilidade absoluta não pertence senão à morte". ${ }^{215}$

No melhor estilo que levaria o crítico literário e teólogo protestante Edmond Schérer (1815-1889) a tratá-lo como um "Voltaire às avessas", Maistre avançou uma comparação orgânica plena de consequências para a futura estética romântica (como a de Baudelaire ${ }^{216}$ ), e a qual, fazendo o melhor uso da ferramenta oratória da vituperação, comparou a igreja ortodoxa russa a um grande corpo em putrefação que atrai uma imensidão de "insetos religiosos que arrastam sobre o mesmo solo os restos de uma vida dividida, imperfeita e repugnante". ${ }^{217}$

E uma vez que a defesa da igreja ortodoxa era inseparável do movimento de independência grego patrocinado na corte russa pelos ortodoxos Stourdza e Capodistrias, era natural que a crítica maistreana à Igreja ortodoxa russa ricocheteasse nas diversas esferas da cultura grega, que não poupou nem mesmo o admirado Platão: "grande, sublime, penetrante" no momento em que assumia a condição de "teólogo" (qualidade esta que Maistre, à guisa de Clemente de Alexandria e dos neoplatônicos cristãos Ficino e Pico, atribuía ao contato do filósofo com os hebreus), era apenas um sofista quando tratava dos demais assuntos. ${ }^{218}$

${ }^{214}$ J. de Maistre, Du Pape, Livro IV, cap. 4.

${ }^{215}$ Idem, Livro IV, cap. 3.

216 Daniel Vouga, Baudelaire et Joseph de Maistre: Essai (Paris: José Corti, 1957); Antoine Compagnon, Les antimodernes: de Joseph de Maistre à Roland Barthes (Paris: Gallimard, 2005), especialmente o capítulo 6.

217 J. de Maistre, Du Pape, Livro IV, cap. 3.

218 J. de Maistre, Du Pape, Livro IV, cap. 7. 
Distintos entre todos os povos por sua "inaptidão a toda grande associação política e moral"219, os gregos (exceção feita à teocrática "Lacedemônia") mostraram-se divididos e ferozes ao longo da história, especialmente Atenas, cujos excessos levaramna a banir ou condenar à morte "Miltíades, Temístocles, Aristides, Címon, Timóteo, Fócio e Sócrates". 220

Nos quadros da Restauração e da Santa Aliança, a inesperada e nova perseguição sofrida pelo clero católico na Rússia ortodoxa - e num momento em que todos os autores concordavam em dizer que a emigração do clero durante a Revolução Francesa produzira uma inédita reaproximação entre Roma e a Europa protestante -, seguida do novo impulso místico e personalista de um autocrático czar (que passou a se imaginar como o "patriarca" de fato não só da Rússia, mas do cristianismo), levaram Maistre a prognosticar (poder-se-ia dizer, profetizar) um futuro de dilacerações e violência para os czares, a formação, dentro de um curto espaço de tempo, de uma intelligentsia revolucionária (através do espinozismo panteísta e do kantismo trazido pelos professores protestantes alemães ${ }^{221}$ ) e, por fim, uma Revolução muito mais radical do que a francesa. Pois "se os russos, que têm certa tendência a levar tudo na brincadeira (não quero dizer com isso que zombem de tudo), brincarem também com essa serpente [Ilustração], nenhum povo terá sido mais cruelmente picado por ela". 222

Fundamentalmente, Du Pape expressa a preocupação cosmopolita e pacifistaracionalista de Maistre com os destinos da Europa pós-napoleônica, segundo ele marcada pela conjunção explosiva de três elementos, respectivamente o militarismo, o nacionalismo e, na esteira deste, o crescente e irracional individualismo (a seu ver, de origem protestante) autocrático dos soberanos. ${ }^{223}$

Assim, por mais que a utopia ultramontana maistreana tenha sido o mais das vezes apreendida numa chave de leitura mais conservadora que a do próprio Maistre (sobretudo após fevereiro de 1848) e, por conseguinte, desperte alguns choques em

${ }^{219}$ J. de Maistre, Du Pape, Livro IV, cap. 9.

${ }^{220}$ Idem, Livro IV, cap. 8.

${ }^{221}$ Vide: C. Armenteros, "Preparing the Russian Revolution: Maistre and Uvarov on the History of Knowledge", in: C. Armenteros e R. Lebrun (ogs.), Joseph de Maistre and his European Readers: from Friedrich von Gentz to Isaiah Berlin (Leiden: Brill, 2011), p. 213-248.

222 J. de Maistre, O.C., VIII:354.

223 Ao lado das Considerações sobre a França (com 40 edições), Du Pape é uma das obras mais influentes e publicadas de Maistre, com 42 edições francesas (das quais 34 só no século XIX) e traduções para o português (em 1845, lavrada por Francisco Candido de Mendonça e Mello sob encomenda da "Bibliotheca da religião catholica"), espanhol (a primeira de 1819), inglês (desde 1850), italiano (desde 1822) e alemão (a primeira delas, em 1822). Para maiores detalhes sobre a fortuna editorial das obras do saboiano, leia-se: Alain de Benoist, Bibliographie générale des droites françaises (Paris: Dualpha, 2005), cap. I. 
nossas suscetibilidades modernas, não há como negar que a obra também poderia ser lida numa chave mais progressista (como de fato ocorreu, através de autores como Lamennais, Philippe Buchez, Pierre-Joseph Proudhon, Saint-Simon, e dos saintsimonianos e socialistas católicos, de Saint-Amand Bazard a Gabriel-Désiré Laverdant e Prosper Barthélémy Enfantin) ${ }^{224}$, uma vez que avançava não apenas um mecanismo político internacionalista (os Anfictiões reunindo os Estados europeus sob a liderança do Papa, cujos detalhes de funcionamento e organização Maistre não forneceu) e racional de controle daquelas poderosas forças que ameaçariam a civilização europeia (e mundial), como um recurso libertário para a autodeterminação dos povos contra o imperialismo (arrestando, porém, seu potencial revolucionário) e, em última análise, uma defesa das respectivas sociedades civis contra a tirania dos soberanos. Sobre este último aspecto, Maistre não manifestara sua surpresa diante do que julgava ser uma profunda incoerência do entusiasmo constitucionalista-liberal de seu tempo, que consistia em pregar (com justiça, admitia) a divisão e a limitação do poder temporal, ao mesmo tempo em que solicitava a redução ou supressão da autonomia da esfera espiritual perante o mesmo? ? $25^{25}$

Com efeito, Maistre era mais "liberal" do que muitos de seus coetâneos ultramontanos franceses (vistos por ele como politicamente irresponsáveis), mas, ao fim e ao cabo, sua obra era lida como um endosso às teses desses "zelotes" da legitimidade religiosa. Apesar dos elogios de Bonald, Chateaubriand, Lamennais, e até de Lamartine, a obra exerceu pouco impacto no momento de sua publicação. A última coisa que a monarquia francesa queria em 1820 era a divulgação de opiniões ultramontanas contra seus aliados galicanos. Do mesmo modo, um recentemente restaurado papado não poderia ofender as suscetibilidades galicanas e, mormente, ortodoxas do czar no contexto da Santa Aliança, razão pela qual aprovou tacitamente o livro de Maistre (como as missivas entre Maistre e o cardeal Consalvi, secretário-geral do Vaticano, demontram), embora negando-se a aprovar uma dedicatória maistreana ao papa escrita em latim para a segunda edição da obra. ${ }^{226}$

Contudo, em meados dos anos 1840, especialmente após fevereiro de 1848, a popularidade de Du Pape alcançou seu pico: ajudou - sobretudo através do jornalista ultramontano Louis Veuillot (1813-1883) - a conquistar a burguesia orleanista e

\footnotetext{
${ }^{224}$ C. Armenteros, The French Idea of History: Joseph de Maistre and his Heirs 1794-1854, cap. 8.

225 J. de Maistre, Du Pape, Livro II, cap. 4.

${ }^{226}$ R. Lebrun, Joseph de Maistre: an Intellectual Militant, p. 241.
} 
"preparar a opinião católica francesa a aceitar a declaração da infalibilidade papal do Concílio do Vaticano I [1870]”, sendo decisivo para a erradicação do galicanismo como força política na França. ${ }^{227}$

Também por esta razão, como bem sublinhou o historiador e político liberal inglês G. P. Gooch, Du Pape deve ser lido como o "testamento político" de Maistre, "figurando entre os clássicos da filosofia política e social como os trabalhos de Burke e Locke, Rousseau e Marx, todos os quais, designados para alterar a perspectiva da Europa, influenciaram profundamente o curso da história".228

${ }^{227}$ R. Lebrun, Joseph de Maistre: an Intellectual Militant, p. 242-245.

${ }^{228}$ G.P.Gooch, French Profiles: Prophets and Pioneers (London: Longmans, 1961), p. 175-6. 


\section{CAPÍTULO 9}

\section{"À sua imagem e semelhança" : humanismo e providencialismo maistreanos em face da Ilustração e da Revolução}

9. 1. Humano, demasiado divino: visão maistreana sobre a dignidade humana

Quando a atenção do historiador se dirige para o estudo do humanismo italiano, a primeira ideia que lhe ocorre, como que por reflexo, é a famosa epístola de Francesco Petrarca (1304-1374) referente à escalada ao monte Ventoux, e a qual, composta em 1336, resume o ethos por trás de toda a sua investigação humanista. Publicada no Familiari (compêndio de 350 epístolas subdividido em 24 livros e redigido entre 13501360), a carta reproduzia a seguinte passagem das Confissões (X. 8. 15) de santo Agostinho:

"Chamo a Deus por testemunha, e ele que estava presente, as primeiras palavras que vi foram: 'Vão os homens a admirar os altos dos montes, os grandes fluxos dos mares, os largos leitos dos rios, a imensidão do oceano e o curso das estrelas, deixando de lado a si mesmos'. Fiquei estupefato, confesso [...], desejoso de continuar a escutar-me [...], fechei o livro, irado comigo mesmo por aquela admiração das coisas terrenas, quando poderia ter aprendido mesmo com os filósofos pagãos que nada é digno de admiração senão a alma, para a qual nada é grande em demasia." 2

Pouco antes de morrer, mais especificamente no De ignorantia (1371), mais do que um valioso testemunho sobre a inquietude de sua alma, o humanista aretino

\footnotetext{
${ }^{1}$ A inspiração para o título foi obtida da obra homônima de Charles Trinkaus sobre o humanismo italiano, In our Image and Likeness: Humanity and Divinity in Italian Humanist Thought (Indiana: University of Notre Dame Press, 1995), 2 volumes, $1^{\text {a }}$ edição em 1970.

2 Citado em P. O. Kristeller, Renaissance Thought and its Sources (New York: Columbia University Press, 1979), p. 171.
} 
ofereceu uma orientação clara sobre qual deveria ser finalidade dos estudos humanísticos quando disse que o conhecimento humano sobre a natureza e as coisas era algo secundário ante a questão primordial, a saber, a investigação sobre a natureza e o destino do homem. ${ }^{3}$

A partir do exemplo de Petrarca, Kristeller criticou a tradicional distinção estabelecida pela historiografia entre a Idade Média e o Humanismo, e a qual, singularmente expressa na obra de Étienne Gilson (1884-1978) ${ }^{4}$, opunha um período centrado em Deus a outro laicizado e centrado no homem. Embora concordasse que o Renascimento, ao fim e ao cabo, representara um momento de maior secularismo, Kristeller advertia que isto não implicava em um total abandono das ideias religiosas, pelo contrário. Segundo ele, problemas como o destino e/ou predestinação e o livrearbítrio do homem não foram menos tratados no Renascimento do que na Reforma, seu indelével desdobramento. ${ }^{5}$

Com base nesta crítica pontual de Kristeller, gostaríamos de sugerir uma abordagem semelhante para a compreensão do pensamento de Maistre, especialmente na relação que o mesmo estabeleceu entre a Providência divina e o homem no seu célebre panfleto termidoriano contra a Revolução Francesa - as Considerações sobre a França -, mas neste caso para ilustrar o ethos humanista que orientou e permeou a sua leitura providencialista do fenômeno revolucionário.

Como bem pontuou Élcio Verçosa Filho, Maistre está longe de ser lido, mesmo por seus admiradores mais fervorosos, como um humanista; pelo contrário, sua imagem é frequentemente associada pelos historiadores das ideias e filósofos como um violento crítico da humanidade, quando não um de seus piores inimigos. ${ }^{6}$ Todavia, o fato de o interesse de Maistre pelo homem ir de encontro com nossas acepções antropológicas e históricas herdeiras da Ilustração - o que, de certo modo, justifica essa imagem - não invalida o fato de que o conhecimento do e sobre o homem ocupou uma posição central na multiforme e vasta produção do contrarrevolucionário saboiano. De acordo com esse estudioso, "se nos esforçarmos em ver as coisas a partir de sua própria perspectiva, se investigarmos os princípios sobre os quais esta perspectiva é fundada e, portanto, nos quais ele baseou seu próprio interesse pelo homem, só nos resta desafiar a visão aceita,

\footnotetext{
${ }^{3}$ P. O. Kristeller, Renaissance Thought and its Sources, p. 171.

${ }^{4}$ E. Gilson, Les idées et les lettres, $2^{\mathrm{a}}$ edição, (Paris: 1955), p. 192.

${ }^{5}$ P. O. Kristeller, Renaissance Thought and its Sources, p. 168.

${ }^{6}$ Vide, por exemplo, I. Berlin. "De Maistre e as origens do fascismo", in: Limites da Utopia. Capítulos da história das idéias (São Paulo: Companhia das Letras, 1991) e E.M. Cioran, "Joseph de Maistre: Essai sur la pensée réactionnaire" (1957), in: Exercices d'admiration (Paris: Gallimard, 1986).
} 
não podemos senão alcançar um entendimento totalmente diferente da própria definição de humanismo (ou preocupação com ou pelo homem), assim como de uma apreciação mais justa da imensidão dos recursos intelectuais mobilizados por Maistre no desenvolvimento de princípios que culminam numa grandiosa visão do homem e de seu mundo." ${ }^{7}$

E quando o tema em questão é o providencialismo maistreano, se levarmos em conta as principais obras publicadas do contrarrevolucionário saboiano sobre o tema na ordem, Discours à Mme Costa (1794), Considerações sobre a França (1797), Sur les Délais de la Providence Divine $(1816)^{8}$, Les Soirées de Saint-Pétersbourg (1821) e Éclaircissement sur les sacrifices (1821) -, as referências a Platão (429 a.C.- 347 a.C.), Plutarco (45 d.C.-120 d.C.), santo Agostinho (354 d.C.-430 d.C.), Luís de Molina (1535-1600), Pierre Charron (1541-1603), Pascal (1623-1662) e Bossuet (1627-1704) saltam à vista do estudioso. Mas em que pese a importância desses autores na formação e no desenvolvimento das ideias de Maistre, o fato é que não só o providencialismo, como, fundamentalmente, a visão sobre o homem (isto é, sobre a sua origem e o seu destino) do saboiano assumiram a forma que conhecemos graças à leitura do filósofo neoplatônico patrístico Orígenes (185 d.C.-254 d.C.). Pois se o contrarrevolucionário saboiano não extraiu sua visão providencialista da história única e exclusivamente a partir da assimilação das ideias do teólogo alexandrino, é certo que foi a partir da leitura do mesmo que o providencialismo maistreano adquiriu maior extensão e profundidade.

Identificada desde os estudos de P. Goureux e Paul Vulliaud sobre o contrarrevolucionário saboiano ${ }^{9}$, esta filiação levou dois importantes estudiosos sobre Maistre, respectivamente o biógrafo Robert Triomphe e o filósofo Jean-Yves Pranchère, a associarem esta marcante presença de Orígenes no providencialismo maistreano como um signo da heterodoxia religiosa do último. Assim, se para o biógrafo excessivamente crítico, mas que teve o mérito de destacar esta herança intelectual ${ }^{10}$ - os

\footnotetext{
${ }^{7}$ Élcio Verçosa Filho, "The pedagogical nature of Maistre's thought", in: C. Armenteros e R. Lebrun (orgs.), Joseph de Maistre and the legacy of Enlightenment (Oxford: Voltaire Foundation, 2011), p. 192. Sobre a necessidade de o estudioso sobre Maistre tentar apreendê-lo em seus próprios termos (isto é, teológicos), sob pena de incorrer em graves desvios de interpretação, vide Jérôme Alexandre, "Joseph de Maistre et le peché originel", in: Valère Novarina, Michael Kohlhauer e Pierre Caran (orgs.), Rencontres autour de Joseph de Maistre (Thonon-les-Bains: Université de Savoie, 2009), p. 81-82.

${ }^{8}$ Tradução do original grego da obra de Plutarco.

${ }^{9}$ P. Goreux, "La philosophie de Joseph de Maistre", in: Nouvelle Revue Théologique, tomo LIII (1926), p. 353; P. Vulliaud, Joseph de Maistre Franc-Maçon (Paris: Nourrit, 1926), p. 35.

${ }^{10}$ Antipatia expressa já no título de sua obra, na qual adjetiva o saboiano como um "materialista místico". Não sabemos dizer se isto é mais grave do ponto de vista da análise epistemológica (pois todo pensamento de Maistre vai na direção contrária, do espiritualismo e religiosidade) ou da análise objetiva
} 
estudos de Orígenes serviam menos a propósitos religiosos do que a práticas ocultistas e gnósticas de Maistre, para o filósofo mais contemporâneo, as constantes referências a Orígenes e Pascal, somadas às poucas referências a são Tomás de Aquino e a santo Agostinho nas Considerações, seriam uma prova de que o catolicismo de Maistre não repousaria sobre boas autoridades. ${ }^{11}$ Na contramão de Triomphe e Pranchère, autores como Pierre Vallin, Marc Froidefont e Élcio Verçosa não apenas destacaram a importância deste parentesco intelectual para a original criação teológica maistreana (sobretudo a expressa nas Soirées de Saint-Pétersbourg), como mostraram sua plena conformidade seja em relação com a tradição judaico-cristã, seja em relação à ortodoxia católica moderna (pós-Vaticano II). ${ }^{12}$

Com efeito, não é possível falar de Orígenes sem mencionar o caráter controverso de sua doutrina, sobretudo após a mesma receber severas críticas de santo Agostinho nas refutações que o bispo de Hipona e seus seguidores dirigiram às teses de Pelágio (350 d.C. - 423 d.C.). ${ }^{13}$ Incorretamente associado às doutrinas pelagianas, o origenismo seria condenado pelo controverso II Concílio de Constantinopla (553 d.C.) menos em função das ideias de seu autor do que pelas ideias a ele atribuídas por seus sucessores tais como a preexistência das almas, a apresentação dos astros como seres vivos, etc. -,

da vida (pois não vemos sob qual ótica é possível atribuir semelhante desígnio ao único senador da alta magistratura da Saboia invadida que renunciou ao convite feito pelos revolucionários franceses de permanecer no cargo - e, consequentemente, a manter seus bens - e que sempre viu sua ascensão política no reino sardo-piemontês prejudicada pela excessiva franqueza com que emitia opiniões tidas como moderadas e liberais pela corte piemontesa, a ponto de bater de frente com seus superiores diretos e, no caso específico da Sardenha, desentender-se pessoalmente com o regente Charles Felix, irmão do seu soberano da Casa da Saboia?) do biografado. Para maiores detalhes, leia-se nossa dissertação de mestrado, As 'Considerações sobre a França' de Joseph de Maistre: revisão (historiográfica) e Tradução (São Paulo: FFLCH-USP, 2009).

${ }^{11}$ Cf. Robert Triomphe, Joseph de Maistre: Étude sur la vie et la doctrine d'un matérialiste mystique (Genève: Droz, 1968), especialmente as páginas 438-447; Jean-Yves Pranchère, L'autorité contre les Lumières: la philosophie de Joseph de Maistre (Genève: Droz, 2004), p. 105. Cabe salientar que a afirmação de Pranchère é apenas parcialmente válida e, mesmo assim, somente quanto às Considerações, que, não podemos jamais perder de vista, eram um panfleto e, como tal, foi designado com vistas a uma intervenção específica (o providencialismo foi a arma escolhida por Maistre para refutar as teses pró-republicanas de Benjamin Constant, que associavam o retorno da Monarquia nas eleições de 1797 ao Terror branco). Pois no que concerne à grande obra teológica de Maistre - e à qual ele se dedicou por mais de uma década -, as Soirées de Saint-Pétersbourg (1821), existem provas mais do que eloquentes do conhecimento e uso das teologias de santo Agostinho e são Tomás para refutar o que avançou peremptoriamente Pranchère. Vide: Jean-Louis Darcel, "Les Bibliothèques de J. de Maistre", Revue des Études Maistriennes, $\mathrm{n}^{\circ} 9$ (1985), p. 38; Agnès Guilland, "L'Érudition de Joseph de Maistre dans les Soirées de Saint-Pétersbourg", Revue des Études Maistriennes, ${ }^{\circ} 13$ (2001), p. 168-169 e p. 231-232; Marc Froidefont, Théologie de Joseph de Maistre (Paris: Garnier, 2010).

${ }_{12}$ Pierre Vallin, "Les Soirées de Joseph de Maistre. Une création théologique originale", in: Recherches de sciences religieuses, tomo 74, $\mathrm{n}^{\mathrm{O}} 3$ (julho - setembro 1986), p. 360; Marc Froidefont, Théologie de Joseph de Maistre (Paris: Classiques Garnier, 2010), p. 427-434; Élcio Verçosa Filho, "The pedagogical nature of Maistre's thought", p. 191-219.

${ }^{13}$ Thomas P. Scheck, Origen and the History of Justification: the Legacy of Origen's commentary on Romans (Indiana: University of Notre Dame Press, 2008), capítulo 3. 
embora importe destacar que esta condenação não levou em conta a obediência expressa do teólogo alexandrino perante a autoridade da Igreja, assim como a clara distinção que ele sempre estabeleceu entre a pregação eclesiástica e a apostólica (a única doutrinalmente válida) em suas obras.

Apesar de estimado por grandes nomes da Idade Média, como são Abelardo (1070-1142) e Dante (1265-1321), o efetivo processo de reabilitação de Orígenes teve início apenas no século $\mathrm{XV}$, mais especificamente no quadro da crise relativa ao prolongado cisma do Ocidente, e o qual levou importantes humanistas, tais como Pico della Mirandola (1463-1494) e, já após a Reforma, Erasmo (1566-1536) - igualmente preocupados em vincular a dignidade humana à sua liberdade na ordem cósmica ordenada por Deus -, a se interessarem por suas obras. ${ }^{14}$ Antes deles, em 1481, Cristoforo Persona (1416-1485) traduzira a principal obra apologética de Orígenes, Contra Celsum (248 d.C.), a qual, dedicada ao papa Sixto IV, representou a primeira tradução latina da mesma desde a empreendida por Rufino, no quinto século da era cristã.

No século XVII, coube ao jesuíta Pierre Haloix, em seu Origenes defensus (1648), contestar definitivamente a validade do $\mathrm{V}$ concílio ecumênico que condenou o teólogo alexandrino, assim como, no século seguinte, faria o renomado crítico de Voltaire, o padre Claude-Adrien Nonotte (1711-1793) em seu Philosophes des trois premiers siècles de l'Église (1789).

E se não encontramos referências a Nonotte seja no catálogo das impressionantes bibliotecas maistreanas ${ }^{15}$, seja em suas anotações ou obras publicadas, não podemos imaginar que uma figura igualmente devota e bem informada sobre os principais debates filosófico-políticos de seu tempo possa ter passado ao largo dos escritos apologéticos de Nonotte, mormente de suas críticas a Voltaire - que ele, Maistre,

${ }^{14}$ Pico assumiu a defesa de Orígenes e de sua teoria da justificação em seu De salute Origenis disputatio (1486) e nas 900 teses (sendo a vigésima primeira dedicada a observar que muitas das teses atribuídas ao alexandrino, e que foram condenadas pelo $\mathrm{V}$ concílio ecumênico, eram, na verdade, obra de comentadores e falsários); Erasmo, admirador da exegese e da filologia origenianas (sobretudo no que dizia respeito à interpretação alegórica da Bíblia e da validade de se estudar os clássicos pagãos), publicou uma edição latina das obras completas de Orígenes, em 1536. Sobre a influência de Orígenes em Erasmo, vide A. Godin, Érasme, lecteur d'Origène (Genève: Droz, 1982) e Rui L. Rodrigues, Entre o dito e o maldito: Humanismo erasmiano, ortodoxia e heresia nos processos de confessionalização do Ocidente 1530-1685 (São Paulo: tese de doutorado em História apresentado à Faculdade de Filosofia, Letras e Ciências Humanas da USP, 2012). Sabemos que Lutero, Calvino e, sobretudo, Melanchthon, não apenas não ignoraram, como foram críticos à teologia do alexandrino, o mesmo se aplicando, no interior do campo católico, para o agostiniano Cornelius Jansen. Leia-se: T. P. Scheck, Origen and the theory of Justification: the lagacy of Origen's commentary on Romans (Indiana: Notre Dame, 2008).

${ }^{15}$ Publicadas por Jean-Louis Darcel em "Catalogue de la Bibliothèque de Joseph de Maistre", in Révue des Études Maistrienes, $\mathrm{n}^{\circ} 1,1975$. 
posteriormente veria como o principal responsável pela Revolução Francesa, ao lado de Rousseau $^{16}$ : o primeiro por corromper a aristocracia, o segundo, o homem comum. ${ }^{17}$

Por sua vez, coube a um apologista ainda mais renomado e autor do Dictionnaire Théologique (1788-1790, em 4 volumes), o abbé Nicolas-Sylvestre Bergier (1718-1790) - a quem Maistre se referiu como um "teólogo sábio e profundo" ${ }^{18}$-, defender Orígenes dos ataques que ele sofria não só dos teólogos protestantes mas também, e sobretudo, dos philosophes, em especial de Voltaire, que o responsabilizava por ter colocado a pedra angular da "metafísica quimérica" católica, tão "inútil à moral" quanto fonte de inúmeras discórdias. ${ }^{19}$

Portanto, na época de Maistre, e apesar das controvérsias, Orígenes era geralmente visto como um autor válido para os cristãos num momento de maior refluxo da autoridade da Igreja (e, portanto, da ortodoxia) após o Concílio de Trento, bem como de pleno ataque dos philosophes na esfera pública, e isto principalmente em razão de sua apologética contra o filósofo epicurista romano Celso, um crítico acerbo do cristianismo e, sobretudo, da Providência divina conforme retratada na tradição veterotestamentária (tida por ele como cruel e vingativa). Referindo-se ao Contra Celso de Orígenes, Nonotte sublinhou que "jamais o cristianismo triunfou com maior glória contra a incredulidade, a impiedade e a libertinagem, do que por este trabalho de Orígenes". $^{20}$

E de Orígenes, Maistre herda sobretudo a ideia de que o homem, apesar do pecado original (que o alexandrino, diferentemente do que faria Pelágio, admitia plenamente),

\footnotetext{
16 "No fundo, a glória de ter feito a Revolução não pertence exclusivamente nem a Voltaire nem a Rousseau. Toda a seita filosófica reivindica sua parte; mas é justo considerá-los como os corifeus: um solapou a política ao corromper a moral; o outro, [solapou] a moral ao corromper a política. Os escritos corrosivos de Voltaire corroeram durante sessenta anos o cimento cristianíssimo deste soberbo edifício cuja queda abalou toda a Europa. [E] Coube a Rousseau, com sua eloquência arrasadora, seduzir a multidão, sobre quem a imaginação tem mais poder que a razão. Ele soprou por toda parte o desprezo pela autoridade e o espírito de insurreição. Foi ele quem traçou o código da anarquia e que, em meio a algumas verdades estéreis e isoladas que todo mundo sabia antes dele, avançou os princípios desastrosos dos quais os horrores que vimos foram apenas as consequências imediatas. Ambos foram levados solenemente ao Panteão em virtude de um decreto da Convenção Nacional, que assim condenou sua memória ao último suplício." Cf. Joseph de Maistre, De la souveraineté du peuple, Livro I, cap. 12.

17 Sobre Nonotte e apologética cristã na cultura francesa da Ilustração, leia-se o imprescindível livro de Robert R. Palmer, Catholics and Unbelievers in Eighteenth Century France (Princeton: Princeton University Press, 1939), p. 89 e seguintes.

18 Joseph de Maistre, Essai sur le principe générateur (O.C., I: 237).

${ }^{19}$ Voltaire, Philosophie générale, Tomo II, in: Oeuvres complètes (Paris: E. A. Lequien, 1821), vol. XXXIV, p. 117. Em seu Essai sur le principe générateur des constitutions politiques (1809), Maistre citou o poeta italiano Giuseppe Parini (1729-1799) que, em seu poema Il Mattino (1763) parodiou Dante para mostrar Voltaire como um anti-Virgílio de sua geração: ao invés de "Maestro di color che sanno", Voltaire seria o "(...) Maestro di coloro che credon di saper". Cf. Joseph de Maistre, Essai sur le principe générateur, in: P. Glaudes (org.), Joseph de Maistre: Oeuvres (Paris: Bouquins, 2007), p. 389.

${ }^{20}$ Nonotte, Philosophes des trois premiers siècles de l'Église (Paris: Crapart, 1792), p. 202.
} 
deve ser encarado como uma criatura privilegiada no plano da criação divina. Diante do rebaixamento promovido pelos filósofos das Luzes ao status ontológico do "homem" reduzido às considerações de caráter biológico e fisiológico ${ }^{21}$-, Maistre, no mesmo pathos com que Orígenes criticava o epicurista e materialista Celso pelo fato do último comparar o homem a um inseto, escreveria o seguinte sobre os "Celsos" de seu tempo em seu ensaio inédito Essai sur les Planètes (1799):

"Todos os caracteres ridículos que caracterizam a filosofia moderna podem ser distinguidos em suas contradições sobre a dignidade do homem. Quando se trata de armar o orgulho contra as verdades primitivas, nada se encontra acima desta grandeza, 'o homem é feito para a verdade; ele deve buscá-la por suas próprias forças: nenhum poder tem o direito de perturbar seu pensamento'. Descrevem detalhadamente seus conhecimentos e descobertas mais pomposas; fazem dele um deus: mas, se da verdadeira grandeza do homem alguém quiser extrair argumentos sobre a sua sorte futura, eles [filósofos] trocam subitamente as palavras e rebaixam o homem por todos os meios possíveis: não falam senão de sua ignorância, de seus excessos, de sua fraqueza, de seus ridículos, de modo que não passa de um animal, de um verme." $^{22}$

Em sua visão antropológica do homem - e a qual serviria de inspiração para importantes humanistas neoplatônicos durante o Renascimento (tais como Ficino, Pico della Mirandola e Erasmo) -, Orígenes sublinhou em diversas obras o trecho do livro do Gênesis (1: 26-27) que comunica ter sido o homem feito à imagem e semelhança de seu Criador, de modo a ilustrar a necessidade de que a humanidade se apropriasse dessa semelhança por seu próprio esforço. ${ }^{23}$ Criado segundo a imagem de Deus - de modo que apenas o Verbo ou Cristo são a própria imagem de Deus e compartilham de sua perfeição -, o homem, no entanto, só pode consumar a semelhança pelo "esforço de sua

${ }^{21}$ Razão pela qual Maistre prefere o termo "homem" aos termos "humanidade" ou gênero humano, justamente para evitar qualquer identidade entre seu humanismo com as acepções neutras eivadas de um ethos naturalista e biológico da Ilustração.

${ }^{22}$ Joseph de Maistre, Essai sur les Planètes (Venise, 1799), in: Registre de Lecture D, p. 653. Um pouco adiante no mesmo texto (o qual jamais foi publicado e se encontra nos Registros de Leitura de Maistre, custodiados pelos Arquivos Departamentais da Sabóia, na França), Maistre não deixa dúvidas quanto ao fato de que sua crítica fora inspirada em Orígenes, que criticou Celso por haver comparado a humanidade a um "inseto"(Essai sur les Planètes, p. 663).

${ }^{23}$ Notadamente em Contra Celso, Livro IV; Homilia sobre o Gênesis I, e no Tratado sobre os Princípios, III, 6. Sobre a influência do referido trecho bíblico no pensamento humanista do Renascimento, leia-se o excelente livro de Charles Trinkaus, In our image and Likeness: Humanity and Divinity in Italian Humanist Thought (Indiana: University of Notre Dame Press, 2012), vol. I, especialmente p. XXIII. 
própria operosidade na imitação de Deus", uma possibilidade inscrita na "dignidade da imagem em sua primeira criação". ${ }^{24}$

De acordo com o alexandrino, a causa do pecado original - e de suas reiterações na ordem do tempo - foi a "negligência" ou "desatenção" das almas com respeito à contemplação. O abandono progressivo da vida espiritual era interpretado como um abandono do movimento e do exercício da alma em direção a Deus, de modo que este otium negligente da alma, oposto à contemplação ou "exercício" da inteligência humana em direção ao bem supremo (Deus), era visto como a causa teológica da queda humana. 25

A liberdade de cada natureza espiritual, explica Orígenes no Tratado sobre os Princípios (220-230 d.C.), foi-lhe dada "seja para progredir na imitação de Deus" (via contemplação), "seja para regredir em razão de sua negligência." ${ }^{26}$ Diante da necessidade ontológica de perseguir indefinidamente o movimento em direção a Deus (por ser feito à imagem de Deus, deve buscar a semelhança), a alma reage com falta de amor e de desejo: resfriando-se na negligência, ela se materializa (poderíamos dizer, "reifica") e se afasta do seu verdadeiro destino, a inteligência divina. Assim, se o chamado amoroso da Providência é válido para todos, o mesmo não depende menos de uma ação contemplativa vigilante da parte dos homens.

Não por acaso, Maistre - que conhecia a obra do alexandrino e possuía uma edição da Origeniana (1668) do padre Pierre-Daniel Huet (1630-1721) - expressaria a mesma visão a respeito da dignidade humana: "O Homem-Deus" - uma definição comum de Cristo nos escritos de Orígenes e dos humanistas neoplatônicos florentinos Ficino e Pico - "chamou-nos de seus amigos, seus filhos e até de seus irmãos; e seus apóstolos não pararam de repetir para que fôssemos semelhantes a ele." 27

O recurso à teologia da imago Dei é um tema recorrente no humanismo de Maistre, o qual, assim como fizeram Ficino e Pico, também integrou Cristo numa

\footnotetext{
${ }^{24}$ Orígenes, Tratado sobre os Princípios, III, 6. 1; ou Manlio Simonetti (org.), I Principi (Torino: UTET, 2002), p. 463-464.

${ }^{25}$ Orígenes, Tratado sobre os Princípios, I. 6. 2.

${ }^{26}$ Orígenes, Tratado sobre os Princípios, II. 9. 6.

27 Joseph de Maistre, Soirées, IV Entretien (O.C., IV:201). Como observou Trinkaus a respeito do Heptaplus (1488-89) de Pico, o humanista florentino atribuía grande parte da dignidade humana à liberdade que Adão, por ser criado à imagem e semelhança de Deus, possuía, até mesmo para pecar. Perdida pelo pecado original, essa dignidade em termos de semelhança (e de liberdade) seria plenamente restaurada pela encarnação e sacrifício na cruz de Cristo ou Deus-Homem, o "verdadeiro mediador" entre o homem e Deus e através de quem "os homens podem se tornar filhos de Deus". Cf. Pico della Mirandola, Heptaplus, Livro VII, cap. 7 e Charles Trinkaus, In our image and Likeness: Humanity and Divinity in Italian Humanist Thought, op. cit., vol. II, p. 507, 522-523.
} 
leitura neoplatônica que o apresentava como um mediador entre o homem e Deus: "No Evangelho, aprendemos a chamar Deus de nosso pai a fim de que essa palavra familiar nos ensine que não estamos excessivamente afastados dele." ${ }^{28}$ Através da leitura e tradução de uma obra do igualmente neoplatônico Plutarco (45 d.C.-120 d.C.) - Sur les délais de la justice divine (Sobre as delongas da justiça divina, publicada em 1816) -, Maistre sintetiza a ideia platônica nos ensinamentos do Evangelho para demonstrar que o summum bonum do homem é a busca da assimilação em Deus ${ }^{29}$ : "Seguindo a doutrina de Platão, Deus se pôs, se nos for permitida a expressão, em meio às coisas para nos servir de modelo (...) pelo qual ele nos colocou em um estado de nos tornar de qualquer maneira semelhantes a ele."

Neste sentido, a proximidade da visão antropológica maistreana com a do humanista florentino e neoplatônico Marsilio Ficino (1433-1499) salta aos olhos, a despeito de encontrarmos uma única e breve referência ao mesmo em uma nota do segundo diálogo das Soirées.

Ficino, por exemplo, descreve a mente humana como um raio do Espírito divino que, após descender até a alma do homem pelo Amor do Criador à sua mais preciosa criatura, ascende novamente para Deus. Para o neoplatônico florentino, o summum bonum ou realização plena do homem consistia na gradual deificação ou assimilação de sua imagem divina em Deus, através da contemplação e da religião - que, mais do que a razão, é o que distingue os humanos dos animais. De forma correlata, o pecado era visto como uma prevaricação do homem com relação ao seu destino, cujo efeito foi o de encerrá-lo no mundo sensitivo-material. A exemplo do que faria Maistre, o humanista florentino não condenava a inclinação da alma sobre o corpo e a matéria como algo ruim em si mesmo, mas apenas a inclinação que, ao excluir a afinidade divina e intelectual da alma, extraviava a mesma de sua verdadeira destinação.

Uma vez corrompida pelo pecado original - mas não suprimida -, a orientação humana para a deificação só se fazia possível pela encarnação e mediação de Cristo, que, através de seu exemplo de vida, ensinamentos e sacrifício na cruz, ou seja, como um autêntico vitae magister, restaurou a orientação perdida da alma em direção a Deus. Nas palavras de Ficino: Christus est idea et exemplar virtutum. A apresentação da Ideia na perceptível e sensível pessoa de Cristo anulou a corrupta orientação da alma apenas

\footnotetext{
${ }^{28}$ Joseph de Maistre, Essai sur les Planètes, p. 662.

${ }^{29}$ Platão, Teeteto (aprox. 369 a.C.), 176b.

${ }^{30}$ Joseph de Maistre, Sur les délais de la justice divine (O.C., V: 382).
} 
para a sua esfera material e sensível. ${ }^{31}$ Ficino, portanto, concedia que o homem fosse a medida do homem, mas desde que um homem deificado e em relação com o seu Criador. Pois não poderíamos ter fé e obter a salvação se Deus não tivesse se tornado homem (Deus-Homem):

"Portanto, que os homens deixem de ter dúvidas sobre sua própria divindade, por conta das quais eles se precipitam nas coisas mortais. Eles deveriam reverenciar a si mesmos como seres divinos, e esperar que possam ascender a Deus, uma vez que foi digno o bastante para a majestade divina descender até eles." ${ }^{32}$

A este respeito, Cassirer sublinhou como a ideia fundamental da mística cristã de Ficino manifesta-se no duplo movimento do Eros platônico, isto é, não só da inteligência humana que anela pela assimilação em Deus, mas também de Deus, por meio de um ato livre de sua graça, em relação à inteligência humana. ${ }^{33}$ Criado à imagem de Deus e destinado a obter a perfeição pela confirmação de sua semelhança, não fazia sentido pensar num humanismo como uma pura humanidade. Uma vez que a inteligência humana é constantemente agitada pelo pensamento de Deus (a ansiedade ou inquietudo animi $)^{34}$, é preciso que a mesma seja entendida e educada (mais até do que governada, como veremos abaixo) pela Providência, que jamais o abandona: tudo o que é humano diz respeito a Deus. ${ }^{35}$

De comum em Ficino, Pico ou Maistre a respeito da dignidade do homem, a noção tipicamente origeniana de que a imagem de Deus implica não apenas na ideia de uma origem divina, mas também impele a uma dinâmica restauradora do espírito através de nossas escolhas e méritos, com a precípua mediação ou pedagogia de Cristo. ${ }^{36}$

E como destacou Werner Jaeger em seu original estudo sobre o cristianismo primitivo, a fusão das duas principais superestruturas do mundo Antigo - isto é, a

${ }^{31}$ Jörg Lauster,"Marsilio Ficino as a Christian thinker: Theological aspects of his Platonism",in: Michael J. B. Allen e Valery Rees, Marsilio Ficino: His Theology, His Philosophy, His Legacy (Leiden: Brill, 2002), p. 49-58.

${ }^{32}$ M. Ficino, De religione Christiana (1477) apud C. Trinkaus, In our Image and Likeness..., op. cit., p.741. Vale lembrar que no capítulo 35 desta obra Ficino teceu um expresso elogio a Orígenes pelo tratamento digno (o homem ocupando o centro na grande cadeia do Ser) que o alexandrino conferiu ao homem.

${ }^{33}$ E. Cassirer, Individu et Cosmos dans la philosophie de la Renaissance (Paris: Minuit, 1983), p. 170.

${ }^{34}$ Sobre a ansiedade da alma humana como prova de sua imortalidade para Ficino, leia-se Charles H. Lohr, "Metaphysics", in: Charles B. Schmitt e Q. Skinner (ogs.), The Cambridge History of Renaissance Philosophy, 8 edição (Cambridge: Cambridge University Press, 2009), p. 574-575.

${ }_{35}$ Élcio Verçosa Filho, "The pedagogical nature of Maistre's thought", op. cit., p. 196.

${ }^{36}$ Pico della Mirandola, Heptaplus; citado em C. Trinkaus, In our Image and Likeness, 509. 
filosofia grega e a tradição judaica - pela escola de Alexandria (e, mormente, por Orígenes) resultou numa teologia que, partindo dos livros das Crônicas, dos Números e da Sabedoria do Antigo Testamento, atribuía à ação da Providência na história uma função pedagógica, a verdadeira paideia. ${ }^{37}$

Com o objetivo de colocar o Antigo Testamento a salvo dos juízos mais críticos (não apenas dos céticos, mas também dos primeiros cristãos) sobre a natureza da ação providencial (sobretudo com respeito às punições ou castigos impostos à humanidade), Orígenes aplicou de forma sistemática o método da interpretação alegórica dos mitos pagãos às fontes da religião cristã, estabelecendo assim no interior da mesma a diferença entre os significados literal, histórico e espiritual dos textos. De acordo com Jaeger, Henri de Lubac e Karen Torjesen, isto permitiu a Orígenes eludir a objeção filosófica a respeito do grosseiro antropomorfismo associado à forma com que Deus era representado no Antigo Testamento (isto é, uma divindade eivada de paixões e reações humanas à outrance), a qual constituía a principal crítica dirigida pelos filósofos pagãos, tais como a de Celso (por volta de 175 a.C.), à Providência judaico-cristã. Diante disso, Orígenes empreendeu a tarefa - que durou toda sua vida - de traduzir a Bíblia de seu significado literal ao sentido espiritual, com o objetivo de colocar a salvo a paideia cristã e seu fundamento bíblico. ${ }^{38}$

Para Orígenes, Cristo era o grande mestre e, neste aspecto, sua concepção do cristianismo como paideia da humanidade permitia-lhe manter-se próximo das Escrituras e da imagem que os Evangelhos atribuíam a Jesus. Mas Cristo, advertia o alexandrino, não era um mestre humano designado pelos homens, mas a encarnação do próprio Logos divino. Esta é a grande diferença entre o cristianismo e toda filosofia meramente humana: o primeiro representa a vinda do Logos ao homem não apenas como um esforço humano, senão como algo que procede da iniciativa divina: Deus é o pedagogo do universo, ho theos paidagogei ton kosmon, argumentava Orígenes à guisa

37 "O contato criador do cristianismo com estas ideias constantes da tradição grega deve ter dado ao pensamento cristão a segurança de sua própria universalidade (catolicidade). A religião cristã havia assegurado desde um princípio e mantivera constantemente que era a verdade. Tal pretensão tinha necessariamente que medir-se com a única cultura intelectual do mundo que havia tentado alcançar a universalidade e o havia logrado: a cultura grega que predominava no mundo mediterrâneo. O sonho de Alexandre ao fundar a cidade que leva seu nome iria realizar-se agora: dois sistemas universais - a cultura grega e a Igreja cristã - iriam unir-se na poderosa superestrutura da teologia alexandrina." Cf. W. Jaeger, Cristianismo primitivo y paideia griega (Buenos Aires: Fondo de Cultura Económica, 1965), p. 62.

${ }^{38}$ Werner Jaeger, Cristianismo primitivo y paideia griega, p. 75; Henri de Lubac, Recherches dans la foi: Trois études sur Origène, saint Anselme et la philosophie chrétienne (Paris: Beauchesne, 1979), p. 70; Karen Jo Torjesen, Hermeneutical Procedure and Theological Method in Origen's Exegesis (Berlin: De Gruyer, 1985), p. 114, 126. 
de Platão das Leis. ${ }^{39}$ E por considerar o homem criado à imagem de Deus, Orígenes não podia senão concordar com a inversão platônica da célebre frase do sofista Protágoras (e a qual viria a ser reelaborada por Montaigne em seus Ensaios): o homem jamais poderia ser a medida de todas as coisas, muito menos para o homem, que deve anelar pela semelhança com Deus, a autêntica medida para a sua divina humanidade. ${ }^{40}$

Antes mesmo de Orígenes, seu mestre, Clemente de Alexandria (150 d.C. - 215 d.C.), designara uma catequese que tinha como modelo a paideia helênica, a ponto de seu livro Paedagogus (198 d.C) referir-se a Cristo como um divino mestre que transcendeu qualquer fenômeno anterior na história humana. Sem negar o valor da tradição helenística, Clemente e Orígenes sustentaram que a fé cristã desempenhava uma missão "paidêutica" junto à humanidade em um grau mais elevado do que o alcançado pela tradição pagã. ${ }^{41}$

Todavia, permanecia o problema de como conciliar esta pretensão pedagógica com outra convicção judaico-cristã igualmente forte, isto é, a condição adâmica (pecaminosa) da humanidade. Ademais, isto era algo ainda mais difícil de aceitar para aqueles que acreditavam que Cristo viera para redimir o mundo, mas que agora tinham de admitir que os homens seguiam pecando mesmo após o seu sacrifício. Sendo onipotente, por que Deus não impediu o pecado ao criar o homem perfeito e impecável? Por que foi preciso que Deus descesse dos céus e assumisse a forma humana a fim de retificar sua "falha" ao não excluir este princípio de transgressão do homem? Diante do pessimismo filosófico a respeito do triunfo das forças do mal sobre a ordem terrena, Orígenes via a filosofia de Platão como uma sólida arma defensiva contra toda manifestação filosófica fatalista ou desalentadora. Através do platonismo, o homem podia construir um mundo cristão e justificar a aprovação que o Criador dera à sua própria obra (imago Dei) quando percebeu que a mesma era boa. Sobre isto, Jaeger observou que:

\section{${ }^{39}$ Platão, Leis, X, 897b.}

${ }^{40}$ Platão, Leis, IV, 716c. A este respeito, Jean-Louis Labussière observou como o projeto moderno do indivíduo da Ilustração é, em grande medida, uma continuação das reflexões de Montaigne. Segundo o autor, "a antropologia filosófica (...) é o conhecimento do homem a partir da meditação sobre si." Cf. J. Louis-Labussière, Individu et individualisation dans la philosophie des Lumières (Dijon, 1988), p. 51.

${ }^{41}$ Werner Jaeger, Cristianismo primitivo y paideia griega, p. 90-91. Clemente sustentava que as máximas verdadeiras da filosofia grega (em especial de Pitágoras e Platão) consistiam em plágios dos profetas hebreus, no que foi refutado por Celso, para quem a doutrina cristã representava uma falsificação grosseira da paideia grega. Nessa disputa, a tendência de Orígenes era demonstrar o inverso de Celso: "Para mim, não duvido de que Platão escreveu as máximas do Fedro depois de tê-las aprendido de certos autores hebreus ou mesmo, como dizem, depois de ter lido os discursos proféticos." Cf. Orígenes, Traité d'Origène Contre Celse (Amsterdã: Henry Desbordes, 1700), p. 240. Curiosamente, esta tradução do Contra Celso (248 d.C.) fora lavrada por um refugiado francês huguenote, Élie Bouhéreau. 
"Orígenes concebeu o homem como um agente moral e livre e, portanto, não lhe parecia que a criação de Deus poderia ser mais perfeita se Ele tivesse privado o homem de sua qualidade essencial: a capacidade para eleger livremente o bem por si mesmo. Desta forma, sua convicção platônica e estoica converteu-se no ponto de partida de toda sua construção da história humana. Tudo depende da habilidade do homem para saber o que é o bom e distingui-lo do mal... A partir daí, a filosofia de Platão havia-se convertido em paideia, a educação do homem. Sob esta forma entendia Orígenes o cristianismo. Tratava-se do maior poder educativo da história e concordava essencialmente com Platão e a filosofia. Assim, Platão e a filosofia se converteram nos mais poderosos aliados do cristianismo em sua luta presente, segundo Orígenes." ${ }^{42}$

Jaeger destacou como Orígenes, a fim de provar sua visão "moralizada" sobre a ação da providencia divina na história humana (isto é, de uma Providência que cuida do mundo e da humanidade e cujos castigos ou punições devem ser entendidos no interior de um desígnio pedagógico), representou um quadro da história humana que reunia todos os fatos tanto da história bíblica como da história pagã (especialmente a grega), de modo que a paideia expressaria o cumprimento gradual da Providência divina. ${ }^{43}$

Além disso, conforme sublinhou Manlio Simonetti em sua notável edição crítica para o Tratado sobre os Princípios, apesar de a doutrina do valor pedagógico das punições divinas, chave para a compreensão da teologia do alexandrino (e, como veremos a seguir, de Maistre), ser de origem platônica ${ }^{44}$, não era difícil encontrá-la nas Escrituras (sobretudo nos livros escritos em grego ${ }^{45}$ ) e também nas obras de Clemente de Alexandria. Mas exceção feita talvez ao neoplatônico pagão Plutarco (45 d.C. - 120 d.C.), nenhum outro filósofo ou pensador cristão traduziu com a mesma clareza e intensidade a relação entre bondade/justiça com a educação/punição divinas, e a qual serviu de fundamento para a elaboração do conceito de apocatastasi (ou restitutio in pristinum statum) final, isto é, a purificação dos pecadores por meio da paideia divina, quanto Orígenes. Em harmonia com esta concepção judaico-cristã helenizada (mais especificamente neoplatônica), Orígenes considerava a morte do corpo (apreendido

\footnotetext{
${ }^{42}$ Werner Jaeger, Cristianismo primitivo y paideia griega, p. 96.

${ }^{43}$ Idem, p. 97-99.

${ }^{44}$ Platão, Górgias, 525a-b; República, II, 380 b-c; Leis, XI, 934 a; Plutarco, De sera numinis vindicta (Da demora da punição divina), 4.

${ }^{45}$ Como no livro da Sabedoria (2: 21-24), o último do Antigo Testamento em ordem cronológica e o qual, redigido por um judeu helenizado de Alexandria por volta de 50 a.C., vincula a punição divina à justiça e, sobretudo, ao desígnio pedagógico da Providência para com os homens (Sabedoria 16: 5-14).
} 
como uma prisão da alma após a queda no pecado original) como um castigo salutar, pois o retorno do espírito a Deus era o que realmente importava. ${ }^{46} \mathrm{Nas}$ palavras de Jaeger, se "a paideia era a vontade de Deus e se o cristianismo é para o cristão o que a filosofia é para o filósofo, segundo Platão - assimilação a Deus -, o verdadeiro cumprimento do ideal de vida cristão é o esforço contínuo para chegar a este fim e para avizinhar-se à perfeição na medida em que for possível ao homem." ${ }^{47}$

Portanto, conforme sugeriu Marc Froidefont, é a partir da assimilação da teologia de Orígenes que devemos compreender a ênfase maistreana na teologia da imagem, e a qual levou-o a vincular a inteligência à liberdade, uma vez que a primeira é condição sine qua non da última, ou seja, graças à inteligência o homem é livre para fazer um bom ou mau uso de seu livre-arbítrio. ${ }^{48}$ Pois "o homem", adverte Maistre ao comentar a referida passagem do Gênesis, "foi declarado pura e simplesmente imagem de Deus, isto é, inteligência: e aqui deteve-se Moisés, pois ele disse tudo." 49

Neste sentido, é certo que o providencialismo maistreano não pretende suprimir a noção de liberdade humana, pois, conforme adverte Maistre nas Soirées, o homem não deve agir "como um instrumento cego da Providência, mas como um ministro inteligente, livre e submisso, com a vontade predeterminada a obedecer aos planos daquele que o envia". ${ }^{50} \mathrm{O}$ paradoxal do providencialismo maistreano está no fato de o mesmo conciliar a admissão de que a causa primária de toda ação política encontra-se na Providência e, consequentemente, que toda inovação política puramente humana coloca o Estado sob risco ${ }^{51}$, com um manifesto sobre a dignidade ontológica do homem. Diferentemente da tradição humanista cívica, que vincula a liberdade humana à ação e à participação dos cidadãos na política, o humanismo devoto maistreano subsume as considerações sobre a liberdade humana no plano metafísico, obtendo, assim, o paradoxal efeito de sobrevalorizar a dignidade ontológica do homem - a qual é inseparável do livre-arbítrio - na proporção em que anula sua autossuficiência e autonomia na esfera política.

\footnotetext{
${ }^{46}$ Manlio Simonetti, I Princìpi, op. cit., 277. Em Orígenes, a expressão punição ou castigo divino sempre aparece associada aos termos "educação" e "ensinamento" (como em Princípios, I. 6. 3.). "Daí se compreende que o furor da vingança de Deus serve para purificar a alma" (Princípios, II. 10. 6).

${ }^{47}$ Werner Jaeger, Cristianismo primitivo y paideia griega, op. cit., p. 125.

${ }^{48}$ Marc Froidefont, Théologie de Joseph de Maistre, p. 53.

49 Joseph de Maistre, Examen de la philosophie de Bacon (O.C., VI:108).

${ }^{50}$ Joseph de Maistre, Soirées, O.C., IV:48 ( $\mathrm{I}^{\mathrm{e}}$ Entretien).

${ }^{51}$ Sobre o risco inerente às reformas constitucionais para os estadistas, vide Essai sur le principe générateur des constitutions politiques (1809), capítulo XLI (O.C., I: 280); e Considerações sobre a França, capítulo 8.
} 
E ainda mais do que Erasmo em seu Enchiridion militis Christiani (1503) - para quem a oração e, sobretudo, o (verdadeiro) conhecimento da Bíblia, constituíam as principais armas para o soldado cristão - e, a exemplo do humanista e teólogo holandês, igualmente amparado na teologia de Orígenes ${ }^{52}$, Maistre via a oração como a principal dinâmica ou ação confiada ao homem:

"O próprio Deus disse-nos que Deus QUER coisas que não acontecem, pois o homem NÃO QUER. Destarte, os direitos do homem são imensos..., mas sua verdadeira ação é a oração... Imaginai do que é capaz a vontade humana no círculo do mal; ela pode contrariar Deus...; o que pode, pois, esta mesma vontade quando ela age com Ele?"${ }^{153}$

Através da afirmação dos direitos da oração - os autênticos e sublimes "direitos do homem" -, o contrarrevolucionário saboiano logra conciliar em seu sistema da autoridade o providencialismo (que faz de Deus o senhor absoluto da história e da natureza) com a afirmação do livre-arbítrio e a denúncia humanista do fatalismo, pois a liberdade humana é a "base" da moral. ${ }^{54} \mathrm{O}$ elogio da oração tem por objetivo recusar a tese de que "nada deve ocorrer, senão o que ocorre; nada ocorre, senão o que deve ocorrer", respondendo: "se vós orais, tal coisa que deveria ocorrer não ocorrerá mais. "

Ao defender a dignidade e a liberdade humanas por meio do elogio da oração, Maistre tinha em vista combater o fatalismo moral - fosse ele de natureza teológica (calvinista ou jansenista) ou científico-filosófica -, segundo ele, uma doutrina absurda que fazia "do homem uma estátua" e conduzia ao "embrutecimento moral". 56

Pois somente pela afirmação do livre-arbítrio é que toda justificativa teológica para o problema do Mal no mundo - mais especificamente, da relação entre "Crime e Castigo" (a chave da leitura providencialista maistreana sobre o Terror) - faria sentido,

\footnotetext{
${ }^{52}$ Sobre a importância da teologia de Orígenes - em matérias como a importância da oração e, sobretudo, o método alegórico para a leitura bíblica - em Erasmo, leia-se: Albert Rabil, Erasmus and the New Testament: The Mind of a Christian Humanist (San Antonio: Trinity University Press, 1972); e André Godin, Érasme, lecteur d'Origène (Genève: Droz, 1982). Sobre o vínculo entre a oração e a liberdade humana em Orígenes, leia-se deste último La Preghiera (Roma: Cità Nuova, 1997), capítulo VI, artigo 4

53 Joseph de Maistre, Soirées, O.C., IV:278-279(V $\mathrm{V}^{\mathrm{e}}$ Entretien). Maiúsculas do próprio Maistre.

${ }^{54}$ Joseph de Maistre, O.C., III:387.

55 Joseph de Maistre, Soirées, O.C., IV:214 (IV Entretien). Grifos do autor.

${ }^{56}$ Joseph de Maistre, Soirées, O.C., IV:212-213 (IV Entretien).
} 
posto que seria uma "infâmia" pretender que Deus tivesse o direito de punir uma humanidade destituída de uma vontade ativa e livre. ${ }^{57}$

Mesmo dividida e alquebrada pelo pecado original - que tornou o homem incapaz de buscar o bem sem o concurso da graça divina -, a vontade não deixa de existir como potência no homem, pois se o mesmo não tivesse o poder de resistir aos "desejos", a liberdade tornar-se-ia ontologicamente impossível. ${ }^{58} \mathrm{E}$ em oposição ao pessimismo antropológico de Lutero e de Pascal, Maistre observou que o pecado original, deixando a percepção e a razão praticamente intactas, afetou gravemente a vontade humana:

"Toda inteligência é, por sua natureza, o resultado simultaneamente ternário e único de uma percepção que apreende, uma razão que afirma, e uma vontade que age. As duas potências iniciais foram apenas enfraquecidas no homem, mas a terceira foi quebrada... É nesta terceira potência que o homem se sente mortalmente ferido. Ele não sabe o que quer; ele quer aquilo que não quer; ele não quer o que quer; ele queria querer". ${ }^{59}$

E é justamente para educar esta vontade humana alquebrada e preservar ao mesmo tempo a sua liberdade que a Providência atua na história: "Deus age com os pecadores da mesma maneira com que os médicos curam os enfermos para restituir-lhes a saúde", advertia Orígenes. Mas enquanto a incômoda e, por vezes, dolorosa ação dos médicos visa à restauração da saúde do corpo, a Providência, por sua vez, visa somente à salvação da alma imortal que há em nós, o que explica o padecimento e, no extremo, a morte corporal. ${ }^{60}$

Orígenes compreendia o problema da justificação humana no sistema intelectual ou providencial em termos de sinergia, ou seja, sem negar que a natureza humana decaída pelo pecado original pudesse buscar e encontrar-se com Deus sem o concurso da Providência e, sobretudo, de Cristo ${ }^{61}$, o alexandrino observou que, sendo o homem uma criatura espiritual, inteligente e feito à imagem de Deus, não faria sentido a Providência forçá-lo a buscar a "semelhança". A própria noção de consciência moral que o homem possui em caráter inato (noção de arrependimento que inicia o processo

\footnotetext{
${ }^{57}$ E isto pelo fato de os homens, adverte Maistre referindo-se explicitamente ao Contra Celso de Orígenes, trazerem em seu espírito "noções de moral comuns e inatas escritas em letras divinas". Cf. Joseph de Maistre, Soirées, O.C., IV: 289 nota 1 ( $\mathrm{V}^{\mathrm{e}}$ Entretien).

${ }^{58}$ Joseph de Maistre, Soirées, O.C., IV:305 (VI ${ }^{\mathrm{e}}$ Entretien)

${ }^{59}$ Joseph de Maistre, Soirées, O.C., IV:67-68 (II ${ }^{\mathrm{e}}$ Entretien). Grifos de Maistre.

${ }^{60}$ Orígenes, Tratado sobre os Princípios, II. 10. 6.

${ }^{61}$ Romanos 9: 16; Orígenes, Tratado sobre os Princípios, III. 1. 18-19.
} 
de retorno do espírito a Deus) ${ }^{62}$ leva-o a procurar a semelhança (por meio de atos justos e virtuosos) e a assimilação final a Deus. ${ }^{63}$

Se Maistre lera ou não Marsílio Ficino (1433-1499) ${ }^{64}$, importa salientar que ambos, como admiradores de Orígenes e profundos conhecedores da filosofia platônica (e apesar das diferenças de estilo e objetivos ${ }^{65}$ ), associavam a dignidade humana à imortalidade da alma e à presença de uma inteligência racional e livre, de modo que o homem era visto por eles como um ser plenamente livre e capaz de imitar a perfeição cósmica do Logos no mundo inferior, a ponto de, por meio de sua arte (e como reflexo de seu status privilegiado na ordem da criação), transformar constantemente a natureza por meio de sua inteligência livre e criadora, de tal forma que a natureza não é "natural" (isto é, eterna e autorregulada), mas plástica; o "homem não é servo da natureza, mas seu competidor": em última análise, ele "imita todas as obras da natureza divina e aperfeiçoa, corrige e modifica os trabalhos da natureza inferior". ${ }^{66}$

Neste sentido, como bem observou C. Trinkaus, Ficino oferece um quadro singular sobre a grandeza do homem, e o qual culmina num paradoxal (por se tratar de um filósofo contemplativo que propôs uma contra-paideia espiritualista como alternativa ao sensualismo dos humanistas averroístas) elogio do homo faber e das artes e indústrias humanas. Apesar de extensa, a citação justifica-se:

"A força do homem é quase similar à natureza divina, pois o homem por si próprio, isto é, através de sua inteligência e habilidade, governa a si mesmo sem ser minimamente limitado por sua natureza física e imita os trabalhos individuais da natureza superior... Nestas artes e indústrias, deve-se observar como o homem em toda a parte utiliza todos os materiais do universo como se todos fossem submetidos ao homem. Ele faz uso dos elementos, isto é, das pedras, dos metais, das plantas e dos animais, e transforma-os em tantas formas e figuras que os animais jamais logram. Tampouco se satisfaz com um elemento ou poucos, como os animais, senão que usa-os todos como se fosse o senhor de tudo... Com virtude celestial, ele ascende aos céus e os mede... Mas o homem não apenas usa os elementos, mas adorna-os, algo que nenhum bruto faz. Quão esplêndido é o cultivo da terra por todo o mundo. Quão estupendas as estruturas

\footnotetext{
${ }^{62}$ Joseph de Maistre, De l'état de nature, O.C., VII: 565.

63 Orígenes, Princípios, IV. 9-10.

${ }^{64}$ Impossível que um estudioso erudito da filosofia platônica no tempo de Maistre ignorasse as traduções críticas de Ficino, como fica claro na alusão ao fiorentino no II Entretien das Soirées.

${ }^{65}$ Algo bastante compreensível se levarmos em conta que Maistre escreve após três séculos de consolidação da Reforma e do Concílio de Trento - o que já seria bastante coisa -, mas também (e sobretudo) em pleno andamento da Revolução Francesa, da qual foi testemunha ocular e vítima (direta e indiretamente, e em todos os níveis imagináveis: familiar, civil e político).

${ }^{66}$ M. Ficino, Theologia platonica; citado em C. Trinkaus, In our Image and Likeness, p. 482.
} 
das construções e das cidades. Quão engenhosos seus trabalhos de irrigação. Ele age como um vigário de Deus, uma vez que ele habita em todos os elementos e cultiva a todos, e presente na Terra, não está ausente do éter... Ele não apenas governa os animais cruelmente, mas também os governa, alimenta e adestra. A providência universal é exclusiva de Deus que é a causa universal... Quem quer que domine o corpo de tantas e grandiosas maneiras e age como o vigário do Deus imortal é, sem dúvida, imortal." ${ }^{67}$

Coincidentemente, o ensaio crítico do contrarrevolucionário saboiano ao Discours sur l'origine et les fondements de l'inegalité parmi les hommes (1755) de Rousseau, qual seja, o De l'état de nature ${ }^{68}$, destacará que o principal erro do "Cidadão de Genebra" foi o de supor a existência de um homem natural desprovido de inteligência e de perfectibilidade, e que levou o autor do discurso a não conseguir demonstrar em termos lógicos aquilo que ele argumentava - a saber, a passagem da natureza para a civilização (através das artes) - senão pelo contínuo recurso à noção de "acidente" ou "acaso".

De acordo com Maistre, o grande equívoco político de Rousseau decorreu de seu profundo erro metafísico, que consistiu em atribuir ao seu hipotético homem natural "faculdades que deviam permanecer como potência, mas que acontecimentos fortuitos... fizeram passar ao ato", de modo que a "perfectibilidade" humana - e Maistre refere-se às artes pelas quais os homens humanizam e transformam a natureza - e as "virtudes sociais" deixam de ser naturais no homem. Assim procedendo, Rousseau esquecera-se de que "a perfectibilidade não é uma qualidade particular do homem; ela é... a qualidade de todas as suas qualidades. Não há nele uma única potência que não seja suscetível de aperfeiçoamento; ele é inteiramente perfectível." ${ }^{69}$

Para ilustrar a inconsistência lógica da hipótese rousseauniana e implodir sua pretensão de orientação normativa para a política, Maistre separou alguns exemplos do que ele, ironicamente, designava como a "filosofia do acaso" do "Cidadão de Genebra": selvagens isolados que, caminhando em sentidos diferentes, se encontram e vislumbram a possibilidade de viverem juntos (segundo o próprio Rousseau, tal encontro ter-se-ia

\footnotetext{
${ }^{67}$ M. Ficino, Theologia platonica; citado em C. Trinkaus Trinkaus, In our Image and Likeness..., p. $483-484$.

${ }^{68}$ Redigido entre maio de 1794 e início de 1796 - portanto, após a formulação da leitura providencialista e origenista da Revolução Francesa - e publicado em 1870 com o título de Examen d'un écrit de J.-Jacques Rousseau sur l'inégalité des conditions, sabemos, graças ao estudioso maistreano Jean-Louis Darcel, que o título original da obra deveria ser De l'état de nature. Sobre as circunstâncias e o contexto de publicação deste ensaio contra Rousseau, leia-se o primeiro capítulo desta tese. Cf. JeanLouis Darcel, De l'état de nature (Geneva: Slatkine, 1980). De modo a facilitar o acesso ao leitor, citaremos a partir das Obras Completas de Maistre.

69 Joseph de Maistre, De l'état de nature, O.C., VII: 551.
} 
dado por "acaso"); o selvagem que recebeu sua primeira (e "infeliz") lição de agricultura da natureza ao observar a queda de uma semente sobre a terra, a qual posteriormente frutifica, etc.

Ao vincular a inteligência humana a uma mera faculdade sensitiva - afinal, a terrível descoberta das artes não se deu pela fatal observação por meio dos sentidos? - e negar a existência dos conhecimentos inatos inseparáveis da noção neoplatônico-cristã de inteligência da imago Dei, Rousseau, de acordo com Maistre, tornava-se o filósofo mais radical da Filosofia das Luzes, na medida em que "suas ideias insanas de liberdade e de independência conduziram-no a invejar a condição dos animais e a buscar a verdadeira destinação do homem na ausência de toda moralidade." ${ }^{70}$ Pois o próprio Rousseau (e Maistre não se cansa de refutar Rousseau a partir das palavras do mesmo) não afirmou que o "povo" (mas o "homem não vivia isolado" e a ideia de povo não supõe a sociedade?) incorreu no engano de acreditar que seria feliz ao substituir sua "felicidade real" pelo "estado em que o direito substituiu ou sucedeu o da violência" (e da vingança), e "a natureza foi submetida à lei"? ${ }^{71} \mathrm{E}$ ao negar a existência de uma intenção primitiva no homem e atribuir a corrupção ou queda do estado de natureza ao estado social a um fatal "encadeamento de causas cegas", Rousseau não estava, por outras vias e sem se dar conta disto, negando a liberdade e a moralidade humanas ${ }^{72}$

Se Maistre, portanto, tratava do estado de natureza de Rousseau como uma absurdidade metafísica, era porque o genebrino ignorava um dado teológico fundamental, o amor divino para com o homem: "o homem, por ser social e, sobretudo, por ser feito à imagem e semelhança de Deus", jamais está abandonado a si mesmo num "pretenso estado natural". ${ }^{73}$

Mas é sobretudo quando vincula a inteligência humana (o caráter propriamente divino no homem) à sua perfectibilidade que a proximidade de Maistre com o humanismo de Ficino se torna mais evidente:

"As faculdades do homem provam, pois, que ele é feito para a sociedade, porque uma criatura não pode ter recebido faculdades para não usá-las. Ademais, sendo o homem ativo e perfectível, e sua ação não podendo se exercer senão sobre os seres que o rodeiam, segue-se que estes seres não são, por si próprios, o que eles devem ser, pois estes seres são coordenados com

\footnotetext{
70 Joseph de Maistre, De l'état de nature, O.C., VII: 537.

71 Joseph de Maistre, De l'état de nature, O.C., VII:535 e 537.

72 Joseph de Maistre, De l'état de nature, O.C., VII: 530.

73 Joseph de Maistre, De l'état de nature, O.C., VII: 535.
} 
a existência e os atributos do homem... Se as substâncias fossem refratárias à ação do homem, sua perfectibilidade seria uma qualidade vã, uma vez que não teria nem objetos, nem materiais. Logo, o boi é feito para arar, o cavalo para ser selado, o mármore para ser esculpido... etc. Portanto, a arte é a natureza do homem." ${ }^{74}$

Ademais, não podemos esquecer que em sua demonstração do caráter imortal e religioso da alma por meio da inquietudo animi, Ficino também definiu a natureza humana como social, e para demonstrar que suas asserções metafísicas em torno da dignidade do homem não eram meras especulações, o humanista florentino apelou a uma teoria psicológica da alma: diante da inquietude que a alma humana experimenta na sua constante atração e busca pelo divino e pela imortalidade, e de modo a evitar a profunda tristeza decorrente da compreensão da impossibilidade de realizar este fim na ordem temporal (afinal, nossa inteligência imortal não se realiza no corpo e na história, mas fora dela), os homens buscam o convívio social para dirimir a sensação de "exílio" e de "tristeza" deste mundo. ${ }^{75}$

E no interior desta ordem secundária do sistema Intelectual (Providencial) do mundo sobressai justamente o homem, cuja atividade inteligente "tem o poder de modificar uma multidão de seres e de modificar a si próprio." Portanto, completa Maistre em sua crítica a Rousseau, para se falar da natureza como pretendia a Ilustração, "era preciso explicar o estado desses seres antes e depois que eles sofreram a ação humana." ${ }^{76}$

Não por acaso, em sua crítica à Filosofia da Ilustração, Maistre apresenta-nos uma concepção teomórfica da natureza tão incomum ao nosso quadro referencial epistêmico, que precisamos retroceder às cosmologias de autores humanistas como Ficino e Pico para situá-la sem incorrer em reduções simplistas que associam seu providencialismo a um dogmatismo religioso obtuso. Quanto ao origenista e neoplatônico Pico della Mirandola, não constitui mera coincidência o fato de que, em seu Heptaplus (1489), ele também tenha definido essa força presente na natureza sob o prisma da ação criadora e unificadora do Logos e/ou da Inteligência:

${ }^{74}$ Joseph de Maistre, De l'état de nature, O.C., VII:553. Um pouco antes, Maistre escreveu algo parecido: "O animal encontra a seu alcance tudo o que lhe é necessário. Ele não tem o poder de se apropriar dos seres que o rodeiam e de modificá-los para seu uso. Pelo contrário, o homem encontra em suas mãos apenas materiais brutos para a sua fruição, cabendo a ele aperfeiçoá-los. Sendo, pois, a arte humana, ou sua perfectibilidade, a natureza do homem." Idem, p. 534.

${ }^{75}$ C. Trinkaus, In our Image and Likeness..., p. 494.

${ }^{76}$ Joseph de Maistre, De l'état de nature..., O.C., VII:525. 
"Deus, portanto, acrescentou à máquina celeste uma substância viva e racional, partícipe da inteligência e, por isto, ele quis que ela governasse sobre esses corpos animados dos quais acabamos de falar, isto é, sobre todos os signos estrelares e planetas que são governados por meio de seu aceno e obedecem a seu comando de tal modo que não há atraso ou desobediência." 77

Assim como seu amigo e mestre Ficino ${ }^{78}$, Pico também destacou que o homem, em razão de sua natureza intermediária e inteligente, tem à sua disposição o conhecimento de seu meio. Cópula do mundo e reflexo da totalidade cósmica divina, cabe a ele percorrer o universo em sua diversidade de formas e de interpretá-lo, de modo que o conhecimento do mundo constitui uma parte eminente da dignitas hominis. É ela que impulsiona o homem para o campo da ação, na medida em que sua intervenção criadora no mundo foi um desejo de Deus, como nos indicam as primeiras páginas da Oratio (1486): "Eu te coloquei no centro do mundo, a fim de poderes inspecionar, daí, de todos os lados, da maneira mais cômoda, tudo que existe."79

Conforme destacou Katrine Safa, se não há como negar a participação do homem na natureza, o fundamental, para Pico, consistirá em assinalar-lhe um lugar especial na ordem cósmica, e o qual o neoplatônico florentino detalhou da seguinte forma: “...o homem foi criado por Deus à sua imagem e semelhança para dominar os peixes, os pássaros e, em geral, todos os animais que foram produzidos pela água e pela terra..

Neste sentido, o homem não somente tem o poder de representar o mundo como totalidade e de torná-lo inteligível, mas também lhe cabe, em função da perfectibilidade inerente à sua inteligência, a responsabilidade de transformar o cosmos, de fazer-lhe alcançar seu sentido e sua unidade. ${ }^{81}$

\footnotetext{
${ }^{77}$ Pico della Mirandola, Heptaplus, Livro II. Citado em C. Trinkaus, In our Image and Likeness..., p. 509.

${ }^{78}$ Como observou Kristeller, Pico concordava com Ficino quanto à natureza universal do homem, sua capacidade de se apropriar das qualidades de todos os seres, fossem os mesmos angelicais ou baixos (minerais, plantas, e animais), mas sua apaixonada preocupação com a liberdade/livre-arbítrio compeliu-o a criticar a noção ficiniana de que o homem ocupava um lugar fixo na hierarquia do ser. Para Pico, o homem não tinha uma natureza determinada e nem tampouco uma hierarquia fixa, estando, por assim dizer, fora da hierarquia. Cf. P. O. Kristeller, Renaissance Thought and its Sources (New York: Columbia University Press, 1979), p. 171-175.

79 Pico della Mirandola, Oratio; citado em Katrine Safa, L'humanisme de Pic de la Mirandole: l'esprit en gloire de métamorphoses (Paris: Vrin, 2001), p. 49.

${ }^{80}$ Pico della Mirandola, Heptaplus; citado em C. Trinkaus, In our Image and Likeness..., p. 511512.

${ }^{81}$ Katrine Safa, L'humanisme de Pic de la Mirandole: l'esprit en gloire de métamorphoses..., p. 44.
} 
Novamente, a comparação entre os nossos neoplatônicos faz-se necessária. No mesmo trecho do De l'état de nature em que critica o rebaixamento ontológico do homem promovido por Rousseau em seu Discurso (principalmente por negar a perfectibilidade na caracterização do homem no estado de natureza e vinculá-la, em sua hipótese perfeitamente laica do "pecado original", à corrupção ${ }^{82}$ ), Maistre relaciona, num ethos indelevelmente humanista (mais especificamente ficiniano), a anatomia com o estatuto ontológico digno e perfectível do homem:

"A anatomia do homem, de suas faculdades físicas e morais, completaria a demonstração se faltasse alguma coisa ao que a história nos fornece. Sua mão lhe submete tudo aquilo que o circunda. As substâncias mais refratárias do reino mineral cedem à sua ação poderosa. No reino vegetal e no reino animal, seu império é ainda mais impressionante: não apenas ele submete uma série de espécies destas duas ordens, mas também as modifica e as aperfeiçoa... O agente universal, o fogo, está sob suas ordens e só obedece a ele. Todas as substâncias conhecidas são unidas, divididas, endurecidas, flexibilizadas, fundidas, vaporizadas pela ação poderosa deste elemento. Sua arte, combinando a água e o fogo, obtém forças incalculáveis." ${ }^{83}$

Em sua Theologia platonica, Ficino não havia tecido uma das mais belas apologias da anatomia humana (com profundas consequências para as artes plásticas renascentistas), recordando que a harmonia entre os vários membros, bem como a agilidade decorrente disso e, sobretudo, a postura ereta (reflexo do tropismo contemplativo da alma humana em direção à Inteligência divina), representavam índices inequívocos da imortalidade da alma humana e de seu status privilegiado na ordem da criação ${ }^{84}$

Não nos surpreende essa similaridade ética e tópica de Maistre em relação a Ficino e Pico, uma vez que o contrarrevolucionário saboiano admirava e conhecia toda

\footnotetext{
${ }^{82}$ Neste sentido, Jean Starobinski, definiu o Discours de Rousseau como um de seus escritos mais diderotianos e menos cristãos do "cidadão de Genebra", e o qual, em sua versão desmistificada e laicizada da história das origens, visava substituir e suplantar filosoficamente o texto do Gênesis. Cf. Jean Starobinski, Introdução a Rousseau, Discours sur l'origine et les fondements de l'inégalité parmi les hommes, (org.) Starobinski (Paris: Gallimard, 1969), p. 19-20.

${ }^{83}$ Joseph de Maistre, De l'état de nature, O.C., VII: 550. No Examen de la philosophie de Bacon (OC VI: 279-280), lê-se o seguinte: "Tais são os títulos augustos e indeléveis do homem: ele exerce sobre todas as partes da natureza um império imenso, ainda que imensamente debilitado [pelo pecado original], pois ele não poderia ser a imagem, mesmo desfigurada do Criador, sem ser ainda até um certo ponto a imagem da ação e do poder daquele que é toda a ação e onipotência." E, finalmente, nas Soirées (IV Entretien), tem-se o seguinte: "Imagens de Deus sobre a terra, tudo o que temos de bom o assemelha; e não poderíeis acreditar o quão esta sublime semelhança esclarece uma série de questões. Não vos surpreendeis se insisto demasiado neste ponto."

${ }^{84}$ C. Trinkaus, In our Image and Likeness..., p. 474-475.
} 
as obras do humanista neoplatônico de Cambridge, Ralph Cudworth, cujo platonismo era manifestamente ficiniano.

Logo no início do De l'état de nature, Maistre cita um trecho do prefácio do The True Intellectual System of the Universe (1678) do filósofo neoplatônico de Cambridge para ilustrar sua concepção (providencial) da natureza. De acordo com Maistre, a palavra natureza, tão cara ao século das Luzes, não devia ser tomada como um "conjunto das peças e das forças" autônomas "que constituem o sistema do universo", pois o natural (que os philosophes apreendiam como o Todo) "é uma obra, não um artista" (isto é, Deus). ${ }^{85}$

Ainda que "o artista" tenha decidido não intervir imediatamente "na geração de uma mosca" - o que afrontaria a sua majestade divina -, nem por isto ele deixa de agir através de uma força secundária "que... nomeamos como natureza"."'Daí", prossegue Maistre, "as expressões comuns em todas as línguas e as quais, sem jamais negar Deus como causa primária do todo", admitiam a existência de uma força secundária designada pela inteligência divina: "a natureza cura", "a natureza quer", "a natureza proíbe", é "contra ou a favor da natureza", "é da sua natureza" etc. ${ }^{86}$ Ou seja, a natureza não cria nada, mas, na condição de obra divina dotada de uma força plástica, é capaz de geração. Mais do que isto, a inteligência humana, pela contemplação da "ordem", da "proporção" e da "simetria" do universo ${ }^{87}$, é capaz de reconhecer um desígnio inteligente e transcendente por trás do último, de um "artista inteligente que o fabricou" ${ }^{88} \mathrm{e}$, a partir disto, imitá-lo na sua ação prática, seja com relação ao próximo (através da ação ética e moral, sempre buscando a harmonia, a ordem e a justiça), seja com relação às coisas (intervindo na natureza tal qual nós, herdeiros da epistemologia Ilustrada, entendemos).

Importa frisar aqui, na contramão do que sugeriu Aimee Barbeau - para quem o constante recurso maistreano ao maquinismo (especialmente à figura do relojoeiro) para se referir à Providência seria um eco da filosofia deísta-ilustrada em seu pensamento ${ }^{89}$ -, que a Providência maistreana não tinha em comum com a imagem do relojoeiro dos filósofos deístas - e que Paul Hazard tão bem definiu como "uma pura operação

${ }^{85}$ Joseph de Maistre, De l'état de nature, O.C., VII: 527.
${ }^{86}$ Joseph de Maistre, De l'état de nature, O.C., VII: 523.
${ }^{87}$ Joseph de Maistre, Examen de la philosophie de Bacon..., O.C., VI: 388.
${ }^{88}$ Joseph de Maistre, Examen de la philosophie de Bacon..., O.C., VI: 392.
${ }^{89}$ Como no início do primeiro capítulo das Considerações sobre a França ou numa epístola de fevereiro de 1805 a um conde, quando se refere a Deus como um "grande maquinista" (O.C., IX:342). Cf. Aimee E. Barbeau, "The Savoyard philosopher: deist or Neoplatonist?", in: C. Armenteros e R. Lebrun (orgs.), Joseph de Maistre and the legacy of Enlightenment (Oxford: Voltaire Foundation, 2011). 
intelectual" que assume a "existência de Deus" apenas como uma "afirmação elementar e suficiente" ${ }^{\prime 90}$ - nada mais do que o recurso retórico, sendo-lhe diametralmente oposta.

Referindo-se ao deísmo nas Soirées, Maistre informa que os homens, ao se aproximarem do deísmo - o qual, segundo ele, "não é nada e não pode nada" - "cessaram de rezar", pois a concepção mecânica da Providência servia de base à epistemologia científica empírico-mecanicista que curvava "os homens sobre a terra" e os deixava "unicamente ocupados das leis e dos estudos físicos (e, consequentemente, "não possuindo mais o menor sentimento de sua dignidade humana"). ${ }^{91}$

Ao suprimir no homem a vontade de rezar, o deísmo não fazia mais do que, para falar em termos origenistas, "esfriar" ou "materializar" a alma humana, enfraquecendo a alma superior ou espiritual no eterno combate interior que a mesma trava com o seu oposto, a alma inferior ou corpórea. ${ }^{92} \mathrm{E}$ se o deísmo, com sua crença nas "leis invariáveis" da natureza não podia nada, era porque tolhia a principal dinâmica ativa reservada ao homem, a oração, pela qual o homem não apenas exercita sua vontade de procurar a semelhança com Deus, como, em casos especiais, chega inclusive a derrogar as próprias "leis naturais" (isto é, na sua acepção Ilustrada), quando não os decretos da Providência. ${ }^{93}$ Conforme destacou Pawel Matyaszewski a respeito do Providencialismo maistreano, "a natureza não apenas prova Deus, como ela não existe senão em relação perpétua com Ele." 94

$\mathrm{Na}$ mesma linha, Élcio Verçosa observou corretamente que Maistre criticou Montesquieu pelo fato de o autor do Espírito das Leis (1748), em seu pathos filosóficoilustrado, ter tido a pretensão de traduzir as leis políticas do mundo de maneira sistemática e sem espaço para a misteriosa e reveladora ação da Providência na história humana. ${ }^{95}$ Se, conforme sublinharam Paul Beik ${ }^{96}$, Sheldon Wollin ${ }^{97}$, e, mais

${ }^{90}$ P. Hazard, La pensée européenne au XVIII ${ }^{e}$ siècle, de Montesquieu à Lessing (Paris: Fayard, 1963), p. 118.

91 Joseph de Maistre, Soirées, O.C., IV:212 (IV Entretien).

92 Assim como em Orígenes, a visão antropológica maistreana também é ternária, isto é, um ser dotado de uma "percepção que apreende, de uma razão que afirma, uma vontade que quer" (Soirées, II Entretien), embora esta vontade, que ele identifica com a alma de Orígenes, tenha sido dividida pelo pecado original numa alma superior (voltada para a contemplação e imitação da divindade) e uma alma inferior e corpórea (voltada para o mundo material). Para mais detalhes, leia-se Marc Froidefont, Théologie de Jopseph de Maistre (Paris: Classiques Garnier, 2010), p. 173-179; Orígenes, Tratado sobre os Princípios, II. 10. 7.

93 J. de Maistre, Soirées, O.C., IV: 213 (IV Entretien).

${ }^{94}$ Pawel Matyaszewski, La philosophie de la société ou l'idée de l'unité humaine selon Joseph de Maistre (Lublin: Red. Wydawnictw Katolickiego, 2002), p.105.

95 Élcio Verçosa Filho, "The pedagogical nature of Maistre's thought", p. 195-196.

${ }^{96}$ Paul H. Beik, The French Revolution Seen From the Right. Social Theories in Motion,17891799 (New York: Howard Fertig, 1970), p. 66. 
recentemente, Carolina Armenteros ${ }^{98}$, o tradicionalismo maistreano, através de seu constante apelo à história como "política experimental", pode ter contribuído - como de fato o fez, através, por exemplo, de Saint-Simon, Philippe Buchez, Pierre-Joseph Proudon, Auguste Comte, etc ${ }^{99}$ - para o desenvolvimento das ciências sociais, permanece o fato de que Maistre não pretendia formular nenhuma ciência do e para o homem que não estivesse subordinada ao princípio e causa de tudo, a Providência divina, razão pela qual Stéphane Rials está certo ao afirmar que o autor das Considerações sobre a França é, antes de tudo, um "teólogo da política" ou um autor "metapolítico" e, como tal, preocupado em "esclarecer" (poderíamos dizer, decifrar) os mistérios acerca do "governo temporal da Providência" aos homens, conforme anuncia o subtítulo verdadeiramente paulino das Soirées. ${ }^{100}$

Se o humanismo maistreano cotejava a relação horizontal homem-homem (e nisto concordava com a leitura tradicional aristotélico-tomista, segundo a qual o homem é um zoon politikon), isto não implicava na formulação de uma teoria imanentista, mas, pelo contrário, no reforço do conhecimento transcendental de Deus pelo homem: o verdadeiro conhecimento do homem coincidia com o "cristianismo transcendental". Diferentemente dos deístas como Voltaire, que admitiam a necessidade instrumental/pragmática e imanente da religião, sobretudo para a parcela vista por eles como a mais "bruta" e menos esclarecida da humanidade (a maior parte, portanto) ${ }^{101}$ de modo que apenas uma minoria social e intelectualmente privilegiada poderia dar-se ao luxo de prescindir da religião revelada como guia para a reta conduta moral -, Maistre não fazia distinção social e de status entre os homens, pois todos (especialmente a elite aristocrática voltaireana, vista por ele como grandemente responsável pela

\footnotetext{
${ }^{97}$ Sheldon S. Wolin, Politics and Vision. Continuity and Innovation in Western Political Thought (Princeton: Princeton University Press, 2004), p. 322-323.

${ }_{98}$ Carolina Armenteros. "From Human Nature to Normal Humanity: Joseph de Maistre, Rousseau and the Origins of Moral Statistics." Journal of the History of Ideas , vol. 68, Number 1 (January 2007), p.128.

${ }^{99}$ Leia-se o excelente livro de Carolina Armenteros, The French Idea of History: Joseph de Maistre and his heirs 1794-1854 (London: Cornell University Press, 2011), especialmente o capítulo 8: "The Metapolitics of History: Socialism, Positivism and Tradition, 1820-1848".

100 S. Rials, "Des Considérations sur la France aux Soirées de Saint-Pétersbourg: Lecture de Joseph de Maistre", in: Jean Louis Darcel (org.), Les Soirées de Saint-Pétersbourg ou le Gouvernement Temporel de la Providence (Genève: Slatkine, 1993), p. 28 e 34.

101 Atitude que pode ser resumida pela frase: "Se Deus não existisse, seria preciso inventá-lo." Cf. Voltaire, Collection complète des Oeuvres de $M^{r}$ de ${ }^{* * * *}$ (Genève, 1771), p. 406. in: http://books.google.com.br/books?id=kQEUAAAAQAAJ\&pg=PA406\#v=onepage \&q\&f=false
} 
Revolução) tinham necessidade de consumir daquele "alimento", o verdadeiro "cimento" ${ }^{102}$ societário.

Como exemplo, portanto, do ethos humanista e pedagógico maistreano no interior de seu providencialismo, tome-se a resposta do saboiano para a questão proposta pelo duque Ferdinando de Brunswick a todas as lojas vinculadas ao movimento maçônico de Estrita Observância Templária ${ }^{103}$ em 1780: "qual é o verdadeiro fim da instituição maçônica?" A resposta maistreana encontra-se logo na epígrafe de abertura de sua Mémoire au Duc de Brunswick (1782) ${ }^{104}$ : "Aprendei, ó miserável! E aprendei as razões das coisas. O que somos? Por que viemos ao mundo?... Qual ordem nos foi dada?... Qual é o lugar da humanidade?" 105

Preocupado com a dispersão e a "anarquia" (vista aqui em termos de expansão dos princípios democráticos através da ideia rousseauniana de "soberania do povo") que caracterizavam a maçonaria de seu tempo e a afastavam de seu verdadeiro objetivo (promover ações sociais beneficentes, esclarecer os governos e, sobretudo, favorecer a unidade entre as denominações cristãs em torno do catolicismo para combater o filosofismo anticlerical), Maistre propunha um critério mais rigoroso para o recrutamento dos "irmãos" (os ingressantes deveriam jurar por escrito que acreditavam em Deus, na imortalidade da alma, e nas recompensas na vida futura) ${ }^{106}$, bem como um estreitamento do intercâmbio entre as diversas lojas que integravam a "república universal cristã", chegando a sugerir a criação de comitês de recrutamento e de correspondência para a consecução daqueles objetivos. ${ }^{107}$

${ }^{102}$ Maistre, Considerações sobre a França, Cap. 5.

${ }^{103}$ Dentre elas, a sua loja de Chambéry, a Parfaite Sincerité.

104 Apesar de sua leitura providencialista da Revolução Francesa coincidir com a "iluminação" de 1794 e aparecer claramente formulada apenas na longa Lettre à Mme Costa (agosto de 1794), julgamos correto afirmar, à guisa de S. Rials e P. Matyaszewski, que a ideia providencial da divindade estava presente no pensamento religioso de Maistre desde muito cedo, mais especificamente em sua educação fortemente jesuítica em Chambéry e nas práticas de religiosidade barroca locais (como a ativa participação em confrarias religiosas). Vide: P. Matyaszewski, La philosophie de la société ou l'idée de l'unité humaine selon Joseph de Maistre, op. cit., p. 106; Stéphane Rials, "Des Considérations sur la France aux Soirées de Saint-Pétersbourg: Lecture de Joseph de Maistre", op. cit., p. 32-34; J. Rebotton."Maistre's Religious Education" (1977), in: R. Lebrun (org.), Maistre Studies (New York: University Press of America, 1988), p. 78-95.

${ }^{105}$ Trata-se de uma citação das Sátiras de Pérsio (34 d.C.- 62 d.C.).

${ }^{106}$ Joseph de Maistre, Mémoire Adressé par Joseph de Maistre au Duc Ferdinand de BrunswickLunebourg, Grand-Maître de la Maçonnerie Écossaise de la Stricte-Observance, 1782, in: http://lamelagrana.net/wp-content/uploads/downloads/2011/11/Joseph-de-Maistre-M\%C3\%A9moire-auDuc-de-Brunswick.pdf, p. 13.

107 Joseph de Maistre, Mémoire au Duc Brunswick..., op. cit., p. 15. Por uma grande ironia do destino, foram precisamente esses dois mecanismos ou soluções práticas sugeridas pelo contra-Ilustrado e futuro contrarrevolucionário saboiano - as quais, apesar do conselho, nunca chegaram a ser aplicadas que permitiram ao clube jacobino se fortalecer após a dissolução da Constituinte e a "apostasia" 
Se considerarmos que o grande objetivo da maçonaria para Maistre deveria ser o conhecimento "das causas da aflição" de cada país e "dos meios de regeneração", observamos um núcleo comum (ainda que em sinais invertidos quanto às finalidades) nas propostas maistreana e Ilustrada, qual seja, o desígnio de educar/ilustrar os cidadãos para emancipá-los.

Mas as semelhanças não vão além disso e tampouco anulam a profunda diferença entre os respectivos projetos humanistas. Antes de mais nada, importa ressaltar, como fizeram respectivamente J. Rebotton ${ }^{108}$ e J.-Louis Darcel ${ }^{109}$, que não havia nada de herético no fato de um católico naquele contexto aderir à maçonaria. À diferença do que se passava na França e na maior parte da Europa, onde, conforme observou F. Furet, "um circuito de sociabilidade não [tinha] nenhuma comunicação com o outro" ${ }^{110}$, a vida religiosa da Sabóia apresentava uma interação entre esses circuitos, de modo que as congregações religiosas típicas da piedade barroca não só conseguiram sobreviver e conquistar novos adeptos até a Revolução Francesa, como inúmeros membros delas e das confrarias também integravam a maçonaria.

E conforme destacou Louis Trénard a respeito do rito escocês retificado do qual a loja de Maistre fazia parte, apesar de o mesmo refletir uma sede de conhecimento e de exaltar as possibilidades do homem características da Aufklärung, prevalecia no interior do mesmo o impulso esotérico que dizia ser o homem um espírito ferido que anela pelo retorno em Deus. ${ }^{111}$ Neste sentido, a postura de Maistre pode ser vista como exemplar. Após dizer que a maçonaria deveria se dedicar à verdadeira "ciência do homem", isto é,

revolucionária dos Feuillants sob a liderança de Barnave. Vide: Lucien Jaume, Le Discours jacobin et la démocratie (Paris: Fayard, 1989), cap. 2.

${ }^{108}$ Jean Rebotton, Jean Rebotton. "Maistre's Religious Education”, in: R. Lebrun (org.), Maistre Studies (New York: University Press of America, 1988), p. 95.

109 Jean-Louis Darcel. "The Sources of Maistrean Sensibility", in: R. Lebrun (org.), Maistre Studies..., p. 101-121.

110 De acordo com F. Furet, a monarquia absolutista pressupunha "um certo tipo de sociabilidade política, através da qual toda a sociedade [era] ordenada concêntrica e hierarquicamente em torno dela, que [era] o centro da vida social. Ela se [encontrava] no cume de um conjunto hierárquico de corpos e comunidades cujos direitos [garantia], e por intermédio dos quais [circulava] de alto a baixo a obediência." No século XVIII, os circuitos dessa sociabilidade política estão cada vez mais esvaziados de sua significação tradicional e de seu conteúdo simbólico, abrindo flancos para "um mundo novo, estruturado a partir do indivíduo, e não mais de seus grupos institucionais, mundo fundado sobre essa coisa confusa que se chama opinião e que é produzida nos cafés, nas lojas maçonicas e nas 'sociedades'. Podemos chamá-la de sociabilidade democrática, mesmo que sua rede não se estenda ao povo todo, para exprimir a ideia de que as suas linhas de comunicação formam-se 'embaixo' e horizontalmente, no nível de uma sociedade desagregada, onde um homem iguala-se a outro homem, entre os indivíduos dessa sociedade". Cf. F. Furet, Pensando a Revolução Francesa (Rio de Janeiro: Paz e Terra, 1989), p. 53-54.

${ }^{111}$ Louis Trénard, "Lumières et maçonnerie dans la seconde moitié du XVIII ${ }^{\mathrm{e}}$ siècle: Synthèse Introductive", Revue des Études Maistriennes n ${ }^{\circ}$ 5-6 (1979-1980), p. 34. 
às investigações sobre a "origem e a destinação" da humanidade ${ }^{112}$, o saboiano fez questão de lembrar que esses estudos deveriam ser orientados pela fé cristã revelada e, portanto, pela leitura das Escrituras:

"Provemos que não somos homens novos, mas façamos uma genealogia digna de nós. Abracemos, enfim, o Evangelho e deixemos aqui as tolices de Mênfis. Remontemos aos primeiros séculos da Lei santa. Folheemos a antiguidade eclesiástica. Interroguemos os Padres um após o outro. Reunamos, confrontemos as passagens. Provemos que somos cristãos. Vamos além. A verdadeira religião tem dezoito séculos. Ela nasceu no dia em que nasceram os dias."113

Ou seja, com o claro objetivo de conter o anticlericalismo e o materialismo filosóficos, Maistre avançou uma proposta pedagógica contrarrevolucionária avant la lettre (quanto aos meios e fins), a qual, identificando a verdadeira ciência do homem com o avanço do cristianismo e a reaproximação das denominações protestantes com o catolicismo (exceção feita ao calvinismo), via na promoção de um Cristianismo transcendente $^{114}$, baseado nos estudos filológicos e alegóricos das Sagradas Escrituras, como a melhor maneira de difundir a "ilustração" e a felicidade ao gênero humano.

Importa destacar que é possível identificar uma grande correspondência conceitual e metódica sobre a visão do cristianismo entre os neoplatônicos Ficino, Pico e Maistre. Pois embora afirmassem a superioridade do cristianismo sobre as demais religiões, tanto Ficino (através dos conceitos de pia philosophia ou prisci theologi avançados De religione Christiana), como Pico (através da noção de Teologia poetica, aludida na segunda parte da Oratio) e Maistre, concordavam que todas as religiões eram verdadeiras na medida em que representavam não apenas verdades reveladas (ainda que parcialmente), como confirmavam o cristianismo.

A este respeito, a posição de Ficino era declaradamente alexandrina (isto é, derivada tanto de Clemente como de Orígenes), pois ele foi categórico ao dizer, a exemplo de Clemente (referido na memória maçônica de Maistre), que os sábios pagãos

\footnotetext{
${ }^{112}$ Joseph de Maistre, Mémoire au Duc de Brunswick..., p. 8. Mais adiante, na página 17, lê-se: "O gênero humano está degradado, a terra divorciou-se do céu. Nossos supostos sábios, ridiculamente orgulhosos por algumas descobertas infantis, escrevem doutamente a respeito do ar fixo, volatizam o diamante, ensinam às plantas o quanto devem durar... mas cuidam para não condescender em perguntar uma única vez em suas vidas o que eles são e qual o seu lugar no universo. O entusiasmo sendo um fanatismo mil vezes mais criminoso do que aquilo que eles nunca cessam de deplorar, golpeiam indiferentemente a verdade e o erro, sem conhecer outro modo de atacar a superstição senão pelo ceticismo." Grifos nossos.

${ }^{113}$ Joseph de Maistre, Mémoire au Duc Brunswick..., p. 12. Grifos de Maistre.

${ }^{114}$ Joseph de Maistre, Mémoire au Duc Brunswick..., p. 18.
} 
- Platão e Proclo incluso - haviam aprendido diretamente dos Hebreus as suas noções sobre o Logos divino. ${ }^{115}$

Assim, enquanto o autor do De religione Christiana avançava sua noção de philosophia perennis afirmando que "toda religião tem algo de bom, contanto que a mesma esteja voltada para o próprio Deus"116, Maistre, por sua vez, e num ethos indelevelmente semelhante, afirmava nas Soirées que "não existe sistema religioso inteiramente falso" (ou "não pode haver religião falsa sem alguma mistura de verdade") ${ }^{117}$ ou ainda que "não há dogma cristão que não tivesse sido apoiado em qualquer tradição universal e tão antiga quanto o homem." ${ }^{118}$

Naquilo que podemos classificar como um ensaio pioneiro de religião comparada, Maistre acreditava ter encontrado junto aos Incas peruanos indícios das premissas do dogma cristão sobre a Trindade. Segundo Maistre: "O templo Ykapa deles foi erguido ao Trovão, ao Relâmpago e ao Raio. Não existe, talvez, um emblema mais justo, pois o relâmpago é a essência do fenômeno, o trovão ou o ruído, a sua palavra, e o raio..., a sua ação, e estas três coisas são apenas uma." ${ }^{119}$

Fundamental no sistema religioso maistreano, a convicção de que todas as religiões possuíam um fundo comum que não poderia ser outro a não ser Deus, e que mesmo as religiões "idólatras" continham reflexos (ainda que imperfeitos) da Revelação Primitiva: "as religiões pagãs aparecem-nos mais como desvios do que como erros", confessava Maistre. ${ }^{120}$ Portanto, mesmo que, em razão do livre-arbítrio, a crença primitiva comum tenha se corrompido "por aquela força que corrompera tudo" 121 (pecado original), permanece válido que "todas as tradições antigas são verdadeiras, que todo o Paganismo não é senão um sistema de verdades corrompidas e deslocadas, e que

115 Ficino, De religione Christiana apud C. Trinkaus, In our Image and Likeness, p. 741.

116 Ficino, De religione Christiana apud C. Trinkaus, In our Image and Likeness, p. 737. De acordo com Ficino, a Providência divina permitiu uma revelação universal - embora parcial - a todos os homens, reservando a revelação autêntica apenas ao povo eleito como parte de um plano para a abertura da revelação definitiva e a possibilidade de salvação para todos. Isto posto, "a Providência divina jamais permitiu que houvesse em qualquer época uma região qualquer inteiramente sem religião; (...) ela permitiu diferentes ritos de adoração em diferentes tempos e lugares", pois "Deus prefere ser adorado, ainda que inepta e humanamente, a não ser adorado ao final, em razão do orgulho humano." Idem, p. 737738.

${ }^{117}$ Citações extraídas respectivamente das Considerações sobre a França, cap. 10 e Essai sur le principe générateur des constitutions politiques, capítulo LXI.

118 Joseph de Maistre, Soirées, O.C., V:175 (X $\mathrm{X}^{\mathrm{e}}$ Entretien).

${ }^{119}$ E. Dermenghen, Pensées inédites de Joseph de Maistre (1817-1821), in: Le Correspondant, 25 de maio de 1922, t. 251, p. 636.

${ }^{120}$ E. Dermenghen, Pensées inédites de Joseph de Maistre..., p. 288.

${ }^{121}$ Joseph de Maistre, Éclaircissement sur les sacrifices, O.C., V:305. 
basta limpá-los, por assim dizer, e de recolocá-los no seu devido lugar, para vê-los resplandecer todos os raios." ${ }^{122}$

Independente das formas históricas que as religiões assumiram na economia providencial - e a qual só faz sentido se considerarmos o livre-arbítrio humano, pois, repitamo-lo, o grande Pedagogo (Providência) jamais força o aluno no processo de aprendizado -, todas contêm um "resíduo divino" ${ }^{123}$ e descendem da mesma árvore espiritual única e eterna, que é Deus. ${ }^{124}$

E como em Ficino e Pico, a philosophia perennis de Maistre serve para ilustrar a significação real do cristianismo, o seu papel primordial e único na história humana, e que faz dele, de acordo com o neoplatônico saboiano, "a única Religião verdadeira". É neste sentido que devemos compreender a afirmação maistreana da memória maçônica, e a qual sustenta que "a verdadeira religião tem bem mais do que dezoito séculos". ${ }^{25}$ Portanto, as analogias que Maistre estabelece entre as religiões pagãs e o cristianismo servem para demonstrar em que medida o último resume perfeitamente a crença universal e expressa o mesmo desígnio pedagógico da Providência. Em termos marxistas, poderíamos dizer que, para o autor das Considerações, o cristianismo era a chave da anatomia do paganismo.

Como escrevera Pico na Oratio em termos que Maistre certamente aprovaria, "as coisas que extraí dos antigos mistérios dos hebreus e citei [foram] para a confirmação da inviolável fé Católica." ${ }^{126}$ E assim como Maistre, Pico adotava Orígenes como modelo teológico e intelectual, pois o teólogo alexandrino admitia a existência dos sentidos misteriosos transmitidos pela poesia religiosa pagã e, sobretudo, pelas Escrituras:

"Orígenes sustenta que Jesus Cristo, o Mestre da Vida, fez inúmeras revelações a seus discípulos, as quais eles preferiram não escrever sob o temor de que se tornassem trivialidades junto ao vulgo. Isto foi confirmado no mais alto grau por Dionísio, o Areopagita, que diz que os

\footnotetext{
${ }^{122}$ Joseph de Maistre, Soirées, O.C., V:239 (XI Entretien).

${ }^{123}$ Joseph de Maistre, Éclaircissement sur les sacrifices, O.C., V:311.

124 Não por acaso, um teólogo contemporâneo não teve dúvidas ao afirmar que, ao menos no que tange ao debate inter-religioso, o tradicionalismo cristão de Maistre está plenamente "conforme ao ensinamento do Concílio do Vaticano II em sua Declaração sobre as relações da Igreja com as religiões não-cristãs." Cf. p. Jean-Louis Soltner, "Le Christianisme de Joseph de Maistre", in: Revue des Études Maistriennes, $\mathrm{n}^{\mathrm{o}}$ 5-6 (1980), p. 103.

${ }_{125}$ Joseph de Maistre, Mémoire au Duc de Brunswick, op. cit., p. 12.

${ }^{126}$ Pico della Mirandola, Oratio apud C. Trinkaus, In our Image and Likeness..., 756.
} 
mistérios ocultos foram transmitidos pelos fundadores de nossa religião... de mente para mente, sem a escrita, por meio da palavra." ${ }^{127}$

Para Orígenes (e também para Pico e Maistre), a principal tarefa do pedagogo cristão consistia em traduzir os mistérios da revelação e da Providência - termo este já presente na memória maçônica - para os homens desabituados ou incapazes de pensá-la corretamente por si próprios, o que pressupunha a adoção de uma dupla doutrina: uma complexa e esotérica, reservada aos indivíduos devidamente treinados para discuti-la, e outra, que conciliasse a esperança com o medo, para os espíritos mais simples ou simpliciores, isto é, aqueles que, diferentemente do amigo de Cristo e do Espírito Santo - o indivíduo contemplativo e versado nos estudos das Sagradas Escrituras - são os cristãos que se contentam em conhecer apenas a superficialidade material da realidade divina e, em razão disso, não raro incorrem no erro de interpretar literalmente as passagens bíblicas misteriosas. ${ }^{128}$

No caso de Maistre, esta paideia cristã tinha a vantagem adicional de representar uma importante arma contra o protestantismo e seu hábito de separar as Escrituras da tradição católica encarregada de explicá-la: como mostrara Orígenes (e, posteriormente, Pico), os apóstolos transmitiram os arcanos sagrados apenas verbalmente, de modo que os emblemas dos mesmos encontram-se diluídos na tradição. A exemplo de Pico na Oratio, o Maistre das Réflexions sur le protestantisme (1798) deixa claro que a "Palavra" ou "Verbo" divinos tomam procedência sobre as Escrituras: o Verbo é a ação criadora, a vida, ao passo que a Escritura é apenas a sua imagem ou tradução. ${ }^{129}$

Conclui-se, pois, que o apelo à teologia da imagem servia perfeitamente ao desígnio maistreano de combater a teofobia do século XVIII $^{130}$ e o efeito cultural destrutivo que o mesmo provocava ao reduzir a dimensão ontológica do homem apenas ao aspecto biológico-natural.

${ }^{127}$ Pico della Mirandola, Oratio apud C. Trinkaus, In our Image and Likeness..., p. 756-757.

${ }^{128}$ Orígenes, Princípios, I. 6. 4. Sobre a defesa da dupla doutrina eucarística, II. 7. 3.

129 Jérôme Alexandre, "Joseph de Maistre et le peché originel", op. cit., p. 86. Importa observar que a crítica de Erasmo ao dogmatismo "carnal" da Igreja foi igualmente inspirado na teologia da dupla doutrina de Orígenes. Curiosamente, Maistre definirá a superioridade e universalidade do cristianismo precisamente pela ausência dos dogmas, cuja existência, segundo ele, deveu-se apenas às heresias (sendo a maior delas o protestantismo, responsável por criar o Concílio de Trento), nunca ao fundador da fé e/ou a seus apóstolos/discípulos. Cf. Thomas P. Scheck, Origen and the History of Justification..., p. 144-146; Joseph de Maistre, Essai sur le principe générateur, capítulos XV e XVII.

${ }^{130}$ J. de Maistre, Soirées, O.C., IV:282 (IV ${ }^{\mathrm{e}}$ Entretien). 
Isto não se deu por acaso. Afinal, o organizador da Encyclopédie, Denis Diderot (1713-1784) - a quem Maistre se referiu como um "energúmeno"131 - não hesitou em dizer, em termos muito próximos daqueles que futuramente seriam utilizados pelo jovem Marx, que "não é Deus quem fez o homem à sua imagem", mas "os homens que, todos os dias, fazem Deus à sua"? ${ }^{132} \mathrm{E}$ o redator do verbete Homem para a Encyclopédie, ninguém menos do que Voltaire (1694-1778), não aludiu à imago Dei em um sentido marcadamente depreciativo e sardônico para se referir ao homem natural? ${ }^{133}$

Ademais, no mesmo artigo Voltaire dirigiu uma severa crítica a Pascal, pelo fato de o agostiniano e neoplatônico de Port-Royal haver identificado o pensamento com a essência humana, o que ia de encontro com a sua epistemologia sensualista, fundamento de sua antropologia biológico-naturalista. Nas palavras de Voltaire (que reproduz Pascal em itálico):

"Posso conceber um homem sem mãos, sem pés, e eu o conceberia até mesmo sem cabeça, se a experiência não me dissesse que é graças a ela que ele pensa. É, pois, o pensamento que constitui o ser do homem, e sem o qual não se pode concebê-lo... Como conceber um homem sem pés, sem mãos e sem cabeça? Isto seria um ser tão diferente do homem quanto uma abóbora... Se todos os homens fossem sem cabeça, como a vossa conceberia que são animais como vós, pois não teriam nada daquilo que constitui principalmente o vosso ser? Uma cabeça é alguma coisa; os cinco sentidos encontram-se nela; o pensamento também." ${ }^{134}$

Ainda que Maistre não tenha respondido a Voltaire neste ponto preciso, é certo que ele conhecia no detalhe a obra do mesmo, a ponto de mais de um autor haver considerado o contrarrevolucionário saboiano um Voltaire rétourné (isto é, às avessas). ${ }^{135}$ Não raramente, Maistre utilizava citações de Voltaire - "cujo coração", de

${ }^{131}$ É assim que Maistre se refere a ele nas Soirées (VI ${ }^{\mathrm{e}}$ Entretien), talvez inspirado pelo tratamento semelhante com que Voltaire dispensara a Rousseau no artigo "Homem" para a Enciclopédia. Cf. Voltaire, "L'Homme", in Oeuvres Complètes de Voltaire, vol. VII (Paris: Furne, 1835), p. 694.

${ }^{132}$ Diderot, Mémoires pour Catherine II, citado por Marian Skrypek, "Diderot théoricien de la religion", Raison Présente, no 67 (1983), p. 20.

133 "... é preciso com frequência que no norte da América uma imagem de Deus percorra de cinco a seis milhas para obter seu jantar, enquanto entre nós a imagem de Deus irriga a terra com os seus suores por todo o ano para obter o pão"? Vide: Voltaire, "L'Homme", in: Oeuvres Complètes de Voltaire, vol. VII, p. 696.

${ }^{134}$ Voltaire, "L'Homme", in Oeuvres Complètes de Voltaire, vol. VII, p. 696.

135 Como o importante historiador e, ao lado de Richard Lebrun, responsável pela renovação dos estudos maistreanos a partir do último quarto do século XX, Jean-Louis Darcel. Vide: J. de Maistre, Considérations sur la France, (org.)., J.-L. Darcel, (Genève: Slatkine, 1980), p. 44. 
acordo com ele, "não valia nada", mas cuja cabeça era "perfeitamente sã"136 - para rebater uma opinião de outro ilustrado, como foi o caso do Discours de Rousseau:

"Vale dizer que o livro de Rousseau é feito para saber o que teria se tornado o gênero humano se não houvesse Deus, ou se os homens tivessem agido sem o seu conhecimento... Eis, é preciso admiti-lo, um livro bastante útil! Voltaire... fez muito bem ao não responder a esta obra senão com uma piada."137

Sabemos que a piada em questão refere-se à célebre boutade anatômica em que Voltaire declara ter tido vontade de andar de quatro patas após a leitura do discurso rousseauniano. Mas, como vimos acima, nem por isto Voltaire deixou de integrar o homem no reino animal e a vincular sua inteligência aos sentidos, uma suposição epistemológica plena de consequências metafísicas, sendo a principal delas a negação do homem como imago Dei.

Apesar do estado de degradação provocado pelo pecado original, tanto Orígenes como Maistre insistiam na dignidade ontológica do homem ${ }^{138}$ e, portanto, no livrearbítrio do mesmo, sem o qual não se poderia explicar a existência do mal no mundo, por ser ele resultado da vontade humana corrompida. "Todo crime sendo o ato de uma vontade livre, resulta disso que todo suplício podia ser prevenido" ${ }^{139}$, adverte Maistre sobre a punição divina em um tom muito parecido com o de Orígenes, segundo o qual "Deus fará sofrer todos aqueles que, tendo sido formados à sua imagem, não viveram de uma maneira consoante à que exigia deles uma natureza formada à imagem de Deus." ${ }^{140}$

E é sobretudo no terceiro livro de seu Tratado sobre os Princípios que se encontra de maneira clara a defesa de Orígenes do livre-arbítrio:

${ }^{136}$ Joseph de Maistre, De l'état de nature, O.C., VII: 529.

${ }^{137}$ Joseph de Maistre, De l'état de nature, O.C., VII: 529.

138 "Não vos deixeis seduzir pelas teorias modernas sobre a imensidão de Deus, sobre nossa pequenez e sobre a loucura em que nós incorremos ao querer avaliá-lo por nós mesmos, belas frases que não tendem em absoluto a exaltar a Deus, mas a degradar o homem." Cf. Joseph de Maistre, Soirées, IV Entretien.

139 Joseph de Maistre, Soirées, IV ${ }^{\mathrm{e}}$ Entretien.

${ }^{140}$ Orígenes, Traité d'Origène Contre Celse..., p. 201. 
"Pois a pregação eclesiástica contém igualmente a promessa do justo julgamento de Deus, o qual, uma vez aceito como verdadeiro, impulsiona e persuade os homens a viverem retamente e a fugir por todos os meios do pecado, convencidos de que depende de nós praticar atos dignos de elogio ou de culpa..."141

Diante da questão de como conciliar o livre-arbítrio com a onipotência divina, Orígenes lançou mão dos argumentos do livro III da Ética a Nicômaco de Aristóteles (de quem, diga-se, costumava ser crítico) para mostrar o que havia de voluntário no homem. Adaptando a explicação do Estagirita para a filosofia cristã, Orígenes sustentou que Deus atribuiu ao homem "noções comuns de vício e de virtude"142, mas que nem por isto ele seria menos livre ou incapaz de pecar: "Deus conduz todas as coisas sem perturbar a liberdade de nossos atos..., sem perturbar a contingência dos acontecimentos." $^{143}$

Neste sentido, Maistre não poderia estar mais de acordo com o alexandrino quando, também nas Soirées, destacou que "Deus, sem dúvida, é o motor universal, mas cada ser é movido segundo a natureza que ele recebeu."144

Mas talvez o maior dos dilemas impostos ao cristianismo por seus adversários pagãos (antigos e modernos) é o que se expressa pela paradoxal convivência entre liberdade humana e onisciência divina, uma verdadeira quadratura do círculo que, do Renascimento à Reforma e à Filosofia das Luzes, impôs-se aos apologistas católicos.

Em uma anotação de 1809 de seu Registro de Leituras, o então embaixador sardo na corte do czar teceu o seguinte elogio a respeito da resposta de Orígenes para o referido dilema:

"Orígenes tinha sobre a predestinação ideias completamente semelhantes àquelas que Molina tornou célebres. Sobre essas palavras de são Paulo: Quos autem praedestinavit (Romanos 8: 30), ele diz: 'Deus, que conhece o futuro e o uso que nós faremos de nossa liberdade, conhece aqueles que se entregarão à virtude e os predestina em virtude deste conhecimento... Não se deve crer que essa prenoção seja a causa das ações, mas ela existe por causa destas ações produzidas livremente... O que é precisamente a ciência mediana. Ele observa em seguida, com grande acerto, que aquilo que acontece certamente, nem por isto acontece necessariamente; pois, ele acrescenta, 'supondo que somos realmente livres, Deus

\footnotetext{
${ }^{141}$ Orígenes, Tratado sobre os Princípios, III, 1; I Principi, op. cit., p. 365.

${ }^{142}$ Orígenes, Traité d'Origène Contre Celse..., p. 3.

${ }^{143}$ Orígenes, Traité d'Origène Contre Celse..., p. 204.

144 Joseph de Maistre, Soirées, O.C., IV:275 ( $\mathrm{V}^{\mathrm{e}}$ Entretien).
} 
preverá ou não nossas ações? Se dissermos que não, ignoramos inteiramente a natureza divina. Se respondermos afirmativamente, segue-se que este conhecimento não prejudica em nada a nossa liberdade.' "145

Diante do que foi exposto, resta a questão de como conciliar o humanismo maistreano, o qual pressupõe a dignidade humana em termos de imago Dei e o livrearbítrio, com sua leitura providencialista da Revolução Francesa e do Terror. É o que procuraremos fazer a seguir.

${ }^{145}$ Joseph de Maistre, Registre de lectures D, p. 4. 
Após a invasão da Saboia pelas tropas francesas (em 22 de setembro de 1792) e uma efêmera e malograda tentativa de adaptação ao novus ordo seclorum na Chambéry revolucionária ${ }^{146}$, Maistre emigra para Lausanne e inicia sua carreira diplomática (como correspondente do governo piemontês em Berna) ${ }^{147}$ e contrarrevolucionária.

Assim que se estabeleceu em Lausanne, no dia 13 de abril de 1793, Maistre se encontrou com o renomado publicista e contrarrevolucionário suíço Jacques Mallet du Pan (1749-1800), que, ao lado do barão saboiano Vignet des Etoles ${ }^{148}$, o incentivou a redigir as quatro primeiras Cartas saboianas (meados de abril) ${ }^{149}$.

Profundamente inspiradas pela leitura das Reflexões sobre a Revolução em França (1790) de Edmund Burke, as Lettres empreendiam uma apologia dos "excelentes preconceitos" $" 150$ - os quais, oriundos da sabedoria das nações e dos particularismos locais, seriam os responsáveis, no domínio do direito, por adaptar as leis "ao gênio dos povos"151 - e da história, que demonstra a impossibilidade da igualdade e a inevitabilidade de que uma aristocracia qualquer governe, mesmo nas repúblicas. ${ }^{152}$

De acordo com Maistre, a torrente revolucionária só poderia ser contida por meio de uma ação eficaz das velhas monarquias junto à opinião pública de seus respectivos países, pois, do contrário, o proselitismo revolucionário, com suas "falsas" e "cômodas" noções de "liberdade, igualdade, direitos do homem, soberania do povo"153, espalharse-ia pelo continente europeu como "moedas falsas". ${ }^{154}$

${ }^{146}$ Por decreto da Convenção Nacional, a Saboia fora anexada à França republicana em 18 novembro de 1792 com base na teoria das "fronteiras naturais".

${ }^{147}$ Nomeado em 3 de agosto de 1793, o cargo equivalia à função de cônsul e garantia-lhe um pífio salário de 100 libras ao ano, apesar do trabalho acachapante a que era submetido - leitura e redação de correspondências e memorandos para informar Turim sobre as condições da Sabóia, prestação de ajuda humanitária aos emigrados, etc.

${ }^{148}$ Responsável pela reforma da justiça na província da Saboia e futuro embaixador do reino do Piemonte-Sardenha em Berna.

${ }^{149}$ Lettres d'un royaliste savoisien a ses compatriotes, a quais se encontram reunidas no sétimo volume das Oeuvres Complètes de Maistre.

${ }^{150}$ Joseph de Maistre, Lettres d'un royaliste savoisien..., O.C., VII:154 ( $3^{\mathrm{a}}$ Lettre).

${ }^{151}$ Idem, p.151 ( $3^{\mathrm{a}}$ Lettre $)$.

152 Ibid.,p. 225 ( $4^{\mathrm{a}}$ Lettre).

153 Joseph de Maistre, Lettres d'un royaliste savoisien a ses compatriotes (O.C., VII: 89, $1^{\mathrm{a}}$ Lettre).

154 Joseph de Maistre, Soirées, I Entretien: "Mas as opiniões falsas são como uma moeda falsa que é inicialmente cunhada por grandes culpados e, posteriormente, circulada por pessoas honestas, que perpetuam o crime sem saber que o fazem." 
Nas Cartas, Maistre denuncia a prática dos revolucionários (descritos como "raça bárbara" ${ }^{155}$ ) em nome dos mesmos princípios - "sistemas aéreos fundados unicamente naquilo que se denomina a razão"156 - que os animaram: em nome da Liberdade, da Igualdade e dos Direitos do Homem, os revolucionários violavam as liberdades, as consciências, e a justiça, resultando naquilo que Maistre designaria como "guerra civil do gênero humano", o solapamento do Estado de Direito que ele, bem ou mal, identificava com a monarquia absoluta piemontesa.

Em contraste com a interpretação providencialista das Considerações, as análises e as sugestões presentes nas Lettres tinham como base os fatores imanentes da dinâmica política. Ainda que tenha se referido à Providência naquelas cartas redigidas como panfletos, ela ainda não desempenhava um papel dominante como fator explicativo do fenômeno revolucionário. Nas Lettres, portanto, a Revolução Francesa era retratada como uma consequência dos abusos e fraquezas do Antigo Regime, assim como da sedução da opinião pública pelos homens de letras. ${ }^{157}$

Conforme dissemos acima, o governo de Turim não apenas ignorou a mensagem implícita sobre a necessidade das reformas para evitar o contágio revolucionário, como identificou nelas uma crítica velada à monarquia, razão pela qual proibiu sua venda nos domínios do reino. $^{158}$

Apesar da precariedade de sua situação política junto ao seu governo, o correspondente saboiano em Lausanne recusava-se a alterar suas convicções políticas. No início de dezembro de 1793, confidenciou a Vignet des Etoles, seu superior imediato, a seguinte crítica a seu governo:

“A meu ver, o projeto de engarrafar a água do lago Genebra é menos insano que o de restaurar as coisas precisamente sobre as mesmas bases em que estavam antes da Revolução... O governo militar é algo que sempre detestei, que detesto agora e detestarei pelo resto de minha vida; todavia, prefiro isto ao jacobinismo. É melhor do que a coisa mais execrável do mundo, eis o único elogio que se possa fazê-lo... Se este belo governo, que é a morte da monarquia, for

${ }^{155}$ Lettres d'un royaliste savoisien à ses compatriotes (O.C., VII:186, $4^{\mathrm{a}}$ Lettre).

${ }^{156}$ Idem, p. 166 (4 Lettre).

157 "Os governos da Europa tinham envelhecido e sua decrepitude era bem conhecida apenas para aqueles que queriam tirar proveito da situação para a execução de seus projetos mortais. Não havia mais coesão, espírito público, energia; uma revolução era inevitável."'In: Lettres d'un royaliste savoisien a ses compatriotes, O.C., VII: 84 ( $1^{\mathrm{a}}$ Lettre).

${ }^{158}$ Numa carta a Vignet des Etoles de 1798, confessaria ter queimado os manuscritos das Lettres, pois os mesmos, segundo ele, foram escritos numa época em que não possuía "a menor iluminação sobre a Revolução francesa, ou melhor, europeia." In: J.-Yves Pranchère, L'autorité contre les Lumières..., p. 36 . 
restaurado, direi o que sempre afirmei: 'Obedeça'. Desculparei os excessos mais escandalosos com o mais filial dos tons. Porém, se por acaso a monarquia for restaurada e separada da bâtonecratie ["governo do porrete"], espero que me permitais ficar contente." 159

Em outra missiva (datada do início de 1794), além de reiterar as críticas a seu governo - inserindo-as num quadro mais amplo de crise do Antigo Regime e de incapacidade de regeneração do mesmo diante de uma revolução total -, Maistre, enfim, confidencia sua "iluminação" providencialista a respeito da Revolução Francesa:

"Há muito que sabeis meu modo de pensar. Por muito tempo suspeitei e agora acredito estar em posição de afirmar que estamos experimentando uma grande época ${ }^{160}$, uma Revolução geral... Para ser franco - e que isto fique entre nós -, acredito firmemente que a Monarquia foi irremediavelmente golpeada (refiro-me à monarquia absoluta) e que resta apenas um meio de se salvar, que é o de se transformar e ganhar as mentes dos povos. Infelizmente, é justamente isto que não fará. Pensa apenas em não recuar. Vereis aonde isso nos conduzirá. $O$ julgamento imposto à monarquia é visível." 161

Portanto, entre o final de 1793 e início de $1794^{162}$, e talvez como um antídoto para não entrar em desespero existencial diante do fracasso da ofensiva austríaco-piemontesa e do recrudescimento do Terror na França, Maistre começa a amadurecer sua leitura providencialista e, vale dizer, marcadamente origeniana do fenômeno revolucionário que o tornaria célebre. Esta interpretação ganhou sua primeira versão completa no Discurso de consolação à Mme. Costa, o qual, redigido entre 29 e 31 de maio de 1794 em ocasião da morte do jovem Eugênio durante a ofensiva militar piemontesa, foi curiosamente publicado em agosto daquele mesmo ano, em Lausanne, mediante a insistência dos padres emigrados franceses.

${ }^{159}$ J. de Maistre, "Carta a Vignet des Etoles", nove de dezembro de 1793, in: R. Lebrun, Joseph de Maistre: An Intellectual Militant (Kingston and Montreal: McGill-Queen's University Press, 1988), p. 129.

${ }^{160}$ Grifos nossos.

${ }^{161}$ J. de Maistre, "Carta a Vignet des Etoles de 6 de janeiro de 1794", in: Jean-Louis Darcel, "La conversion de Joseph de Maistre", Annales historiques de la Révolution française, 1978, n 231, p. 89.

${ }^{162}$ Numa carta a Vignet des Etoles (22 de março de 1794), Maistre faz o seguinte comentário a respeito dos massacres de Lyon: "Aguardo apenas infortúnios até que verdadeiros milagres restaurem a ordem". Noutra carta (26 de abril de 1794) ao mesmo destinatário, faz o seguinte pronunciamento, após relatar a invasão francesa ao Piemonte: "O julgamento de Deus segue seu curso... Não vos espanteis pela cegueira geral, mesmo da parte dos padres e nobres: esta cegueira é necessária para a execução dos desígnios da Providência”. Cf. R. Lebrun, Joseph de Maistre: An Intellectual Militant, p. 132. 
O discurso deixava claro que seu autor atingira uma interpretação original e, se nos for permitido expressar assim, origenista da Revolução, e a qual já continha em germes os principais temas de seu tradicionalismo providencialista, quais sejam: a ideia da Revolução como punição/pedagogia divina, o sacrifício dos inocentes e a reversibilidade das penas, bem como a crítica à epistemologia científica da Ilustração. Além disso, o discurso representou o primeiro escrito em que Maistre colocou em prática seu desígnio pedagógico cristão em meio à turbulência revolucionária, e o qual procurava desvendar os mistérios do governo da Providência para um(a) simplicior, no caso a Mme Costa. ${ }^{163}$

Após declarar logo na abertura da carta que a Revolução constituía uma "época"164, isto é, que ultrapassava todas as relações normais de causa e efeito, Maistre anunciou o fundo teológico-moral que estava por trás da mesma. "Cúmulo da absurdidade e da corrupção moral", a Revolução era "eminentemente perigosa para os povos" em razão de seu caráter enfermiço, pois "a sanidade não é contagiosa", mas "a doença é que, mui amiúde, o é." Em seguida, o saboiano detalhou a natureza daquela enfermidade política como "uma expansão do orgulho imoral, livre de quaisquer limites", o que explicava o "espantoso proselitismo" que agitava "toda a Europa". ${ }^{165}$

Para ele, a Revolução Francesa (e europeia) era um produto do progressivo abandono da "paideia cristã" pelos franceses, abandono este promovido pelos philosophes e seus acólitos, os quais, mais preocupados em "fazer sábios" do que "homens", incorreram no grave erro de apresentar "a moral como uma tese, não como um código", menosprezando "a simplicidade antiga e a educação religiosa". ${ }^{166}$

Em termos pedagógicos origenista-maistreanos, poderíamos dizer que a ênfase na epistemologia ilustrada - e Maistre elogia o casal Costa justamente por ter preservado o seu filho Eugenio o máximo possível daquela influência, substituindo-a pela educação

\footnotetext{
${ }^{163}$ Não por acaso, a mãe do falecido militar confidenciou a seu marido e grande amigo de Maistre, Henry Costa, que o conteúdo da carta parecera-lhe mais político do que consolador, demonstrando assim sua profunda incompreensão (apesar do esforço pedagógico do correspondente saboiano) do conteúdo eminentemente teológico e consolador da missiva. Vide: R. Lebrun, Joseph de Maistre: An Intellectual Militant, p. 133.

164 "É preciso ter a coragem de confessá-lo, Madame: por muito tempo, não compreendemos a revolução da qual somos testemunhas; por muito tempo, nós a tomamos por um acontecimento. Estávamos errados: [a revolução] é uma época; e infelizes as gerações que assistem às épocas do mundo! Felizes mil vezes os homens que não são chamados a contemplar na história as grandes revoluções, as guerras gerais, as febres de opinião, os furores partidários, os choques dos impérios e os funerais das nações!" J. de Maistre, Discours à Mme. la Marquise de Costa sur la vie et la mort de son fils Eugène (1794), in: Philippe Barthelet (org.), Joseph de Maistre: les dossiers H (Paris: L'Age d'Homme, 2005), p. 39.

${ }^{165}$ J. de Maistre, Discours à Mme. la Marquise de Costa, p. 32.

166 J. de Maistre, Discours à Mme. la Marquise de Costa, p. 28.
} 
tradicional clássico-humanista e, il va sans dire, jesuítica (a mesma que Maistre recebera e posteriormente recomendaria aos russos) - ensejava o "abandono" ou "relaxamento" da ação contemplativa e, consequentemente, um bloqueio da comunicação humana com o divino. Embora não extraia todas as consequências desta premissa na carta, a lógica subjacente não pode ser outra: ao separar os jovens do princípio divino transmitido pela tradição, a pedagogia filosófica desinteressou a alma dos homens pelo "exercício" da contemplação, que é a fonte das virtudes morais e práticas e, sobretudo, o cimento social que une o homem aos seus semelhantes na sociedade ${ }^{167}$ :

"Os charlatães modernos, que usurparam e difamaram o título de philosophes, ditaram métodos bem diferentes: trabalharam sem trégua para separar a moral da religião; disseram ainda que não existia a moral, que esta ciência ainda estava no berço. Recomendaram-nos sobretudo não entregar aos padres os primeiros anos do homem. Um deles chegou até mesmo a sustentar que não se devia falar de Deus às crianças ${ }^{168}$; paradoxo que se aproxima o bastante da demência para não excitar a não ser a piedade." 169

Para entendermos todas as implicações desta clara alusão a Rousseau do Emílio na economia providencialista do Discurso, precisamos revisitar alguns postulados providencialistas que Maistre avançou no seu ensaio anti-rousseauniano De l'état de nature, cuja redação deu-se num período imediatamente posterior ao da carta de consolação acima. ${ }^{170}$

Com o objetivo de refutar a hipótese rousseauísta em torno da bondade do homem natural e implodir seu potencial político revolucionário, Maistre apelará à história como valor normativo para o julgamento da política:

167 Conforme sublinhou Samuel P. Huntington, a "sociedade" constitui o "credo", o tema onipresente do pensamento tradicionalista. Cf. S. Huntington, "Conservatism as an Ideology", in: The American Political Science Review, vol. 51, n 2, (Junho de 1957), p. 454-473.

${ }^{168}$ Claramente, o padre em questão é o vigário saboiano do Emílio (1762) de Rousseau.

169 J. de Maistre, Discours à Mme. la Marquise de Costa, p. 29-30.

${ }^{170}$ No final de março de 1794, Maistre envia o rascunho daquela que deveria ser a quinta Carta saboiana a François de Bovet, antigo bispo de Sisteron, que lhe recomenda as leituras do Discurso sobre a desigualdade dos homens e do Contrato Social de Rousseau, uma vez que as ideias do "Cidadão de Genebra" pouco apareciam na carta. Assim, entre julho 1794 e meados de 1795, Maistre trabalhou simultaneamente nos dois tratados políticos de refutação a Rousseau, os quais nada mais são senão desdobramentos da Quinta Carta saboiana: o De la souveraineté du peuple e o De l'état de nature, ambos inacabados e publicados postumamente, em 1870. 
"Não se pode imaginar conhecer o destino do homem a não ser de duas maneiras: a história e a anatomia. A primeira mostra o que ele sempre foi; a segunda..., como seus órgãos respondem à sua destinação e a certificam... Para conhecer a natureza do homem, o meio mais curto e mais sábio é incontestavelmente o de saber o que ele sempre foi. Desde quando as teorias podem se opor aos fatos? A história é a política experimental, é a única, ou melhor, a única boa." ${ }^{171}$

Apesar de Rousseau construir uma hipótese sobre o passado da humanidade, não podemos esquecer que seu pensamento político estava orientado para um futuro utópico (a despeito de suas inúmeras declarações ao contrário e que anunciavam um pensador mais pessimista, sobretudo quanto à viabilidade e aos resultados das revoluções) ${ }^{172}$, posto que não acreditava no retorno à era de ouro da "sociedade nascente" (na renúncia às infelizes aquisições que a sociedade fizera), mas na criação artificial da ordem através do Estado e, mais especificamente, pela ação de um Legislador que fosse capaz de suprimir o "amor-próprio" (a sua versão leiga para o pecado original) por meio da persuasão e sem jamais apelar à força, de modo que os homens assimilassem seus "eus" particulares na vontade geral. ${ }^{173}$

Ao apelar à história como "política experimental", Maistre pretendia subverter o sentido progressista do tempo ${ }^{174}$, identificando o sentido normativo de sua política ao que fosse concreto e empiricamente provado: a seu ver, "o homem imaginário dos filósofos" era "estranho à política", pois ela "só trabalha sobre o que existe... Se

171 Joseph de Maistre, De l'état de nature, O.C., VII: 539-540.

172 Conforme sublinhou Colette Ganouchaud, Rousseau não acreditava que um Estado qualquer pudesse ser instituído pela via revolucionária, uma vez que o próprio momento de instituição é um período de crise, que só cessa com a paz e a abundância. Do contrário, ou seja, quando um governo for estabelecido num desses momentos de crise ou revolução (que Rousseau compara às "tempestades" políticas), estaremos diante de governos usurpadores que destroem o que restava de são no Estado. Mesmo que um novo governo substitua o anterior, Rousseau insiste no fato de que o corpo político foi destruído e as novas leis não resultam da vontade livre e racional do povo: se são aceitas, é porque o povo ficou impedido de raciocinar diante do cortejo de violência e corrupção que o atormenta. Cf. C. Ganouchad, "Révolution et opinion publique chez Rousseau: autour des idéaux de liberté, d'égalité et de fraternité", in: Colette Ganochaud, "Révolution et opinion publique chez Rousseau: autour des idéaux de liberté, d'égalité, de fraternité", in: Studies on Voltaire and Eighteenth Century, no 324 (1994), p. 2.

${ }^{173}$ Vide: C. Kelly. "To Persuade without Convincing: The Language of Rousseau's Legislator", in: American Journal of Political Science, vol. 31, n 2, 1987.

174 " Para o pensamento progressista, tudo deriva seu sentido, em última análise, de algo que está acima ou além dele, de uma utopia futura ou de sua relação com uma norma transcendente. O conservador, ao contrário, busca todo o sentido de uma coisa no que está atrás dela, seja em seu passado temporal ou em seu germe evolutivo. Onde o progressista usa o futuro para interpretar as coisas, o conservador usa o passado; o progressista pensa em relação a normas, o conservador, em relação a germes." Cf. Karl Mannheim, "El Pensamiento Conservador", in: Ensayos sobre Sociología y Psicología Social (México: Fondo de Cultura Económica, 1963), p. 124-125. 
perguntarmos à história o que é o homem, a história nos responderá que o homem é um ser social, e que sempre o observaram em sociedade." ${ }^{175}$

Profundamente amparado na distinção burkeana (aristotélica) ${ }^{176}$ entre saber teórico (sofia) e o saber prático/prudencial (fronesis) que via na experiência uma "garantia, uma segurança contra o erro"177, importa observar que o empirismo maistreano não deve ser confundido com o método experimental do século XVIII ${ }^{178}$ - e do qual, diga-se, o próprio Burke era confessadamente despositário, como bem demonstrou Leo Strauss ${ }^{179}$ - pois a conquista maistreana do saber histórico expressa menos o resultado do livre exercício de nossas faculdades sobre um determinado objeto (escolhido e manuseado/"torturado" pela ação humana) do que a sabedoria humana aferida pelas lições providenciais da história. E quando se trata de descobrir a natureza humana, a história ensina que a natureza do homem é ser social:

"Por onde quer que o homem pôde observar o homem, ele sempre o encontrou em sociedade: este estado é, pois, para ele, o estado de natureza. Pouco importa que esta sociedade seja mais ou menos aperfeiçoada entre as diferentes famílias humanas: é sempre a sociedade. Os próprios selvagens não fazem exceção..., pois eles também vivem em sociedade."180

À primeira vista, portanto, a refutação maistreana a Rousseau guarda estreita semelhança com a concepção ilustrada da sociabilidade natural humana, e a qual, de Locke a Voltaire, insistia que o homem, sendo um animal sociável, não fora feito para viver isolado. Entretanto, não se pode esquecer que esta concepção antropológica do século XVIII, amparada na noção de sociabilidade natural do homem, era acima de tudo

175 Joseph de Maistre, De l'état de nature..., O.C., VII: 541.

176 Cf. Diferentemente de I. Berlin (segundo o qual Maistre não foi discípulo de Burke) e Pranchère, para quem a adoção da tese providencialista por Maistre a partir de 1794 foi antes o resultado de uma ruptura, e não de um desenvolvimento doutrinal dos temas teóricos de Burke, concordamos com a tese de Pawel Matyaszewski, que associou o conservadorismo maistreano a um desenvolvimento tradicionalista e providencialista das doutrinas do conservador irlandês. Vide Pawel Matyaszewski, $L a$ philosophie de la société ou l'idée de l'unité humaine selon Joseph de Maistre, p. 196; J.-Yves Pranchère, L'autorité contre les Lumières, p. 88; I. Berlin,"De Maistre e as origens do fascismo...", op. cit., p. 109.

${ }_{177} \mathrm{P}$. Hazard, La pensée européenne au XVIII ${ }^{e}$ siècle, de Montesquieu à Lessing, p. 37.

${ }^{178}$ J. de Maistre, Soirées, IV ${ }^{\mathrm{e}}$ Entretien (O.C., IV: 282-283).

${ }^{179}$ Leo Strauss, Direito Natural e História (Lisboa: Edições 70, 2009), p. 266.

${ }^{180}$ Joseph de Maistre, De l'état de nature, O.C., VII: 549. 
uma "antropologia sem providência"181, segundo a qual a sociabilidade era uma obra imanente, isto é, um trabalho do homem sobre ele mesmo no interior de um processo evolutivo puramente humano, daí os elogios aos valores civilizatórios e morais, bem como a visão de que os homens podiam dominar a marcha de sua própria história. Ademais, Maistre não podia aceitar a definição contratualista Ilustrada e a qual, de Hobbes a Locke, definia a sociedade a partir do indivíduo, isto é, como uma superação voluntária dos indivíduos que decidiram estabelecer regras comuns de convívio e, sobretudo, a soberania.

$\mathrm{Na}$ contramão desta antropologia ilustrada, Maistre insistia no fato de que "a sociedade não é obra do homem, mas o resultado imediato do Criador, que quis que o homem fosse o que ele sempre e por toda a parte foi." 182

Neste sentido, é impossível compreender o conservadorismo do contrarrevolucionário saboiano, com toda sua ênfase na ordem e na harmonia social, sem recorrer ao providencialismo e, no interior deste, à noção teológica de pecado original que "explica tudo", e sem o qual "não se explica nada", e que, infelizmente, "repete-se a cada instante no tempo, ainda que de uma maneira secundária." 183

Pois o mesmo homem que é inteligente, racional, livre, feito à imagem de Deus e, portanto, traz os germes daquela semelhança (que ele deve conquistar através do bom uso de seu livre-arbítrio ${ }^{184}$ ), é igualmente o homem cuja vontade foi alquebrada e dividida pelo pecado original:

"Concluamos, pois, sempre como Marco Aurélio: O homem é social porque ele é racional. Acrescentemos: mas ele é corrompido em sua essência e, portanto, é-lhe preciso um governo... O homem é um enigma cujo cerne não cessou de ocupar os observadores. As contradições que ele abriga surpreendem a razão e impõem-lhe o silêncio... Todos os seres que

${ }^{181}$ Simone Goyard-Fabre, La philosophie des Lumières (Paris: Klincksieck, 1972), p. 61.

${ }^{182}$ Joseph de Maistre, De la souveraineté du peuple, Livro I, cap. 2.

${ }^{183}$ Joseph de Maistre, Soirées, O.C., IV: 61 (II Entretien).

${ }^{184}$ Como dissera na memória maçônica de 1782, o homem "não foi criado para especular numa poltrona e é fazendo o bem que se toma o gosto pelo mesmo"(Mémoire au Duc Brunswick..., p. 16). Amparado na teologia de Orígenes, podemos dizer que Maistre absorveu o sentido convencional de otium e negotium legado pela tradição humanista do renascimento italiano (em especial a ênfase dos neoplatônicos florentinos Ficino e Pico pelo ócio contemplativo) de modo a inverter o seu sentido: se a ação prática, expressa pelas boas ações, é fundamental para a justificação da alma humana, a mesma não deixa de ser uma consequência da contemplação, responsável por fortalecer a vontade contra os impulsos egoístas e materiais. Não por acaso, o Cícero de Maistre será o mesmo de Ficino e Pico, ou seja, menos o homem público do que o moralista que contempla a influência da ação divina na vida dos homens. Cf. Skinner, As fundações do pensamento político moderno (São Paulo: Companhia das Letras, 2006), $5^{\text {a }}$ reimpressão, p. 136-137 
nos cercam têm somente uma lei e a seguem em paz. Apenas o homem possui duas; e ambas atraindo-o simultaneamente em sentidos contrários, ele experimenta uma dilaceração inexplicável. Ele possui um fim moral ao qual se vê impelido a caminhar, possui o sentimento de seus deveres e a consciência da virtude; mas uma força inimiga o arrasta, e ele a segue, ruborizando." 185

Uma vez que o homem é constituído por "um princípio que aconselha o bem" e "outro que faz o mal", Maistre questiona como um tal ser poderia viver com seus semelhantes sem o concurso de uma força superior. Após observar que Hobbes tinha "perfeita razão" - com a ressalva de que "não se dê muita extensão aos seus princípios" ao postular que "a sociedade é realmente um estado de guerra"186, o contrarrevolucionário saboiano completa sua explicação sobre a natureza social do homem, a qual é indissociável do governo e da soberania:

"(...) sendo o homem pérfido, é preciso que ele seja governado; é preciso que, no momento em que muitos queiram a mesma coisa, um poder superior a todos os pretendentes julgue a questão e os impeça de se agredirem; logo, são necessários o soberano e as leis... Não observamos que, no momento em que as revoluções políticas suspendem este poder divino, as infelizes nações que sofrem estas comoções caem bruscamente neste estado de guerra em que a força se apodera do cetro, e que esta nação é atormentada por um dilúvio de crimes?"187

Portanto, ao invés de ser "uma questão de escolha", o governo "resulta da própria natureza das coisas". Sendo o homem o que ele é após o pecado original, "é impossível que não seja governado, pois um ser social e injusto deve estar sob jugo" de outro homem, uma vez que "o autor de todas as coisas, não julgando correto submeter o homem a seres de uma natureza superior, e o homem devendo ser governado por seu semelhante, é claro que aquilo que há de bom no homem devia governar o que há de ruim." 188

${ }^{185}$ Joseph de Maistre, De l'état de nature, O.C., VII: 556-557.

${ }^{186}$ Está claro que Maistre se equivoca aqui. O estado de guerra hobbesiano refere-se ao estágio pré-social ou natural do homem.

${ }^{187}$ Joseph de Maistre, De l'état de nature, O.C., VII: 562-563. Cumpre observar que a referência ao dilúvio (grifo do próprio Maistre) não é casual, mas uma representação alegórica de sua economia providencial.

${ }^{188}$ Joseph de Maistre, De l'état de nature, O.C., VII: 563-564. 
Diante da questão crucial de como articular a onipotência divina com a liberdade humana sem incorrer seja no ocasionalismo ${ }^{189}$, seja no seu inverso pelagiano ${ }^{190}$, Maistre encontrou nas teologias do jesuíta espanhol Luís de Molina e, sobretudo, de Orígenes, a resposta para sua dialética transcendental.

O origenismo permitiu-lhe conciliar dinamicamente o pressuposto providencialista com uma convicção ontológica humanista que preconiza o livre-arbítrio e a existência efetiva de uma causalidade humana na história.

E é justamente pelo fato de o homem ainda ser um ente dotado de liberdade e de iniciativa (apesar de sua condição adâmica) que a Providência divina se faz necessária, pois a mesma jamais abandona sua criatura privilegiada na História, cujo sentido (individual e coletivo) deve ser entendido em termos de restituição ou assimilação final em Deus.

De acordo com esta concepção judaico-cristã neoplatônica, o real é dado pelo concurso ou soma de duas causalidades distintas (mas desiguais), a humana e a divina. O homem é efetivamente livre, mas Deus é realmente onipotente e subordina a causalidade independente dos homens aos seus desígnios. Em sua eternidade e onisciência, Deus conhece as vontades dos homens, as quais, apesar de livres, nem por isto são ilimitadas. Maistre concorda com o tomismo ao negar que o Mal, produto da liberdade humana (mais especificamente, de seu abuso), seja de origem divina, ou que se possa "admitir uma existência qualquer independente de Deus". ${ }^{191}$ Assim, em que pese a liberdade humana ser um poder independente de Deus, ela não pode existir independentemente de seu Criador. Com efeito, o advento do Mal coincide justamente com a vontade livre dos homens de extremar esta independência: desde que o homem "se separa de Deus e que ele age sozinho, ele não deixa de ser poderoso, pois é um privilégio de sua natureza; mas sua ação é negativa e logra apenas destruir". ${ }^{192}$

\footnotetext{
${ }^{189}$ Ao contrário do teólogo oratoriano Nicolas Malebranche (1638-1715), Maistre não incorre no ocasionalismo, isto é, na doutrina teológica que nega a causalidade da ação humana (em termos tomistas, "causas secundárias") na ordem providencial. Ciente de que Malebranche havia exacerbado ao ceder "em excesso a Deus", nem por isto Maistre deixou de admirá-lo e segui-lo na convicção de que "uma falsa crença sobre a eficácia das causas secundárias..." - isto é, humanas - "podia levar à idolatria" (Soirées, $\mathrm{X}^{\mathrm{e}}$ Entretien) Cf. Richard Lebrun (org.), Maistre Studies (New York: University Press of America, 1988), p. 229.

190 Doutrina formulada pelo monge Pelágio (350 d.C. - 423 d.C.), e a qual nega a existência do pecado original e atribui a morte corporal, bem como a realidade e a universalidade do pecado, ao mau exemplo dado por Adão, de modo que a vontade humana, desde que bem orientada, é vista como plenamente capaz de obter o bem por si mesma. Cf. Tzvetan Todorov, Os inimigos íntimos da democracia (São Paulo: Companhia das Letras, 2012), especialmente o capítulo 2.

191 Joseph de Maistre, Examen de la Philosophie de Bacon, in: O.C., VI:384.

192 Joseph de Maistre, Essai sur le principe générateur, capítulo XLV.
} 
Que o tradicionalismo maistreano pense a soberania em termos de uma dialética entre humano e divino na qual a Providência desempenhe o papel causador principal, fica claro logo na primeira página do De la souveraineté du peuple:

"É bem verdadeiro, num sentido inferior e grosseiro, que a soberania está fundada no consentimento humano; pois se um povo qualquer decidisse, de repente, não obedecer, a soberania desapareceria, e é impossível imaginar o estabelecimento de uma soberania sem imaginar um povo que consinta em obedecer. Portanto, se os adversários da origem divina da soberania não querem dizer mais do que isto, eles estão com a razão, e a discussão seria inútil. Deus, não tendo julgado conveniente empregar instrumentos sobrenaturais para $\mathrm{o}$ estabelecimento dos impérios, está certo de que tudo teve de ser feito pelos homens. Mas dizer que a soberania não vem de Deus porque ele se serve dos homens para estabelecê-la, é dizer que ele não é o criador do homem porque todos temos um pai e uma mãe."193

Uma vez que Deus "criou o homem sociável" e "quis também a soberania e as leis sem as quais a sociedade não existe", Maistre adverte que todos "os teístas ${ }^{194}$ do universo" deveriam concordar que aquele "que viola as leis se opõe à vontade divina e se torna culpado perante Deus". ${ }^{195}$ De acordo com a lógica providencial maistreana:

"(...) as leis vêm de Deus, no sentido que ele quer que haja leis e que se as obedeça; e, no entanto, estas leis também vêm dos homens, posto que são feitas pelos homens. Do mesmo modo, a soberania vem de Deus, pois ele é o autor de tudo, exceto do mal, e, em particular, da sociedade que não pode subsistir sem a soberania. Todavia, esta mesma soberania vem igualmente dos homens em um determinado sentido, isto é, na medida em que este ou aquele modo de governo é estabelecido e declarado pelo consentimento humano."196

Diante disto, resta a questão quanto ao aspecto operativo do consentimento humano sob o pano de fundo de um ente dilacerado e dividido pelo pecado original, seja ele admitido em sua acepção cristã, seja na sua concepção rousseauniana laica. Pois, falando nos termos do próprio Rousseau, se as leis são a condição para a associação

${ }^{193}$ Joseph de Maistre, De la souveraineté du peuple, Livro I, cap. 1.

${ }^{194}$ Como o próprio Maistre adverte na primeira nota de rodapé do De la souveraineté du peuple, o termo "teísta" emprega-se não só em oposição ao ateísmo, mas também ao deísmo, pois, em que pese a origem comum dos termos, o deísmo excluía a crença na revelação divina e na transmissão da mesma pela tradição.

${ }^{195}$ Joseph de Maistre, De la souveraineté du peuple, Livro I, cap. 1.

${ }^{196}$ Joseph de Maistre, De la souveraineté du peuple, Livro I, cap. 1. 
civil, devendo o povo, na qualidade de autor das mesmas (lembremos que a vontade geral não pode ser representada), submeter-se a elas, como será possível semelhante passo se os "particulares discernem o bem que rejeitam"197; se o "espírito social, que deve ser a obra da instituição...", é uma consequência das leis, de modo "que os homens fossem antes das leis o que deveriam tornar-se depois delas"? ${ }^{198}$ Para Rousseau, tratavase de uma autêntica quadratura do círculo, e sua resposta é de nosso interesse na medida em que trouxe reflexos à visão constitucional-providencialista maistreana.

E a resposta de Rousseau para este impasse encontra-se na paradoxal figura do Legislador, responsável pela mediação entre a vontade geral ainda cega e a expressão racional da mesma, isto é, por sua tradução em termos de linguagem inteligível e acessível a todos os espíritos. ${ }^{199}$ Ou seja, para que a vontade seja 'geral' - e não do demos e/ou do governo de ocasião ${ }^{200}$-, será preciso o concurso simultâneo de dois elementos incompatíveis, a saber, a intervenção de uma 'representação' (legislador) dotada de qualidades "extraordinárias" e que, ao mesmo tempo, exerça uma "autoridade que nada é", embora empreenda algo "acima das forças humanas", sendo, pois, quase um milagre. ${ }^{201}$ Para lograr tal efeito, o "Legislador - não podendo empregar nem a força nem o raciocínio - recorre necessariamente a uma autoridade de outra ordem, que possa conduzir sem violência e persuadir sem convencer". ${ }^{202} \mathrm{O}$ sistema legislativo, que deve traduzir o imperativo racional da vida em comum, não se dirige, na realidade, à virtude dos indivíduos, e quanto a isto Rousseau mostrou-se mais realista do que boa parte dos revolucionários franceses. Como bom leitor de Montesquieu, Rousseau era consciente da necessidade de o Legislador levar em consideração a especificidade, a particularidade dos Estados e de suas populações (tais como território, fronteiras, clima, demografia, valores e preconceitos). Por este motivo, como demonstrou Christopher

${ }^{197}$ Rousseau, Contrato Social, Livro II, cap. 6.

${ }^{198}$ Idem, Livro II, cap. 7.

199 Interessante pensar a figura do Legislador de Rousseau como um pedagogo origenista cívicolaico que adapta seu discurso para os cidadãos simpliciores.

200 “Aquele, pois, que redige as leis, não tem nem deve ter nenhum direito legislativo. O próprio povo não poderia, se o desejasse, despojar-se desse direito incomunicável, porque, segundo o pacto fundamental, só a vontade geral obriga os particulares e só podemos estar certos de que uma vontade particular é conforme à vontade geral depois de submetê-la ao sufrágio livre do povo." Cf. Rousseau, Contrato Social, Livro I, cap. 7.

${ }^{201}$ Idem.

${ }^{202}$ Contrato Social, Livro II, cap. 7. Ou como sublinhou Rousseau no Manuscrito de Genebra, não se trata de ensinar ao povo o que seja a justiça, mas sim de mostrar-lhe que é do seu interesse ser justo. Trata-se do "interesse bem compreendido", que ganharia desdobramentos nas reflexões de Maistre (Considerações sobre a França, 1797) e Tocqueville. In: Victor Gourevitch (ed.) Rousseau: The Social Contract and other Political Writings (Cambridge: Cambridge Univ. Press, 1997), p. 157. 
Kelly em seu artigo sobre o Legislador de Rousseau ${ }^{203}$, a linguagem filosófica racional, como a que permeia todo o discurso do Contrato Social ou da Enciclopédia de d'Alembert e Diderot ${ }^{204}$, era vista por Rousseau como a menos adaptada para o processo persuasivo do Legislador, que, pelo contrário, deveria apelar às emoções (daí a importância da música, das festas patrióticas e, por fim, dos exemplos de virtude oferecidos pelo próprio Legislador, que se sacrifica pelo bem público e se retira de cena assim que conclui seu trabalho) e gravar as leis nos corações dos homens para que se tornassem efetivas. Daí a importância atribuída à dimensão "moral", ao aspecto ético da Lei, tido por Rousseau como o mais importante de todas (mais do que as civis e as penais). ${ }^{205}$ Vale a pena citar essa passagem na íntegra:

"A estas três espécies de leis acrescenta-se uma quarta, a mais importante de todas, que não se grava nem sobre o mármore nem sobre o bronze, mas no coração dos cidadãos; que faz a verdadeira constituição do Estado, que toma todos os dias novas forças; que, quando as outras leis envelhecem ou se extinguem, reanima-as ou supre-as, conserva um povo no espírito de sua instituição e substitui insensivelmente a força do hábito à da autoridade. Refiro-me aos usos, aos costumes e, sobretudo, à opinião; parte desconhecida de nossos políticos, mas da qual depende o sucesso de todas as outras; parte de que o grande Legislador se ocupa em segredo enquanto parece limitar-se a regulamentos particulares que não são mais do que o arco da abóbada, da qual os costumes, mais lentos para nascerem, formam por fim a chave indestrutível". ${ }^{206}$

Portanto, é sobre esta moral encarnada que deve se inspirar a legislação. O costume e a opinião têm força porque, embora não sendo 'naturais' (posto que engendrados pela vida em sociedade), estão ainda bastante próximos da natureza, a ponto de constituírem a 'natureza' artificial de um determinado povo. A mola propulsora da vida em sociedade, responsável por converter o amor-de-si do homem primitivo em amor-próprio do homem em sociedade, é a tirania da opinião. ${ }^{207}$ Daí a

203 C. Kelly. "To Persuade without Convincing: The Language of Rousseau's Legislator", American Journal of Political Science, vol. 31, n 2, 1987.

${ }^{204}$ Daí a crítica de Rousseau à definição de 'vontade geral' avançada por Diderot na Enciclopédia, a saber, "um ato de entendimento puro, raciocínio no silêncio das paixões". Encyclopédie, "Droit Naturel", seção 9.

${ }^{205}$ Como salientou Franco Venturi no seu clássico estudo sobre o Iluminismo. Cf. Franco Venturi. Utopia e Reforma no Iluminismo (Bauru-SP: Edusc, 2003), p. 139-141.

${ }^{206}$ Rousseau, Contrato Social, Livro II, cap. 12.

207 "Como pode, então, o governo agir sobre os costumes? Respondo que é pela opinião pública. Se na solidão nossos hábitos nascem de nossos próprios sentimentos, na sociedade, nascem da opinião do outro. Quando não se vive em si mesmo, mas nos outros, são os julgamentos deles que tudo regulam; nada parece bom ou desejável aos particulares a não ser o que o público julgou como tal, e a única 
necessidade de o Legislador atuar no nível das paixões humanas para tornar concreta a República. Longe de pretender que os homens ignorem o juízo alheio, o Legislador deverá tirar proveito desta paixão para obter êxito em sua empreitada. Novamente, nos encontramos diante da seguinte questão: se assim for, como o Legislador logrará fazer com que o interesse geral prevaleça sobre as tendências egoístas, em outras palavras, como uma ordem política racional pode ser auferida através da 'paixão'? Para o 'cidadão de Genebra', a resposta consistia em suscitar entre os membros da comunidade o "amor pela pátria", o 'patriotismo', por meio de festas, dos espetáculos cívicos, dos jogos e da educação.

O legislador deve fazer com que os indivíduos amem a pátria e seus compatriotas, o que supõe uma pedagogia patriótica ou uma Religião Civil $^{208}$, dada a inclinação natural dos particulares para o amor-próprio. Uma vez que o 'aparecer' para o outro é a premissa da vida social e a tendência para se distinguir é sua decorrência natural, o Legislador deve tirar proveito desta última, revertendo a distinção do amor-próprio em distinção patriótica.

E quando, no encerramento de seu Contrato Social, Rousseau destaca a importância da religião cívica para a consecução desses objetivos patrióticos, o mesmo avança uma forte crítica ao cristianismo ${ }^{209}$, visto por ele como um fator político desagregador no interior dos Estados, seja por suscitar a indiferença dos cidadãos pelos assuntos públicos ("preocupados unicamente com as coisas do céu"), seja por dar-lhes dois "sistemas legislativos, dois líderes, duas pátrias". Assim procedendo, o autor do Emílio pretendia demonstrar, contra a tese Ilustrada de Pierre Bayle, que "jamais se fundou um Estado cuja base não fosse a religião", ao mesmo tempo em que afirmava ser a religião cristã - em especial o catolicismo - "mais prejudicial do que útil à firme constituição do Estado." 210

Dada a centralidade da figura do Legislador na filosofia política de Rousseau, nada mais natural que a crítica maistreana, desenvolvendo-se a partir dela, alcançasse

felicidade que a maioria dos homens conhece é a de serem considerados felizes". Cf. Rousseau, Carta a d'Alembert (Campinas: Editora Unicamp, 1993), p. 191.

${ }^{208}$ Rousseau, Contrato Social, Livro IV, cap. 8.

${ }^{209}$ Desde a Profissão de fé do vigário saboiano (presente no Emílio), Rousseau distinguia entre a "religião do homem", que ele dizia ser "a do Evangelho" e classificava como "santa, sublime, verdadeira", ao "cristianismo de hoje", isto é, as manifestações dogmáticas e eclesiásticas do mesmo. Cf. Rousseau, Contrato Social, Livro IV, cap. 8.

${ }^{210}$ Rousseau, Contrato Social, Livro IV, cap. 8. 
conclusões diametralmente opostas. ${ }^{211}$ Maistre sustenta que o governo, a exemplo da sociedade, não pode ser um produto da deliberação humana, de modo que o mesmo é o resultado da ação providencial, que age de duas maneiras, conforme ele próprio indica:

"Quase sempre ele reserva mais imediatamente a si próprio a formação ao fazê-la, por assim dizer, germinar imediatamente como uma planta, pelo concurso de uma infinidade de circunstâncias que designamos como fortuitas; mas quando ele quer simultaneamente lançar os fundamentos de um edifício político e mostrar ao universo uma criação deste gênero, é aos homens raros, aos verdadeiros eleitos que ele confia os seus poderes: dispostos em longos intervalos na duração dos séculos, eles se erguem como obeliscos..., e à medida que a espécie humana envelhece, eles aparecem mais raramente. Para torná-los aptos a estas obras..., Deus os investe de um poder extraordinário, frequentemente desconhecido de seus contemporâneos e, possivelmente, deles próprios." 212

Como bem ilustrou Carolina Armenteros, enquanto o legislador de Rousseau é racional e duplo (vela seu poder para que o povo acredite que é livre e reclama a inspiração divina a fim de reforçar a aceitação), o de Maistre, ao contrário, é um gênio que age instintivamente, com uma ingênua ignorância de suas habilidades. É criativo, tanto quanto o homem pode ser, na medida em que organiza o que a Providência ofereceu. À diferença do legislador revolucionário de Rousseau, que concerta para a aniquilação da vontade individual e o nascimento da nova sociedade da vontade geral, o legislador maistreano é um diretor silencioso, cujo 'infalível instinto' inconscientemente encoraja tendências já existentes na sociedade e na natureza, organizando o real nos interesses de Deus de uma maneira antes imperceptível e intuitiva do que convulsiva. ${ }^{213}$

${ }^{211}$ Para uma leitura comparada entre Rousseau e Maistre, leia-se o interessante artigo de Graeme Garrard, "Rousseau, Maistre, and the Counter-Enlightenment", History of Political Thought, vol. XV $\left(\mathrm{n}^{\mathrm{o}} 1\right), 1994, \mathrm{p} .97-120$.

${ }^{212}$ Joseph de Maistre, De la souveraineté du peuple, Livro I, cap. 7.

${ }^{213}$ Carolina Armenteros, The French Idea of History: Joseph de Maistre and his heirs 1794-1854, p. 56. Leia-se o que escreveu Maistre: "O instituidor de um povo é precisamente esta mão hábil; dotado de uma penetração extraordinária, ou, o que é mais provável, de um instinto infalível (pois frequentemente o gênio não se dá conta daquilo que ele opera, e é nisto sobretudo que ele difere do espírito), ele adivinha estas forças e estas qualidades ocultas que formam o caráter de sua nação; ele adivinha os meios de fecundá-las, de colocá-las em ação e de tirar o melhor partido possível delas. Não se lhe vê jamais a escrever ou a argumentar: sua maneira advém da inspiração; e se algumas vezes ele toma a pluma, não é para dissertar, mas para ordenar... Um dos grandes erros deste século é acreditar que a constituição política dos povos é uma obra puramente humana; que se pode fazer uma constituição como um relojoeiro faz um relógio. Nada mais falso..." Cf. Joseph de Maistre, De la souveraineté du peuple, Livro I, cap. 7. 
Ademais, o principal aspecto da crítica maistreana à concepção revolucionária do Legislador de Rousseau diz respeito à relação triangular entre Legislador-TradiçãoPovo. Pois o Legislador só logrará êxito em sua iniciativa na medida em que agir de acordo com os costumes e com a tradição (aqui entendida sobretudo pelo prisma religioso). Em contrapartida, o povo só poderá conservar seu papel ativo, bem como resguardar seus direitos fundamentais, mediante a observância da tradição ou dos costumes por parte dele e de seu soberano. No tradicionalismo maistreano, os costumes não apenas respaldam a eficiência da ação legisladora, como, principalmente, servem de garantia contra os desígnios ilimitados de um Legislador voluntarista ou, em termos contemporâneos, de um Estado totalitário. ${ }^{214}$

O caso de Licurgo, em Esparta, que Maistre admirava tanto quanto Rousseau ${ }^{215}$, ilustra o nosso caso. Num pequeno panfleto redigido em 1794, Trois Fragments sur la France, Maistre teceu a seguinte observação:

"Dir-se-á que o governo faz os costumes? Nego-lhe expressamente. São os costumes, ao contrário, que fazem os governos; um e outro, sem dúvida, auxiliam-se mutuamente e produzem aquilo que se poderia chamar de círculo virtuoso; mas o primeiro impulso, o princípio gerador, parte sempre dos costumes e do caráter nacional. Licurgo, com seu governo extraordinário, agiu realmente sobre o caráter de seus concidadãos e fez deles outros homens, sim; mas os espartanos aceitaram este governo com pleno conhecimento de causa, com um sangue frio e uma liberdade absolutos: e, certamente, era preciso já ter um alto grau de sabedoria e de energia para desejar as leis de Licurgo." 216

${ }^{214}$ Não por acaso, Mussolini foi enfático ao reconhecer que "a doutrina fascista não escolheu de Maistre como profeta. Um partido que governa uma nação 'totalitariamente' é um fato novo na história." Cf. B. Mussolini, Le Fascisme: doctrine-institutions. (Paris: Denoël et Steele, 1933), p. 49. Para uma leitura do tradicionalismo maistreano em uma chave antitotalitária, vide: Richard Lebrun, Against Rousseau (London: McGill-Queen's University Press, 1996), p. XXIII; Darrin M. McMahon, "The genius of Maistre", in: C. Armenteros e R. Lebrun (orgs.), Joseph de Maistre and the legacy of Enlightenment..., op. cit., p. 19-30.

${ }^{215}$ Jean-Louis Darcel observou que Maistre e Rousseau admiravam Esparta por razões diferentes. Enquanto o genebrino via a cidade-estado grega como um exemplo de virtude cívica, patriotismo, igualitarismo e frugalidade, o saboiano destacava nela as vantagens de uma constituição não escrita e a aliança entre a política e a religião. Curiosamente, os dois fizeram abstração do caráter militarista de Esparta, a despeito de serem grandes críticos do militarismo. Cf. J.-Louis Darcel, De l'état de Nature (Chambéry: Institut d'Étude Maistriennes, 1976), p. 115, nota 32. Vide também: Judith N. Shklar, "Rousseau's Two Models: Sparta and the Age of Gold", Political Science Quarterly, vol. 81, nº 1 (1966), p. $25-51$

${ }^{216}$ Joseph de Maistre, Trois Fragments sur la France (1794), in: Jean-Louis Darcel (org.), Joseph de Maistre: Écrits sur la Révolution (Paris: PUF, 1989), p. 81. 
Referindo-se novamente a Licurgo no De la souveraineté du peuple, Maistre destacará que "as grandes instituições políticas são perfeitas e duráveis à medida em que a união da política e da religião se encontre mais perfeita nelas", tendo sido o grande mérito de Licurgo haver adaptado o seu gênio à religião, razão pela qual ele "nada imaginou, propôs ou ordenou a não ser pela fé dos oráculos", de modo que "todas as suas leis foram preceitos religiosos". ${ }^{217}$ Paradoxalmente, no providencialismo maistreano a ação do Legislador será mais eficaz quanto menos sua ação for marcada pelas características de seu próprio gênio, tomado aqui no sentido que lhe atribuiu Diderot no verbete génie para a Encyplopédie, isto é, um indivíduo sensível, apaixonado e ativo que, dotado de uma grande imaginação, é pouco indicado para a política (onde se exige acima de tudo autocontrole e sangue-frio). ${ }^{218}$

E a história, advertia Maistre, demonstra que "nunca houve, jamais haverá, e não pode haver nação constituída a priori." Pois, desafia o saboiano, "que olho é capaz de, num piscar de olhos, abraçar todas as circunstâncias que devem tornar uma nação preparada para esta ou aquela constituição? Sobretudo, como vários homens seriam capazes deste esforço de inteligência?"219 Pois além de constituir um fenômeno milagroso e raro (o mais das vezes, presente apenas no início das civilizações), o Legislador "não produziria nada se ele não tivesse em suas mãos uma matéria, isto é, um povo feito para obedecer sua ação". 220

E foi precisamente esta matéria ou substrato para uma possível ação do Legislador que a filosofia das Luzes dissolveu, ao atacar, desde a "infame Regência"221 (1715-1723), os fundamentos tradicionais da fé cristã, protetora das manners europeias e, ao contrário do que afirmara Rousseau no Contrato Social, fonte do patriotismo:

"E se refletirmos mais atentamente, descobriremos que... não há verdadeiro patriotismo sem religião: não o vemos brilhar senão nos séculos crentes, e ele sempre declina e morre com

${ }^{217}$ Joseph de Maistre, De la souveraineté du peuple, Livro I, cap. 8.

${ }^{218}$ Denis Diderot, "Génie", in: Encyclopédie, ou, Dictionnaire raisonné des sciences, des arts et des métiers, organizada por Jean Le Rond d'Alembert e Denis Diderot Paris: 1751-1765), vol. VII, p. 581584.

${ }^{219}$ Joseph de Maistre, De la souveraineté du peuple, Livro I, cap. 9.

${ }^{220}$ Joseph de Maistre, De la souveraineté du peuple, Livro II, cap. 7.

221 "Todos os sábios, todos os literatos, todos os artistas da França formaram, ao pé da letra, uma verdadeira conjuração contra os costumes públicos; estes conjurados haviam logrado conquistar a seu partido os grandes senhores e as mulheres, de modo que o vício, fortalecido com esses poderosos aliados, e possuindo ao mesmo tempo tudo o que se respeita e o que se ama, operou na França destruições incríveis... As artes, que são a expressão do gênio dos povos, pintavam a corrupção geral, aumentando-a a cada dia; não sabiam fazer mais nada de grandioso e tinham absolutamente se prostituído ao vício." Cf. Joseph de Maistre, Trois Fragments sur la France (1794), op. cit., p. 78. 
ela. Assim que o homem se separa da divindade, ele se gangrena e gangrena tudo aquilo que toca. Sua ação é falsa, ele não se agita senão para destruir. À medida que este poderoso liame se enfraquece em um Estado, todas as virtudes conservadoras se enfraquecem na mesma proporção; todos os caracteres se degradam, e até as boas ações são mesquinhas... Mas desde que a ideia da divindade é o princípio da ação humana, esta ação é fecunda, criativa e invencível."222

Em termos rousseauístas, portanto, Maistre questiona a possibilidade de "persuadir sem convencer" a um povo que foi ensinado a ter "ódio pela autoridade"223 e que, ademais, arrogou para si a função de legislar. Como acreditar no êxito político dos legisladores franceses em consolidar o regime republicano - "espécie de governo que prescinde das virtudes menos do que os outros"224 - se os mesmos, ao invés de dissolver seus respectivos gênios nos costumes e na religião (fundamentos das virtudes públicas e privadas), tratavam de combatê-los?

Conforme insistirá o contrarrevolucionário saboiano em termos que nos remetem a Rousseau, a liberdade "nasce no silêncio, na paz, na obscuridade", jamais "entre as tempestades" ou por meio de uma "multidão turbulenta, agitada por paixões vis e frenéticas". Ela até pode se defender e se fortalecer nas tempestades, mas o poder criador "não se anuncia senão pela brisa" e, com frequência, "o pai de uma constituição não sabe o que ele faz ao criá-la". ${ }^{225}$ Referindo-se a Tom Paine (personagem símbolo do projeto construtivista democrático-liberal revolucionário), Maistre insistirá no fato de que a lei escrita é apenas "a declaração de uma lei anterior e não escrita", de modo que o homem "não pode atribuir direitos a si próprio", mas "apenas defender aqueles que lhe

${ }^{222}$ Joseph de Maistre, De la souveraineté du peuple, Livro I, cap. 12.

223 "A razão eterna falou, e seus oráculos infalíveis mostraram-nos o orgulho como o começo de todos os crimes; este princípio terrível foi desencadeado sobre a Europa, depois que estes mesmos filósofos vos arrancaram da fé de vossos pais. O ódio da autoridade é o flagelo de nossos dias: não há remédio a este mal a não ser nas máximas sagradas que vos fizeram esquecer... É o ateísmo, é a imoralidade, que sopram a revolta e a insurreição."Cf. Joseph de Maistre, De la souveraineté du peuple, Livro II, cap. 7.

224 "Se há uma verdade certa em política, é que um povo corrompido, e profundamente corrompido, não é feito para a liberdade e nela não chegará jamais... A infância das nações livres possui caracteres tão surpreendentes que é impossível enganar-se a respeito. Nesta época, o amor pela pátria é uma religião, e o respeito pelas leis é uma superstição; os caracteres são fortemente pronunciados, os costumes são austeros; todas as virtudes brilham simultaneamente; suas facções voltam-se para o benefício da pátria, para que não se dispute a não ser o benefício de servi-la: tudo, mesmo os crimes, carrega a insígnia da grandeza. Como acreditar na duração de uma liberdade que começa pela gangrena? $\mathrm{Ou}$, para falar mais exatamente, como acreditar que esta liberdade pudesse se estabelecer (pois não há nenhuma ainda), e que, do seio da corrupção mais asquerosa, pudesse sair esta espécie de governo que prescinde das virtudes menos do que os outros?" Cf. Maistre, Trois Fragments sur la France..., p. 80.

${ }^{225}$ Joseph de Maistre, De la souveraineté du peuple, Livro I, cap. 8. 
foram atribuídos por um poder superior, e estes direitos são os bons costumes", os quais são "bons porque não são escritos" e não podemos "atribuir-lhes o começo ou o autor". ${ }^{226}$ Posteriormente, em seu Essai sur le principe générateur des constitutions politiques (1809), Maistre afirmaria que tudo o que é legítimo ${ }^{227}$ não teve grandes começos, de modo que a frase de Horácio, a saber, Crescit occulto velut arbor aevo, representa "a divisa eterna de toda grande instituição". 228

Mas se o homem, por si só, é incapaz de criar instituições políticas e a soberania voltada para o passado, a legitimidade política não pode jamais começar humanamente, sendo imemorial por definição: "a soberania, por sua natureza, assemelha-se ao Nilo: ela oculta sua cabeça"229 -, o mesmo é capaz de conhecer as causas que levaram ao fracasso da iniciativa constitucional revolucionária. Do contrário, seria preciso supor que Deus enviara "anjos sob formas humanas, encarregados de dilacerar uma constituição". Assim, o providencialismo maistreano admite que "sempre será preciso que as causas segundas sejam empregadas". 230

Em uma passagem do Essai sur le principe générateur, Maistre destacará a especificidade do século das Luzes, sem a qual não se compreende a violência revolucionária no interior da ordem providencial. Após informar a seus leitores que o século XVIII não se parecia com nenhum outro em matéria de combate à religião (a régua sob a qual era preciso julgá-lo) ${ }^{231}$, o contrarrevolucionário saboiano observa que, "por mais que os ímpios sempre tenham existido, nunca, antes do século XVIII e no seio do cristianismo, houve uma insurreição contra Deus; jamais... viu-se uma conjuração sacrílega de todos os talentos contra o seu autor", razão pela qual era "preciso ter reservas com respeito a estas máximas gerais" - isto é, de "que todos os séculos se

${ }^{226}$ Joseph de Maistre, De la souveraineté du peuple, Livro I, cap. 9.

227 "Quanto à legitimidade, se no seu princípio ela pôde parecer ambígua, Deus se explica por seu primeiro ministro no departamento deste mundo, o tempo." Cf. Joseph de Maistre, Essai sur le principe générateur des constitutions politiques, capítulo XXVII.

${ }^{228}$ Joseph de Maistre, Essai sur le principe générateur des constitutions politiques, capítulo XXIII. Sobre o uso da metáfora vegetativa por Shakespeare para designar a legitimidade da soberania monárquica, leia-se o penetrante ensaio de Antonio Candido em: "A culpa dos reis: mando e transgressão no 'Ricardo II'", in: Adauto Novaes (org.), Ética (São Paulo: Companhia das Letras/Secretaria Municipal de Cultura, 1992).

${ }^{229}$ J. de Maistre, Du Pape, Livro II, cap. 6.

${ }^{230}$ J. de Maistre, Essai sur le principe générateur des constitutions politiques, capítulo XXVI.

231 "Sempre houve religiões sobre a terra, e sempre houve ímpios que as combateram...; pois assim como não pode haver religião falsa sem alguma mistura de verdade, não pode haver impiedade que não combata alguma verdade divina mais ou menos desfigurada; mas não pode haver verdadeira impiedade a não ser no seio da verdadeira religião; e, por uma consequência necessária, jamais a impiedade produziu nos tempos passados os males que ela produziu em nossos dias... É sob esta régua que é preciso julgar o século XVIII; pois é sob este ponto de vista que ele não se parece com nenhum outro." Cf. Joseph de Maistre, Essai sur le principe générateur des constitutions politiques, capítulo LXI. 
assemelham, e que os homens sempre foram os mesmos" - que "a preguiça ou a ligeireza inventam para se dispensar da reflexão". ${ }^{232}$

E no interior dessa "insurreição", Rousseau, a despeito das críticas dirigidas aos demais filósofos de sua geração (especialmente a Voltaire), merecia pleno destaque, na medida em que condenou o catolicismo no Emílio (a ponto de advertir seu leitor que o padre saboiano da Profissão de fé era um "protestante disfarçado") e defendeu o verdadeiro espírito da Reforma - descrita, na Lettre à M. de Beaumont, como a mais "racional" e "santa" religião que existe sobre a terra - como aquele que reconhece apenas a "razão particular" como autoridade na interpretação do Evangelho ${ }^{233}$; ou seja, Rousseau "trabalhou toda a sua vida" a favor da "substituição dos dogmas nacionais pela razão individual". ${ }^{234}$

Conforme Maistre detalharia nas Reflexões sobre o Protestantismo (1798), se "o cristianismo é a religião da Europa" e a mão que "modela estas nações novas" (a ponto de ser a religião "civil" dos europeus), o protestantismo, ao solapar "o princípio fundamental desta religião", qual seja, "o da infalibilidade do ensinamento, do qual resulta o respeito cego pela autoridade, a abnegação de todo razoamento individual e, por conseguinte, a universalidade da crença", substituiu "o julgamento particular ao julgamento católico"; substituiu "a autoridade exclusiva de um livro àquela do ministério pedagógico, mais antigo que o livro e encarregado de no-lo explicar." ${ }^{235}$

Ao substituir a paideia cristã pela "razão individual", o filosofismo (legítimo filho da Reforma e que "não produz e não conserva nada para o bem geral"236 ) de Rousseau, Voltaire e Diderot afastou os franceses do grande princípio gerador das constituições políticas e do progresso (as manners cristãs), atraindo para si as fúrias revolucionárias, uma vez que a "filosofia não age senão para menos, de modo que um homem abandonado à sua razão individual é perigoso à ordem moral e política precisamente na

${ }^{232}$ Joseph de Maistre, Essai sur le principe générateur des constitutions politiques, capítulo LXI.

${ }^{233}$ Como bem observou Robert Derathé a respeito da Profissão de fé do vigário saboiano, se, por um lado, Rousseau pretendia expandir o cristianismo numa era de crítica racional (isto é, preparar os céticos a receberem o Evangelho através da iniciação moral na religião natural ou deísta), por outro, o mesmo estava plenamente consciente de que atacava o catolicismo através do "católico" (na verdade, um "protestante disfarçado") vigário saboiano. Vide: R. Derathé, "Jean-Jacques Rousseau et le Christianisme", in: Revue de Métaphysique et Morale, no 4, Outubro de 1948, p. 384.

${ }^{234}$ Joseph de Maistre, De la souveraineté du peuple, Livro I, cap. 12.

${ }^{235}$ Joseph de Maistre, Réflexions sur le Protestantisme, in: Jean-Louis Darcel (org.), Joseph de Maistre: Écrits sur la Révolution (Paris: PUF, 1989), p. 220.

${ }^{236}$ Joseph de Maistre, De la souveraineté du peuple, Livro I, cap. 12. 
proporção de seus talentos: quanto mais gênio, atividade e perseverança ele tiver, mais sua ação será funesta." 237

Portanto, sob o pretexto de libertar a humanidade do "fanatismo" e da "superstição" religiosos que obstaculizavam o patriotismo e a racionalização da ordem social e política, os filósofos não fizeram mais senão desumanizá-la: pois "quanto mais a razão humana confia nela própria, mais ela procura subtrair todos os meios para si" e, uma vez limitada às suas forças individuais, a mesma "não passa de uma bruta cujo poder integral limita-se a destruir." ${ }^{238}$ Pela lógica do humanismo providencialista maistreano, sempre que o homem se coloca "em relação com o seu Criador" através da observância dos costumes e da religião, ele logra ser "sublime, e sua ação é criadora"; por outro lado, "desde que ele se separa de Deus e age sozinho, ele não cessa de ser poderoso" (pois "trata-se de um privilégio de sua natureza"), mas "sua ação é negativa e não consegue senão destruir." ${ }^{239}$ Apesar de os filósofos do século XVIII celebrarem "suas luzes" e seu humanismo, os mesmos, ao se separarem "do princípio de toda existência", demonstravam ignorar "a si próprios", pois "não sabem o que são nem o que podem." 240

A partir disto, Maistre ressalta que "não apenas a criação não pertence ao homem", como, ao que tudo indica, não parece que o poder humano "desassistido se estenda ao ponto de alterar para melhor as instituições vigentes". Referindo-se expressamente ao providencialismo de Orígenes, Maistre sustentou que "nada pode mudar para melhor entre os homens INDIVINAMENTE"241, pois se o "homem é inteligente", "livre", e "sublime", ele não é menos um instrumento de Deus". ${ }^{242}$ Inspirado em um discurso

${ }^{237}$ Joseph de Maistre, De la souveraineté du peuple, Livro I, cap. 12.

${ }^{238}$ Joseph de Maistre, De la souveraineté $d u$ peuple, Livro II, cap. 8. Leia-se o que Maistre escreveu a respeito da filosofia da Ilustração e em especial sobre Diderot: "E vós, filósofos insensatos, que, em seu presunçoso saber, pretendíeis dirigir o universo; apóstolos da tolerância e da humanidade; vós que preparastes nossa GLORIOSA Revolução, que celebreis os progressos da Luz e da razão: Saí de vossas tumbas; vinde em meio a estas ruínas e destes cadáveres, e explicai-nos como, neste século tão elogiado, trinta tiranos que comandaram a morte puderam encontrar trezentos mil carrascos para executála? Vossos escritos estão nos seus bolsos; vossas máximas, em suas bocas...; foi em nome da humanidade que dois milhões de homens pereceram; foi em nome da liberdade que cem mil Bastilhas se ergueram: não há apenas um de vossos escritos que não esteja sobre a mesa de nossos... Comitês revolucionários. Deixavam-te por um instante, Diderot, para assinar os afogamentos!... O único fruto de vossas vigílias foi o de ensinar ao crime a se cobrir de uma linguagem polida para desferir golpes mais perigosos."Cf. Joseph de Maistre, De la souveraineté du peuple, Livro I, cap. 12. Grifos e maiúsculas de Maistre.

${ }^{239}$ J. de Maistre, Essai sur le principe générateur des constitutions politiques, capítulo XLV.

240 J. de Maistre, Essai sur le principe générateur des constitutions politiques, capítulo XLVI.

${ }^{241}$ J. de Maistre, Essai sur le principe générateur des constitutions politiques, capítulo XL. Grifos e maiúsculas do próprio Maistre.

${ }^{242} \mathrm{~J}$. de Maistre, Essai sur le principe générateur des constitutions politiques, capítulo X. 
pronunciado em 1793 pelo arcebispo da Tarentaise, Maistre resumiu da seguinte forma o sentido teológico ou providencial da Revolução Francesa:

"Com seu orgulho, a Filosofia exclamou: 'A mim pertence a sabedoria, a ciência e o domínio, a mim pertence a conduta do homem uma vez que sou Eu quem o ilumina'. Para punila, cobri-la de opróbrio, Deus tinha de condená-la a reinar por um momento.' Com efeito, ela reinou, e reinará novamente, sem dúvida, e isto foi apenas um momento para o senhor dos momentos. Neste período, experimentou a onipotência humana e, em todos os atos da Revolução francesa, pode-se ouvir a voz da divindade a dizer: 'Quero mostrar-vos o que podeis fazer sem mim.' Nunca o orgulho humano foi mais longe, nunca foi mais ridículo."243

Na visão de Maistre, portanto, a trama 'satânica' da Revolução não foi dada pelo jacobinismo ${ }^{244}$ nem pelo Terror, mas pelo triunfo do "individualismo" ${ }^{245}$ e da sociedade liberal contemporâneos que solapa o "sistema da autoridade"246 e nega os princípios políticos, religiosos e/ou metafísicos da sociedade que devem compor a $\operatorname{artificialidade~}^{247}$ da natureza humana, impedindo-a de recair num estado pré-social marcado pela violência e barbárie. ${ }^{248}$ Assim, enquanto autores como A. Cochin ${ }^{249}$ e F. Furet ${ }^{250}$

${ }^{243}$ J. de Maistre, De la souveraineté du peuple, Livro I, cap. 8. Maistre retomará este raciocínio no Essai sur le principe générateur des constitutions politiques (1809), onde se lê: "Deixe-nos! Será preciso tremer eternamente diante dos padres, e receber deles a instrução que mais lhes aprouver para nos dar? A verdade, por toda Europa, está oculta pelas fumaças do turíbulo; é chegado o momento dela sair desta nuvem fatal. Não falaremos mais de você a nossos filhos; caberá a eles, assim que se tornarem homens, saber se você existe, e o que você é, e o que você quer deles. Tudo o que existe nos desagrada, pois o seu nome está escrito em tudo o que existe. Nós queremos tudo destruir e tudo refazer sem você. Saia de nossos conselhos; de nossas academias; de nossas casas: saberemos agir por conta própria, a razão nos basta. Deixe-nos!... Como Deus puniu este execrável delírio? Ele o puniu como ele criou a luz, por uma única palavra. Ele disse: FAÇA-SE! E o mundo político desmoronou." Cf. Essai sur le principe générateur des constitutions politiques, capítulo LXVI (grifos e maiúsculas do próprio Maistre).

244 "'Se pensarmos bem, veremos que, uma vez estabelecido o movimento revolucionário, a França e a Monarquia só poderiam ser salvas pelo jacobinismo" (Considerações..., cap. II). Ou então: "Prestai atenção, pois não há modo de transigir com o século XVIII. Valeria mais ser Jacobino do que um Feuillant, valeria mais participar de sua triste glória de destruição do que se plantar em meio ao fogocruzado dos exércitos inimigos, recebendo as balas e os ultrajes de ambas as partes." In: Lettre à Ouvaroff sur le projet d'une academie asiatique, 1810, in: S. Ouvaroff, Études de philologie et de critique (Paris: Didot, 1845), $2^{\mathrm{a}}$ ed., p. 54.

245 Joseph de Maistre, O.C., XIV:286

${ }^{246}$ No último e inconcluso undécimo diálogo das Soirées de Saint-Pétersbourg, (1821), declara que a "autoridade é a base de nosso sistema".

247 "Repitamos que a natureza de um ser não é senão a reunião das qualidades atribuídas a este ser pelo Criador. Mr. Burke foi profundo ao dizer que é impossível admirar o suficiente 'que a arte é a natureza do homem': sim, indubitavelmente, o homem com todas as afecções, todos seus conhecimentos, todas as suas artes, é verdadeiramente o homem da natureza, de modo que a tela do tecelão é tão natural quanto a teia da aranha.’In: J. de Maistre, De la souveraineté du peuple, Livro I, cap. 2.

248 "Uma nação ilustre, chegada ao máximo degrau de civilização e urbanidade, ousou, todavia, num acesso de delírio diante do qual a história não oferece outro exemplo, suspender formalmente esta lei [a "lei do amor" cristão]: o que vimos? Num piscar de olhos, os costumes dos iroqueses e dos alonquinos, 
explicaram, grosso modo, a Revolução e o Terror nos termos de uma hipertrofia dessa artificialidade (como produto da ação ideológica dos clubes revolucionários sobre a sociedade francesa), Maistre, por sua vez, explicou-os em termos contrários: ao promoverem seus ideais filosóficos e se voltarem contra o clero católico, os clubes e as sociedades nada mais fizeram senão despojar a sociedade de todos os artifícios encarnados na tradição que, acumulados de forma insensível na história, cimentavam e norteavam o progresso social. ${ }^{251}$ Como bem destacou Stéphane Rials a respeito do pensamento conservador de Maistre, "a tradição é menos um produto do que uma fonte da história", ${ }^{252}$ de modo que a herança histórica é o fundamento do devir (sem no entanto escravizá-lo) e um rico depósito ou intermediário civilizador entre o tempo passado e o futuro para o usufruto das próximas gerações. ${ }^{253}$

Mas se o homem se perde unicamente em razão de sua vontade, o mesmo não pode fazer nada sem o concurso da Providência, pois é Deus que dispõe o mundo de tal maneira para que os planos humanos se realizem ou não. Trata-se de uma consequência necessária do providencialismo maistreano a admissão de que nada ocorre sem o conhecimento de Deus, e que, à exceção do mal engendrado pela ação humana, nada

as leis sagradas pisoteadas, sangue inocente cobrindo os cadafalsos... Eis aí o homem natural!.” Cf. J. de Maistre. Eclaircissement sur les sacrifices, O.C., V:387.

${ }^{249}$ Vide A. Cochin, Les sociétés de pensée et la démocratie moderne: Études d'histoire révolutionnaire (Paris: Plon-Nourrit et Cie, 1921); e L'Esprit du jacobinisme. Une interprétation sociologique de la Révolution française (Paris: Presses Universitaires de France, 1979).

${ }^{250}$ Amparado nos estudos de Cochin, Furet concluiu que o jacobinismo poderia ser visto como a forma clássica da consciência revolucionária, vale dizer, "ao mesmo tempo uma ideologia e um poder, um sistema de representação e um sistema da ação" (p. 45). Essa consciência teria se formado a partir da "sociabilidade democrática", da opinião que se desenvolveu nos cafés, salões, lojas maçônicas e "sociedades" ainda sob o Antigo Regime. Porém, esta ideologia revolucionária teria nascido somente durante as batalhas em torno da eleição de 1789 , não estando presente nem mesmo nos cadernos de queixas do Terceiro Estado. Apesar de admitir que o poder estava disponível havia pelo menos dois anos, Furet sustenta que "o fenômeno só aparece claramente nesse momento com a revolta vitoriosa das 'Comunas' contra as ordens do rei": a Revolução só ocorreu quando se deu uma reviravolta no imaginário do Antigo Regime, quando a imagem do poder "absoluto" dos reis reverteu-se em proveito de outro absoluto, o "povo" (p. 61). A partir disso, Furet sustentou que o Terror poderia ser deduzido do discurso revolucionário, pois a "vontade do povo" e a "conspiração" seriam as duas faces do "imaginário democrático do poder". O único obstáculo para o poder ilimitado do "povo" (ideia mestra que a Revolução herdara de Rousseau, ainda que não sem distorções) era representado pela conspiração, que deveria ser esmagada e punida. Neste ínterim, as circunstâncias chamadas pela historiografia clássica a "justificar" a violência revolucionária seriam antes o resultado de uma representação do social que supervalorizava tais circunstâncias: "Não há circunstâncias revolucionárias, mas sim uma Revolução, que se alimenta das circunstâncias". Cf. F. Furet, Pensando a Revolução Francesa, p. 78.

${ }^{251}$ Owen Bradley, A Modern Maistre: the social and political thought of Joseph de Maistre (Lincoln-London: University of Nebraska Press, 1999), p.209.

${ }^{252}$ S. Rials, "Lecture de Joseph de Maistre", in: Révolution et Contre-Révolution au XIXe siècle (Paris: Albatros, 1987), p. 27. Grifos do autor.

${ }^{253}$ Conforme destacamos no início deste capítulo, o tradicionalismo maistreano parte de uma rigorosa tomada de consciência histórica que vê a restauração pura e simples da ordem pré-revolucionária como algo desprovido de bom-senso. 
ocorra sem a sanção divina. Em última análise, é Deus que permite que os projetos humanos (bons ou ruins) tenham um determinado fim, com o propósito de que realizem seus desígnios divinos: "Todos os instrumentos são bons nas mãos do grande artista". ${ }^{254}$

E foi sobretudo nas Considerações sobre a França (1797) que Maistre tratou de esclarecer aos modernos simpliciores alguns dos dilemas impostos aos cristãos pelo fenômeno revolucionário francês, sendo os principais deles o Terror e a morte de tantos inocentes.

Como é sabido, o desígnio maistreano para redigir seu célebre panfleto providencialista e contrarrevolucionário surgiu em maio 1796, quando o periódico governista francês Le Moniteur Universel publicou o panfleto pró-republicano de Benjamin Constant (no qual percebia-se também a "mão" de Mme de Stäel), Da força do governo atual da França e da necessidade de apoiá-lo, e o qual, com vistas às eleições francesas de março de 1797, não apenas apresentava uma habilidosa defesa do governo do Diretório e da forma republicana de governo, como avançava um pioneiro ensaio de balanço histórico favorável ao fenômeno revolucionário francês, na medida em que procurava separar uma "boa" revolução ( a revolução da "liberdade" de 17891791) da má (a perversão da liberdade pelos jacobinos e o Terror entre 1792-1794), buscando desfazer o par Revolução-Terror.

Naquele contexto, a defesa de Constant do governo do Diretório procurou enfatizar que não era mais possível recuar diante das conquistas da Revolução, ou seja, que a mera tentativa de anular os direitos adquiridos (principalmente no que dizia respeito aos bens do clero e da nobreza confiscados e vendidos) precipitaria a nação numa "nova revolução". ${ }^{255}$ Nestas circunstâncias, o pensador liberal suíço chama a atenção de seus leitores para o fato de que a prudência política tipicamente conservadora - a qual repudia as transformações políticas súbitas e violentas recomendava não o retorno à Monarquia, mas o apoio ao governo republicano do Diretório, pois, do contrário, o retorno das querelas despertaria paixões políticas ainda mais violentas, uma vez que os defensores da república apoiavam-se em princípios e não somente em interesses pessoais. ${ }^{256}$

${ }^{254}$ Joseph de Maistre, Essai sur le principe générateur, capítulo XXVI.

${ }^{255}$ B. Constant, Da força do governo atual da França e da necessidade de apoiá-lo, cap. III. Citamos a partir da tradução de Josemar Machado de Oliveira publicada na Revista de História (USP), $\mathrm{n}^{\mathrm{o}} 145$ (2001), p. 181-230.

${ }^{256}$ B. Constant, Da força do governo atual da França e da necessidade de apoiá-lo, cap. II. 
Portanto, os eleitores "conservadores" conscientes deveriam cerrar fileiras em torno do governo do Diretório, concluía Constant em seu panfleto, pois só o mesmo lograria assegurar o repouso, as garantias constitucionais e a ordem.

Não obstante terem sido escritas com o propósito de refutar as teses de Constant e apresentarem um manifesto político em defesa da monarquia, as Considerações representam acima de tudo uma interpretação religiosa do fenômeno revolucionário francês ${ }^{257}$, razão pela qual seu título original deveria ser Considerações religiosas sobre a França. ${ }^{258}$ Com efeito, Maistre elaborou uma reflexão que, apesar de profundamente contrarrevolucionária, negou-se a ver a Revolução como algo essencialmente negativo, e isto graças à função providencial que atribuiu à mesma: ela não foi só um castigo, mas também um meio de que se serviu a Providência para regenerar a França, evitar sua desintegração ante os exércitos coligados, difundir o cristianismo pela Europa (através dos padres refratários emigrados) e preparar o retorno da monarquia.

E como dissemos acima, a principal fonte do humanismo providencialista maistreano encontra-se nas obras de Orígenes, como o Discurso à Mme Costa e, sobretudo, as Considerações, permitem entrever.

Apesar de não existir nenhum registro preciso da leitura de Orígenes pelo saboiano anterior a dezembro de 1797, não resta dúvida de que ele já absorvera o pensamento do teólogo alexandrino desde o Discurso de consolação de 1794, razão pela qual as Considerações não apenas mencionam o autor do Contra Celso, como desdobram o principal conceito de seu providencialismo, a saber, a ideia da punição/castigo nos quadros de uma pedagogia divina.

257 Importa salientar que dos 11 capítulos que compõem a obra, apenas o nono e o décimo capítulos- especialmente o último - assumem de forma categórica a refutação ao panfleto de Constant. Além disso, quando se trata de refutar o desígnio construtivista liberal-revolucionário de Rousseau e/ou o constitucionalismo democrático de Paine, Maistre retoma ipsis litteris os argumentos já produzidos no De la souveraineté du peuple. Como sublinhamos na dissertação de mestrado, constitui um ponto pacífico entre os principais autores maistreanos o fato de que as Considerações, mais que do que um mero panfleto de refutação às teses de Benjamin Constant, apresentam um "diálogo trágico entre a liberdade absoluta de Deus e a liberdade relativa dos homens", o que dota o panfleto com as características de um tratado filosófico atemporal. Cf. Jean-Louis Darcel, "Introduction" às Considérations sur la France (Genève: Slatkine, 1980), p. 19. Vide também: Richard Lebrun, "Introduction”, in: Considerations on France (Montréal: McGill-Queen's University Press, 1974), p. IV; Stéphane Rials, "Des Considérations sur la France' aux Soirées de Saint-Pétersbourg”, in: J.-Louis Darcel (org.), Les Soirées de SaintPétersbourg (Genève: Slatkine, 1993), p. 32; Jean-Yves Pranchère, L'Autorité contre les Lumières, p. 392-3; Pierre Glaudes, "Introduction" às Considérations sur la France, in: Joseph de Maistre: Oeuvres (Paris: Robert Laffont, 2007), p. 184-185.

${ }^{258}$ Aconselhado por Mallet du Pan, Maistre suprimiu a alusão religiosa para não afastar certo tipo de leitores. 
Tome-se, por exemplo, o seguinte trecho do Discurso de consolação à Mme. Costa, o qual, após destacar a "multidão de grandes culpados imolados uns pelos outros com uma precisão verdadeiramente sobrenatural" (um dos principais argumentos das Considerações), expressa o grande problema filosófico e/ou teológico - ao menos para os crentes - por trás da Revolução Francesa, a saber, as "torrentes de sangue inocente que se misturam ao sangue dos culpados", através da seguinte advertência:

"Ao invés de desesperarmos loucamente contra uma ordem de coisas que não compreendemos, aferremo-nos às verdades práticas. Pensemos que o epíteto de boníssimo é necessariamente ligado ao de grandíssimo, e isto basta para nós. Compreendamos que, sob o império do ser que reúne essas duas qualidades, todos os males de que somos testemunhas ou vítimas não podem ser a não ser atos de justiça, ou meios de regeneração igualmente necessários. Não foi ele quem disse, pela boca de um de seus enviados: 'Eu vos amei de um amor eterno'? ${ }^{259}$ Esta palavra deve servir-nos de solução geral para todos os enigmas que poderiam escandalizar nossa ignorância. Ligados a um ponto do espaço e do tempo, temos a mania de relacionar tudo a este ponto: somos igualmente ridículos e culpados."260

Em um mesmo parágrafo, Maistre reelabora os principais conceitos do providencialismo origeniano, respectivamente a noção de uma Providência divina que jamais abandona o homem mesmo após e, sobretudo, por causa do pecado original, e que seus "atos de justiça" ou punições devem ser entendidos como atos amorosos de um educador que visa à "regeneração" da alma (mesmo quando isto implica no sacrifício do corpo), razão pela qual é impossível dissociar o providencialismo de Orígenes e/ou de Maistre da dialética entre o livre-arbítrio e o pecado original. Do contrário, não se compreenderá a origem humana do mal, bem como o desígnio pedagógico-salvífico da Providência divina, que não poderia ser o resultado senão do pecado original humano decorrente do abuso do livre-arbítrio. ${ }^{261}$ De acordo com Orígenes, a Providência:

${ }^{259}$ Trata-se de uma citação do livro de Jeremias, 31: 3.

${ }^{260} \mathrm{~J}$. de Maistre, Discours à Mme. la Marquise de Costa, p. 40.

${ }^{261}$ No primeiro Entretien ou diálogo das Soirées - obra na qual desenvolve plena e extensivamente seu ethos paidêutico junto aos modernos simpliciores -, Maistre reitera, à guisa de Orígenes e de santo Agostinho, que Deus não poderia ser a origem do mal sobre a terra, de modo que o mesmo não é senão "o resultado da queda e da degradação do homem" pelo pecado original. Em termos humanos, o saboiano esclarece que "Deus é o autor do mal que pune, não daquele que mancha." Cf. J. de Maistre, Soirées, O.C., IV: 23 (I Entretien). 
"(...) é uma a força que contém e abraça toda a diversidade do mundo e guia a um único fim os vários movimentos... Portanto, mantemos que Deus, pai de todos, para a salvação de todas as suas criaturas, por meio de suas inefáveis sapiência e palavra, dispôs cada coisa para que nenhum dos espíritos... seja constrangido pela força e, contra a sua vontade livre, a agir diversamente de sua inclinação - de outro modo, o livre-arbítrio estaria suprimido e a própria natureza deles seria alterada -; por sua vez, os diversos movimentos e inclinações adaptam-se apropriada e utilmente à concórdia de um único mundo."262

E quanto à moral da carta de consolação, designada, repitamos, como um instrumento pedagógico/catecúmeno, Maistre observa - não sem se compadecer do sofrimento materno da Mme. Costa, para ele a maior vítima da trágica perda do jovem Eugenio - que, em última análise, e por mais doloroso que fosse para os familiares, o sacrifício do jovem devia ser visto como um bem ${ }^{263}$, pois ele não apenas morrera inocente, sem mácula, como seu espírito, em razão disso, fora prontamente aceito no céu:

"Quem mais do que vós, Madame, tem necessidade de se elevar a estes altos e consoladores pensamentos? Em meio a este terrível cortejo de males que a revolução derrubou sobre nossas cabeças, vossos sofrimentos, por um funesto privilégio, elevam-se acima de mil outros. O próprio sacrifício imposto a vosso filho desaparece, se o comparamos ao vosso: o dele foi apenas a morte; o seu, de sobrevivê-la. Arrancai, pois, os olhos desta terra, que para vós não é mais do que um deserto ensanguentado. O homem não parece tão pequeno senão porque ele está curvado sobre sua morada: a estatura deste ser é imensa... Levantai a tela: Eugênio está atrás. Outrora, Sócrates, antes de tomar a cicuta, dizia a seus amigos: 'Quando forem tratar de

${ }^{262}$ Orígenes, I Princìpi (Tratado sobre os Princípios), II. 2. 2, in: Manlio Simonetti (Milano: UTET, 2010), p. 235- 236; $1^{\text {a }}$ edição de 1968.

263 A este respeito, é de fundamental importância destacar alguns pontos que Maistre posteriormente desenvolveria nas Soirées, sua grande obra filosófica dedicada à catequização dos modernos simpliciores: segundo ele, em decorrência do pecado original, "a inocência não existe" (II Entretien, O.C., IV:82), de modo que "todo homem, na qualidade de homem, está sujeito a todos os infortúnios da humanidade": "a lei [é] geral, ela não é injusta" (I ${ }^{\mathrm{e}}$ Entretien, O.C., IV:26). Neste sentido, independente da conduta irrepreensível dos homens - isto é, para os padrões humanos destituídos da onisciência divina -, o sofrimento de um homem virtuoso deve ser encarado ou como necessário ou como merecido (em razão de uma falta passada recôndita aos homens ou de uma prevaricação futura que só o desígnio providencial conhece), razão pela qual "ao colocar o homem de bem às voltas com o infortúnio, Deus o purifica de seus crimes passados" (IX ${ }^{\mathrm{e}}$ Entretien, O.C., V:130) ou "o coloca em alerta contra os crimes futuros e o amadurece para o céu." Constitui, portanto, "um traço particular da bondade divina" o castigo neste mundo, "no lugar de castigar com muito mais severidade no outro" (VIII ${ }^{\mathrm{e}}$ Entretien, O.C., V:85). Pois os "sofrimentos são para o homem virtuoso o que os combates são para os militares: eles o aperfeiçoam e acumulam os seus méritos" (VIII ${ }^{\mathrm{e}}$ Entretien, O.C., V:85). 
meu corpo, jamais digam que estão cremando ou enterrando Sócrates; NÃO ME CONFUNDAM COM O MEU CADÁVER... ${ }^{\prime 264}$

Ora, se extrairmos a frase "arrancai, pois, os olhos desta terra, que para vós não é mais do que um deserto ensanguentado" e a transferirmos para o contexto das Considerações, perceberemos o mesmo leitmotiv e fundamento retórico. Pois a razão que contempla o terrível e sublime (na acepção clássico-burkeana do termo ${ }^{265}$ espetáculo dos desastres e das mazelas humanas ao longo da história - entendida como uma paradoxal epifania de Deus - só conseguirá compreender a sacralidade dessa história irracional (ao menos para os nossos padrões Ilustrados e imanentes) se considerar essa irracionalidade à luz da ideia racional da ordem e da justiça divinas a que ela se opõe. Sobretudo no que diz respeito à Revolução Francesa (e a "horrível efusão de sangue humano ocasionada por essa grande comoção"), Maistre anuncia a necessidade de a mesma passar a ser vista como "um meio terrível" que, "todavia, é um meio tanto quanto um castigo". ${ }^{266}$

Isto posto, permanece a questão de como a leitura providencialista maistreana das Considerações concilia (ou não) o axioma humanístico do livre-arbítrio com a noção de uma Revolução cujo "turbilhão arrasta como uma leve palha tudo o que a força humana soube opor-lhe", de um fenômeno providencial que "conduz os homens mais do que é" conduzido "pelos mesmos", a ponto de Robespierre, Collot d'Herbois e Barère jamais terem pensado em estabelecer o governo revolucionário e o regime do Terror, mas "foram levados a isso, insensivelmente, pelas circunstâncias". ${ }^{267}$ Em outras palavras, como se sustenta o argumento relativo ao humanismo maistreano, bem como o seu pressuposto sobre a bondade ou a justiça divinas, com a noção de uma Revolução providencial que instrumentaliza mecanicamente os homens num inaudito cortejo de violências?

${ }^{264}$ J. de Maistre, Discours à Mme. la Marquise de Costa, p. 40; grifos e maiúsculas do texto.

265 "A paixão a que o grandioso e sublime na natureza dão origem, quando essas causas atuam de maneira mais intensa, é o assombro, que consiste no estado de alma no qual todos os seus movimentos são sustados por um certo grau de horror. Nesse caso, o espírito sente-se tão pleno de seu objeto que não pode admitir nenhum outro nem, consequentemente, raciocinar sobre aquele objeto que é alvo de sua atenção. Essa é a origem do poder do sublime, que, longe de resultar de nossos raciocínios, antecede-os e nos arrebata como uma força irresistível. O assombro, como se disse, é o efeito do sublime em seu mais alto grau; os efeitos secundários são a admiração, a reverência e o respeito." Cf. Edmund Burke, Uma investigação filosófica sobre a origem de nossas idéias do sublime e do belo (Campinas-SP: Papirus, 1993), Parte II, Seção I; Longino, Do Sublime (São Paulo: Martins Fontes, 1996) Livro I, cap. 4.

${ }^{266}$ Joseph de Maistre, Considerações sobre a França, cap. 2.

${ }^{267}$ Joseph de Maistre, Considerações sobre a França, cap. 1. 
Também aqui, entendemos que a resposta para esta verdadeira quadratura de círculo ontológica encontra-se na teologia de Orígenes, mais precisamente nos seus comentários à Carta aos Romanos de são Paulo, e a qual, em outro período histórico e por motivos semelhantes, foi tão cara a Erasmo na sua defesa do livre-arbítrio ${ }^{268}$ e na refutação das teses luteranas ${ }^{269}$ expostas no De Servo Arbitrio (1525). ${ }^{270}$

A grande questão do referido comentário paulino de Orígenes era a de conciliar a noção de uma Providência boa e justa com o texto do Éxodo que narrava a ruína do faraó do Egito em razão do endurecimento de seu coração pela ação providencial. Pois se as Escrituras informam que "o Senhor endureceu o coração do faraó" que, em razão disso, não "quis deixar os hebreus partirem"271, onde está a responsabilidade do imperador egípcio e a justificação de sua pena?

Após ter classificado metodicamente os diversos tipos de interpretação equivocada para esta delicada passagem bíblica, Orígenes advertia que a abordagem dos textos das Escrituras deveria priorizar a descoberta do sentido "oculto" da narrativa: tudo o que nos remete às intervenções punitivas de Deus junto aos homens deveria ser visto à luz de uma pedagogia beneficente à humanidade, inclusive e sobretudo no controverso caso do faraó.

Orígenes começa sua demonstração salientando que a ação de Deus é comparável às ações da chuva ou do sol, cujos efeitos, variando de acordo com os terrenos sobre os quais recaem, não tornam os elementos responsáveis pelos mesmos. Deus age sobre os homens de uma maneira uniforme, mas como as ações recaíram sobre o coração argiloso do faraó (argiloso em razão das escolhas do próprio soberano), este, por sua vez, endureceu-se ainda mais pela excessiva exposição à luz divina do Deus dos hebreus. ${ }^{272}$ Assim, os mesmos atos de Deus (os prodígios, as injunções, as ameaças) que

${ }^{268}$ Como em sua obra De libero arbitrio diatribe sive collatio (1524).

${ }^{269}$ Mormente na obra Hyperaspistes (1526). Não por acaso, Lutero retoma as críticas de santo Agostinho a Orígenes em seu ataque às teses de Erasmo, o que de certo modo explica o tom um tanto crítico do humanista holandês em relação ao bispo de Hipona. Em uma carta ao teólogo católico e igualmente refutador de Lutero, John Eck (1486-1543), Erasmo confessou ter aprendido mais de "filosofia cristã" em "uma única página de Orígenes do que em dez de Agostinho." Citado em T. P. Scheck, Origen and the History of Justification, op. cit., p. 135.

270 A ponto de Godin ter logrado demonstrar que a exegese do teólogo alexandrino ter sido "onipresente" nas Anotações sobre os Romanos encontrados na última edição erasmiama do Novo Testamento (1535), com nada menos do que 139 citações explícitas, ante 67 de santo Agostinho e 14 de Lorenzo Valla. Cf. A. Godin, "Fonction d'Origène dans la pratique exégètique d'Erasme: Les Annotations sur l'Épitre aux Romains", in: O. Fatio e P. Fraenkel (ogs.), Histoire de l'exégèse au XVI siècle (Geneva: Droz, 1978), p. 17.

${ }^{271}$ Êxodo 10: 27.

${ }^{272}$ Orígenes, Tratado sobre os Princípios, III. 1. 9-10 
converteram um sem-número de pagãos que decidiram acompanhar o povo hebreu em seu êxodo ou facilitar-lhe a fuga, produziram efeitos diversos sobre o faraó.

Todavia, a preocupação de Orígenes de encontrar a exegese adequada - isto é, que estivesse conforme às exigências de retratar a Providência como fundamentalmente boa e justa - levou-o a uma segunda conclusão: o Senhor endureceu o argiloso coração do faraó (e a natureza argilosa deste coração devia-se, frise-se, apenas ao livre-arbítrio do homem em questão) pelo bem do mesmo. E para explicar esta nova leitura, apelou à metáfora medicinal: para curar certas doenças, o médico provoca abscessos que forçam a exposição do mal à superfície e finalmente o expulsam. Em outras palavras, trata-se de tornar o enfermo cada vez mais enfermo a fim de salvá-lo. E assim como o médico deve recorrer ao método radical dos abscessos para obter a cura em casos extremos, Deus também deve recorrer à "saciedade do mal" para salvar a alma dos nossos corações endurecidos. ${ }^{273}$ A este respeito, Margherite Harl pontuou o seguinte:

"A ideia de que a morte dos pecadores lhes é salutar quando a mesma é enviada por Deus a título de punição por seus pecados permite ao exegeta interpretar de maneira honrosa a Deus as menções bíblicas de sua 'cólera', de suas 'ameaças', de sua 'vingança', do 'fogo destruidor', etc. Ela faz parte da apologética judia e se explica também no meio 'judaico-cristão' diante das objeções gnósticas que atingiam o Deus do Antigo Testamento. Desse modo, tudo pode ser remetido à pedagogia divina, à sua 'economia' visando à salvação do pecador." 274

Isto posto, importa salientar que na exegese cristã de Orígenes, a morte da carne, que pode assegurar a salvação do espírito, não é uma morte espiritual: simboliza a renúncia ao pecado e a conversão. Por meio do arrependimento, o pecador deve contribuir com sua mortificação para o abrandamento de sua pena. Em Orígenes, e também para Maistre, o livre-arbítrio é a chave para a compreensão não só do pecado, mas também de sua remissão.

Assim como o Terror na Revolução Francesa, a morte do faraó não entra na categoria da morte espiritual (morte pelo pecado), mas na categoria bíblica das mortes salutares, uma vez que elas são enviadas por Deus a título de punição neste mundo. Como não se cansava de repetir Orígenes, "o bom Deus não pode querer senão a

\footnotetext{
${ }^{273}$ Marguerite Harl, Le déchifrement du sens: études sur l'herméneutique chrétienne d'Origène à Grégoire de Nysse (Paris: Institut d'Études Augustiniennes, 1993), p. 212.

${ }^{274}$ Marguerite Harl, Le déchifrement du sens..., p. 275-276.
} 
salvação do pecador." ${ }^{275}$ Pois o cúmulo do infortúnio para o pecador é o de ser abandonado pela Providência divina, de não receber a pedagogia terapêutica para sua alma.

Portanto, foi com a intenção de provar a bondade e a justiça da Providência divina que Orígenes dedicou especial atenção à explicação paulina da passagem do Exxodo referente ao endurecimento do coração do faraó. ${ }^{276}$ Deus jamais pretendeu condenar a alma do soberano egípcio e, diante de sua teimosia, lançou mão dos expedientes mais milagrosos (e, vale dizer, punitivos) para educá-lo. A ação divina, observou Orígenes contra as acusações gnósticas que identificavam a fúria punitiva de Deus do Velho testamento com um amoralismo antropomórfico, é única e exclusivamente orientada para o bem dos homens, mas estes, dotados de livre-arbítrio, reagem de maneira distinta à ação providencial, podendo até mesmo contrariá-la, a ponto de, a exemplo do faraó, infligirem-se um dano ainda maior através da ação pedagógico-salvífica de Deus. ${ }^{277}$

Em se tratando das Considerações, pensamos que o contrarrevolucionário saboiano tenha colocado em prática seu desígnio pedagógico cristão manifestado já na memória maçônica de 1782, e que ele, lançando mão de todos os recursos retóricos disponíveis a um típico panfleto do século XVIII - isto é, "um breve texto de prosa argumentativa, que trata de uma questão mais ou menos tópica, endereçado a um público bastante amplo, buscando exercer algum tipo de persuasão" por meio de apelos "racionais, emocionais e éticos bem específicos" ${ }^{278}$-, procurou traduzir as dificuldades teológicas implícitas na Revolução Francesa a um público mais amplo possível e, consequentemente, incapaz de compreender, por si só, as sutilezas providenciais do fenômeno.

E a principal mensagem teológica das Considerações, e a partir da qual Maistre elaborou sua refutação ao principal argumento político do panfleto de Constant, qual seja, o de que o retorno da monarquia traria consigo uma revolução contrária e a reabertura das dilacerações revolucionárias, consistiu em mostrar - sobretudo para os príncipes emigrados e às forças realistas -, a exemplo de são Paulo na Carta aos Romanos, que as vinganças políticas contrariavam os desígnios divinos, na medida que

${ }^{275}$ Idem, p. 277.

${ }^{276}$ Romanos 9: 14-18.

${ }^{277}$ Orígenes, Tratado sobre os Princípios, III. 1. 10.

278 F. P. Lock, "Politics, Pamphlets, and Ideas in Eighteenth-Century England" apud Richard Lebrun, "Joseph de Maistre as pamphleteer", in: Carolina Armenteros e Richard Lebrun (orgs.), The new enfant du siècle: Joseph de Maistre as a writer (St Andrews: Univ. of St. Andrews, 2010), p. 19-20. 
a própria Revolução, em seu caráter providencial, operou os atos de justiça: "A mim pertence a vingança; eu mesmo vou retribuir, disse o Senhor."279

Portanto, a recusa maistreana à ação não recaía apenas sobre o projeto construtivista liberal-revolucionário, mas também sobre a ação contrarrevolucionária concebida pelos emigrados franceses e levada a cabo pelos soberanos europeus. Isto fica claro quando o saboiano tece um paradoxal elogio ao "gênio infernal de Robespierre" e ao Comitê de Salvação Pública, pois somente eles seriam capazes de, naquelas circunstâncias revolucionárias ${ }^{280}$, "garantir a obediência cega dos soldados" e evitar o desmembramento da França, consequência inevitável da vitória dos exércitos coligados: "o movimento revolucionário uma vez estabelecido, a França e a monarquia não podiam ser salvas a não ser pelo jacobinismo". ${ }^{281}$ De maneira análoga aos revolucionários e de um modo ainda pior, os emigrados acreditavam que apenas a força e a iniciativa humanas seriam capazes de (re)instaurar a ordem, não percebendo que sua dinâmica beligerante - a qual, como bem demonstrara Constant (e, antes dele, no campo conservador, Mallet du $\operatorname{Pan}^{282}$ ), fortalecia politicamente o governo revolucionário - nada mais era que uma "revolução contrária" e não o "contrário da revolução":

"O retorno à ordem não pode ser doloroso, porque será natural, e porque será favorecido por uma força secreta, cuja ação é totalmente criadora. Ver-se-á precisamente o contrário do que se tem visto. Ao invés daquelas comoções violentas, daquelas dilacerações dolorosas, daquelas

\footnotetext{
${ }^{279}$ Romanos 12: 19-20.

${ }^{280}$ Poucos historiadores, fossem os mesmos favoráveis ou contrários à Revolução de 1789, conseguiram ilustrar tão bem e com raro equilíbrio essas circunstâncias quanto o liberal norte-americano e discípulo/tradutor de Georges Lefebvre, a saber, Robert Palmer. Em uma de suas primeiras obras sobre a Revolução, Twelve Who Ruled (1941), e de modo a criticar as interpretações de Albert Sorel, Alphonse Aulard e Albert Mathiez sobre o Terror - o primeiro, retratando-o como uma "simples explosão de furor dos extremistas" conduzidos pelo fanatismo jacobino; o segundo e o terceiro (que, não por acaso, citava o elogio aos jacobinos e a crítica aos emigrados das Considerações) como "uma pura reação de defesa" -, Palmer diz que o Terror foi, sim, um fruto das circunstâncias, mas sem deixar de demonstrar que as referidas circunstâncias foram uma consequência da anarquia gerada pela própria Revolução, em especial pela incapacidade de seus sucessivos líderes de responder às demandas político-econômicas internas. Por outro lado, e diferentemente de Maistre (e, paradoxalmente, do jacobino-marxista Mathiez, para quem o Terror, a exemplo do saboiano, fora fruto do esforço de guerra contra as forças coligadas), Palmer destacou que não é possível explicar o Terror, sobretudo o do primeiro semestre de 1794 (quando o perigo externo já havia sido dissipado), somente por meio da teoria das circunstâncias, como o discurso de Robespierre (ignorado por Aulard e brevemente aludido por Mathiez) de 18 pluvioso do ano II (5 de fevereiro de 1794) demonstra: "Se a força moral do governo popular na paz é a virtude, a força moral do governo popular em revolução é ao mesmo tempo virtude e terror: a virtude, sem a qual o terror é funesto; o terror, sem o qual a virtude é impotente" (Princípios de moralidade política que devem guiar a Convenção Nacional na administração interna da República). Cf. Robert R. Palmer, Le Gouvernement de la Terreur: l'année du Comité de Salut Publique (Paris: Armand Colin, 1989), p. 60 e 243.

${ }^{281}$ Joseph de Maistre, Considerações sobre a França, cap. 2.

${ }^{282}$ Jacques Mallet du Pan, Considérations sur la nature de la révolution et sur les causes qui en prolongent la durée, 1793.
} 
oscilações perpétuas e desesperadoras, uma certa estabilidade, um repouso indefinível, um bemestar universal, anunciarão a presença da soberania. Não haverá abalos, nem violências, nem sequer suplícios, salvo aqueles que a verdadeira nação aprovar: mesmo o crime e a usurpação serão tratados com uma severidade comedida, com uma justiça tranquila que só pertence ao poder legítimo." 283

Quando, no segundo capítulo, Maistre insta seu leitor a "admirar a ordem na desordem", é para dizer que, "por menos que se reflita a respeito", "os grandes culpados pela Revolução só podiam cair sob os golpes de seus cúmplices", pois se "apenas a força tivesse operado aquilo que se chama a contrarrevolução e restabelecido o Rei sobre trono, não teria havido meio de fazer justiça." Conforme ele indica nas Considerações:

"A maior desgraça que poderia suceder a um homem sensível seria o ter de julgar o assassino de seu pai, de seu parente, de seu amigo, ou, simplesmente, o usurpador de seus bens. E teria ocorrido precisamente isto no caso de uma contrarrevolução, tal como a concebiam; pois os juízes superiores, somente pela natureza das coisas, teriam pertencido quase todos à classe ofendida; e ainda que a justiça não tivesse feito senão punir, teria assumido ares de vingança. Ademais, a autoridade legítima conserva sempre uma certa moderação na punição dos crimes que têm uma multidão de cúmplices." 284

Portanto, ao salientar que "jamais Robespierre, Collot ou Barère, pensaram em estabelecer o governo revolucionário e o regime do terror...", de modo que "foram

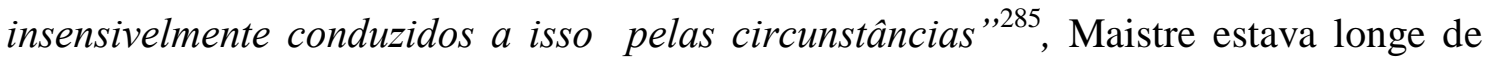
confessar alguma simpatia pela Revolução ou de atenuar seus excessos, e, sobretudo, de negar a dignidade ontológica do homem reduzindo-o a um mero instrumento providencial.

Pelo contrário, o caráter satânico da Revolução pode ser traduzido em termos maistreanos justamente pela reificação humana decorrente de uma alienação primitiva, e a qual consistiu na privação da paideia divina - isto é, do reconhecimento de sua origem e finalidade divinas pelo filosofismo e sua epistemologia materialista -, de modo que ao se entregarem à "deusa Razão" a fim de recriar um mundo com base unicamente em suas próprias forças (poderíamos dizer, um mundo "demasiado humano"), os franceses

\footnotetext{
${ }^{283}$ Joseph de Maistre, Considerações sobre a França, cap. 10.

${ }^{284}$ Joseph de Maistre, Considerações sobre a França, cap. 2.

${ }^{285}$ Joseph de Maistre, Consideraçõess sobre a França, cap. 2.
} 
alienaram-se da liberdade ontológica de que gozavam (liberdade esta transmitida e protegida pela tradição religiosa) e se transformaram em instrumentos mecânicos, em autômatos de "Vaucanson" de sua própria epistemologia materialista. Pois se jamais "o déspota mais sanguinário dispôs da vida dos homens com tamanha insolência, e jamais um povo passivo apresentou-se à carnificina com maior complacência "286, se "homens desprovidos de talento e de conhecimento mantiveram absoluto controle daquilo que designavam como carro revolucionário" e "não cometeram erros em sua carreira revolucionária, pela mesma razão que o flautista de Vaucanson ${ }^{287}$ jamais executou notas falsas"; se, enfim, "não são os homens que conduzem a revolução", mas é "a revolução que emprega os homens", é porque "jamais a Divindade se revelou de uma maneira tão clara em algum acontecimento humano": se ela emprega "os instrumentos mais vis, é porque pune para regenerar." 288

E assim como, em Dante, a punição divina reitera e exacerba o aspecto material e corpóreo da alma humana que foi a causa de sua condenação ${ }^{289}$, a Providência maistreana acentua o materialismo, ou melhor, o filosofismo, deixando-lhe reinar para que os franceses, que escolheram trair sua "missão" cristã na Europa ${ }^{290}$, fossem educados/castigados - "era preciso que se cumprisse a grande depuração, e que os olhos fossem golpeados"291 - pela "saciedade do mal". Ademais, como "era do povo propriamente dito, ou da multidão, que os facciosos necessitavam para agitar a França", era necessário "que o poder usurpador agravasse por muito tempo a condição" do mesmo, para que ele desgostasse profundamente da Revolução, vale dizer, dos princípios em nome dos quais ela foi feita. ${ }^{292}$

${ }^{286}$ Joseph de Maistre, Considerações sobre a França, cap. 2.

287 Jacques de Vaucanson (1709-1782). Mecânico francês nascido em Grenoble e que Maistre conhecera. Construtor de vários autômatos (os flautistas, os patos nadadores) que o levaram a adquirir renome por toda Europa.

${ }^{288}$ Joseph de Maistre, Considerações sobre a França, cap. 2.

${ }^{289}$ Vide Eric Auerbach, Mimesis: a representação da realidade na literatura ocidental (São Paulo: Perspectiva: 2004), p. 175; e Antonio Soro, La 'Divina Commedia' e l'apocatastasi di Origene (Sassari: Facoltà di Lettere e Filosofia -UniSS, 2009).

${ }^{290}$ "Cada nação, como cada indivíduo, recebeu uma missão que deve cumprir. A França exerce sobre a Europa uma verdadeira magistratura, seria inútil contestar, mas da qual abusou da maneira mais repreensível. Encontrava-se, sobretudo, ao vértice do sistema religioso, de modo que, não sem razão, designava-se seu rei como cristianíssimo: Bossuet não cometeu exageros neste ponto. Como ela se serviu de sua influência para contradizer sua vocação e desmoralizar a Europa, não é preciso surpreender-se pelo fato de que tenha sido a ela reconduzida pelos meios mais terríveis." Cf. Joseph de Maistre, Considerações sobre a França, cap. 2.

291 Joseph de Maistre, Considerações sobre a França, cap. 2.

292 Joseph de Maistre, Considerações sobre a França, cap. 2. 
Longe de negar o livre-arbítrio - como uma leitura desatenta e superficial do panfleto termidoriano poderia sugerir -, as Considerações afirmam-no com todas as letras, na medida em que, para o contrarrevolucionário saboiano, os franceses tiveram total e absoluta liberdade para prevaricar de sua liberdade, a ponto de a Providência divina, para puni-los, não fazer mais senão exacerbar o mesmo princípio por meio do absoluto abandono da humanidade a si própria. Como Maistre escreveu no De la souveraineté du peuple e no Essai sur le principe générateur, o castigo providencial consistiu simplesmente em obedecer plenamente à vontade "demasiado humana" dos homens, dando livre curso ao "reino da Filosofia".

Graças a este "ardil" providencial ${ }^{293}$ - "que sabe estender, restringir, paralisar ou dirigir a vontade, sem alterar sua natureza", mas que, em "épocas" de revolução, encurta bruscamente "a corrente que ata o homem", diminuindo sua ação e iludindo-o ${ }^{294}$-, o voluntarismo revolucionário que gerou a anarquia e, em última análise, o maior de todos os crimes revolucionários, a morte do soberano ${ }^{295}$, foi também o responsável por endurecer a alma dos franceses e, "mergulhando-os no sangue", exasperando "o espírito dos soldados" e redobrando "suas forças graças a um desespero feroz e a um desprezo pela vida", evitar "a conquista da França e, portanto, sua divisão, o amesquinhamento de sua influência e o aviltamento de seu rei, ou seja, massacres talvez de três séculos, consequência infalível de uma semelhante ruptura do equilíbrio."296

${ }^{293}$ S. Rials chega a comparar o "ardil" da "Razão" hegeliana, que realiza seus fins mesmo através das mais inusitadas e inesperadas circunstâncias engendradas pela ação humana, à Providência de Maistre. Leia-se S. Rials, "Lecture de Joseph de Maistre", op. cit., p. 32. Neste sentido, compare-se com a seguinte passagem do Essai: "Tudo que nasce de um abuso é um abuso!" Pelo contrário; constitui uma das leis mais gerais e mais evidentes desta força ao mesmo tempo oculta e espantosa que opera e se faz sentir por todos os lados, que o remédio do abuso nasce do abuso, e que o mal, chegado a um certo ponto, estrangula-se a si mesmo, e assim deve ser; pois o mal, que não é senão uma negação, tem por medidas de dimensão e de duração aquelas do ser ao qual ele está agarrado e devora. Ele existe como o cancro que não pode acabar a não ser acabando." Cf. Joseph de Maistre, Essai sur le principe générateur des constitutions politiques, capítulo XLII. Frase sublinhada trata-se de uma citação de Précis du siècle de Louis $X V$, de Voltaire.

294 Joseph de Maistre, Considerações sobre a França, cap. 1. É sempre o homem que age de acordo com tal ou qual desígnio, mas, repitamos, cabe à Providência decidir se e como determinada ação humana frutificará.

295 "Um dos maiores crimes que se pode cometer é, sem dúvida, o atentado contra a soberania, não havendo outro de consequências mais funestas... Porém, se esse soberano não mereceu esta sorte por qualquer crime anterior; se suas próprias virtudes armaram as mãos dos culpados contra si, não há designação para tal crime... O que mais importa observar, é que jamais um crime tão grave teve tantos cúmplices... Resta fazer uma observação importante: que todo atentado cometido contra a soberania, em nome da Nação, é sempre, em maior ou menor grau, um crime nacional; pois, de certo modo, é sempre uma responsabilidade da Nação se um dado número de facciosos logrou obter condições para cometer o crime em seu nome... Ora, todos os crimes nacionais contra a soberania são punidos sem dilação e de uma maneira terrível; trata-se de uma lei que nunca admitiu exceção." Cf. Joseph de Maistre, Considerações sobre a França, cap. 2.

${ }^{296}$ Joseph de Maistre, Considerações sobre a França, cap. 2. 
E como sempre "há ordem na desordem", o Terror - obra humana à outrance também dera curso à regeneração do clero $^{297}$, punindo com a morte inúmeros "apóstatas" que decidiram fazer o juramento constitucional e lançando à emigração milhares de padres franceses para que "fossem mostrados às nações... protestantes", dirimindo assim "os ódios e os preconceitos" recíprocos. ${ }^{298}$ Uma vez que a "igreja galicana era uma pedra angular do edifício católico" ou "cristão", resulta disso que, "sendo a reação entre as potências opostas sempre igual à ação, os maiores esforços da deusa Razão contra o cristianismo tenham se dado na França: o inimigo atacava a cidadela." Diante disso, Maistre afirmava que o clero francês tinha "mil razões para crer que fora chamado a uma grande missão", e as mesmas conjecturas que lhe permitiam desvendar as razões de seu sofrimento, permitiam-lhe "também crer-se destinado a uma obra fundamental", de modo que "se a Europa não passar por uma revolução moral, se o espírito religioso não for revigorado nessa parte do mundo, o tecido social ficará dissolvido." 299

Se Maistre anunciava o caráter epocal e secular da Revolução Francesa, que deitava suas raízes no passado distante (a Reforma) e se projetava para um futuro indefinido, era porque enxergava na missão nacional francesa (o proselitismo cristão através de sua língua) o centro de todo o combate. O futuro da França, da Europa e do mundo estava diretamente entrelaçado ao domínio daquela força titânica: se permanecesse nas mãos do filosofismo - o que era possível, pois a pedagogia/punição divina, por mais severa que fosse, jamais chegaria ao ponto de suprimir a liberdade humana -, se os homens não prestassem atenção às lições da Providência através da história da Revolução, a mesma estaria fadada a se repetir não como uma farsa, mas como uma tragédia (ou pedagogia providencial) de dimensões mais profundas.

Portanto, mais do que formular uma "teoria das circunstâncias" avant la lettre, Maistre identificou no projeto revolucionário do Iluminismo, isto é, no projeto de (re)fundar a sociedade por meio da razão individualista (a qual teve origem na Reforma Protestante do século XVI), as causas da instabilidade política dos sucessivos governos

\footnotetext{
${ }^{297}$ "Não se pode negar que o sacerdócio, na França, tinha necessidade de ser regenerado, e, ainda que me encontre longe de adotar as declamações vulgares contra o clero, parece-me não menos incontestável que as riquezas, o luxo e a inclinação geral dos espíritos para o relaxamento, fizeram decair esse grande corpo; que sob a túnica estivesse amiúde um cavaleiro no lugar do apóstolo; e, por fim, que nos tempos que precederam imediatamente a Revolução, o clero se encontrava despojado, a exemplo do exército, do lugar que havia ocupado na opinião geral." Cf. Joseph de Maistre, Considerações sobre a França, cap. 2.

298 Idem.

${ }^{299}$ Joseph de Maistre, Considerações sobre a França, cap. 2.
} 
revolucionários (que ele, mesmo após a Restauração, julgava longe de um final feliz para sua causa) e do Terror, de modo que se torna impossível separar uma "era feliz" daquilo que Constant e, posteriormente, a historiografia liberal da Restauração, desde Mme de Stäel, classificou como traição dos princípios. Conforme destacou F. Furet, ao negarem-se em separar uma "boa" Revolução da "má", as Considerações avançaram uma leitura da "Revolução-bloco" de tão brilhante futuro ${ }^{300}$ : "A Revolução francesa percorreu um período cujos momentos, sem dúvida, diferem entre si; porém, seu caráter geral jamais variou, e desde o berço dava sinais daquilo que viria a ser" ${ }^{301}$ No mesmo sentido, Pierre Manent observou que as Considerações, "mais do que as Reflections de Burke", "fundam a tradição da reação, ou da contrarrevolução, dessa corrente de pensamento que, ao invés de criticar a Revolução por uma medida ou outra, ou por seus excessos em geral, rejeita-a por inteiro, em seu princípio, como contrária à própria natureza do homem social e moral", 302

Por fim, importa salientar que, muito embora a liberdade humana e a causalidade própria das causas segundas não sejam ontologicamente anuladas pelo posterior uso instrumental que a Providência divina faz das mesmas, o mesmo não se pode dizer sobre o plano histórico-político: afinal, todos nascem em uma determinada nação e têm sua liberdade delimitada pela missão que a Providência atribuiu a seus países de origem.

Ademais, é tão difícil não extrair consequências politicamente fatalistas do providencialismo maistreano, que ele próprio chega a confessar esta possibilidade em suas correspondências diplomáticas. Referindo-se à vitória de Napoleão na célebre batalha de Austerlitz (dezembro de 1805), Maistre expressou o seguinte numa longa missiva endereçada ao rei Victor-Emmanuel I da Sardenha e datada em 31 de janeiro de 1806: "o dedo divino está tão profundamente marcado nestes acontecimentos, que me torno em um certo sentido fatalista". ${ }^{303}$ Ainda a respeito de Napoleão, Maistre confessou em uma missiva de 1810 que "se pudesse dar-lhe a morte por um único ato" de sua vontade, abster-se-ia "certamente de fazê-lo", pois teria "medo de misturar" sua "ignorância humana aos planos que são demasiado vastos para que seja permitido a um filho de um homem e de uma mulher atravessá-los." Apesar de, adverte Maistre em seguida, "não permanecer menos firme" na convicção de que "este homem milagroso

\footnotetext{
${ }^{300}$ François Furet, A Revolução em debate (Bauru-SP: Edusc, 2001), p. 8.

301 Joseph de Maistre, Considerações sobre a França, cap. 5.

302 P. Manent, 'Introdução' às Considérations sur la France (Paris: Complexe, 2006), p. VII.

${ }^{303}$ Joseph de Maistre, O.C., X:38.
} 
exerce apenas uma força puramente negativa, e que ele não tenha outra força que a do relâmpago, ele é o que deve ser e não pode durar." ${ }^{304}$

Por mais que o tempo da ação política seja inseparável da urgência do presente, a legitimidade só se cristaliza após a ação e, não raro, a despeito dela, através da confirmação trazida pelo tempo, o primeiro-ministro providencial de Maistre. Isto implica em admitir que a legitimidade, no momento de sua instauração, quase sempre é ilegítima ${ }^{305}$, mais especificamente, uma "usurpação legítima". 306

Mesmo admitindo que a guerra e a violência acompanham a legitimidade em seu nascimento, Maistre, para não deixar dúvidas sobre o que julgava ser o caráter ilegítimo do projeto construtivista revolucionário francês, destacou o exemplo da constituição inglesa, cuja moderação e equilíbrio entre os poderes não foram resultados de raciocínios a priori de legisladores, mas da reunião involuntária de inúmeras ações e vontades ao longo do tempo:

"A constituição é obra das circunstâncias, e o número das circunstâncias é infinito. As leis romanas, as leis eclesiásticas, as leis feudais, os costumes saxões, normandos e dinamarqueses; os privilégios, os preconceitos e as pretensões de todas as ordens; as guerras, as revoltas, as revoluções, a conquista, as cruzadas; todas as virtudes, todos os vícios, todos os conhecimentos, todos os erros, todas as paixões; todos esses elementos, agindo conjuntamente e formando, por sua mistura e por sua ação recíproca, combinações multiplicadas por miríades de milhões, produziram, enfim, após muitos séculos, a unidade mais complicada e o mais belo equilíbrio de forças políticas que já se viu no mundo." ${ }^{307}$

Em todas as instituições legítimas, o momento da "ação" política (com tudo o que ela traz de barulho, força e violência) fica circunscrito ao início das mesmas, pois assim como a tranquilidade e a paz são símbolos de aprovação divina, a violência é um claro sinal de ilegitimidade: "Todas as operações legítimas, de qualquer gênero que elas sejam, constroem-se sempre de uma maneira insensível. Aonde quer que se encontre o barulho, o choque, a impetuosidade, as destruições, etc., pode-se estar seguro de que é o crime ou a loucura que agem." 308

${ }^{304}$ Joseph de Maistre, O.C., XI: 447.

${ }^{305}$ Em Du Pape, Maistre chega a admitir que não haveria poder europeu "em estado de justificar todas as suas possessões perante Deus e a razão". In: Joseph de Maistre, Du Pape, Livro II, cap. 6.

${ }^{306}$ Joseph de Maistre, "Preface" do Essai sur le principe générateur (O.C., I: 232).

${ }^{307}$ Joseph de Maistre, Essai sur le principe générateur, capítulo XII.

${ }^{308}$ Joseph de Maistre, Du pape, Livro III, cap. 2. 
Seja como for, prevalece o fato de que o providencialismo maistreano, coerente com suas premissas metafísicas (daí ser ele fundamentalmente uma metapolítica), não foi designado para servir de guia para a ação política dos homens. Pelo menos não da política tomada em sua acepção mais concreta e moderna que, iniciada por Maquiavel, entende a mesma como o conhecimento e conquista dos meios para a tomada, preservação e expansão do poder.

Isto fica explícito quando Maistre, em uma carta de 1812 endereçada ao favorito de Luís XVIII e seu colega diplomático na corte do czar (trata-se do conde Blacas), teceu a seguinte observação sobre a política a ser seguida pela monarquia Bourbon (futuramente) restaurada: "todos devem estar de acordo sobre este axioma: é preciso conservar da antiga constituição tudo aquilo que as circunstâncias não destruíram irrevogavelmente. Porém, o que elas destruíram desta forma? Só Deus o sabe." 309

O fato é que a condenação maistreana ao artificialismo revolucionário e à ideia de direitos universais, o "horror pela vontade" ${ }^{310}$ e pela igualdade, podem dar a impressão de que a concepção constitucionalista maistreana - a qual, como vimos, é inseparável de sua visão providencialista - culmina numa total renúncia à política e, neste ínterim, na renúncia a todo valor universal na definição dos fins últimos da vida em sociedade. No limite, podemos inclusive concordar com o historiador do pensamento econômico Albert Hirschman, para quem a denúncia maistreana à vontade planificadora e construtivista da sociedade revestiu-se de uma retórica perversa inspiradora dos futuros argumentos neoliberais nos planos político-econômicos. ${ }^{311}$

Todavia, o pensamento constitucional maistreano é mais nuançado, na medida em que a condenação de toda fundação voluntária e o acento posto sobre a tradição e a prescrição histórica não significam que o saboiano negue o caráter evolutivo das constituições. Pelo contrário, Maistre era firme na crença de que uma constituição

\footnotetext{
${ }^{309}$ E. Daudet, Joseph de Maistre et Blacas, leur correspondance inédite et l'histoire de leur amitié (Paris: Pion, 1908), p. 270-271.

${ }^{310}$ S. Rials, "La droite ou l'horreur de la volonté", in: Révolution et Contre-Révolution au XIX siècle (Paris: Albatros, 1987), p. 53-68.

311 A. O Hirschman, A retórica da intransigência: perversidade, futilidade, ameaça (São Paulo: Cia das Letras, 1992), p. 23. No entanto, após consultar e analisar cuidadosamente os breves escritos econômicos do contrarrevolucionário saboiano, Cara Camcastle destacou como Maistre, apesar de geralmente simpático às ideias de Adam Smith e dos fisiocratas franceses sobre a liberdade comercial (a ponto de divergir diametralmente da posição tradicionalista adotada por Bonald, para quem o comércio e a indústria engendravam a corrupção moral e física da sociedade), preferia uma abordagem que primava por uma intervenção moderada do Estado (cujo intervencionismo excessivo ele condenava) na economia, ciente de que a absoluta liberdade do mercado produzia efeitos devastadores sobre a população mais pobre sem os devidos marcos regulatórios e intervenções conjunturais. Vide: Cara Camcastle, The More Moderate Side of Joseph de Maistre. Views on Political Liberty and Political Economy (Montréal \& Kingston: McGill-Queen's University Press, 2005), p. 164-165.
} 
qualquer não seria capaz de sobreviver à usura do tempo a menos que demonstrasse capacidade de adaptação às mutações impostas pelo mesmo, de modo que a defesa empedernida do status quo e o insistente recurso legalista às leis primitivas eram encarados por ele como ações tão ou mais perniciosas quanto a tábua rasa revolucionária. Como as Considerações deixam claro, "toda constituição livre é por sua natureza variável, e variável na proporção em que é livre". ${ }^{312}$ Ainda que a visão histórica de Maistre esteja indelevelmente ligada ao conceito providencialista cristão, a mesma está longe de incorporar o imobilismo em seu quadro referencial, pois isto implicaria em negar o livre-arbítrio humano tão defendido pelo saboiano.

Portanto, a despeito de o providencialismo maistreano implicar numa limitação da capacidade de ação política humana, ele está longe de negar-lhe a capacidade de organizar, modificar e melhorar sua realidade através da ação autônoma e racional de sua inteligência sobre os dados preexistentes (os quais, por sua vez, determinam os limites do "possível" ou do legítimo para o julgamento político).

Afinal, Maistre não se cansou de repetir que, apesar de "quebrado" pelo "pecado original", o poder da vontade humana não é menos real. Mais do que uma negação de toda política, o providencialismo maistreano oferece uma lição de prudência política, uma advertência contra os perigos da abstração e do voluntarismo que a Revolução de 1789 ilustrara tão tragicamente, uma exortação a preferir o possível a uma perfeição inatingível e, ademais, explosiva. É o que ele pretende explicar ao insistir sobre "a necessidade de só inovar muito raramente, e sempre com moderação e temor". ${ }^{313}$

Conforme pontuou Patrice Gueniffey a respeito da doutrina conservadora de Maistre, se o saboiano volta as costas tão resolutamente ao espírito revolucionário, ele não se opõe menos à "desesperante" ${ }^{314}$ acepção tradicionalista que, em suas proposições imobilistas, sonhava com a restauração de uma ordem que jamais existira, recaindo naquilo que Benjamin Constant definiu de maneira tão perspicaz como uma espécie de utopia tão revolucionária quanto à dos revolucionários. ${ }^{315}$

Neste sentido, não podemos concordar com aqueles que consideram a religião do saboiano como "um sistema político e nada mais" ${ }^{316}$, como apenas "uma explicação de

\footnotetext{
312 J. de Maistre, Considerações sobre a França, cap. 8.

${ }^{313}$ J. de Maistre, Considerações sobre a França, cap. 6.

${ }^{314}$ G. Gegembre, La Contre-révolution ou l'histoire désespérante (Paris: Imago, 1989).

315 Patrice Gueniffey, Histoires de la Révolution et de l'Empire (Paris: Perrin, 2011), p. 426.

${ }^{316}$ E. Schérer, "Joseph de Maistre", in: Mélanges de critique religieuse (Paris: Cherbouliez, 1860),
} p. 286. 
sua política e uma justificação de sua filosofia" ${ }^{317}$ fundamentada "ao mesmo tempo no desprezo e no temor do homem, na ideia de que ele é corrompido demais para merecer a liberdade". ${ }^{318}$

Pelo contrário, cabe observar que a visão maistreana sobre o pecado original coincide plenamente com a ortodoxia católica, na medida em que ela é indissociável do ato amoroso redentor e pedagógico da Providência divina que jamais abandona o homem na história. Como bem observou o teólogo Jérôme Alexandre a respeito do cristianismo de Maistre, "o trágico da degradação humana devido ao pecado jamais está dissociado do seu contrário", ou seja, "é o pecado original que permite compreender dialeticamente a grandeza da inocência, o valor do bem, o benefício da solidariedade entre os homens, o incessante esforço da inteligência para se superar", etc. ${ }^{319} \mathrm{E}$ na medida em que é indissociável de um pensamento sobre a origem e a destinação do homem em toda a sua produção, o providencialismo maistreano pode ser considerado como irrevogavelmente humanista, por mais que isto soe demasiado estranho aos nossos critérios modernos e ilustrados.

${ }^{317}$ E. Faguet, Politiques et moralistes du dix-neuvième siècle (Paris: Boivin \& Cie, 1899), p. $42-$ 43.

${ }^{318}$ E. M. Cioran, "Joseph de Maistre: Ensaio sobre o pensamento reacionário", in: Exercícios de admiração: ensaios e perfis. Trad. de José Thomaz Brum (Rio de Janeiro: Rocco, 2001), p. 22-23.

${ }^{319}$ Jérôme Alexandre, "Joseph de Maistre et le peché originel", p. 98. 


\section{Conclus ão}

Em seu clássico estudo sobre as relações entre o direito natural e a história, o filósofo conservador Leo Strauss destacou como "os conservadores eminentes que fundaram a escola histórica" adotaram uma postura crítica ao direito natural que não apenas prosseguiu como acentuou o "esforço revolucionário dos seus adversários" - na medida em que os mesmos se dirigiam "tanto contra o antinatural ou convencional como contra o supranatural ou supramundano." ${ }^{1}$

Se aplicarmos esta sentença ao caso de Maistre, não restam dúvidas de que a sua reação ao projeto construtivista revolucionário fundado no direito natural culmina numa rejeição a toda ideia de princípios políticos universais valendo para o homem enquanto homem, razão pela qual um autor como Pierre Manent identificou na crítica do contrarrevolucionário saboiano à Revolução de 1789 uma ruptura tão ou mais radical com a tradição da filosofia política clássica do que a empreendida pelos próprios revolucionários. $^{2}$

Deflagrada para reconquistar o domínio da razão prática invadida pelo doutrinarismo revolucionário, a crítica maistreana anulará por completo esse domínio na fundamentação de sua política. Afinal, como salientou Karl Mannheim em seu célebre estudo sobre o pensamento conservador, o pensamento revolucionário "deriva sua força do desejo de realizar um tipo racionalmente bem definido de perfeição da ordem social e política. O pensamento conservador, oposto à realização desta utopia, está obrigado a pensar por que o estado da sociedade que realmente existe não corresponde àquele tipo racional". Assim, enquanto o pensamento revolucionário concebe essas irracionalidades "como imperfeições da realidade comparada com a norma da razão", o pensamento conservador - incorrendo num de seus meios favoritos, o paradoxo - "atribui-lhes o

\footnotetext{
${ }^{1}$ Leo Strauss, Direito Natural e História (Lisboa: Edições 70, 2009), p. 15. Mais adiante, Strauss teceu a seguinte observação sobre a forma "extrema" de "intramundaneidade" assumida pelo historicismo moderno: "Ao negar o significado, se não a existência, de normas universais, a escola histórica destruiu a única base sólida de todos os esforços sérios para transcender o atual." Cf. Strauss, op. cit., p. 17.

${ }^{2}$ P. Manent. 'Introdução' às Considérations sur la France de J. de Maistre (Paris: Complexe, 2006), p. XIII.
} 
caráter de super-racionalidade." Em suma, a "História, reduzida ao seu essencial, não é mais do que uma experiência; e é na confiança na experiência mais do que no abstrato e no poder dedutivo em questões humanas que o conservadorismo baseia sua fé na história."

Esta atitude, especialmente na particularíssima articulação maistreana entre providencialismo e a história, culmina numa concepção política que esconde uma tentação quietista e uma contradição consubstancial a seu pensamento: o que existe, mesmo que à primeira vista agrida à razão, é racional, uma vez que fora sancionado pela história, a única e válida "política experimental" e "primeiro-ministro da Providência". Por outro lado e dentro desta lógica, nada impediria que a democracia, apesar de seu início turbulento e "ilegítimo", adquirisse o selo da legitimidade providencial-histórica.

Isto posto, temos sérias dúvidas quanto ao fato de que a última parte do juízo de Strauss - que, importa observar, não se refere a Maistre na referida passagem e muito menos em sua obra - possa ser aplicada sem reparos ao providencialismo maistreano, uma vez que o mesmo foi completamente orientado pela subsunção do mundano ao supramundano. Como bem pontuou Douglas Hedley a respeito da crítica de Pranchère ao que este denomina como o "historicismo maistreano" - e a qual sustenta que o providencialismo maistreano tende a emprestar um caráter absoluto ao relativo através da afirmação de que a vontade de Deus é "perfeitamente declarada pelos fatos" ${ }^{5}$-, não podemos esquecer de que Maistre combina, "numa sutil dialética", o "transcendente com o particular, o eterno com o histórico". ${ }^{6}$

A nosso ver, é precisamente esta "sutil dialética" transcendental no interior do providencialismo maistreano que permite explicar a eclética combinação entre o eterno e o histórico no pensamento do saboiano. Assim, se Maistre admitia que uma soberania era absoluta - mesmo a do modelo constitucional liberal inglês pós-Revolução Gloriosa - apenas "no interior do círculo de legitimidade traçado pelas leis fundamentais de cada país"", ele não deixava de admitir variações locais e históricas daquele círculo, posição

\footnotetext{
${ }^{3}$ K. Mannhein. "El Pensamiento Conservador", in: Ensayos sobre Sociología y Psicología Social (México-DF: Fondo de Cultura Económica, 1963), p. 165.

${ }^{4}$ R. Nisbet, O Conservadorismo (Lisboa: Estampa, 1987), p. 48.

5 J.-Yves Pranchère, "The Persistence of Maistrean thought", in: R. Lebrun (org.), Joseph de Maistre's Life, Thought and Influence (London: McGill-Queen's University Press, 2001), p. 314.

${ }^{6}$ Douglas Hedley, "Enigmatic images of an invisible world: sacrifice, suffering and theodicy in Joseph de Maistre", in: C. Armenteros e R. Lebrun (orgs.), Joseph de Maistre and the legacy of Enlightenment (Oxford: Voltaire Foundation, 2011), p. 127.

${ }^{7}$ J. de Maistre, Du Pape, Livro II, cap. 3. Grifos de Maistre.
} 
esta que, conforme sublinhou Strauss, não conduz necessariamente à negação do direito natural em sua acepção clássica:

"(...) A diversidade de opiniões sobre o direito ou sobre a justiça não só é compatível com a existência do direito natural ou com a ideia de justiça, como é uma das suas condições. Poderse-ia dizer que a diversidade de concepções de justiça refuta a existência do direito natural se esta tivesse como condição o consentimento efetivo de todos os homens relativamente aos princípios do direito. Mas aprendemos com Sócrates, ou com Platão, que o consentimento não tem de ser senão potencial."

Apesar da forte influência neoplatônica orientar seu cristianismo para uma abordagem perenialista que admitia um núcleo comum em todas as religiões, Maistre não pressupunha a existência de uma escala de valores que o levava a designar a tradicional e legal prática hinduísta que consistia em queimar as viúvas (a PitrimedhaYaga) como uma "atrocidade" ou um "preconceito bárbaro" ${ }^{9}$, ao mesmo tempo em que reconhecia "o quão bem uma lei humana" podia "ser injusta" quando a mesma violava "uma lei divina, revelada ou inata"? ${ }^{10}$

Como bem observou Richard Lebrun a respeito do direito natural no pensamento de Maistre, em sua reação contra o projeto construtivista do século XVIII feito em nome do direito natural, o autor das Considerações elaborou uma filosofia política teocrática que atribuiu à Providência divina o papel gerador das constituições, razão pela qual evitou conscientemente o termo em suas obras publicadas (tamanha sua identificação com a "anarquia revolucionária"), mas sem abandoná-lo por completo. ${ }^{11}$ Prova-o a seguinte passagem em que, referindo-se à natureza humana, diz o seguinte: "Eis aqui o homem natural. Não é que ele não traga em si próprio os germes inextinguíveis da verdade e da virtude: os direitos de sua nascença são imprescritíveis; mas sem a fecundação divina, esses germes não eclodirão jamais, ou não produzirão a não ser seres equívocos e malsãos." 12

Paradoxalmente, a crítica maistreana ao projeto construtivista revolucionário (designado por ele como "ateísmo prático") ${ }^{13}$, e a qual levara o saboiano a rejeitar a

\footnotetext{
${ }^{8}$ Leo Strauss, Direito Natural e História, p. 109.

9 J. de Maistre, Éclaircissement sur les sacrifices, O.C., V: 317.

${ }^{10}$ Joseph de Maistre, Les Soirées de Saint-Pétersbourg, O.C., V: 104 (VIII Entretien)

${ }^{11}$ R. Lebrun, "Maistre and Natural Law", in: R. Lebrun (org.), Maistre Studies (London: University Press of America, 1988), 204-205.

12 J. de Maistre, Éclaircissement sur les sacrifices, O.C., V: 325.

${ }^{13} \mathrm{~J}$. de Maistre, Essai sur le principe générateur, capítulo XLVI.
} 
intervenção autônoma da razão na esfera prática ou política (isto é, fazendo abstração do real concreto), fez-se em nome de uma concepção humanista que, apesar de seu caráter indelevelmente conservador, acentuou com traços fortes a dignidade ontológica do homem.

É bem verdade que, contrastada com o humanismo em sua acepção contemporânea, a concepção humanística maistreana ostenta um caráter anacrônico ou, na feliz expressão de Michael Kohlhauer, mécontemporain ${ }^{14}$, na medida em que avança ideias atemporais contra a sua época, e a qual, conforme destacou Tzvetan Todorov, caracteriza-se pela substituição da transcendência vertical por uma transcendência lateral, horizontal, que coloca o humano no lugar do divino. ${ }^{15}$ Fruto de uma "revolução lenta... no espírito dos europeus", esta revolução "consiste em afirmar que a melhor justificativa de um ato, a que o torna mais legítimo, provém do próprio homem", "de sua vontade, de sua razão, de seus sentimentos", de modo que o "centro de gravidade passa do cosmos para o anthropos, do mundo objetivo ao querer subjetivo". Em vez de se submeter "a uma ordem que lhe é exterior", o ser humano "quer fundar pessoalmente essa ordem" através de um duplo movimento: "um desencanto do mundo e uma sacralização do homem; retirados de um, os valores serão confiados ao outro."16

Em sua absoluta crença na autonomia do sujeito, o humanismo moderno não atribui à interação humana um papel particular e considera legítimo que cada indivíduo progrida de acordo com o que ele julga ser o seu ideal, razão pela qual é "preferível não mais falar aqui de 'moral', pois esta implica sempre uma regra comum, transindividual, mas apenas de valores, e designar sua codificação como uma arte de viver". Na ótica individualista do humanismo moderno, a busca pelo summum bonum não conduz à investigação das verdades comuns a cada um dos membros da sociedade, mas consiste em "ensiná-los a caminhar para uma maior expansão, para o cumprimento de seu próprio destino, para aquilo que pode constituir sua felicidade." ${ }^{17}$

Como bem observou P. Manent, a fim de "combater os efeitos corruptores de uma religião que impunha a verdade", a modernidade separou "o mais completamente possível" a questão da liberdade da questão da verdade, definindo o homem pela

${ }^{14}$ M. Kohlhauer, "Contre l'air du temps. Joseph de Maistre, actualité d'un 'mécontemporain' ", in: Valère Novarina, Michael Kohlhauer e Pierre Caran (orgs.), Rencontres autour de Joseph de Maistre (Thonon-les-Bains: Université de Savoie, 2009), p. 33.

15 T. Todorov, O Jardim Imperfeito: o Pensamento Humanista na França (São Paulo: Edusp, 2005), p. 128

${ }^{16}$ T. Todorov, O Jardim Imperfeito: o Pensamento Humanista na França, p. 19-20.

${ }^{17}$ T. Todorov, O Jardim Imperfeito: o Pensamento Humanista na França, p. 149. 
liberdade ou declarando "que a verdade residia na liberdade". Em seu triunfo completo sobre a ideia da verdade e privada da relação conflituosa com a mesma, a liberdade, nas palavras de Manent, "tende a desmoronar sobre si própria": "Ao invés de ser um esforço para a autonomia, para o governo de si e para si, ela se torna aceitação e declaração de si, acompanhada da exigência de que os outros reconheçam e respeitem esta aceitação e declaração de si. Tendo vencido a verdade, ou tendo-a absorvido, a liberdade é vencida pela propriedade, ou absorvida por ela"18 e, ademais, elimina qualquer conteúdo específico do próprio conceito de summum bonum.

Esta observação de Manent ajuda a compreender o ethos "mécontemporain" do humanismo maistreano em sua reação contra a modernidade, pois, à maneira dos clássicos - Maistre era tão ou mais leitor de Platão, Cícero, Tácito, etc., do que das fontes cristãs -, o contrarrevolucionário saboiano acreditava num summum bonum, cuja descoberta exigia o conhecimento do homem, o que, como bem demonstrou Leo Strauss (e acreditamos também ser válido para Maistre), pressupunha uma ordem hierárquica da constituição natural do homem:

"De uma forma ou de outra, todos distinguem o corpo da alma; e todos podem ser forçados a admitir que é impossível negar que a alma é superior ao corpo sem incorrerem numa contradição. O que distingue a alma humana dos animais selvagens... é a palavra ou a razão ou o entendimento. Por conseguinte, o próprio do homem consiste em viver refletidamente, em compreender, e na ação pensada. A vida boa é a vida conforme à ordem natural do ser do homem, a vida que flui de uma alma harmoniosa ou sã... Pode-se, então, chamar 'lei natural' às regras que circunscrevem o caráter geral da vida boa... A vida de acordo com a natureza é a vida da excelência ou da virtude humanas, é a vida de uma pessoa que não se guia pelo prazer." ${ }^{19}$

Criado à "imagem de Deus", a "vida boa" para o homem - ao menos na acepção cristã neoplatônica de Maistre - consiste em buscar, através dos esforços de seu livre arbítrio, a "semelhança" com a inteligência divina ${ }^{20}$, semelhança esta que o predispõe a conhecer e a amar. ${ }^{21}$ Apesar de livre, a vontade humana não é indiferente quanto aos seus motivos, devendo ser guiada pela razão a fim de que se articule com a sua natureza, isto é, com a busca do bem (a dispensa da caridade e da justiça para com o próximo) e, mais profundamente, com a busca de Deus. ${ }^{22}$ Devido ao pecado original, a vontade

\footnotetext{
${ }^{18}$ P. Manent, Cours familier de philosophie politique (Paris: Gallimard, 2001), p. 54.

${ }^{19}$ Leo Strauss, Direito Natural e História, p. 111.

${ }^{20}$ Joseph de Maistre, Les Soirées de Saint-Pétersbourg, O.C., IV: 200-201 (IV Entretien).

${ }^{21}$ Joseph de Maistre, Les Soirées de Saint-Pétersbourg, O.C., IV: 66 (II Entretien).

${ }^{22}$ M. Froidefont, Théologie de Joseph de Maistre, p. 114.
} 
humana foi "quebrada", razão pela qual o homem, na tradução poética de Racine às palavras de são Paulo, não faz o bem que ama, mas o mal que odeia. ${ }^{23}$ Atirado em sentidos contrários por sua vontade dividida (isto é, atraído seja pelos motivos de sua alma superior ou espiritual, seja pelos motivos de sua alma corpórea ou "princípio vital"), o homem "não pode fazer o bem e viver feliz sem reduzir à servidão essa potência da alma onde reside o mal, e sem pôr em liberdade aquela que é a sede e o órgão da virtude". ${ }^{24}$ Resultado ao mesmo tempo trino e uno de uma "percepção que apreende", de uma "razão que afirma" e de uma "vontade que age" - sendo que as duas primeiras potências foram apenas enfraquecidas mas não quebradas pelo pecado original -, é a inteligência que deve prevalecer nesta complexa unidade humana; é ela quem deve esclarecer e guiar a vontade, pois o cúmulo da miséria humana para um homem seria o viver de acordo com o seu desejo ${ }^{25}$ : o mesmo não seria livre se não tivesse o poder de resistir aos impulsos de seu princípio vital. ${ }^{26}$

$\mathrm{Na}$ teodiceia origenista de Maistre, o homem só logra realizar plenamente sua natureza livre se ele travar um combate moral consigo mesmo que o leve a um profundo e honesto exame de consciência, pois somente assim ele conseguirá dirigir racionalmente sua vontade para além dos motivos materiais e egoísticos que o "reificam"27, e colocar-se no caminho da assimilação em Deus.

A exemplo do que postulava a solução socrático-platônica do direito natural, Maistre acreditava que a única sociedade civil verdadeiramente justa "é a sociedade humana global sujeita a um só governo", a saber, o do "cosmos governado por Deus, que, por sua vez, é a única verdadeira cidade, ou a cidade absolutamente conforme à natureza, porque é a única cidade que é absolutamente justa. Os homens só são cidadãos desta cidade, ou nela são homens livres, quando são sábios; a sua obediência à lei que ordena a cidade natural, a sua obediência à lei natural, coincide com a prudência." ${ }^{28}$

Como os sábios e legisladores são muito raros e os homens precisam ser permanentemente governados por seus semelhantes em razão de sua condição adâmica, Maistre, à guisa dos clássicos, defendia que este governo deveria ser atribuído aos gentis-homens, vale dizer, pelo patriciado urbano detentor de terras que, além de

\footnotetext{
${ }^{23}$ Joseph de Maistre, Soirées, O.C., IV: 67, 69 (II ${ }^{\mathrm{e}}$ Entretien).

${ }^{24}$ Joseph de Maistre, Soirées, O.C., IV: 70 (II ${ }^{\mathrm{e}}$ Entretien). Grifos de Maistre.

${ }^{25}$ Joseph de Maistre, Soirées, O.C., IV: 385 nota 5 (VI ${ }^{\mathrm{e}}$ Entretien).

${ }^{26}$ Joseph de Maistre, Soirées, O.C., IV: 305 (VI ${ }^{\mathrm{e}}$ Entretien).

${ }^{27} \mathrm{~J}$. de Maistre, Éclaircissement sur les sacrifices, O.C., V: 285.

${ }^{28}$ Leo Strauss, Direito Natural e História, p. 130.
} 
estimar as coisas nobres, belas e sagradas, era dotado de boas maneiras e de um espírito cívico que davam um caráter e forma à sociedade.

Apesar das especificidades históricas e das diferenças quanto aos fins entre as tradições clássica e cristã (isto é, tomista) do direito natural, Maistre considerava a monarquia europeia, com a sua união entre trono e altar, plenamente capaz de dar prosseguimento à tradição de formar gentil-homens para o governo da sociedade.

Com efeito, por sua origem e meio social, Maistre era burguês e nobre a um só tempo: a nobilitação de sua família (1778) foi a coroação de um longo esforço de ascensão social de uma casa de comerciantes que logrou se enriquecer e integrar gradativamente seus rebentos no seio do funcionalismo estatal piemontês. De acordo com o próprio Maistre, "todos os dias" eram promovidos à nobreza homens que, "sem se tornar repentinamente iguais ao gentil-homem de raça", obtinham por seu turno uma "ilustração marcante", o que o levaria a caracterizar aquela monarquia como uma "aristocracia alternante". Ao definir a monarquia como uma "aristocracia alternante" em que "todas as honras, todos os cargos são dispostos ao cabo de uma disputa na qual todos têm o direito de concorrer" ${ }^{29}$, Maistre, num ethos semelhante ao demonstrado por Burke, combinava "uma concepção burguesa da sociedade civil e uma concepção aristocrática do Estado", na medida em que admitia e defendia a liberdade comercial (não com o mesmo radicalismo de Burke, é verdade) e a plena preservação de todas as

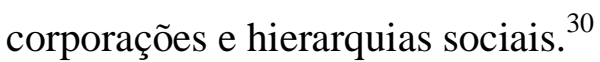

Portanto, cabia aos educados, prudentes e urbanos gentil-homens - parecidos, mas não iguais aos sábios - efetuar a necessária diluição do direito natural no direito convencional, sob pena de o direito natural em seu estado puro explodir a sociedade civil. Radicalmente distinto do ancestral, o bem puro e simples precisa "se converter no bem político, que é, por assim dizer, o quociente do bem puro e simples e do ancestral: o bem político é o que 'suprime uma grande quantidade de mal sem chocar uma grande quantidade de preconceitos.' É nesta necessidade que a conveniência da inexatidão na política ou nos assuntos morais em parte se funda". ${ }^{31}$

É bem verdade que Maistre, na esteira de Burke, se separa radicalmente dos clássicos ao rejeitar a ideia de que as constituições podem ser feitas (isto é, por meio da ação consciente e planejada de um ou vários homens) em favor de uma noção

\footnotetext{
${ }^{29}$ J. de Maistre, Lettres d'un royaliste savoisien a ses compatriotes, in: O.C., VII:226.

${ }^{30}$ Modesto Florenzano, Começar o Mundo de Novo: Thomas Paine e outros estudos (Trabalho para o concurso de Livre-Docência em História Moderna na FFLCH-USP, 1999), p. 177.

${ }^{31}$ Leo Strauss, Direito Natural e História, p. 132.
} 
providencialista que estipula que elas germinam ou crescem insensivelmente no tempo, através de uma grande variedade de acidentes e sem que os homens tenham consciência dos resultados de seus atos. ${ }^{32}$

Por outro lado, o apelo maistreano à experiência contra a 'tirânica' pretensão revolucionária de instaurar uma nova ordem ex nihilo difere frontalmente da acepção empírica burkeana, pois, como bem observou Strauss, a última é francamente tributária do sensualismo de Locke e, como tal, nega (em seu Sublime and Beautiful) "que exista uma relação entre a beleza... e a perfeição, a proporção, a virtude, a conveniência, a ordem", o que em última análise pressupõe a negação das ideias inatas e do conhecimento dos fins. Segundo Strauss, esta "emancipação da beleza sensível relativamente à afinidade com a beleza intelectual pressuposta pela tradição" desemboca numa espécie de "oposição ao 'racionalismo' enquanto tal", bem como numa concepção plenamente secularizada da ordem providencial da parte do commoner irlandês (ordem secularizada e tendente naturalmente ao liberalismo, pois o indivíduo era o fim último da política burkeana). ${ }^{33}$

Longe de enxergar a experiência como fundamento de toda ciência, a epistemologia maistreana não deixou de reconhecer seu papel (ainda que subordinado à razão ou à inteligência) no processo do conhecimento, o qual, aplicado à política (inseparável da natureza adâmica do homem, que exige que homens sejam governados por seus semelhantes), tinha a finalidade de devolver os homens à humildade, isto é, demovê-los de suas pretensões voluntaristas e reconduzi-los àquelas considerações prudenciais que, tornadas célebres por Montesquieu, não deixavam de ecoar um espírito clássico. ${ }^{34}$ Conforme advertiu inúmeras vezes Maistre, uma constituição nada mais é senão o modo de existência política que, "dados a população, os costumes, a religião, a situação geográfica, as relações políticas, as riquezas, os bons e maus atributos", mais convém a "uma determinada nação". ${ }^{35}$

A exemplo de Platão e Aristóteles, Maistre acreditava que todo direito natural é mutável na medida em que se assenta, em última análise, em decisões concretas, e não em regras gerais. Para ser capaz de lidar com a engenhosa perfídia de nossa condição adâmica, o direito natural precisa ser mutável; a justiça não pode ser decidida

\footnotetext{
${ }^{32}$ Leo Strauss, Direito Natural e História, p. 266-267.

${ }^{33}$ Leo Strauss, Direito Natural e História, p. 265-266, 269, 274.

${ }^{34}$ Leo Strauss, Direito Natural e História, p. 142.

${ }^{35}$ J. de Maistre, Considerações sobre a França, cap. 6. Grifos de Maistre.
} 
antecipadamente através de regras universais, mas tem de ser decidida no momento crítico pelo estadista mais competente e mais consciencioso. ${ }^{36}$

Se Maistre considerou a exposição de uma "fórmula universal do dever" (algo como o imperativo categórico kantiano) "uma abstração que se evapora desde que se inicia sua aplicação", isto não se deveu, conforme sustentou Pranchère ${ }^{37}$, em razão de um possível desdobramento fatalista e/ou historicista de seu providencialismo, e sim pela constatação de que se ninguém duvida da existência dessas regras, permanece sempre a questão de saber "qual é o dever nesta ou naquela ocasião. E, neste caso, o que significa a regra universal? Nada!" 38

Em vez de recair "na Cila do absolutismo" ou na "Caríbdis do relativismo", o providencialismo de Maistre admitia a existência de uma hierarquia de fins universalmente válida, mas não de regras de ação universalmente válidas. Suficiente para que se formulem julgamentos sobre o grau de nobreza dos indivíduos ou dos grupos, das ações e das instituições, este padrão era insuficiente para orientar as ações políticas humanas, que requerem o máximo de prudência e, consequentemente, o imprescindível apoio da tradição. ${ }^{39}$

É sob este prisma, isto é, de supressão de uma ordem política providencial (ou natural) responsável pela formação de um tipo específico de homem (a elite responsável pela transmissão das manners cristãs à sociedade europeia), que podemos compreender o virulento ataque à Revolução de 1789 pelo saboiano.

"Consequência direta, uma conclusão visível e inevitável dos princípios expostos nos séculos XVI e XVIII"40, o que na visão de Maistre caracterizava a Revolução Francesa como "satânica" 41 era o bloqueio - imposto pela circulação de uma cultura teofóbica ${ }^{42}$ junto à opinião pública europeia (tanto na sua vertente política como, superiormente, epistemológico-científica) - da comunicação dos homens com o divino, o qual, iniciado com a Reforma Protestante e desdobrado pelo filosofismo do século XVIII (nas suas vertentes políticas, epistemológicas e religiosas/deístas), não apenas

\footnotetext{
${ }^{36}$ Leo Strauss, Direito Natural e História, p. 139.

37 Jean-Yves Pranchère, L'autorité contre les Lumières, p. 381

${ }^{38}$ Joseph de Maistre, O.C., XIV: 143.

${ }^{39}$ Leo Strauss, Direito Natural e História, p. 140.

${ }^{40}$ Joseph de Maistre, "Lettre à M. le Marquis... sur l'état du christianisme en Europe" $\left(1^{\circ}\right.$ de maio de 1819), O.C., VIII: 487.

41 Joseph de Maistre, Considérations sur la France, cap. 5.

42 Joseph de Maistre, Soirées, O.C., IV: 284 ( $\mathrm{V}^{\mathrm{e}}$ Entretien)
} 
preparou a Revolução de 1789, como anunciava novas explosões revolucionárias na França e no mundo.

O ponto em comum entre as duas principais doutrinas era a afirmação da razão individual em detrimento da razão geral cristalizada na tradição. "A grande base do protestantismo sendo o direito ao exame", este direito não encontra limites: "aplica-se sobre tudo e não pode receber freio." ${ }^{43}$ Ao vincular a autêntica experiência religiosa à consulta sem intermediários das Escrituras e substituir a autoridade da tradição que deveria orientar aquela prática pela razão individual, o protestantismo enfraqueceu as verdades da revelação e pavimentou o caminho para a Ilustração, cujo projeto de completa autonomia da razão era indissociável de um absoluto desencantamento do mundo ou expulsão da fé da esfera pública.

Não por acaso, Maistre dedicou quase duas décadas de sua existência aos estudos epistemológicos, pois estava convencido de que o núcleo mais resistente daquele bloqueio não era representado pela filosofia política de Rousseau ou pelas clássicas diatribes anticlericais de Voltaire, mas pelo método indutivo da ciência moderna inspirado nas formulações de Bacon e de Locke, e o qual, em razão de seu materialismo (isto é, da crença nas leis invariáveis da natureza), conduzia inevitavelmente ao fatalismo moral e à negação da espiritualidade da alma - daí a defesa do inatismo intelectual em linhas acentuadamente platônicas, seja através do próprio Platão ou de seus modernos intérpretes de Cambridge.

Para esta "Cassandra" da ciência moderna, a epistemologia sensualista/materialista seria apenas mais uma etapa (a mais perigosa, porém) do processo de negação da transcendência da autoridade, o qual iniciara com a Reforma e prosseguira com a filosofia das Luzes e a Revolução. Maistre descreve a história desta vontade, que genuinamente interpreta como um desdobramento do niilismo ${ }^{44}$, como uma história que produz dialeticamente sua própria negação, em virtude de uma "regra divina e invariável" que estipula que o erro "sempre se estrangula a si mesmo". 45

Assim, no Examen de la philosophie de Bacon, Bacon é atacado como o ídolo da filosofia moderna experimental, ao passo que nas Soirées de Saint-Pétersbourg o alvo seria John Locke, o principal responsável pelo "ateísmo prático" do século XVIII, por haver "aprisionado" ("Locked fast in") o espírito na matéria (ou melhor, vinculando-o

\footnotetext{
43 Joseph de Maistre, Réflexions sur le Protestantisme, O.C., VIII: 91.

${ }^{44}$ Maistre emprega a palavra riénisme, que na época era sinônimo de niilismo, ao denunciar o niilismo moderno. Cf. J. de Maistre, O.C., XIII:291.

${ }^{45}$ Joseph de Maistre, O.C., XIII:189.
} 
aos efeitos que os objetos exteriores suscitam nos sentidos) e bloqueado o circuito comunicativo dos homens com o plano transcendental (uma vez que a crença nas leis invariáveis da natureza produzida por aquela epistemologia sensualista servia apenas para demover os homens de orar) ${ }^{46}$, razão pela qual adotou a precaução de jamais empregar o termo "Luzes" ou "Ilustração" para uma filosofia que negava a transcendência como causação final do mundo natural e reduzia a inteligência humana apenas às relações horizontais e niveladas com os seus semelhantes, tornando-a indiferente à atração divina.

Enquanto que o Deus deísta/mecanicista de Bacon, Hobbes e Locke é no máximo um Deus absconditus, para o platônico e origenista Maistre, Deus é a fonte transcendente da justiça e da ordem terrenas. Conforme sintetizou Dante em termos paulinos que Maistre certamente endossaria com entusiasmo: "la gloria di colui che tutto move/per l'universo penetra e risplende/in una parte più e meno altrove". 47

Neste sentido, o mérito do homem - cujo principal atributo ontológico consiste justamente em seu livre-arbítrio - coincidirá com o maior grau de aceitação daquela atração divina, pois apesar de a graça de Deus incliná-lo para o bem, ela não determina de uma maneira necessária a sua vontade, razão pela qual o concurso da tradição se faz preciso para que a inteligência humana prevaleça sobre os impulsos sensíveis e materiais de nossa alma inferior ou carnal, ligada à nossa condição adâmica ou terrestre após o pecado original. Mas se os homens, vencidos pelas teorias materialistas do filosofismo, negligenciam aquela atração e não admitem outra realidade a não ser a deste mundo, a Providência, para educá-los, retira-se provisoriamente de cena a fim de permitir que os mesmos se saciem no próprio mal engendrado pelo triunfo de sua vontade extraviada. Limitando sua inteligência à atração terrestre, o homem perde a capacidade de optar pelo bem e de resistir às atrações do mal, o que, cedo ou tarde, resulta numa perda de seu autocontrole e liberdade.

Logo, o caráter satânico da Revolução não se deveu apenas ao movimento descristianizador, mas também (e sobretudo) à negação de todo princípio de legitimidade tradicional, condenando o projeto construtivista revolucionário às "revoluções permanentes: a vitória revolucionária representou uma "profunda e terrível divisão dos espíritos", um "protestantismo político levado ao individualismo mais absoluto". Maistre conservaria até o final de sua vida a noção de que só o processo

\footnotetext{
${ }^{46}$ Joseph de Maistre, Soirées, O.C., IV: 221 (IV Entretien)

${ }^{47}$ Dante Alighieri, A Divina comedia, Paraíso (Canto I).
} 
instável da Revolução - um "despedaçamento ao infinito de todas as doutrinas" que era estável ${ }^{49}$, antecipando os ciclos pelos quais a mesma teria de passar no século XIX.

A defesa da fé cristã contra o filosofismo vinculava-se a uma defesa da razão, pois a convicção maistreana, a saber, de que a obediência à ordem estabelecida pela tradição equivalia à obediência para com Deus, não era senão uma constatação "racionalista" de seu providencialismo, que postulava que não podemos conhecer os fins transcendentais de Deus, mas podemos aceder ao conhecimento dos mecanismos do mundo - do mundo natural, moral e político -, os quais foram designados, dispostos e movidos por uma Providência ao longo de tempo.

O homem participa das criações políticas e religiosas apenas na condição de instrumento de Deus, e é nesta condição que deve permanecer se quiser manter as "correntes" que o atam à ordem Providencial "flexíveis". Em nome de uma liberdade absoluta, os revolucionários não colheram mais senão alienação e tirania:

"Os tiranos se sucedem, e o povo segue obedecendo. Jamais se viu triunfar um único esforço de sua parte para escapar à sua nulidade. Seus senhores chegaram a aniquilá-lo, escarnecendo-se dele ao mesmo tempo. Disseram-lhe: Credes que não quereis esta lei, mas podeis estar seguros de que a quereis. Se ousardes recusá-la, sereis metralhados como punição por não quererdes o que quereis. - E assim o fizeram."

Por meio de uma releitura providencialista inspirada sobretudo em Orígenes, Maistre pôde justificar a irracionalidade da história como a história de uma comunicação truncada (pelo pecado original) do gênero humano com Deus.

Por sua vez, a compreensão dessa ordem requer a constatação simultânea de duas verdades contraditórias: de um lado, em virtude do pecado original, o reconhecimento de que "só há violência no universo" e que tudo está "fora de lugar" (Considerações, cap. 3) e, de outro, o reconhecimento de que nada é por acaso e que não há desordem propriamente dita (Considerações, cap. 10). O providencialismo maistreano culmina na seguinte conclusão paradoxal: a violência da história (produto do abuso do livre-arbítrio humano) é utilizada por Deus para restabelecer a ordem, visto que "não há desordem que o Amor Eterno não dirija contra o princípio do mal” (Considerações, cap. 3).

\footnotetext{
${ }^{48}$ Joseph de Maistre, O.C., XIV:286.

${ }^{49}$ Joseph de Maistre, O.C., XI:33.

${ }^{50}$ Joseph de Maistre, Considérations sur la France, cap. 8.
} 
A ordem da história - e talvez este constitua o maior de todos os paradoxos do providencialismo maistreano - não se revela para a maioria dos homens na regularidade ou num desenvolvimento linear e inteligível, mas na irracionalidade (aparente) da história, através de suas guerras, revoluções, conquistas, etc. Pois são nestes momentos, em que a "corrente flexível" se estreita, que podemos vislumbrar, com mais clareza, os mecanismos de que se serve a Providência para recompor a ordem, compreender o caráter pedagógico da ação divina. ${ }^{51}$

Razão pela qual o estilo paradoxal de sua escrita nada mais fez senão refletir o conteúdo paradoxal de sua cosmologia. Contra o fácil otimismo daqueles que pensavam que o homem, uma vez esclarecido e despojando-se das instituições anacrônicas e carcomidas do passado, poderia trazer à luz um novo mundo sem o concurso do divino, Maistre insistiu nos aspectos sombrios e trágicos inseparáveis de nossa condição "adâmica", isto é, marcada indelevelmente pelo pecado original.

Priorizando a "conversão" à persuasão, sua estética reforça os traços violentos da existência humana com o objetivo de suscitar o "assombro" e o "terror" em seu leitor, despertando-o assim para o caráter sublime das verdades transcendentais.

Por outro lado, esta leitura verdadeiramente teologal não o impediu de reconhecer que, assim como a Revolução nasceu de um esforço de longo prazo dos philosophes pela conquista da hegemonia cultural junto aos órgãos da opinião pública, também a contrarrevolução deveria pautar suas ações no sentido de reconquistar a hegemonia cultural perdida, sob pena de perder-se em estéreis e custosas manobras militares que só logravam aumentar a espiral de violência e favorecer o campo jacobino/revolucionário. Pois, de acordo com a célebre antimetábola maistreana (que Hannah Arendt, equivocadamente a nosso ver, interpreta como uma vazia estratégia retórica que trai as verdadeiras intenções de Maistre) $)^{52}$, a meta a ser alcançada pelos estadistas europeus pós-napoleônicos era o contrário da revolução (que transcendia o aspecto militar e privilegiava o domínio cultural, especialmente o religioso), não uma revolução contrária.

\footnotetext{
51 A este respeito, leia-se o excelente artigo de Élcio Verçosa Filho, "The pedagogical nature of Maistre's thought", in: Carolina Armenteros e R. Lebrun (eds.), Joseph de Maistre and the legacy of Enlightenment, p. 191-219.

${ }^{52}$ H. Arendt, Sulla Rivoluzione (Torino: Einaudi, 2006), p. 11.
} 


\section{B I B L I O GRA F I A}

\section{Fontes Primárias}

Archives de Joseph de Maistre et de sa famille. CD-ROM du fonds de Maistre, Archives départamentales de la Savoie, 1996.

\section{Obras Publicadas de Maistre}

MAISTRE, Joseph de. Discours à Mme. la Marquise de Costa sur la vie et la mort de son fils Eugène (1794), in: BARTHELET, Philippe (org.), Joseph de Maistre: les dossiers H. Paris: L'Age d'Homme, 2005.

Considérations sur la France, in: DARCEL, Jean-Louis (ed.), Ecrits sur la Révolution. Paris: PUF, 1989.

Du Pape. Paris: Charpentier, 1854.

. De la souveraineté du peuple. Un anti-contrat social, in:

DARCEL, Jean-Louis (ed.), Paris: Presses Universitaires de France, 1992.

Réflexions sur le protestantisme dans ses rapports avec la

souveraineté, in: DARCEL, Jean-Louis (ed.), Ecrits sur la Révolution. Paris: PUF, 1989.

. Essai sur le principe générateur des constitutions politiques, in: MANENT, Pierre (ed.), Paris: Editions Complexe, 2006.

Les Soirées de Saint-Pétersbourg. In: GLAUDES, Pierre (org.), Joseph de Maistre. Oeuvres. Paris: Robert Laffont, 2007.

Examen d'un écrit de J.-J. Rousseau sur l'inégalité des conditions, in: http://gallica.bnf.fr/ark:/12148/bpt6k418514 
MAISTRE, Joseph de. Lettres et opuscules inédits du comte Joseph de Maistre (2 volumes), in: http://gallica.bnf.fr/ark:/12148/bpt6k246120 . De l'Eglise Gallicane (1821), in: Oeuvres complètes de Joseph de Maistre. Lyon: Vitte et Perussel, 1886-1893, vol. III. . Examen de la philosophie de Bacon (1836), in: Oeuvres complètes de Joseph de Maistre. Lyon: Vitte et Perussel, 1886-1893, vol. VI. . Oeuvres complètes de Joseph de Maistre. Lyon: Vitte et Perussel, 1886-1893, 14 volumes. . Correspondance (1786-1805), in: Oeuvres complètes de Joseph de Maistre. Lyon: Vitte et Perussel, 1886-1893, vol. IX. Correspondance (1806-1807), in: Oeuvres complètes de Joseph de Maistre. Lyon: Vitte et Perussel, 1886-1893, vol. X.

. Correspondance (1808-1810), in: Oeuvres complètes de Joseph de Maistre. Lyon: Vitte et Perussel, 1886-1893, vol. XI. Correspondance (1811-1814), in: Oeuvres complètes de Joseph de Maistre. Lyon: Vitte et Perussel, 1886-1893, vol. XII. . Correspondance (1815-1816), in: Oeuvres complètes de Joseph de Maistre. Lyon: Vitte et Perussel, 1886-1893, vol. XIII. Correspondance (1816-1821), in: Oeuvres complètes de Joseph de Maistre. Lyon: Vitte et Perussel, 1886-1893, vol. XIV. . Correspondance Diplomatique de J. de Maistre: 1811-1817, in: ALBERT, Blanc (ed.), Paris: Lévy, 1860, 2 vols. 


\section{Obras de Referência}

ADORNO, T. e HORKHEIMER, M. La dialectique de la Raison (1947). Paris:

Gallimard, 1983.

ALBERT, Jacques. Joseph de Maistre: État et Réligion. Paris: Tequi, 1990.

ALLEN, Michael B. J. e REES, Valery (orgs.). His Theology, his Philosophy, his Legacy. Leiden: Brill, 2001.

ANDERSON, Perry. Linhagens do Estado Absolutista. Trad. de João R. Martins Filho. São Paulo: Brasiliense, 2004, $3^{\mathrm{a}}$ edição.

AQUINO, são Tomás de. Somme de la foi catholique contre les Gentils. Paris: Louis Vivès, 1854.

ARMENTEROS, Carolina. The French Idea of History. Joseph de Maistre and his heirs: 1794-1854. London: Cornell University Press, 2011.

"From Human Nature to Normal Humanity: Joseph de Maistre, Rousseau, and the Origins of Moral Statistics", in: Journal of the History of Ideas, LXVIII, 1 (2007): 107-130.

."Parabolas and the Fate of Nations: Early Conservative Historicism in Joseph de Maistre's De la souveraineté du peuple', History of Political Thought, XXVIII, 2 (2007): 230-252.

ARMENTEROS, Carolina e LEBRUN, Richard (orgs.). Joseph de Maistre and the legacy of Enlightenment. Oxford: Voltaire Foundation, 2011.

ARMENTEROS, Carolina e LEBRUN, Richard (orgs.). Joseph de Maistre and his European Readers: from Friedrich von Gentz to Isaiah Berlin. Leiden: Brill, 2011. 
ARMENTEROS, Carolina e LEBRUN, Richard (orgs.). The New Enfant du siècle: Joseph de Maistre as a writer. St. Andrews: University of St. Andrews, 2010.

ASTON, T, H. \& PHILPIN, C. H. E. (orgs.). The Brenner Debate: Agrarian Class Structure and Economic Development in Pre-Industrial Europe (1985). Cambridge: Cambridge University Press, 2002.

AUERBACH, Eric Auerbach. Mimesis: a representação da realidade na literatura ocidental. São Paulo: Perspectiva: 2004.

AULARD, Alphonse. “Les Premiers Historiens de la Révolution Française.”In: Études et Leçons sur la Révolution Française. Paris: Félix Alcan, 1910, p.32-134.

BADINTER, Elisabeth e BADINTER, Robert. Condorcet: un intellectuel en politique. Paris: Fayard, 1988.

BAKER, Keith M. The French Revolution and the Creation of Modern Political Culture. vol.1: Political Culture of the Old Regime. Oxford: Pergamon, 1987. Inventing the French-revolution: essays on French political culture in the eighteenth century. New York: Cambridge University Press, 1994. - "Le trasformazioni del repubblicanesimo classico nella Francia del Settecento", in: VIROLI, Maurizio (org.), Libertà política e virtù civile. Significati e percorsi Del repubblicanesimo classico. Torino: Edizione della Fondazione Giovanni Agnelli, 2004.

BALLANCHE, P.-S. Essai de palingénésie sociale, in: Euvres (Paris-Genève, 1830), vol. III.

BARBEY D'AUREVILLY, Jules, "Joseph de Maistre", in: Les prophètes du passé. Paris: Calmann Lévy, 1889. 
BARON, Hans. The Crisis of the Early Italian Renaissance: Civic Humanism and Republican Liberty in an Age of Classicism and Tyranny (1955). Princeton: Princeton University Press, 1966.

BARTHELET, Philippe (org.). Joseph de Maistre. Lausanne: L'Age d'Homme, 2005.

BARTHELET, P. "The Cambridge Platonists mirrored by Joseph de Maistre", in: ARMENTEROS, Carolina e LEBRUN, Richard (orgs.), Joseph de Maistre and the legacy of Enlightenment . Oxford: Voltaire Foundation, 2011.

BARTHES, Roland. Le plaisir du texte. Paris: Éditions du Seuil, "Points”, 1973.

BAUDIN, Rodolphe; BERNARD-GRIFFITHS, Simone e GRETCHNAIÄ, Elena (orgs). Exil et épistolaire aux XVIII ème et XIX ème siècles. Des éditions aux inédits Clermont-Ferrand: Presses Universitaires Blaise Pascal, 2007.

BAUMAN, Zygmunt. Modernidade líquida.Trad. de Plínio Dentzien. Rio de Janeiro: Jorge Zahar, 2001.

BAYLE, F. Les idées politiques de Joseph de Maistre. Paris: Editions Domat Montchrestien, 1945.

BEIK, Paul. The French Revolution seen from the Right. New York: Howard Fertig, 1970.

BELL, David. Lawyers and Citizens: The Making of a Political Elite in Old Regime France. Oxford: Oxford Univ. Press, 1994.

BENOIST, Alain de. Bibliographie générale des droites françaises. Paris: Éditions Dualpha, 2005. vol. 4.

BERLIN, I."De Maistre e as origens do fascismo”, in: HARDY, Henry (org.), Limites da Utopia. Capítulos da história das idéias. Trad. de Valter Lellis Siqueira. São Paulo: Companhia das Letras, 1991.

BEST, Geoffrey Best. The Permanent Revolution: the French Revolution and its legacy: 1789-1989. Chicago: University of Chicago Press, 1989. 
BÉTOURNÉ, Olivier \& HARTIG, Aglaia. Penser l'histoire de la Révolution. Deux siècles de passion française. Paris: Éditions La Découverte, 1989.

BOFFA, Massimo. "La Rivoluzione e la Controrivoluzione", in: F. Furet, $L$ ' Eredità della Rivoluzione Francese. Roma: Laterza, 1989.

. "Joseph de Maistre: la défense de l'autorité", in: Le Débat, março-maio $1986, \mathrm{n}^{\mathrm{o}} 39, \mathrm{p} .81-93$.

BONALD, Louis de. De l'unité religieuse en Europe, in: Oeuvres Complètes de L. de Bonald. Paris: J.-P. Migne, 1859.

Réflexions sur l'intérêt général de l'Europe. Paris: Le

Normant, 1815.

Démonstration philosophique du principe constitutif de la societé (1830), in: Oeuvres complètes. Paris: Leclère, 1847-54, t. IV.

BONCOMPAIN, Claude e VERMALE, Francois. Joseph de Maistre. Paris: Éditions du Félin, 2004.

BONGIOVANNI, Bruno e GUERCI, Luciano (orgs.). L'albero della Rivoluzione. Le interpretazioni della Rivoluzione francese. Torino: Einaudi, 1989.

BOSSUET, Jacques. Discours sur l'histoire universelle (1681), In: Oeuvres Complètes de Jacques Bénigne Bossuet. Besançon: Outhenin-Chalandre fils, 1840, tomo IX.

BRADLEY, Owen. A Modern Maistre: the Social and Political Thought of J. de Maistre. London: University of Nebraska Press, 1999.

BRAUDEL, Fernand. Civilização material, economia e capitalismo : séculos XVXVIII, vol. II: Os jogos das trocas. São Paulo: Martins Fontes, 1998.

BRAUDEL, Fernand. La Dynamique du Capitalisme. Paris: Champs/Flammarion, 1985. 
BRUNETIÈRE, Ferdinand. Histoire de la littérature française classique 1515 1830. Paris: C. Delagrave, 1914, tomo III.

BUCHEZ, Philippe et ROUX, Pierre-Célestin. Histoire parlementaire de la Révolution (1834). Paris: Paulin Librairie, 1838.

BURKE, Edmund. Reflexões sobre a Revolução em França (1790). Trad. de Renato de Assumpção Faria, Denis Fontes de S. Pinto e Carmen Lidia R. R. Moura. Brasília: UNB, 1982.

BURRIN, Philippe. "Le fascisme", in: SIRINELLI, J. F. Histoire des droites en France (Paris: Gallimard, 1992), vol 1, p. 623-638.

BURROUGHS, Josephine L. "Introduction" a Marsilio Ficino: Five Questions Concerning the Mind", in: CASSIRER, Ernst; KRISTELLER, Paul Oskar; e RANDALL, John Herman (orgs.), The Renaissance Philosophy of Man (1948). Chicago and London: The University of Chicago Press, 1969.

CABANIS, Pierre Jean George. Rapports du Physique et du Moral de l'Homme. Paris: Chez Béchet Jeune, 1824.

CAMCASTLE, Cara. The More Moderate side of Joseph de Maistre: views on Political Liberty and Political Economy. Montreal: McGill-Queen's University Press, 2005 .

CARPINELLI, G. "Augustin Cochin: Storico della Rivoluzione", in: BONGIOVANNI, Bruno e GUERCI, Luciano (org.) L'albero della Rivoluzione. Le interpretazioni della Rivoluzione francese. Torino: Einaudi, 1989.

CASSIRER, E. The Platonic Renaissance in England. New York: Nelson and Sons, 1953.

CASSIRER, Ernest. A Filosofia do Iluminismo. Trad. de Álvaro Cabral. Campinas-SP: Editora da Unicamp, 1992.

CASSIRER, Ernest. Individu et Cosmos dans la philosophie de la Renaissance. Paris: Minuit, 1983. 
CHABOT, Jean-Luc. "Théologie et politique chez Joseph de Maistre: les insuffisances théologiques de la pensée maistrienne", in: Revue des Études Maistriennes, $\mathrm{n}^{\mathrm{o}}$ 14, 2004.

CHARTIER, Roger. Origens Culturais da Revolução Francesa (1990). Trad. de George Schlesinger. São Paulo: Editora Unesp, 2009.

CHATEAUBRIAND, François-René de Chateaubriand. Genio del Cristianesimo (1802), in: FARAONI, Sara. Bompiani: Milano, 2008, edição bilíngue.

CHATEAUBRIAND, François-René de. De Buonaparte, des Bourbons, et de la nécesité de se rallier à nos princes légitimes, pour le bonheur de la France et celui de l'Europe (1814), in: CLÉMENT, Jean-Paul. Grands écrits politiques. Paris: Imprimerie nationale, 1993.

CHEVALIER, Jean-Jacques. "Un libro muy extraño: las Consideraciones sobre Francia de Joseph de Maistre (1797).” In: Revista de Estudios Politicos, XLIV, n ${ }^{\circ}$ 64, julio-agosto 1952, p.91-108.

CIORAN, E. M. "Joseph de Maistre. Essai sur la pensée réactionnaire", in: Exercices d'admiration. Paris: Gallimard, 1986.

CLARK, J. C. D. English Society 1688-1832. Ideology, Social Structure and Political Practice during the Ancien Regime. Cambridge: Cambridge University Press, 2000 .

The Language of Liberty 1660-1832. Political discourse and social dynamics in the Anglo-American world. Cambridge: Cambridge University Press, 2004.

COCHIN, Augustin. L'esprit du jacobinisme: une intertprétation sociologique de la Révolution française. Paris: PUF, 1979.

COGORDAN, George. Joseph de Maistre. Paris: Hachette et cie, 1894.

COMPAGNON, Antoine. Les antimodernes: de Joseph de Maistre à Roland Barthes. Paris: Gallimard, 2005. 
CONDORCET. Esquisse d'un tableau historique des progrès de l'esprit humain. Paris: Agasse, 1794.

CONSTANT, Benjamin. Da força do governo atual da França e da necessidade de apoiá-lo (1796). Tradução de Josemar Machado de Oliveira. Revista de História, $\mathrm{n}^{\mathrm{o}}$ $145,2001$.

CONSTANT, Benjamin. Principes de Politique (1815), in: GAUCHET, Marcel (ed.), Benjamin Constant: Écrits politiques. Paris: Gallimard, 1997.

CORREIA, Priscila Gomes. História, política e revolução em Eric Hobsbawm e François Furet. São Paulo: Annablumme-Fapesp, 2008.

CUDWORTH, Ralph. The true intellectual System of the Universe. New York: Gould and Newman, 1837.

DARCEL, Jean-Louis. De l'état de Nature. Chambéry: Institut d'Étude Maistriennes, 1976.

DARCEL, Jean-Louis e LEBRUN, Richard. (orgs.). Revue des Études Maistriennes: Joseph de Maistre et les livres, n 9 (Paris: Société d'Edition "Les Belles Lettres", 1985).

(org.). Revue des Études Maistriennes: De la Terreur à la Restauration. Correspondances inédites, $\mathrm{n}^{\mathrm{O}} 10$ (Paris: Société d'Edition "Les Belles Lettres", 1986-1987).

. "Maistre and the French Revolution". In: LEBRUN, Richard (org). Maistre Studies. London: University Press of America, 1988. . "Maistre's Libraries" (1985). In: LEBRUN, Richard (org). Maistre Studies. London: University Press of America, 1988. . "The Sources of Maistrean Sensibility ". In LEBRUN, Richard (org). Maistre Studies. London, University Press of America, 1988. 
DARCEL, Jean-Louis. "Présentation" de Joseph de Maistre, Écrits sur la Révolution (Paris: Quadriage, 1989).

De la souveraineté du peuple. Un anti-contrat social. Paris:

Presses Universitaires de France, 1992.

. "Genèse et publication des Soirées de Saint-Pétersbourg".

in: DARCEL, Jean-Louis (org.). Les Soirées de Saint-Pétersbourg ou Entretiens sur le Gouvernement Temporel de la Providence de Joseph de Maistre. Geneve: Slatkine, 1993.

"The Roads of Exile, 1792-1817", in: LEBRUN,

Richard (org)., Joseph de Maistre's Life, Thought and Influence. Quebec: McGillQueen's University Press, 2001.

"The apprentice years of a counter-revolutionary: Joseph de Maistre in Lausanne, 1793-97." in: LEBRUN, Richard (org). Joseph de Maistre's Life, Thought and Influence. Quebec: McGill-Queen's University Press, 2001.

"Joseph de Maistre and the House of Savoy: some aspects of his Career", in: LEBRUN, Richard (org). Joseph de Maistre's Life, Thought and Influence. Quebec: McGill-Queen's University Press, 2001.

DAUDET, E. Joseph de Maistre et Blacas, leur correspondance inédite et l'histoire de leur amitié. Paris: Pion, 1908.

DAVIES, Peter. The Extreme Right in France, 1789 to the Present. London: Routledge, 2002.

DELAPLACE, Gérard. "La Tradition, principe d'une politique dans la pensée de Joseph de Maistre", in: Revue des Études Maistriennes, n 5-6 (Paris: Société d'Editions "Les Belles Lettres", 1980), p. 259-271.

DENIZET, Jean. “Joseph de Maistre Economist”, in: LEBRUN. R. (org.), Joseph de Maistre's Life, Thought and Influence. Quebec, McGill-Queen's University Press, 2001. 
DERATHÉ, Robert. Jean-Jacques Rousseau e a Ciência Política do seu tempo. Trad. de Natalya Maaruyama. São Paulo: Barcarolla, 2009.

DERATHÉ, Robert. "Jean-Jacques Rousseau et le Christianisme", in: Revue de Métaphysique et Morale, $\mathrm{n}^{\mathrm{o}}$ 4, Outubro de 1948, p. 379-414.

DERRÉ, Jean-René. "Ballanche: continuateur et contradicteur de Joseph de Maistre", in: Revue des Études Maistriennes, n 5 5-6 (Paris: Société d'Editions "Les Belles Lettres", 1980), p. 297-316.

DESCARTES, René. "Objections faites par des personnes très doctes contre les précédantes méditations avec les réponses de l'auteur", in: AIMÉ-MARTIN, L. (org.), Oeuvres Philosophiques de René Descartes. Paris: Panthéon Littéraire, 1852.

DESCOSTES, François. Joseph de Maistre avant la Révolution. Paris: Elibron Classics, 2006.

DESCOSTES, François. Joseph de Maistre pendant la Révolution: ses débuts diplomatiques, le marquis de Sales et les émigrés, 1789-1797. Tours: A. Mame et fils, 1895.

D’HONDT, Jacques. “ Lumières et Romantisme. Le choc de la Révolution.” Cahiers de Philosophie Politique et Juridique. Actes du Colloque de Mai 1989, n. 16.

DINET, Dominique, "Le jansénisme et les origines de la déchristianisation au XVIIIe siècle: L'example des pays de l'Yonne", in: HAMON, Léo (org.), Du jansénisme à la laïcité: Le jansénisme et les origines de la déchristianisation. Paris: Éditions de la Maison des Sciences de 1'Homme, 1987, p. 1-33.

DOYLE, William. The Oxford History of the French Revolution. Oxford: Oxford University Press, 1992.

Jansenism: Catholic resistence to authority from the Reformation to the French Revolution. New York: St. Martin's Press, 2000.

EATWELL, Roger \& SULLIVAN, Nöel (orgs.). The Nature of the Right. London, Pinter Publishers, 1989. 
EDELSTEIN, Dan. The Terror of Natural Right: Republicanism, the Cult of Nature, and the French Revolution. Chicago: University of Chicago Press, 2009.

ELIAS, Norbert. A Sociedade de corte: investigação sobre a sociologia da realeza e da aristocracia de corte. Rio de Janeiro: Zahar, 2001.

ELliOTT, J. H. A Europa Dividida: 1559-1598 (1968). Trad. de Conceição Jardim e Eduardo Nogueira. Lisboa: Editorial Presença, 1985.

ECHEVERRIA, Durand. The Maupeou Revolution. A Study in the History of Libertarianism. France 1770-1774. Baton Rouge: Louisiana State University Press, 1985.

FAGUET, Émile. “Joseph de Maistre”, in: Politiques et moralistes du XIXe siècle. Paris: Lecène \& Oudin, 1891.

FERRAND, Antoine. L'esprit de l'histoire, ou lettres politiques et morales d'un père à son fils. Paris: Nyon, 1803.

FISICHELLA, Domenico. Joseph de Maistre, pensatore europeo. Roma, Laterza, 2005.

FLORENZANO, Modesto. As Reflexões sobre a Revolução em França de Edmund Burke: uma Revisão Historiográfica. São Paulo: Faculdade de Filosofia, Letras e Ciências Humanas-USP, 1994.

Começar o Mundo de Novo. Thomas Paine e outros estudos. São Paulo: Faculdade de Filosofia, Letras e Ciências Humanas-USP, 1999. . "Tocqueville diante da democracia e da Revolução". Revista do Instituto Histórico e Geográfico de São Paulo, vol. XCV, p.25-55, 1999.

FROIDEFONT, Marc. Théologie de Joseph de Maistre. Paris: Classiques Garnier, 2010.

FURET, François e OZOUF, Mona (org.) Dictionnaire critique de la Révolution française. Paris: Flammarion, 1988. 
FURET, François. Pensando a Revolução Francesa (1978). Trad. Martha Gambini e Luiz Marques. São Paulo: Paz e Terra, 1989, $2^{a}$ edição.

FURET, François. L'Eredità della Rivoluzione Francese. Roma, Laterza, 1989.

FURET, F. A Revolução em debate (1999). Trad. de Regina Célia Bicalho Prates e Silva. Bauru-SP, EDUSC, 2001.

GANOUCHAUD, Colette. "Révolution et opinion publique chez Rousseau: autour des idéaux de liberté, d'égalité, de fraternité", in: Studies on Voltaire and Eighteenth Century, n 324 (1994), p. 1-19.

GARIN, Eugenio. L'umanesimo italiano (1952). Roma-Bari: Editori Laterza, 2008.

GARRARD, Graeme. "Rousseau, Maistre and the Counter-Enlightenment". History of Political Thought. Vol. XV. n 1 (1994), p. 97-120.

. "Joseph de Maistre's Civilization and its Discontents". In: Journal of the History of Ideas, vol. 57, N 3 (1996), p. 429-446.

."Joseph de Maistre and Carl Schmitt”. In: LEBRUN, R. (org). Joseph de Maistre's Life, Thought and Influence. Montreal \& Ithaca. McGillQueen's University Press, 2001, p. 220-238.

GAUCHET, Marcel. Le désenchantement du monde: une histoire politique de la religion. Paris: Gallimard, 1985.

GAXOTTE, Pierre. La Révolution Française. Paris: Editions Complexe, 1988.

GAY, Peter. The Enlightenment: The Rise of Modern Paganism (1966). New York/London: W.W. Norton \& Company, 1977.

GENGEMBRE, Gerard. La Contre-Révolution ou l'histoire désespérante. Paris: Imago, 2001.

GÉRARD, Alice. A Revolução Francesa. Mitos e interpretações. (1970) trad. Sérgio Joaquim de Almeida. São Paulo: Ed. Perspectiva, 1999. 
GODECHOT, Jacques. La Contre-Révolution. Doctrine et Action 1789-1804. Paris: P.U.F,1961.

. "Introduction" de: Considérations sur la Révolution française (1818) de Mme de Stäel. Paris: Tallandier, 1983.

GODECHOT, Jacques. "As grandes correntes da historiografia da Revolução Francesa, de 1789 aos nossos dias.” Revista de História-USP. nº 80,vol. XXXIX,1969.

GODIN, A. Godin, Érasme, lecteur d'Origène. Genève: Droz, 1982.

GOOCH, G. P. Historia e historiadores en el siglo XIX (1913). Trad. espanhola de E. Champourain e R. Iglesia. México: Fondo de Cultura Econômica, 1942. . French Profiles: Prophets and Pioneers. London: Longmans, 1961.

GOUREVITCH, Victor (ed.). Rousseau: The Social Contract and other Political Writings. Cambridge: Cambridge Univ. Press, 1997.

GRAMSCI, A. Il Risorgimento. Torino: Riuniti, 1991.

GRANGE, Henri. Benjamin Constant: amoureux et républicain, 1795-1799. Paris: Belles-Lettres, 2004.

GRÉGOIRE, Abbé. Essai historique sur les libertés de l'eglise gallicane. Paris: Chez Baudoin Frères,1818.

GREIFER, Elisha. "Joseph de Maistre and the reaction against the eighteenth century." The American Political Science Review. Vol. XV, 1961.

GUENIFFEY, Patrice. Histoires de la Révolution et de l'Empire. Paris: Perrin, 2011.

GUILLAND, Agnès."La Rhétorique dans les Soirées de Saint-Pétersbourg de J. de Maistre: réfuter et convaincre", in: Revue des Études Maistriennes, n ${ }^{\circ} 12$. (Paris: Champion, 1996), p. 77-203.

- "L'érudition de Joseph de Maistre dans les Soirées de Saint-Pétersbourg", in: Revue des Études Maistriennes, $\mathrm{n}^{0} 13$ (Paris: Champion, 2001), p. 144-239. 
GUSDORF, Georges. As Revoluções da França e da América: a violência e a sabedoria. (1988). Trad. de Henrique Mesquita. Rio de Janeiro: Nova Fronteira, 1993.

GUSDORF, Georges. L'Homme Romantique. Paris: Payot, 1984.

HAMON, Léo. Du jansénisme à la laïcité. Le jansénisme et les origines de la déchristianisation. Paris: Maison des Sciences de Homme, 1987.

HARL, Marguerite. Le déchifrement du sens: études sur l'herméneutique chrétienne d'Origène à Grégoire de Nysse. Paris: Institut d'Études Augustiniennes, 1993.

HARTZ, Louis. The Necessity of Choice: Nineteenth-Century Political Thought. London: Transaction Publishers, 1990.

HAYWARD, Jack. After the French Revolution: six critics of Democracy and Nationalism. New York: University Press. New York, 1991.

HAZARD, Paul. O Pensamento Europeu no século XVIII: de Montesquieu a Lessing. Lisboa: Editorial Presença, 1974.

La pensée européenne au XVIII siècle, de Montesquieu à Lessing. Paris: Fayard, 1963.

HELVÉTIUS, Claude-Adrien. "De l'Homme", in: Oeuvres Complètes d'Helvétius. Paris: Caprelet, 1818.

HIGONNET, Patrice. Goodness beyond virtue: jacobins during the French Revolution. Cambridge: Harvard Univ. Press, 1987. . Sister Republics: the Origins of French and American Republicanism. Massachussets: Cambridge Univiversity Press, 1988.

HIMMELFARB, Gertrud. The Roads to Modernity: the British, French, and American Enlightenments. New York: Alfred A. Knopf, 2004.

HIRSCHMANN, Albert O. Retórica da intransigência : perversidade, futilidade, ameaça. São Paulo: Companhia das Letras, 1992.

HOBBES, Thomas. Leviathan. London: Penguin Classics, 1981. 
HOBSBAWM, Eric J. A Era das Revoluções. São Paulo, Paz e Terra, 2005. 19 edição.

HOBSBAWM, Eric J. Ecos da Marselhesa: dois séculos revêem a Revolução Francesa (1990) . Trad. Maria Celia Poli. São Paulo: Companhia das Letras, 1996.

HOFMANN, Etienne. Les 'Principes de politique' de Benjamin Constant: la genèse d'une oeuvre et l'évolution de la pensée de leur auteur, 1789-1806. Geneva: DROZ, 1980.

HOFMAN, Amos. "Opinion, Illusion, and the Illusion of Opinion: Barruel's Theory of Conspiracy." In: Eighteenth-Century Studies, Vol. 27, No. 1 (Autumn, 1993),p.27-60.

HUDSON, Nora E. Ultra-Royalism and the French Restoration. Cambridge: Cambridge Univ. Press, 1936.

HUGUENIN, François. "Souveraine Modernité de J. de Maistre". In: Philippe Barthelet (org.). Joseph de Maistre. Lausanne: L'Age d'Homme, 2005, p. 417-422.

HUNTINGTON, Samuel P. "Conservatism as an Ideology". The American Political Science Review. Vol. LI, n. 2, 1957.

JAEGER, W. Cristianismo primitivo y paideia griega. Buenos Aires: Fondo de Cultura Económica, 1965.

JASMIN, Marcelo Gantus. “Tocqueville, a Providência e a História”. Dados, vol. 40, $\mathrm{n}^{\mathrm{o}}$ 2, Rio de Janeiro 1997, p.199-227.

JAUME, Lucien. Le discours jacobin et la démocratie. Paris: Fayard, 1989.

JENNINGS, J. R. "Conceptions of England and its Constitution in the Ninetheenth-Century French Political Thought", in: The Historical Journal, 29, I, 1986.

KAPLAN, Steven Laurence. Farewell, Revolution. The historians' feud. 17891989. Ithaca and London: Cornell University Press, 1993. 
KELLY, Christopher. "To Persuade without Convincing: The Language of Rousseau's Legislator", in: American Journal of Political Science, vol. 31, n 2, 1987.

KOHLHAUER, Michael (ed.). Autour de Joseph et Xavier de Maistre: Mélanges pour Jean-Louis Darcel. Chambéry: Université de Savoie, 2007.

KOHLHAUER, Michael (ed.). Rencontres autour de Joseph de Maistre. (Thonon: Académie Chablaisienne, 2009).

. "A Dialectical Reading of Joseph de Maistre by Herbert Marcuse", in: ARMENTEROS, Carolina e LEBRUN, Richard (orgs.). Joseph de Maistre and his European Readers. Boston: Brill, 2011.

KOSELLECK, Reinhart. Crítica e crise: uma contribuição à patogênese do mundo burguês (1954). Trad.: Luciana Villas-Boas Castelo-Branco. Rio de Janeiro: EdUERJ/Contraponto, 1999.

KRISTELLER, Paul Oskar; RANDALL, John Herman (orgs.). The Renaissance Philosophy of Man (1948). Chicago and London: The University of Chicago Press, 1969.

KRISTELLER, P. O. Renaissance Thought and its Sources. New York: Columbia University Press, 1979.

KRISTELLER, Paul O. Renaissance Thought and the Arts. Princeton: Princeton University Press, 1980.

LAMARTINE, Alphonse. "Vie et œuvres du comte de Maistre", in: Cours familier de littérature, Paris, 1859, vol. VII, pp. 393-472; vol. VIII, pp. 5-80.

LANSON, Gustave. Histoire de la littérature française (Paris: Hachette, 1895).

LASKI, Harold. "De Maistre and Bismarck", in: Studies in the Problem of Sovereignty (New Haven: Yale University Press, 1937). 
LASLLET, Peter. John Locke: Dois Tradados sobre o Governo. Trad. Júlio Fisher. São Paulo: Martins Fontes, 1998.

LATREILLE, Camille, "Les derniers jours de Joseph de Maistre racontés par sa fille", in: La Quinzaine, 16 VII 1905, vol. 65, pp. 149-161

LATREILLE, Camile. Joseph de Maistre et la papauté. Paris: Hachette, 1906.

LEBRUN, Richard Allen. Throne and Altar: the Political and Religious Thought of Joseph de Maistre. Ottawa: University of Ottawa Press, 1965.

. "L'Épistemologie Maistrienne: rationalité et connaissance transcendante", in: Revue des Études Maistriennes, n 5-6. Paris: Société d'Editions "Les Belles Lettres", 1980, p. 225-241.

LEBRUN, Richard Allen. Joseph de Maistre: an intellectual militant. Quebec: McGill-Queen's University Press, 1988.

LEBRUN, Richard Allen (ed). Maistre Studies. London: University Press of America, 1988.

LEBRUN, R. Allen. "Maistrian Epistemology", in: LEBRUN, Richard (ed.), Maistre Studies. London: University Press of America, 1988.

. "Maistre and Natural Law", in: LEBRUN, Richard (org.), Maistre Studies. London: University Press of America, 1988.

. “Maistre's Reading”, in: LEBRUN, R.(org.), Maistre Studies. London: University Press of America, 1988.

.Considerations on France. New York: Cambridge University Press, 1994.

Against Rousseau.London: McGill-Queen's University Press, 1996. 
LEBRUN, R. Allen. (org). Joseph de Maistre's Life, Thought and Influence Quebec: McGill-Queen's University Press, 2001. . "Joseph de Maistre and Edmund Burke: a comparison", in:

LEBRUN R. (org.), Joseph de Maistre's Life, Thought and Influence. Quebec, McGillQueen's University Press, 2001.

LEFEBVRE, Georges. A Revolução Francesa (1930). Trad. de Ely Bloem de Melo Pati. São Paulo: Ibrasa, 1989. . O Nascimento da Moderna Historiografia (Lisboa: Sá da Costa, 1981). Réflexions sur l'histoire (Paris: Maspero, 1978).

LEFEBVRE, Georges. "Introduction", in: J.-P. Mayer (org.), Tocqueville. Euvres Complètes. Paris, Gallimard (Tomo II, vol. 1), 1953.

Études sur la Révolution Française (Paris: PUF, 1963). 1789 : O surgimento da Revolução Francesa (1939). Trad. de Cláudia Schilling (Rio de Janeiro: Paz e Terra, 2008).

LÉONARD, E.-G. Problèmes et expériences du Protestantisme français: l'urbanisation, l'embourgeoisement, les déviations ecclésiastiques, l'attrait catholique. Paris: Fischbacher, 1940.

LÉVI-STRAUSS, Claude. De près et de loin (Paris: Odèle Jacob, 1988).

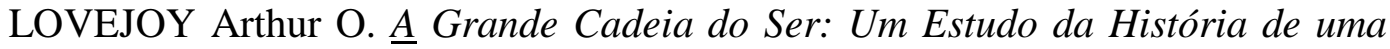
Ideia (1933). Trad. de Aldo Fernando Barbieri. São Paulo: Palíndromo, 2005.

LUBAC, Henri. Recherches dans la foi: Trois études sur Origène, saint Anselme et la philosophie chrétienne. Paris: Beauchesne, 1979. 
LUCAS, Colin (org.). The French Revolution and the Creation of Modern Political Culture, vol II: The Political Culture of the French Revolution. Oxford, Pergamon Press, 1989.

MABLY, Gabriel Bonnot de. Des droits et des devoirs du citoyen (1758). Paris: Bureau de la Publication, 1868, $2^{\text {a }}$ edição.

McMANNERS, John. "The Historiography of the French Revolution", in: The New Cambridge Modern History (1965), vol. 8, cap. XXII. . The French Revolution and the Church. London: Harper Torchbooks, 1969.

MADELIN, Louis. Le Consulat et l'empire. Paris: Hachette, 1932-33.

MADOUAS, Yves. "Joseph de Maistre, lecteur de Kant", in: Revue des Études Maistriennes, $\mathrm{n}^{\mathrm{0}} 12$ (Paris: Champion, 1996), p. 1-63.

MAIRE, Catherine-Laurance. Jansénisme et Révolution (Paris: Chroniques de Port-Royal, 1990).

De la cause de Dieu a la cause de la nation: Le jansenisme au XVIIIe siècle (Paris: Gallimard, 1998).

MANENT, Pierre. Cours familier de philosophie politique (Paris: Gallimard, 2001).

MANENT, Pierre. História Intelectual do Liberalismo: dez lições. Rio de Janeiro: Imago, 1990.

MANNHEIM, Karl. "El Pensamiento Conservador." In: Ensayos sobre Sociología y Psicología Social. México-DF: Fondo de Cultura Económica, 1963.

MARTIN, Jean-Clément (org.) Religion et Révolution. Paris: Anthropos, 1994.

MARTIN, Xavier. Human Nature and the French Revolution: From the Enlightenment to the Napoleonic Code. New York: Berghahn, 2001. 
MARX, Jacques. "L'idée de Palingenesie chez Joseph de Maistre", in: Revue des Études Maistriennes, n5-6 (Paris: Société d'Editions "Les Belles Lettres", 1980), p. 113-124.

MASSONET, Stéphane. "Révolution/Contre-Révolution." In: Philippe Barthelet (org). Joseph de Maistre. Les Dossiers H. Lausanne: L'age d'Homme, 2005.

MATHIEZ, Albert. História da Revolução Francesa (1822-4). O Terror (vol.III). Trad. de Paulo Zincg. São Paulo: Atena Editora, s/d.

MATHIEZ, Albert. La Théophilanthropie et le culte décadaire 1796-1801. Paris: Félix Alcan, 1904.

Contributions à l'histoire religieuse de la Révolution Française. Paris: Félix Alcan, 1907. La Révolution et l'Église. Paris: Armand Colin, 1910.

MATYASZEWSKI, Pawel. La philosophie de la société ou l'idée de l'unité humaine selon Joseph de Maistre (Lublin: Katolickiego Uniwersytetu Lubelskiego, 2002).

MAZA, Sarah. "Le tribunal de la nation: Les mémoires judiciaires et l'opinion publique à la fin de l'ancien régime", in: Annales E.S.C. (Jan. - Fev. 1987), p. 73-90.

McMAHON, Darrin M. Enemies of the Enlightenment. The French CounterEnlightenment and the making of the Modernity. New York: Oxford University Press, 2001.

McMAHON, Darrin M. "The genius of Maistre", in: ARMENTEROS, Carolina e LEBRUN, Richard (orgs.), Joseph de Maistre and the legacy of Enlightenment. Oxford: Voltaire Foundation, 2011, p. 19-30.

McMANNERS, J. "The historiography of the French revolution."In: A. Goodwin (org.), The American and French Revolutions, 1763-93. Cambridge: Cambridge University Press, 1965, vol. 8.

Church and Society in Eighteenth Century France: The Religion of the People and the Politics of Religion (New York: Oxford University Press, 1998), volume 2. 
MELlON, Stanley. Political Uses of History. Stanford: Stanford University Press, 1958.

MERRICK, Jeffrey W. The Desacralization of the French Monarchy in the XVIII century. London: Louisiana State Universisty Press, 1990.

MICHELET, Jules. Histoire de la Révolution française. Paris: Robert Laffont, 1979, 2 vols.

MICHELET, Jules. Histoire de France ("Guerres de Religion" e "La Ligue et Henri IV"), in: VIALLANEIX, P. (org.), Oeuvres Complètes de J. Michelet (Paris: Flammarion, 1978), t. VIII.

MICHELET, Jules e QUINET, E. Des Jésuites. Paris: Hachette, 1843.

MIGNET, François. Histoire de la Révolution française depuis 1789 jusqu'en 1814. Paris: F. Didot père et fils, 1824.

MILTCHYNA, Vera. "Joseph de Maistre in Russia: A look at the reception of his work." Joseph de Maistre's Life, Thought and Influence. Richard Lebrun (org.). Quebec, McGill-Queen's University Press, 2001.

MOORE, Barrington Jr. Social Origins of Dictatorship and Democracy: lord and peasants in the making of the modern world (Boston: Beacon Press, 1967).

NGUYEN, Victor. "Maistre, Vico et le retour des Dieux", in: Revue des Études Maistriennes, nº-6 (Paris: Société d'Editions "Les Belles Lettres", 1980), p. 243-257.

NICOLAS, Jean. La Savoie au XVIII siècle. Noblesse et bourgeoisie (Montmélian: La Fontaine de Siloé, 2003).

NIEBUHR, Reinhold. The Nature and Destiny of Man. New York: Charles Scribner's Sons, 1943.

NISBET, Robert. Os Filósofos Sociais. Brasília: Unb, 1982. 
NISBET, Robert."De Bonald and the concept of the social group", in: Journal of the History of Ideas, January 1944, vol. $5, \mathrm{n}^{\mathrm{o}} 1$.

NISBET, Robert. O Conservadorismo. Lisboa: Estampa, 1987.

NOVALIS, La Cristianità o Europa (1802), in: REALE, Alberto (ed.), Milano: Bompiani, 2002. Edição Bilíngue.

OMODEO, Adolfo. La cultura francese nell'età della Restaurazione (Torino: Arnoldo Mondadori Editori, 1946).

ORÍGENES. Traité d'Origène Contre Celse. Amsterdã: Henry Desbordes, 1700.

ORTEGA Y GASSET, José. O Homem e a Gente: intercomunicação humana (1957). Trad. de J. Carlos Lisboa. Rio de Janeiro: Libro Ibero-Americano, 1973, $2^{\text {a }}$ edição, 1973.

OZOUF, Mona. Festivals and the French Revolution. Cambridge/MA: Harvard University Press, 1989.

PAINE, Thomas. Rights of Man, Common Sense and Other Political Writings. Oxford: Oxford University Press, 2008.

PALMER, Robert Roswell. Catholics and Unbelievers in Eighteenth Century France. Princeton: Princeton University Press, 1939.

The Age of the Democratic Revolution, vol. I: The Challenge. Princeton University Press, 1959; e vol. II: The Struggle. Princeton University Press, 1964.

Le Gouvernement de la Terreur: l'année du Comité de Salut Publique. Paris: Armand Colin, 1989. 
PALMER, Robert Roswell. The Two Tocquevilles, Father and Son: Hervé and Alexis de Tocqueville on the coming of the French Revolution. Princeton: Princeton University Press, 1987.

PASTORI, Paolo. Tradizione e tradizionalismi. Lecce: Milella, 1997.

PERREAU-SAUSSINE, Emile. "Why Maistre became Ultramontane", in: ARMENTEROS, Carolina e LEBRUN, Richard (orgs.), Joseph de Maistre and the legacy of the Enlightenment. Oxford: Voltaire Foundation, 2011.

PETIT, Jacques. Barbey d'Aurevilly critique. Paris: Annales Littéraires de l’université de Besançon, 1963.

PITT, Alan. "The Religion of the Moderns: Freedom and Authenticity in Constant De la Religion", in: History of Political Thought, vol. XXI, nº 1, 2000.

POCOCK, J. G. A. Linguagens do Ideário Político. Trad. de Fábio Fernandez. São Paulo: Edusp, 2003.

POCOCK, J. G. A. Historia e Ilustración. Doce estudios. trad. espanhola de A. Casado, X. Gil, J. A. Pardos, J. Pérez, J Pimentel e P. Sánchez. Madrid: Marcial Pons, 2002.

POLAND, Burdette C. French Protestantism and the French Revolution: a study in Church and State, Thought and Religion, 1685-1815. Princeton: Princeton University Press, 1957.

PORCHNEV, Boris. Les soulèvements populaires en France au XVII siècle. Paris: Flammarion, 1972.

PORTER, Roy. The Creation of the Modern World: the untold history of the British Enlightenment . New York: W.W. Norton \& Company, 2000.

PRANCHÈRE, Jean-Yves. L'autorité contre les Lumières: la philosophie de Joseph de Maistre. Genève: DROZ, 2004. 
PRANCHÈRE, Jean-Yves. “Joseph's de Maistre Catholic Philosophy of Authority", in: LEBRUN, R. (org.), Joseph de Maistre's Life, Thought and Influence. Montreal \& Ithaca, McGill-Queen's University Press, 2001.

PRANCHÈRE, Jean-Yves. "The Persistence of Maistrian Thought" (1996). In: LEBRUN, Richard (org.). Joseph de Maistre's Life, Thought and Influence. Montreal \& Ithaca. McGill-Queen's University Press, 2001.

PRÉCLIN, Edmond. Les jansénistes du XVIIIe siècle et la Constitution civile du clergé. Le développement du richérisme, sa propagation dans le bas-clergé, 1713-1791. Paris: Librairie Universitaire J. Gamber, 1929.

QUINET, Edgar. Le Christianisme et la Révolution française. Paris: Au Comptoir des Imprimeurs-Unis, 1845. . La Révolution. Alençon: Belin, 1987, $1^{\mathrm{a}}$ edição de 1865.

REBOTTON, Jean. "Maistre's Religious Education”, in: LEBRUN, Richard (ed.), Maistre Studies. London: University Press of America, 1988, p. 78-95. "Josephus a Floribus during the Revolution", in: LEBRUN, Richard (org.). Maistre Studies. London, University Press of America, 1988.

REEDY, W. Jay. "Maistre's Twin? Louis de Bonald and the Enlightenment”, in: LEBRUN, Richard (ed.), Joseph de Maistre's Life, Thought and Influence. Quebec: McGill-Queen's University Press, 2001.

REMUSAT, Charles de, "Du traditionalisme: Joseph de Maistre", in: Revue des Deux Mondes, 15 mai 1857, pp. 241-270.

RIALS, Stéphane. Révolution et Contre-Révolution au XIX ${ }^{e}$ siècle. Paris: Albatros, 1987. . “Des Considérations sur la France’ aux Soirées de SaintPétersbourg", in: DARCEL, Jean-Louis (ed.), Les Soirées de Saint-Pétersbourg. Genève: Slatkine, 1993. 
RIQUET, Michel, "Joseph de Maistre et le père Barruel", in: Revue des Etudes Maistriennes, 5-6/1980, pp. 283-295.

RIVERA, Marco. Joseph de Maistre: pensatore dell'origine. Milano: Mursia, 1986.

RODRIGUES, Rui Luis. Entre o dito e o maldito: Humanismo erasmiano, ortodoxia e heresia nos processos de confessionalização do Ocidente 1530-1685. São Paulo: Tese de doutorado em História apresentado à Faculdade de Filosofia, Letras e Ciências Humanas da USP, 2012.

ROSENBLATT, Helena. Liberal Values: Benjamin Constant and the Politics of Religion. Cambridge: Cambridge University Press, 2011.

ROSSI, Paolo. O nascimento da ciência moderna na Europa (1997). Trad. de Antonio Angonese. Bauru-SP: Edusc, 2001.

ROUSSEL, Jean. Jean-Jacques Rousseau en France après la Révolution: 1795 1830. Paris: Armand Colin, 1972.

SAFA, Katrine. L'humanisme de Pic de la Mirandole: l'esprit en gloire de métamorphoses. Paris: Vrin, 2001.

SAINTE-BEUVE, C.-A. de. Portraits littéraires. Paris: Garnier Frères, 1860.

SAINTE-BEUVE, Charles A. "Joseph de Maistre", in: Portraits littéraires (Paris, Garnier, 1862-1864), vol. II.

SALVEMINI, Gaetano. Scritti di storia moderna e contemporanea. Milano: Feltrinelli, 1973.

SAUVIGNY, G. de Bertier de. La Restauration. Paris: Flammarion, 1955.

SCHECK, Thomas P. Origen and the History of Justification: the Legacy of Origen's commentary on Romans. Indiana: University of Notre Dame Press, 2008.

SCHUMPETER, Joseph A. Capitalismo, Socialismo e Democracia. Rio de Janeiro: Editora Fundo de Cultura, 1961. 
SÉNART, P. "Maistre et Tocqueville" In: Philippe Barthelet (org). Joseph de Maistre. Les Dossiers H. Lausanne: L'age d'Homme, 2005.

SERRA, Teresa. La critica alla democrazia in Joseph de Maistre e Louis de Bonald. Roma: Aracne, 2005.

SHKLAR, Judith. "Rousseau's Two Models: Sparta and the Age of Gold", in: Political Science Quarterly, vol. 81, nº 1 (1966), p. 25-51.

SIMONETTI, Manlio. I Principi di Origene. Torino: UTET, 2002.

SKINNER, Quentin. As fundações do pensamento político moderno (1978). Trad. portuguesa de Renato Janine Ribeiro e Laura Teixeira Motta. São Paulo: Cia das Letras, 2006, $5^{\text {a }}$ reimpressão.

. Lenguaje, política e historia (2002).Trad. espanhola de Cristina Fangmann (Bernal: Univ. Nacional de Quilmes, 2007).

SOBOUL, Albert. A Revolução Francesa. São Paulo, Difel, 1974.

SOLTNER, Jean-Louis. "Le Christianisme de Joseph de Maistre", in: Revue des Études Maistriennes, n5-6 (Paris: Société d'Editions "Les Belles Lettres", 1980), p. 97 110.

SOREL, Albert. L'Europe et la Révolution française. Paris: Librairie Plon, 1927, 8 vols.

SPEKTOROWSKI, Alberto. "Maistre, Donoso Cortés and the Legacy of Catholic Authoritarianism", in: Journal of the History of Ideas. 2002, p.283-302.

STÄEL, Mme de. Considérations sur la Révolution française (1818). Paris, Tallandier, 1983.

STÄEL, Mme de. Des circonstances actuelles qui peuvent terminer la Révolution et des principes qui doivent fonder la République en France. Paris: Librairie Fischbacher, 1905.

. De l'Allemagne. New York: Roe Lockwood and Son, 1860. 
STONE, Lawrence. As Causas da Revolução Inglesa 1529 -1642 (1972). Trad. de Modesto Florenzano. Bauru-SP: Edusc, 2000.

STOURDZA, Alexander. Considérations sur la doctrine et l'esprit de l'église orthodoxe. Weimar: Bureau d'Industrie, 1816.

STRAUSS, Leo Strauss. Direito Natural e História. Lisboa: Edições 70, 2009.

SUTHERLAND, Donald M. G. The French Revolution and Empire: Quest for a Civic Order. Oxford: Blackwell, 2003.

TACKETT, Timothy. Becoming a Revolutionary: the Deputies of the French National Assembly and the Emergence of a Revolutionary Culture, 17891790.Princeton: Princeton University Press, 1996.

TAINE, Hippolyte A. Les origines de la France contemporaine. Paris: Hachette, 1891.

TODOROV, T. O Jardim Imperfeito: o Pensamento Humanista na França. Trad. de Mary Amazonas Leite de Barros. São Paulo: Edusp, 2005.

TOCQUEVILLE, Alexis de. L'Ancien Régime et la Révolution. Paris, Flammarion, 2006. L'Ancien Régime et la Révolution. Fragments Inédits sur la Révolution. In: J.-P. Mayer (org.), Oeuvres Complètes de Alexis de Tocqueville. Paris: Gallimard, 1953, t. II, 4 a edição.

TOCQUEVILlE, Alexis de. De la Démocratie en Amérique. Paris: Flammarion, 1981, 2 vols.

TORJESEN, Karen Jo. Hermeneutical Procedure and Theological Method in Origen's Exegesis. Berlin: De Gruyer, 1985.

TRENARD, Louis. "Lumières et Maçonnerie dans la seconde moitié du XVIII ème siècle. Synthèse introductive", in: Revue des Études Maistriennes, n5-6. (Paris: Société d'Editions "Les Belles Lettres", 1980), p. 13-45.

TRINDADE, Liana Salvia. As raízes ideológicas das teorias sociais. São Paulo: Editora Ática, 1978. 
TRINKAUS, Charles Trinkaus. In our image and Likeness: Humanity and Divinity in Italian Humanist Thought. Indiana: Univ. of Notre Dame Press, 2012, 2 vol.

TRIOMPHE, Robert. J. de Maistre. Étude sur la vie et sur la doctrine d'un matérialiste mystique. Genève: Droz, 1968.

VAN KLEY, Dale K. "Du parti janseniste au parti patriote: l'ultime sécularisation d'une tradition religieuse à l'époque du chancelier Maupeou 1770-1775", in: MAIRE, Catherine (ed.), Jansénisme et Révolution. Paris: Chroniques de Port-Royal, 1990.

(ed.). The French Idea of Freedom: The Old Regime and the Declaration of Rights of 1789. Stanford/California: Stanford University Press, 1994. The Religious Origins of the French Revolution: From Calvin to the Civil Constitution, 1560-1791. New Haven: Yale University Press, 1996.

VENTURI, Franco. Utopia e Reforma no Iluminismo (1971). Trad. de Modesto Florenzano. Bauru: Edusc, 2003.

VERÇOSA FILHO, Élcio. "The pedagogical nature of Maistre's thought", in: ARMENTEROS, Carolina e LEBRUN, Richard (orgs.). Joseph de Maistre and the legacy of Enlightenment. Oxford: Voltaire Foundation, 2011.

VIALLANEIX, Paul. "Réformation et Révolution", in: FURET, François e OZOUF, Mona (orgs). The French Revolution and the Creation of Modern Political Culture: vol. III (Oxford/New York: Pergamon Press, 1989).

VIER, Jacques. "Apologétique des Lumières et Apologétique Maistrienne", in: Revue des Études Maistriennes, $\mathrm{n}^{0} 8$ (Paris: Société d'Editions "Les Belles Lettres", 1982-1983), p. 10-28.

VIGUERIE, Jean de. Christianisme et Révolution: Cinq Leçons d'histoire de la Révolution Française. Paris: Nouvelles Éditions Latines, 1986.

VIROLI, Maurizio. Republicanism (1999). New York: Hill and Wang, 2002. 
VOLTAIRE. Lettres sur les anglais, in: Oeuvres. Paris: Leguien, 1821, vol. XXVI.

VOUGA, Daniel . Baudelaire et Joseph de Maistre. Paris: J. Corti, 1957.

VOVELLE, Michel. Piété baroque et déchristianisation en Provence au XVIII' siècle. Les attitudes devant la mort d'après les clauses des testaments. Paris, Plon, 1973.

(org.). França Revolucionária (1789-1799). Trad. Denise Bottman. São Paulo: Brasiliense, 1989.

- Combates pela Revolução Francesa (2001). Trad. de Maria Lucia Panzoldo. Bauru-SP: Edusc, 2004.

VULLIAUD, P. Joseph de Maistre Franc-Maçon. Paris: Nourrit, 1926.

WATT, E. D. “Locked in”: De Maistre's Critique of French Lockeanism." Journal of the History of Ideas. January-March 1971, vol. XXXII.

WEBER, Max. A ética protestante e o "espírito" do capitalismo. Trad. de José Marcos Mariani de Macedo. São Paulo: Cia das Letras, 2009.

WHICHCOTE, Benjamin. The Works of the learned Benjamin Whichcote. Aberdeen: J.Chalmers, 1751.

WHICHCOTE, Benjamin. Moral and Religious Aphorisms. Wherein are contained Many Doctrines of Truth, and Rules of Practice, which are of Universal Concernment, and of the Greatest Importance in the Life of Men. London: J. Payne, 1753.

WINKLER, Kenneth P. "Perception and Ideas, Judgement", in: HAAKONSSEN, Knud (org.), The Cambridge History of the 18th Century Philosophy. Cambridge: Cambridge University Press, 2006.

WINOCK, Michel (org.). Histoire de l'extrême droite en France. Paris: Seuil, 1993. 
WINOCK, M. "L’héritage contre-révolutionnaire”, in: WINOCK, M. (org.), Histoire de l'extrême droite en France. Paris: Seuil, 1993.

WOLIN, Sheldon. Politics and Vision. Continuity and Innovation in Western Political Thought. Princeton: Princeton University Press, 2004.

WOOLF, Stuart. A History of Italy: 1700-1860. New York: Routledge, 1979.

WORONOFF, Denis. La République bourgeoise 1794-1799 de Thermidor à Brumaire. Paris: Seuil, 1972.

ZAGANIARIS, Jean. Spectres Contre-Révolutionnaires: interpretations et usages de la pensée de Joseph de Maistre XIX ${ }^{e}$ XX $X^{e}$ siècles. Paris: L'Harmattan, 2005. 